\title{
OXFORD
}

\section{THE CHRONICLE OF SEERT}

Christian Historical Imagination in Late Antique Iraq

Philip Wood

OXFORD EARLY CHRISTIAN STUDIES

1.

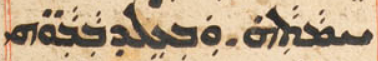
. Q

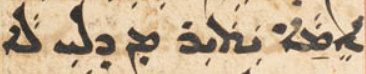
تَّة كذان

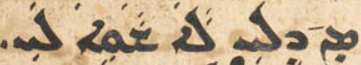
مجل

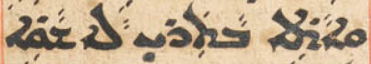

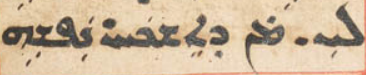

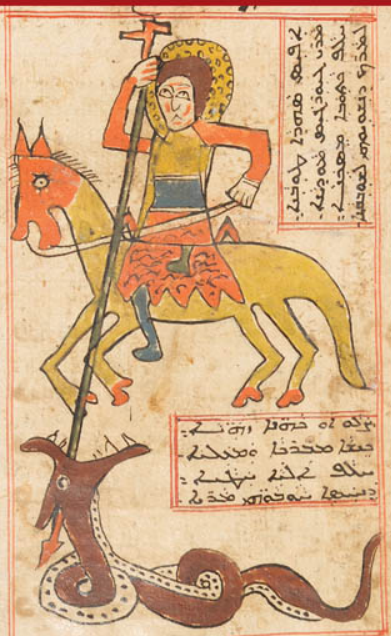




\title{
OXFORD EARLY CHRISTIAN STUDIES
}

\author{
General Editors
}

Gillian Clark Andrew Louth

This is an open access version of the publication distributed under the terms of the Creative Commons Attribution-NonCommercialNoDerivs licence (http://creativecommons.org/licenses/by-nc-nd/3.0/), which permits non-commercial reproduction and distribution of the work, in any medium, provided the original work is not altered or transformed in any way, and that the work is properly cited. For commercial re-use, please contact academic.permissions@oup.com 
THE OXFORD EARLY CHRISTIAN STUDIES series includes scholarly volumes on the thought and history of the early Christian centuries. Covering a wide range of Greek, Latin, and Oriental sources, the books are of interest to theologians, ancient historians, and specialists in the classical and Jewish worlds.

Titles in the series include:

Basil of Caesarea, Gregory of Nyssa, and the

Transformation of Divine Simplicity

Andrew Radde-Gallwitz (2009)

The Asceticism of Isaac of Nineveh

Patrik Hagman (2010)

Palladius of Helenopolis

The Origenist Advocate

Demetrios S. Katos (2011)

Origen and Scripture

The Contours of the Exegetical Life

Peter Martens (2012)

Activity and Participation in Late Antique and Early Christian Thought

Torstein Theodor Tollefsen (2012)

Irenaeus of Lyons and the Theology of the Holy Spirit

Anthony Briggman (2012)

Apophasis and Pseudonymity in Dionysius the Areopagite

"No Longer I"

Charles M. Stang (2012)

Memory in Augustine's Theological Anthropology

Paige E. Hochschild (2012)

Orosius and the Rhetoric of History

Peter Van Nuffelen (2012)

Drama of the Divine Economy

Creator and Creation in Early Christian Theology and Piety

Paul M. Blowers (2012)

Embodiment and Virtue in Gregory of Nyssa

Hans Boersma (2013)

This is an open access version of the publication distributed under the terms of the Creative Commons Attribution-NonCommercialNoDerivs licence (http://creativecommons.org/licenses/by-nc-nd/3.0/), which permits non-commercial reproduction and distribution of the work, in any medium, provided the original work is not altered or transformed in any way, and that the work is properly cited. For commercial re-use, please contact academic.permissions@oup.com 


\title{
The Chronicle of
} Seert

\section{Christian Historical Imagination \\ in Late Antique Iraq}

\author{
PHILIP WOOD
}

\section{OXFORD}

This is an open access version of the publication distributed under the terms of the Creative Commons Attribution-NonCommercialNoDerivs licence (http://creativecommons.org/licenses/by-nc-nd/3.0/), which permits non-commercial reproduction and distribution of the work, in any medium, provided the original work is not altered or transformed in any way, and that the work is properly cited. For commercial re-use, please contact academic.permissions@oup.com 


\title{
OXFORD \\ UNIVERSITY PRESS
}

Great Clarendon Street, Oxford, OX2 6DP, United Kingdom

Oxford University Press is a department of the University of Oxford.

It furthers the University's objective of excellence in research, scholarship, and education by publishing worldwide. Oxford is a registered trade mark of

Oxford University Press in the UK and in certain other countries

$$
\text { (C) Philip Wood } 2013
$$

The moral rights of the author have been asserted

First Edition published in 2013

$$
\text { Impression: } 1
$$

All rights reserved. No part of this publication may be reproduced, stored in a retrieval system, or transmitted, in any form or by any means, without the prior permission in writing of Oxford University Press, or as expressly permitted by law, by licence or under terms agreed with the appropriate reprographics rights organization. Enquiries concerning reproduction outside the scope of the above should be sent to the Rights Department, Oxford University Press, at the address above

You must not circulate this work in any other form and you must impose this same condition on any acquirer

\author{
British Library Cataloguing in Publication Data \\ Data available \\ ISBN 978-0-19-967067-3 \\ Printed and bound in Great Britain by \\ CPI Group (UK) Ltd, Croydon, CR0 4YY
}

This is an open access version of the publication distributed under the terms of the Creative Commons Attribution-NonCommercialNoDerivs licence (http://creativecommons.org/licenses/by-nc-nd/3.0/), which permits non-commercial reproduction and distribution of the work, in any medium, provided the original work is not altered or transformed in any way, and that the work is properly cited. For commercial re-use, please contact academic.permissions@oup.com 


\section{Contents}

Preface

ix

Notes on Transliteration and Terminology xi

Map

xii

Abbreviations

Introduction

The Chronicle of Seert

Approaching the Chronicle

Trusting the Chronicle

The Texture of the Chronicle

Structures of the Sasanian State 13

Religion and the Sasanian State 19

Geography of a Christian Minority 22

Babylonia 23

Khuzistan $\quad 25$

Assyria 26

1. Collaborators and Dissidents: Writing the Hagiographies

of the Fifth-century Persecutions 31

The 410 Synod of Seleucia-Ctesiphon 32

The War of 421 and the New Persecutions 37

The Martyrs of Yazdegard and Vahram $\quad 39$

Abgar's Cycle: Loyalty and Persecution 44

The Vandals Remembered 48

Conclusions $\quad 50$

2. The Martyrs and the Catholicos: The Acts of the Symeon and

Their Reinvention

The Relic Cult and the Invention of History 52

Symeon bar Sebba' e: Martyr for a Christian People $\quad 55$

Developing the Acts of Symeon: Authority and the Catholicos 57

The Acts of Symeon and the Control of History 60

Conclusions 64

3. The Patriarchal Histories: Genesis of a Centralizing Narrative 66

The Medieval Compilations: Bar Hebraeus, Mari, and 'Amr 67

The Medieval Compilations: The Chronicle of Seert and the Haddad Chronicle $\quad 70$

Acacius' History $\quad 71$ 
The Fifth Century in the Acacian History 74

The School of 'Abda $\quad 75$

Miles and Papas: The Council of Dadisho ${ }^{c} \quad 78$

Miles and Papas: The Reconstructions of the Histories 84

Papas and Demetrianus: Histories of Exile and

the Rights of Gundishapur $\quad 87$

Conclusions 91

4. The Church and the World 93

Clerical Reform: Acacius and Barsauma 95

Clerical Reform: Narsai, Elishe, and the History of a Crisis 100

The School of Nisibis: Barsauma, Acacius, and Christology 106

The School of Nisibis: Nisibene Theology in Ctesiphon 108

The Church and the Shahs: Seeking Favour 112

Conclusions 118

5. Roman Ecclesiastical History in the Sasanian World: Reception, Adaptation, and Reaction

The Expansion in History-writing

The Identity of the Ecclesiastical Historians 122

A New Roman Past 124

The Dyophysite Fathers and the Reception of the Fifth-century

Histories 125

Isho 'yahb I and the Incorporation of Roman Ecclesiastical History 128

Nisibis and the Dyophysite History of Barhadbeshaba 131

Chalcedon in the Church of the East 134

The Anti-Chalcedon Tradition 135

A Nestorian Church 140

Conclusions 142

6. Beyond Ctesiphon: Monasteries and Aristocrats

in the Christian Histories

Abrahamic Monasticism at Izla 146

Monasticism after the Henanian Crisis 149

The Hagiographic Collections: The Book of Chastity 150

The Book of the Governors 153

Authority and Conflict in the Accounts of Babai the Great 156

Monastic Hagiography in the Chronicle of Seert: The Catholicoi and the Jacobites 160

Monastic Foundations and Iranian Aristocracy 163

Local Hagiographies and Iranian Patrons 166

Iranian Histories and Christian Authors: The Acts of

Mar Qardagh

Iranian Histories in the Chronicle of Seert 171

Conclusions 174

This is an open access version of the publication distributed under the terms of the Creative Commons Attribution-NonCommercialNoDerivs licence (http://creativecommons.org/licenses/by-nc-nd/3.0/), which permits non-commercial reproduction and distribution of the work, in any medium, provided the original work is not altered or transformed in any way, and that the work is properly cited. For commercial re-use, please contact academic.permissions@oup.com 
7. The Last Great War of Antiquity: The Reaction of Christian Iraq

The Great War between Rome and Persia

Historiography of the Great War

Narrative Families in the History of the Great War 184

Khusrau and the Christians

The Life of Sabrisho ${ }^{c}$

$\mathrm{Nu}^{\mathrm{c}} \mathrm{man}$ and Sabrishoc

The Election of Sabrishoc

Christians in a Time of War: The Invasion of Dara 196

Christians in a Time of War: Khusrau and the Miaphysites 199

Gregory of Nisibis

Gregory and the Sack of Nisibis

The Election of Gregory of Pherat (605-9)

Rivals and Successors: Christian Political Ideas after 612

The Fall of Jerusalem in the Khuzistan Chronicle

The Fall of Jerusalem in Antiochos Strategos 213

The Murder of Khusrau $\quad 215$

The Reign of Shahrbaraz $\quad 218$

Conclusions $\quad 219$

8. The Church of Baghdad: A New Past for Christian Iraq 221

An Indian Summer 222

The Catholicoi and the Arabs 224

Writing Christian History under Arab Rule 229

Tales of Constantine 232

An Expanding Church 236

A New History of Monasticism: The Nestorians in the West 241

Remembering Muhammad: Taxation and Narratives of Surrender 243

Remembering Muhammad: The Histories of Najran 249

Remembering Muhammad: Christians, Jews, and Muslims 253

Conclusions 255

Conclusions 257

Episcopal and Regnal Lists $\quad 262$

Synods of the Church of the East 265

History-writing in the Church of the East 266

Contents of the Chronicle of Seert 268

Bibliography 274

Index $\quad 299$ 


\section{This page intentionally left blank}

This is an open access version of the publication distributed under the terms of the Creative Commons Attribution-NonCommercialNoDerivs licence (http://creativecommons.org/licenses/by-nc-nd/3.0/), which permits non-commercial reproduction and distribution of the work, in any medium, provided the original work is not altered or transformed in any way, and that the work is properly cited. For commercial re-use, please contact academic.permissions@oup.com 


\section{Preface}

This study of the Chronicle of Seert grew out a series of interests that developed while researching my doctorate. While my DPhil was concerned with the eastern Roman Empire, my eyes were increasingly drawn across the frontier, to the reception of the ideas, narratives, and institutional structures of the eastern Roman world in the Sasanian Empire. The Chronicle of Seert stood out in particular as a text that scholars sometimes mentioned in passing, but never treated as a whole, let alone situating it into its Sasanian and Abbasid contexts.

My study of the Chronicle was aided by the opportunity to use a closely related text, the Mukhtasar al-'akhbār al-bi 'ciya. This was discovered by Father Butrus Haddad in Baghdad immediately before the second Iraq war, and students of Iraqi history should be most indebted to him for bringing this text to the light of day. Following the custom of calling the Khuzistan Chronicle after its discoverer, Ignazio Guidi, I have used the term Haddad Chronicle, as a shorthand reference. In addition, I am personally very grateful to Robert Hoyland for allowing me to photocopy his copy of the chronicle.

I was very fortunate to be funded by a British Academy postdoctoral fellowship, which allowed me time to work on this project. I am also very grateful to Corpus Christi College, Oxford, for providing such a wonderful base for my Junior Research Fellowship and for the membership of the Corpus Classics centre. They were very happy years. My fellowship also allowed me to start work on Arabic, which I pursued in Damascus, and to spend time in the Syrian orthodox patriarchal monastery at $\mathrm{Ma}^{\mathrm{c}}$ arat Seidnaya. The book was completed at Sidney Sussex College, Cambridge, to whom I also owe a debt of gratitude.

I have accumulated a great many debts in the course of this project. My very great thanks go to Averil Cameron, my doctoral supervisor, who read the whole text in draft and made many highly pertinent observations. James Howard-Johnston was my British Academy mentor for the fellowship and was assiduous in offering advice on the text and urging me to remember the geography of my subject. David Taylor has been helpful and humorous in equal measure, and guided me out of several pitfalls, and Mazan Rabica taught me Arabic for several summers, sitting under the fig tree in his garden in Damascus: both have the patience of saints.

My thanks also goes to Richard Payne and Elizabeth Campbell, who were travelling companions for trips to Iran, Iraq, and Turkey and offered much valuable advice. I must also thank the various poor souls who I persuaded to read sections of the text in various stages of preparation, especially Rosamond McKitterick, Daniel Hadas, Harry Munt, Phil Booth, Adam Becker, Khodadad

This is an open access version of the publication distributed under the terms of the Creative Commons Attribution-NonCommercialNoDerivs licence (http://creativecommons.org/licenses/by-nc-nd/3.0/), which permits non-commercial reproduction and distribution of 
Rezakhani, Greg Fisher, and Sarah Savant. John Watt offered invaluable suggestions in his role as OUP's external reader. Mat Dalton prepared the map. Father Mikael Oez gave great help with the Syriac, and Haydar al-Lami with the Arabic. The late Tom Sizgorich was also kind enough to share with me a chapter from an unpublished manuscript. I remain in their debt. Finally, my greatest thanks goes to Katherine, Charlotte, and all my family, for all their love and kindness. 


\section{Notes on Transliteration and Terminology}

Syriac and Arabic proper names that have a common Anglicized form have not been fully transliterated. Citations from sources and titles of works have been transliterated. Where the published translations include clear pagination for the edition, I have only cited the editions in my notes, but I have employed the translations noted in the bibliography. My adaptations are mostly for style and to modernize language.

I have referred to 'Iraq' throughout. For the late antique period, this may feel anachronistic, but I preferred to retain a single term for the region across the work.

'Roman' and 'Western' generally refer to the region west of the Sasanian Empire and are used interchangeably. 'Iranian' and 'Persian' are also used interchangeably: both terms are found in the primary sources. I use the more commonly understood terms Ghassanid and Lakhmid for the Arab phylarchates, though 'Jafnid' and 'Nasrid' would probably be more acccurate.

Earlier versions of parts of chapters 1 and 5 were published in collected volumes edited by Adam Silverstein and Teresa Bernheimer (Late Antiquity: Eastern Perspectives, Edinburgh, 2012) and by myself (History and Identity in the Late Antique Near East, Oxford, 2013). They are reproduced here with permission. Further discussion of the sources of the Chronicle of Seert will appear in an article in the journal Oriens Christianus.

This is an open access version of the publication distributed under the terms of the Creative Commons Attribution-NonCommercialNoDerivs licence (http://creativecommons.org/licenses/by-nc-nd/3.0/), which permits non-commercial reproduction and distribution of the work, in any medium, provided the original work is not altered or transformed in any way, and that the work is properly cited. For commercial re-use, please contact academic.permissions@oup.com 


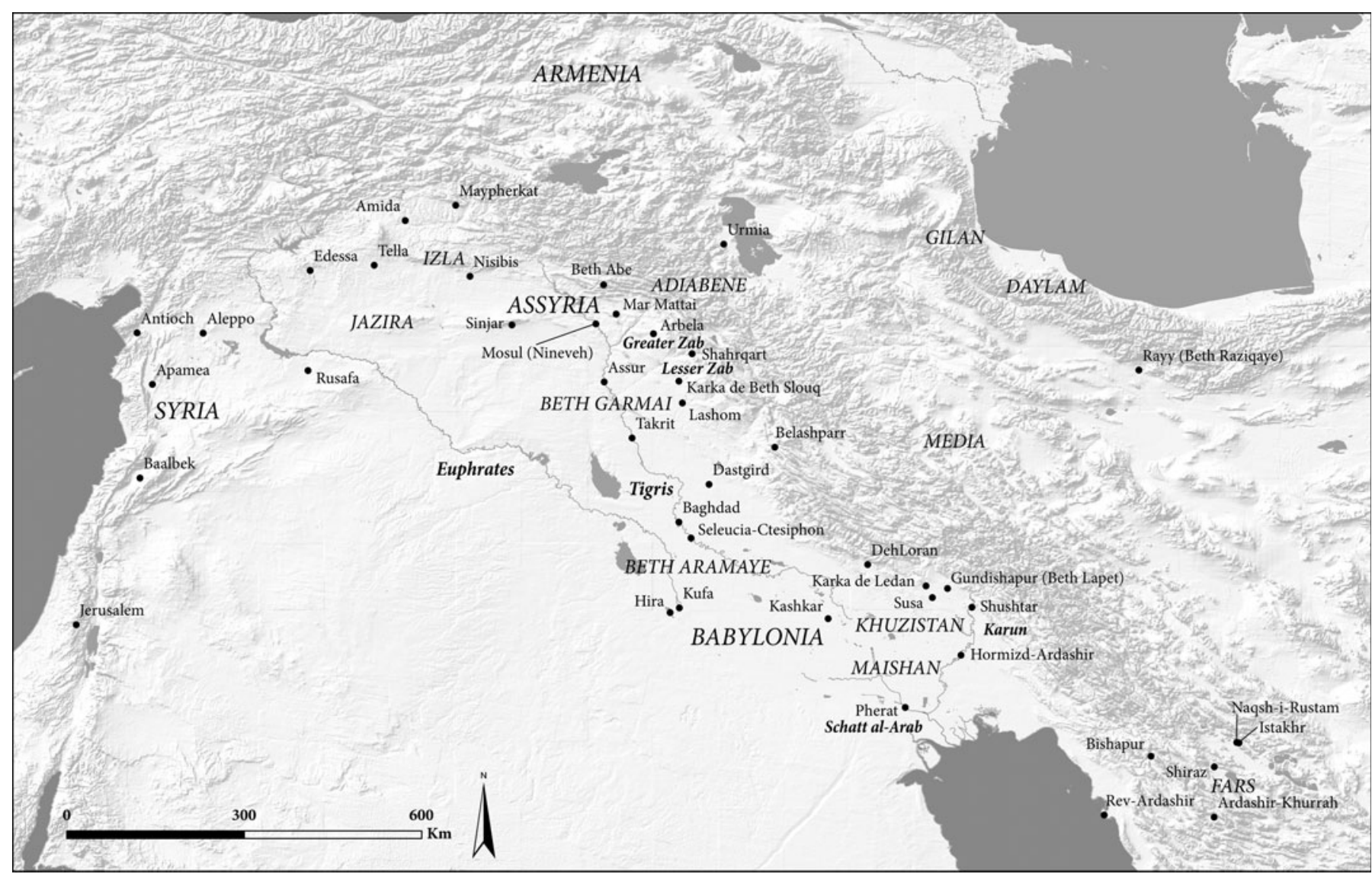

This is an open access version of the publication distributed under the terms of the Creative Commons Attribution-NonCommercialNoDerivs licence (http://creativecommons.org/licenses/by-nc-nd/3.0/), which permits non-commercial reproduction and distribution of the work, in any medium, provided the original work is not altered or transformed in any way, and that the work is properly cited. For commercial re-use, please contact academic.permissions@oup.com 


\section{Abbreviations}

$A A E$

$A B$

AC

AJN

AMS

$B A I$

$B J R L$

BO

BSOAS

CSCO

DHGE

DOP

DS

EI2

EIr

GCS

GRBS

$H E$

HTR

IrAnt

$J A$

JAOS

JECS

JESHO

JJS

$J L A$

JRAS

$J R S$

JSAI

Arabian Archaeology and Epigraphy

Analecta Bollandiana

L'Assyrie chrétienne: contribution à l'étude de l'histoire et de la géographie ecclésiastiques et monastiques du Nord de l'Iraq, 3 vols. (Beiruit, 1966-8)

American Journal of Numismatics

Acta Martyrorum et Sanctorum, ed. P. Bedjan, 7 vols. (Paris, 1896)

Bulletin of the Asia Institute

Bulletin of the John Rylands Library

Bibliotheca Orientalis, 4 vols. (Vatican City, 1719-28)

Bulletin of the School of Oriental and African Studies

Corpus Scriptorum Christianorum Orientalium

naire d'histoire et de géographie ecclésiastique, ed. A. Baudrillat et al.

(Paris, 1912-)

\section{Dumbarton Oaks Papers}

Dictionnaire de spiritualité: ascétique et mystique, doctrine et histoire, ed. M. Viler et al. (Paris 1937-95)

Encyclopaedia of Islam, 2nd edn, ed. P. J. Bearman et al. (Leider 1960-2005)

Encyclopaedia Iranica, online edition ( $<\mathrm{URL}>$ http://www.iranicaonline. com), ed. E. Yarshater (New York, 1996-). Articles consulted on 30/1/13.

Die Griechischen Christliche Schriftseller

Greek, Roman, and Byzantine Studies

Ecclesiastical History

Harvard Theological Review

Iranica Antiqua

Journal Asiatique

Journal of American Oriental Studies

Journal of Early Christian Studies

Journal of the Economic and Social History of the Orient

Journal of Jewish Studies

Journal of Late Antiquity

Journal of the Royal Asiatic Society

Journal of Roman Studies

Jerusalem Studies in Arabic and Islam

This is an open access version of the publication distributed under the terms of the Creative Commons Attribution-NonCommercialNoDerivs licence (http://creativecommons.org/licenses/by-nc-nd/3.0/), which permits non-commercial reproduction and distribution of the work, in any medium, provided the original work is not altered or transformed in any way, and that the work is properly cited. For commercial re-use, please contact academic.permissions@oup.com 
JTS Journal of Theological Studies

LM Le Muséon

MUSJ Mélanges de l'université de S. Joseph

MW $\quad$ Muslim World

OC Oriens Christianus

OCA Orientalia Christiana Analecta

OCP Orientalia Christiana Periodica

OS L'Orient syrien

PdO Parole de l'Orient

PG Patrologia Graeca

PLRE Prosopography of the Later Roman Empire ed. A. H. M. Jones and J. Martindale, 3 vols. (Cambridge, 1971-92)

PO Patrologia Orientalis

POC Proche-Orient Chrétien

PS Patrologia Syriaca

RHR Revue de l'histoire des religions

ROC Revue de l'Orient Chrétien

SC Sources chrétiens

StIr Studia Iranica

T\&M Travaux et mémoires

TTH Translated Texts for Historians

VC Vigiliae Christianae

ZDMG Zeitschrift der Deutschen morgenländischen Gesellschaft 


\section{Introduction}

When the Church of the East held its first synod in Ctesiphon in 410, Christians had already been present in Iraq for a long time. Converts from Judaism and 'paganism' mingled in the cities of the Sasanian (Persian) empire with Christian prisoners of war from the Roman world. ${ }^{1}$ Many of these Sasanian Christians were also linked to one another, and to their co-religionists across the Roman frontier, by their shared Syriac language. ${ }^{2}$

At certain points, however, the Sasanian regime subjected its Christian subjects to a series of 'persecutions'. ${ }^{3}$ It is difficult to estimate the size of this Christian community, or to enumerate or quantify the persecutions it suffered, but these events provided the major source of the Christian community's selfidentity. The church of the Sasanian empire, which we glimpse in the acts of its first synod, was clearly divided by language and by administrative practices. However, a shared experience of persecution, and reverence for the martyrs of the fourth century, may have come to represent a powerful source of unity for these different communities: one of the first secure pieces of information we have for the Church of the East is a Syriac language martyrion (a list of martyrs), dated to the year 411, listing the martyrs killed under Shapur II $(309-79){ }^{4}$

${ }^{1}$ Note especially S. P. Brock, 'Christians in the Sasanian Empire: a case of divided loyalties', Studies in Church History 18 (1982), 1-19 and his 'Nestorian church: a lamentable misnomer', BJRL 78 (1996), 23-53. General surveys are provided by J. Labourt, Le christianisme dans l'empire Perse (Paris, 1904); C. Baumer, The Church of the East: An Illustrated History of Assyrian Christianity (London, 2006) and W. Baum and D. Winkler, The Church of the East: A Concise History (London/New York, 2003). Underlying much of this work is J.-M. Fiey, L'Assyrie chrétienne: contribution à l'étude de l'histoire et de la géographie ecclésiastiques et monastiques $d u$ Nord de l'Iraq, 3 vols. (Beiruit, 1966-8).

${ }^{2}$ On the existence of a shared Syriac religious culture on both sides of the border see R. Murray, Symbols of Church and Kingdom: A Study in the Early Syriac Tradition (London, 2004), esp. 343-4. Also note E. Kettenhoffen, 'Deportations ii. In the Pathian and Sasanian periods', in EIr.

3 J. Rist, 'Die Verfolgung der Christen im spätantiken Sasanidenreich', OC 80 (1996), 17-42, esp. 40 (though he tends to take the hagiographers' reports at face value).

${ }^{4}$ W. Hatch, An Album of Dated Syriac Manuscripts (Boston, Mass., 1946), 52. These martyria may be based on a slightly earlier Greek original.

This is an open access version of the publication distributed under the terms of the Creative Commons Attribution-NonCommercialNoDerivs licence (http://creativecommons.org/licenses/by-nc-nd/3.0/), which permits non-commercial reproduction and distribution of the work, in any medium, provided the original work is not altered or transformed in any way, and that the work is properly cited. For commercial re-use, please contact academic.permissions@oup.com 
A list of martyrs' names may seem a humble beginning. Yet it represents an early stage in the development of a written history of the Church of the East. It is an important way point in the evolution of a sense of shared history that made different Christian communities conscious of their membership of a single church, a history that was constantly rearticulated in response to changing events. In short, changes in the church's historical awareness altered the behaviour and identity of Christians.

There is also a second feature of the 411 martyrion that deserves our attention. It was composed in the city of Edessa, a centre for the Syriac language that lay well inside Roman territory, rather than within the Sasanian Empire. Its contents were said to have been collected by one Marutha, bishop of Maypherkat, the Roman emissary who helped to convene the 410 synod. $^{5}$ The conjunction of the collection of a martyr list with the first church's inaugural synod should remind us of the role of administrative centralization in stimulating the creation of history, both real and invented. The church's shared experience was a good point of emphasis when the bishop of Ctesiphon intended to proclaim himself 'catholicos' over all the other bishops of the East. ${ }^{6}$ The origins of the document also point to the role of earlier Roman models for the Church of the East. ${ }^{7}$ This is true most clearly at the level of theology, since the Church of the East imported the dogma of the Western church wholesale. But it is equally important for the politics and history. In the Roman emperor Constantine, Iraqi Christians saw a model of state sponsorship that they would continue to wish for in their own rulers, while the church of the Roman world provided a centralized model that the bishops of the Sasanian capital Ctesiphon sought to emulate.

\section{THE CHRONICLE OF SEERT}

Many of the sources for the history of Christians in late antique Iraq are much later medieval compilations. This study will attempt to unpeel the layers of the later compilations, some of which go back to the fifth to seventh centuries, and

\footnotetext{
${ }^{5}$ Marutha's role here is a matter of debate. See Labourt, Le christianisme, 53-4 and M. Van Esbroek, 'Abraham le confesseur (Ve siècle), traducteur des passions des martyres perses', $A B 95$ (1977), 169-79.

6 The catholicos Ahai would himself collect martyrs' relics and hagiographic accounts (c.414). See chapters $2-3$.

7 S. P. Brock, 'Review of Wiessner, Untersuchungen ...', JTS (new series) 19 (1968), 300-9, at 303 observes that it was contact with the Roman world that ensured that the Shapurian persecutions were remembered, while others, known from inscriptions in the third century, were mostly forgotten by the Christians.
}

This is an open access version of the publication distributed under the terms of the Creative Commons Attribution-NonCommercialNoDerivs licence (http://creativecommons.org/licenses/by-nc-nd/3.0/), which permits non-commercial reproduction and distribution of the work, in any medium, provided the original work is not altered or transformed in any way, and that the work is properly cited. For commercial re-use, please contact academic.permissions@oup.com 
use them as indications of the changing use of tradition by different generations of historians. This is a study of the Church of the East seen through its imagination of its own past.

The most important of these medieval texts is the tenth-century Chronicle of Seert, a universal history, written in Arabic, that was discovered by the Chaldean archbishop Addai Scher at the start of the twentieth century. ${ }^{8}$ The Chronicle's surviving material covers the period c.251-423 and c.483-650, and there is a substantial gap in its coverage of the fifth century. We are left with only part of a work that may have once extended from Christ to the tenth century, though it is impossible to judge how dense this missing material might have been. Even as it stands, the text is very long, comprising some four fascicles of the Patrologia Orientalis.

The Chronicle was probably composed in the tenth century, since it employs the Melkite historian Qustā ibn Lùqā (d.910) and refers to Isho 'yahb III as 'the last catholicos of that name', placing it before the reign of Isho' yahb IV in 1023. ${ }^{9}$ It is a dense text, and the Chronicle includes a number of different layers of composition, each of which may abbreviate material from other sources, and, in some cases, blend this material together. While the Chronicle is written in Arabic, much of it derives from material that was originally in Syriac, the chief written language of Sasanian Christians before the coming of the Arabs. Many of the sources cited in the Chronicle are ecclesiastical histories of the seventh century, though these would have included even earlier sources. ${ }^{10}$ In addition, the compiler has included extracts from earlier Syriac texts that are still extant, such as the Lives of the catholicoi Aba and Sabrishoc.

I argue that it is possible to reconstruct the agendas and, in some cases, the content of earlier histories by reading this later text in the context of earlier late antique material. Following this method, I propose that the Chronicle was based around a fifth-century 'patriarchal history' that was continued into the middle of the sixth century. After this point, the range of material expands greatly. New histories based around monasticism, scholastic culture, and the ecclesiastical history of the West and secular history were added from the late sixth century, and historians began to integrate their accounts of the catholicoi with these other narrative traditions. This expansion of an episcopal history

\footnotetext{
8 J.-M. Fiey, 'L'apport de Mgr Addai Scher (+1915) à l'hagiographie orientale', AB 83 (1965), 121-45.

9 See R. Hoyland, Seeing Islam as Others Saw It: A Survey and Evaluation of Christian, Jewish and Zoroastrian Writings on Early Islam (Princeton, NJ, 1997), 444; J.-M. Fiey, Jalons pour l'histoire de l'église en Iraq (Beiruit, 1970), 21; R. Degen, 'Zwei Miszellen zur Chronik von Se'ert', OC 54 (1970), 76-95. There is also one reference in the text to a thirteenth-century Fatimid caliph (Chronicle of Seert, I/ii, 263), but this seems to be a later scribal addition. The manuscript, written in a hand that is 'old-fashioned, large, and clear', probably dates to this time (A. Scher, PO 4, 215-18).

${ }^{10}$ L. Sako, 'Les sources de la chronique de Seert', PdO 14 (1987), 155-67 lists these.
}

This is an open access version of the publication distributed under the terms of the Creative Commons Attribution-NonCommercialNoDerivs licence (http://creativecommons.org/licenses/by-nc-nd/3.0/), which permits non-commercial reproduction and distribution of the work, in any medium, provided the original work is not altered or transformed in any way, and that the work is properly cited. For commercial re-use, please contact academic.permissions@oup.com 
into something as voluminous as the Chronicle of Seert is an indication of the development of many different ways to assert a Christian identity or think about the Christian past, and the efforts of the catholicoi to subordinate these ideas to a 'universal' history, structured around the catholicosate.

The layered composition of the Chronicle provides rich evidence for patterns of history-writing in the Church of the East. This in turn, grants us an insight into the complex relationships that existed between church structures, laymen, and monastic institutions, all of which developed their own historical traditions. In all of these spheres, the reinvention of the past by each new generation of East Syrian Christians points to the changing contours of their self-conception as followers of a catholicos and as a 'Christian people' within the Sasanian world.

\section{APPROACHING THE CHRONICLE}

Addai Scher's discovery has not received great attention as a contribution to the history and historiography of late antiquity. It has been quarried as a repository of information about the Sasanian world and its Christians, but without many real attempts at source criticism, to determine how information entered the Chronicle and why. We cannot dismiss the Chronicle as untrustworthy merely because of its late date and the translation of older material into Arabic from other languages. For instance, François Decret has observed that the Chronicle's entry on the third-century martyr-bishop Cyprian of Carthage is surprisingly accurate, in spite of the distance between the milieux of historian and subject. ${ }^{11}$ That said, we must not simply take the Chronicle at face value, especially where we cannot check its account against other sources. Though one might like to reconstruct the history of Christianity in thirdcentury Iraq, it does not follow that we can use the Chronicle to do so, even where it is our only source. ${ }^{12}$ Indeed, it will be argued here that this early history was a particular target for inventions by Eastern historians, who replaced scanty early material with narratives that supported the claims of later eras. ${ }^{13}$

Approaches to the chronicle sources of late antiquity and the early Middle Ages have been greatly enriched over the last thirty to forty years. Western

11 F. Decret, 'L'affrontement des empires romain et sassanide', Recherches Augustiniennes 14 (1979), 91-152, at 100-102. Also n.b. Fiey, Jalons, 21-3.

12 E.g. M.-L.Chaumont, La christianisation de l'empire iranien, des origines aux grandes persécutions du IVe siècle (Louvain, 1988). Other possible sources for this period are also problematic: C. Jullien and F. Jullien, 'La Chronique d'Arbèles: propositions pour la fin d'une controverse', Oriens Christianus 85 (2001), 41-83.

${ }^{13}$ See this volume, chapters 3 and 8. 
medievalists in particular have come a long way from the assessment of sources merely as 'plausible witnesses'. Instead, chronicles have been increasingly seen as sources for the history of ideas, as 'coherent statements designed to have an effect on a contemporary audience', with regard to the 'salient features of society'. ${ }^{14}$ Studies on the Carolingian world have explored histories as statements on divine agency, on ideal hierarchy, and on the relationship between the localities and royal centres. ${ }^{15}$ In particular, Rosamond McKitterick's study of the Royal Frankish Annals has explored the successive layers of a sequential annalistic history as a testimony to the changing attitudes and self-representation of the royal court of Charlemagne. ${ }^{16}$ Other studies have addressed the distinctively Christian vision of early medieval historians, whether in their suppression of the heroic past or their treatment of the history of language. ${ }^{17}$

Another important perspective on the study of historiography has come from historians working on the Far East. Breuker's study of medieval Korea has observed that the intellectual environment of the kingdom of Koryo was an ideological landscape littered with philosophical, religious, mythical and historical constructs... some remnants of other times, some more recently constructed'. He proposes that the writing of history can be seen as a kind of codification, a response to the breakdown of practical unity that provides the illusion of a reality that was never there. ${ }^{18}$

Many of these studies have much to offer this investigation of a historical compilation of the tenth century. It is particular appropriate to read each of the different levels of the Chronicle of Seert as a comment on the 'salient features of society' and their supposed relationship to the past. Moreover, as in Breuker's study of Korea, these comments may assert a unity of identity that was never previously present, rendering it legitimate through appeals to a 'continuous' tradition. Indeed, it is important to remember that the historians

${ }^{14}$ M. Innes and Y. Hen (eds.), The Uses of the Past in the Early Middle Ages (Cambridge, 2000), 2-4. Cf. R. McKitterick, History and Memory in the Carolingian World (Cambridge, 2004), 2, who writes of 'the shift towards the study of historical texts as constructed narratives and bearers of memory' and Averil Cameron, 'Form and meaning: the Vita Constantini and the Vita Antonii', in T. Hägg and P. Rousseau (eds.), Greek Biography and Panegyric in Late Antiquity (Berkeley, 2000), 72-88, at 86, who calls for a focus on hagiographies as 'texts' rather than as 'sources'.

15 Y. Hen, 'The Annals of Metz and the Merovingian past', in Innes and Hen, Uses of the Past, 175-90.

16 R. McKitterick, Charlemagne: The Formation of a European Identity (Cambridge, 2008), 27-43.

17 W. Goffart, 'Conspicuously absent: martial heroism in the Histories of Gregory of Tours and its likes', in W. Goffart, Barbarians, Maps and Historiography (Aldershot, 2009), VI; W. Pohl, 'Telling the difference: signs of ethnic identity', in W. Pohl and H. Reimitz (eds.), Strategies of Distinction (Leiden/Cologne, 1998), 19-71, at 22-7.

18 R. Breuker, Establishing a Pluralist Society in Medieval Korea, 918-1170. History, Ideology and Identity in the Koryo Dynasty (Leiden, 2010), 3-9.

This is an open access version of the publication distributed under the terms of the Creative Commons Attribution-NonCommercialNoDerivs licence (http://creativecommons.org/licenses/by-nc-nd/3.0/), which permits non-commercial reproduction and distribution of the work, in any medium, provided the original work is not altered or transformed in any way, and that the work is properly cited. For commercial re-use, please contact academic.permissions@oup.com 
of the Church of the East did not just continue older histories. They also elaborated their record of the distant past to accommodate the needs of a changing present.

A third historiographical approach that is of particular relevance here is the work of historians of early Islam. They are faced with a similar problem to students of Middle Eastern Christianity: they are reliant on ninth- and tenthcentury compilations to write the histories of the seventh and eighth centuries. As Stephen Humphreys puts it: 'If our goal is to comprehend the way in which Muslims of the late 8th and 9th centuries understood the origins of their society, then we are very well off indeed. But if our aim is to find out what really happened ... then we are in trouble. ${ }^{19}$ Persuasive solutions to these problems have been proposed. Fred Donner and Antoine Borrut have argued that early Islamic history appears to have passed through a number of filters in successive generations of oral and written transmission, which exalted the ancestors of later sponsors and removed inconsistencies or inconvenient truths. ${ }^{20}$ In this model, if we are sufficiently attuned to the process of 'filtration', of the criteria on which information might be excluded, adapted, or expanded, we can make basic statements about what the material originally looked like.

Like some Islamicists looking at Muslim Arab sources, there is a temptation for us to see the Chronicle purely as a product of the tenth century, a work created entirely in the cities of Abbasid Iraq. ${ }^{21}$ There is certainly evidence of changes to place names to fit an Islamic context, changes that could well have been introduced at the moment of translation. Yet there are also good reasons to be hopeful of reconstructing earlier layers in the Chronicle. Indeed, I argue that we can be much more confident in unpicking the layers of the Chronicle of Seert than Islamicists can be in dissecting al-Tabari, al-Baladhuri, and their contemporaries.

\section{TRUSTING THE CHRONICLE}

Firstly, it is clear that the compiler of the Chronicle has adopted a very conservative attitude to editing, preserving contradictory accounts of the same events alongside one another. We see this at the scale of whole narratives

19 R. S. Humphreys, Islamic History: A Framework for Enquiry (Princeton, 1992), 69.

20 F. Donner, Narratives of Islamic Origins: The Beginnings of Islamic Historical Writing (Princeton, 1998); A. Borrut, Entre mémoire et pouvoir: l'espace syrien sous les derniers Omeyyades et les premiers Abbassides (v. 72-193/692-809) (Leiden, 2011).

${ }^{21}$ J. Howard-Johnston, Witnesses to a World Crisis: Historians and Histories of the SeventhCentury Middle East (Oxford, 2010), 519-20 for this trend in the historiography.

This is an open access version of the publication distributed under the terms of the Creative Commons Attribution-NonCommercialNoDerivs licence (http://creativecommons.org/licenses/by-nc-nd/3.0/), which permits non-commercial reproduction and distribution of the work, in any medium, provided the original work is not altered or transformed in any way, and that the work is properly cited. For commercial re-use, please contact academic.permissions@oup.com 
in his divergent accounts of Constantine's conversion, the Life of Ephraem, or the reign of Julian. ${ }^{22}$ This pattern points to great respect for earlier material and an inability to differentiate between different versions of the same event: in many cases, the tradition that the compiler depended on seems to have been isolated from Western sources that might have been used to check or alter his material. Indeed, the Chronicle is filled with anachronisms, misdated events, and obscure passages that have been mutilated during abbreviation.

Secondly, the Chronicle, like a number of similar histories, has been structured around the reigns of catholicoi, the bishops of Seleucia-Ctesiphon, and the catholicosate provided a consistent central interest to the compiler's predecessors, who provided his raw material. Sections on 'the fathers of the church' are especially important for this structural diagnosis: they list holy men and theologians active at the time of a given catholicos and read like a list of contents from other compilations very similar to the Chronicle itself. ${ }^{23}$ The Chronicle's compiler has included these earlier, more abbreviated, attempts to organize this material. The succession of catholicoi, therefore, provided a core around which other information was organized from an early date.

Thirdly, a number of dateable sources exist in Syriac from the period described by the Chronicle that we can use as controls on its material. Most prominent among these is the so-called Synodicon Orientale, the record of synods of the Church of the East held in the fifth to eighth centuries. These sources also include a variety of hagiographic material, on the martyrs of the fifth-century persecutions; on prominent catholicoi and on the monastic founders of the late sixth and seventh centuries. In all these cases, the Syriac sources are important not only because they confirm or deny the 'data' of the Chronicle, but also because they provide plausible contexts for the composition of different parts of the Chronicle, and allow us an insight into the development of the historical tradition on which the Chronicle relies. In addition, this historiographical analysis is aided by a later, thirteenth-century list of earlier historians by 'Abdisho' of Nisibis, which gives a sense of how an increasing number of historians worked within this tradition. ${ }^{24}$ Similarly, the chronological range of the texts of foreign origin in the Chronicle (such as ecclesiastical history from the Roman Empire) allows us to establish 'termini post quem' for the incorporation of this foreign material into the tradition.

Fourthly, and finally, we can also use a number of related medieval chronicles to shed further light on the material available to the compiler of the

${ }^{22}$ Chronicle of Seert, I/i, XIV (Constantine); I/ii, XXXIII-XXXIV (Julian); XXVI/LIV (Ephraem).

${ }^{23}$ Chronicle of Seert I/i, VIII (236); XXV (292); XXX (311); I/ii, LVII (305).

${ }^{24}$ Published with an extensive Latin commentary in J. S. Assemani, Bibliotheca Orientalis, 4 vols. (Vatican City, 1719-28), IIIa, a collection that provides the groundwork for all nineteenthand twentieth-century surveys of Syriac literature.

This is an open access version of the publication distributed under the terms of the Creative Commons Attribution-NonCommercialNoDerivs licence (http://creativecommons.org/licenses/by-nc-nd/3.0/), which permits non-commercial reproduction and distribution of the work, in any medium, provided the original work is not altered or transformed in any way, and that the work is properly cited. For commercial re-use, please contact academic.permissions@oup.com 
Chronicle and provide alternative reconstructions of events. In particular, cases where the same material has been organized differently by the various compilers suggest points at which the original account of the events had not been divided into sections based around each catholicos in turn, and where these divisions had to be inserted later.

We can never take the information included in these chronicles at face value. We should never lose sight of their late date of compilation, or the fact that they rely on Arabic translations of earlier Syriac sources. However, too much of their material, especially their shared material, does not make sense as a tenth-century invention. Instead, I suggest that it is possible to isolate material in these chronicles that is either related to known sources or fits into narrative strands that run between different sections. Each of these narrative strands may be internally linked either by the succession of dramatis personae (often successive bishops or secular rulers or chains of scholars and disciples) or by similar political or theological agendas. In this way, it is possible to isolate the components of later compilations, each of which show signs of development by different anonymous authors. Many of these authors can be dated to the sixth or seventh centuries, rather than later, because of the individuals and places they praise or vilify. ${ }^{25}$

This study is an attempt to analyse the production of histories as a series of events in themselves. The Chronicle of Seert is organized into distinct sections, many of which are gobbets of narrative taken wholesale from other histories and embedded in this later medieval compilation. By isolating the shared biases and interests of these sections, I suggest that we can locate a series of different traditions within the Chronicle and sometimes identify when and how the material entered the historical tradition that was shared with other medieval compilations. This study aims to use each layer of the historical tradition as a testimony to the changing cultural awareness and intellectual agenda of the mostly anonymous historians whose work is embedded in the Chronicle. The different layers of historical writing allow us an insight into the social and rhetorical construction of orthodox belief and of the church as an institution in successive generations. ${ }^{26}$

25 There are some important exceptions where this method has not worked so well. Several sections provide 'timeless' morality tales, and I have been unable to suggest a plausible context for their invention: Chronicle of Seert, II/i, VII; XVI; II/ii, LVII. Others (e.g. I/ii, XLIV-XLVII) are clearly adapted from Western ecclesiastical history, but these narratives could have achieved their final form at any point after the late sixth century.

${ }^{26}$ Compare S. Davis, The Early Coptic Papacy (Oxford, 2004), xi and M. Swanson, The Coptic Papacy in Islamic Egypt (641-1517) (Cairo/New York, 2010) for a good example of the assertion of a distinctive Christian identity through the themes of apostolicity, martyrdom, and orthodoxy.

This is an open access version of the publication distributed under the terms of the Creative Commons Attribution-NonCommercialNoDerivs licence (http://creativecommons.org/licenses/by-nc-nd/3.0/), which permits non-commercial reproduction and distribution of 


\section{THE TEXTURE OF THE CHRONICLE}

The method proposed here compares each section against available contemporary sources and situates the section within one of a number of narrative strands within the Chronicle to try to establish the agenda of the original writer, as well as the presence of later adaptations. To illustrate this method, and to give a sense of the texture and form of the material, here I examine three short extracts from the Chronicle.

\section{Part I, Section LXIX, The history of Ahai, the fifteenth catholicos}

At the death of Ishaq, the catholicos, Marutha of Maypherkat chose Ahai, disiciple of Mar 'Abda, [as catholicos in his place], and, at the command of Yazdegard, the fathers agreed. [Before his election as catholicos], his master established him as superior of his monastery and its students. After his election to the catholicosate, Yazdegard favoured him. A short time after he had taken over the catholicosate, Yazdegard sent him to Fars [to inspect] the merchandise and pearls taken by sea from the lands of India and China, which Nahrouz, son of his brother Shapur, governor of Fars, claimed had been stolen by pirates, so that the catholicos could check the truth of these allegations and inform him about it. On his arrival in Fars, the catholicos asked to see the tombs of those martyrs killed by Shapur and learnt the cause of their deaths. He recorded their stories and returned to Yazdegard to report what he had found out. He was even more favoured by the king... He demanded that all the fathers burn the houses of wizards and destroy magical objects, since the Christians were mixed among Marcionites and Manichees and were participating in these customs. Then he wrote a book on some of the martyrs of the East. Daniel bar Mariam, established this in his ecclesiastical history. He (Ahai) also wrote a life (tašita) of his master 'Abda. His catholicosate lasted four years, seven months and a few days. May God grant his soul eternal rest.

This section illustrates the 'patriarchal history', the sequential accounts of the catholicoi that provided the organizing structure for most Eastern historians up to the time of medieval compilers. Ahai's life (410-14) is clearly placed in a sequence following his predecessor Ishaq (c.399-410), but the author also observes the role of Marutha, the Western emissary, in selecting Ahai. The period 410-20 saw the first regular use of church synods in the Church of the East, and Marutha's presence was an important stimulus to the use of Western norms of church organization. In addition, the memory of this Western confirmation continued to be important long after this event: earlier connections with the West were invented by later historians, inspired by accounts such as this one.

This section also highlights Ahai's close relationship with the shah Yazdegard. This, like the presence of Marutha, is invoked as an important feature of the catholicos' legitimacy in the synods of the period. The section also includes the historian's reflection on Ahai's own role in collecting accurate 'histories' of

This is an open access version of the publication distributed under the terms of the Creative Commons Attribution-NonCommercialNoDerivs licence (http://creativecommons.org/licenses/by-nc-nd/3.0/), which permits non-commercial reproduction and distribution of the work, in any medium, provided the original work is not altered or transformed in any way, and that the work is properly cited. For commercial re-use, please contact academic.permissions@oup.com 
the martyrs of the Shapurian persecutions and the early monastic tradition in Ctesiphon. Several catholicoi of the early fifth century were associated with the 'school of 'Abda'. This school is only rarely referred to in the later record, and 'Abda's reputation as a monastic founder was eclipsed by earlier, fictitious figures such as Awgin. This reference, therefore, and the connection it makes between 'Abda and a school in Ctesiphon seems to be a real one, and we can put some faith in his account of Ahai as an early collector of traditions on martyrdom and monasticism. The reference to the early seventh-century historian Daniel bar Mariam is essentially subsidiary: the emphasis here is that Ahai was the ultimate source for Daniel's martyrdom accounts, and Daniel is not the author of the section as a whole. ${ }^{27}$

The first two chapters of the book treat this fifth-century commemoration of the martyrs, both the dimly remembered Shapurian martyrs and those of later persecutions. These hagiographies elaborated on simple lists of early martyrs to provide political models that discussed the nature of Christian loyalties to a potentially destructive Sasanian state, doing so by presenting this era as a golden age of martyrdom.

The stories of Ishaq, Ahai, and his contemporaries were strung together into a patriarchal history in the late fifth century, at the same time that church synods were reconvened after a long hiatus. The early fifth-century stories were organized around the reigns of catholicoi and were placed into a sequence with the martyred catholicoi of the Shapurian persecutions. This patriarchal history linked contemporary catholicoi to their martyred predecessors and to earlier moments when a temporarily centralized church had asserted the importance of the see of Ctesiphon. Thus, the disjointed memories of earlier eras were woven together into a single narrative that underlined the importance of the catholicosate as the central institution of the church (even if its importance may have actually fluctuated considerably). Lists of bishops, modelled on much older near eastern king lists, probably also underlie such 'patriarchal histories'. ${ }^{28}$ Unlike in the earlier hagiographies of the Church of the East, the connection between the golden age and the present was set into a chain of succession that could be further elaborated into an accretive, continuous history that combined a number of different formative 'golden ages'. I discuss this early patriarchal history in chapter 3.

\section{Part II, Section VIII The history of Acacius (Aqaq), the twenty-first Catholicos}

After the martyrdom of Babowai the catholicos, Acacius the teacher (malfäna)

was elected to the catholicosate. And he was from Babowai's family, which was $45-80$.

27 E. Degen, 'Daniel bar Maryam: ein nestorianischer Kirchenhistoriker', OC 52 (1968),

${ }^{28}$ On these lists in the Roman east, see M. Debié, 'Record keeping and chronicle writing in Antioch and Edessa', Aram 12 (2000), 409-17. Her L'historiographie syriaque (Paris, 2009) also provides important background for this study.

This is an open access version of the publication distributed under the terms of the Creative Commons Attribution-NonCommercialNoDerivs licence (http://creativecommons.org/licenses/by-nc-nd/3.0/), which permits non-commercial reproduction and distribution of the work, in any medium, provided the original work is not altered or transformed in any way, and that the work is properly cited. For commercial re-use, please contact academic.permissions@oup.com 
mentioned by him in his letter to Barsauma. Acacius ${ }^{29}$ studied at the school (ask $\bar{u} l)$ of Edessa and met Theodoulos the disciple of the Interpreter [i.e. Theodore of Mopsuestia] there, and he blessed him and named him 'the column of the east'. ${ }^{\star} \mathrm{He}$ was good and virtuous. During the squabbles of Babowai and Barsauma, Acacius went from Edessa to al-Madāin [Ctesiphon], where he remained as a teacher for all the time that Babowai was there, aiding him and supporting him with the other bishops against Barsauma. He refuted the letter that he [Barsauma] wrote against the catholicos. When he was at the head of the church he conducted his affairs well. He opposed the Magians, who imprisoned him for a time and mistreated him. The followers of Barsauma, who detested his rule, accused him of adultery $\left(z i n \bar{a}^{\prime}\right)$, but they did not achieve their desire: In order to defy those who accused him, Acacius was forced to strip naked before the bishops to show them that he was a eunuch. And he was embarassed by the things he had done.

*Acacius went to the land of the Greeks (bilād al-rūm) at the time of Zeno and asked him to restore the bishops he had exiled. He composed a treatise on faith, in which he confounded those who argued for a single nature (jauhar-an wähid-an) in Christ, and he wrote three other treatises on fasting. The Greeks and Persians remarked on his virtue and wisdom.

This section on the late fifth-century catholicos Acacius represents a continuation of the patriarchal history seen above in the section on Ahai. The difference is that this text has been more heavily overwritten using different historical traditions and with the perspective of mid-sixth-century hindsight.

The original core of the text may have begun at the first asterisk, with an assertion of the catholicos' virtue that is a familiar feature of the biographies of earlier catholicoi. This original text probably included the references to Acacius as an opponent of Barsauma and as an ally of Babowai, as well as his connection to the school of Edessa and his opposition to the Magians. But even if this core text is earlier, it does not necessarily make it more reliable: this account makes the association with Babowai part of Acacius' claim to legitimacy, and ignores the numerous accusations of misconduct that had been made against his predecessor. This silence is understandable if we realize that Babaowai's opponent, Barsauma of Nisibis, had threatened to enact the necessary reforms of clerical marriage without the support of the catholicos. Thus the account has reimagined Babowai as a competent predecessor to avoid any challenges to the authority of the catholicos.

The sexual accusations against Acacius should also give us pause for thought. The synodica make clear that Acacius was responsible for the abolition of clerical celibacy, in response to the sexual scandals of Babowai's reign (these reforms were annulled some sixty years later under the catholicos Aba). The section passes over these reforms in silence, but the emphasis on Acacius as a eunuch, whether true or not, may be included to defend his reputation.

29 The text reads 'Barsauma': Scher (PO 9, 112, note 3) identifies this as a copyist's error.

This is an open access version of the publication distributed under the terms of the Creative Commons Attribution-NonCommercialNoDerivs licence (http://creativecommons.org/licenses/by-nc-nd/3.0/), which permits non-commercial reproduction and distribution of the work, in any medium, provided the original work is not altered or transformed in any way, and that the work is properly cited. For commercial re-use, please contact academic.permissions@oup.com 
The dissident Barsauma often appears as a scapegoat for the Acacian reforms, primarily because of the threat he had posed to the catholicosate as an institution, but other sources included in the Chronicle remember him as an important Dyophysite theologian (e.g. sections IX and XI).

The asterisks mark the limits of this hypothetical core text of this section. The material at the very start emphasizes Acacius' position as teacher and his connection to the School of the Persians at Edessa, before its settlement at Nisibis after their expulsion under Zeno. It has probably been added as a supplement to the core text. Like the references at the end to Acacius' intercession with Zeno and his scholarly writing, it probably derives from a tradition of ecclesiastical history and biography originating within Nisibis. The inclusion of this Nisibene material probably occurred in the last quarter of the sixth century, when catholicoi were consistently connected to the School and when a number of ecclesiastical historians are said to have worked. I discuss the clerical reforms and their impact on the historiography, as well as the changing relationship between catholicos and shah, in chapter 4 .

\section{Part II, Section VI History of Gennadius, Patriarch of Constantinople}

At the death of Anatolius, patriarch of Constantinople, Gennadius came in his place. In his time, wars and strife broke out in the empire and in the priesthood (al-kohenüta) of East and West. In the east, Barsauma struggled with Babowai. Peter the Fuller, patriarch of Antioch, at the command of the emperor Zeno, stirred up the West and anathematized whoever confessed two natures in Christ. Gennadius and Felix resisted him: they reunited the fathers, re-established the faith and anathematized whoever confessed a single nature in Christ. Gennadius was patriarch for fifteen years. His successor Hilidiyon died in a fire that broke out in the town three years later.

This brief section seems to have originated in Greek Dyophysite circles before being transmitted to the East. The Eastern historical tradition had reused a large amount of Western ecclesiastical history running up to Chalcedon in 451. Sections such as this one show that the East continued to be aware of church affairs even after Chalcedon, and that it viewed the patriarchs of Rome and Constantinople as fellow Dyophysites working to uphold orthodoxy. This author seems to have been ignorant of the Chalcedonians' condemnation of the extreme Dyophysite patriarch Nestorius, who would achieve a totemic status in the seventh-century Church of the East.

The inclusion of the Pope Felix implies a Western origin, but the text has also been reworked to link it to an event in the East, the struggle between Barsauma and Babowai (d.484) (which did not actually have the same theological composition as the Christological crises in the Roman world). The section is part of a series of accounts of the Constantinopolitan patriarchs that terminates in the middle of the sixth century and which was incorporated into the Eastern tradition in subsequent generations, when the catholicoi took an increasingly

This is an open access version of the publication distributed under the terms of the Creative Commons Attribution-NonCommercialNoDerivs licence (http://creativecommons.org/licenses/by-nc-nd/3.0/), which permits non-commercial reproduction and distribution of 
sophisticated stance in their theology and emphasized their preservation of an original orthodoxy, once shared by the Roman world but now abandoned by Justinian (527-65). This kind of sentiment, which saw the Church of the East and the Chalcedonian churches as fellow Dyophysites, was challenged by an alternative anti-Chalcedonian tradition, ${ }^{30}$ which paved the way for the church's heavy identification with Nestorius in the seventh and eighth centuries.

Roman ecclesiastical history represents just one of a number of additional strands that were added to the pre-existing patriarchal history. Other examples include monastic biographies of the late sixth and seventh centuries and the Persian royal tradition, the Xwadāy-Nāmag. ${ }^{31}$ These additions were the product of a new generation of ecclesiastical historians writing after c.580, a generation that coincided with growing connections between the Sasanian state and the church, the expansion of monasticism and the development of new connections with the Roman world. The expansion of this tradition allows us a wider insight into how the Church's leaders incorporated, annexed, and opposed other strands of history in the East and reacted to the Church's changing political situation, all the time preserving claims to continuity with the past. This 'additional material' is discussed in chapters 5 and 6 .

The process of history writing needs to be set within two different contexts. The first of these is the changing behaviour of the Sasanian state, which moulded the social and political environments in which the Christian church developed and its leaders sought patronage. The second is the changing distribution and importance of Christians across the lands ruled by the shahs, the geographical context for the different societies that became Christian and that were 'ruled', to varying degrees, by catholicoi in Ctesiphon. Understanding this variety in state structures and in the forms of society that played host to the Church of the East is a necessary prerequisite for understanding how the histories of settlements and institutions outside Ctesiphon were integrated into a central historical tradition. From this basis, we can then examine how the catholicosate positioned itself vis-à-vis its rulers and other Christians, gradually incorporating and annexing the other pasts of Iraq.

\section{STRUCTURES OF THE SASANIAN STATE}

Ardashir I (224-40) had come to power on the back of a revolution based in the province of Fars and drew on propaganda produced by his predecessors,

${ }^{30}$ E.g. Barsauma of Susa's attack on Chalcedon in II/ii, XCIV.

${ }^{31}$ S. Shahbazi, 'On the Xwadāy-Nāmag', in Iranica Varia: Papers in Honour of Ehsan Yarshater (Leiden, 1990), 208-29; M. Macuch, 'Pahlavi literature', in R. Emmerick and M. Macuch (eds.), The Literature of Pre-Islamic Iran (London, 2009), 116-96, at 173-7.

This is an open access version of the publication distributed under the terms of the Creative Commons Attribution-NonCommercialNoDerivs licence (http://creativecommons.org/licenses/by-nc-nd/3.0/), which permits non-commercial reproduction and distribution of the work, in any medium, provided the original work is not altered or transformed in any way, and that the work is properly cited. For commercial re-use, please contact academic.permissions@oup.com 
local rulers of Fars, that underscored their connection to the fire shrine dedicated to Anahita at Istakhr. ${ }^{32}$ Ardashir's rock inscriptions, and those of his son, Shapur I (240-72), commemorate their divine mandate, which flowed from their deeds of martial prowess, especially their defeat of the Romans. ${ }^{33}$ But this divine mandate does not seem to have been monopolized by any 'Zoroastrian church': the institutional sponsorship of the magi by the shah seems only to have begun after Shapur (and even then, it only proceeded in fits and starts).$^{34}$ At this early stage, it was still possible for a prophet outside the military aristocracy of the empire to include the Sasanians' divine mandate into his cosmological system. Shapur I was a major sponsor of the prophet Mani, whose Middle Persian Shaburaghan deliberately conflates the roles of God, prophet, and king in the dissemination of his true religion. ${ }^{35}$

It was only after the death of Shapur, with the accession of the more vulnerable Vahram II, that we see a move away from earlier sponsorship of Mani towards a Zoroastrian cleric. Kartir, mobad of Istakhr, the traditional religious centre of the Sasanians in Fars, publicized his prominence at court under the shah Vahram II (276-93), as well as his promotion to the shrine of Istakhr and his defeat of other religious groups. ${ }^{36}$ In a great inscription at Naqsh-i-Rustam, Kartir celebrated his promotion by successive shahs and their foundation of fire shrines, emphasizing his prestige in the eyes of the shahs, even calling himself Vahram's 'soul-saviour'. ${ }^{37}$

32 For the Parthian coins of Fars see V. Curtis, 'Iranian revival in the Parthian period', in V. Curtis and S. Stewart (eds.), The Idea of Iran vol. 2: The Age of the Parthians (London, 2006), 7-25, at 21, and for the Sasanian graffiti at Persepolis, suggesting a sense of continuity with the Achaemenid past, see D. Huff, 'Formation and ideology of the Sasanian state in the context of archaeological evidence', in V. Curtis and S. Stewart (eds.), The Idea of Iran volume III: The Sasanian Era (London, 2008), 32-9, at 32. For a useful survey of Sasanian history see J. Wiesehöfer, Ancient Persia: From 550 B.C. to 650 A.D. (2nd edn., London, 2001), Part IV.

33 The inscriptions show Ardashir and Shapur being crowned by Anahit, Mithra, and Nike: G. Herrmann, The Iranian Revival (Oxford, 1977), 90-1 and 104-6. For a survey of royal titles and their association with the gods see P. Huyse, 'Die sasanidische Königstitulatur: eine Gegenüberstellung der Quellen', in P. Huyse and J. Wiesehöfer (eds.), Ėrān ud Anērān (Stuttgart, 2006), 182-201.

34 S. Shaked, Dualism in Transformation: Varieties of Religion in Sasanian Iran (Jerusalem, 1994), esp. 108, has presented Shapur I as a Platonic philosopher king, using religion as a tool to unite and educate his people.

35 D. Mackenzie, 'Mani's Šāburaghān', BSOAS 42 (1979), 500-34, at 505-21. See also M. Hutter, 'Manichaeism in the early Sasanian Empire', Numen 40 (1993), 2-15 and W. Sundermann, 'Manichaean literature in Iranian languages', in R. Emmerick and M. Macuch (eds.), The Literature of Pre-Islamic Iran (London, 2009), 197-265, at 219-22.

${ }^{36}$ On the Istakhr shrine see M.-L. Chaumont, 'Le culte d'Anahita à Staxr et les premiers Sassanides', RHR 153 (1958), 154-75. Al-Tabari, I, 819 describes Ardashir dedicating the heads of his enemies at the shrine.

37 D. MacKenzie, 'Kerdir's inscription', in G. Herrmann, D. MacKenzie, and R. Howell (eds.), The Sasanian Rock Reliefs at Naqsh-i Rustam. Naqsh-i Rustam 6 (Berlin, 1989), 35-72 provides a full discussion.

This is an open access version of the publication distributed under the terms of the Creative Commons Attribution-NonCommercialNoDerivs licence (http://creativecommons.org/licenses/by-nc-nd/3.0/), which permits non-commercial reproduction and distribution of the work, in any medium, provided the original work is not altered or transformed in any way, and that the work is properly cited. For commercial re-use, please contact academic.permissions@oup.com 
The inscriptions point to the existence of a weaker shah forced to rely more heavily on an Istakhr-based Zoroastrian cleric as a source of legitimacy. Given that Ardashir and Shapur had seemed much more free to pick and choose between religious alternatives, Vahram's reliance on Kartir may be a sign of weakness, in which a conservative aristocracy was courted to preserve power against rival family members.

The legitimacy of Vahram's predecessors was drawn overwhelmingly from military success. Shapur I's victory inscriptions in his home province of Fars contrasted his homeland of èrān with anerrān, the conquered, ethnically distinct lands to the west. ${ }^{38}$ This word 'érān' was a Sasanian invention that is first used to designate the conquests of Ardsahir, and is later contrasted to 'anerān', the regions conquered by Shapur. The inscriptions project a view of the world where érān came to be defined by its conquest of anerrān under the leadership of the shahs. ${ }^{39}$

It was through investment in the conquered lands of ànerrān, where their capitals of Ctesiphon and Beth Lapet were situated, that powerful shahs were able to develop 'crown lands', disconnected from the control of the Persianspeaking aristocracy. Islamic era sources preserve several different lists of royal foundations that are not identical, but the dominant trends are that cities were built in Mesopotamia rather than Iran and created by shahs who were successful in war: Ardashir I, Shapur I, Shapur II (309-79), and (to a lesser extent), Yazdegard I (399-420), Vahram V (421-38), Kavad I (488-531), and Khusrau I (531-79). ${ }^{40}$

The ascription of individual cities to their founders may sometimes be a function of the fame of the shah in question, rather than an accurate statement. But it does reinforce the fact that city foundation was a practice associated with successful shahs, and not, for instance, with their aristocratic

38 G. Gnoli, The Idea of Iran: An Essay on its Origin (Rome, 1989), 151-6 emphasizes that the Manichees did not use the term 'ērān' and 'anērān' found in Shapur's victory inscription, which had both ethnic and geographical connotations, and continued to use the term 'king of Persia'.

39 D. Mackenzie, 'Eranshahr', in EIr. P. Gignoux, 'Aneran', in EIr also notes that the term 'anēr' has a religious connotation in post-Islamic writing and may have also had this in some Sasanian-era texts. See further, S. Shaked, 'Religion in the late Sasanian period: eran, aneran and other designations', in Curtis and Stewart, Sasanian Era, 98-109; T. Daryaee, 'The idea of ērānshahr: Jewish, Christian and Manichaean views in late antiquity', in C. Cereti (ed.), Iranian Identity in the Course of History (Rome, 2010), 91-107; M. Canepa, The Two Eyes of the Earth: Art and Ritual of Kingship between Rome and Sasanian Iran (Berkeley/Los Angeles/London, 2009), ch. 4.

40 See the list in P. Christensen, The Decline of Iranshahr: Irrigation and Environments in the History of the Middle East, 500 B.C. to A.D. 1500 (Copenhagen, 1999), 30, taken from al-Tabari and Hamza al-Isfahani, as well as the seventh-century Middle Persian foundation list, the Shahrestan-i Eranshahr (tr. Daryaee). The Sasanian period is taken to be a high point in the pre-twentieth-century settlement history of some parts of Iran: K. Alizadeh and J. Ur, 'Formation and destruction of pastoral and irrigation landscapes of the Mughan steppe, North-west Iran', Antiquity 81 (2007), 148-60.

This is an open access version of the publication distributed under the terms of the Creative Commons Attribution-NonCommercialNoDerivs licence (http://creativecommons.org/licenses/by-nc-nd/3.0/), which permits non-commercial reproduction and distribution of the work, in any medium, provided the original work is not altered or transformed in any way, and that the work is properly cited. For commercial re-use, please contact academic.permissions@oup.com 
followers or rivals. ${ }^{41}$ References in Christian sources to the resettlement of captives also suggests that city foundations, often using Aramaic and Greek speaking Christians, were associated with victorious shahs because they gave them access to new manpower, which they could use for their investment in the sawa $d$, the irrigated alluvial lands of southern Mesopotamia and Khuzistan. ${ }^{42}$ Saints' lives and synodical records refer to Christians holding ranks as guildmasters (qarugbed) in Khuzistan, in trades such as silk-weaving and goldworking, so the shahs' resettled population may have brought in revenue from industrial as well as agricultural production. This production was developed using professional hierarchies ${ }^{43}$ that were distinct from the warrior elites to whom shahs appealed with images of themselves as hunter and fighter. ${ }^{44}$

The creation of new cities in the sawa d and elsewhere was not accompanied by the kind of civic prestige building seen in the Roman world. In observations that focus on Iran proper, Hugh Kennedy notes that fire temples, fortresses, and khans were located outside cities along major roads, and not in new cities such as Bishapur. He remarks that this reflects 'the infrastructure of an itinerant monarchy', where the countryside was the focus for the shah's declarations of legitimacy, where elite society had a rural focus on fortified estates outside the cities, and where Zoroastrian cult sites had a similar distribution, often closely associated with elite estates or situated to receive the offerings of pilgrims. ${ }^{45}$ By contrast, cities themselves do not seem to have been characterized by central planning, public spaces, or state-commissioned monuments: the Talmudic texts, and excavations at Merv and Ctesiphon, suggest that the building encroached onto roads and that workshops and markets annexed public areas. ${ }^{46}$ Thus there appears to be a dichotomy

${ }^{41}$ Notably, Ardashir's foundation of the city of Jur was seen as a sign of rebellion by the Parthian king Ardawan. Al-Tabari, I, 817.

42 See F. Altheim and R. Stiehl, Finanzgeschichte der Spätantike (Frankfurt, 1957), esp. 44 and Z. Rubin, 'Sasanian Persia', in Averil Cameron, P. Garnsey, and B. Ward Perkins (eds.), The Cambridge Ancient History, Vol. XIV : Late Antiquity: Empire and Successors A. D. 425-600 (Cambridge, 2000), 650.

${ }^{43}$ On the role of guilds, note the importance of the qarugbed and martyr Pusai during the Shapurian persecution in Khuzistan (e.g. Acts of Symeon A, 775-7) and in local synods in the same province in the sixth century (Synodicon Orientale, 79). See the discussion in N. Pigulevskaja, Les villes de l'état iranien aux époques parthe et sassanide, (Paris, 1963), 159-61.

${ }^{44}$ For the record of the gilded silver plate that disseminated the image of the victorious shahs seen in the rock inscriptions see P. Harper, In Search of a Cultural Identity: Monuments and Artefacts of the Sasanian Near East (Third to Seventh Centuries A.D.) (New York, 2006), 120-1. The fourth-century Manichaean homilies report that Vahram II condemned Mani as one who 'did not hunt or fight' (cited in S. Lieu and I. Gardner, Manichaean Texts from the Roman Empire (Cambridge, 2004), 84). Without claiming that this was an accurate report, it may reflect something of how early shahs wished to be seen and the allies with whom they sought to be associated.

${ }^{45}$ H. Kennedy, 'From Shahrestan to Medina', Studia Islamica 102 (2006), 5-35, at 10-18. On fire temples and their distribution in rural Fars and Media see L. Vanden Berghe, 'Nouvelles découvertes de monuments de feu d'époque sasanide', IrAnt 5 (1965), 128-47.

46 St J. Simpson, 'Ancient Merv: archaeological insights into the economy of the city during the Sasanian period (3rd-7th centuries AD)', in The Turkmen Land as a Centre of Ancient

This is an open access version of the publication distributed under the terms of the Creative Commons Attribution-NonCommercialNoDerivs licence (http://creativecommons.org/licenses/by-nc-nd/3.0/), which permits non-commercial reproduction and distribution of the work, in any medium, provided the original work is not altered or transformed in any way, and that the work is properly cited. For commercial re-use, please contact academic.permissions@oup.com 
between an aristocracy based around the fortified countryside, and concentrated in the Iranian highlands, and cities that, while founded on royal initiative, were not the audience for the early shahs' declaration of their own legitimacy. These cities may have been prosperous centres for artisanal production and, in some cases, trade, but the lack of urban monumental building implies that they were not, for the most part, centres of the military manpower that might support or topple a shah. ${ }^{47}$

James Howard-Johnston has articulated a model of the Sasanian world with a highly developed state structure: it is only this, he argues, that renders comprehensible the empire's massive investment in irrigation, roads, fortifications, and armies that allowed it to hold its own against a Roman opponent with all the logistic advantages of the Mediterranean. ${ }^{48}$ Ze'ev Rubin offers a different model, in which the Sasanian rulers appear much more fragile, and where the rule of successful shahs is dependent on the cooperation of the aristocracy. ${ }^{49}$ This view that has been extended by Parvaneh Pourshariati, who has emphasized this aristocracy's distinctive identity as 'Parthian', with an ancestry going back to Ardashir's Arsacid opponents, and their ultimate rebellion against the centralizing reforms of the shah Khusrau II (590-628) at the beginning of the seventh century. ${ }^{50}$

Both arguments have a logic that recommends them, and some level of synthesis may be possible through emphasizing the connection between Iraq and the provision of revenue and bureaucratic manpower for the state and between Iran and military manpower. Coins and seals provide evidence for the increased standardization and sophistication of the Sasanian bureaucracy by the sixth century, a process that had its origins in the poorly attested fifth century. ${ }^{51}$ Sasanian shahs had always wished to find ways to extract revenue

Cultures and Civilizations: Materials of the International Scientific Conference, 1-3 October 2008 (Ashgabat, 2008), 247-57 and A. Invernizzi, 'Ten years' research in the al-Mada'in area, Seleucia and Ctesiphon', Sumer 32 (1976), 167-75. For observations on the Talmud, A. Oppenheimer, Babylonia Judaica in the Talmudic Period (Wiesbaden, 1983), 228-9.

${ }^{47}$ Every century of the Sasanian Empire saw a number of coups against weaker shahs, a pattern that was only really broken in the sixth century by Kavad I and Khusrau II.

${ }^{48}$ J. Howard-Johnston, 'The two great powers in late antiquity: a comparison', in J. HowardJohnston, East Rome, Sasanian Persia and the End of Antiquity (Aldershot, 2006), I.

49 Z. Rubin, 'The Reforms of Khusro Anushirwān', in Averil Cameron (ed.), The Byzantine and Early Islamic Near East III: States Resources and Armies (Princeton, 1995), 225-97. At 292 he notes how reforms depended on a powerful monarch with external resources of his own in trade and booty, and that marzbans were already acquiring personal fiefs by the end of Khusrau's reign.

50 P. Pourshariati, Decline and Fall of the Sasanian Empire: The Sasanian-Parthian Confederacy and the Arab Conquest of Iran (London, 2008).

${ }_{51}$ R. Gyselen, La géographie administrative de l'empire sasanide (Paris, 1989) and S. Sears, 'Monetary revision and monetization in the late Sasanian Empire', in R. Gyselen and M. Szuppe (eds.), Matériaux pour l'histoire économique du monde iranien (Paris, 1999), 149-167 for the sixth-century peak in minting and seals. See further S. McDonough, Power by Negotiation:

This is an open access version of the publication distributed under the terms of the Creative Commons Attribution-NonCommercialNoDerivs licence (http://creativecommons.org/licenses/by-nc-nd/3.0/), which permits non-commercial reproduction and distribution of the work, in any medium, provided the original work is not altered or transformed in any way, and that the work is properly cited. For commercial re-use, please contact academic.permissions@oup.com 
from the settled populations of the sawād, through tithes and direct taxes. But the reforms of Khusrau I were an attempt to use a state apparatus to enforce this more efficiently by making taxation predictable, by gathering a poll tax and raising fixed revenue land taxes that targeted the cash crops of the sawäd and Fars (dates and palms), but also encouraging landowners to engage in crop rotation, by not taxing land that was left fallow. ${ }^{52}$

Thus there existed a state apparatus that could tap the economy of Iraq increasingly effectively. Simultaneously, the shah could also disseminate an image of himself as an ideal ruler to the kinds of elite groups to whom his rural monuments were addressed. From the fifth century onwards, mirroring the developments in the fiscal system, shahs experimented with and propagated the image of their dynasty as a continuation of the much older, fictional, Kayanid kings, which made them the heirs to a history of eternal Iranian kingship. ${ }^{53}$ This emphasis on the eternal nature of the Sasanian dynasty must be recognized as one of the most successful features of the state's selfrepresentation. Only by the 590s would a non-Sasanian even attempt to make himself shah, and even after the death of all adult Sasanian males, in the wake of Khusrau II's assassination, it was considered less revolutionary to have a female shah than a non-Sasanian. ${ }^{54}$ Throughout the sixth century, the histories originating in royal circles, the Xwadāy-Nämag or 'Book of Kings', represented an overarching narrative of royal deeds stretching back to ancient times that both suppressed the reign of the previous dynastry, the Arsacids, and presented a framework for the local histories of noble houses, histories that focused the ambitions of aristocrats towards royal service. ${ }^{55}$ On the one hand, this initiative represents the royal promotion of a Sasanian-focused history as an aid to stability, but, on the other, it also illustrates the enduring importance of an Iranian aristocracy, who might in turn reuse and subvert the royal histories for their own ends.

Institutional Reform in the Fifth-Century Sasanian Empire (UCLA, 2002, unpublished PhD thesis).

52 The content of the reform is summarized in M. Morony, Iraq after the Muslim Conquest (Princeton, 1984), 99-100.

53 T. Daryaee, 'History, epic and numismatics: on the title of Yazdegard I', AJN 16 (2004), 89-92. Vahram V clearly uses a Kayanid slogan in the phrase 'Mazda-worshipping lord', evoking the Kayanid heroes of the Avesta: McDonough, Power by Negotiation, 168.

54 A. Panaino, 'Women and kingship: some remarks about the enthronisation of Queen Boran and her sister Azarmigduxt', in P. Huyse and J. Wiesehöfer (eds.), Ėrān ud Anērān: Studien zu den Beziehungen zwischen dem Sasanidenreich und der Mittelmeerwelt (Stuttgart, 2006), 221-40.

55 E. Yarshater, 'Iranian National History' in E. Yarshater (ed.), The Cambridge History of Iran, Vol. III: The Seleucid, Parthian and Sasanian Periods (Cambridge, 1983), 359-481. On the exclusion of the Arsacids see M. Boyce, The Zoroastrians: Their Religious Beliefs and Practices (repr., London, 2001), 127. Harper, In Search of a Cultural Identity, 83 and 122-3 observes that centrally produced images from the tales of kings were imitated in 'provincial' workshops, which may show the successful diffusion of these ideas. See further chapter 6 in this volume.

This is an open access version of the publication distributed under the terms of the Creative Commons Attribution-NonCommercialNoDerivs licence (http://creativecommons.org/licenses/by-nc-nd/3.0/), which permits non-commercial reproduction and distribution of the work, in any medium, provided the original work is not altered or transformed in any way, and that the work is properly cited. For commercial re-use, please contact academic.permissions@oup.com 
Our assessment of the stability of the empire and of the success of its shahs hinges on the ability of its rulers to manage both its agricultural heartlands and the highland zones of Fars, Media, and Azerbaijan that produced its main source of manpower. The Sasanian fiscal state was undeniably highly articulated by the sixth century, but this never reduced the shah's dependence on the affections of the Farsi-speaking aristocracy, who might subvert the centralizing reforms of the shahs. ${ }^{56}$ Even a shah like Yazdegard I who successfully developed his economic base with royal foundations could be eliminated by his own aristocrats. Only the support of foreign troops in unusual circumstances, such as Kavad I's alliance with the Hephthalites of Central Asia, or spectacular foreign victories, such as those of Khusrau I, allowed a shah to be free from these constraints and innovate more freely in his religious policy or his economic reforms.

\section{RELIGION AND THE SASANIAN STATE}

The monumental building and self-representation of the shah often appealed to Zoroastrian ideas, from the Avestan stories of Zoroaster's royal sponsors to the construction of royal fire shrines on mountain sites and the images of Zoroastrian gods Ohrmazd and Anahit bestowing kingship on the shahs. ${ }^{57}$ But we should not imagine that there was any neat symbiosis between shahs and a monolithic Zoroastrian religion. The aristocracy too were supporters of Zoroastrian cult buildings, and the career of the famous mobad (priest) Mihr Narseh, advisor to Vahram V (421-38) and Yazdegard II (438-57), show a man deeply embedded in aristocratic land-holding and family structures. ${ }^{58}$ The dominance of Mihr Narseh over the shahs he advised is emblematic as much of his personal accumulation of wealth and influence as it is of his religious and legal position: indeed, we might emphasize his role as an aristocrat as much as his role as a mobad. The wish of the shahs to organize and to patronize Zoroastrian religious institutions should be seen as a reflection of the threat posed by such powerful men, who could topple an

${ }^{56}$ Pourshariati, Decline and Fall, 98-121 discusses the example of the office of spähbed, the four generals of the empire, whose power was enlarged under Khusrau but which remained heritable within a small caste of noble families. See al-Tabari, I, 894.

${ }^{57}$ K. Schippman, Die iranische Feuerheiligtümer (Berlin, 1971) observes the distribution of temples on mountain sites.

58 The connection between aristocratic estates and 'chahar taqs', free-standing 'Zoroastrian' cult structures, is suggested by the excavation of M. Azarnoush, The Sasanian Manor House at Hājjīābād (Florence, 1994), 23. For Mihr Narseh's widespread wealth see al-Tabari, I, 869-70 and the assembly of evidence in Pourshariati, Decline and Fall, 61-2.

This is an open access version of the publication distributed under the terms of the Creative Commons Attribution-NonCommercialNoDerivs licence (http://creativecommons.org/licenses/by-nc-nd/3.0/), which permits non-commercial reproduction and distribution of the work, in any medium, provided the original work is not altered or transformed in any way, and that the work is properly cited. For commercial re-use, please contact academic.permissions@oup.com 
uncooperative shah like Yazdegard I, as well as an effort to use mobads as part of a bureaucracy centred on the shah. ${ }^{59}$

Yet, as we have seen, shahs who did not face such powerful aristocratic controllers might be much more free to innovate in the religious affairs of their non-Zoroastrian subjects, a pattern that is visible from Shapur I's sponsorship of Mani, to Kavad I and the egalitarian prophet Mazdak, and to Khusrau II and the Christian catholicoi. In many of these cases, royal intervention seems to have taken the form of strengthening religious institutions and centralization, as well as more straightforward investment in infrastructure, in order to enhance the state's ability to gather revenue and develop new forms of legitimacy.

The Talmudic evidence presents the shahs as relatively tolerant rulers, even if they did seek a much greater role in Jewish affairs than their predecessors. ${ }^{60}$ In Shapur II's interviews with rabbis over their burial customs, the shah seems critical, but not outwardly hostile. ${ }^{61}$ The relationship between the shah and his Jewish subjects was not always irenic: Jewish leaders were twice purged after they backed the wrong side in the civil wars of Kavad I and Khusrau II. ${ }^{62}$ But the shahs' relationship with the Jews, at least initially, seems to have been much more productive than their relations with the Christian leadership in Ctesiphon and elsewhere. Christians suffered persecution under Vahram II, Shapur II, and by most of the shahs of the fifth century: Yazdegard I, Vahram V, Yazdegard II, and Peroz.

Hagiographies of the fifth century record the role of the magi (and sometimes the Jews) in encouraging the shah or his officers to persecute Christians. ${ }^{63}$ The hagiographies imagined that the Sasanians objected to Christian asceticism and refusal to participate in public rituals, ${ }^{64}$ or feared that Christians in the East represented a Roman fifth column. ${ }^{65}$ But we should also

59 On the bureaucratic role of mobads see R. Gyselen, La géographie administrative, 30-5 on the development of the mobads and the office of 'mogbed' as a land administrator for the Magi and R. Gyselen and P. Gignoux, 'Empreintes des sceaux sasanides', StIr 93 (1992), 49-56, at 53 for the association of magi with specific towns and provinces.

${ }^{60}$ J. Neusner, A History of the Jews in Babylonia, 6 vols. (Leiden, 1960), II, 71 and 95 for the decline in exilarch's legal autonomy under the Sasanians.

61 Neusner, Jews in Babylonia, IV, 49.

62 See Morony, Iraq, 319, on the suppression of worship under Peroz and the later revolts.

63 E.g. the fifth-century Acts of Narsai and Acts of Tataq, which emphasize the role of the mobad Mihr Narseh.

64 The Acts of Candida, describing events in the third century, record the saint's refusal to 'drink blood and worship the sun', as prescribed in Zoroastrian rituals, or to break her vow of celibacy by marrying a magus. For the targeting of the lay ascetic bnay qyama ('sons of the covenant') see, for instance, The Martyrs of Khuzistan, 241 and Acts of Thecla, 308.

${ }^{65}$ Sasanian suspicion of Christians in the reign of Shapur II is reflected in the later hagiographies (e.g. Acts of Symeon A, 735 and 739). T. Barnes, 'Constantine and the Christians of Persia', JRS 75 (1985), 126-36 suggests that Eastern Christians such as Aphrahat hoped for a Roman conquest, but this may involve an overreading of his evidence (Aphrahat's discourse V, On Wars).

This is an open access version of the publication distributed under the terms of the Creative Commons Attribution-NonCommercialNoDerivs licence (http://creativecommons.org/licenses/by-nc-nd/3.0/), which permits non-commercial reproduction and distribution of the work, in any medium, provided the original work is not altered or transformed in any way, and that the work is properly cited. For commercial re-use, please contact academic.permissions@oup.com 
recognize that two of the most serious persecutions, that of Shapur II and Yazdegard I, were prompted by the failure of royal attempts to orchestrate Christians into malleable clients. Both Shapur and Yazdegard began their relationships as patrons of the Christians. Symeon bar Sebba'e (c.329-41), the catholicos who perished under Shapur, is described as a 'friend of the shah' in the later hagiographies and was able to secure the promotion of his friends to high office. ${ }^{66}$ In the same vein, Yazdegard was praised as a beneficent ruler in the first synod of the church in 410, which was celebrated in the wake of the visit of the Roman emissary Marutha of Maypherkat, an event that must have had the blessing of the shah. ${ }^{67}$

Yet in both cases, the shahs expected something out of their relationship. In Shapur's case it was Symeon's cooperation in collecting a poll tax from Christians during war time: Symeon's refusal resulted in ongoing persecution throughout Iraq, which may reflect the shah's wishing to avoid loss of face after the disobedience of his client as well as the straightforward desire to expropriate church property. ${ }^{68}$ Similarly, Yazdegard seem to have expected a guarantee that the newly elevated bishops of Ctesiphon could both enhance his legitimacy among Christians and prevent interreligious tension and the proselytism of Zoroastrians. The failure of the catholicoi to accomplish this for more than a decade forced Yazdegard, like Shapur, to reverse his policy of toleration in an effort to maintain his prestige among his traditional aristocracy. ${ }^{69}$ His failure, and subsequent assassination, would entrench an antiChristian policy under his successors, who preferred to restrict their religious patronage to the institutions of the Zoroastrian 'church', partly under the influence of the mobad Mihr Narseh.

The sixth century saw a much more successful rapprochement between Christians and the shah, when they received the patronage of Khusrau I and his successors. In spite of oscillation in the shah's actual treatment of Christians, the histories of the catholicoi composed around the middle of the century accentuated the close relationships that existed between shahs and catholicoi. The memory of earlier persecutions remained, but the 'patriarchal history' of the mid-sixth century would emphasize the antipathy between Christians and the magi, and de-emphasize the connection between the shah and Zoroastrianism. ${ }^{70}$ By the end of this century and in the next, this

${ }^{66}$ Acts of Symeon A, 751, 767 for Symeon's patronage of Gushtazad and his reputation for 'beauty'. The Acts of Shahdost, Symeon's successor but one, also describes Symeon as the shah's former friend.

67 See this volume, chapter 1.

68 Acts of Symeon $B, 793-801$. Using later hagiographic sources to reconstruct fourth-century events is obviously problematic, but tax features as the initial motive for Shapur's interview with Symeon in both narratives of his martyrdom (A and B). I discuss these texts further in chapter 2 .

69 This volume, chapter $1 . \quad 70$ This volume, chapter 4.

This is an open access version of the publication distributed under the terms of the Creative Commons Attribution-NonCommercialNoDerivs licence (http://creativecommons.org/licenses/by-nc-nd/3.0/), which permits non-commercial reproduction and distribution of the work, in any medium, provided the original work is not altered or transformed in any way, and that the work is properly cited. For commercial re-use, please contact academic.permissions@oup.com 
symbiosis between Persian elites and the Church would be even further strengthened, when the historical tradition included the whole history of the shahs, drawn from the Xwadāy-Nàmag, and celebrated the role of Khusrau II as the patron of the Christians par excellence. ${ }^{71}$

\section{GEOGRAPHY OF A CHRISTIAN MINORITY}

The presence of Christians east of the Tigris is recorded from the middle of the second century. The second-century philosopher and astrologer, Bardaisan of Edessa, remarks, in a work compiled by his pupils, that the Christians have become 'a new people' and are liberated from the customs of the peoples around them, including the Persians and the Gelians of the Caspian. ${ }^{72}$ Many converts to Christianity were Aramaic-speakers, former pagans and Jews who were converted by missions coming out of the eastern Roman world, from cities such as Edessa. These missions spread the use of the Syriac language as a high dialect of Aramaic, which transcended the many different Aramaic dialects spoken by Christians in Mesopotamia and the Levant. ${ }^{73}$

The late-sixth century Acts of Mari purport to describe this early process of missionary activity and place it in the first century. Much of this work is probably a later fiction, a composite text that functioned as a vehicle for different cities to assert their pre-eminence. However, it does appear to have been built out of earlier (related) foundation stories, and, as such, it suggests the existence of distinct conversion narratives that have been united into a single text. Much of this text is focused on Mari's conversion of Ctesiphon, but there is also a long earlier section that describes his conversion of a series of northern cities, from Nisibis and Arzun on the Roman frontier, to Arbela and Assur in Adiabene and Shahrqart and Darabhar in Beth Garmai. The apostle concludes his mission in Khuzistan and Fars, only to find that these regions have already been converted by merchants who had travelled to Edessa, the origin point of Mari's own mission.

I do not propose that we can derive a real record of conversion from this narrative, but it does give us the impression of the discrete memories of conversion that existed in three different zones, in Assyria in the north, in Babylon to the south, and in Khuzistan to the south-east. These stories have all been included in a single compilation that concentrates on Ctesiphon as the focus of

71 This volume, chapters 6 and 7.

72 Bardaisan, Laws of the Countries, 60.

73 See P. Wood, We Have No King but Christ: Christian Political Thought in Greater Syria on the Eve of the Arab Conquest (c.400-580) (Oxford, 2010), chapter. 3. Note especially Sozomen, $H E$, II, 8 and VI, 33-4 (ed. Bidez, 68 and 289-91).

This is an open access version of the publication distributed under the terms of the Creative Commons Attribution-NonCommercialNoDerivs licence (http://creativecommons.org/licenses/by-nc-nd/3.0/), which permits non-commercial reproduction and distribution of the work, in any medium, provided the original work is not altered or transformed in any way, and that the work is properly cited. For commercial re-use, please contact academic.permissions@oup.com 
the mission to 'the land of Babel', but the text also includes sections that reflect different attempts to change this focus, to assert the importance of other sites as the see of Mari or to assert independence from the Mari narrative. Like the composite history of the early missions, the historical tradition that evolved out of the hagiographies and bishop lists of fourth- and fifth-century Ctesiphon served as a way of asserting the connections between Ctesiphon and other sees and defining the nature of that relationship.

\section{BABYLONIA}

Ctesiphon was not only a long-standing capital of the Sasanian shahs, but also host to large numbers of Jews and Christians, along with both the exilarch and the catholicos. It was in Ctesiphon's hinterland that the rabbinic schools of Sura and Pumbedita were located, as well as the Christian school of 'Abda and the monasteries that played a crucial role in education and proselytism. This region witnessed the production of hagiographies that articulated a modus vivendi with the shah and differentiated him from the Zoroastrian instigators of persecution. ${ }^{74}$ The economic and social context of Ctesiphon, and its relationship to the other Christian centres of Iraq, is crucial to understanding how the central historical tradition came into being and how it related to the Sasanian state and other Christian places and institutions.

The metropolitan see of Beth Aramaye, the region that surrounded the capital, extended from Kashkar in the south to the zone just north of the future site of Baghdad, from the point where the Tigris and Euphrates are at their closest until they reach their confluence at the Schatt al-Arab. Kokhe, the seat of the catholicos that lay in the suburbs of Ctesiphon, had five direct tributary bishoprics, of which the most important were Deir Qoni, supposed site of a visit by the apostle Mar Mari and later a major Christian school, and Kashkar itself, which produced a number of prominent catholicoi and laymen in the fifth and sixth centuries. ${ }^{75}$

The land under the authority of the catholicos was located in rich alluvial soil produced by the two rivers, but was also subject to very low rainfall, especially along the Euphrates: all settlement in the 1930s would be restricted to the banks of the rivers or to a few major irrigation canals that were cut between the rivers. This land could support valuable cash crops, such as palms,

74 On the rabbinic schools see J. Neusner, Israel's Politics in Sasanian Iran (Lanham, 1986), 123. On Christian monasteries near Ctesiphon, notably the monastery of Abgar and its production see P. Devos, 'Abgar: un hagiographe perse méconnu', $A B 83$ (1965), 303-28 and J.-M. Fiey, 'Topographie chrétienne de Mahoze’, OS 2 (1967), 407-19. See further, this volume, chapter 1.

75 See Fiey, AC, III, 148-63. Later tradition would make Kashkar the second most ancient see after Kokhe.

This is an open access version of the publication distributed under the terms of the Creative Commons Attribution-NonCommercialNoDerivs licence (http://creativecommons.org/licenses/by-nc-nd/3.0/), which permits non-commercial reproduction and distribution of the work, in any medium, provided the original work is not altered or transformed in any way, and that the work is properly cited. For commercial re-use, please contact academic.permissions@oup.com 
sesame, dates, and rice, but was also highly dependent on the maintenance of massive-scale irrigation, which could often only be funded by the state. ${ }^{76}$

One important side effect of the dependence on irrigation was the continual cycling of settlement patterns. Where cities in Syria or Italy have consecutive layers built on top of one another, southern Iraq seems to have experienced dramatic exhaustion of the soil through salinization caused by irrigation. In addition, the Tigris often proved a false friend, shifting its course through settlements that it had previously nourished. The effect of both processes was that settlements constantly moved location. The most extreme example of this is the capital, probably also the most intensive site of irrigation: Ctesiphon, Seleucia, Veh Ardashir, Rumagan, and Kokhe all seem to have occupied different locations within a tight cluster. We cannot differentiate each of these sites accurately. The impression of 50 square miles of continuous conurbation, strung out in ribbon settlements, much of it abandoned at any one time, may have struck a late antique traveller as much as it would British travellers in the nineteenth century. ${ }^{77}$ Throughout the sawād the shahs intervened to establish new towns, which must have drawn people from other settlements: the net result was a constant alteration of settlement sites every few generations, but always in a restricted pattern that hugged the Tigris valley.

I speculate that the continual shift in population sites may have had a marked effect on the way that memory was preserved between generations, and on the way that people articulated their attachment to the land. Several cities in the north of Iraq, such as Arbela and Karka de Beth Slouq (modern Kirkuk) had a keen sense of their own history. But this expression of a localized connection with the past was more tenuous in the south. Instead of a strong focus on individual cities and their histories, the hagiographies and chronicles sought to preserve or create memory focused on the history of the church as an institution and on the idea that Ctesiphon lay at the heart of 'the east' ${ }^{78}$ Local sites of martyrdom and missionary activity were venerated, but the fifth-century texts produced in the wake of Ishaq's claim to be catholicos

${ }^{76}$ Naval Intelligence Survey: Iraq and the Persian Gulf (Oxford, 1944), 60-8 on the situation in the 1930s; Christensen, Decline of Iranshahr, 36 and G. Le Strange, Lands of the Eastern Caliphate (London, 1905), 35-9 on the massive wealth of this region, the future site of Umayyad Wasit.

77 J. Fraser, Travels in Koordistan, Mesopotamia etc., including an account of those parts hitherto unvisited by Europeans, 2 vols. (London, 1840), II, 6. Note also St. John Simpson, Aspects of the Archaeology of the Sasanian Period in Mesopotamia (unpublished DPhil thesis, Oxford, 1992), 168-84 on the changing settlement patterns of the Ctesiphon area. For identification of sites within the Ctesiphon conurbation see J.-M. Fiey, 'Topography of al-Mada 'in', Sumer 23, (1967), 3-36.

78 E.g. the final prayers of Acts of Symeon A, 763 and Symeon B, 955, going back to an earlier shared source, where the saint prays for 'all the peoples of the east'.

This is an open access version of the publication distributed under the terms of the Creative Commons Attribution-NonCommercialNoDerivs licence (http://creativecommons.org/licenses/by-nc-nd/3.0/), which permits non-commercial reproduction and distribution of the work, in any medium, provided the original work is not altered or transformed in any way, and that the work is properly cited. For commercial re-use, please contact academic.permissions@oup.com 
already focus much more on the deeds of Ishaq's predecessors and successors, the schools they were involved with, and the missions they sponsored. ${ }^{79}$

\section{KHUZISTAN}

Ctesiphon was not the only royal capital of the Sasanians: in the third and fourth centuries, capitals were also established at Beth Lapet (Gundishapur) and Karka de Ledan (Ërān-xwarrah-šābuhr) in the nearby province of Khuzistan, located to the south-west of Beth Aramaye and watered by the tributaries of the Schatt al-Arab, especially the Karun river. This region, like the hinterland of Ctesiphon, was dedicated to growing rice and water-hungry crops such as sugar cane that require irrigation. The two royal capitals were new foundations, built by victorious shahs transferring populations from the Roman world. In this sense, the Sasanian state sought to improve the land by civic foundations and irrigation investment in the same way that it did in southern Iraq. ${ }^{80}$

But we should also note that two other important cities preceded these new foundations and would outlast them (and form major cities of the province in modern times): Susa and Shushtar. ${ }^{81}$ This region seems to have been relatively peaceful in Sasanian times. Adams notes that there is a major departure from older patterns of fortification: 'Linear settlement along canals is not indicative of peasant villages hugging the fortified seats of the nobility. ${ }^{, 82}$ As in Beth Aramaye, agricultural productivity and population growth were closely tied to the state, to its ability to provide peaceful conditions and maintain irrigation, but the region does seem to have had some settlements with a longer continuous history than the newer royal foundations.

The new capital cities, with their close connections to the shah and his court, may have made natural allies of the catholicos in Ctesiphon: they appear in the synodica as 'loyalists' ranged against the 'dissident' bishops based in the other settlements here and in Fars. This alliance is preserved by the hagiographies that commemorate the death of the catholicos Symeon, in which Beth Lapet and Karka de Ledan appear as important sites alongside Ctesiphon (as the sites of his death and the collection of his relics). However, it is clear that

79 This volume, chapters 2 and 3.

${ }^{80}$ S. Shahbazi, 'Gundishapur', in EIr; M. Morony, 'Beth Lapat', in EIr.

81 This is explicitly stated in the Acts of Mar Mari, 31 (ed. Harrak, 70), and is confirmed by R. Wenke, 'Elymaeans, Parthians and the evolution of empires in southwestern Iran', JAOS 101 (1981), 303-13, especially in his reconstructions of settlement size, though he is obviously unable to make size estimates for cities with modern populations.

82 R. Adams, The Land Behind Baghdad: A History of Settlement on the Diyala Plains (Chicago, 1967), 73.

This is an open access version of the publication distributed under the terms of the Creative Commons Attribution-NonCommercialNoDerivs licence (http://creativecommons.org/licenses/by-nc-nd/3.0/), which permits non-commercial reproduction and distribution of the work, in any medium, provided the original work is not altered or transformed in any way, and that the work is properly cited. For commercial re-use, please contact academic.permissions@oup.com 
the joint prestige implied in this narrative, as well as the connections of these cities to older sees in the Roman world, was not acceptable in the longer term. The first stages of the historical tradition, composed in the fifth century, rework the history of these civic foundations to ensure that the Khuzistani bishops did not claim any direct succession from Antioch, and their predecessors are presented as acknowledging the superiority of the catholicos. These developments are described in chapter 3 , the first chapter to deal specifically with the Chronicle of Seert and its related medieval compilations.

The sources for the sixth-century Church imply that Khuzistan's relative importance diminished. Important bishops do not disappear: a bishop of Beth Lapet is a prominent figure in the civil war between Narsai and Elishe in the 530s and one Barsauma of Susa emerges as a major critic of the catholicos Isho yahb II in the 630s. But Khuzistan's significance as a region coequal to Beth Aramaye seems to have dwindled. In particular, it does not seem to have produced famous exegetical schools or monasteries to match those founded in Assyria and Babylonia in the sixth century. ${ }^{83}$ This need not be the result of economic decline in Khuzistan per se, but rather a contrast with the growing importance of the monasteries and cities of Assyria and their symbiosis with Ctesiphon. ${ }^{84}$

\section{ASSYRIA}

The earliest stages of the patriarchal history have a relatively limited geographical focus: their concern is mainly with Ctesiphon and the neighbouring provinces of Maishan and Khuzistan. But by the second half of the sixth century a greater variety of historical traditions are added to the central core, each of which reflect the importance of other Christian centres and institutions within the Church, and many of which were based in the north of Iraq, where a multitude of smaller cities had preserved their own independent memories of their conversion to Christianity.

${ }^{83}$ J.-M. Fiey, 'L’Elam: la première des métropoles ecclésiastiques syriennes orientales', Melto 5 (1969), 221-69; PdO 1 (1970), 123-55, at 152.

84 The effect of cumulative centuries of investment by shahs in the region around Ctesiphon, most notably in the construction of a major canal around Kashkar early in the sixth century, may have transferred irrigation water away from Khuzistan and Maishan. See P. Verkinderen, Tigris, Euphrates, Karun, Karhe and Jarahi: Tracing the changes of five rivers in Lower Iraq and Khuzistan in the early Islamic Period (unpublished PhD thesis, Ghent, 2009), 151-7 for discussion of the Kashkar/Wasit canal and the possible dates (ranging from c.520-628) given for the eastward shift in the course of the Tigris, which greatly benefited this city, to the detriment of Khuzistan. See also the summaries in Morony, Iraq, 156-7 and Simpson, Sasanian Mesopotamia, 206.

This is an open access version of the publication distributed under the terms of the Creative Commons Attribution-NonCommercialNoDerivs licence (http://creativecommons.org/licenses/by-nc-nd/3.0/), which permits non-commercial reproduction and distribution of the work, in any medium, provided the original work is not altered or transformed in any way, and that the work is properly cited. For commercial re-use, please contact academic.permissions@oup.com 
Northern Iraq is separated from the south by a substantial section of the Tigris and Euphrates where there is little settlement outside the sites of the cities of Takrit and Samarra. North of this zone, where the Greater and Lesser Zab join the east bank of the Tigris, there is a marked increase in rainfall across more hilly terrain. As one moves north towards the Caucasus this terrain becomes almost impassable, especially during winter. Throughout this region, even up to the 1930s, village settlement on the hills outside areas with perennial streams could vary considerably depending on rainfall, and only formed a large, permanent bloc in a few substantial plains, especially the plain of Nineveh (modern Mosul). ${ }^{85}$

Unlike the lands further south, this terrain has historically produced wheat and barley fed by rainwater rather than irrigation. In consequence of this, crop yields have been lower per unit, but they have also been more consistent in the long term and have not been subject to salinization. Thus, while cities have tended to be smaller than the metropoleis of the south, they have also been more numerous, and more permanent. In places such as Nisibis, Arbela, and Karka de Beth Slouq, the ruins of antiquity may have encouraged imagined connections with the extinct empires of the past. ${ }^{86}$ In addition, these cities were Christian centres of some significance: Arbela and other cities in the north produced the majority of the early martyrs commemorated in Edessa in the 411 martyr list, and Karka was subject to the last (alleged) mass persecution commemorated in hagiography, in the reign of Yazdegard II. ${ }^{87}$ Both distant antiquity and Christian martyrdom would serve as twin bases for the construction of developed histories for these regions at the end of the sixth century.

One of the most important of the cities of northern Iraq was the border city of Nisibis, ceded by the Romans in the 363 peace negotiations. This city, which had produced the great scholar-theologian Ephraem, was partially resettled by Persians, who also formed a minority community in many of the other cities of the north such as Karka de Beth Slouq. ${ }^{88}$ But in spite of this change of government, Nisibis retained close connections with the nearby city of Edessa and sent Christian scholars to its famous school. The School of 'Abda near Ctesiphon appears in the early sections of the patriarchal history, but its destruction by Peroz (459-84) may have left the door open for the emergence

${ }^{85}$ Naval Intelligence Survey: Iraq, 82-95.

${ }^{86}$ On the invention of history in northern Iraq see J. Walker, 'The legacy of Mesopotamia in Late Antique Iraq: the Christian martyr shrine at Melqi (Neo-Assyrian Milqia)', Aram 19 (2007), 471-96. P. Crone and M. Cook, Hagarism: The Making of the Islamic World (Cambridge, 1977), 55-8 remains thought-provoking on the distinction between Babylonia and Assyria, especially the importance of the latter's aristocracy and their claims to primordial history.

87 See 411 Martyrion, 23-6 and the discussion of P. Peeters, 'Le Passionaire d'Adiabene', $A B$ 43 (1925), 261-304. The persecution of Yazdegard II is the core of the History of Karka de Beth Slouq.

${ }^{88}$ Morony, Iraq, 181-2.

This is an open access version of the publication distributed under the terms of the Creative Commons Attribution-NonCommercialNoDerivs licence (http://creativecommons.org/licenses/by-nc-nd/3.0/), which permits non-commercial reproduction and distribution of the work, in any medium, provided the original work is not altered or transformed in any way, and that the work is properly cited. For commercial re-use, please contact academic.permissions@oup.com 
of Nisibis as a new educational centre, which would spawn imitators across Iraq and dominate the training of catholicoi by the $550 \mathrm{~s}$.

Nisibis produced its own internal histories, and there are clear signs that this record of the succession of theologians was added into the core history of the Church at the end of the sixth century. There are marked differences between the different records of the same individuals within the Chronicle of Seert, which reflects contradictory memories of them as politicians and as theologians who brought the Dyophysite teachings of Theodore of Mopsuestia to the East. The new role of the School of Nisibis and its successors across Iraq, including the capital, heralded its inclusion in an influential symbiosis with the catholicoi, and this was reflected in the union of the historical traditions, which is discussed in chapter 4 .

The organization of the catholicosate itself, the arrangement of church synods and the development of a cult of the martyrs in the early fifth century can all be traced to the influence of clerics from the Roman Mesopotamia, led by Marutha of Maypherkat. But there were also substantial lacunae in this relationship with the Roman world. The reign of Acacius (485-96), which saw the adoption of Dyophysitism and the first patriarchal history, was shaped by the catholicos' training at the School of the Persians in Edessa. Acacius' centralizing initiative would only last a decade before the Church's hierarchy was beset by internal disagreement. It would only be in the reign of Aba (540-52) and his successors that a continuous pattern emerged of catholicoi trained at Nisibis who were increasingly interested in the theological politics of the Roman world. This new international awareness of the late sixth century was also reflected in additional material that was added to the central tradition. This additional historical material set out the theological and ecclesiological position of the Church in terms of Roman ecclesiastical history, which is discussed in chapter 5 . This development too, should be seen as a result of the catholicos' more positive relationship with the shah and the growing role of Nisibis as a bridge for information from the West.

Northern Iraq also witnessed a second social and intellectual revolution that changed the way that the Church of the East operated. This was the monastic reformation of Abraham of Kashkar, whose monastery of Izla developed a new monastic rule and inspired new monastic foundations across Iraq, Iran, and the Persian Gulf. Assyria may have provided an especially suitable nursery for this movement, since its rainfall-based agriculture and pastoral economy allowed groups of men to found new communities with relatively little initial investment. This monastic movement provided a third pillar of the Church by the end of the sixth century, alongside the catholicosate and the system of Christian schools. The monasteries cooperated in the dissemination of religious knowledge and providing another focus for the ecclesiastical historians,

This is an open access version of the publication distributed under the terms of the Creative Commons Attribution-NonCommercialNoDerivs licence (http://creativecommons.org/licenses/by-nc-nd/3.0/), which permits non-commercial reproduction and distribution of the work, in any medium, provided the original work is not altered or transformed in any way, and that the work is properly cited. For commercial re-use, please contact academic.permissions@oup.com 
which is analysed in chapter $6{ }^{89}$ The effects of the new importance of the north is most clearly seen in the shift in the geographical origins of catholicoi from the late sixth century: Isho'yahb I (582-96), Sabrisho' (596-604), Isho' yahb II (628-46), Maremmeh (646-50), Isho'yahb III (650-60), and Giwargis (661-80) all came from the north of Iraq, from Assyria and Beth Garmai, rather than Beth Aramaye or Khuzistan..$^{90}$

The sponsorship of monasticism in the north is also an indicator of a broader shift of power within the church. The end of the sixth century also saw a number of Christian texts, such as the Acts of Mar Qardagh or the History of Karka de Beth Slouq, that celebrated the heritage of the Persianized aristocracies of the north in terms of an imagined 'Assyrian' past and/or membership of a wider Iranian culture. Prominent conversions by elites brought with them new emphases in the memorialization of the past and in the patronage of the present, and these aristocrats were also important supporters of a growing monastic movement. If the catholicosate had come to emphasize the importance of its relationship with the shah, the unitary nature of this relationship was reimagined by the end of the century, when Eastern Christians sought patrons from a wider spectrum of the elite.

This deeper relationship between the Church and its lay patrons came to a head with the accession of Khusrau II, whose reign generated a wide variety of an alternative accounts, all of which have been embedded in the Chronicle of Seert. Khusrau's reign saw a breakdown in the old symbiosis between the catholicosate, the monastic movement, and the School of Nisibis. After the death of Khusrau's appointee Sabrisho', the shah grew dissatisfied with his successor and dissolved the catholicosate. This produced a vacuum in authority within the church. Notably, it was the northern metropolitans, led by the abbot Babai the Great (d.628), who asserted the orthodoxy of the Church's Dyophysite theology before the shah in 612, phrased now in increasingly uncompromising language. Babai's prestige was connected to his importance as a monastic leader and theologian, but other strands in the Chronicle present other figures as a pseudo-catholicos, most notably Gregory, bishop of Nisibis and opponent of the 'heretic' Henana. In the absence of a catholicos, we see authority being claimed by the prestigious centres of the north. These changes in authority are reflected in the diversity of history-writing in this period, which is investigated in chapter 7. But equally, there was no single centre that could rival Ctesiphon, and the Abbasid period witnessed a reunification of the Iraqi historical tradition (chapter 8), which continued to tell a history of

89 See A. Camplani, 'The revival of Persian monasticism: church structures, theological academy and reformed monks', in A. Camplani and G. Filoramo (eds.), Foundations of Power and Conflicts of Authority in Late Antique Monasticism (Louvain, 2007), 277-97 for the model of the three-way symbiosis of the late sixth-century Church.

90 See the biographies given in 'Amr.

This is an open access version of the publication distributed under the terms of the Creative Commons Attribution-NonCommercialNoDerivs licence (http://creativecommons.org/licenses/by-nc-nd/3.0/), which permits non-commercial reproduction and distribution of the work, in any medium, provided the original work is not altered or transformed in any way, and that the work is properly cited. For commercial re-use, please contact academic.permissions@oup.com 
the Church focused on the catholicos, a tradition that would be preserved into the eighteenth century. ${ }^{91}$

The Church of the East faced a series of radical changes in the course of the long sixth century. Its political relations with the shah and other elites moved from resistance and animosity to cooperation and supplication. And its theological position became increasingly clearly defined in reaction to its awareness of debates in the West. Around the same time, the gradual establishment of symbiosis between catholicos and the monastic and scholastic movement suddenly broke down in an era of political and theological turmoil.

In the face of these twists of fortune, the historical tradition of the catholicosate represented an overarching discourse against which all claims to contemporary legitimacy could be judged and, if found worthy, embedded. The early development of a historical tradition based around the catholicoi meant that it presented a magnet for the histories of other institutions. The historical tradition represented a universalizing vehicle through which other understandings of the past could be connected and repackaged as part of the shared history of the Church of the East, focused on its catholicoi.

91 R. Ebied and M. Young, 'List of the Nestorian patriarchs', LM 87 (1974), 87-113.

This is an open access version of the publication distributed under the terms of the Creative Commons Attribution-NonCommercialNoDerivs licence (http://creativecommons.org/licenses/by-nc-nd/3.0/), which permits non-commercial reproduction and distribution of the work, in any medium, provided the original work is not altered or transformed in any way, and that the work is properly cited. For commercial re-use, please contact academic.permissions@oup.com 


\section{Collaborators and Dissidents: Writing the Hagiographies of the Fifth-century Persecutions}

The fourth century saw a series of persecutions against Sasanian Christians by their temporal rulers. Though these demonstrations of public violence may have only been directed against a small number of prominent trouble-makers, the deaths of men such as the bishop of the Sasanian capital of Ctesiphon, Simeon bar Sebba'e, provided the core of a later martyr literature that made the Church of the East a church of the martyrs.

However, we should also be aware that the bishops of Ctesiphon had no continuous history as rulers of the Church of the East. This impression, which is created by later medieval compilations such as the Chronicle of Seert, is, in effect, a retrojection of a situation that only arose in the fifth century, when bishops of Ctesiphon asserted their importance as servants of the shah and as beneficiaries of a special relationship with the Christian Roman Empire. The peace negotiations between Rome and Iran at the beginning of the fifth century presented an opportunity for Ishaq, bishop of Ctesiphon, to assert his importance as 'catholicos'.

Ishaq's coup is visible from the Syriac Synodicon Orientale, a compilation of the synods of Ctesiphon. The Synodicon allows us an insight into the ambitions and limitations of the Church of the East as an institution. But it also shows us the existence of a dissident tradition, of bishops who were excluded from the court influence that the catholicos and his allies claimed for their own. In addition, the martyr acts composed around contemporary holy men show that many did not respect the ranks of clerical hierarchy or the spirit of cooperation with the state that Ishaq emphasized at his synod in 410 . The religious vandalism of these holy men, coupled with the dissatisfaction of many bishops, underlay the disintegration of catholical authority under Ishaq's successor Dadisho', when the Sasanian state removed its support for an ineffectual institution and returned to the persecution of the Christians.

This is an open access version of the publication distributed under the terms of the Creative Commons Attribution-NonCommercialNoDerivs licence (http://creativecommons.org/licenses/by-nc-nd/3.0/), which permits non-commercial reproduction and distribution of the work, in any medium, provided the original work is not altered or transformed in any way, and that the work is properly cited. For commercial re-use, please contact academic.permissions@,oup.com 
These events provided the context and the inspiration for the rival constructions of history in hagiographies set in the fourth and fifth centuries. These hagiographies gave in turn the raw material for the subsequent re-inventions of the patriarchal chronicles. There are several important points of contrast between them and the Chronicle of Seert, especially in their depiction of conflict between recalcitrant martyrs and the Sasanian authorities. Firstly, they allow us to see how the Chronicle has altered the version of events found in these hagiographies, to present a more irenic model of relations between Christians and fifth-century shahs. Secondly, the hagiographies presented here provide an example of an older strand of historiography, one that was essentially subverted and replaced by the histories of the catholicoi.

\section{THE 410 SYNOD OF SELEUCIA-CTESIPHON}

The first synod of the Church of the East was held in Ctesiphon in $410 .{ }^{1}$ It was convened under the auspices of the shah Yazdegard I (399-420), the Roman emissary Marutha of Maypherkat, and Ishaq (399-410), 'grand metropolitan' of Ctesiphon, and sought to transform the Church of the East along the same lines as the Roman church.

This synod was also convened in the context of broader Persian-Roman diplomacy, which sought to scale down confrontation on Rome's eastern border. After an initial treaty in 399, Marutha made a first visit in 402, in the context of diplomatic overtures between the court of Arcadius (395-408) and the Persians, which was followed by Yazedgard's declaration of religious toleration. This was succeeded by a second visit in 409 , which probably followed internal strife within the church in Iraq, to confirm Ishaq's prominence. ${ }^{2}$

The initial session of the synod articulated the relationship between the shah, the Church of the East and the other dignitaries. Yazdegard is called 'the victorious king of kings, on whom the churches rely for peace'; and he is praised for putting a stop to the persecutions of earlier years. Ishaq is honoured as catholicos (the first use of the title), 'judged by God worthy of

${ }^{1}$ Synodical records were compiled under the ninth-century patriarch Timothy I. Though the titles of earlier bishops of Ctesiphon were inflated to match ninth-century expectations, these alterations were both inconsistent and do not seem to have involved alteration of the rest of the text. S. Gero, 'The status of the patriarchs of Seleucia-Ctesiphon', in N. Garsoïan, Th. F. Mathews and R. W. Thomson (eds.), East of Byzantium: Syria and Armenia in the Formative Period (Washington 1982), 45-51. V. Erhart, 'The development of Syrian Christian canon law in the Sasanian Empire, in R. Mathisen (ed.), Law, Society and Authority in Late Antiquity (Oxford, 2001), 115-30 provides an introduction to the Synodicon.

2 M. Higgins, 'Metropolitans of Seleucia-Ctesiphon', Traditio 9 (1953), 46-99, at 77-83 reconstructs the events, which have been compressed in the sources. The references to internal strife come from the 424 synod of Dadisho', but are have been suppressed in the earlier synodica.

This is an open access version of the publication distributed under the terms of the Creative Commons Attribution-NonCommercialNoDerivs licence (http://creativecommons.org/licenses/by-nc-nd/3.0/), which permits non-commercial reproduction and distribution of the work, in any medium, provided the original work is not altered or transformed in any way, and that the work is properly cited. For commercial re-use, please contact academic.permissions@oup.com 
the gift (mawhabtā) of all the East' and Marutha is called 'the mediator of peace between East and West'. ${ }^{3}$ The text also notes the presence of the bishops of Antioch, Aleppo, Edessa, Tella, and Amida, that is, of a sizeable delegation from the Syriac-speaking sections of the Roman world, and that of the metropolitans of Nisibis, Adiabene, Beth Garmai, Khuzistan, Maishan, and Kashkar: the leaders of the church in Iraq (though not of Christian leaders further to the east). ${ }^{4}$

The opening text goes on to demand that each city should only have a single bishop and that all should have the same sacred days that were established in the Nicene canons, 'as was established under the just and God-loving emperor Constantine'. This text ends with a prayer for the king and for all the notables 'who wish to live in peace with the church of God'. ${ }^{5}$

The synodical record presents an image of unity between the Church in the East and in the Roman Empire, accentuated by the physical presence of the Roman bishops and employs the rhetoric of peaceful co-operation while presenting Yazdegard's involvement in the synod as a sign of his 'victory', on the model of Constantine. Constantine's claim to rule over all Christians had been seen as a threat in the previous century during the Shapurian persecutions, so the presentation of Yazdegard as 'a new Constantine' and the shah's self-presentation as a 'ruler over the whole world, East and West' can be seen as the adoption of Constantinian claims to universal rule by a Persian shah. Shapur I had claimed on his inscriptions to be ruler of érān and anèrān, an idea that carried a claim to universal rule, but here we have Yazdegard making these claims, and having claims made for him, in the context of a Christian synod. Shapur I's inscriptions had been addressed to Iranian elites and carried a sense of ethnic difference, but Yazdegard's claims are aimed towards, and re-echoed by, a new interest group, whose declarations were also heard by the Roman delegation.

The image of Yazdegard's victory may have also been important in the context of the need of both Rome and Persia to re-orientate themselves away from war with one another and towards the Huns. This diplomatic re-orientation may explain both the Romans' willingness to allow Yazdegard to employ the terms of Constantinian universal rule and the emphasis on Yazdegard the peacemaker as victorious. This image was also intended for the shah's notables, who are one of the principal objects of the magnification of the shah and who also are enjoined, at the end of the preamble, to align themselves to the shah's policies and not adopt 'a high and stubborn (qašy $\bar{a})$ attitude before the people and church of God'. ${ }^{6}$

${ }^{3}$ Synodicon, 18-19. $\quad{ }^{4}$ Synodicon, 18 and $34 . \quad{ }^{5}$ Synodicon, $20-2$.

6 Synodicon, 22. Yazdegard is also called the 'peacebringer' (rämšahr) in the Middle Persian inscriptions of his coins. T. Daryaee, 'History, epic and numismatics. On the title of Yazdegard I', American Journal of Numismatics 16 (2004), 89-92.

This is an open access version of the publication distributed under the terms of the Creative Commons Attribution-NonCommercialNoDerivs licence (http://creativecommons.org/licenses/by-nc-nd/3.0/), which permits non-commercial reproduction and distribution of the work, in any medium, provided the original work is not altered or transformed in any way, and that the work is properly cited. For commercial re-use, please contact academic.permissions@oup.com 
This initial session was followed by an agreement on the creed and on the disciplinary canons of the Roman world of the fourth century (Ankara, Neocaesarea, Antioch, Gangra, and Laodicaea). The Western disciplinary canons included bans on heresies never known in the East: the issue at stake was uniformity as part of a universal communion, rather than the actual function of the canons per se. ${ }^{7}$

The final session of the synod issued the new disciplinary canons of the Church of the East. They show that, while the hierarchy of a church existed, and that its delegates could agree on a single creed, there were few norms about the 'abuse of office', the election of bishops or the relationship between bishops and institutional property. These canons of the final session articulate the need for a centralized church, where all elected bishops must be 'perfected' by the catholicos in a secondary ordination and be gathered at a biannual synod at Ctesiphon to 'honour the [catholicos]'. ${ }^{8}$ Bishops could not ordain one another alone, nor could an anathemized bishop be replaced without the agreement of the catholicos or a metropolitan. Additionally, it was the catholicos who could determine the liturgical year. ${ }^{9}$

The canons present the image of a clergy and episcopate that had been unregulated and that lacked guidelines for 'proper behaviour': they legislate against dishonest and illiterate clergy, against the ordination of deacons who do not know the psalms and against violence between bishops. ${ }^{10}$ These declarations on 'proper behaviour' flow from the general prescriptions of the first canon, which sets out the qualities of a bishop: to receive strangers, feed the poor, aid the oppressed, nourish orphans, refuse presents and to meditate on the scriptures. ${ }^{11}$ But as much as this image of a disorganized church probably does reflect the pre-410 reality, we should remember that it was also an opportunity for the council's conveners to abrogate great powers to themselves, an alliance between the catholicos and his metropolitans that was confirmed by the presence of the Westerners and the power of the shah, rather than being a 'bottom-up' wish for the regulation of the church. The shah himself asserted that the wishes of the catholicos were to be regarded as laws, and he personally claimed the right to summon bishops, enforce church discipline and to nominate the catholicos, theoretical powers that he would try to use in future years. ${ }^{12}$ Similarly, the bishops of the major sees of Iraq benefited from their

7 The Synodicon reports that the agreed formula for the creed was the Nicene creed, but texts of the Synodicon preserved in the western Syrian tradition show that another older creed was employed at this stage: Marutha and his companions seem to have judged this orthodox, and it was only later generations' concern to demonstrate their own unimpeachable orthodoxy that caused this later alteration. W. Baum and D. Winkler, The Church of the East: A Concise History (London, 2003), 16.

8 Synodicon, 23-5 (Canons 1 and 6).

10 Synodicon, 24 and 32 (Canons 4, 16, and 19).

9 Synodicon, 26-30 (Canons 11, 17, and 13).

12 Synodicon, 32-3 (Canons 20, 21, and 25).

This is an open access version of the publication distributed under the terms of the Creative Commons Attribution-NonCommercialNoDerivs licence (http://creativecommons.org/licenses/by-nc-nd/3.0/), which permits non-commercial reproduction and distribution of the work, in any medium, provided the original work is not altered or transformed in any way, and that the work is properly cited. For commercial re-use, please contact academic.permissions@oup.com 
status as the great men of the church, while the bishops of congregations further east, including the leaders of prestigious communities of Roman exiles in Gundishapur and elsewhere, gained no such recognition. Before we accept too readily the claims of Ishaq as 'grand metropolitan and head of all bishops', ${ }^{13}$ we should remember how much the shah, the Roman bishops, and the six metropolitans of Iraq stood to gain from such an arrangement.

One example of how the 'reform' of ecclesiastical organization might have benefited the catholicos is provided by the canon against multiple holders of sees: the synod demanded in these instances that there could only be a single bishop. Yet only two bishops, Batai of Meshmahig and Daniel, were removed from their sees. In the province of Khuzistan, which seems to have had many more than its fair share of incumbents, four bishops were all allowed to retain their positions simultaneously as long as the catholicos could appoint their successor. As Labourt observed, this may reflect their influence at court, but the actions of Ishaq and the synod also show their wish to centralize decisionmaking on the person of the catholicos, rather than leave the decision to local election. ${ }^{14}$

Ishaq's successors Ahai (410-14) and Iaballaha (415-20) benefited from this period of entente between the shah and the Romans. The Chronicle of Seert reports that Ahai was selected by Yazdegard to investigate false claims by his nephew Nahrouz in Fars that a state shipment of pearls via India and China had been captured by pirates. It also informs us that Iaballaha was chosen to make diplomatic overtures to the Romans after receiving a Roman embassy from one Acacius of Amida, where he was given impressive presents at the court of Theodosius II, which he used to build and restore churches. ${ }^{15}$ Iaballaha received, in turn, a second visit from Acacius in 420, when he convened a synod to hear his letter of greeting and to reaffirm the disciplinary canons of the Anatolian councils. ${ }^{16}$ The traditions embedded in the Chronicle seem to reflect a close relationship between shah, catholicos, and the Romans, where peace negotiations opened the potential of charitable donations from the Roman church and where a catholicos based in the shah's Iraqi capital could monitor his relatives in the original Sasanian military heartland of Fars.

However, the profitable relationship did not imply that the rest of the ecclesiastical hierarchy was complicit with the behaviour of the catholicoi. Quarrels over the treatment of religious minorities in both empires and the Christian self-representation of the Theodosian court led to a brief war in 421-2 and a renewed spell of persecution under Yazdegard I and his

13 Synodicon, 33 (Canon 21).

14 J. Labourt, Le christianisme dans l'empire perse (Paris, 1904), 98-9.

${ }^{15}$ Chronicle of Seert, I/ii, LXIX (324); LXXI, (326-7).

16 Synodicon, 39-40.

This is an open access version of the publication distributed under the terms of the Creative Commons Attribution-NonCommercialNoDerivs licence (http://creativecommons.org/licenses/by-nc-nd/3.0/), which permits non-commercial reproduction and distribution of the work, in any medium, provided the original work is not altered or transformed in any way, and that the work is properly cited. For commercial re-use, please contact academic.permissions@oup.com 
successor Vahram V. ${ }^{17}$ The acts of the synod of 424, held under the catholicos Dadisho $^{c}$, give a different perspective on the stability of the reigns of Ishaq, Ahai, and Iaballaha, as the smokescreen of earlier rhetoric is blown away to reveal the weakness of Ctesiphon's authority over other bishops.

The 424 synod follows the theme of earlier synods by issuing a preamble in which the signatories profess their loyalty, but it also reveals the existence of a party of dissidents, of which eleven are named, who, it is now revealed, were condemned by both Ishaq in 410 and by Iaballaha at a second synod in $420{ }^{18}$ These men include Batai of Hormizd-Ardashir, possibly the same Batai who was condemned by Ishaq, and one Pharabokht of Ardashir-Khurrah, who had previously been nominated as catholicos. ${ }^{19}$ Among these dissident sees were major cities such as Dastgird, Belashparr, Darabgerd, Hormizd-Ardashir, and Ardashir-Khurrah. At least one of the dissident bishops, Abner of Kashkar, seems to have been a 'dual-incumbent' displaced from his see by an alternative line of episcopal succession. ${ }^{20}$ These bishops are said to have accused the catholicos of not being properly ordained or educated, and of denying the authority of the catholicosate before the Zoroastrians and being an apostate. $^{21}$

Thus, the impression of unity and centralization that we receive from the synods of Ishaq and Iaballaha is, in part, an illusion, aimed to impress the dignitaries who were present. The catholicoi desired short-term diplomatic gains from the upper echelons of Roman and Persian administration, but ignored grievances and alternative lines of patronage in the provinces, even if we cannot reconstruct these in detail. ${ }^{22}$ If the decade of 410-20 had brought the rewards of high-level cooperation, then the final year of Yazdegard's reign would bring an end to 'the peace of the church' and to peace with Rome.

17 For this war and its causes see O. Schrier, 'Syriac evidence for the Romano-Persian War of 421-422', GRBS 33 (1992), 75-86, who emphasizes that the Romans only declared war after Vahram's succession and that conciliatory diplomacy was still attempted by Acacius in 420 . Also see K. Holum, 'Pulcheria's crusade A.D. 421-2 and the ideology of imperial victory', GRBS 18 (1977), 164-71 on the treatment of Zoroastrian minorities in Anatolia and G. Greatrex, 'The two fifth-century wars between Rome and Persia', Florilegium 12 (1993), 1-14 on the course of the war.

18 Synodicon, 44. 11 dissidents are named compared to 36 signatories at the council of 424, though there were only 12 signatories at its predecessor in 420 .

19 Pharabokht is mentioned in Mari, $H E, 36 / 31$.

20 The 'loyalist' incumbent was Mari of Kashkar (Synodicon, 43). Kashkar's central location and its position in the catholicos' own see might have made it easy for such bishops to generate influence at court. The 'loyalist' sees of Karka de Ledan and Beth Lapet, capital cities that are associated with Ctesiphon in the Acts of Symeon, are absent from this list.

${ }^{21}$ Synodicon, 45.

22 A parallel is offered by Armenian objections to interference by 'Syrian' bishops, who seem to have been supported by political authorities (both Persian and Armenian) against the line of Gregory the Illuminator. See the comments of D. Winkler, 'An obscure chapter in Armenian church history', Revue des études arméniennes 19 (new series) (1985), 85-180, at 96-104.

This is an open access version of the publication distributed under the terms of the Creative Commons Attribution-NonCommercialNoDerivs licence (http://creativecommons.org/licenses/by-nc-nd/3.0/), which permits non-commercial reproduction and distribution of the work, in any medium, provided the original work is not altered or transformed in any way, and that the work is properly cited. For commercial re-use, please contact academic.permissions@oup.com 


\section{THE WAR OF 421 AND THE NEW PERSECUTIONS}

The end of Yazdegard's reign saw a major volte-face by the shah in which he resumed the periodic persecution of Christians. This change in policy was prompted in part by Christian vandalism of fire temples and the shah's need to distance himself from his Christian clients. Yazdegard seems to have initially attempted to install Persian Christians, Ma'na and Pharabokht, as catholicoi, and accepted the intercession of major bishops on behalf of the wider Christian community. ${ }^{23}$ This desire by the shah to exercise closer control over Christians through the catholicosate helps to explain the accusations against

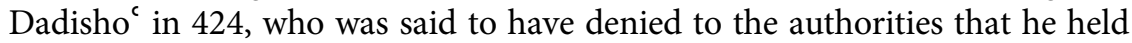
any position of leadership and apostatized, which may reflect real attempts to deny responsibility for Christian vandalism. ${ }^{24}$

However, Yazdegard's actions did not prevent the shah's loss of prestige, and he went on to make examples of certain prominent apostates from Zoroastrianism. Yazdegard's religious and political experimentation seems to have drawn the anger of a number of notables at court, including the Magian priest MihrNarseh. These men were not satisfied by Yazdegard's attempts to control the situation and ultimately arranged his assassination and killed his son Shapur. The throne was initially given to Shapur's cousin, Khusrau, until he was challenged by another son of Yazdegard, Vahram, who ruled as Vahram V.

The Persian royal tradition, which is elaborated in later extant Arab histories such as al-Tabari and in the New Persian Shahnameh, may illustrate some of the distrust of Yazdegard's behaviour. Al-Tabari reports that Yazdegard was known as 'the sinful one', a criticism that may reflect his support for Christianity. The histories complain that he did not trust those who spoke out for the oppressed, putting his trust only in foreign ambassadors and imposing monetary penalties and physical punishment on aristocrats. In this tradition, Yazdegard was killed by being thrown from a white horse, symbolizing his failure to fulfil his divine mandate for kingship. ${ }^{25}$ By contrast, Vahram Gur denounces his father's evil and is crowned by the chief mobad, proving his right to rule through displays of heroism and his adventures in India. ${ }^{26}$ Much of this material is legendary, but it does suggest that the attitudes of Persian elites towards the shahs differed greatly and that they expressed this in terms

${ }^{23}$ Chronicle of Seert, I/ii, LXXI-II (327-9). Also note Mari, HE, 36/31, who provides the description of the short-lived Pharabokht. The description of Ma'na as a translator may stem from a confusion of the catholicos with the sixth-century translator Ma'na of Rev-Ardashir. S. Gero, Barsauma of Nisibis and Persian Christianity in the 5th Century (Louvain, 1981), 21 and 43 , note 96.

24 Synodicon, 45.

25 Al-Tabari, I, 847-50.

26 Al-Tabari, I, 855-68. The discussion of Vahram Gur in the Persian tradition is also concerned with proving Sasanian legitimacy even after the disastrous reign of Yazdegard.

This is an open access version of the publication distributed under the terms of the Creative Commons Attribution-NonCommercialNoDerivs licence (http://creativecommons.org/licenses/by-nc-nd/3.0/), which permits non-commercial reproduction and distribution of the work, in any medium, provided the original work is not altered or transformed in any way, and that the work is properly cited. For commercial re-use, please contact academic.permissions@oup.com 
of heroic myth and Zoroastrian mythology. Importantly, Yazdegard is portrayed rejecting the advice of his aristocrats and using the state's power against them, while Vahram is praised for lowering taxes and courting the mobads, especially his chief mobad Mihr Narseh, who, the tradition reports, acquired extensive landed property during his reign. ${ }^{27}$ Though our sources are late, they indicate that Yazdegard's murderers used Zoroastrian ideas to legitimate their actions, and criticized of his attempts to broaden his pool of advisors, and that certain Zoroastrian clergy benefited greatly during the reign of his successor.

The analogue to these accusations is provided by the Christian historical traditions. Yazdegard used Ahai and Iaballaha to monitor his relatives and conduct diplomacy. And Greek ecclesiastical history also accentuates the proximity of Marutha to Yazdegard. Socrates Scholasticus, writing in the 430-40s, narrates that 'the king loved Marutha' and that Marutha detected the tricks of the Magi, who claimed that their god could speak to the king out of the flames, and that Marutha expelled demons from the king's son. ${ }^{28}$ While neither the Roman ecclesiastical history nor the Arabic recensions of the Persian royal annals are a precise source, they present a relatively unified image here of a shah content to use foreign advisors, to create institutions, and to challenge the governance of local aristocrats.

Scott McDonough has usefully placed both Yazdegard's reign and that of his 'persecuting' successors Vahram Gur and Yazdegard II into the context of the reform of the Sasanian state, where the personal rule of earlier shahs was gradually and experimentally replaced by more stable structures. The period 350-480 saw the replacement of regional sub-kings with governmentappointed marzbans; the centralization of silver manufacture (an important vehicle for royal propaganda); the issuing of mint-marked coins; and an appeal to 'ancient' Kayanid myths as part of royal self-presentation..$^{29}$ McDonough's observations build on earlier studies of the government seals by Rika Gyselen that saw the fifth century as an era of bureaucratic expansion in the Sasanian world and as the period when mobads were regularly given government functions. ${ }^{30}$

27 For tax relief under Vahram see al-Tha' alibi, 555. For Mihr Narseh's wealth, al-Tabari, I, 869-70.

28 Socrates, HE, VII, 8.

29 S. McDonough, Power by Negotiation: Institutional Reform in the Fifth-Century Sasanian Empire (UCLA, 2002, unpublished PhD thesis), 136-65. Also see R. Gyselen, 'New evidence for Sasanian numismatics', in R. Gyselen (ed.), Contributions à l'histoire et géographie historique de l'empire sasanide (Bures-sur-Yvette, 2004), 52-67, at 52-62 for the dating of mint marks.

30 R. Gyselen, La géographie administrative de l'empire sasanide (Paris, 1989), 30-5 on the development of the mobads and the office of 'mogbed' as a land administrator for the Magi and R. Gyselen, 'Empreintes des sceaux sasanides', StIr 93 (1992), 49-56, at 53 for the association of Magi with specific towns and provinces. However, this was only the beginning of this process: E. Venetis 'The Zoroastrian priests and the foreign affairs of Sasanian Iran and the Later Roman

This is an open access version of the publication distributed under the terms of the Creative Commons Attribution-NonCommercialNoDerivs licence (http://creativecommons.org/licenses/by-nc-nd/3.0/), which permits non-commercial reproduction and distribution of the work, in any medium, provided the original work is not altered or transformed in any way, and that the work is properly cited. For commercial re-use, please contact academic.permissions@oup.com 
This focus on the creation of more permanent institutions is important because it allows us to understand the experimentation of Yazdegard and later shahs with Christian structures in terms of the Sasanian state, rather than purely from the perspective of churchmen. What Yazdegard shared with his successors was the creation of institutions that bound specific groups within the empire to the shah, using these institutions to balance different interests while allowing the shah to retain control over appointments and the fiscal-military apparatus. We should remember, of course, that three of Shapur II's immediate successors had been assassinated at the end of the fourth century. The use of the catholicoi as spies and diplomats, diplomatic recognition by the Roman bishops, Kayanid ideology, bureaucratic reform, and the institutional reform of the Magi were all experiments aimed at creating long-term legitimacy for the shahs and engendering loyalty and an ability to intervene in different localities.

Therefore, the centralization of the church that Yazdegard promised was important for Christians because it offered great power to those who were willing to cooperate with the shah and successfully act on his behalf. But it also threatened tension, both with other competitors for the shah's favour and with other Christians, who stood to lose out in various ways from the relationship between shah and catholicos. The relationships between the catholicos and the shah, and between the catholicos and his bishops, were closely connected to the relationships between Persians and Romans and between the shah and the Magi. It is with this nexus of patronage in mind that we should analyse the persecutions of the reigns of Yazdegard and Vahram and the controversy about loyalty that was associated with these events.

\section{THE MARTYRS OF YAZDEGARD AND VAHRAM}

The Roman ecclesiastical historian Theodoret of Cyrrhus reports (c.440) that one Abdas, 'adorned with virtue and stirred by undue zeal to destroy paganism' tore down a fire temple in Khuzistan. He reports that Yazdegard made moderate requests to Abdas to restore the temple, but that these were refused and that Yazdegard responded by having him killed and the churches destroyed. He goes on to describe the death or imprisonment of other martyrs under Yazdegard: Hormisdas 'an Achaemenid and the son of a prefect', Suenes 'master of a thousand slaves' ${ }^{31}$ and Benjamin, a deacon who refused to renounce proselytism. He adds that 'just as Diocletian destroyed churches in

Empire (5th Cent.)', Nāme-ye Irān-e Bāstān 3 (2003), 47-78, esp. 52 over-emphasizes the effects of these reforms, which we cannot assess at this early date.

31 This may reflect the Sasanian title 'hazarbandag', also ascribed to Mihr narseh (al-Tabari, I, 868).

This is an open access version of the publication distributed under the terms of the Creative Commons Attribution-NonCommercialNoDerivs licence (http://creativecommons.org/licenses/by-nc-nd/3.0/), which permits non-commercial reproduction and distribution of 
the Roman Empire on the day of our saviour's Passion', he, like Yazdegard, 'perished in iniquity'.

Theodoret's report suggests that Yazdegard's chief concern was the conversion of high-ranking Persians and the destruction of Zoroastrian shrines, and that Christian churches presented a suitable target to threaten Christians into greater obedience. Theodoret was clearly anxious about the wisdom of Abdas' actions: he notes that 'not even [Paul] destroyed the altars of the Athenians', though he agrees that it is 'honourable to seek a martyr's crown and to refuse to rebuild a temple of paganism'. ${ }^{32}$ This account inspired Neusner's observation that Christian expectations of imminent conversion generated tension with the Magi that led to persecution. ${ }^{33}$ Van Rompay has noted in turn that this ignores the emphasis on loyalty and obedience in many of the contemporary Syriac hagiographies, especially those produced by the monk Abgar, from a monastery close to Ctesiphon. ${ }^{34}$ I suggest here that, instead of looking for a single Christian pattern of behaviour, we must read the Syriac martyrologies alongside the Synodicon to reveal the contradictory tensions within the Church in the East and its recent institutional framework.

The first of these martyrologies is a fragmentary account of the same 'Abda of Hormizd-Ardashir that Theodoret reports. ${ }^{35}$ The text is dated to the 22nd year of Yazdegard, and it purports to describe the beginning of Yazdgerad's persecution of the Christians. It begins by telling how the Magi went to the king, warning him that in the lands of your dominion, these Nasarenes, who are called bishops, priests, deacons, and bnay qyama, transgress your command and disobey your kingship: they disgrace your gods and mock fire and water and overturn the fire temples, the buildings where we worship, and greatly disobey our laws'. Next the king gathered all the nobles (rawrbāne) of his dominion and asked them whether the things he heard were true. 'Then the nobles and the Magi oppressed our people and prevailed [in argument] and from this time a harsh order went down from the king that the churches and monasteries should be uprooted in all the lands of his dominion.' 36

'Abda and his companions ${ }^{37}$ are brought before the king, where he asks them, 'why don't you follow [lit. 'lower yourselves before'] the teaching that we

32 Theodoret of Cyrrhus, HE, V. 38. A very similar account, stripped of Theodoret's observations of the wider political context, is preserved in Armenian: P. Peeters, 'Une passion arménienne des SS Abdas, Hormisdas, Šahin (Suenes) et Benjamin’, AB 28 (1909), 399-415.

${ }^{33}$ Neusner, A History of the Jews in Babylonia, V, 8.

34 L. Van Rompay, 'Impetuous martyrs? The situation of the Persian Christians in the last years of Yazdegard I (419-20)', in M. Lamberigts and P. van Deun (eds.), Martyrium in a MultiDisciplinary Perspective: Memorial Louis Reekmans (Louvain, 1972), 363-75, at 372-3.

${ }^{35}$ For a description of the text see F. Jullien, 'La passion syriaque de Mār 'Abdā: quelques relations entre chrétiens et mazdéens', in R. Gyselen, C. Jullien, and F. Jullien (eds.), Rabban l'Olmyn: Florilège offert à Phillippe Gignoux pour son 80e anniversaire (Leuven, 2011), 195-205.

${ }^{36}$ Acts of ${ }^{\mathrm{A}} \mathrm{Abda}, 251$.

37 There are seven companions, including two priests, a deacon, and 'Abda's brother Papas.

This is an open access version of the publication distributed under the terms of the Creative Commons Attribution-NonCommercialNoDerivs licence (http://creativecommons.org/licenses/by-nc-nd/3.0/), which permits non-commercial reproduction and distribution of the work, in any medium, provided the original work is not altered or transformed in any way, and that the work is properly cited. For commercial re-use, please contact academic.permissions@oup.com 
received from our fathers [and] follow a wandering path (urhạ $d$-tawš $\bar{a}$ ) according to the will of your own hearts?' The Christians reply that it is senseless to worship created things, such as the stars and the elements, instead of the creator.

Next Yazdegard proceeds to criticize 'Abda's style of government, implying that it is a kind of democracy: 'Since you are the shepherd and governor of these men, why do you neglect them so much that you disobey our kingship and neglect our command and govern according to their will?' His specific objection, it transpires, is to 'Abda's destruction of a fire temple: 'For we have received places of worship and fire temples that have been glorified from the time of our fathers' fathers, but you have overturned them and uprooted them!' 'Abda's defence is simply that this is a false accusation: the Magi have lied against the Christians at court, though the king denies this strenuously. ${ }^{38}$

The issues of 'Abda's debate with Yazdegard, of church 'democracy' and the accusation of the destruction of a fire temple, remain the focus of the debate when 'Abda's deacon Hosea (Hašu) enters the debate:

Then Hosea the priest took up the power of God and said, 'We did not attack the building of God and we did not go against a holy altar.' Then the king said, 'I did not speak to you but to your leader and it is he who must give me a reply.' Then the blessed Hosea said, 'Our teaching commands thus: that great and small should not be ashamed of the word of God when speaking before the king. Also our Saviour told us, "I have brought you speech and wisdom that your persecutors will not be able to withstand."39 And because of this, our words are true whether they come from great or small.' Then the king said 'What is your teaching, o bold one (marāha $\bar{a}$ ), That you should speak instead of your leader and that you should be clothed in zealotry (țnannā) on behalf of your people?' Then the holy man said, 'I am a Christian, a servant of the living God and I cannot blame my own hand and say "what are you doing?" Then the king said, 'Is it true that you attacked the fire and quenched it and transgressed our command.' Then the holy Hosea said, 'I did attack a building and quench a fire because it is not a house of God and fire is not the daughter of God, but it is a servant, which serves both kings and paupers, both the rich, the poor and the beggars, and is generated from dry wood. ${ }^{40}$

The text then presents an environment where the Magians have challenged Christians at court for their role in religious vandalism. Other hagiographies set in the reign of Shapur II often include a topos of false accusation by Zoroastrians and Jews against Christians, but here the denunciation is specific and is only denied in part: Hosea admits to destroying the temple, but not that it is a "holy thing. ${ }^{41}$ The hagiographer intends the Acts to seem provocative, to

38 Acts of 'Abda, 252.

39 Luke 21:15.

40 Acts of ${ }^{\mathrm{C}} \mathrm{Abda}$, 252. The manuscript breaks off shortly afterwards.

${ }^{41}$ For Jewish accusations, a feature of the fourth-century lives, see Acts of Tarbo, 254; Acts of Symeon A, 740.

This is an open access version of the publication distributed under the terms of the Creative Commons Attribution-NonCommercialNoDerivs licence (http://creativecommons.org/licenses/by-nc-nd/3.0/), which permits non-commercial reproduction and distribution of the work, in any medium, provided the original work is not altered or transformed in any way, and that the work is properly cited. For commercial re-use, please contact academic.permissions@oup.com 
remind audiences accustomed to hagiography that the Magi will denounce them, but also that it is Christian norms, rather than Zoroastrian ones, that are a true criteria for judgement. Moreover, by emphasizing this distinction he shows that, while the shah is controlled by the Magi, Christians are only bound by a higher law. Yazdegard's objection that he can rely on his trustworthy advisors may well reflect the self-presentation of the court, especially given Yazdegard's conscious promotion of Christians and Jews and the notables' complaints of interference in local governance, and this policy may have involved statements that all were equal before the law and that all might seek his ear at court. But 'Abda refuses to participate in this invitation: following another topos of the martyria, the inversion of social norms, he denies the testimony of the Magi, because it involves a category error (i.e. that they do not understand what is really holy), rather than because they did not really destroy the fire. ${ }^{42}$

Similarly, the Acts reflect a second aspect of Yazdegard's self-presentation in his appeal to Zoroastrianism as an ancestral religion, the religion of 'our fathers'. This presentation shows the ethnic language that had been employed by earlier shahs that connected érān with the religion of the 'Mazda-worshipping shahs', an image that Yazdegard and his successors would extend with their propagation of an ancient Kayanid history for their dynasty. ${ }^{43}$ Importantly, Yazdegard appeals to 'Abda to respect this ancestral religion, perhaps implying that 'Abda and Hosea are also bound by this inheritance from the past and that they were identified as 'Iranians'.

Thus, the Acts of 'Abda rejects Yazdegard's attempts to include Christians in a political framework or to get them to respect the bonds of common ancestry. Instead, Hosea repeats the most popular defence of Christianity against Zoroastrianism, which may be copied from defences against idolatry in older martyr literature: it is better to worship the creator than created things. Indeed, by following the topoi of Magian accusation, subversion of earthly justice, and the attack on Zoroastrianism as idolatry, the Act's protagonists act out the hagiography of earlier martyrs to show that Christians of all kinds, laymen as well as priests, owe no allegiance to the false justice of a government that remains inclined towards idolatry.

This resistance is most strikingly seen in the shah's criticisms of church government. Yazdegard asks 'Abda why, as 'leader of the men', he 'neglects them so much that you disobey our kingship and neglect our command and govern according to their will (i.e. the will of the mob)'. Yazdegard envisions a tripartite model of authority, where 'Abda's role is to serve as conduit for royal

42 E.g. Gushtazad's audience with Shapur II in Acts of Symeon A, 756.

43 T. Daryaee, 'History, epic and numismatics: on the title of Yazdegard I', AJN 16 (2004), 89-92; T. Daryaee, 'Kingship in early Sasanian Iran', in V. Curtis and S. Stewart (eds.), The Sasanian Era: The Idea of Iran vol. III (London, 2008), 60-6.

This is an open access version of the publication distributed under the terms of the Creative Commons Attribution-NonCommercialNoDerivs licence (http://creativecommons.org/licenses/by-nc-nd/3.0/), which permits non-commercial reproduction and distribution of the work, in any medium, provided the original work is not altered or transformed in any way, and that the work is properly cited. For commercial re-use, please contact academic.permissions@oup.com 
authority, being obedient to it himself and encouraging obedience in others. Instead, 'Abda is behaving at the behest of the mob. This issue is pursued in Hosea's reply, which is phrased in terms of parrhesia, the bold speech of a martyr before his accuser, modelled on that of Christ before Pilate. ${ }^{44}$ Hosea presents his ability to speak before the king as a sign of his God-given reason, his freedom to act outside the confines of ceremony, while to Yazdegard his act of 'boldness' is a subversion of the proper chain of authority: Hosea speaks instead of his leader and has taken on the 'zealotry' of the crowd. Hosea's reply returns to the topos of justice: his act of vandalism was caused by God and it illustrates the flaw in Yazdegard's model of authority.

In this highly hierarchical environment, the egalitarian protestations of Hosea are shocking. ${ }^{45}$ Where the shah had imagined that authority ought to flow through the bishop 'Abda to his men, and that 'Abda and Hosea had subverted this by taking on the behaviour of the mob, Hosea emphasizes instead that authority flows from God to all Christians, and that he is as capable of speaking before the shah as any bishop. Finally, Hosea incorporates fire itself into this debate, while fire is an object of worship for the Zoroastrians; Hosea calls it 'a servant of kings and paupers'. Ultimately, Hosea draws a parallel between the shah's false chain of authority, leading to himself, and the Zoroastrian elevation of fire into an object of worship, which also underlines the Zoroastrian nature of government, even by a shah who had made efforts to include Christians in governance.

This text is only a fragment, but, given its opposition to the powers that be, it seems that scribes and patrons would have had many incentives not to copy such a text during the rapprochements between the shah and the Church of the East at the end of the sixth century. Moreover, it is significant that Theodoret's account of Persian converts and controversial proselytism makes 'Abda's behaviour the major trigger for persecution. I suggest that the Acts of 'Abda reflects wider sentiment that opposed the inclusion of some high-ranking Christians into government patronage. Given the adversarial attitude taken by the Christian protagonists in this text, it may have been composed during the lacuna in the authority of the catholicos in the middle of the fifth century.

The text's geographical location in Khuzistan becomes significant when we read it alongside the Synodicon and the East Syrian ecclesiastical histories. As we have seen, Hormizd-Ardashir was a centre of resistance to the catholicos in 424, at a time when Dadisho' stood accused of usury, the closet practice of

${ }^{44}$ G. Bartelink, 'PARRHESIA', Greacitas et Latinitas Christianorum, supp. 3 (Nijmegen, 1970), 5-57, esp. 12-14 and 35-44 summarizes the models of 'positive parrhesia', based on Christ's relationship with God, and 'negative parrhesia', based on Christ before Pilate.

${ }^{45}$ P. Brown, 'The study of elites in late antiquity', Arethusa 33 (2000), 321-46, at 331 contrasts the blood aristocracies of Armenia and Iran with the relative social mobility of the Roman elite, with their emphasis on education and office-holding.

This is an open access version of the publication distributed under the terms of the Creative Commons Attribution-NonCommercialNoDerivs licence (http://creativecommons.org/licenses/by-nc-nd/3.0/), which permits non-commercial reproduction and distribution of the work, in any medium, provided the original work is not altered or transformed in any way, and that the work is properly cited. For commercial re-use, please contact academic.permissions@oup.com 
Zoroastrianism, and inciting the shah to persecution. ${ }^{46}$ We are never told explicitly about the saint's attitude to the catholicos, but it is plausible that 'Abda's hagiographer intended to evoke a contrast between the democratic behaviour of the saintly heroes and the catholicoi who were patronized by the shah. The hagiographer encouraged instead a continued conversion from Zoroastrianism. ${ }^{47}$ As the shah struggled to find a catholicos who was both pliable and effective, the public connection between the upper echelons of the church and a persecuting state must have tarnished the catholicosate in the eyes of its Christian critics.

\section{ABGAR'S CYCLE: LOYALTY AND PERSECUTION}

Four saints' lives, the lives of Narsai, Tataq, the ten martyrs of Beth Garmai, and Jacob the notary, were all composed in a monastery near Ctesiphon around the middle of the fifth century and recount the events that are similar to those in the Acts of 'Abda. ${ }^{48}$ They retain its emphasis on the justice of the king, but lack its concern for the inversion of hierarchy, focusing instead upon the connection between the martyrs under Yazdegard and Vahram and their predecessors under Shapur II. Paul Devos notes that all of these lives were composed by the same hagiographer, a monk named Abgar, who lived in a monastery near Ctesiphon. All these texts share the same site of martyrdom, the field of 'Sliq harubta' outside the city of Ctesiphon itself, from which the monks of Abgar's monastery gathered the relics of the slain. ${ }^{49}$

In the first, and most famous ${ }^{50}$ of these accounts Abgar describes how Narsai, a priest of Rayy in northern Iran, whom we have already encountered in the patriarchal histories, and his friend Shapur acquires a land title from a Zoroastrian convert, Adarparwa, and uses this land to build a church. This convert is then persuaded to recant by a local mobad, Adurboze, and, while

46 Synodicon, 45.

47 Another rebel see, Belashparr, was the site of a later hagiography, the Acts of Yazdin, AdurHormizd, his daughter Anahid and Pethion, composed c.500, that celebrated conversion from Zoroastrianism, even imagining the conversion of a famous magus and his daughter. This text is highly sensitized to Iranian language and Zoroastrian ideas: see R. Payne, Christianity and Iranian Society 500-700 CE (unpublished PhD thesis, Princeton, 2010), 38-70.

48 A general summary is provided in Labourt, Christianisme, 106-12.

49 P. Devos, 'Abgar: un hagiographe perse méconnu', AB 83 (1965), 303-28 who summarizes and translates large sections of these lives. See esp. 325-6 for his list of stylistic parallels. J.-M. Fiey, 'Topographie chrétienne de Mahoze', OS 2 (1967), 407-19, at 418 identifies the convent as Mar Sergius at Mabraktha or Kokhe, suburbs of Ctesiphon beyond the city walls.

50 In addition to the references in the ecclesiastical histories, Narsai is seen as an antecedent for the Acts of Tataq and the Acts of Mihrshapur. The latter is set during the same persecutions but is probably written later in the century.

This is an open access version of the publication distributed under the terms of the Creative Commons Attribution-NonCommercialNoDerivs licence (http://creativecommons.org/licenses/by-nc-nd/3.0/), which permits non-commercial reproduction and distribution of the work, in any medium, provided the original work is not altered or transformed in any way, and that the work is properly cited. For commercial re-use, please contact academic.permissions@oup.com 
Narsai is absent, the church he had built is transformed into a fire temple. On his return, Narsai throws out the sacred objects and puts out the fire: 'should I leave these impure objects in God's house?' Then a crowd is raised in the village and Narsai is brought before Adurboze in Ctesiphon. The mobad asks him, 'Do you have no fear of the king's judgement?', to which he replies, 'Who should I fear more: God who gave the king his crown and who has authority over all created things, or an ephemeral king ( $\left.m a l k \bar{a}{ }^{c} \bar{a} b o r \bar{a}\right)$, who lives today but who will give his kingdom to another? ${ }^{51}$ At this, Adurboze asks Narsai to repair the shrine, but Narsai refuses, saying that he did not enter the house of a man, 'but that of God,... who called it a house of prayer and a place of atonement (husāya $)$ for all the nations, and nothing unclean (tanputā) shall enter it'. ${ }^{52}$

Narsai is then ransomed, but is brought back later to answer the questions of a marzban, who is under orders from Yazdegard to release Narsai if he denies putting out the fire or is willing to replace it. The marzban tells him that he knows he did not put out the fire, but Narsai replies 'I was interrogated in the criminal court by the mobad Adurboze and told the truth: I did put it out. Should I now deny (kpar) ${ }^{53}$ this before you?' The marzban repeats the king's orders, but Narsai refuses to apologize and declares that 'a death for God's sake is better than living wrapped up in sin'. He is then condemned to death. ${ }^{54}$

As he is taken to the place of execution, he passes the monastery [of Abgar] and the monks offer him water, but he refuses, asking instead that they pray for him. The Magians are initially concerned that Narsai will be rescued by the large crowd come to see his execution, but the crowd reassure them that they would not disobey the king, but wish to receive a blessing from the martyr. First a 'lictor', a Christian apostate, goes to kill Narsai, but he is struck down by God before he can strike Narsai. Eventually Narsai allows himself to be struck by a Magian, and is 'crowned by the blood of his neck'. ${ }^{55}$

Finally, the Christians take Narsai's head, body, and blood to 'the place built by holy Mar Marutha, bishop of Suf [Sophanene i.e. Maypherkat], the companion of the martyrs' for the 118 martyrs killed under Shapur II. Later, Abgar adds, 'when the present persecution occurred, we removed his bones lest the Magians despoil them and took them to the martyrion of Lawarne, for the people's benefit and healing'. The life concludes by asking Christ 'lord of the martyrs' to grant us an inheritance in the kingdom of heaven alongside the martyrs 'who were crowned with his love'. ${ }^{56}$

The Acts of Narsai, like the hagiographies that succeed it, address the issue of loyalty to the shah and the origins and limitations of his authority. Obedience to the shah and avoidance of punishment are represented as the prime reason

\footnotetext{
51 Acts of Narsai, $173 . \quad 52$ Acts of Narsai, 174.

53 This verb is also used in the martyrologies for the denial of Christ by an apostate.

54 Acts of Narsai, 175-6. $\quad 55$ Acts of Narsai, 178-9. ${ }^{56}$ Acts of Narsai, 180.
}

This is an open access version of the publication distributed under the terms of the Creative Commons Attribution-NonCommercialNoDerivs licence (http://creativecommons.org/licenses/by-nc-nd/3.0/), which permits non-commercial reproduction and distribution of the work, in any medium, provided the original work is not altered or transformed in any way, and that the work is properly cited. For commercial re-use, please contact academic.permissions@oup.com 
given by the Magi to convert, both in the lives of the Shapurian martyrs and in these lives. ${ }^{57}$ These texts admit that the shah's authority comes from God, but they also articulate the conditions for the shah's just rule. Unlike the Acts of 'Abda, Narsai's vandalism of the fire shrine is justified as the restoration of a church that had been expropriated unfairly. Likewise, Tataq, explaining his conversion, tells his interrogators that 'I was not neglectful of anything during my service for the king and also his kingdom did not persecute the Christians, but was given succour by Christ, because of the vision and knowledge of his great honour, which exceeds all honours, and the exalted greatness of his kingdom, which exceeds all kingdoms. ${ }^{58}$ Passages in the Acts of Narsai also suggest Christian obedience to the shah or an idea that his authority comes from God, such as the crowd's placid behaviour at the execution or Narsai's conversation with the shah.

However, such 'loyalist' expressions must be read alongside the text's differentiation of the Magi and Zoroastrianism from the shah. The Acts of Narsai present the shah as forgiving, possibly reflecting a real attempt by the authorities to diffuse religious tension, and Narsai himself observes the contrast between the justice of the mobad and the marzban. This contrast evokes the Gospels' contrast between the justice of the Jews and that of Pilate, and may be intended to identify the mobads as the cause of Narsai's death, with the marzban as a mere agent of the law. ${ }^{59}$ This contrast may also show us that the Magi's jockeying for institutional power within the Sasanian political system was visible to Christian commentators and that the hagiographer sought exploit the distinctions between the shah and the Magi, i.e. to criticize Zoroastrianism while proclaiming loyalty to the state. Like Hosea in the Acts of 'Abda, Narsai refuses to acknowledge that the fire temple is holy, calling it 'the house of a man': the chief objection is to the practice of Zoroastrianism and to a state that recognizes this as holy.

Thus, the hagiographer was attempting to drive a wedge between the legitimate state and the Magi whom it supports and who advise the shah. This contrast is heightened in the final life of the collection, that of Jacob the Notary. Here, in the final interrogation scene, Jacob tells Vahram that 'Yazdegard ruled for twenty-one years in peace, but his life ended when he became a persecutor'. ${ }^{60}$ We have already seen the idea of persecution removing the shah's divine mandate in the Acts of Tataq, but here the hagiographer provides a Christian retelling of the story of the death of Yazdegard: instead of dying for an impiety against Zoroastrianism, here the impiety of Yazdegard that causes

57 E.g. The 10 Martyrs of Beth Garmai, 185.

58 Acts of Tataq, 182. Also note the examples and comments of Devos, 'Abgar', 323.

59 The mobad Mihr Shapur is a recurrent persecutor in these hagiographies.

60 Acts of Jacob the Notary, 195-6.

This is an open access version of the publication distributed under the terms of the Creative Commons Attribution-NonCommercialNoDerivs licence (http://creativecommons.org/licenses/by-nc-nd/3.0/), which permits non-commercial reproduction and distribution of the work, in any medium, provided the original work is not altered or transformed in any way, and that the work is properly cited. For commercial re-use, please contact academic.permissions@oup.com 
his death is his persecution of the Christians. ${ }^{61}$ Abgar gives a conditional authority to Yazdegard, which he relinquishes when he follows the dictats of the Magi and is then punished by God.

The near-contemporary Acts of Peroz, composed by a different hagiographer, provides a parallel criticism of the connection between the shah and the Magi. Here the mobad Mihr-Shapur is explicitly labelled as the murderer of Yazdegard and called an 'enemy of the Christian people'. ${ }^{62}$ This accusation shows that some Christians, were aware of the role of the Magi in the removal of the shah. ${ }^{63}$ The same knowledge may also underlie the criticism of the Magi placed into the mouths of the saints by Abgar the monk.

We should be wary, therefore, of accepting Van Rompay's presentation of fifth-century hagiography as straightforwardly 'loyalist'. The deal that had been struck between Yazdegard and the catholicoi had never included a large number of Eastern sees. And there remained groups of Christians, of whom 'Abda and Narsai are examples, who rejected the authority of the shah and deliberately disobeyed the law by destroying fire temples and recruiting converts of high status. We cannot measure such incidents beyond noting that it was these more violent actions that were observed by Theodoret of Cyrrhus in the West. Yazdegard's failure to control the Christians prompted his own persecution (probably on a limited scale) and eventually contributed to his assassination. And the role of high-profile mobads such as Mihr-Shapur encouraged his successor Vahram to give greater institutional powers to the Magian priesthood and to prosecute a war with Rome as a demonstration of his strength to the aristocracy.

The hagiographer, Abgar, was placed near the capital, and possibly, therefore, more connected to the catholicos and his interests. He asserted that Narsai and his supporters had been obedient to the king and the role of the Magi in the persecutions. Devos dated Abgar's writing to the 420s, since he was able to differentiate between different phases of the persecution and claims to be a eyewitness to the events, but it is possible that he wrote several decades later. ${ }^{64}$ Abgar may have known several shifts in royal policy in his lifetime and this may have shaped his hopes for more sympathetic government.

Sections of Narsai's life, especially his refusal to rebuild the fire temple, show stark similarities to the Acts of 'Abda. These similarities may suggest that

${ }^{61}$ This may underlie the idea in Chronicle of Seert, I/ii, LXXIV (331-2) of Yazdegard's murder by a demon.

62 Acts of Peroz, 254 and 258.

${ }^{63}$ Peroz's hagiographer is highly sensitized to distinctions of rank and lineage. Note the description of Peroz's origins in Acts of Peroz, 257.

64 Devos, 'Abgar', 326 identifies Dadisho's 424 synod as a terminus ad quem, but I see no reason to see the synod as the start of a rapprochement between Christians and the shah, or, necessarily, to situate Abgar's writings in a period of royal favour.

This is an open access version of the publication distributed under the terms of the Creative Commons Attribution-NonCommercialNoDerivs licence (http://creativecommons.org/licenses/by-nc-nd/3.0/), which permits non-commercial reproduction and distribution of the work, in any medium, provided the original work is not altered or transformed in any way, and that the work is properly cited. For commercial re-use, please contact academic.permissions@oup.com 
Narsai's legend, at one time, presented a hero as recalcitrant as 'Abda and Hosea, and that his behaviour did not reflect well on the ability of the catholicos to keep order. Abgar's greater acceptance of the shah's government, when compared with the Acts of 'Abda, may reflect a wish for peace, where the Christians of Ctesiphon preferred to emphasize the suffering of the martyrs and the machinations of the shah's Magian advisors over the shah's personal initiative as a persecutor. Abgar's hagiography deliberately avoids the immediate confrontation of the Acts of 'Abda, where the saint engages in much more explicit criticism.

\section{THE VANDALS REMEMBERED}

The reigns of Yazdegard and Vahram witnessed attempts by bishops and churchmen to set out the position of Christians within the Sasanian world. These included acts of religious vandalism that refused to accept the legitimate presence of non-Christian religion and the limits of acceptable proselytism. The deeds of these vandals were even seen by external Christian observers as the triggers for persecution.

There were multiple Christian reactions to these events and some, such as the monk Abgar, sought to place the focus on Christian suffering during the shahs' backlash against prominent apostates such as Tataq or descendants of Greek captives such as Jacob the notary. However, it seems highly probable that the withdrawal of royal approval led to sudden loss in the authority of the catholicosate, as witnessed by the shrill complaints of Dadisho', at a synod held in exile outside Ctesiphon. It would not be until the end of the century that a synod could be convened again.

The medieval compilations devote a substantial sections to these persecutions, which conclude their dense, detailed treatment of Ishaq's successors. These descriptions occur shortly before a major lacuna in their coverage events in the Church of the East: no events are recorded between Dadisho"s 424 synod and the death of Babowai in $484 .^{65}$ The high level of detail in the report of the Chronicle of Seert suggests that later historians were able to draw on a 'patriarchal history' written immediately before this lacuna.

The Chronicle of Seert's account of the persecution is especially interesting for its alternative presentation of the martyrs Narsai and Hosea and their relationship to shah and catholicos. The Chronicle places an initial persecution at the end of the reign of Iaballaha, which is terminated when the catholicos cures the shah of a headache. After this Iaballaha prays for an early death, to

65 This observation is based on Mari, 'Amr, and Bar Hebraeus, since the manuscript of the Chronicle of Seert is missing for much of the middle of the fifth century.

This is an open access version of the publication distributed under the terms of the Creative Commons Attribution-NonCommercialNoDerivs licence (http://creativecommons.org/licenses/by-nc-nd/3.0/), which permits non-commercial reproduction and distribution of the work, in any medium, provided the original work is not altered or transformed in any way, and that the work is properly cited. For commercial re-use, please contact academic.permissions@oup.com 
avoid the sight of Christian blood. Following Iaballaha's death, Yazdegard begins a second persecution, which is caused by the destruction of the fire temple by Hosea. This second persecution is terminated at the intervention of Ishaq, patriarch (fatriq) of Armenia. ${ }^{66}$

The shah's 'general' Mihr-Shapur ${ }^{67}$ suggests the election of the Persian $M a^{\prime}$ na as catholicos, possibly leaving a brief interregnum after the death of Iaballaha. However, the shah is said to seek another excuse to persecute the Christians, and demands that he be accorded the same rights as Caesar within his own territory. The Chronicle of Seert reports that a priest, Narsai, replied on Ma'na's behalf, saying that the shah could indeed demand that Christians pay tax or fight the shah's enemies but not deny their religion. The shah responded by attempting to force Narsai's conversion, before ultimately ordering his execution, and by banishing $\mathrm{Ma}^{\mathrm{C}}$ na to Fars, where he died. ${ }^{68}$ Other sections of the Chronicle, which are less immediately focused on the catholicoi, describe how, after these events, Yazdegard was killed by a demon that had long been suppressed by the ministrations of the Christians and was succeeded by Vahram, under whom there was a general persecution of the church. ${ }^{69}$

The patriarchal histories have been garbled in the different medieval compilations: the close succession of shahs and patriarchs means they have placed the persecution of Christians at different points, possibly influenced by a later impression of Yazdegard as a protector of the Christians. ${ }^{70}$ Their narrative produces two features that accord with the material in the Synodicon and the saints' lives. Firstly, the shah selected two catholicoi from Fars, emphasizing the importance of relations with Christians in this, the home province of the Sasanians. Secondly, two figures, Hosea and Narsai are identified as troublemakers, even though the tradition has smoothed over their departure from the diplomatic policies of catholicoi. Hosea is named a 'priest of 'Abda of Ahwaz' during the reign of Iaballaha. He vandalizes a fire temple after a persecution of Christians by the shah's general 'Shapur', and this prompts a wider persecution by the shah.

Narsai appears as a religious vandal in his Syriac saint's life, but this is not mentioned in the Chronicle of Seert. Instead we see him speaking out against

${ }^{66}$ Chronicle of Seert, I/ii, LXI (327-8).

67 This may be the same individual as the mobad Mihr-Shapur who appears in the hagiography of Abgar.

${ }_{68}$ Chronicle of Seert, I/ii, LXII (328-30); Mari, HE, 33/29. Ma'na's successor Pharabokht is only given a brief note in Mari $H E, 36 / 31$.

${ }^{69}$ Chronicle of Seert, I/ii, LXXIV (331-2). This section may be influenced by the Persian royal tradition, since it shares its focus on the objections of the mobads to Yazdegard.

${ }^{70}$ On the later image of Yazdegard see S. McDonough, 'A second Constantine? The Sasanian king Yazdegard I in Christian history and historiography', JLA 1 (2008), 127-40, at 133-4. 'Amr, $H E, 27 / 16$ shifts the persecution to the reign of Iaballaha, Mari, HE, 33-4/29 places the persecution under Ma'na.

This is an open access version of the publication distributed under the terms of the Creative Commons Attribution-NonCommercialNoDerivs licence (http://creativecommons.org/licenses/by-nc-nd/3.0/), which permits non-commercial reproduction and distribution of the work, in any medium, provided the original work is not altered or transformed in any way, and that the work is properly cited. For commercial re-use, please contact academic.permissions@oup.com 
the shah: when Yazdegard claims 'the rights of Caesar within his own domain', Narsai speaks up in place of the catholicos $\mathrm{Ma}^{\text {' }}$ na and tells the shah that 'Caesar does not have the power to force his subjects to change their religion' ${ }^{71}$

The image of a sequence of escalating acts of persecution by the shahs that we receive from the Chronicle has the ring of truth to it, and the presence of a series of minor characters in this account also suggests that early sources have been deployed in the sections on Iaballaha and Narsai. But at several points we can identify important points of difference with the hagiographic tradition, though we cannot necessarily tell when these changes were introduced. Most notably, the image of Hosea's vandalism as a response to earlier persecution, of which there is no indication in the Acts of ' $A b d a$, seems to be an attempt to exonerate Christians from triggering the persecutions themselves. The Chronicle's report of Narsai's interruption of Ma'na seems to imitate that of 'Abda by Hosea in the Acts, which may suggest that the two tales of religious vandalism exchanged material before becoming embedded in the patriarchal history.

The narrative, which may have been included in the patriarchal history at the end of the fifth century, changes several of the features of these stories that conflicted with the authority of the catholicoi. Iaballaha is made to pray for his own death before persecution starts again after Ishaq's intervention, which is probably an invention to preserve the reputation of a famous catholicos and absolve him of any blame for the persecution. ${ }^{72}$ Moreover, by placing a persecution of Christians before Hosea's vandalism, the saint's extreme actions, which produced mixed responses in both Iraq and the Roman world, were rendered more palatable. Similarly, Narsai is relocated from Rayy to Ctesiphon and his own vandalism is replaced by a more reasonable appeal to the equal treatment of religions. Even if Narsai's interruption of the catholicos is based on the Hosea's interruption in the Acts of ${ }^{\mathrm{C}} \mathrm{Abda}$, it is not given any of the egalitarian subtext that we see in the Syriac text.

Thus the Chronicle of Seert reflects a later rewriting of these events, in which the volatile actions of two famous holy men were made to accord with the political positions of later catholicoi. Earlier hagiographies were co-opted into a history centred in Ctesiphon.

\section{CONCLUSIONS}

The career of Ma'na, together with the rebellious factions in the synod of Dadisho' and the Acts of ${ }^{c} A b d a$, point towards the existence of groups of Christians east of Iraq who refused to accept the authority of the shah or to

${ }^{71}$ Chronicle of Seert, I/ii, LXXI-LXXII (327-9).

72 See further discussion in chapter 3.

This is an open access version of the publication distributed under the terms of the Creative Commons Attribution-NonCommercialNoDerivs licence (http://creativecommons.org/licenses/by-nc-nd/3.0/), which permits non-commercial reproduction and distribution of the work, in any medium, provided the original work is not altered or transformed in any way, and that the work is properly cited. For commercial re-use, please contact academic.permissions@oup.com 
curtail proselytism. Perhaps like the Donatists of late Roman Africa they used the language of earlier martyrdoms to continue to accentuate the differences between themselves and the 'secular' society. ${ }^{73}$ This analogy might also extend to their opposition to the catholicos, implied in the 'democratic' language of the Acts of ${ }^{\prime} A b d a$ and explicit in the rebel faction of 424. The shah's attempt to use men like $\mathrm{Ma}^{\text {c }}$ na to control these troublemakers failed, possibly because of the involvement of court figures in selecting unsuitable proxies who were rejected by the rest of the church.

The persecutions unleashed in this era suppressed effective central leadership within the Church of the East: there were no central synods between the years of 424 and 485 . However, the restoration of an influential catholicosate under Acacius in 485 rested on the earlier reforms of Ishaq, not least for the very idea of an Eastern catholicos. The restored catholicosate of the sixth century and beyond would remember a sanitized version of its own history, preserved in the Chronicle of Seert, continuing a trend already seen in the works of Abgar. Here the saint Narsai was reinvented as an ally of the catholicos, which expunged many of the political complexities of the relationship between the shah and the Christians, rewriting history to suit a later era of compromise and cooperation. At the same time, the very idea of forging a history around the person of the catholicos demonstrates a different kind of focus to the hagiographies of the martyrs: the histories of Ishaq and his successors used in the Chronicle of Seert stem from the early fifth century and mirror the centralized image of the church portrayed in the Synodicon. We have seen here that this centralized image was a smokescreen, which obscured real divisions over episcopal authority and the relationship with the state. Yet this mirage would, in time, start to turn itself into a reality: the self-representation of Ishaq's generation would be confirmed by their successors and placed into an imagined lineage that stretched back into the fourth century.

73 P. Brown, Augustine of Hippo: A Biography (London, 1967), 216-19.

This is an open access version of the publication distributed under the terms of the Creative Commons Attribution-NonCommercialNoDerivs licence (http://creativecommons.org/licenses/by-nc-nd/3.0/), which permits non-commercial reproduction and distribution of the work, in any medium, provided the original work is not altered or transformed in any way, and that the work is properly cited. For commercial re-use, please contact academic.permissions@oup.com 


\section{2}

\section{The Martyrs and the Catholicos: The Acts of the Symeon and Their Reinvention}

The hagiographies that we examined in the previous chapter focused on very recent events. They emphasized certain patterns in the relationship between the shah and the mobads, and between Christians and the state, but also discussed events that were very public and probably widely known. Their freedom to alter the details of these stories was curtailed. However, the stories of earlier martyrs from the fourth century could be much more readily adapted, because the older stories were much less detailed and because the events they described lay far from human memory.

In this chapter, I argue that a sense of the historical succession of the martyria, and the connection between fifth-century martyria and their fourth-century predecessors, allowed hagiographers writing in Ctesiphon the freedom to develop the image of the catholicoi as successors to the martyrs. The relic cult of the martyrs itself may have strengthened the importance of the institutional church, which popularized it through episcopal hagiographies. This process was supplemented by the rewriting of important hagiographies into a collection that was built around the great martyr Symeon bar Sebba ${ }^{c}$ e. Symeon provided a model example of martyr, priest, and catholicos, whose reputation could be harnessed by his successors. This chapter investigates the changing role of stories about Symeon and the movement of these stories from hagiography into history, which can be accessed through the early layers of the Chronicle of Seert.

\section{THE RELIC CULT AND THE INVENTION OF HISTORY}

The codas of Abgar's lives all continue the narrative to account for the fate of the saints' relics. The Acts of Narsai describe how the monks took all the separate parts of the saint first to a martyrion built by Marutha and then to a

This is an open access version of the publication distributed under the terms of the Creative Commons Attribution-NonCommercialNoDerivs licence (http://creativecommons.org/licenses/by-nc-nd/3.0/), which permits non-commercial reproduction and distribution of the work, in any medium, provided the original work is not altered or transformed in any way, and that the work is properly cited. For commercial re-use, please contact academic.permissions@oup.com 
second martyrion at Lawarne. ${ }^{1}$ Tataq's body is similarly placed next to that of Narsai 'to cause it to increase and multiply'. ${ }^{2}$ The martyrs of Beth Garmai are 'buried in a pure place'. A bar qyama gathers all of their blood from the trench where they were executed in his cloak, and their relics 'smell as fragrant as spices' and attract people 'from all over their land'. ${ }^{3}$ Most striking of all is the account in the Acts of Jacob the Notary, which describes how the saint's digits and limbs are amputated in turn, before being smuggled in by a barge on the Tigris to a monastery and then to a church in the suburbs of Ctesiphon. ${ }^{4}$ The texts' focus on each of the saints' body parts and their blood, in particular the detailed account in the Acts of Jacob, ${ }^{5}$ suggests that the relic cult already had a popular following when these lives were composed and that several places, possibly all with connections to Abgar's monastery, had a claim on the relics of each saint.

These texts also provide a glimpse into the process of relic collection and the associated propagation of hagiography. Jacob's mother is compared to Shmuni, mother of the Maccabean martyrs, and the text records how she told her story to one Sawmai, bishop of Karka de Ledan. ${ }^{6}$ This same Sawmai appears again in the martyr acts of the fourth-century martyr Martha, daughter of Pusai, a contemporary of the bishop of Ctesiphon, Symeon bar Sebba ${ }^{c}$. She, like Symeon, was killed at Easter for refusing to renounce her faith (and, in her case, marry one of the mobads). Her bones are inherited by her nephew, but when his sons quarrel over her bones, which are kept in the house she had lived in, Sawmai intervened and 'persuades' them to take the bones and present them to the church of Karka de Ledan in $428 .^{7}$

This Sawmai also appears as one of the allies of the catholicos in the 410 synod of Iaballaha and his role in Abgar's hagiographies and those of the companions of Symeon provides a link between the gathering of the relics and stories of the Shapurian persecutions and those of Yazdegard I and

1 Acts of Narsai, $180 . \quad{ }^{2}$ Acts of Tataq, 184.

310 Martyrs of Beth Garmai, 187-8.

4 Acts of Jacob the Notary, 197-200. Also note the creation of a fourth-century martyrion for Mar Miles: Acts of Mar Miles, 274-5.

${ }_{5}$ The torture scene in these Acts provided the core of the fictitious Acts of Jacob the Sliced: P. Devos, 'Le dossier hagiographique de S. Jacques l'Intercis I. La passion grecque inédite (BHG, 772)', AB 71 (1953), 157-210; P. Devos, 'Le dossier hagiographique de S. Jacques l'Intercis. la passion grecque inédite (deuxième article)', $A B 72$ (1954), 213-56; Labourt, Christianisme, 117 note 2. Jacob the Sliced is mentioned in Chronicle of Seert, I/ii, LXXV (332-3). On the collection of this Jacob's 'relics' in the West and the translation of his Acts see C. Horn, Asceticism and Christological Controversy in Fifth Century Palestine (Oxford, 2006), 68 and 200-1.

6 Acts of Jacob the Notary, 199-200.

7 Acts of Martha, 238 and 240-1. R. Payne, 'The emergence of martyr shrines in late antique Iran', in P. Sarris, M. Dal Santo, and P. Booth (eds.), An Age of Saints? Power, Conflict and Dissent in Early Medieval Christianity (Leiden, 2011), 89-113, at 98-9, argues for the delegitimation of the private ownership of relics in these lives, which prioritize the alliance between bishop and city in acquiring the relics of Pusai and Martha.

This is an open access version of the publication distributed under the terms of the Creative Commons Attribution-NonCommercialNoDerivs licence (http://creativecommons.org/licenses/by-nc-nd/3.0/), which permits non-commercial reproduction and distribution of the work, in any medium, provided the original work is not altered or transformed in any way, and that the work is properly cited. For commercial re-use, please contact academic.permissions@oup.com 
Vahram. ${ }^{8}$ His activities mirror those of the catholicos Ahai, who collected the legends of martyrs killed by Shapur in 'Persia' (which may refer to Khuzistan rather than, or in addition, to Fars). ${ }^{9}$ Even more famously, Marutha of Maypherkat was also closely associated with collecting relics in the Sasanian Empire and recording their stories, in an era when the discovery of relics, including those of the proto-martyr Stephen, was an important feature of the religious display of the court of Theodosius II. ${ }^{10}$ The Armenian Life of Marutha, a late sixth-century Armenian adaptation of a Syriac original, relates that Marutha created a martyrion in Ctesiphon and took parts of the same relics to his new city of Martyropolis ( $\left.\operatorname{Cop}^{c} k^{c}\right)$, where he also brought relics from the Roman Empire, 'Asorestan', Persia, and Armenia. ${ }^{11}$

The diplomatic endeavours of Marutha exposed the Church of the East to the organization and heresiology of the Roman church and to sponsorship from the shah and the Roman emperor. The description of Vahram's persecution in the Acts of Peroz show us a church that had found recent wealth from patronage. The author laments the destruction of 'elaborate churches, martyria, monasteries, and the dwellings of anchorites': Mschkena was looted of the treasures of 'Caesar' that had been given thanks to the intercession of Acacius, and Ctesiphon of the treasures given by Iaballaha and Marutha. ${ }^{12}$ But if its recent wealth was robbed, then the pattern of commemoration, which it had also borrowed from Rome, was continued by the catholicos and his allies after Marutha's mission and the later persecutions. And these allowed the Church of the East to emphasize a deeper antiquity, in which it had suffered the same persecutions as the Roman church and which, in time, would provide the root of an independent hagiographical-historical tradition. The indigenous activity is visible in the hagiographic tradition itself, in the recording and development of stories of the Shapurian persecutions in the course of the fifth century. Crucially, the acquisition of relics by Marutha, Ahai, Sawmai, and others was accompanied by the telling and retelling of earlier stories about the persecutions.

These hagiographies were the subject of a detailed study by Gernot Wiessner. Wiessner examined a series of manuscripts, dating from the sixth to the nineteenth century, and observed that the martyrdoms of the bishop of Ctesiphon, Symeon bar Sebba ${ }^{c}$, and the martyrs of Khuzistan stood at the core of all different arrangements of these martyria, which were dated by an

8 Synodicon, $42 . \quad 9$ Chronicle of Seert, I/ii, LXIX (325).

10 On the popularity of martyr discoveries in this era in the West see, e.g., Sozomen, HE, VII, 10; VII, 21; VII, 29 for the relics of Meletius of Antioch, John the Baptist, and the Prophet Habbakuk.

11 Armenian Life of Marutha (tr. Marcus, 67-8). A confused reference to Kavad I as Yazdegard I's grandson suggests that the text as it stands is at least late sixth century, though the main body of the text may be earlier.

12 Acts of Peroz, 256.

This is an open access version of the publication distributed under the terms of the Creative Commons Attribution-NonCommercialNoDerivs licence (http://creativecommons.org/licenses/by-nc-nd/3.0/), which permits non-commercial reproduction and distribution of the work, in any medium, provided the original work is not altered or transformed in any way, and that the work is properly cited. For commercial re-use, please contact academic.permissions@oup.com 
'era of the persecution', possibly modelled on the dating system used by Eusebius in his own account of the Martyrs of Palestine. ${ }^{13}$ Wiessner grouped these texts into two sub-collections, differentiated by plot, style, and geographical location, based respectively around Ctesiphon and Khuzistan and around Adiabene. ${ }^{14}$ Though individual texts might differ substantially in complexity, the parallel message of the accounts all emphasize the defiance of the martyrs and the refusal to worship the elements in spite of the orders of the king. They reflect, in Paul Peeters' words, 'the mutilated debris of a mostly vanished literature' ${ }^{15}$ Here, following Wiessner's work, I focus on the historiographical and cultural historical significance of the texts, viewing these texts as invented histories of the fourth-century written in the fifth and sixth.

\section{SYMEON BAR SEBBA'E: MARTYR FOR A CHRISTIAN PEOPLE}

The Shapurian persecutions presented the raw material from which different actors within the Church of the East could use their history to make their present, presenting themselves, in different ways and in different contexts as a 'church of the martyrs'. The leading example of this elaboration of older martyria following later agendas are the Acts of Symeon bar Sebba'e, fourthcentury bishop of Ctesiphon, which formed the kernel for later collections of martyria set near Ctesiphon and Khuzistan.

The story of Symeon's death is related in two different narratives (A and B) in manuscripts dating from the late fifth and sixth centuries, but seem to originate in an earlier text $(\mathrm{ABx})$ from which both derive common features. This original text told how Symeon, along with various minor characters, was captured and interrogated after quarrels over the payment of 'tribute' by Christians. ${ }^{16}$ The story concludes with his refusal to worship the shah and the elements and his subsequent martyrdom. Certain exact parallels between

13 G. Wiessner, Zur Martyrenüberlieferung aus der Christenverfolgung Shapurs II (Göttingen, 1967), 35-6. Wiessner's work is reassessed by K. Smith, The Persian Persecution: Martyrdom, Politics and Religious Identity in Late Ancient Syriac Christianity (Duke University, unpublished $\mathrm{PhD}$ thesis, 2011).

14 Wiessner, Martyrenüberlieferung, 39. His table of the saints' lives in different manuscripts at 289 is also extremely useful.

15 P. Peeters, 'Le Passionaire d'Adiabene', $A B 43$ (1925), 261-304, at 262. Assemani, BO, IIIa, 74, had attributed these lives to Marutha on the basis of the thirteenth-century catalogue of 'Abdisho' of Nisibis. The dissimilarities between these lives and Marutha's only known sermon suggest this attribution is a later invention. See Murray, Symbols, 34-5.

${ }^{16}$ Smith, Persian Persecution, 240 criticizes Wiessner's reconstruction of ABx's sources (the 'Steuerequelle' and the 'Judenquelle'). At 251-9 he suggests that the anti-Jewish passage found in

This is an open access version of the publication distributed under the terms of the Creative Commons Attribution-NonCommercialNoDerivs licence (http://creativecommons.org/licenses/by-nc-nd/3.0/), which permits non-commercial reproduction and distribution of the work, in any medium, provided the original work is not altered or transformed in any way, and that the work is properly cited. For commercial re-use, please contact academic.permissions@,oup.com 
the later versions A and B probably indicate phrases that were present in the shared source. Symeon's martyrdom was compared to that of Jesus: like him, he was killed on the Friday before Easter. ${ }^{17}$ Symeon was accused of sorcery before the shah and refused to adore the shah, reminding him that his power was transient and ultimately came from $\mathrm{God}^{18}$ and that Jesus alone is Lord of the sun, which the shah worships. ${ }^{19}$ Both $\mathrm{A}$ and $\mathrm{B}$ also include final prayers for 'all the peoples of the east'. ${ }^{20}$

$\mathrm{ABx}$ itself inspired further adaptation and reworking. In $\mathrm{ABx}$, Symeon's sacrifice was seen in terms of an imitation of Jesus on behalf of the East; a principal martyr who eclipsed all others. Symeon is seen as an inspiration for those around him at Shapur's court. What is less clear is how far and when this idea of self-sacrifice was tied to allowing Christians freedom of worship or from excessive taxation. It is possible that references to tax reflect the realities of the fourth-century persecutions, where the shah may have indeed attempted to extract revenue from a population suspected of pro-Roman sympathies.

The first extant narrative about Symeon is the A Acts. It is distinctive for its emphasis on the defiance of the shah by the Christians as a sign of their freedom, not only from tyranny, but also from paganism and from death. Following the original account, the martyrdom of Symeon is represented as an analogue to Christ's death and as a sign of his confidence in the resurrection. It also shows Symeon's vision of authority, which shares much with the attitude of the fifth-century hagiography we have already seen. Here, Symeon justifies his decision not to prostrate himself before the shah, because true authority belongs to Jesus, the true king of kings.

The main body of the text, preceded by a lengthy introduction, proclaims that Symeon, bishop of Ctesiphon, 'died for God and his people' and was their champion, like Judas Maccabeus, in their time of tribulation. This tribulation is clearly connected to the payment of tribute: 'Just as Juda was encouraged by El, God of spirits and removed his people's tribute from the kings of Greece and Syria, so Symeon was made victor by Jesus, son of God, and removed tribute from the kings of Persia and Syria. ${ }^{21}$ The narrative proper opens by describing how Symeon replied to the king's messengers. Symeon tells them that 'Christ has redeemed his church through the shedding of his own blood',

$\mathrm{A}$ is an interpolation based on the B tradition, rather than a reflection of a shared common source.

17 Symeon A, 735-8/Symeon B, 814-15. This emphasis is better preserved in A and appears again in the first interrogation scene (Symeon $A, 746)$. For the location of the events on Good Friday see Symeon A, 763-6/Symeon B, 907-10.

18 Symeon A, 747/Symeon B, 862 and Symeon A, 750/Symeon B, 863. B's focus here is more on the promise of eternal life.

19 Symeon A, 746/Symeon B, 859.

20 Symeon A, 763/Symeon B, $915 . \quad{ }^{21}$ Acts of Symeon A, 731.

This is an open access version of the publication distributed under the terms of the Creative Commons Attribution-NonCommercialNoDerivs licence (http://creativecommons.org/licenses/by-nc-nd/3.0/), which permits non-commercial reproduction and distribution of the work, in any medium, provided the original work is not altered or transformed in any way, and that the work is properly cited. For commercial re-use, please contact academic.permissions@oup.com 
and that he, Jesus, is the true 'king of kings'. Therefore, he says, 'it is not suitable for free men to serve a man'. ${ }^{22}$

The text is focused on Symeon as an inspiration for the whole of his church. The passages immediately before his martyrdom compare him to Simon Peter, 'a fisherman who fished for the divine fish', and present him as 'an example for all the people of the east'. ${ }^{23}$ This emphasis draws us back to the original presentation of Symeon as a bishop-martyr at the start of the text, dying 'for God and his people' and 'freeing the people with his blood'. ${ }^{24}$ The shah's accusation of pride is met by a self-sacrifice on behalf of God's people, circumventing the shah's authority by an action that both honours God and serves his people. The response of others in joining Symeon demonstrates his mandate, as bishop-martyr, as first among equals of the Christian people of the East.

Thus the traditions that evolved around Symeon allow us to see several strands of Christian self-conception coming together. Rather than emphasizing the common nature of Christians everywhere, the people for whom Symeon suffers are his own, 'the people of the east'. Moreover, the association between Jesus' suffering and Symeon's gives the bishop of Ctesiphon a position of leadership by deliberately modelling the text on the Passion narrative. In version A, we are left with a contrast between the people of God, who are led and inspired by Symeon and their priests, and the shah and his mobads, who are never named, and who always remain without personality or arguments and who have relinquished any possible claim to true authority.

\section{DEVELOPING THE ACTS OF SYMEON: AUTHORITY AND THE CATHOLICOS}

The later Acts of Symeon B, is much longer than A, but is derived from the same shared source and follows many of the same points in the narrative. It considerably expands Symeon's prayers and conversations with the shah and inserts a lengthy sermon to his followers. $B$ also develops the issues of taxation that A had touched on and emphasizes the role of the Jews as instigators of the persecution.

Version $B$ begins with two introductory sections that represents the latest levels added to the narrative. The first of these situates Symeon, the 'the first of the blessed martyrs of God in the land of the east' within a longer list of those who died alongside him, while the second provides a political context for the

24 Symeon $A, 727$ and 734.

${ }^{23}$ Symeon A, 758-9 and 763.

This is an open access version of the publication distributed under the terms of the Creative Commons Attribution-NonCommercialNoDerivs licence (http://creativecommons.org/licenses/by-nc-nd/3.0/), which permits non-commercial reproduction and distribution of the work, in any medium, provided the original work is not altered or transformed in any way, and that the work is properly cited. For commercial re-use, please contact academic.permissions@oup.com 
martyrdom, giving Constantine's accession in the Roman world and his death as the reason for Shapur's persecutions. Following this, B begins the account of the narrative proper with Shapur sending out letters for the arrest of priests in Khuzistan. ${ }^{25}$

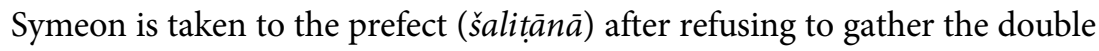
poll tax that the shah has imposed on the Christians, though he emphasizes that he still serves the shah and is prepared to pray for all people. ${ }^{26}$ Then Symeon is brought before the shah in Karka de Ledan after he refuses to enforce the tax. After being taken away along with many of his clergy, he inspires them with a sermon about the apostles and martyrs, and warns them against falling into heresy, after which they acclaim him as a new Simon Peter. $^{27}$

Next Symeon is brought again before the shah, where 'the Magians, prefects, and tyrants' come against him to condemn him for disobedience to the shah and to the gods. Here the accusation links Symeon's refusal to impose the double poll tax with his denial of the gods, whom the Magi invoke to justify their demands and whom they connect with the shah's authority. ${ }^{28}$

However, even at the point of his martyrdom he promises to pray for the shah and offers a summary of his political theology and a lengthy sermon before being put to death. ${ }^{29}$ Finally, the text concludes, with Symeon asking for his spirit 'to join the martyrs, together with the crowd [of martyrs] in West and the holy apostles and prophets', after which the bodies of the deceased are taken away by 'the children of the Roman captives who lived in the city of Karka de Ledan'. 30

As in the A Acts, the parallel between Symeon and Jesus is connected to his death on behalf of the people of the East. In particular, it develops Symeon's role as a model priest. The priests mourn that 'Simon Peter is taken from us; in you we see the apostles. Who will give us such a bishop as you? . . Let God's Cross protect the people of Jesus and the peace of God be with his servants.' 31 More so than in A, there is a sense of the future peace and prosperity of the church. Symeon is made an ideal bishop of the past, responsible for securing the later protection of God's people through his moment of sacrifice.

This image of Symeon as a new Peter is much more prominent in the B Acts: he is acclaimed as such by the crowd of priests. ${ }^{32}$ On one hand, it strengthens the Acts' role as a foundational charter for the authority of the catholicos, by showing Symeon as a touchstone of orthodoxy, whose guidance and leadership is recognized by the priests. But this version of the Acts also emphasizes

25 Symeon B, 784-91.

28 Symeon B, 843-61.

30 Symeon B, 955-8.

32 The comparison to Peter was also present in the original Acts (cf. A, 758), but receives greater emphasis here. 
that Symeon's story is set in the past, an age of persecution that is contrasted with later prosperity. And this idealization of Symeon may provide a benchmark by which the behaviour of later catholicoi might be judged: a perfect bishop-martyr whose memory was intended to both legitimize and constrain the actions of catholicoi at the time of writing. Symeon is not represented here in the model of Judas Maccabeus. Instead he is presented in a more passive role, quietly admitting the state's authority in the material realm while demonstrating faith in God's promises and His protection of the church, an image that also presents a different model of the relationship between shah and catholicos. ${ }^{33}$

Symeon's role as an ideal bishop is further defined through the subject of his arguments with the shah. Unlike version A, these Acts treat the issue of Symeon's obedience to the shah and the worship of the pagan gods in the context of arguments over taxation. The shah orders Symeon's capture in order to gather a double tribute from the Christians in the context of his war with Rome. ${ }^{34}$ The prominence of the issue of tax here suggests that high taxes may have indeed represented a fourth-century grievance. ${ }^{35}$ But the B Acts' emphasis on the role of bishops in collecting tax points to a different problem, the catholicos' problematic role as middleman between the state and the Christian community, which may have emerged as a particularly live issue.

In his initial interview with the prefect, Symeon states that he honours the shah, but refuses to gather a tax from his people-'my power is invisible, not visible' - and he objects that he would be unable to act as a priest if he held secular power. The prefect is initially happy with Symeon's reply: 'Since all authority is from God, then you are subject to Shapur, king of kings and lord of the whole earth.' But Symeon retorts that Christians only have to give [normal] tribute to the tribute-gatherer, but not a double tax (ksep riš $\bar{a}$ 'apipā), and that conversion or accepting the honours of the shah is not a way out of this situation: 'We will give you our bodies, property, homes and possessions but not our souls ... do not let him force us to be like tyrants or prefects over our brothers, who are God's people, for our power is not from earthly kings but from the heavenly king.' Symeon refuses to be 'a tyrant over his humble people. ${ }^{36} \mathrm{He}$ is denounced for his refusal to 'oppress the poor' by the 'Magians,

${ }^{33}$ It is only in B that Symeon is referred to as catholicos, instead of 'metropolitan', suggesting a development in the authority of Ctesiphon over time, which is mirrored by the changing terminology of the synodal acts. Symeon B, 958. See further below on the dating of B.

34 Symeon B, 790.

35 D. Goodblatt, 'The poll-tax in Sasanian Babylonia: The Talmudic evidence', JESHO 22 (1979), 233-95 sees the tax as a serious burden for the Jews at this time. Smith, Persian Persecution, 152-3 and 277-9 doubts that specific religious groups were actually targeted, though there may have been war taxes of some form during conflicts in Central Asia or with the Romans.

36 Symeon B, 799-802.

This is an open access version of the publication distributed under the terms of the Creative Commons Attribution-NonCommercialNoDerivs licence (http://creativecommons.org/licenses/by-nc-nd/3.0/), which permits non-commercial reproduction and distribution of the work, in any medium, provided the original work is not altered or transformed in any way, and that the work is properly cited. For commercial re-use, please contact academic.permissions@oup.com 
prefects, and tyrants'. In reply, he contends that he has no secular power, but that his power comes from God 'in whom all are free'. ${ }^{37}$

The B Acts are always careful to acknowledge the shah's authority: unlike in A, Symeon here makes obeisance to the shah and acknowledges that 'the king of kings controls the whole world' and that Christians must pray for him. ${ }^{38}$ This is not A's strident assertion of Jesus, rather than the shah, as king of kings. Instead of this, B presents an image of Symeon that emphasizes his role as priest and passive martyr and sees this as the root of the catholicos' authority. The text distinguishes this authority from other possible sources of authority, such as helping the shah to tax the Christians, which is tantamount to tyranny and apostasy. These may represent particular concerns of the author that he has picked out from his sources, details that will help us to situate the text. Discrimination in the tax laws and the involvement of the catholicos in secular government represent the anxieties of the author about the political actors of his own day, anxieties that he has projected onto his account of Symeon.

\section{THE ACTS OF SYMEON AND THE CONTROL OF HISTORY}

The Acts of Symeon are much more significant as examples of the historical reinvention of the Church of the East than as sources for a 'kernel' of fourthcentury social realities. ${ }^{39}$ How we analyse these texts depends on when we date them. I suggest that the A Acts seem to fit into the context of the mid-fifth century, injecting a Maccabean emphasis on active martyrdom into the earlier emphasis on Jesus. Here Symeon's role as a martyr is at the centre of his demonstration of freedom and his leadership of Christian people, a role that seems to present parallels to the active opposition to the Sasanian state seen in the Acts of 'Abda.

Version B seems to be the product of a subsequent era. The sense of the renewed economic prosperity of the church in the future differs from the sense of continued struggle in A. References to obscure heretical groups such as the 'Kataye' suggests a late fifth-century terminus post quem for the creation of the text as it stands. ${ }^{40}$ Finally, in spite of the emphasis on Symeon as a chief priest, the concerns over the catholicos' cooperation with the shah's government does suggest that the author has bad, 'tyrannical' catholicoi in

37 Symeon B, 846-7. $\quad 38$ Symeon B, 843, 858, 922.

39 See the comments of S. Brock, 'Review of Wiessner', JTS (new series) 19 (1968), 300-9.

40 Symeon B, 824-6. On the Kataye and their appearance in the heresy list see W. Madelung, 'Abū İsā al-Warrāq über die Bardesaniten, Marcioniten und Kantäer', in H. R. Roemer and A. Noth (eds.), Studien zur Geschichte und Kultur des Vorderen Orients: Festschrift für Bertold Spuler zum siebzigsten Geburtstag (Leiden, 1981), 221-4 and W. Madelung, 'Battai Yazdani', in EIr. The text's anti-Theopaschite theology also gives a late fifth-century terminus post quem.

This is an open access version of the publication distributed under the terms of the Creative Commons Attribution-NonCommercialNoDerivs licence (http://creativecommons.org/licenses/by-nc-nd/3.0/), which permits non-commercial reproduction and distribution of the work, in any medium, provided the original work is not altered or transformed in any way, and that the work is properly cited. For commercial re-use, please contact academic.permissions@oup.com 
mind, even if he supported the rule of a good catholicos who followed the model of Symeon. This image might reflect the division of the catholicosate between Narsai and Elishe in the 530s. By this era, the catholicos-martyrs remained the most important symbol of the authority of Ctesiphon, but there was less of a wish to actively oppose the shah. Instead, the focus is more upon the boundaries between Christian groups and the catholicos' cooperation with the shah. The Chronicle of Seert presents the catholicos Narsai as a pious theologian and his rival Elishe as a medical doctor with court connections. ${ }^{41}$ If this dating is accurate, then the emphasis on Symeon as a priest may be a product of Narsai's faction in this episcopal dispute.

Both cases show us how the golden age of the Shapurian persecutions could be invoked in later eras to fit changing circumstances and attitudes to the state. The B Acts in particular show how a simple story was worked up into a much longer narrative, which established the hagiography's connection to parallel events in the West and promoted an awareness of a relic cult based around in the saint. An assertion of the prestige of the catholicosate, as successors to the catholicos-martyr, was tied to requirements for the good behaviour of future catholicoi, where Symeon's example provided a set of conditions for the holder of his office. And, significantly, by circulating as the first and most developed piece of a longer hagiographic collection describing the martyrs of Ctesiphon and Khuzistan, the Acts also emphasized the superiority of the catholicosate as successor to the martyrs, and transcended the fame of individual sites of martyrdom and martyrs' relics, such as Karka de Ledan ${ }^{42}$ and HormizdArdashir in Khuzistan or Karka de Beth Slouq and Arbela in the north of Iraq. ${ }^{43}$

The rewriting of the Acts of Symeon places a heavy focus on the personalities of the catholicos-martyr and the shah and presents Symeon as the lynchpin of Christian hopes and ideals, whose sacrifice is made on behalf of the whole land. The use of an era of persecution beginning with Symeon implies that other hagiographies were co-opted into this image. Many hagiographies are dated according to the year of the persecution, seeing Symeon's death as the beginning of a defining era. However, this is not a uniform feature of all saints' lives set in during the Shapurian persecutions. Others use Shapur's reign or are arranged into collections dated by another saint, Mar Miles, a prominent opponent of Papas, Symeon's predecessor as bishop of Ctesiphon. ${ }^{44}$ Various places and traditions preserved or developed

${ }^{41}$ Chronicle of Seert, II/i, XXV (147-52).

42 The site of Sawmai's martyrion and source for a very early list of confessors: Symeon $B, 830$. See Wiessner, Martyrenüberlieferung, 74.

43411 Martyrion, 23-6. See also the list of martyr sites at the end of the section on Symeon in 'Amr, $H E, 18 / 11$.

${ }^{44}$ Wiessner, Martyrenüberlieferung, 34 on the use of 'years of the persecution'; 39 on the division of the cycles into 'episch-narrative Martyrerakte' and 'Martyrerkatalog' and 276-81 on

This is an open access version of the publication distributed under the terms of the Creative Commons Attribution-NonCommercialNoDerivs licence (http://creativecommons.org/licenses/by-nc-nd/3.0/), which permits non-commercial reproduction and distribution of the work, in any medium, provided the original work is not altered or transformed in any way, and that the work is properly cited. For commercial re-use, please contact academic.permissions@oup.com 
their own martyr histories without direct reference to or incorporation in these collections based around the catholicos-martyr.

Much as we recognize the importance of Symeon's reputation for the later development of hagiographic collections in the Church of the East, we should also note that it was not all-encompassing, and that the accounts of Symeon's successors as bishops of Ctesiphon were never developed into ideals of priesthood and martyrdom to the extant that he was. The Lives of Symeon's successors Shahdost and Barba'shemin follow several of the themes of the portrayal of Symeon, refusing the shah's honours in favour of a heavenly reward and passively accepting the authority of the shah, and the latter at least seems to have been rewritten in the spirit of the B Acts. But, notably, neither text matches the Acts developed for the minor characters of Symeon's martyrdom, such as Pusai, Martha, and Tarbo, whose lives continued to be elaborated and developed as late as the early sixth century. ${ }^{45}$ I suspect that it shows that Symeon's reputation and prestige was only weakly associated with the office of the catholicos per se and that hagiographers and scribes did not initially draw great attention to the institutional position of Symeon and his successors as catholicoi. ${ }^{46}$

An important stage in the political representation of the bishops of Ctesiphon, with regard to other Christians, the shah and the churches in the West, was the emphasis on their connection to this line of martyred bishops as a guarantee of their prestige. As we have seen, one way of organizing the historical information to do this that we have seen was a dating system based on 'years of the persecution', probably modelled on Eusebius' account of the martyrs of Palestine. Another was the production of a 'history of the patriarchs' that presented the deeds and education of the fifth-century patriarchs in a continuum with earlier holy men, and, most especially, the catholicoi martyred under Shapur II. This structure may be indebted to Eusebius' Ecclesiastical History, which includes a great deal of material on the martyrs but places it in a broader framework that also considers the succession of bishops and of 'schools' of theologians. ${ }^{47}$ This patriarchal history, which will

the Arbela 'Redaktor'. See the Martyrs of Beth Zabdai for dating by the shah's reign or the Acts of Barsaba for association with Miles.

${ }^{45}$ G. Wiessner, 'Zum Problem der zeitlichen und örtlichen Festlegung der erhaltenen syroPersichen Märtyrerakten: das Pusai-Martyrium', in Paul De Lagarde und die syrische Kirchengeschichte (Göttingen 1968), 231-51.

${ }^{46}$ E.g. Barba'shemin is only referred to as catholicos in the title of his Syriac Acts, but not in the text itself, suggesting this is a later addition. The section on Symeon in the Chronicle of Seert (I/i, XXVII (304-5) does not mention Symeon's immediate successors, suggesting that Shahdost and Barba'shemin were unknown to the author of the hagiography used by the compiler. Sections on these two men in the Chronicle must therefore come from alternative hagiographic traditions.

${ }^{47}$ Eusebius' Ecclesiastical History also culminated in the conversion of Constantine, providing a precedent for the incorporation of secular affairs into Iraqi ecclesiastical history in the sixth century. See further T. D. Barnes, Constantine and Eusebius (Cambridge, Mass., 1981).

This is an open access version of the publication distributed under the terms of the Creative Commons Attribution-NonCommercialNoDerivs licence (http://creativecommons.org/licenses/by-nc-nd/3.0/), which permits non-commercial reproduction and distribution of the work, in any medium, provided the original work is not altered or transformed in any way, and that the work is properly cited. For commercial re-use, please contact academic.permissions@oup.com 
be discussed in the following chapter, provided a framework that tied the bishops of Ctesiphon much more firmly to the golden age of the fourthcentury martyrs and to other prestigious aspects of Christian culture.

Historians allied to later catholicoi produced a more radically pruned version of the Acts of Symeon. These texts, embedded in later Arabic historical compilations, render Symeon as a much less complicated figure. 'Amr produces a particularly bland account, which emphasizes Symeon's priesthood without making him an opponent of tyranny, and it may be most representative of the early image of Symeon in the 'patriarchal histories' ${ }^{48}$ Like the Syriac B Acts, the Arabic accounts emphasize Symeon's position as priest and 'alter Christus', and they add comments on Symeon's deeds as the source of a priest's actions during the liturgy. ${ }^{49}$ They also spell out much more clearly the fact that Symeon was succeeded by Shahdost and Barba'shemin and by later catholicoi. ${ }^{50}$

The history embedded in the Chronicle of Seert provides us with the fullest, though not the least altered, version of Symeon's martyrdom. ${ }^{51}$ Like the B Acts it emphasizes Symeon's passivity before the shah and his acceptance of Shapur's right to rule. Symeon is taken for granted as a type both for priesthood and for martyrdom in general. The author re-emphasizes the primacy of Symeon's example, briefly passing over other martyrdoms in northern Iraq, and recalls the gathering of Symeon's relics by Greek captives at Karka de Ledan. ${ }^{52}$

Yet this version of the martyrdom has been adapted, both to fit later political concerns and its new position within a history, juxtaposed to political events that had not been considered by the hagiographic tradition. Thus the resistance of the Roman city of Nisibis to the Persians, under its famous bishop Jacob, is anachronistically seen as a cause of the shah's anger and his persecution of Symeon, which reflects the adaptor's awareness of West Syrian hagiography (though not of its accurate date). ${ }^{53}$ Similarly, Symeon's demands that monks be protected from taxation probably represent an addition of the

48 'Amr, HE, 16-9/10-11. All of the narratives in the medieval compilations derive from the same tradition that also gave rise to the B Acts. 'Amr's description of Symeon's companions has 'priests and deacons', while Mari and the Chronicle of Seert adds 'bishops and metropolitans', which might suggest that 'Amr reflects a tradition about Symeon that is older, or at least less comprehensively revised, than those in the other chronicles or the B Acts that survive in Syriac.

${ }^{49}$ Mari, $H E, 17 / 15$.

50 'Amr, HE, 19-20/11-12; Mari, HE, 19-21/16-18. The sections on Symeon's successors here are no more than perfunctory entries, vehicles for unrelated material from Roman ecclesiastical history, reflecting the paucity of the hagiographies.

${ }^{51}$ Chronicle of Seert, I/i, XXVII (298-305).

${ }^{52}$ Chronicle of Seert, I/i, XXVII (305). Wiessner (Martyrenüberlieferung, 84 note 4) suggested that this section formed the introduction to a hagiographic collection. If so, then it may have formed part of a movement to reduce the individuality of other saints' lives and to re-present them as lesser images of Symeon's martyrdom.

${ }^{53}$ Chronicle of Seert, I/i, XXVII (297-9). On the (exaggerated) representation of Nisibis as a Christian city, and its connection to the eastern persecutions in West Syrian and Greek historiography, see Smith, Persian Persecution, esp. 15.

This is an open access version of the publication distributed under the terms of the Creative Commons Attribution-NonCommercialNoDerivs licence (http://creativecommons.org/licenses/by-nc-nd/3.0/), which permits non-commercial reproduction and distribution of the work, in any medium, provided the original work is not altered or transformed in any way, and that the work is properly cited. For commercial re-use, please contact academic.permissions@oup.com 
sixth century or later, following the explosion of monastic foundations under Abraham of Kashkar (c.560). ${ }^{54}$

As we saw in the presentation of the fifth-century martyrs, the Chronicle of Seert has incorporated Symeon into its universal narrative. Symeon has a starring role in a long section that presents him as both martyr and catholicos, whose presence grants some of the prestige of the martyrs to his successors as catholicos. Yet, at the same time, Symeon's image is altered to fit his context: not only is he relatively passive, following the example of the B Acts, he has also been used to press for monastic exemptions and connected to figures in the West. In both cases, the image of Symeon serves the agendas of sixthcentury catholicoi, who presented themselves as allies of the monastic movement and as peers of the patriarchs of the West. ${ }^{55}$

If the Syriac B Acts reflect the problems of the catholicos' role in government and of the idea of tyranny, then the abbreviated use of Symeon's Acts in the patriarchal history may have deliberately avoided such questions and concentrated on Symeon's role as a priest, and, by implication, on the catholicos as his successor as head of the priests. ${ }^{56}$ Most importantly, the embedding of Symeon into history based around the succession of catholicoi would attach the prestige of his memory, as an ideal martyr and priest, to the institution of the catholicosate, a memory that was not attached to the ideal relationship between catholicos and shah that is seen in the B Acts.

\section{CONCLUSIONS}

The inclusion of Symeon's Acts in the medieval compilations and the form they take reflect several layers of rewriting. Symeon had been associated with the catholicoi from at least the gathering of brief lists of martyrs under Ahai and the writing of hagiography that followed it. ${ }^{57}$ Early traditions fed into our two extant Syriac Acts: A, produced in the mid-fifth century and B, produced in the early sixth. The versions found in the medieval compilations belong in tradition of the B Acts, though they may derive from texts composed before the B Acts themselves. The longer account found in the Chronicle of Seert is part of this family of narratives, but shows signs of substantial later editing.

The Acts of Symeon could serve as a vehicle for different political sentiments, both with regard to opposition to an impious state and the creation of

${ }^{54}$ For this later expansion of 'Abrahamic' monasticism see chapter 6.

55 For these trends see chapters 5-6. Also note W. de Vries, 'The college of patriarchs', Concilium 8 (1965), 35-43.

56 This is especially visible in 'Amr's account (HE, 16-9/10-11).

57 Chronicle of Seert, I/ii, LXIX (327-8) for Ahai's role as a hagiographer. The 411 Martyrion reflects the very low level of detail such martyr lists must have had.

This is an open access version of the publication distributed under the terms of the Creative Commons Attribution-NonCommercialNoDerivs licence (http://creativecommons.org/licenses/by-nc-nd/3.0/), which permits non-commercial reproduction and distribution of the work, in any medium, provided the original work is not altered or transformed in any way, and that the work is properly cited. For commercial re-use, please contact academic.permissions@oup.com 
an ideal priestly image for the behaviour of the catholicos. Embedding this material in a history strengthened the connection to later catholicoi, and this was probably an obvious motive for the composers and compilers of later history.

This chapter and its predecessor have shown how the tensions present in the Syriac hagiographies were reworked when embedded into sequential histories. More neutral representations of the martyrs as ideal priests and passive victims suited the agenda of later catholicoi, who wished to pursue peaceful relations with the shah and stress their own authority over their coreligionists. The construction of their 'patriarchal' historical tradition, which had this centralizing agenda at its core, will be the focus of the next two chapters. 


\section{The Patriarchal Histories: Genesis of a Centralizing Narrative}

The development of histories focused on the acts and succession of the catholicoi represented an important means of linking incumbents of the see of Ctesiphon to their prestigious forebears, and asserting their importance over the other sees of the Sasanian world. We have seen how Ishaq benefited from a period of peace between Yazdegard and the Romans to assert his new authority, with the aid of the Roman bishop Marutha. Ishaq's coup was followed by a new interest in the relic cult for the fourth-century martyrs: mirroring trends in the West, Ishaq's successor Ahai collected the first martyr acts for the Church of the East.

Renewed antipathy to Christianity from Yazdegard's successors meant that Ahai's initiative was not developed immediately (perhaps because educational and scribal centres were starved of the funds they briefly enjoyed at the start of the century). I have argued that the A version of the Acts of Symeon was composed in this era, and that it tended to focus on the role of Symeon as an opponent of the shah, rather than as a model for catholicoi in the fifth century, who did not take such a strong stance against the state.

The 480s witnessed a renewed centralization of church structures, focused once more on Ctesiphon. I suggest that this era saw the first collation of a history of the catholicoi, based around older bishop lists and fleshed out using hagiographies. This history asserted the connection between contemporary catholicoi and previous golden ages of the church, the martyrdom of Symeon and his successors and the first synod of the church under Ishaq and its aftermath. This history attempted a totalizing view of the past, addressing popular hagiographic traditions from outside Ctesiphon that painted earlier catholicoi as tyrants and filling in the embarrassing lacunae in the church's memory that occupied much of the fourth century.

Earlier chapters have concentrated on the hagiographies that represented the older, traditional vehicles for ideas about the past, and have only occasionally glanced ahead to how these memories were transformed in the historical tradition. Since the sources do not survive in their original form,

This is an open access version of the publication distributed under the terms of the Creative Commons Attribution-NonCommercialNoDerivs licence (http://creativecommons.org/licenses/by-nc-nd/3.0/), which permits non-commercial reproduction and distribution of the work, in any medium, provided the original work is not altered or transformed in any way, and that the work is properly cited. For commercial re-use, please contact academic.permissions@oup.com 
I adopt a slightly different approach here, setting out the medieval redactions of the fifth- and sixth-century patriarchal chronicles before attempting to reconstruct these early compositions and investigate their significance for the cultural and political self-presentation of the catholicosate of Acacius through its reorganization of the past.

\section{THE MEDIEVAL COMPILATIONS: BAR HEBRAEUS, MARI, AND 'AMR}

The reconstruction of the composition and content of a Christian historical tradition in Iraq is dependent on five medieval histories, four in Arabic and one in Syriac. The Chronicle of Seert is the richest and most important of these, but the other compilations also provide important information on the material available to medieval Christian historians and their working methods. Following the methodology outlined in the introduction, I argue that it is possible to isolate material in these chronicles pertaining to the catholicoi that is either related to known sources (such as the Acts of Symeon) and/or fits into narrative strands that run through the history. In this way, it is possible to isolate the components of later compilations, each of which show signs of development by different anonymous authors.

Three of these five texts also include large amounts of additional material drawn from Roman ecclesiastical history, monastic saints' lives, and the histories of the School of Nisibis. This material represents additions of the late sixth century and after. In my view, the earlier patriarchal histories of the late fifth and middle sixth centuries were a single, connected tradition, distinct from these later additions, which can still be traced in the medieval sources. Similarly, the extension of the patriarchal lists back to Thomas and Addai as apostles of the East also represents a later innovation. Thus, the history expanded both 'horizontally', including new areas of interest, and 'vertically', both through successive continuations and through the elaboration or invention of a poorly known past.

The three simplest of the medieval sources are also the latest in date. These are the Ecclesiastical Histories of the Syrian orthodox maphrian ${ }^{1}$ and polymath Bar Hebraeus, and of Mari ibn Sulayman and 'Amr ibn Matta of the Church of the East. Bar Hebraeus (d.1268) composed a detailed ecclesiastical history in three volumes, of which the first two describe the political history of the world and the history of the (Miaphysite) patriarchs of Antioch, while the third is

${ }^{1}$ Bishop of the Jacobite East, second only to the patriarch of Antioch. See W. Hage, Die syrisch-jakobitisch Kirche in frühislamischer Zeit: nach orientalischen Quellen (Wiesbaden, 1966), 23-32.

This is an open access version of the publication distributed under the terms of the Creative Commons Attribution-NonCommercialNoDerivs licence (http://creativecommons.org/licenses/by-nc-nd/3.0/), which permits non-commercial reproduction and distribution of the work, in any medium, provided the original work is not altered or transformed in any way, and that the work is properly cited. For commercial re-use, please contact academic.permissions@oup.com 
dedicated to 'the East'. 'This history presents the early catholicoi as precursors to the late sixth-century Miaphysite maphrians Ahudemmeh and Marutha of Takrit, the leaders of the Syrian Orthodox in 'the East'.

Bar Hebraeus presents events under each catholicos in turn, with a narrative focused upon their actions until the time of Barsauma. Bar Hebraeus imagines Dadisho ' (reigns from 422) as the last 'orthodox' catholicos before the heresy of Barsauma destroyed 'orthodoxy', by importing Nestorianism, and monasticism, by removing clerical celibacy. He emphasizes the resistance of Miaphysite centres (Armenia, Takrit, and the monastery of Mar Mattai) to Barsauma and to Nestorianism, and he uses this resistance to claim a continuity of Miaphysite orthodoxy down to the missionary bishop Ahudemmeh and, ultimately, to himself. ${ }^{3}$ Bar Hebraeus' vision of the catholicoi as antecedents of the maphrianate, coupled with the ecumenism of his own theology, make him a credible transmitter of the history of the catholicoi, especially since he presents it in Syriac, the original language of these traditions, rather than in Arabic.

Mari and 'Amr composed their respective histories around the 1140s and 1320s. Both histories were written as parts of a longer work, the Books of the Tower, encyclopaedic texts that described and defended the theology, liturgy, and religious traditions of the Church of the East. ${ }^{4}$ Both texts seem to rely on identical Syriac sources, often transcribing the Syriac directly into Arabic, though their translations are independent. Mari's Book of the Tower includes 'a history of Christ and the apostles and a history of the patriarchs' and declares his intention to describe the patriarchs' birthplaces and teachers, their places of ordination, the length of their reigns, the 'saints, kings, and rulers of their time and their places of burial' (book V). Notably, he complains about the lack of historical works and the paucity of manuscripts dealing with the catholicoi, and presents his effort as a work of original research written on behalf of the catholicos. ${ }^{5}$

${ }^{2}$ On his career see H. Takahashi, Barhebraeus: A Bio-bibliography (Piscataway, NJ, 2005).

${ }^{3}$ See esp. Bar Hebraeus, HE, III, 67-73 on Barsauma and sites of resistance against him. On Mar Mattai and its rivalry with Takrit see Hage, Die syrisch-jakobitisch Kirche, 38.

${ }^{4}$ B. Holmberg, 'A reconsideration of the Kitab al-Magdal', PdO 18 (1993), 256-73 argues that the chronicle in the text attributed to Mari was written $c .1000$ and embedded later in this religious encyclopaedia, because of the author's claims to be an eyewitness to these events and the text's theological vocabulary. He also questions the identification of the authors, though I refer to them by their traditional names because no other works are attributed to either men.

${ }^{5}$ This description is based on G. Putrus, Kitab al-Magdal (Paris, Sorbonne, unpublished PhD thesis, 1968), 8-12 and 51-65, who chiefly consulted MS Paris Arabe 190. Also see Assemani, BO IIIa, 554-5 and 582; G. Graf, La littérature nestorienne, tr. J. Sanders (Heemstede, 1985), 140-3 and E. Yousif, Les chroniqueurs syriaques (Paris, 2002), 377-9. G. Westphal, Untersuchungen über die Quellen und die Glaubwürdigkeit der Patriarchenchroniken des Marī ibn Sulaimān, 'Amr ibn Mattai und Șalība ibn Johannān. Abschnitt 1 Bis zum Beginn des Nestorianischen Streites (Kirchain, 1901) remains thought-provoking. All manuscripts of Mari are eighteenthcentury copies.

This is an open access version of the publication distributed under the terms of the Creative Commons Attribution-NonCommercialNoDerivs licence (http://creativecommons.org/licenses/by-nc-nd/3.0/), which permits non-commercial reproduction and distribution of the work, in any medium, provided the original work is not altered or transformed in any way, and that the work is properly cited. For commercial re-use, please contact academic.permissions@oup.com 
'Amr's Book of the Tower adopts a slightly different theological focus that made a more polemical use of history in asserting 'Nestorian' primacy. It begins by asserting the East as the place of origin of all things necessary for salvation: it is the most glorious land, the first place inhabited by men; the prophecies of Christ come from the East, especially from among the Zoroastrians, and the apostles first spread the word in 'Babylon and Chaldea'. ${ }^{6}$ This assertion of the East as a chosen land is a preparation for declaring it the site of the first church as well, a suitable fountainhead of orthodoxy. 'Amr continues by setting out various lists of ecclesiastical and political figures: of the patriarchs of Rome, Alexandria, and Antioch, of the successors to James at Jerusalem, of the pagan emperors at Rome, of the men who attended the council of Nicaea, and of the patriarchs and emperors at Constantinople (book III). After a condemnation of Jews and heretics (book IV), he then provides his history of the apostles and of the patriarchs of the East (book V). ${ }^{7}$

Both Books of the Tower employ history as part of an encyclopaedic initiative that sought to defend the faith of the Church of the East and employed older records in doing so. The similarity of their accounts of the patriarchs to one another, and to that of Bar Hebraeus, especially for the period between the fourth and sixth centuries, suggests the existence of shared Syriac sources for this information. All three accounts focus on the lives and deeds of the catholicoi, and Mari and 'Amr in particular give the origins, burial places, and reign lengths of the catholicoi (though their dating for their reigns do not always agree, which may indicate that it was sometimes produced by later calculation). And all three accounts incorporate related material on apostolic origins of the church, the martyr-bishops of the fourth century, and the more historical catholicoi of the fifth century.

The principal differences between the texts is that Mari supplements his account of the catholicoi with an additional narrative drawn from Roman ecclesiastical history, similar to the kind of material included in Eusebius or Sozomen. Mari begins to inject this additional material into his text in the reign of Shalupha, the (probably mythical) predecessor to Papas, and intersperses this additional material into the lives of the patriarchs until the period of Acacius and Babai. After this point Mari continues to include material peripheral to the lives of the catholicoi, but it tends to be drawn from East Syrian saints' lives, ${ }^{8}$ rather than from Roman ecclesiastical sources. 'Amr's history, on the other hand, is much more closely focused on the deeds of the catholicoi: where Mari attempts to splice two quite distinct narratives, 'Amr restricts his additional information to Eastern holy men who are somehow

${ }^{6}$ Putrus, Kitab al-Magdal, 23; Assemani, BO IIIa, 586-9; Graf, Littérature nestorienne, 166-7.

Compare the claims of the patriarch Timothy, Letter 26.

7 Putrus, Kitab al-Magdal, 25-9.

${ }^{8}$ E.g. the Life of the monastic founder Abraham of Kashkar: Mari, HE, 52/45-6.

This is an open access version of the publication distributed under the terms of the Creative Commons Attribution-NonCommercialNoDerivs licence (http://creativecommons.org/licenses/by-nc-nd/3.0/), which permits non-commercial reproduction and distribution of the work, in any medium, provided the original work is not altered or transformed in any way, and that the work is properly cited. For commercial re-use, please contact academic.permissions@oup.com 
involved with the catholicos (such as Mar 'Abda) or simply lists churchmen, martyrs, or heretics living at the same time as the catholicos. ${ }^{9}$ He only includes information not found in Mari when it directly pertains to the catholicos, such as lengthy sermons attributed to Symeon bar Sabba'e and the invented descriptions of the catholicoi that begin most sections (e.g. 'Tomarsa was an old man with a large beard, and he was self-controlled and pious'). ${ }^{10}$ Bar Hebraeus is the most terse of the three chroniclers until the crisis with Barsauma, when his history becomes a mixture of information focused upon Mar Mattai and Takrit with Miaphysite exegesis of the traditional historical narrative of the Church of the East.

\section{THE MEDIEVAL COMPILATIONS: THE CHRONICLE OF SEERT AND THE HADDAD CHRONICLE}

The three later chronicles are all structured around the lives of the catholicoi, and these provide the headings within their histories. The two earlier chronicles, the Chronicle of Seert and the Haddad Chronicle differ in that the catholicoi do not provide such a dominant focus for the text. This more confused, voluminous structure was caused by the accretion of large amounts of new material onto earlier records of the catholicoi in the production of several similar histories that incorporated this patriarchal tradition. All of these histories then provided material for medieval compilers, who juxtaposed sections drawn from earlier ecclesiastical historians, sometimes registering the differences between the historians and sometimes including contradictory accounts alongside one another without comment.

The second of the longer chronicles is a recent discovery: it was identified by Butrus Haddad from a collection of manuscripts in the Chaldean patriarchate in Baghdad before being published in 2000, and its similarities to the Chronicle of Seert meant that it was originally identified as a missing portion of it. However, the inclusion of different material, particularly several histories of Hira, shows that it was the work of a different compiler. The manuscript is dated by colophon to 1137, though Haddad argued that the work itself had been composed in the tenth century, on the basis of the catholicoi known to the author. ${ }^{11}$ This chronicle, Mukhtasar al-akhbār al-bi ${ }^{\mathrm{i}} \mathrm{y} y a$, referred to here as

\footnotetext{
${ }^{9}$ In passages similar to the lists of churchmen in the Chronicle of Seert (e.g. I/i, VIII (236); XXV (292).

10 For the speeches see 'Amr, HE, 15-6/9 and 24/14. See HE, 21/12 for the description of Tomarsa.

${ }^{11}$ Letter from Fiey to Haddad (1988). See further H. Teule, 'L'abrégé de la chronique ecclésiastique Muhtasar al-akhbar al-bi'iyya et la chronique de Séert: quelques sondages', in Debié, L'historiographie syriaque, 161-77.
}

This is an open access version of the publication distributed under the terms of the Creative Commons Attribution-NonCommercialNoDerivs licence (http://creativecommons.org/licenses/by-nc-nd/3.0/), which permits non-commercial reproduction and distribution of the work, in any medium, provided the original work is not altered or transformed in any way, and that the work is properly cited. For commercial re-use, please contact academic.permissions@oup.com 
the Haddad Chronicle, is only the first volume of a longer text and only extends from the birth of Jesus to the end of the fourth century, devoting its final section to Epiphanius of Salamis. It begins by recounting the events of the Gospels, before describing the origins of the sacraments. ${ }^{12}$ Next the compiler devotes around a third of the book to the activities of the apostles, including Mari and Addai, apostles of the East. After this he describes the ranks of the priesthood and the organization of the church, as well as the comparative standing of the patriarchs, in a short but dense passage that is separated from the narrative episodes that follow it. ${ }^{13}$ All of this material, while not found in the Chronicle of Seert as it now stands, has parallels in the inclusion of Christ's life and the deeds of the apostles in Mari and in the ecclesiological content of book III of 'Amr's work.

The final third of the text is a narrative of the church fathers from the early catholicoi to the time of Ephraem and Theodore of Mopsuestia. This final part of the history is similar in composition to the Chronicle of Seert, and it includes the catholicoi in the same sequence and intersperses these accounts with stories of other fathers of the church.

\section{ACACIUS’ HISTORY}

The medieval sources all employ traditions built around the catholicoi and show signs, more marked in the later, simpler chronicles, that the catholicoi represented the principal criteria for dating material. Indeed, material drawn from dated sources (by year or by the shah's reign) has been repositioned to fit into this sequence of the catholicoi. This structural primacy of the catholicoi suggests that it represented the chief model for East Syrian historiography from a relatively early date, and that this common pattern represents the shared sources of the more complex ecclesiastical histories composed in the sixth century and after, which in turn formed the raw material for the medieval compilations.

In addition to these medieval compilations, our reconstruction can also use a series of lists of the patriarchs. These correspond to the kind of information on the patriarchs presented by 'Amr, except that they are frequently limited to length of reign, origin, and place of burial. Three examples exist, composed in the fifth, ninth, and eighteenth centuries. ${ }^{14}$ The composition of such lists

12 Haddad Chronicle, XIX and XX (35).

${ }^{13}$ Haddad Chronicle, LXXVII-LXXXIII (116-22).

${ }^{14}$ I. Guidi, 'Nomina Catholicorum', Rendiconti: Reale Accademia dei Lincei, ser. 4, vol. 2, pt. 2 (1885-6), 556-7 (I am grateful to Scott McDonough for providing a copy of this text); R. Ebied and M. Young, 'List of the Nestorian patriarchs', LM 87 (1974), 87-113; Solomon of Basra, Book of the Bee, LI (tr. E. Wallace-Budge, 116-20).

This is an open access version of the publication distributed under the terms of the Creative Commons Attribution-NonCommercialNoDerivs licence (http://creativecommons.org/licenses/by-nc-nd/3.0/), which permits non-commercial reproduction and distribution of the work, in any medium, provided the original work is not altered or transformed in any way, and that the work is properly cited. For commercial re-use, please contact academic.permissions@oup.com 
became linked to 'history proper' and shaped the way in which information from Iraq and beyond was recorded and analysed. Records of the patriarchs, whether stripped of extraneous narrative passages or not, came to represent the core of the historical tradition. We see this reflected in the surviving sources, which vary in brevity from these lists; to the sparse information on each catholicos that 'Amr and Bar Hebraeus include, occasionally supplemented by lists of 'famous men of the time'; to the inclusion of Roman ecclesiastical history alongside the lives of the patriarchs in Mari; and finally to the much more expansive Chronicle of Seert. In this last case, the importance of the patriarchs has been almost eclipsed, but it can still be traced in sections entitled 'on famous men', which have been drawn from more abbreviated ecclesiastical histories.

At what point was this patriarchal history composed and what information did it include? Given the late date for the compiled sources we are reliant upon, there always remains the possibility for later revision (e.g. juxtaposing one event to another to imply causation $)^{15}$ and the introduction of anachronism (e.g. the use of later names for cities or ethnic groups). ${ }^{16}$ But it is still possible to trace the outlines of earlier compositions and the inclusion of information for which there was little motive for later invention.

This process of composition occurred in at least three phases before it took the form of a sequential history organized around each catholicos in turn. The first was the raw material of the hagiographies of the martyrs, possibly supplemented by a bishop list without any additional information, except certain dates. ${ }^{17}$ These hagiographies were then collected, organized, and expanded in connection with a developing relic cult under the catholicos Ahai and continued under his successors. ${ }^{18}$ In addition this period saw the composition of two 'contemporary' histories: one of them an account of the catholicoi after Ishaq and of the visitations of Marutha and Acacius, the other, Ahai's Life of the monastic founder, Mar 'Abda, whose monastery trained

15 E.g. Chronicle of Seert, I/i, IX (237-9), where the influx of the Manichees is used to explain the persecutions of Vahram II.

${ }^{16}$ E.g. Chronicle of Seert, II/i, XVII (132) where the Hephthalites are referred to as 'Turks', though they are 'Heftāāin' at II/i, XII (124); II/ii, LXXVI (514) for the anachronistic use of 'Mosul' instead of Nineveh.

17 Wiessner, Martyrenüberlieferung, 74 notes the presence of 'unworked' lists of martyrs in the Acts of Symeon B, 779-82 and lists of martyrs read from the diptychs would continue to be a major feature of the liturgy: J.-M. Fiey, 'Diptyques nestoriens du XIVe siècle', AB 81 (1963), 371414. Bishop lists had always been an important source for ecclesiastical historians and religious commentators: H. Campenhausen, Ecclesiastical Authority and Spiritual Power in the Church in the First Three Centuries, tr. J. Baker (London, 1967), 163-73 and R. L. Williams, Bishop Lists: The Formation of Ecclesiastical Succession in Ecclesiastical Crises (Piscataway, NJ, 2005). Such lists were also important early sources in West Syrian historiography: see Debié, 'Record-keeping'.

18 Chronicle of Seert, I/ii, LXIX (325). Wiessner, Martyrenüberlieferung, 276-9 observes that the Arbelan hagiograpahies, such as the Acts of John of Arbela, are 'worked-up' versions of lists of names from the diptychs, to which narrative has later been added.

This is an open access version of the publication distributed under the terms of the Creative Commons Attribution-NonCommercialNoDerivs licence (http://creativecommons.org/licenses/by-nc-nd/3.0/), which permits non-commercial reproduction and distribution of the work, in any medium, provided the original work is not altered or transformed in any way, and that the work is properly cited. For commercial re-use, please contact academic.permissions@oup.com 
several of the catholicoi of this era. As we will see, this second phase at the beginning of the fifth century also saw the elucidation of the life of Papas, the semi-legendary predecessor to Symeon whose contest with Miles of Susa would make him a controversial symbol of the authority of the catholicos. ${ }^{19}$

This material was developed into sequential history based around the reigns of catholicoi towards the end of the century in a third phase. The end of the fifth century witnessed the resumption of the Ctesiphon synod following a long gap (424-86), and we can take the 486 synod of Acacius as an important sign of the restoration of central authority soon after the see of Ctesiphon had been subjected to serious external challenge the powerful bishop of Nisibis, Barsauma. Acacius had been trained in the School of the Persians in Edessa and was a relative of his predecessor, Babowai. ${ }^{20}$ This background, and his role in re-establishing the Ctesiphon synod after a long interlude, makes his reign a plausible point to date the creation of a 'patriarchal history' that asserted the rights and antiquity of Ctesiphon, especially its connections to the martyrs and the bishops of the West.

There are also good textual reasons for this dating of the 'patriarchal history', both in the Syriac patriarchal lists and in the Arabic compilations. The earliest list of catholicoi found in Guidi's edition has a strong stylistic break after the death of Babowai, and the original text probably concluded with the struggle with Barsauma, which indicates a point of composition shortly afterwards, in the reign of Acacius. ${ }^{21}$ The existence of such a list suggests a terminus a quo for the creation of a history where pre-existent material was ordered around the lives of the patriarchs (henceforth the 'Acacian history'). Moreover, it is unlikely that a structure based around patriarchal reigns was introduced much earlier, since the sources disagree how to date the same information from the early fifth century: the act of reordering information around the reigns of catholicoi must have taken place when this chronology had already been forgotten. It is also notable how little material is available to the medieval compilations for the middle of the fifth century, which confirms our impression of the absence of central authority that could commission history-writing until the end of the century. ${ }^{22}$

19 Guidi's list, which is the earliest record of the catholicoi, begins with Papas, rather than the earlier apocryphal figures found in (e.g.) the Haddad Chronicle.

20 Labourt, Le christianisme, 132 and143.

21 After this there is a narrative of the flight of the followers of Nestorius from Edessa, before the text concludes with the catholicoi up to Gregory of Pherat. This points to a final date for the continuation of the text during Babai the great's stewardship. It also includes an alternative list of incumbents between Barba'shemin and Qayoma.

22 The different styles of the section on Babowai (Chronicle of Seert, II/i, I), with its interest in the court and its AG dating (i.e. the Seleucid era), may demonstrate that material for this catholicos was rewritten later, or that 'the Acacian history' did not come up to the composer's own time.

This is an open access version of the publication distributed under the terms of the Creative Commons Attribution-NonCommercialNoDerivs licence (http://creativecommons.org/licenses/by-nc-nd/3.0/), which permits non-commercial reproduction and distribution of the work, in any medium, provided the original work is not altered or transformed in any way, and that the work is properly cited. For commercial re-use, please contact academic.permissions@oup.com 


\section{THE FIFTH CENTURY IN THE ACACIAN HISTORY}

The Chronicle of Seert's account is relatively straightforward in its content on the early fifth century. Apart from asides on shahs and emperors that, in my view, were included later, it is focused upon two narrative strands: the catholicoi and their succession, and the acts of the monastic founder Mar 'Abda and his successors. By looking at the patterns of the early phases of history-writing by Christians at Ctesiphon that is preserved in this material, we can investigate the relationship of catholicoi and 'Abda's legacy, as well as the memory of these institutions in the time of Acacius.

The descriptions of the catholicoi Tomarsa and Qayoma are essentially without detail: both are merely paragraphs that describe the circumstances of their election and relate it to other events in terms of chronology. ${ }^{23}$ It is only with Ishaq that we receive more information: the catholicos, 'good, virtuous, and wise', is a major participant in the narrative that includes Arcadius, Marutha, and the shah Yazdegard, all of whom are celebrated as the organizers of a new golden age that begins with the 410 Synod of Seleucia. ${ }^{24}$ Then, from Ishaq's reign onwards, the Chronicle was based around a coherent narrative of the relationship between the catholicoi, Yazdegard, and the Romans, in contrast to the 'hollow' sections on his predecessors that have been filled out with hagiographic material.

Ishaq's successors Ahai and Iaballaha have brief sections devoted to them, but these are dense and seem to reflect larger passages that have been subsequently reduced. Ahai is remembered for his intervention in the royal pearl trade, his contests with Manichees and Marcionites and his role in recording saints' lives, and Iaballaha is remembered for his confirmation of the Western decrees and his reception of a second Western emissary, Acacius of Amida. ${ }^{25}$ Mari, by contrast, presents very similar material to the Chronicle of Seert but allocates it to different catholicoi. Notably, he divides Marutha's mission between the reigns of Qayoma and Ishaq (greatly reducing the importance of Ishaq and Yazdegard in the council of Seleucia). ${ }^{26}$

A similar reordering of material is visible for the beginning of Yazdegard's persecution. In the Chronicle of Seert, Iaballaha's reign witnesses Yazdegard's change of heart and the order to destroy the monasteries, and Iaballaha manages to delay the persecution by interceding with the shah. Iaballaha then prays that he should die before there is any further bloodshed. Hosea's

${ }^{23}$ Chronicle of Seert, I/ii, LIX (305) and LXIII (315). Higgins, 'Metropolitans', 49 and 61 discusses the specifically chronographic problems related to these reigns.

${ }^{24}$ Chronicle of Seert, I/ii, LXVII (317-18).

${ }^{25}$ Chronicle of Seert, I/ii, LXVII (324-5) and LXIX (327-8).

${ }^{26}$ Mari, HE, 29-31/25-7. 'Amr, HE, 22-3/13 follows the Chronicle of Seert but adds long invented speeches for Qayoma and Yazdegard.

This is an open access version of the publication distributed under the terms of the Creative Commons Attribution-NonCommercialNoDerivs licence (http://creativecommons.org/licenses/by-nc-nd/3.0/), which permits non-commercial reproduction and distribution of the work, in any medium, provided the original work is not altered or transformed in any way, and that the work is properly cited. For commercial re-use, please contact academic.permissions@oup.com 
religious vandalism is then met by another successful appeal to the shah by Ishaq of Armenia, but this too appears to have been short-lived. Ma'na, Iaballaha's successor, attempts to intercede with Yazdegard after further persecution. As we have seen, when Yazdegard questions Ma'na, Narsai replies to his questions instead and condemns him for his actions, after which he is taken away and killed, and the catholicos imprisoned. ${ }^{27}$ By contrast, Mari places the whole persecution under Ma'na, and Iaballaha's request for an early death is caused by his anticipation of persecution, which does not occur in his lifetime. ${ }^{28}$

In both the account of Marutha's embassy and Yazdegard's persecution, the compilers differ in where they place the same material. In the latter case, this may be connected to a wish to remove blame for the persecution from Iaballaha and attach it more firmly to Ma na, a figure with court connections instead of the monastic education of Iaballaha. Indeed, Iaballaha's prayer for death may be a device intended to underline the fact that the persecution, and the breakdown in Ctesiphon's authority shown by Hosea's vandalism, only occurred after the reign of this favoured catholicos. The Chronicle of Seert's presentation of numerous attempts to delay persecution by various figures is probably closest to the historical reality; a narrative that has been smoothed out in Mari's account. But in addition to the manipulation of one individual's reputation, the differences in the allocation of the same events between reigns also suggests that this information was not initially divided in this way. Material may well have been recorded at an early date, especially the complex accounts of the persecutions or Marutha's mission, but the structure based around the reigns of catholicoi is probably the work of the later fifth-century chroniclers, who may also be responsible for the variations in where material is placed chronologically. The period from Ishaq to Ma'na (and possibly Dadisho $^{\text {) }}$ seem to have been written as a single unit, which was subsequently allotted to the reigns of individual catholicoi and manipulated to minimize the culpability of favoured catholicoi or conflict with the shah.

\section{THE SCHOOL OF ${ }^{`}$ ABDA}

A different kind of material is present in the period between Tomarsa and Ma'na that is less immediately focused on the deeds of the catholicoi, namely the Life of ${ }^{c} A b d a$ of Deir Qoni and the activities of his disciples. The seventhcentury ecclesiastical historian Daniel bar Mariam reports that Ahai composed this Life while he was catholicos, and the Chronicle of Seert also includes

27 Chronicle of Seert, I/ii, LXXXII (328-9).

28 Mari, $H E, 33 / 28-9$.

This is an open access version of the publication distributed under the terms of the Creative Commons Attribution-NonCommercialNoDerivs licence (http://creativecommons.org/licenses/by-nc-nd/3.0/), which permits non-commercial reproduction and distribution of the work, in any medium, provided the original work is not altered or transformed in any way, and that the work is properly cited. For commercial re-use, please contact academic.permissions@oup.com 
several related saints' lives that discuss his successors and 'Abda's school, to which Ahai and Iaballaha were closely connected. The section on 'Abda in the Chronicle is derived from a saint's life, beginning with the saint's birth 'to a woman of low origins', who gives the child to the church. The Life describes how 'Abda was educated at his village school before founding the first monastery in 'the land of the Nabati', along with a 'school for all'. From here he converted pagans, eventually leaving for the village of Tella. At the end of the Life, the compiler also adds a list of his miracles: creating bread for hungry monks, miraculously escaping from the Zoroastrians, and defeating Marcionites and Manichees. ${ }^{29}$

The Life of ${ }^{c} A b d a$ is followed in the Arabic compilations by another hagiographic account that is peripherally related. The scene describes how a miraculous cross was seen above the earth during the persecutions. The place where this occurred was then bought by a local chief, who built a monastery there, after which 'Abda performed miracles there and converted pagans. ${ }^{30}$ This story probably represents the later attachment of 'Abda to the monastery's foundation legend to emphasize its antiquity, since 'Abda's role here is secondary and the saint's Life seems self-contained. But the selection of 'Abda for this invented association is significant: to the adapter of the original account, 'Abda signified an early era of missionary endeavour in a time of persecution. ${ }^{31}$

A second tale that is associated with the Life of ${ }^{c} A b d a$ in the Arabic compilations describes the missions of 'Abdisho' of Arphelouna in Maishan, who was trained at 'Abda's school. He is credited with the conversion of the village of Baksaya (possibly in Beth Arabaye), where he met the shah Vahram, and of the village of Rimioun in Maishan. Later, he is briefly made bishop of Deir Mahraq by Tomarsa, before fleeing for solitude to 'Bahrayn and Yamama' and converting more pagans. Here too he exorcizes a demon, who complains that the Christians have pursued him 'even here'. He imprisons the demon on 'the island now called Ramath', before founding another monastery in Hira and returning to his monastery at Maishan, which he directs until his death. ${ }^{32}$

The fact that this cycle of stories was placed under Tomarsa probably reflects the lack of information about this catholicos. Indeed, Tomarsa's presence in the Life of ${ }^{c}$ Abdishoc is probably a later attempt to link him into the narrative and compensate for the embarrassing lack of information in the history of the catholicoi. The same point might be made about the holy man Bokhtisho' whom the Chronicle of Seert, Mari, and 'Amr all place in Tomarsa's reign: ${ }^{33}$ lack of information on the catholicos meant that other information was used, and

29 Chronicle of Seert, I/ii, LX (307-8).

${ }^{30}$ Chronicle of Seert, I/ii, LXI (308-9).

31 This association may precede the creation of the Acacian history.

${ }^{32}$ Chronicle of Seert, I/ii, LXII (310-12).

${ }^{33}$ Chronicle of Seert, I/ii, LIX (305); Mari, HE, 28/24; 'Amr, HE, 21/12.

This is an open access version of the publication distributed under the terms of the Creative Commons Attribution-NonCommercialNoDerivs licence (http://creativecommons.org/licenses/by-nc-nd/3.0/), which permits non-commercial reproduction and distribution of the work, in any medium, provided the original work is not altered or transformed in any way, and that the work is properly cited. For commercial re-use, please contact academic.permissions@oup.com 
the information to which the late fifth-century historians had access was mostly hagiographic. Probably all that was actually known of Tomarsa and Qayoma at the time of Acacius were names in a bishop list.

These hagiographies that described the late fourth century highlighted the missionary history of the church in Maishan; its opposition to pagans, Manichees, and Marcionites and the institutional backgrounds of several early fifthcentury catholicoi. Not only did this connection to contemporary catholicoi prompt Ahai's composition of the Life of 'Abda, but a later 'Life of Iaballaha' was composed and embedded in the Chronicle of Seert, which represents him in his capacity as a disciple of 'Abda, as distinct from his position as catholicos: one section portrays him as 'Abda's disciple and the other as Ahai's successor and catholicos in the traditional manner. The hagiography describes how he was educated at 'Abda's school and founded a monastery in the newly converted village of Daskart de 'Abdisho', where he established a tradition of continual psalm singing and performed rain miracles. ${ }^{34}$ Thus, Iaballaha was remembered in two different historical traditions (one focused on catholicoi, the other on missionary holy men), and both of these accounts have become embedded in the Chronicle via the patriarchal history.

The continuation of this narrative strand based around 'Abda and his disciples points towards one of the major focuses of historical and hagiographic composition at the start of the fifth century. Alongside an emphasis on the martyred bishops earlier in the fifth century, Ahai also celebrated a relatively recent monastic founder and his disciples, whose monasteries in southern Iraq might have been useful elements of the patronage network of the church in Ctesiphon. Moreover, this link was still celebrated after Iaballaha's death, when a record of his own reputation as a monastic founder in 'Abda's tradition was composed. This emphasis may also have been an attempt to draw a contrast with Iaballaha's successors, Ma'na and Pharabokht, whose court connections and Persian background indicate that they were supported by different kinds of interest groups, mirroring the controversy over the dating of the persecutions to the period after Iaballaha's reign.

It is hard to gauge the continuing importance of the monastery and school of 'Abda in any detail, especially because much of its history lies in the missing part of the Chronicle of Seert. It is not necessary to think of it as a school with the degree of sophistication achieved by the schools of Edessa and Nisibis. But there are traces of information in the sources of several texts that extolled its founder and several of its pupils, and these suggest that the school was significant in its own regional context. In particular, Mari associates it with Babowai, the first catholicos to be drawn from a 'pagan family' from Tella

${ }^{34}$ Chronicle of Seert, I/ii, LXVIII (321-2). This life was treated by the compilers as one of 'the famous men of the time': 'Amr, $H E, 25 / 15$, brackets him with John Chrysostom and places the reference to him in the reign of Ishaq.

This is an open access version of the publication distributed under the terms of the Creative Commons Attribution-NonCommercialNoDerivs licence (http://creativecommons.org/licenses/by-nc-nd/3.0/), which permits non-commercial reproduction and distribution of the work, in any medium, provided the original work is not altered or transformed in any way, and that the work is properly cited. For commercial re-use, please contact academic.permissions@oup.com 
(which seems to confirm the school's reputation as a missionary centre and the association of 'Abda with the village). Subsequently, Mari reports that Peroz suppressed the school as part of his persecution following the death of Babowai. ${ }^{35}$

The material pertaining to Mar 'Abda and his school in the histories also confirms a late fifth- or sixth-century date for the first composition of the patriarchal histories. After the time of Abraham of Kashkar and the refoundation of celibate monasticism in Iraq there would be little need to remember Mar 'Abda. Stories of the antiquity of monasticism in Iraq were indeed necessary, but these would be provided by Mar Awgin, a fourth-century figure with his legendary connections to Antony and Pachomius in Egypt. Notably, no Syriac saint's life survives for Mar 'Abda or any of his disciples: they are recorded only in the historical tradition, even though their provenance is undoubtedly hagiography. ${ }^{36}$

The 'Abda tradition, therefore, provided a source of prestige and institutional identity for several fifth-century catholicoi. This tradition, alongside the narratives surrounding the council of Seleucia, the era of stability that followed it, and the persecutions of Yazdegard I, formed the basis for the description of the early fifth century in the first patriarchal history. This collection of hagiographies, with its focus on the missions to Maishan, would suit the need for early sources of prestige of an expanding church in southern Iraq. For the late fifth-century historian, it provided the only source of raw material for the reigns of Tomarsa and Qayoma, as well as filling its original function, of reinforcing the connection between the monastic school and the catholicosate, particularly the catholicos Iaballaha. In addition, the association between the school of 'Abda and Babowai, Acacius' relative and predecessor as catholicos, may have been another incentive to preserve the memory of the institution after its destruction.

\section{MILES AND PAPAS: THE COUNCIL OF DADISHO ${ }^{c}$}

The stories of Ishaq and his successors, and the hagiographies of ${ }^{\mathrm{c}} \mathrm{Abda}$, had all been products of a new golden age for the Church, which celebrated an era of missionary expansion in the teeth of heretical opposition, as well as the negotiation of the relationship between shah and catholicos and the importation of Roman models for church governance. These themes remained

${ }^{35}$ Mari, $H E, 42 / 36-7$.

36 A. Vööbus, History of Asceticism in the Syrian Orient. Volume II: Early Monasticism in Mesopotamia and Syria (Louvain, 1960), 266-72 observes the striking omission of any material on 'Abda by Barhadbeshaba or by Isho'dnah of Basra, both of whom purport to cover this period. On Awgin, see Chapter 8, under 'A new history of monasticism: the Nestorians in the West'.

This is an open access version of the publication distributed under the terms of the Creative Commons Attribution-NonCommercialNoDerivs licence (http://creativecommons.org/licenses/by-nc-nd/3.0/), which permits non-commercial reproduction and distribution of the work, in any medium, provided the original work is not altered or transformed in any way, and that the work is properly cited. For commercial re-use, please contact academic.permissions@oup.com 
significant to the Acacian historian and his successors, either because they represented the only information to be gleaned for a respected but unknown past, or because they represented a paradigm, an ideal of royal patronage and orthodoxy from the West, which might remain attractive to later catholicoi.

One of the effects of the creation of a history of a succession of catholicoi, which juxtaposed the reigns of different men into a single text, is that it also found a place for a second, earlier golden age, the reign of the martyr Symeon bar Sebba'e and his successors. In this respect, chronicle-writing represented a more comprehensive discourse, a structure that provided a space for different accounts of the foundation of the catholicosate, where they could be reconciled into an authoritative whole. The recording and elaboration of the fourthcentury martyrdoms in later histories acquired the charisma of the martyrs, commemorated in liturgy and hagiography, for the catholicoi. By presenting Symeon as the archetype of catholicos, priest, and martyr, these histories sought to appropriate a cult of the martyrs that had achieved substantial popularity by the beginning of the fifth century.

The importance of the Shapurian persecutions as a golden age in the church's historical imagination is illustrated by the relative paucity of information for the period that followed it: only the 410s-20s, with their synods and the collection of the martyria, is equally well attested. The information that survives in the medieval chronicles was not the product of a continuous historical tradition, but the result of two moments of ecclesiastical centralization, in the $410 \mathrm{~s}$ and $480 \mathrm{~s}$, and of corresponding historical invention, which related these two moments to an original 'golden age' of the fourth-century martyrs.

However, as we have seen, the catholicoi had their opponents in their quest for centralized power over the church and cooperation with the shah. Both Ishaq and Dadisho' were briefly imprisoned, probably as the result of denunciations. ${ }^{37}$ Moreover, the acts of Dadisho's synod in 424 demonstrate that the catholicoi did not have a monopoly on the invention or reuse of history, and that not all memories of this age were equally positive. Dadisho' had stood accused of apostasy, theft, and usury: he was suspected for his overly close cooperation with the court and the money it brought. ${ }^{38}$ In reply, a supporter of the catholicos, Agapetus of Beth Lapet, who had been present at the councils of Ishaq and Iaballaha, ${ }^{39}$ read out a letter, supposedly sent by the Western fathers to Symeon's predecessor Papas. It is here, in the contested histories of Papas and his opponents, that we see the survival of memories of tyrannical bishops of Ctesiphon that coexisted with the image of the catholicos-martyr, which forced the self-presentation of fifth-century catholicoi to take a much more

37 Syndoicon, 44 and $49 . \quad 38$ Synodicon, $45-6$.

$39 \mathrm{He}$ is mentioned third in the signatory list of the 420 synod (Synodicon, 44). He may have been appointed to Beth Lapet by Ishaq, since the see lay vacant in 410, though the catholicos asserted its theoretical authority over the other sees of Khuzistan (Synodicon, 33).

This is an open access version of the publication distributed under the terms of the Creative Commons Attribution-NonCommercialNoDerivs licence (http://creativecommons.org/licenses/by-nc-nd/3.0/), which permits non-commercial reproduction and distribution of the work, in any medium, provided the original work is not altered or transformed in any way, and that the work is properly cited. For commercial re-use, please contact academic.permissions@oup.com 
defensive attitude. Some version of the Papas narrative was likely to have been part of the Acacian history, since this controversial story was an important site for competition over central authority. However, the continued importance of the narrative has meant that it continued to be adapted in later eras, and dateable evidence is provided in Syriac sources, especially the Synodicon and the Acts of Mar Miles. This section uses these sources to consider the fifthcentury development of these stories of a tyrannical catholicos. The remainder of the chapter will use the medieval compilations to address their reception and continuing elaboration in the late sixth century.

The letter reported by Agapetus tells us that various bishops had testified against Papas' bad conduct (of 'his violence and impurity') and that these accusations were judged by one Miles. Papas was angry that those who had no authority sought to judge him and struck the Gospels crying, 'Speak, Gospels, speak!' Papas was then struck down, for his lack of respect to the Gospels. Following this, Agapetus notes that Papas' accusers included many good men, some of whom would later be martyred under Shapur, but that they were naïve and had been deceived by rebels against his authority. Their complaints were heard by the fathers of the West, who responded by affirming Papas as 'head over all of them' and naming Symeon bar Sebba'e, who had replaced Papas while he was incapacitated, as his archdeacon. Their letter asserts that 'only Christ can be the judge of a patriarch [catholicos] ${ }^{\text {'40 }}$ and compares Papas to Peter, 'on whom Christ built his church'. ${ }^{41}$ The acts of the synod spell out the consequences of this authority further: bishops in 'the East' will have no right of appeal to the West and no right to assemble unless commanded to do so by the catholicos, they complain against the opposition to Ishaq and Iaballaha, and they entreat Dadisho ${ }^{c}$ to return as catholicos (after being briefly imprisoned). ${ }^{42}$ Agapetus emphasizes the visit of Marutha and his confirmation of Ishaq's rule in the face of opposition, and presents it as a second intervention from the West to confirm the catholicos in the face of rebellion. By inventing Papas' Western letter, Agapetus generates an ancient precedent for the external confirmation of the catholicos and uses it to bolster the position of all catholicoi.

Agapetus' invocation of the figure of Papas as a model for the authority of Ctesiphon is essentially a retelling of a story that was originally directed against the catholicos. We can see this from his story in the reason Agapetus gives for Papas' 'stroke'. The scene was originally an invocation of God as Papas' judge and presented the divine condemnation of the patriarch. Similarly, several aspects of his story that support the authority of the catholicosate, especially the point where Papas strikes the Gospels, seem to derive from an earlier version of the contest between Miles and Papas, which was originally opposed to the catholicos and presented Papas as a proud tyrant. The Western

40 The text reads 'patriarch', but this must be a later addition.

${ }^{41}$ Synodicon, 46-8. $\quad 42$ Synodicon, 49-51.

This is an open access version of the publication distributed under the terms of the Creative Commons Attribution-NonCommercialNoDerivs licence (http://creativecommons.org/licenses/by-nc-nd/3.0/), which permits non-commercial reproduction and distribution of the work, in any medium, provided the original work is not altered or transformed in any way, and that the work is properly cited. For commercial re-use, please contact academic.permissions@oup.com 
confirmation of Papas' authority has been added to a story that was critical of the bishop of Ctesiphon.

Agapetus' interpolation is seen most clearly by comparing his account with the Syriac Acts of Miles, the famous martyr and Papas' accuser, which illustrates several features of the story that underlay the politically charged adaptation of the 424 council. These Acts describe Miles' travels near his home city of Susa, before his pilgrimage to visit Jerusalem, the monastery of Antony in Egypt, and Nisibis, where he helps Jacob build his church. ${ }^{43}$ In the second part of the Acts he arrives in Ctesiphon to find the church split by a schism (harinā) caused by its bishop, ${ }^{44}$ Papas, who 'was exalted over the bishops of [other] lands who were gathered [in Ctesiphon] as if before his judgement' and behaved arrogantly towards the priests and deacons of the city. ${ }^{45}$ Miles announces the accusations brought against Papas and chides him saying, 'Isn't it written that the first among you should be like your servant?' Papas asks whether Miles presumes to teach him anything, to which Miles responds that he is only a man, but that Papas has failed to learn from the Gospels: 'You do not see [God's] commandment because the inner sight of your mind is shut away (b-'aynā ksitā $d$-tar ${ }^{\mathrm{C}} i t \bar{k} k$ ).' At this point, the hagiographer places the judgement scene used by Agapetus: Papas angrily seizes the Gospels and cries, 'Speak, Gospels, speak!' But here the author also adds an explanation of the scene by Miles, who denounces Papas for his pride and tells the crowd that an angel will come to strike down Papas for his pompous behaviour (šubhārā) towards 'the living word of our Lord'. Before an amazed crowd, Papas is then 'struck down' by a bolt of lightning that withers half of his body, and remains incapacitated until his death twelve years later. ${ }^{46}$ Finally, Miles leaves Ctesiphon and performs several miracles, after which he is captured and killed by Shapur and buried with his companions, Aborsima and Sina, at Malcan, which becomes an impregnable fortress thanks to his protection. ${ }^{47}$

Miles' Acts have clearly been subject to later adaptation. The very distinct phases of his life (foreign travel, Ctesiphon, and martyrdom), the last of which associates him with companions who are buried with him, may mean that Labourt was correct in his hypothesis that the Acts of Miles combine the activities of several saints. ${ }^{48}$ The foreign travels at the start of the Acts are especially suspicious and closely resemble the itinerary of the sixth-century

43 Acts of Miles, 263-6.

${ }^{44}$ Notably, he is not referred to as a catholicos, which further indicates an early date for this section of the text.

${ }^{45}$ Acts of Miles, 266-7. This sentence implies that these other bishops ought not to be subject to Ctesiphon, in contrast to the normal assumptions of the fifth-century sources.

${ }^{46}$ Acts of Miles, 267-8.

47 Acts of Miles, 268-75. Miles, Aborsima, and Sina are also included in the primary list of confessors: 411 Martyrion, 23.

${ }^{48}$ Labourt, Le christianisme, 23.

This is an open access version of the publication distributed under the terms of the Creative Commons Attribution-NonCommercialNoDerivs licence (http://creativecommons.org/licenses/by-nc-nd/3.0/), which permits non-commercial reproduction and distribution of the work, in any medium, provided the original work is not altered or transformed in any way, and that the work is properly cited. For commercial re-use, please contact academic.permissions@oup.com 
catholicos Mar Aba, and the final version of the text may date to this era. ${ }^{49}$ But the association of the denouncer of Papas with a man martyred under Shapur was at least accepted by Agapetus, since he is forced to defensively explain away the denunciation of Papas to the Westerners. The defensive alterations in Agapetus' speech (his alteration of the Gospel trial and his representation of Miles) show that the Acts of Miles reflects the original story more closely and that it continued to circulate and remain popular. ${ }^{50}$

The thrust of Miles' denunciation is the contrast between the wishes of Papas' many accusers, and the arrogance of a bishop who has led the church to schism. The crux of this is the requirement for the leader of the church to live a life determined by the Gospels and to be like a servant. Papas initially refuses to see the debate in these ideal terms and represents Miles' criticism as a claim to authority by the saint. Miles maintains that Papas has failed according to the tenets of the Gospels rather than any human judgement. It is in this context that Papas' phrase 'Speak, Gospels, speak!' makes sense: he has already been taken to task for his failure to live according to their tenets. Agapetus has removed this scene from context in order to render Miles as a pious and naïve judge, who is persuaded to act on behalf of the crowd, taking away the sting of his criticism that the catholicos is also bound by God. Agapetus has repeated the most significant phrase from the confrontation, but he doesn't provide any of the substance of Miles' criticism and limits the story to Papas' refusal to be judged by any man, a sentiment that he subsequently justifies with the letter from the West.

The criticism of Papas in the 'opposition' tradition reflects, in broad terms, those made by the theologian Aphrahat in the fourth century against corrupt leaders of the church of his day. These older criticisms are reflected in the Acts of Miles and provide a deeper context for our understanding of Agapetus' stance and his preservation and defence of the controversial idea that Papas could not be judged by men.

In his Demonstration X, On Pastors, Aphrahat attacks those who 'clothe [themselves] with the wool of the sheep and devour the flesh of fatlings yet do not feed them' and warns that the moment will come when 'the Great Shepherd will come to inspect the sheep and make an account with his shepherd'. ${ }^{51}$ In Demonstration XIV, On Exhortation, addressed to his brothers in Seleucia-Ctesiphon, he goes on to attack 'the leaders who have left the

\footnotetext{
49 See S. P. Brock, 'Saints in Syriac: a little-tapped resource', Journal of Early Christian Studies 16 (2008), 181-96.

50 The accumulation of new scenes in the Acts and the transmission of the Acts in a Miles cycle with other shorter martyr acts in much later manuscripts demonstrate the story's continuing appeal. See Wiessner, Martyrenüberlieferung, 283 for the Acts of Daniel and Warda and their circulation alongside the Acts of Miles.

51 Aphrahat, Demonstration X, 3.
}

This is an open access version of the publication distributed under the terms of the Creative Commons Attribution-NonCommercialNoDerivs licence (http://creativecommons.org/licenses/by-nc-nd/3.0/), which permits non-commercial reproduction and distribution of the work, in any medium, provided the original work is not altered or transformed in any way, and that the work is properly cited. For commercial re-use, please contact academic.permissions@oup.com 
law', lamenting that they 'love the rich and hate the poor' and that 'priest has become like layman'. ${ }^{52} \mathrm{He}$ condemns priests who rely on the imposition of hands for their authority rather than on their fear of God: 'The Lord will judge the princes and elders of the people for they have burned the vineyard. ${ }^{53}$ Ultimately, he laments that all the land is not sufficient for kings, who will always desire war, and the priestly leaders of the flock, with their love of ceremony, are grouped with kings as the source of the misfortune of the people. ${ }^{54}$ In general, Aphrahat addresses similar themes to the Acts of Miles and his testimony allows us to further focus upon the chief issues at stake in fourth-century debates that continue to be reflected in the later texts, namely the idea that the leaders of the church were also subject to God's will and that close involvement with the state damaged 'the vineyard'.

The dating of these demonstrations is controversial, and their criticisms might not be directed against the historical 'Papas' himself, ${ }^{55}$ but they do seem to point towards traditional criticisms of powerful bishops that were re-echoed in the charges brought against Dadisho' ${ }^{c}$ and in the tales of the era of Papas that were told and retold before and after Dadisho"s synod. The emphasis on the duties of powerful churchmen to their flock and the primacy of God's judgement is shared with both versions of the story of Miles and Papas, as well as the core ideas of the Acts of Symeon.

This intellectual history of the criticism of the catholicos helps to explain the focus on Christ as the judge of the catholicos in the 'letter of the Western fathers' that Agapetus invokes. Like the actual narrative of Miles' contest with Papas, the emphasis of the letter represents a manipulation of the earlier tradition. Aphrahat's emphasis on Christ's judgement of the mighty was used to reduce the prestige of the catholicos, who is subject to the judgement of the Great Shepherd. The same motif of Christ's judgement is used in the letter of the Westerners, except that Agapetus uses it to deny the right of other bishops to stand in judgement over the catholicos: 'Disciples cannot stand in judgement over their master, because Christ, their master, did not give them that authority. ${ }^{56}$ Agapetus draws on a longstanding image of Christ as judge, but uses it to magnify the authority of the catholicos and to remove it from the context of public consensus and humility where it is placed by the Acts of Miles. This phrase also develops a parallel between the catholicos as master

52 Aphrahat, Demonstration XIV, 3.

53 Aphrahat, Demonstration XIV, 5 (and 25).

54 Aphrahat, Demonstration XIV, 24.

55 Demonstration X is dated to 336/7 and XIV to 343/4, based on Aphrahat's own statements. Therefore, Labourt, Le christianisme, 26 suggests that the Demonstration XIV was directed against Symeon bar Sebba'e. J.-M. Fiey, 'Notule de la littérature syriaque', LM 81 (1968), 44954 argues that Demonstration XIV should be dated to the reign of Papas (i.e. before 329) and that the colophon date reflects the point of compilation.

56 Synodicon, 47.

This is an open access version of the publication distributed under the terms of the Creative Commons Attribution-NonCommercialNoDerivs licence (http://creativecommons.org/licenses/by-nc-nd/3.0/), which permits non-commercial reproduction and distribution of the work, in any medium, provided the original work is not altered or transformed in any way, and that the work is properly cited. For commercial re-use, please contact academic.permissions@oup.com 
and Christ as master: the rebellion of the bishops is made, by implication, the equivalent of the disciples opposing Christ. ${ }^{57}$

\section{MILES AND PAPAS: THE RECONSTRUCTIONS OF THE HISTORIES}

The version of events that Agapetus gave was contradicted at several points by the Acts of Miles, and this text too reflects the defensive invention of history to compete with other versions. In other words, the dissident version of the history was also developing and reacted to the changes made in the versions produced by sources focused on Ctesiphon. I suggest that these adaptations include the travels of Miles to the West, and his association with Antony's successor Ammonius in Egypt and with Jacob of Nisibis, as well as the assertion that Papas remained afflicted by his punishment until his death. In both cases, we see the dissident Acts of Miles reacting to the changes that occurred to the story of Miles and Papas in the patriarchal histories in the generation of Acacius and beyond.

The Chronicle of Seert does not include a section on Papas, since the text breaks off before the point where it should have stood, but the Haddad Chronicle provides three sections on Papas that can help to reconstruct the material that had been used in the Acacian history. The last of these sections is a retelling of the confrontation with Miles. In it, the Chronicle describes how Papas dedicated money to protecting the Christians, but that he allowed two bishops in each see, which prompted the objections of Miles and of one Boulida $^{c}$ of Dastamaisan. Papas refused to listen and caused disagreement, striking the Bible and crying 'Speak of me', whereupon his right hand was withered for twelve years. ${ }^{58}$ After this, the people wrote to the Westerners for judgement in the matter 'according to the tradition of the time', who declared all the accusations false at the council of Nicaea. The Westerners declared that 'no one can argue with his lord, who holds the patriarchate of the East, nor complain to the West in letters or speech. And [the] governor of the patriarch is Christ. ${ }^{59}$ The final third of this section consists of a series of stories relating the correspondence between Papas and Helena (mother of Constantine), Jacob of Nisibis, and Ephraem, in which they add their weight to the rejection of the criticisms of Papas. The author also explains why there is no saint's life

57 The ideas developed in this synod were enshrined in a brief forgery, the Second Letter of the Western Fathers, which circulated independently from the Synodicon itself: Fiey, Jalons, 69 note 20. The idea of the Western confirmation of Papas is also invoked in the eleventh-century canons of Ibn al-Tayyib, Fiqh al-Nașrānīya (ed. and tr. W. Hoenerbach and O. Spies), II, 116.

${ }^{58}$ Haddad Chronicle, XCVIII (158-9).

59 Haddad Chronicle, XCVIII (159).

This is an open access version of the publication distributed under the terms of the Creative Commons Attribution-NonCommercialNoDerivs licence (http://creativecommons.org/licenses/by-nc-nd/3.0/), which permits non-commercial reproduction and distribution of the work, in any medium, provided the original work is not altered or transformed in any way, and that the work is properly cited. For commercial re-use, please contact academic.permissions@oup.com 
devoted to Papas: he observes that Ephraem offered to compose one but that Papas had refused out of modesty. ${ }^{60}$

This version of the story reflects two adaptations of the original narrative that seem to have drawn responses in the Acts of Miles. Firstly, in the story presented by the Haddad Chronicle, Papas is explicitly said to recover from his paralysis, which makes his punishment a lighter example. This may reflect a recognition of the popularity of the dissident tradition: the story admits a popular aspect of the narrative, Papas' stroke, but adopts the focus of Agapetus' story on the letter of the Westerners and on the authority of the catholicos. And it is this kind of change in emphasis that prompts the counter-assertion in the Acts of Miles that Papas, in actual fact, never recovered from his angelic punishment.

Secondly, the connection drawn between Papas and prominent figures of fourth-century Roman ecclesiastical history reflects the importance of the West in maintaining Papas' dignity and the integration of the episode into the developing historical traditions of the Church of the East. The inclusion of Papas in a narrative history clearly produced a host of problems caused by the lack of information about this supposed first bishop of Ctesiphon. The medieval chronicles accord Papas a remarkable longevity, crediting him with some seventy years as catholicos (this may stem from the recording of all bishops before Symeon as 'father' [Papa], which has then been treated as a single proper name). The Haddad Chronicle in particular remarks that 'Christ did not place anyone on the chair of the church for such a long time'. ${ }^{61}$ The overlap of Papas' supposed reign with important events in the foundation of the Western church also prompted a series of inventions by later ecclesiastical historians who tried to reconcile their early dating of Papas' life with his nonattendance at the council of Nicaea, variously proposing that Symeon bar Sebba ${ }^{c}$, Shahdost, or Jacob of Nisibis had been sent as his representatives, or asserting that Papas had in fact been present. ${ }^{62}$

The same movement to integrate Papas into a prestigious Western history continued with the invention of letters by Ephraem and Jacob, to support the anonymous letter cited by Agapetus. It is these that the Haddad Chronicle summarizes at the end of its section on Papas and which Bar Hebraeus

${ }^{60}$ Haddad Chronicle, XCVIII (159-60). Mari, HE, 9/7 includes a précis of a very similar account, though he also includes the miracles of Miles, probably derived from his Acts: another testimony to the saint's very long-lasting popularity. Conversely, 'Amr and Bar Hebraeus do not mention Miles by name at all.

${ }_{61}$ Haddad Chronicle, XCVII (158). Mari, HE, 9/7 also notes the list of shahs contemporary with Papas, who have probably been derived from a comparative chronological table similar to Eusebius' Chronicon.

${ }^{62}$ Haddad Chronicle, XCVIII (159); 'Amr, HE, 14/9; Mari, HE, 9/7; Chronicle of Seert, I/i, XXVIII (277); Bar Hebraeus, HE, III, 27. Given the importance of Nicaea to the Church of the East after 410, these histories could well depend on earlier inventions from the fifth century.

This is an open access version of the publication distributed under the terms of the Creative Commons Attribution-NonCommercialNoDerivs licence (http://creativecommons.org/licenses/by-nc-nd/3.0/), which permits non-commercial reproduction and distribution of the work, in any medium, provided the original work is not altered or transformed in any way, and that the work is properly cited. For commercial re-use, please contact academic.permissions@oup.com 
specifically denounced as forgeries made by the catholicos Joseph (555-65). ${ }^{63}$ I suggest that the continued invention of Western connections for Papas in the tradition of Agapetus' letter prompted a later hagiographer to adapt the Acts of Miles. This later hagiographer inserted a travel narrative that linked the saint to his own Western allies, in scenes modelled on the travels of the esteemed catholicos Mar Aba (d.555). If this is true, then this passage might well be a response to the adaptations to Papas' life under Aba's hated successor Joseph.

If the embedding of Papas into a broader history prompted the invention of Western connections, then it also created a variety of problems in the association of this controversial first 'patriarch' with his successor, the martyr Symeon. Symeon is not present in the Acts of Miles, which may indicate that the earliest stories of Miles and Papas did not consider the succession to the catholicos. ${ }^{64}$ However, the nature of Symeon's succession does seem to have presented a problem for historians using a sequential narrative of the catholicoi: which of the two opponents did Symeon support? Agapetus imagined that Symeon only replaced Papas while he was incapacitated and that the Westerners confirmed him as Papas' archdeacon and successor, but the tradition that Bar Hebraeus reports makes Symeon the appointee of those who had conspired against Papas. ${ }^{65}$

The report of Symeon's election in the Chronicle of Seert attempts to reconcile the centralist and dissident traditions, and seems to belong to the cluster of stories surrounding Papas rather than to the traditions of Symeon's martyrdom that make up the rest of the section on Symeon. The episode states that Symeon governed the affairs of the church as archdeacon after Papas' hand was paralysed, and that 'in some stories' he was elected metropolitan by force by those who opposed Papas. After this, Papas condemns Symeon: 'Christ will not forgive you until you have spilt your blood and endured martyrdom', but 'the Greeks' write to Papas and ask him to forgive Symeon, which he does, making him his successor. ${ }^{66}$ At the core of this account is the idea that the dissidents had supported Symeon: the original root of the account had allied the tradition of Miles to that of the martyred catholicos and contrasted Symeon with his predecessor Papas. ${ }^{67}$

However, this idea seems to have proved too revolutionary for later authors, who either present Symeon's martyrdom as atonement to God for his

63 Bar Habraeus, HE, III, 31.

64 Given that 'Papas' is probably a composite figure combining the memories of many bishops of Ctesiphon, the historical Symeon may not have been the immediate successor of Miles' opponent.

65 Synodicon, 47; Bar Hebraeus, HE, III, 33.

66 Chronicle of Seert, I/i, XXVII (296).

67 The idea of Symeon's election by the dissidents may also point to the use of the Symeon tradition to criticize his successors who were accused of straying from his example, as I have argued for the Acts of Symeon B in the reigns of Narsai and Elishe.

This is an open access version of the publication distributed under the terms of the Creative Commons Attribution-NonCommercialNoDerivs licence (http://creativecommons.org/licenses/by-nc-nd/3.0/), which permits non-commercial reproduction and distribution of the work, in any medium, provided the original work is not altered or transformed in any way, and that the work is properly cited. For commercial re-use, please contact academic.permissions@oup.com 
rebellion against Papas' authority or make Symeon's succession a specific clause of the Western letters (both explanations are incorporated in the Chronicle's narrative). ${ }^{68}$ These levels of adaptation are hard to date. The first stage (where Symeon was seen as an ally of Papas' opponents) could well reflect the divided rule of Narsai and Elishe, when a debate over the qualities of a good catholicos might make sense. The later emphasis on Papas' authority would fit the reign of Joseph (or his successors), who emphasized his own personal control of the church and who may have invented other letters from the West. A late sixth-century date would also fit my dating of the Chronicle's section on Symeon as a whole, because of its chronological calibration of events in Ctesiphon with events in the Roman world. ${ }^{69}$

The embedding of the stories of Miles, Papas and Symeon into a sequential historical narrative brought out many of the contradictions that had only been implicit in the way these stories were told as independent narratives. Agapetus had been free to remove much of the personality of Miles from his story and focus on the external confirmation of Papas by the Western fathers. But equally, it is clear that the dissident tradition represented by the Acts of Miles fed on longstanding criticisms of tyrannical priests and their collusion with government and continued to be copied and adapted. By juxtaposing the different versions of the story of Miles and Papas, later historians had to try to reconcile two opposing ways of telling the story. The fact that they did this has two major corollaries. First, it shows that both remained popular ways of interpreting the fourth-century past. And second, this implies that historians, and the political world they wrote for, wished to underline the limits on the power of the catholicos as well as to emphasize the claims of the see of Ctesiphon.

\section{PAPAS AND DEMETRIANUS: HISTORIES OF EXILE AND THE RIGHTS OF GUNDISHAPUR}

The opposition of Miles and Papas was not the only story that involved this semi-mythical first catholicos. In a second story, unrelated to the tale of Miles, Papas is also credited with welcoming the exiled patriarch of Antioch, Demetrianus, to Gundishapur (Beth Lapet) and granting his successors rights as the second bishops of the Church of the East. Here a distinct narrative strand, concentrating on the Western exiles and the rights of their places of settlement, has been attached to 'Papas' as a supposed contemporary of these events and spokesman for the rights of the Church.

${ }^{68}$ Ibn al-Tayyib, Fiqh al-Nașrānīya, I, 90-1 also reports that the Western letter confirmed Symeon.

${ }^{69}$ See chapters 2 and 5 , this volume.

This is an open access version of the publication distributed under the terms of the Creative Commons Attribution-NonCommercialNoDerivs licence (http://creativecommons.org/licenses/by-nc-nd/3.0/), which permits non-commercial reproduction and distribution of the work, in any medium, provided the original work is not altered or transformed in any way, and that the work is properly cited. For commercial re-use, please contact academic.permissions@oup.com 
The versions presented by 'Amr, Mari, and the Haddad Chronicle are all very similar. Demetrianus denies that he has any right to govern as patriarch since he lies in Papas' jurisdiction, but Papas allows him to retain the honour of patriarch and to govern the captives as metropolitan of Gundishapur. Demetrianus is also allowed to sit at the right hand of the catholicos in synods and to hold the right to be the first to consecrate his successor. ${ }^{70}$ The Haddad Chronicle also notes that the Zoroastrians held Demetrianus in great respect and that the liturgy was held in Greek and Syriac 'in Fars and the East', while the privileges of Gundishapur 'continue to this day'. ${ }^{71}$

The story acknowledges the connection between Antioch and Ctesiphon and acts as an external justification of the importance of the catholicos. In this regard, it fulfils a role similar to that of Agapetus' letter of the Westerners and the visit of Marutha. The meeting with Demetrianus also precludes any Antiochene claims to precedence over the catholicos: this relationship is not articulated here in the language of canon law, but it is clear in the story that the Holy Spirit will only act on a bishop within his own jurisdiction. This emphasis here may be connected to the claims of Ctesiphon as seat of a catholicos, i.e. as an autocephalous church beyond the Roman Empire. ${ }^{72}$ This title is only securely attested after 410: Ishaq is sometimes referred to as 'grand metropolitan' and sometimes 'catholicos' in his synod, which indicates that references to Symeon as 'catholicos' reflect later interpolation. ${ }^{73}$ Certainly, Bar Hebraeus' assertion that Papas received the rank of catholicos at Nicaea is a later invention. ${ }^{74}$

The celebration of Demetrianus as bishop of Antioch and therefore second bishop of the Church of the East may also tie into the changing importance of the cities of Khuzistan and their relationship with the catholicos. Gundishapur (Beth Lapet) had become the new capital of Khuzistan after its settlement by Shapur I using Roman prisoners of war. Robert Wenke's survey of Khuzistan argued that this royal initiative concentrated the population of central Khuzistan into the new city, draining several other smaller settlements of their population. He emphasizes the degree to which the prosperity of Khuzistan as a whole, and Gundishapur in particular, were dependent on royal investment and peaceful conditions, which allowed the irrigation that made its sugar

${ }^{70}$ Haddad Chronicle, XCVII (158); Mari, $H E$, 9/7 'Amr, HE, 14/8.

${ }^{71}$ Haddad Chronicle, XCVII (158). P. Peeters, 'Demetrianus, évêque d'Antioche?', AB 42 (1924), 288-314 argues that Daniel bar Maryam has suppressed the meeting of Demetrianus and Papas in the account used by the Chronicle of Seert. However, the reference to Demetrianus that uses Daniel in $\mathrm{I} / \mathrm{i}$, II is only given as additional information and Daniel is not the main source of the section. I suspect that the Chronicle did include the scene in a section on Papas that was placed before the beginning of the text as it stands.

72 G. Amadouni, L'autocephalie du Katholicat arménien, OCA 181 (1968), 137-78 and Fiey, Jalons, 69-72.

73 Synodicon 33, canon 21; Symeon B, 959.

74 Bar Hebraeus, HE, III, 27.

This is an open access version of the publication distributed under the terms of the Creative Commons Attribution-NonCommercialNoDerivs licence (http://creativecommons.org/licenses/by-nc-nd/3.0/), which permits non-commercial reproduction and distribution of the work, in any medium, provided the original work is not altered or transformed in any way, and that the work is properly cited. For commercial re-use, please contact academic.permissions@oup.com 
plantations and textile industry profitable. ${ }^{75}$ Wenke's findings illustrate the close connections between the new cities of Khuzistan and the older capital of Ctesiphon.

Khuzistan itself features prominently in the hagiographies of the persecutions of the fourth century. Three episcopal martyrs attested in the 411 synaxarion come from Beth Lapet and Hormizd-Ardashir in Khuzistan and are mentioned at the start of the list, and two of them also appear in the Acts of Symeon. ${ }^{76}$ Two very famous early martyrs, Miles and Pusai, are associated with Khuzistan (with Susa and Beth Lapet, respectively), and a hagiographic collection was dedicated to the martyrs of the province as a whole. Wiessner observes that this text, On the Great Martyrdom of Khuzistan, was one of the first martyr acts to be appended to the Acts of Symeon ${ }^{77}$ This textual history would also fit the role of a Khuzistani bishop in collecting the martyria (Sawmai of Karka de Ledan) and the longstanding memory of Karka de Ledan as the site of the martyrdom of Symeon, which is brought out at the end of the B Acts. ${ }^{78}$ Indeed, the composition of a hagiographic collection for Khuzistan might be an attempt to compensate for Karka de Ledan's lack of native martyrs. The B Acts justifies this as the shah's wish not to damage his recent foundation, a fact that then explains Karka de Ledan's role in collecting relics 'from places across the East'. While Arbela and Karka de Beth Slouq in northern Iraq also feature prominently as sites of martyrdom, the hagiography produced there does not seem so closely related to the catholicos and his companions, or to the relic cult that developed around them: it is only with later sources produced in the sixth and seventh centuries that sites in northern Iraq would assume importance. ${ }^{79}$

Khuzistan, then, was both a centre for the production of martyrs in the fourth century and for their commemoration in the fifth. And its commemoration was strongly linked to Ctesiphon. Such literary links may have come naturally given the ease of communications: the region was dependent on external investment and on trade and Gundishapur and Karka de Ledan were both royal foundations that served as the seat of the shah under Shapur I and

75 R. Wenke, 'Elymaeans, Parthians and the evolution of empires in southwestern Iran', JAOS 101 (1981), 303-13, esp. the map on 308. He emphasizes the transition from a linear distribution of settlement size to a primate distribution, skewed by certain major sites such as Gundishapur. Also see R. Wenke, 'Parthian and Sasanian Khuzistan', Mesopotamia 10 (1975), 31-217, esp. 134 for the city as an uncompleted project, and R. Adams and D. Hansen, 'Archaeological reconnaissance and soundings in Jundi-Shapur', Ars Orientalis 7 (1968), 158-70. D. Potts, The Archaeology of Elam (Cambridge, 1999), 421, sees Gundishapur as the continuation of an older settlement on etymological grounds.

76411 Synaxarion, 24; Acts of Symeon B, 781.

77 Wiessner, Martyrenüberlieferung, 128-44.

78 Acts of Symeon B, 958.

79 The hagiography of these regions is also probably later. Wiessner, Martyrenüberlieferung, 280-1 sees the Arbela cycle as the expansion of a simple list into a hagiographic collection, modelled on southern precedents.

This is an open access version of the publication distributed under the terms of the Creative Commons Attribution-NonCommercialNoDerivs licence (http://creativecommons.org/licenses/by-nc-nd/3.0/), which permits non-commercial reproduction and distribution of the work, in any medium, provided the original work is not altered or transformed in any way, and that the work is properly cited. For commercial re-use, please contact academic.permissions@oup.com 
Shapur II. ${ }^{80}$ The commemoration of the martyrs also served to underline the connections between the two capital cities of Karka de Ledan and Ctesiphon. But as well as providing men like Sawmai of Karka de Ledan and Agapetus of Beth Lapet, Khuzistan was also the home province of the martyr 'Abda of HormizdArdashir, and was remembered as the home of several opponents of Papas in the clash with Miles. ${ }^{81}$ Bishops from Hormizd-Ardashir and Susa also head the list of dissidents who denied Dadisho"s authority in $424 .{ }^{82}$ Some Khuzistani bishops sought to emphasize the authority of the catholicos and the interlinked Christian histories of these centres of Sasanian royal power, but others celebrated dissident traditions that remembered the role of its bishops in opposing a tyrannical catholicos or that promoted martyrdom and ignored the status quo that Ishaq and his immediate successors tried to establish with Yazdegard.

I suggest that Khuzistan features so strongly on both sides of arguments about patriarchal rights because of the proximity of Ctesiphon and the local significance of the martyr cult: the fifth century placed the region at the forefront of central claims to power in a way that was not true for Christian populations in the north of Iraq, who had produced many martyrs but who may have been less immediately connected to Ctesiphon by trade and government, and in terms of the histories of their local martyrs. There may also be a distinction between the older cities of Khuzistan, Susa, Shushtar, and Hormizd-Ardashir, and the newer royal foundations of Gundishapur/Beth Lapet and Karka de Ledan. Though our data does not go beyond the behaviour of individual bishops, the general impression is that the opponents of the catholicos were associated with the older cities, while the new royal cities of Khuzistan sided with the catholicos in the fifth century.

The story of Demetrianus may be intended to enhance the connections between Gundishapur and the catholicos, since it emphasizes the Greek origins of this new community and gives it special rights within the church. Greek communities had been settled in the Iranian world since Alexander, but the deportations under Shapur I (in c.256-61) were the only ones to leave such a significant mark in the Christian histories of Iraq. ${ }^{83}$ The section on the death of Valerian and Shapur's sack of Antioch in the Chronicle of Seert incorporates a list of Shapur's foundations using Greek captives in Iraq, Khuzistan, and Fars and a brief note from the seventh-century historian Daniel bar Maryam that

${ }^{80} \mathrm{~J}$.-M. Fiey, 'L'Elam: la première des métropoles ecclésiastiques syriennes orientales', Melto 5 (1969), 221-69 and PdO 1 (1970), 123-55, at 234-5; Potts, Elam, 419-22; C. Jullien and F. Jullien, Aux origines de l'église perse: les actes de Mar Mari (Louvain, 2003), 16-17. See also Chronicle of Seert, I/i, XXIII (288) for Shapur II's foundation of Karka de Ledan and the later movement of the population to Susa.

${ }^{81}$ Chronicle of Seert I/i, VIII (236): Gadiab of Gundishapur, Abraham of Shushtar and Miles of Susa (half of the list of six).

82 Synodicon, 44.

83 On the deportations in general see C. Jullien, 'La minorité chrétienne grecque en terre d'Iran à l'époque sasanide', in R. Gyselen (ed.), Les chrétiens en terre de l'Iran (Yves, 2006), 105-43.

This is an open access version of the publication distributed under the terms of the Creative Commons Attribution-NonCommercialNoDerivs licence (http://creativecommons.org/licenses/by-nc-nd/3.0/), which permits non-commercial reproduction and distribution of the work, in any medium, provided the original work is not altered or transformed in any way, and that the work is properly cited. For commercial re-use, please contact academic.permissions@oup.com 
Azdaq succeeded Demetrianus as bishop in Gundishapur while Paul of Samosata succeeded him as patriarch of Antioch. ${ }^{84}$ We cannot determine how this third-century material related to the missing earlier parts of the Chronicle of Seert, but the focus of the section is on how Shapur I's Roman wars created new communities in Iraq and on their effect on the church. This material was probably included in one of the sixth-or seventh-century ecclesiastical histories used in the compilation of the Chronicle. The inclusion of these lists of civic foundations shows that the third century was still seen as a formative moment by these communities and that this was acknowledged by the compilers of the historical tradition. ${ }^{85}$

The prestige of the Greek histories of the new royal foundations may also explain the creation of the meeting between Demetrianus and Papas. By focusing on the Western origins of the city's inhabitants, the author accentuates the connection between Iraq's new settlements and the persecutions of the thirdcentury West. The prestige of Papas and his church was confirmed through his involvement in these important events of the universal church, while also explaining the ties of the catholicos to the new royal foundations. In the case of Khuzistan, while other cities might have been older, the Western origins of Gundishapur gave it a longer Christian history and allowed the inclusion of the Sasanian Empire's second city into a suitable place in the hierarchy.

There may well be a historical core to the story of Demetrianus: a bishop by his name did reign in Antioch before Paul of Samosata. ${ }^{86}$ But the story of Demetrianus and Papas as we have received it should be dated to the period after 410 because of its assertion of the autocephalous rights of the catholicos. The story's focus on Gundishapur might reflect the early competition between the sees of Khuzistan, but the preservation and inclusion of the story in later histories was also prompted by the continuing importance of the city of Gundishapur/Beth Lapet, and the need to maintain major allies of the catholicos in this region.

\section{CONCLUSIONS}

Strands of earlier history were reconciled in the patriarchal history composed towards the end of the fifth century. The first, abortive phase in the centralization

${ }^{84}$ Chronicle of Seert, I/i, II (221). It is worth comparing this to a later note on Khusrau I's sack of Antioch in 540 and his foundation of Rumagan, which is much more brief: Chronicle of Seert, II/i, XXXII (182).

${ }^{85}$ The fifth- or sixth-century text, the Martyrs of Beth Zabde, continued to celebrate its heroes and its audience as 'sons of the captivity' and imagines a third-century community led by its exiled bishops, Heliodorus and Dausas. On the descendants of Roman captives, see further Smith, Persian Persecution, ch. 6.

${ }^{86}$ Eusebius, HE, VII, xxvii. Also see P. Peeters, 'Demetrianus', in Acta Sanctorum (Brussels), Nov, IV, 308-11.

This is an open access version of the publication distributed under the terms of the Creative Commons Attribution-NonCommercialNoDerivs licence (http://creativecommons.org/licenses/by-nc-nd/3.0/), which permits non-commercial reproduction and distribution of the work, in any medium, provided the original work is not altered or transformed in any way, and that the work is properly cited. For commercial re-use, please contact academic.permissions@oup.com 
of the Church of the East in the 410s had brought it doctrine and organizational canons from the West, as well as a model for the commemoration of the martyrs. Earlier hagiographic material was edited to focus on the succession of the three 'catholicos-martyrs' of the early fourth century, who provided a prestigious justification for the later authority of the see of Ctesiphon. Additionally, the early fifth century produced saints' lives that emphasized the connection of Ahai and Iaballaha to the 'school of 'Abda', which claimed a role in the proselytism of south-central Iraq.

The choice of a late fifth-century historian to structure his record around the lives of the catholicoi was surely influenced by contemporary succession lists that were produced without any historical detail. But the paucity of information for some catholicoi, such as Tomarsa and Qayoma, points to the fact that this structure was a later development, forcing the historian to stretch his available hagiographic material in his account of the late fourth century.

Finally, there are also traces of an alternative point of origin for the see of Ctesiphon in the reports of the squabbles of Miles and Papas, which were invoked against the catholicos and may have emerged from a real contest for power in the early fourth century. However, these dissident claims were spectacularly inverted by the supporters of Dadisho' in 424 . This story continued to be contested and reworked in later centuries, and it provided a focal point for interlinked discourses of authority and dissent. The obscure figure of Papas also provided a vehicle for other claims about the past and confirmation from the West, where the indigenous histories of Gundishapur were incorporated into a tradition focused on the catholicoi, and where the city's Western connections rendered it a guarantor of Ctesiphon's authority rather than a challenge to it.

This is an open access version of the publication distributed under the terms of the Creative Commons Attribution-NonCommercialNoDerivs licence (http://creativecommons.org/licenses/by-nc-nd/3.0/), which permits non-commercial reproduction and distribution of the work, in any medium, provided the original work is not altered or transformed in any way, and that the work is properly cited. For commercial re-use, please contact academic.permissions@oup.com 


\section{4 \\ The Church and the World}

The reign of Acacius (485-96) was an important moment of recentralization for the Church of the East. Acacius reacted strongly against the challenges of Barsauma of Nisibis, who had attempted to assert the dependence of the catholicosate upon his bishops in a synod in $484 .{ }^{1}$ But the ideal of regular central synods was only realized during a brief window in the last decades of the fifth century. It was followed by yet another period without synods, 496-544, when there is no evidence that the bishops of the East could be gathered in Ctesiphon. Catholicoi continued to reign in Ctesiphon, often gaining their election through close cooperation with the court, and peaceful conditions allowed the rebuilding of churches. But the rule of these catholicoi was not accompanied by the kind of assertions of legitimacy that had been seen in the past. This period of 'anarchy' culminated in the division of the catholicosate between Elishe and Narsai (524-37), and the election of multiple bishops for many of the sees of the East. Only after the death of Elishe did the shah Khusrau I intervene and appoint Paul as catholicos, who was replaced after his death a few months later by the great reformer Mar Aba. ${ }^{2}$

The impression of 'anarchy' may be coloured by the antipathy of many of the sources to the reform of clerical and monastic celibacy. From 486 onwards, priests and bishops, including catholicoi, were encouraged to marry, and this is often identified by the ecclesiastical historians as a source of lax government in the church. Similarly, many of the catholicoi enjoyed close relationships with figures at court, and this too is sometimes a source of criticism. We do not have to accept these explanations of the 'anarchy' of the Church of the East in this period, but there is an impression of insecurity or even apathy in the chronicles' descriptions of the early sixth century that accords with the

${ }^{1}$ C. Baumer, The Church of the East (London, 2006), 86-8 provides a narrative, though he does not take into account S. Gero, Barsauma of Nisibis and Persian Christianity in the Fifth Century (Louvain, 1981) and his source criticism, which has demolished older views of the reformation of asceticism in this period. See also W. Macomber, 'The vicissitudes of the patriarchate of Seleucia-Ctesiphon from the beginning to the present day', Diakonia 9 (1974), $35-55$, at 37.

${ }^{2}$ Chronicel of Seert, II/i, XXV (147-52); Mari, 49/43; 'Amr, 37-40/22-3.

This is an open access version of the publication distributed under the terms of the Creative Commons Attribution-NonCommercialNoDerivs licence (http://creativecommons.org/licenses/by-nc-nd/3.0/), which permits non-commercial reproduction and distribution of the work, in any medium, provided the original work is not altered or transformed in any way, and that the work is properly cited. For commercial re-use, please contact academic.permissions@oup.com 
patterns in the synodica. The reign of Aba (540-52) is striking both for the first new synod to be held for fifty years and for his visitations to distant sees and his meetings with local bishops.

Aba, a convert from Zoroastrianism, was an important public defender of Christianity and legislated against the adoption of Persian and Zoroastrian customs by Christians. Like his predecessors, Aba is depicted as a friend of the shah, though he took this position even further by helping the shah Khusrau I to quell a revolt by his Christian son Anoshazad in Gundishapur. He was also responsible for reversing the Acacian legislation against clerical celibacy and re-emphasizing the importance of asceticism. Finally, Aba was a product of the School of Nisibis, as well as being educated in Edessa, Alexandria, and Constantinople, and his anti-Zoroastrian polemic emerges from the tradition of the School and its interest in the translation of the Old Testament, as well as from his own Magian background. ${ }^{3}$ Aba died in prison after being accused by the Magians of converting Zoroastrian aristocrats and apostatizing from Zoroastrianism, but his reign marks an important watershed in the history of the church. In particular, it saw the production of the first Christian lawcode in the East: the first attempt by the church to regulate lay society.

We have already seen how the reign of Acacius probably saw the creation of a 'patriarchal history' that linked together the earlier hagiography and history of the Church of the East. Material for the period after c.480 is much more mixed than before, and the narratives of different institutions, of the school of Nisibis and Roman and Sasanian secular history, are more integrated (esp. Chronicle of Seert, II/i). At the same time, the centrality of the catholicoi across much of this material suggests that a continuation of the Acacian history underlies the accounts in the medieval compilations. These wider interests may have begun in this phase of history-writing and been extended by ecclesiastical historians writing in the late sixth century. I argue here that this history was developed in two major phases, but that both of these considered some of the same events in the early decades of the sixth century.

The first phase of composition occurred during the schism between Narsai and Elishe. As I have suggested, the period may have seen Narsai's faction deploy the image of Symeon as the ideal catholicos to criticize an opponent with a strong relationship with the shah. In addition to producing this

3 Chronicle of Seert, II/i, XXVII-XXX (154-70), which includes a version of the Acts of Aba. See also the summaries and discussions in Labourt, Christianisme, 169-90; W. Baum and D. Winkler, The Church of the East: A Concise History (London, 2003), 33-4; M. Hutter, 'Mar Aba and the impact of Zoroastrianism on Christianity' in C. Cereti, M. Maggi, and E. Provasi (eds.), Religious Themes and Texts of Pre-Islamic Iran and Central Asia. Studies in Honour of Professor Gherardo Gnoli (Wiesbaden, 2003), 167-72; Payne, Christianity and Iranian Society, ch. 3. On the historicity of the Syriac Acts of Aba, see P. Peeters, 'Observations sur la vie syriaque de Mar Aba, catholicos de l'église perse (540-52)', in Miscellanea Giovanni Mercati V: Storia ecclesiastica-Diritto (Vatican City, 1946), 69-112.

This is an open access version of the publication distributed under the terms of the Creative Commons Attribution-NonCommercialNoDerivs licence (http://creativecommons.org/licenses/by-nc-nd/3.0/), which permits non-commercial reproduction and distribution of the work, in any medium, provided the original work is not altered or transformed in any way, and that the work is properly cited. For commercial re-use, please contact academic.permissions@oup.com 
hagiography set in ancient times, Narsai's party seems to have also commented on more contemporary history, in order to champion Narsai's own right to rule. A second phase of historical composition occurred under Joseph (552-67). Here too was a catholicos whose rule was challenged, and who would ultimately be deposed. But Joseph was also probably the first to claim the title of patriarch, and his reign witnessed a major celebration of his predecessor Aba's reign, which took the form of a lengthy, and historically aware, piece of hagiography, the Acts of Aba.

Several themes link the historical material for 484-c.540 that was composed in these two phases. Much of this, especially sections on the catholicoi themselves, is concerned with the relationship between the catholicos and the shah; the connections between the catholicos and the schools of Edessa and Nisibis and the changing attitude to clerical marriage. ${ }^{4}$ For each of these relationships, the Chronicle of Seert and the other medieval compilations provide a view of how the circle of the catholicos represented other important institutions and events, and how these images were used to assert a powerful and politically active role for catholicoi within the Church of the East and the wider Sasanian Empire.

\section{CLERICAL REFORM: ACACIUS AND BARSAUMA}

A key opponent of the catholicos Babowai, and the prestige of Ctesiphon in general, was the controversial theologian and bishop Barsauma of Nisibis. Acacius' predecessor Babowai had presided over a church troubled by abuses of the liturgy and clerical behaviour, which confirms the general impression that the silence of the sources in the middle of the fifth century reflects an absence of church government. ${ }^{5}$ Barsauma was a product of the School of the Persians in Edessa and may have been more exposed to the more regulated practice of church government in the Roman world. After convening a synod without the catholicos in 484 he condemned Babowai for his bad governance. Shortly afterwards, however, Babowai was caught corresponding with the Roman emperor Zeno (474-91) and executed. ${ }^{6}$ In spite of the accusations levelled against Babowai, he was subsequently presented as a martyr, and Barsauma

\footnotetext{
${ }^{4}$ Despite the variety of material, the medieval compilations all share roughly the same narrative of the actions of the catholicoi, and they are significant personalities in all the stories that are set in this period. The Haddad Chronicle's coverage is not extant this late, and Bar Hebraeus represents a Miaphysite commentary on 'eastern' history after Dadisho', so my analysis here is restricted to Mari, 'Amr, and the Chronicle of Seert.

5 Gero, Barsauma.

${ }^{6}$ Chronicle of Seert, II/i, I (99-102); 'Amr, HE, 29-30/17-8; Mari. HE, 42/37. There is also a brief Syriac Acts of Babowai, which presents him as a martyred catholicos of the church, in the
}

This is an open access version of the publication distributed under the terms of the Creative Commons Attribution-NonCommercialNoDerivs licence (http://creativecommons.org/licenses/by-nc-nd/3.0/), which permits non-commercial reproduction and distribution of the work, in any medium, provided the original work is not altered or transformed in any way, and that the work is properly cited. For commercial re-use, please contact academic.permissions@oup.com 
provided a convenient scapegoat for Babowai's arrest because of his close relationship with the hated shah Peroz (457-84). ${ }^{7}$

Barsauma's importance has been exaggerated by all parties. Depending on their agenda, later historians would blame Barsauma for introducing clerical marriage and/or Dyophysite Christology into the Church of the East. Both could be represented as the innovation of a lax and disobedient priest. However, as Stephen Gero has argued, both innovations are best ascribed to the policies of Acacius rather than those of Barsauma: Acacius' 486 synod was clearly focused on the regulation of monasticism. ${ }^{8}$ Later historians have confounded the original issue of authority with other issues.

The dissident bishops did not remain a coherent party after the death of Babowai, and Barsauma appears to have made his peace with Acacius. Acacius' reforms focused upon the regulation of monasticism, clerical celibacy, and marriage laws, reforms that may have been designed to distance the Church of the East from Miaphysite refugees from the Roman world. ${ }^{9}$ Acacius would go on to establish good relations with the shah: he served as Peroz's ambassador to Zeno and was well-received by the short-lived Valash (484-8). ${ }^{10}$

The events of this era have been reimagined after the 540s with the restoration of clerical celibacy. The continuations of the patriarchal history were probably already critical of Barsauma for his alleged role in Babowai's death, but to this criticism were added further accusations of the abolition of clerical celibacy. The extent of this rewriting can be seen by comparing the declarations of the synods to the records of the medieval compilations.

The record of Barsauma's synod of Beth Lapet in 484 seems to have been stripped of all detail. Unlike the other synodical records, there is no record of its content or its signatories: both must be reconstructed from other sources, of which Acacius' synod of 486 is the most important. ${ }^{11}$ The 484 synod resolutions were probably aimed at the illegitimate marriage of priests under Babowai and provided for the regularized release from vows of celibacy. ${ }^{12}$ The second (486) synod focuses on abuses within asceticism: it proclaims that it will confirm the precepts of earlier 'fathers and bishops' and amend the rules in the church that have been 'perverted'. Canon I emphasizes the Christology of Theodore of Mopsuestia, condemning any who mix the two natures of

company of Symeon and Aba. The brevity of this account may indicate that it was only his death that made him a suitable object of veneration.

7 Gero, Barsauma, 40-9.

${ }^{8}$ Gero, Barsauma, 40-9 and Labourt, Christianisme, 140-2.

9 On the Miaphysite 'invasion', see Fiey, Jalons, 127.

${ }^{10}$ Chronicle of Seert, II/i, XI (122); Mari, 32-3/37-8; 'Amr, 35/20-1.

11 Synodicon, 61. Ibn al-Tayyib (II, 116) credits Barsauma with removing the need for metropolitans to be 'perfected' by the catholicos after their ordination, which would have removed their dependence on Ctesiphon.

12 Chronicle of Seert, II/i, I (99-100).

This is an open access version of the publication distributed under the terms of the Creative Commons Attribution-NonCommercialNoDerivs licence (http://creativecommons.org/licenses/by-nc-nd/3.0/), which permits non-commercial reproduction and distribution of the work, in any medium, provided the original work is not altered or transformed in any way, and that the work is properly cited. For commercial re-use, please contact academic.permissions@oup.com 
Christ. Canon II attacks those who go around 'clothed in black' and deceive the poor, noting that while ascetics of old lived in the desert, these men wander in cities and villages. Acacius accuses them of sowing discord between priests and their congregations and of offering baptism, and demands that they live in monasteries, built in remote places, and obey the priests, deacons, and periodeutes that have authority over these places. Individual laymen and priests are similarly banned from giving sanctuary to such ascetics, and Acacius threatens to expel them from communion. Finally, Canon III permits clerical marriage, noting that many 'fall [into sin] through adultery and fornication' and that is better 'to take a wife than to burn with lust'. Following this idea, Acacius allows marriage to bishops and to those already in the diaconate, and allows second marriages to priests whose first wives have died, without any episcopal interference. $^{13}$

Acacius' strong appeals to apostolic precedent are accompanied by nervous assertions of the unity of the church and threats against 'any bishop, priest, or monk' who will not obey the synodal decree. ${ }^{14}$ Similarly, he emphasizes Barsauma's retraction of 'his' synod, 'which was held against the canons of the church'. ${ }^{15}$ Thus Acacius' synod tries to impose legislation on the church that he expects many will oppose, namely clerics and monks (as well as just the 'dissident bishops' that Dadisho c condemned in his 424 synod) ${ }^{16}$ His canons reflect, on one hand, the growth of the church in the fifth century in spite of its lack of central leadership, to such an extent that ascetic missionaries were offering baptism outside clerical control, while, on the other, they show that this expanded church also found it hard to enforce moral behaviour on its own clergy. Acacius' main focus in this legislation may have been the restoration of an appropriate divide between clergy and laity, and to use admission to communion as a means of demarcating membership of the Christian community.

Babai's 497 synod is a brief recapitulation of Acacius' canon on clerical marriage and an attempt to regulate its practice. Its preamble reflects on the schism between Acacius and 'the excellent Barsauma and his followers' and annuls all of their mutual interdicts. This schism seems to have been primarily viewed as a challenge to the authority of Ctesiphon, since the following paragraph reiterates the importance of 'the orthodox laws of the fathers and the primacy of the apostolic see of Kokhe, ${ }^{17}$ before acknowledging Babai as catholicos. The synod continues by imploring unnamed bishops not to separate themselves from 'this holy see of the fathers'. It also requests that the

13 Synodicon, 57-9. 14 Synodicon, 59.

15 Synodicon, 61. Notably there is no individual denunciation of Barsauma. Gero, Barsauma, 52.

16 Discussed above in chapter 1.

17 Kokhe lay slightly to the south of Ctesiphon proper, across the empty former bed of the Tigris.

This is an open access version of the publication distributed under the terms of the Creative Commons Attribution-NonCommercialNoDerivs licence (http://creativecommons.org/licenses/by-nc-nd/3.0/), which permits non-commercial reproduction and distribution of the work, in any medium, provided the original work is not altered or transformed in any way, and that the work is properly cited. For commercial re-use, please contact academic.permissions@oup.com 
bishops should convene every four years with the catholicos, a hope that was unfulfilled. $^{18}$

The overwhelming issue for the unity of the church was Barsauma's right to challenge the authority of the catholicos, first Babowai and later Acacius. By holding a synod without the catholicos in Beth Lapet, the shah's winter capital, Barsauma was threatening the authority of all of Babowai's successors and their see. Though Acacius does foresee monastic opposition to his canons, Babai's synod focuses on the relationship between the catholicos and his bishops. As Gero observes, there is no reason to see celibacy as the greatest source of discontent in the Church of the East during 484-97. ${ }^{19}$ The synodical records show it was an important feature of legislation, but all conveners of synods saw reform as necessary: the point of disagreement between them was an issue of authority rather than 'policy'.

The medieval compilations' treatment of Barsauma and Acacius can be divided into two major strands. The first emphasizes Barsauma's role as an opponent of Babowai and Acacius in terms of their authority, as well as his influence with the shah, while the second focuses on his role in bringing Dyophysitism to the Church of the East and his connection with the Schools of Edessa and Nisibis. By referring to the titles of sections in the Chronicle of Seert, it is clear that the first of these strands were associated with the patriarchal histories: all characterizations of Barsauma as an opponent of the catholicos are placed in sections that treat just the catholicos or the relationship between the shah and the Christians (e.g. II/i, I and VIII). By contrast, sections that focus on Barsauma's Christology and his connections to important 'orthodox' figures are all devoted to individual theologians trained at the School of Nisibis and seem to reflect a distinct historical tradition that was later united with the patriarchal histories (e.g. IX and XI).

The compilations place the origin of clerical marriage at two points in the narrative: in the time of Babowai and the time of Acacius. The Chronicle of Seert reports that Babowai was reproached for his bad conduct for allowing malpractice in the church. It says that the laity ran the affairs of the church, ... bishops allowed women inside to see baptism, ... adultery was commonplace, priests and monks married without licence' and excommunicated people received the sacraments in the houses of the laity. ${ }^{20}$ But this section does not name Barsauma as the convener of the unnamed bishops who criticize Babowai: it only records that he authorized priests and monks to

18 Synodicon, 63-6. $\quad 19$ Gero, Barsauma, 40-5.

20 Chronicle of Seert, II/i, I (99-100). Mari, HE, 41/36 specifies that the bishops demanded an end to incestuous marriage, which foreshadows Aba's later legislation. 'Amr, 33/19 does not mention any of Babowai's faults, which makes his account more straightforward in its criticism of Barsauma.

This is an open access version of the publication distributed under the terms of the Creative Commons Attribution-NonCommercialNoDerivs licence (http://creativecommons.org/licenses/by-nc-nd/3.0/), which permits non-commercial reproduction and distribution of the work, in any medium, provided the original work is not altered or transformed in any way, and that the work is properly cited. For commercial re-use, please contact academic.permissions@oup.com 
marry, 'using Paul's words as his pretext: it is better to marry than to burn'. ${ }^{21}$ It then reports that Babowai complained to Zeno about the persecution of Christians in the empire, but that his letter was intercepted by 'the party of Barsauma' at Nisibis and that he was handed over and executed. It then adds that 'some say it was Barsauma that did this'. ${ }^{22}$

This section is unusually detailed, and seems to come from an ecclesiastical history based around annual entries dated in AG (the Seleucid era). It seems to have combined a series of distinct, but probably still similar, narratives of the same events. Its account of the faults of Babowai matches Acacius' later complaints about abuses in the church and explains his reformations as an attempt to regulate morality and reaffirm clerical influence. But a later focus on clerical celibacy, which followed the reversal of these reforms under Aba, coupled with the need to defend the institution of the catholicos, has led later authors to reduce the role of Barsauma in the reform of church governance and implicate him to varying degrees in Babowai's murder.

The Chronicle's section on Acacius also shows bias against Barsauma. Here Acacius is presented as an ally of Babowai against Barsauma, and, after his election, Barsauma's 'faction' accuses the catholicos of adultery, a charge that Acacius only dispels by showing that he is a eunuch. ${ }^{23}$ The Chronicle also provides a second account of Acacius' reign, this time drawn from an ecclesiastical history that mixes up the secular affairs of the shahs with the deeds of churchmen in the Church of the East and in the Roman world. This account is more positive about Barsauma: it observes how Acacius reconciled himself with him and annulled the mutual anathemas of him and Babowai. But when this second account records Acacius' ascetic legislation its omissions are striking: it presents Acacius' reforms only as a crackdown on the false use of sacraments by wandering ascetics, especially by 'the heretics who were coming into Persia' (i.e. the Jacobites), and omits any reference to his reform of clerical celibacy. ${ }^{24}$

Thus, the Chronicle of Seert testifies to a variety of approaches to the memory of the events of 484-97 that emphasized different points in the narrative: Barsauma could be condemned as the killer of the catholicos and distanced from any legitimate opposition to Babowai, while Acacius could be set apart from his reformation of clerical morals and was remembered chiefly as an opponent of the Jacobites. This complexity is itself an indication of how the Chronicle was compiled. A simple narrative of the deeds of the catholicoi lies at the core of these accounts, but it has been overwritten with new material, and with differing opinions about contentious events, by the ecclesiastical historians of later generations, many of whom who found a suitable villain in the figure of Barsauma of Nisibis.

${ }^{21}$ Mari has 'usurping Paul's words'.

${ }^{23}$ Chronicle of Seert, II/i, VIII (113).
${ }^{22}$ Chronicle of Seert, II/i, I (101).

${ }^{24}$ Chronicle of Seert, II/i, XI (122-3).

This is an open access version of the publication distributed under the terms of the Creative Commons Attribution-NonCommercialNoDerivs licence (http://creativecommons.org/licenses/by-nc-nd/3.0/), which permits non-commercial reproduction and distribution of the work, in any medium, provided the original work is not altered or transformed in any way, and that the work is properly cited. For commercial re-use, please contact academic.permissions@oup.com 


\section{CLERICAL REFORM: NARSAI, ELISHE, AND THE HISTORY OF A CRISIS}

The legislation on celibacy and asceticism within the Church of the East, by which priests and monks were allowed to marry, was a central feature of the criticism of Barsauma. But criticism of married clergy per se is not a consistent feature of the material in the compilations for the early sixth century. Many narratives continue to uphold the reputations of most of the married catholicoi of this period and still treat these men as part of the chain of authority linking the church of the time of writing to the past. The counter-reformation of Aba did alter the presentation of the past, but it did not do so consistently.

The distinctiveness of the catholicoi of the era $484-540$ is visible even in the brief lists of catholicoi discovered by Ebied and Young: Babai and Shila are both recorded as 'married', even though few catholicoi receive any note whatsoever. ${ }^{25}$ Mari and 'Amr too note their marriages and present Shila's marriage as the source of Elishe's claim to the see of Ctesiphon, and therefore as a cause of the schism that followed. ${ }^{26}$

The Chronicle of Seert gives a much more expansive account of both Babai and Shila. The Chronicle presents Babai according to the topoi of a good catholicos: he is unwilling to be elected, and it notes his generosity and scriptural knowledge. It also credits Babai with annulling the anathemas that had been instated between Acacius, Babowai, and Barsauma and with ensuring that clerical marriages be public and monogamous. ${ }^{27}$ By contrast, Shila is marked out by his avarice, which is associated with the influence of his wife. ${ }^{28}$ In addition, the Chronicle of Seert is similar to 'Amr and Mari in linking Shila by marriage with Elishe's family and Elishe's own claims as catholicos. Thus, while the Chronicle confirms the testimony of the more abbreviated sources that all of these catholicoi were married, it only renders this a criticism for the reigns of Shila and Elishe.

The histories' impression of who was responsible for these celibacy reforms are complex, because of the importance of the reformers Acacius and Barsauma in bringing Dyophysite Christology into the Church of the East as well as Aba's later counter-reformation. Acacius was famous for his role in asserting a new theological orthodoxy, but his celibacy reforms seemed like heteropraxy from a mid-sixth-century perspective, which meant that the event was passed over and that 'blame' was put elsewhere.

However, the history of Acacius' successors does not seem to reflect this 'counter-reformation' agenda. The narrative of the reign of Babai does not incorporate this later negative attitude towards clerical marriage. The attack

${ }^{25}$ R. Ebied and M. Young, 'List of the Nestorian patriarchs', LM 87 (1974), 87-113, at XXIII-XXV.

26 'Amr, HE, 35-8/21-2; Mari, HE, 48-9/42-3. $\quad{ }^{27}$ Chronicle of Seert, II/i, XV (129).

${ }^{28}$ Chronicle of Seert, II/i, XIX (136-7).

This is an open access version of the publication distributed under the terms of the Creative Commons Attribution-NonCommercialNoDerivs licence (http://creativecommons.org/licenses/by-nc-nd/3.0/), which permits non-commercial reproduction and distribution of the work, in any medium, provided the original work is not altered or transformed in any way, and that the work is properly cited. For commercial re-use, please contact academic.permissions@oup.com 
on married priests is focused on the behaviour of one catholicos, Shila, and his role in providing Elishe with court connections during his struggle with Narsai in the 530s. The thrust of the criticism here is on the role of clerical marriage in facilitating court connections, rather than a generalized objection. ${ }^{29}$

I propose that Narsai's reign and its aftermath also saw a continuation of the patriarchal histories, which showed sympathy with Narsai's position in the face of Elishe's political successes. A relatively early record of the reigns of Babai and Shila, which focused only on the negative attributes of the latter, fits the politics of Narsai's reign better than the counter-reformation of the generations that followed, which would be likely to have condemned all married catholicoi.

Material composed under Narsai survives in the medieval compilations and accounts for the narratives that particularly highlight the importance of 'tradition' and the succession of the catholicoi, but it does not contain the criticisms of married clergy seen after Aba's reforms. Evidence for the composition of a history under Narsai comes from several other points in the Chronicle of Seert. At the end of its account of the martyrdom of Barba'shemin, there is a note that 'a monastery and school', founded at that time, was enlarged under Narsai, which suggests that this coda was added to the text during revisions in or shortly after his reign. ${ }^{30}$ This reference shows both Narsai's wish to appeal to monastic supporters in Ctesiphon and to present his building programme in an ancient tradition that stretched back to the golden age of the martyrs. ${ }^{31}$

Another indication of the polemical use of history by Narsai's faction is also found in the terms in which Elishe is condemned during his victory over Narsai: after giving many presents to the ministers of the king he obtained for himself 'the seat of the church of Mada' in [Ctesiphon], which was built by the apostle Mar Mari, peace be upon him'. ${ }^{22}$ This too indicates the use of a legend of a past golden age, this time the story of the evangelization of Ctesiphon by Addai's disciple Mari, to elucidate contemporary legitimacy and illegitimacy.

The account of the schism itself focuses on the dispute over the canonicity of election and consecration of the two men and the subsequent creation of a dual hierarchy. The Chronicle of Seert provides a long, dense narrative on this subject. This narrative repays close attention. It reports that Bouzaq of Susa convened the faithful for the election of Narsai at Aspanir, a suburb of

29 The Acts of Symeon B may also criticize the court connections of candidates for the catholicosate in the early sixth century (see chapter 2 in this volume). See Chronicle of Seert, II/i, XXV (148) for a possible political context for this.

${ }^{30}$ Chronicle of Seert, I/ii, XXXI (224).

${ }^{31}$ Note that the author of this account did not select either the school of 'Abda or the school of Nisibis as a suitable ancestor for Narsai's foundation: the former seems to have ceased to have had any prestigious successors after its destruction and the latter may have only really become significant in circles around the catholicos in the era of Aba and his successors.

${ }^{32}$ Chronicle of Seert, II/i, XXV (149).

This is an open access version of the publication distributed under the terms of the Creative Commons Attribution-NonCommercialNoDerivs licence (http://creativecommons.org/licenses/by-nc-nd/3.0/), which permits non-commercial reproduction and distribution of the work, in any medium, provided the original work is not altered or transformed in any way, and that the work is properly cited. For commercial re-use, please contact academic.permissions@oup.com 
Ctesiphon, and that the bishops dispatched one Taiman of Basra to consecrate him. However, a group of priests reject Narsai, accusing him of being a layman who 'does not know the laws of the church', and select Elishe, a native of Ctesiphon who had studied medicine among the Greeks, allowing him to win Khusrau's friendship and the support of Shila, who had given him his daughter in marriage. This party argue that Elishe should be accepted since 'the Magi honour him and think him truthful'. After some delay, Elishe is then ordained by David of Merv and 'other contrarian (mahālifin) bishops' in the church of Aspanir, instead of the cathedral of Ctesiphon at Kokhe, 'as the canons decree'. ${ }^{33}$ Elishe is able to win considerable influence by giving bribes and to occupy the church of Mar Mari, though not before Narsai is ordained in the cathedral. However, Jacob of Gundishapur and Samuel of Kashkar, the bishops necessary to ratify any election, do not endorse either candidate. ${ }^{34}$

This section seems to combine material that is biased against Elishe and connected to the earlier sections on Shila and Babai with material that is neutral to both candidates. Thus, a neutral source has reported objections to Narsai, while a pro-Narsai source within the same section also describes him as an educated, virtuous, and charitable man, similar qualities to those ascribed to Babai. Similarly, the neutral source reports the objections of Samuel and Jacob, while the pro-Narsai source reports those who consecrated him and attacks David of Merv. Additionally, the pro-Narsai source focuses on the problem of where the catholicoi were consecrated and condemns Elishe's use of the church at Aspanir. This objection is attached to the pro-Narsai source's other emphases on 'tradition', but it also corresponds to the changing topography of the Ctesiphon conurbation. ${ }^{35}$

St. John Simpson has argued that over-irrigation and localized flooding at Kokhe had caused a considerable displacement of population by the end of the fifth century, though the continuation of ceramic and glass production shows that some people remained. In the fourth and fifth centuries, Kokhe had seen heavy settlement, with subdivided tenements and the encroachment of property onto public space. This was not just associated with the Christian and Jewish administrations that were based here, but also with the production of books, glass, and pottery and with trade in these products and in agricultural goods and metalwork. However, this pattern changed rapidly with the abandonment of the northern and southern parts of the suburb, which was mostly encircled in a bend in the river, and the reconstruction of much of the centre

${ }^{33}$ Note Synodicon, 48 for the establishment of Kokhe as the see of the catholicos in the reign of Dadishoc'.

${ }^{34}$ Chronicle of Seert, II/i, XXV (148-9). Mari and 'Amr provide abbreviated versions of this account, except that 'Amr, 38/22 also gives a list of Narsai's supporters, which confirms the importance of Narsai's faction in the composition of some kind of history.

35 On the central Mesopotamian conurbation see Simpson, Mesopotamia, 174.

This is an open access version of the publication distributed under the terms of the Creative Commons Attribution-NonCommercialNoDerivs licence (http://creativecommons.org/licenses/by-nc-nd/3.0/), which permits non-commercial reproduction and distribution of the work, in any medium, provided the original work is not altered or transformed in any way, and that the work is properly cited. For commercial re-use, please contact academic.permissions@oup.com 
into a colonnaded open courtyard. ${ }^{36}$ Aspanir, further to the south, has not been excavated, but, as a sixth-century royal city with its own impressive monuments, it may well have attracted settlement from populations transferred from elsewhere. ${ }^{37}$

This movement of populations may lie behind the objections of the proNarsai source and its emphasis on 'tradition'. As well as Elishe's court connections he was also from Ctesiphon itself, which may have made it much easier for him to control the church in Aspanir where Narsai had originally been elected. The neutral source says that it was 'priests and others' who objected to Narsai, so possibly Elishe's support was drawn from the local population and its clergy, as opposed to the bishops (who may have been without any local power base in Ctesiphon). This impression of local clerical (rather than episcopal) support for Elishe may also fit the delay in his consecration until suitable bishops could be found. If the previous fifty years had seen population move away from Kokhe, the old seat of the catholicos, to Aspanir, then this may account for why the 'local' candidate was consecrated there. The distinction between the candidates, and the appeal to tradition by the pro-Narsai faction, may rest on the creation of a new suburb and the attempts of its inhabitants to assert their importance and to support one of their own, an act which prompted the shrill appeals of Narsai that asserted the importance of Kokhe and of the scholars and monks that Narsai tried to associate himself with.

The account of the conflict continues with a lament at the duplication of the episcopal and clerical hierarchy, which 'caused the monks living in the mountains to weep' and to hope that Kavad (488-531) and his son Khusrau (531-79) would restore the church to order. Elishe has Narsai imprisoned with Khusrau's support, but he is later released by Khusrau's own son. ${ }^{38}$ Elishe then goes to visit recalcitrant bishoprics that have resisted his orders, imprisoning bishops in Rayy and Merv and creating new metropolitans for Khuzistan and Bahrayn, which prompts Jacob of Gundishapur to write a treatise on ecclesiastical administration to censure him, 'On the duties of those in command'. Elishe even deposes Samuel of Kashkar for his refusal to acknowledge him, but the Kashkarians reject Barshaba, Elishe's candidate for the see. Elishe is made to exclaim before the Seleucians, 'How can the citizens of Kashkar, that vile city, think to defy me, who have been victorious over all lands?' The Kashkarians hear his boast and one of them goes to seek an audience with Elishe after he receives a royal edict confirming his rule and seizes it from Elishe while

36 Simpson, Mesopotamia, 183-7. See further R. Venco Ricciardi, 'The excavations at Choche', Mesopotamia 3-4 (1968-9), 57-68 and R. Venco Ricciardi, 'Trial trench at Tell Baruda', Mesopotamia 12 (1977), 11-14 for the restriction of settlement in the sixth century.

37 Simpson, Mesopotamia, 189-90. Simpson also locates the Iwan-i-Khusrau in Aspanir.

38 Narsai's ally here could be Anoshazad, who later led a rebellion at Gundishapur. Note the discussion of this figure in M. R. J. Bonner, Three Neglected Sources of Sasanian History in the Reign of Khusraw Anushirvan (Paris, 2011).

This is an open access version of the publication distributed under the terms of the Creative Commons Attribution-NonCommercialNoDerivs licence (http://creativecommons.org/licenses/by-nc-nd/3.0/), which permits non-commercial reproduction and distribution of the work, in any medium, provided the original work is not altered or transformed in any way, and that the work is properly cited. For commercial re-use, please contact academic.permissions@oup.com 
pretending to kiss his hand. ${ }^{39}$ After Narsai's death, Biron, the royal doctor and Elishe's patron, tries to get Elishe elected, but instead the shah nominates Paul of Susa, who allows the exiled Samuel of Kashkar to return to his see. ${ }^{40}$

This second half of the account is mostly drawn from the 'neutral source', which objected to the election of both Narsai and Elishe and supported the position of the metropolitans who refused to confirm either. ${ }^{41}$ This source's objection to Elishe is based less on his treatment of Narsai than on his suppression of incumbent bishops and his arrogance, which also prompts John of Gundishapur's theoretical treatment of the duties of ecclesiastical leadership. The same source also draws a distinction between the arrogant Elishe and his supporters at Ctesiphon and the Kashkarians who oppose him. This contrast seems distinct from the emphasis on the traditional role of Kokhe as the seat of the catholicos in the pro-Narsai source. Instead it focuses on the dependence of the catholicos on his fellow metropolitans and on the legitimacy of the 'neutral' position of Jacob and Samuel. At the same time, however, this source also confirms our impression that Elishe's supporters were concentrated in Ctesiphon, and that it was his attempt to use support in the capital to dominate other sees that drew accusations of tyranny.

This neutral source bases its criticism of the era of schism on the general absence of morals and on the illegitimacy of both candidates. As such it reflects the ideas of the reign of Aba, under whom the anti-ascetic legislation of the 480s was reversed, and was probably written after the pro-Narsai material. The reference in the centre of the section to monks lamenting in the wilderness may connect the disorder of the reigns of Narsai and Elishe to the Acacian legislation against public asceticism in cities and tries to conflate the two issues. As we have seen, the narrative at the beginning of the section, drawn from an earlier pro-Narsai account, had criticized Elishe's marriage into Shila's dynasty as a corrupt means of generating influence at court, but it did not criticize it as an abuse of the duty to clerical celibacy per se, which would have become an obvious criticism after Aba's legislation.

The reference to the lamenting monks connects the squabble of the catholicoi and the creation of a dual hierarchy to the decline in morals that began in the 480s and was terminated by Aba. Aba's 'counter-reformation' provided a lens through which the whole reformed period was seen, but the material produced by the pro-Narsai party has still left traces in later compilations of history that pertain to this era. Specific criticisms of Shila and Elishe from the reign of Narsai may have been incorporated into later, more generalized

${ }^{39}$ Kashkar, as the second city of southern Iraq, may have had a natural rivalry with Ctesiphon, which would also explain the animosity against Elishe.

${ }^{40}$ Chronicle of Seert, II/i, XXV (150-2).

41 The section on Paul (Chronicle of Seert, II/i, XXVI (153) is also drawn from this source, since it continues to emphasize the importance of Jacob and Symeon.

This is an open access version of the publication distributed under the terms of the Creative Commons Attribution-NonCommercialNoDerivs licence (http://creativecommons.org/licenses/by-nc-nd/3.0/), which permits non-commercial reproduction and distribution of the work, in any medium, provided the original work is not altered or transformed in any way, and that the work is properly cited. For commercial re-use, please contact academic.permissions@oup.com 
criticisms of the period of 'anarchy' dating from after Aba's 'counterreformation'.

Both this change in moral legislation and the condemnation of earlier divisions are pillars of the synod of Aba in 542. Aba proclaims the unity of the clerical hierarchy and adjudicates disputed sees in Fars and Maishan, he condemns the corruption of church canons and invokes the Old Testament for his 'regulation of morals' and his condemnation of incestuous and polygamous marriage. ${ }^{42}$ These reforms are also emphasized in his saint's life, which is preserved in Syriac, and in the Arabic text used in the Chronicle of Seert. ${ }^{43}$ Of these two, the longer Syriac text is especially critical of previous catholicoi: ' $\mathrm{He}$ [Aba] was chosen for the office of catholicos by all the metropolitans and bishops and clerics and faithful laymen, though it was against his will ... for [in the past] many had been appointed to the office by the shah but did not tend the flock.' The hagiographer continues that Aba

inherited the chair of Mar Symeon [bar Sebba $\mathrm{e}$ e], the victorious catholicos-martyr and his blessed companions, and he also inherited their blessed struggle. And he made peace in the church and uprooted the animosity that the Devil had laid down when the leadership of the church was divided ... and renewed the ancient customs... and confirmed the canons of the apostles of the east. ${ }^{44}$

Like the pro-Narsai source, Aba's hagiographer is keen to make its hero a successor to an earlier golden age of martyrs and apostles. Aba himself was considered as a martyr of the church and recorded in the 'Book of Life', which was recited at the liturgy to commemorate the martyred catholicoi. ${ }^{45}$ Aba's hagiographer anticipates his martyrdom by this comparison with Symeon, and it attaches a special legitimacy to his deeds, representing both his reform of the church and his personal asceticism as indications of a perfect character. The hagiographer's image of Symeon is quite different from that found in the Acts of Symeon. The A Acts in particular had presented the catholicos' virtue in his refusal to cooperate with the shah. But, for Aba, in the hagiography preserved in the Chronicle of Seert, Symeon's virtue was his celibacy: the martyr-catholicos represented a vehicle for different characteristics as the past was rewritten to suit present requirements. ${ }^{46}$ And it was the problems of clerical celibacy and public asceticism that were projected onto earlier generations.

42 Synodicon, 69-72 and 81-2.

43 The Arabic text is an abbreviation of the Syriac that has stripped out many of the details of Aba's opponents and the nuances of their arguments. However, the Arabic text also includes additional scenes that describe Aba's foundation of schools in Ctesiphon (II/i, XXVIII-XXIX) and lists of his disciples (XXX). I argue below that these additional scenes are late sixth-century productions that reflect the growing importance of these schools.

44 Syriac Acts of Aba, 224-5.

45 Note the examples given in J.-M. Fiey, 'Diptyques nestoriens du XIVe siècle', $A B 81$ (1963), 371-414, where martyred catholicoi are distinguished from those who died a natural death.

${ }^{46}$ Chronicle of Seert, II/i, XXVII (159).

This is an open access version of the publication distributed under the terms of the Creative Commons Attribution-NonCommercialNoDerivs licence (http://creativecommons.org/licenses/by-nc-nd/3.0/), which permits non-commercial reproduction and distribution of the work, in any medium, provided the original work is not altered or transformed in any way, and that the work is properly cited. For commercial re-use, please contact academic.permissions@oup.com 


\section{THE SCHOOL OF NISIBIS: BARSAUMA, ACACIUS, AND CHRISTOLOGY}

As we have seen, the primary focus of the patriarchal history was the authority of the catholicos. A secondary issue, that of clerical celibacy, was overlaid onto this, and the loss of a celibate clergy was used to account for the turmoil of the early sixth century by commentators working after Aba's 'counterreformation'. But there was also a third issue that preoccupied historians in their descriptions of the 480-540 period, namely the changes in the theology of the Church and the important role of the School of Nisibis in this process.

Barsauma of Nisibis is a significant character in the histories of this process. Some histories focused on Barsauma's Christology, rather than his reform of ascetics, and these were transmitted within a different body of sources, which focused upon School of Nisibis rather than the catholicosate.

The School of Nisibis played a major role in transmitting Roman Dyophysite theology to the Sasanian world. A former Roman city, situated close to the border, it received refugees from Edessa's 'School of the Persians', an expatriate community of scholars who taught the Dyophysite Christology of Theodore of Mopsuestia. Acacius was himself a product of the School of the Persians, and his canons show an emphasis on Theodoran Christology in reaction to recent Miaphysite arrivals. But other theologians, such as Mar Narsai and Barsauma have a much higher reputation than the catholicos in the scholarly histories of the School of Nisibis itself. ${ }^{47}$

The Chronicle of Seert devotes two sections to 'doctors of Nisibis', to Mar Narsai and Mar Elishe (IX and XIII). ${ }^{48}$ The first of these presents Narsai as a companion of Acacius at Edessa, and notes that both men were trained under Theodoulos, a pupil of Theodore of Mopsuestia, who named Narsai 'the tongue of the East'. It reports how Narsai led the Diophysites at the School of Edessa to Nisibis, where they joined with the small school of one Simeon of Beth Garmai. With the support of Barsauma, this school 'attracted people from far and wide'. The section goes on to record the literary production of Narsai, and of his disciples John and Abraham, and his opposition to the Miaphysite Jacob of Serug. ${ }^{49}$ A different version of the material present in this section is employed in earlier Syriac sources, which acknowledge that Barsauma had been a pupil of Theodoulos alongside Narsai and Acacius, a fact that is skimmed over in the Arabic compilations. ${ }^{50}$

This kind of information about masters and disciples in an intellectual tradition and their literary production is quite different from the material

47 A. Becker, Fear of God and the Beginning of Wisdom: The School of Nisibis and Christian Scholastic Culture in Late Antique Mesopotamia (Philadelphia, 2006).

48 To be distinguished from the catholicoi mentioned above.

49 Chronicle of Seert, II/i, IX (115-17).

50 Cause of the Foundation of Schools, 380. Compare Mari, 44/38.

This is an open access version of the publication distributed under the terms of the Creative Commons Attribution-NonCommercialNoDerivs licence (http://creativecommons.org/licenses/by-nc-nd/3.0/), which permits non-commercial reproduction and distribution of the work, in any medium, provided the original work is not altered or transformed in any way, and that the work is properly cited. For commercial re-use, please contact academic.permissions@oup.com 
used by the patriarchal histories and may belong to a distinct historical genre, the Cause of Foundation of Schools, the first of which was composed by one Elishe early in the reign of Khusrau. ${ }^{51}$ Elishe's text, from which the Chronicle's material may derive, has not survived. But a later document, ascribed to Barhadbeshaba 'Arbaya in the 590s, does. ${ }^{52}$ This work relates the development of education from Creation, seeing all religious systems as schools that attempt to imitate God's own education of mankind. It relates the importance of the doctors of the past, of Eustathius, Jacob, and Athanasius in Antioch, Nisibis, and Alexandria, and of the intellectual succession of Theodore of Mopsuestia. ${ }^{53}$ The Cause goes on to record how the school of Edessa transmitted Theodore's theology as well as that of Ephraem, and how the two were combined in Narsai and his successors. ${ }^{54}$ And it also gives a major role to Barsauma in persuading Narsai to emigrate to Nisibis. He tells him that Nisibis is a great city, set in the borderlands, and all people gather to it from all regions ... many will throng here now that heresy looks out openly from its surrounds in Mesopotamia. ${ }^{55}$

This chain of doctors presents the school community as 'a diachronic succession' that generates a group biography for the whole institution. ${ }^{56}$ Adam Becker has observed that the school of the Persians in Edessa was one of a number of immigrant cultures that acquired Edessene forms of study and academic behaviour, and that the Cause represents an explanation of these Edessene cultural practices and institutions in the new context of the Persian world. ${ }^{57}$ Moreover, the emphasis on Theodoran theology in this institutional history may have also served to bind together the disciples of the school after their departure. Whether students of the School of Edessa served within the ecclesiastical hierarchy or set up their own schools, the school system and its history were tied to the ability to propagate and accurately reproduce 'orthodox' Theodoran doctrine. ${ }^{58}$

One defensive sentence in the Cause suggests that the presence of Barsauma in this history was awkward. In a section that deals with the era of Barsauma, it notes

51 Chronicle of Seert, II/i, XIII (127).

${ }^{52}$ On the identity of this figure, see Becker, Fear of God, 100 and 199.

${ }^{53}$ Cause of the Foundation of Schools, 377-80. Theodore's reputation in the Church of the East was second to none, and knowledge of his theology was probably passed through the schools of Edessa and Nisibis.

${ }^{54}$ Cause of the Foundation of Schools, 381-3.

55 Cause of the Foundation of Schools, 385-6. Barhadbeshaba, HE, XXXI (604) does not mention Barsauma's role here, though he does report that Narsai studied alongside Barsauma (597). This history terminates in 569.

${ }^{56}$ G. Fowden, 'Varieties of religious community', in P. Brown, G. Bowersock, and O. Grabar (eds.), Interpreting Late Antiquity: Essays on the Postclassical World (Cambridge, Mass., 2001), $82-107$, at $87-8$.

57 Becker, Fear of God, 64-75 and 107-10.

58 Becker, Fear of God, 159-66 on village and monastery schools across Mesopotamia (especially Ctesiphon, Arbela, and Hira). Note also the list in E. Yousif, Les chroniqueurs syriaques (Paris, 2002), 311-15.

This is an open access version of the publication distributed under the terms of the Creative Commons Attribution-NonCommercialNoDerivs licence (http://creativecommons.org/licenses/by-nc-nd/3.0/), which permits non-commercial reproduction and distribution of the work, in any medium, provided the original work is not altered or transformed in any way, and that the work is properly cited. For commercial re-use, please contact academic.permissions@oup.com 
that it is not our intention to speak of their way of life, but the manner of their teaching. ${ }^{59}$ The author of the Cause is careful to declare that his genre excuses him from making any judgement about the legislation attributed to Barsauma. Barhadbeshaba's Ecclesiastical History is similarly cautious in its description of the squabble between Mar Narsai and Barsauma's wife Mamai: it emphasizes that Barsauma was modest and it was only Mamai's avarice that caused the strife. ${ }^{60}$ Both notes show that the authors of these histories of scholarship were aware of the criticisms made of Barsauma that associated the married bishop with the decision to abandon clerical celibacy. But Barsauma's reputation as a conduit of Dyophysite Christology alongside Acacius and Mar Narsai and as a co-founder of the School of Nisibis preserved an alternative tradition that was more positive.

Indeed, attacks on Barsauma by Miaphysite sources, while they build on the blackening of his reputation in the patriarchal histories, also confirm the impression of the sixth-century Nisibene sources that Barsauma was also an important link in the Dyophysite theological canon. Dionysius of Tel-Mahre and Bar Hebraeus conflate the different issues of the reform and attach them all to the person of Barsauma, as the killer of Babowai, the oppressor of the monks of Mar Mattai, and as the bringer of Nestorianism. ${ }^{61}$ Notably it is Barsauma, rather than Acacius, who is blamed for all of these 'crimes'. The Miaphysite criticisms are built around earlier attacks on Barsauma that originated within the Church of the East in his opposition to Babowai. ${ }^{62}$ But Barsauma's reputation as an archNestorian may also be a reaction to his good reputation in the Nisibene sources, often more interested in the development of theology than the patriarchal histories, which may reflect his real importance as a defender of Dyophysitism.

\section{THE SCHOOL OF NISIBIS: NISIBENE THEOLOGY IN CTESIPHON}

The presence of these Nisibene traditions in the medieval compilations, and the corresponding contradictions in the reputation of Barsauma, are

${ }^{59}$ Cause of the Foundation of Schools, 387.

${ }^{60}$ Barhadbeshaba, HE, XXXI (609-12).

${ }^{61}$ Dionysius is cited in Michael the Syrian, XI. iv (ed. and tr. Chabot, II, 413/417); Bar Hebraeus, HE, III, 73-5 and 87. The theological emphasis of the synods is actually antiTheopaschite rather than heavily Dyophysite or 'Nestorian' cf. W. Macomber, 'The Christology of the synod of Seleucia-Ctesiphon, AD 486', OCP 24 (1958), 142-54, esp. 142-5 and S. P. Brock, 'Christology of the Church of the East in the synods of the fifth century to early seventh century: preliminary considerations and materials', in Aksum Thyateira (London, 1985), 126-32, esp. 130 emphasizing the Antiochene slant of Nisibene exegesis.

62 Note how much of Bar Hebraeus' narrative for the 484-540 period (HE, III, 73-97) follows the image of 'good and bad catholicoi' used in the other medieval compilations, to which material focusing on Mar Mattai and its opposition to Barsauma has later been added.

This is an open access version of the publication distributed under the terms of the Creative Commons Attribution-NonCommercialNoDerivs licence (http://creativecommons.org/licenses/by-nc-nd/3.0/), which permits non-commercial reproduction and distribution of the work, in any medium, provided the original work is not altered or transformed in any way, and that the work is properly cited. For commercial re-use, please contact academic.permissions@oup.com 
connected to the educational background and reforms of Aba. As well as sections on the Nisibene theologians, the Chronicle also includes a series of narratives that describe Aba engaging in public disputation and founding schools in Ctesiphon on the model of Nisibis. These descriptions are relatively discrete sections of the Chronicle and they reflect the growing connection between Nisibis and Ctesiphon. The importance of these ties in the last decades of the century may suggest that these narratives were composed later than the other narratives of the period c.485-552.

Aba had been trained in Nisibis as well as in the Roman world. ${ }^{63}$ Several sections in the Chronicle of Seert connect him to the foundation of a school of Ctesiphon, an institution that seems to have brought Nisibene traditions of scholarship and exegesis into the capital. Aba was, of course, an important enough figure in his own right for historians to record his foundation, but the school would also produce a number of famous exegetes by the 590s, play a role in the election of the catholicos, and became a famous landmark that was shown to a visiting Roman bishop in the same decade. ${ }^{64}$ Moreover, the School of Nisibis was at the height of its importance at the end of the sixth and beginning of the seventh centuries, as a training ground for catholicoi, abbots, and theologians, and it trained several of Aba's successors as well as ecclesiastical historians such as Barhadbeshaba. The schools of Ctesiphon and Nisibis were joined by a continuity of personnel who were also influential in the church at large at a time when many of the ecclesiastical historians were writing, and Aba's importance was magnified as the man who imported the educational system employed at the School of Nisibis.

The sections describing Aba's scholastic foundations are not present in his Syriac Acts and they are later compositions that reflect the growing power of the School of Ctesiphon at the end of the sixth century. These accounts describe a series of religious disputations between Aba and his Zoroastrian opponents that are used to account for the acquisition of property by the school of Ctesiphon. In the first of these, Aba is accosted by the mobadan mobad (chief priest), who asks him why he has left the religion of his ancestors. Aba replies that he will only venerate a single God, whereas the Zoroastrians venerate both the sun and the moon. He goes on to prove that his God is the only true God by walking through the fire of a fire temple unharmed after making the sign of the cross. The magus converts and gives Aba money to transform the fire temple into a school, the School of Ctesiphon. When Aba places a cross in the centre of the building, the school is immediately overrun by demons in the form of animals, by cats, mice, and lizards, who used to live in the fire temple, until Aba exorcises them. After this, the hagiographer adds, 'the house where those who worshipped fire heard their murmuring chants has become a library for the spiritual books

${ }^{63}$ Chronicle of Seert XXVII (155-7). It was from Nisibis that he was first summoned to the catholicosate by messengers of the shah. Syriac Acts of Aba, 224 .

${ }^{64}$ See full references in Becker, Fear of God, 157-8.

This is an open access version of the publication distributed under the terms of the Creative Commons Attribution-NonCommercialNoDerivs licence (http://creativecommons.org/licenses/by-nc-nd/3.0/), which permits non-commercial reproduction and distribution of the work, in any medium, provided the original work is not altered or transformed in any way, and that the work is properly cited. For commercial re-use, please contact academic.permissions@oup.com 
of the church, and the house of the mobadan mobad has become a cell of the fathers' ${ }^{65}$

The second of these texts is part of a disputation between Aba and a magus. It seems to be the second half of a longer story, which has been omitted here, in which Aba has already responded correctly to three questions from the magus and then asks him a question that he cannot answer. Aba asks 'What should a girl do if she is caught outside by surprise in the rain and is constrained both by the rain and by your laws?' This disputation seems to be part of a wager for a fire temple and Aba takes possession of it and turns it into a school. This building is later restored under Ezekiel (567-81), implying that the story was first recorded towards the end of the century.

In the same section, the shah Khusrau is said to be saddened by the revolt of his son (the Christian Anoshazad), and Aba demands to ask a question of the mobadan mobad to revive his spirits. This question consists of a parable, involving a pot ( $q a d r a$ ), the water inside it, a fire beneath it, and the wood that the fire burns. Aba asks what each of the protagonists in the riddle say to one another. The mobad cannot reply, so Aba tells the shah the following: 'The water begins by telling the pot that it should not oppress it by heating it up, since water helped to make it by being mixed with clay. The pot then tells the wood that it should not cause the water to boil because it grew thanks to the water. Finally the wood tells the fire that "you alone oppress society, because you brought us [together] to harm our fathers ... and your heat has become excessive upon us... You are the real cause of these injustices." ${ }^{\text {"66 }}$

Neither of the riddles in this section are clear, and they have almost certainly been garbled in transmission. The first seems to hinge on Zoroastrian taboos against the presence of women in a fire temple, which makes the situation a practical challenge for the magus. The second riddle is explained in the text as a reference to the ties between fathers and sons, and Khusrau's duty of leniency in Anoshazad's revolt, but another reading of the riddle is also possible. In the context of Aba's dispute with the unnamed mobad, the identification of fire as the source of oppression between the different protagonists in the riddle might mean that fire should be read as a metaphor for the Magi, whose influence causes the different levels of society to oppress one another. Thus, while the riddle does refer to Anoshazad and ask for leniency, it also makes his revolt, ultimately, a product of the importance of the Magi in society.

These disputation accounts should not be read as reports of any real disputation (and the narrative passes over the fact that Khusrau's treatment of Anoshazad was far from lenient). Aba's legislation shows him to be cognisant of Zoroastrian myths, especially the myth of creation that 
was used to justify incestuous marriage. ${ }^{67}$ But the content of the riddles used here are much more simplistic, and take real or imagined Zoroastrian practices, such as reverence for the elements, and misrepresent them or expose them to ridicule. These accounts of disputation probably represent popular Christian perceptions of the debates of Aba, and its arguments rely on commonplace stereotype rather than scriptural knowledge of Zoroastrianism. As such, the inclusion of these accounts shows the impact of scholastic tradition upon Christian self-awareness in an era of interreligious dialogue in Ctesiphon. In addition, the two alternative foundation stories for the school in Ctesiphon indicate the growing importance of the intellectual credentials of the Church of the East outside the scholastic circles that created and used them in debate, and how the creators of these stories, in the era of Zoroastrian importance of the late sixth and early seventh centuries, wished to tie together the reputation of the catholicos Aba and scholastic culture.

The importance of the School of Nisibis affected the historiography of the Church of the East in four distinct ways in the early sixth century. Firstly, the School produced a chain of intellectual biographies of its scholars, of which Mar Narsai's is the most prominent, and which also accentuated their role in bringing the ideas of Theodore to the East. This version of history was embedded into the ecclesiastical histories written from the end of the sixth century and preserves a very different image of Barsauma and the events of the 480s to that included in the continuation of the patriarchal histories. Secondly, the spread of institutions modelled on Nisibis, at Ctesiphon and elsewhere, is seen in the connection of Aba to this intellectual inheritance. The narrative emphasizes his role in intellectual dispute and his academic disciples. Thirdly, Nisibene scholars seem to have had a particular interest in historiography, and the growing importance of the School may have had a direct effect on the expansion of history-writing at the end of the century. ${ }^{68}$

Finally, the School left its mark on the content of history-writing, namely through the record of the treatises produced by Nisibene scholars on the death of the shah Khusrau and their polemic against Zoroastrianism (material that has not survived but is referred to in medieval sources). ${ }^{69}$ Though it is possible

67 Though note A. Panaino, 'The Zoroastrian incestuous unions in Christian sources and canonical laws: their (distorted) aetiology and some other problems', in C. Jullien (ed.), Controverses des chrétiens dans l'Iran sassanide (Paris, 2008), 69-87.

68 This expansion in history-writing is discussed in the following chapter.

69 Assemani, BO IIIa, 71-3 on the lost works of Abraham and John of Beth Rabban 'Against the Magi' and 'On the death of Khusrau', mentioned in the thirteenth-century catalogue of 'Abdisho' of Nisibis (see also Cause, 387-8). Barhadbeshaba, HE, XXXII (620) also mentions Elishe bar Qosbaye's ‘Against the Magians'.

This is an open access version of the publication distributed under the terms of the Creative Commons Attribution-NonCommercialNoDerivs licence (http://creativecommons.org/licenses/by-nc-nd/3.0/), which permits non-commercial reproduction and distribution of the work, in any medium, provided the original work is not altered or transformed in any way, and that the work is properly cited. For commercial re-use, please contact academic.permissions@oup.com 
that the medieval compilations may preserve parts of the Nisibene material on Khusrau, these lost works are most important for what they tell us about the church's political alignment in the sixth century in general. This interest in the deeds of the shahs and a more informed and polemical opposition to Zoroastrianism is also a feature of the presentation of the $484-540$ period in the Chronicle of Seert. The fact that the attitude of the Chronicle matches both the attitude of the mid-sixth-century hagiography of Mar Aba and the lost Nisibene texts suggests that it was a prominent trend in the behaviour of Christian leaders, who sought the patronage of the shah to defend Christians and to humiliate their Zoroastrian opponents.

\section{THE CHURCH AND THE SHAHS: SEEKING FAVOUR}

A continuous feature of all the medieval compilations that discuss this period from the perspective of Ctesiphon is the increased importance of court relations to secure the election of the catholicos, both through the intervention of 'friends at court' or through the personal favour of the shah. We are told the story of the election of Babai thanks to the request of Mousa, astrologer to the shah Zamasp (496-8) and secretary to the marzban of Beth Aramaye. ${ }^{70}$ Similarly, Kavad's favour to the avaricious Shila is explained by his friendship with Bouzaq of 'al-Ahwaz' (Susa) who had healed the shah and his daughter. ${ }^{71}$ This Bouzaq continued to be identified as the power behind the throne in subsequent elections as well: after Shila's death he refused to be elected himself and nominated Narsai (524-37), and Paul, his archdeacon, was also elected catholicos. ${ }^{72}$ With the exception of Narsai, these court connections seem to have been accepted by the electors: in Babai's case, the Chronicle of Seert reports that they immediately insisted on his election in spite of his own protestations. Of course, we cannot take these assertions of unanimity at face value, but they do show the patriarchal sponsorship of a history that asserted that court connections represented a normal and acceptable route to power, both in the past and in the eras of composition. ${ }^{73}$

${ }^{70}$ Chronicle of Seert, II/i, XV (129). Babai also praises the peace-loving Zamasp in his 497 synod (Synodicon, 62).

71 Chronicle of Seert, II/i, XIX (136).

${ }^{72}$ Chronicle of Seert, II/i, XXXV (148); XXXVI (153).

73 Sometimes this discourse of royal involvement could be inverted to attack an opponent of Ctesiphon. Barsauma's condemnation of the catholicos Babowai's martyrdom is an example of this, where Barsauma and 'Persian Christians' are accused of misusing their relationship with Peroz and causing the death of the catholicos (Acts of Babowai, 633-4).

This is an open access version of the publication distributed under the terms of the Creative Commons Attribution-NonCommercialNoDerivs licence (http://creativecommons.org/licenses/by-nc-nd/3.0/), which permits non-commercial reproduction and distribution of the work, in any medium, provided the original work is not altered or transformed in any way, and that the work is properly cited. For commercial re-use, please contact academic.permissions@oup.com 
The chronicles also give weight to personal relationships between the catholicoi and the shahs. Acacius' relationship with Valash, Babai's relationship with Zamasp, and Paul's with Khusrau all receive emphasis, alongside references to their service to the shah in diplomacy or rescuing his troops from drought. ${ }^{74}$ This theme of the shah's patronage in the terse accounts of the catholicoi in the compilations for 484-540 is given even more emphasis in the lengthier account taken from the Acts of Aba. Here Aba is accused by an apostate to Zoroastrianism, Peter of Gurgan, of turning traitor and going over to the Romans. Aba responds by presenting himself before the shah, Khusrau I, to defend himself and to admit the shah's right to put him to death as a Persian subject. It is notable that Khusrau does not punish Aba himself, but gives him over to the mobadan mobad to try as an apostate: the hagiographer is underlining the distinction between the shah's absolute authority, which Aba respects, and the religious law of the Zoroastrian clergy. The hagiography goes on to note that it is the shah who releases Aba from prison, even though he killed other Christians. Seemingly the hagiographer wished to highlight royal cooperation with Aba while downplaying his brief persecution (which lasted 542-5). ${ }^{75}$

A similar tension exists in the Chronicle of Seert's account of the catholicos' role in the revolt of Khusrau's son Anoshazad at Gundishapur. ${ }^{76}$ The Chronicle reports that the Magian priests told the shah that the revolt was instigated by Aba. Khusrau threatens to punish Aba on their account. Aba protests that, while he is the leader of the Christians, he only deserves to be their servant and cannot 'be held responsible for the deeds of a whole community': the shah is 'head of the Magians and all other peoples, but he is not reponsible for the crimes of the general populace'. We have already seen how the division of the Sasanian Empire between èrān and anèrān were used by third-century shahs, when geographic boundaries, with accompanying ethnic and religious connotations, were invoked to assert the distinction between rulers and ruled. ${ }^{77}$ Aba's hagiographer returns to the same issues here. His presentation of Aba as a servant of the Christians removes an element of the distinction between Magians and Christians: all are subjects of the shah and have the same duties of obedience as a consequence. The Acts of Symeon had also presented the catholicos as a servant of the shah, and requests only that the shah respect his right to religion, but this account differs by developing service to the shah into a claim for equality with his other servants. The distinction between the shah's justice and that of the Magian clergy is accompanied in the Chronicle of Seert by the presentation of Magians and Christians as equal subjects of the shah:

${ }^{74}$ Chronicle of Seert, II/i, XXVI (153); XV (130); XI (122).

75 Chronicle of Seert, II/i, XXVII (160). For Peter of Gurgan and his accusation see Syriac Acts of $A b a, 249$. Martyrs of this era include George and Iazbozid: see Scher, note 2.

76 Chronicle of Seert, II/i, XXVII (163). See Shahnameh, VI, 173-83 for the account of this revolt in the Middle Persian tradition.

77 See S. Shaked, 'Religion in the late Sasanian period: eran, aneran and other designations', in Curtis and Stewart, Sasanian Era, 98-109.

This is an open access version of the publication distributed under the terms of the Creative Commons Attribution-NonCommercialNoDerivs licence (http://creativecommons.org/licenses/by-nc-nd/3.0/), which permits non-commercial reproduction and distribution of the work, in any medium, provided the original work is not altered or transformed in any way, and that the work is properly cited. For commercial re-use, please contact academic.permissions@oup.com 
the text's loyalism is mixed with an expanded claim for status. Such a claim may also be rooted in a new social context. The participation of Christians in a revolt by a prospective Christian shah itself demonstrates the existence of Christian militarized elites and their potential to involve themselves in high politics. So, the image of equality before the shah may rest on the new political potential of Christians in the empire, even if Aba's hagiographer is keen to show that the catholicos himself did not participate in any revolt.

Khusrau demands that Aba write to the inhabitants of Gundishapur and tell them to stop their revolt. Aba does so, threatening them with excommunication, and they open the doors of the city. After this Khusrau demands that Aba levy an additional tax on the citizens in exchange for leaving the churches of the city intact. Aba obeys him again, remembering the example of Symeon bar Sebba 'e's resistance to Shapur. However, Khusrau does not keep his half of the bargain and ravages the city. ${ }^{78}$ Here the Chronicle clearly excuses Aba from Symeon's precedent of resistance to the shah. The Acts of Symeon reflected a time when the participation of the catholicos in the Sasanian fiscal system was controversial and ancient precedent was invoked to condemn it. This account, by contrast, justifies a further level of cooperation with the state, in keeping with its more general emphasis on loyalty to the shah. However, Khusrau very publicly failed to keep his promise and the text is incapable of removing this important contradiction: instead, the focus of the narrative is transferred to Aba's behaviour as an ideal catholicos (rather than emphasizing the shah's reaction) and on his opposition to the Magian clergy, in which his loyalty to the shah plays an important role.

The proximity of the catholicoi to the sixth-century shahs might have seemed somewhat shocking, given the role played by their fourth- and fifthcentury predecessors in large-scale persecution. These negative associations may have been deliberately muted by the depiction of the shah as a religiously neutral figure, presiding over a religiously pluralistic empire and encouraging free religious discussion at court. ${ }^{79}$ In one scene, the shah Zamasp is said to have asked Babai to justify the veneration of relics by Christians, which he does by elucidating the belief in the eventual resurrection of the dead. ${ }^{80}$ Burial of the dead had long been a contentious issue in Zoroastrianism: several saints' lives end with the attempts of the Magians to prevent the burial of the bodies of converts to Christianity. ${ }^{81}$ The conversation of Babai and Zamasp, in which the shah is said to have 'shown favour to what he [Babai] said', does not phrase the debate directly in terms of the competition between Christianity and

78 Chronicle of Seert, II/i, XXVII (163-4).

79 E.g. Chronicle of Seert, II/i, XIII (126) and XXIV (147).

${ }^{80}$ Chronicle of Seert, II/i, XV (129-30).

${ }^{81}$ E.g Acts of Narsai, 180 and Acts of Shirin, ch. 27 emphasize the miraculous prevention of the desecration of the saints' bodies. The secret recovery of martyrs' relics is also a hagiographic topos, e.g. Acts of Dadu, 221. See also J. Russell, 'Burial iii. In Zoroastrianism', in EIr.

This is an open access version of the publication distributed under the terms of the Creative Commons Attribution-NonCommercialNoDerivs licence (http://creativecommons.org/licenses/by-nc-nd/3.0/), which permits non-commercial reproduction and distribution of the work, in any medium, provided the original work is not altered or transformed in any way, and that the work is properly cited. For commercial re-use, please contact academic.permissions@oup.com 
Zoroastrianism. But the author does approach this issue obliquely by presenting a shah who, in contrast to his predecessor Peroz, is willing to provide a neutral forum for religious discussion and is shown here assessing Christianity on its own terms. The Zamasp of the compilations, therefore, is shown tacitly agreeing with the Christians in their rejection of a Zoroastrian cultural practice (which was, at any rate, never uniformly obeyed in Iran itself).

Some texts go even further in differentiating the shah from his Zoroastrian advisors. One scene in the Acts of Aba describes how Aba refuses to accompany Persian forces in their invasion of the Roman Empire, whereupon a series of charges are made against him by the Magi. He stands accused of apostasy, forbidding Christians from engaging in polygamous marriage, annulling the decrees of Zoroastrian judges, and baptizing Zoroastrians. ${ }^{82}$ Proselytizing to Zoroastrians had been a contentious issue during the fifth century, but it is noteworthy that here it is the catholicos himself who stands accused, and also that the shah Khusrau is distanced from these accusations. There is no scene to parallel Shapur's interview with Simeon bar Sebba ${ }^{\text {e }}$ inserted into this account.

The other charges brought against Aba, moreover, are novelties. They do not deal with individuals changing religious category, but the boundaries of those categories, i.e. in what situations should individuals be treated as Christians or Zoroastrians? By settling lawsuits for Christians, Aba was seen to be challenging the rights of the Magi as judges, which was officially part of their role as state functionaries. ${ }^{83}$ By governing Christians under a different law, Aba seemed to be trying to carve out a distinct legal space for Christians in the empire. Aba's law-code, which remains extant, carries a strong Old Testament influence, dominated by notions of external pollution taken from the Book of Leviticus. ${ }^{84}$ This articulation of a different set of laws for all Christians challenged the dominance of Zoroastrian customs. Notably, the legal objections of the Magi seem to be prompted by Aba's exclusion of Zoroastrian practices from Christian norms. Aba banned Christians from eating 'the meat

${ }^{82}$ Chronicle of Seert, II/i, XXVII (158-9). A more detailed account of Aba's deeds, and the accusations made against him, is given in the Syriac Acts of Aba: see especially 226-7 for accusations of proselytism and treason; 229 for Aba's ban on Christians from eating meat blessed by Zoroastrians and the complaints of the 'Magians' Shahradur and Adarparwah; 235 for the ban on incestuous marriage.

${ }^{83}$ Payne, Christianity and Iranian Society, 160-9, emphasizes that Aba never directly challenges the rights of the Zoroastrian officials, of the rad (judge/high official) and mobad, to formal judicial powers, such as the confiscation of goods or corporeal punishment. Aba only asserted his right to use 'informal' powers of excommunication to punish Christians who failed to adhere to the canons. These nuances are much more visible in the Syriac Acts (229-32) than in the version given by the Chronicle of Seert.

${ }^{84}$ Laws of Mar Aba, ed. and tr. E. Sachau, Syrische Rechtsbücher III (Berlin, 1914), 258-85. Aba himself is said to have spent much of his time presiding over judicial disputes: Syriac Acts of $A b a, 226$.

This is an open access version of the publication distributed under the terms of the Creative Commons Attribution-NonCommercialNoDerivs licence (http://creativecommons.org/licenses/by-nc-nd/3.0/), which permits non-commercial reproduction and distribution of the work, in any medium, provided the original work is not altered or transformed in any way, and that the work is properly cited. For commercial re-use, please contact academic.permissions@oup.com 
of murmur' (i.e. blessed by Zoroastrian priests) and from engaging in incest and polygamous marriage, which are identified as Zoroastrian practices. ${ }^{85}$

Khusrau I was a man of ambition, who enjoyed much greater economic security and political independence than his predecessors. ${ }^{86}$ And his court was a multicultural hub ${ }^{87}$ that acknowledged and reflected the munificence of the shah in histories, ${ }^{88}$ texts of etiquette, ${ }^{89}$ and translation projects. ${ }^{90}$ Christian scholars and clergymen benefited from the shah's sponsorship. ${ }^{91}$ But they also had to justify their involvement with an institution that had persecuted the church in the past and would continue to destroy Christians who showed any disloyalty or threatened the status quo, such as the rebel Anoshazad. Several Syriac hagiographies celebrated martyrs from Khusrau's reign, many of them high profile 'apostates' from Zoroastrianism, but none of them are recorded in the medieval compilations. ${ }^{92}$ Given the criticism that had once been levelled against collaborators with the state, the patriarchal histories are concerned to present the shah, as far as possible, as an ally of the catholicos and as a religiously neutral figure who could be distanced from the Zoroastrian clergy who sought to control him.

85 Synodicon, 82; Syriac Acts of Aba, 229 on diet and 235 on marriage rulings. Avoidance of these issues could have been problematic for Christians seeking political inclusion in a world that relied on Zoroastrian marriage practices to keep property within families. Note here M. Macuch, 'Zoroastrian principles and the structure of kinship in Sasanian Iran,' in C. Cereti, M. Maggi, and E. Provasi (eds.), Religious Themes, 23-46. For refusal of 'Zoroastrian' food, see Acts of Shirin, ch. 21. Note also P. Gignoux, 'Dietary laws in pre-Islamic and post-Sasanian Iran', JSAI 17 (1994), 16-42, at 21 on differences in slaughtering practice.

86 Z. Rubin, 'The reforms of Khusro Anushirwān,' in Averil Cameron (ed.), The Byzantine and Early Islamic Near East III. States Resources and Armies (Princeton, 1995), 225-97. For the expansion of the monetary economy see especially S. Sears, 'Monetary revision and monetisation in the late Sasanian empire', in R. Gyselen and M. Szuppe (eds.), Matériaux pour l'histoire économique du monde iranien (Paris, 1999), 149-63, at 161-3.

${ }^{87}$ Note the self-description of Khusrau's realm in the geographical texts of the era, analysed in T. Daryaee, 'Ethnic and territorial boundaries in late antique and medieval Persia', in F. Curta (ed.), Borders, Barriers and Ethnogenesis. Frontiers in Late Antiquity and Middle Ages (Louvain, 2005), 123-38, esp. 129-33.

88 Such as the Letter of Tansar and the Karnamg Ardashir-i-Papagan: N. Pigulevskja, Les villes d'iran, 99-100; M. Boyce, The Zoroastrians (London, 2nd edn., 2001), 135; J. Howard-Johnston, 'State and society in late antique Iran', in Curtis and Stewart, The Sasanian Era, 127-50.

89 E.g. Khusrau and the Page.

90 F. de Blois, Burzōy's Voyage to India and the Origin of the Book of Kalilah wa Dimnah, London (1990). Also see T. Daryaee, 'Mind, body and the cosmos: chess and backgammon in ancient Persia', Iranian Studies 35 (2002), 281-312 for other intellectual connections to India, especially in philosophy and astrology.

${ }_{91}$ As well as the catholicoi note Barsauma of Beth Qardu (Chronicle of Seert, XXIV (147), and the famous 'apostate' Paul the Persian: J. Teixidor, 'Aristote en syriaque: les philosophes de la Haute Mésopotamie au VIème siècle', Annuaire du Collège de France 97 (1997), 723-43.

92 George, Iazbozid, and Shirin were all prominent martyrs of this era who are mentioned in Syriac or Greek saints' lives but are not mentioned in the Chronicle of Seert or the other medieval compilations. On these martyrs, note P. Devos, 'Les martyrs persans à travers leurs actes syriaques', in La Persia e il mondo Greco-romano (Rome, 1966), 213-25.

This is an open access version of the publication distributed under the terms of the Creative Commons Attribution-NonCommercialNoDerivs licence (http://creativecommons.org/licenses/by-nc-nd/3.0/), which permits non-commercial reproduction and distribution of the work, in any medium, provided the original work is not altered or transformed in any way, and that the work is properly cited. For commercial re-use, please contact academic.permissions@oup.com 
It is also worth emphasizing here that the account of Aba and his relationship with the shah was probably originally composed during the reigns of his late sixth-century successors, especially his immediate successor Joseph. Joseph enjoyed a very close relationship with the shah, but was also the object of serious criticism from within the Church, which ultimately led to his deposition. ${ }^{93}$ In addition, Joseph is often identified as a composer (or forger) of history, whether as a 'reviser' of earlier lists of catholicoi or the inventor of a letter from the Western Fathers to Papas, emphasizing the authority of the catholicos. ${ }^{94}$ The image of Aba preserved in the Chronicle, of a charismatic ascetic who also cooperates with the state (even in an era of low level persecution) may be an image produced for the benefit of his successors, in an era when they stood to gain much from proclamations of loyalty and from emphasizing the prestige of the office of catholicos: it was in the same era that the catholicoi first branded themselves patriarchs, the equals of the great bishops of the West. ${ }^{95}$

Another side to this closer relationship between the catholicos and the shah was the need to prevent other Christians from acquiring roles as intermediaries with the Sasanian authorities. The focus on the relationship between the catholicos and the shah's court is noticeable in the synodical records. Aba's synod in 540 praised Khusrau as 'a new Cyrus' and justifies the use of civil officers (including Zoroastrian mobads) to press charges against one Abraham of Beth Aramaye. ${ }^{96}$ But the growing prominence of Christian lay elites is also apparent in the synodica. Joseph's synod (554) complains about the use of state law in disputes between churches, citing the example of one church that had a nearby newer church destroyed by the rad in the course of a legal dispute. ${ }^{97}$ Part of the background to this engagement between local churches and the secular law may have been the emergence of more powerful lay patrons who could dominate elections and may have had connections with the civil authorities: Joseph also complains that these men should not judge members of the clergy, 'whether within their communities or in a general

93 Zachariah of Mytilene, XII, vii, p (tr. Greatrex, Horn and Phenix, 454); Chronicle of Seert, II/i, XXXII (179); Bar Hebraeus, HE, III, 72. Note also Labourt, Christianisme, 192-7.

${ }_{94}$ For Joseph as 'reviser' of earlier lists see Assemani, BO, IIIa, 435 on the Nomocanon of Elias of Damascus; for Joseph as forger see Bar Hebraeus, HE, III, 31. One version of the Letter of the Western Fathers is preserved by 'Abdisho' of Nisbis in the thirteenth century (ed. Mai, 325), called here the second letter, and placed after a later (ninth-century) invention that purports to be from the first century. Joseph's synod was also the first to be dated (in AG), which further suggests a new concern for history in his reign.

95 W. Macomber, 'The authority of the catholicos-patriarch of Seleucia-Ctesiphon', OCA 181 (1968), 179-200, at 194 and 196-7. Also note J.-M. Fiey, 'Les étapes de la prise de conscience de son identité patriarcale par l'église syrienne orientale', OS 12 (1967), 3-22.

96 Synodicon, 70 and 73 . The symbiosis of shah and catholicos would receive even greater emphasis in later synods. Ezekiel's synod of 576 would equate the patriarch's jurisdiction to 'all the lands ruled by Khusrau' (Synodicon, 120-1).

97 Synodicon, 99 (Canon 2).

This is an open access version of the publication distributed under the terms of the Creative Commons Attribution-NonCommercialNoDerivs licence (http://creativecommons.org/licenses/by-nc-nd/3.0/), which permits non-commercial reproduction and distribution of the work, in any medium, provided the original work is not altered or transformed in any way, and that the work is properly cited. For commercial re-use, please contact academic.permissions@oup.com 
assembly' and bans their secret involvement in episcopal elections. ${ }^{98}$ Use of state influence or alliances with the laity had become acceptable, but only for the catholicos, and not for different Christian interests acting independently. ${ }^{99}$

The emphasis on the relationship between shah and catholicos in the histories and the synodicon shows the use of the shah's reign as a source of authority. Instead of condemning over-involvement with the state, these texts of the middle sixth century represent it as legitimate behaviour to benefit the whole Christian community. Thus, the histories and synodica of the middle sixth century celebrated the connections of the catholicos, but they also opposed attempts by other Christians to evade the catholicos as the point of contact between the shah and the Christians.

\section{CONCLUSIONS}

The accounts of the early and middle sixth century appear much more complex in the Chronicle of Seert than the material that precedes them. This is in part the result of internecine squabbles in the catholicosate that took place in an era when a tradition of history writing was already well established, and when changes in clerical celibacy needed to be understood and justified without condemning revered catholicoi of previous generations. But this complexity is also the result of the emergence of a new institution that existed in symbiosis with the catholicosate: from the reign of Aba the School of Nisibis would become a training ground for catholicoi and play a major role in the 'preservation' of the Dyophysite orthodoxy of the Church of the East.

The relative stability of this institution must also be tied to the ever-greater prominence of lay Christians in the state and the willingness of the shah to support and use Christians in his service. The representations of Khusrau's reign in hagiography and history both point to a willingness to sponsor Christians at court, and downplay the shah's small-scale persecutions. The sharper delineation of the boundaries of the Christian community in the reign of Aba should be read alongside the new emphasis of the historical tradition on the patronage of the Sasanian court. By asserting the independence of religious groups in a 'pluralist' state, the catholicos also defended his monopoly as an arbiter of Christian behaviour within this state, and justified his

98 Synodicon, 100 and 103 (Canons 4 and 13). See also J.-M. Fiey, 'Les laïcs dans l'histoire de l'église syrienne orientale', POC 14 (1969), 169-83 and M. Morony, 'Religious communities in Late Sasanian and Early Muslim Iraq', JESHO 17 (1974), 113-35, at 118-20.

99 Note Synodicon, 82, which forbids appeals to 'patronage' by laymen who the clergy have involved in their quarrels. Payne, Christianity and Iranian Society, 153-7 argues against the role of ethnicity in triggering clerical factionalism of this kind, which he attributes instead to the abolition of clerical celibacy.

This is an open access version of the publication distributed under the terms of the Creative Commons Attribution-NonCommercialNoDerivs licence (http://creativecommons.org/licenses/by-nc-nd/3.0/), which permits non-commercial reproduction and distribution of the work, in any medium, provided the original work is not altered or transformed in any way, and that the work is properly cited. For commercial re-use, please contact academic.permissions@oup.com 
'collaboration' with the Sasanian authorities. Even if the sources examined here may show a degree of 'wishful thinking' on the part of some Christians, a greater pluralism of religious and political groups may have benefited the shah in turn, by broadening the pool of servants who were tied to his patronage.

The material from the period 480-555 that derives from the patriarchal histories has itself been combined with additional material, with the deeds of shahs, Roman emperors, and Western churchmen, which was collected by later historians. From the end of Khusrau I's reign, Christians appear to have become ever more prominent, both within the empire and in its relations with Rome. This situation is reflected in the changing form taken by the historical compositions that they used to understand and shape their contemporary position and identity in the period c.570-660, which will be examined in the following chapters. 


\section{5}

\section{Roman Ecclesiastical History in the Sasanian World: Reception, Adaptation, and Reaction}

The School of Nisibis achieved great prominence in the course of the sixth century. The School makes an important impact on the development of the Church of the East as a whole. It was a gateway for Western theology; a training ground for powerful bishops and an engine for the creation of a selfpromoting historical tradition. The prominence of catholicoi trained at Nisibis was a major factor in promoting a growing interest in the Church's definition of a formal Christology.

Christology was the major focus of theological discussion in the Roman world, and had been since before the council of Chalcedon in 451. But though the 'School of the Persians' at Edessa had been involved in such disputes, and Barsauma and Mar Narsai had articulated a Dyophysite theology for the Church of the East at the end of the fifth century, it was not a central issue for the catholicoi, at least as seen from the perspective of the synodica or the 'patriarchal histories'. However, the end of the sixth century sees signs of a growing awareness of theological developments in the West, and this prompted attempts to define the theology of the Church of the East more closely and to set out its relationship with the Christian confessions of the Roman world.

In the reigns of Ezekiel (567-81) and Isho yahb I (582-95), the catholicoi came to enjoy an ever closer relationship with the shah and his regime, and this period of central authority and stability meant that they could devote more time and energy to issues of dogma that had once seemed peripheral. In this period, we see the impact of the closer definition of the Church's theology in its historiography. The addition of new forms of history from foreign historical traditions enabled the Church of the East to give itself a defensible, 'orthodox' past, and articulate its contemporary relationship with other Christian confessions.

This is an open access version of the publication distributed under the terms of the Creative Commons Attribution-NonCommercialNoDerivs licence (http://creativecommons.org/licenses/by-nc-nd/3.0/), which permits non-commercial reproduction and distribution of the work, in any medium, provided the original work is not altered or transformed in any way, and that the work is properly cited. For commercial re-use, please contact academic.permissions@oup.com 


\section{THE EXPANSION IN HISTORY-WRITING}

The material that we have encountered from the Chronicle of Seert and the other compiled histories had its origins in 'patriarchal histories': an initial text written towards the end of the fifth century and continuations written around the middle of the sixth. The author(s) of these histories had wanted to highlight the strength of the office of catholicos in the face of external challenges. This reoccurring need to maintain authority prompted a rewriting of the history of the period 484-540 in the middle of the century, probably coinciding with the greater claims to authority by the catholicos Joseph and his declaration of Ctesiphon as a patriarchate. ${ }^{1}$

However, the text of the Chronicle of Seert is clearly not the result of a single strand of composition with periodic continuations. Material from new sources was added which did not always retain the catholicos as its focus. These additional sources described the actions of Roman emperors and the church in the West, the deeds of Persian shahs, monastic foundations in Iraq and, as we have already seen, the disciples of the School of Nisibis. This material all had its origins in discrete historical traditions, such as the Persian 'book of kings' or Roman ecclesiastical history, or in hagiographic collections and lists of saints. It accounts for some three quarters of all the material of the Chronicle of Seert.

An important parallel to this use of additional material in the medieval compilations is the development of the diptychs in the liturgy of the Church of the East. These were lists of famous men whose intercession was sought during the Eucharist. They functioned as highly conservative accretive repositories of the church's historical memory in successive ages and a record of its communion with the living and the dead. A good example of this are the diptychs taken from a rite used at Urmia, in what is now western Iran, in the 1890 s. $^{2}$ The diptychs begin by praying for 'Adam, Abel, Seth, Enosh, Noah, and Shem', and proceed through the figures of the Old and New testaments, culminating in the evangelists and apostles, especially 'Addai and Mari, converters of this eastern region'. After this comes a long list of patriarchs and a shorter list of martyred patriarchs, beginning with Simeon, Shahdost, and Barba'shemin.

Next, the diptychs record 'holy fathers' under a series of different categories: the 318 fathers of Nicaea, former bishops of Urmia; doctors of the church, hermits 'noted for their edifying conversations', 'illustrious athletes and

${ }^{1}$ Barhebraeus, HE, III, 31 accuses Joseph of historical forgery. For Joseph as 'patriarch' see Fiey, Jalons, 77 and W. Macomber, 'The authority of the catholicos-patriarch of SeleuciaCtesiphon', OCA 181, 179-200, at 190 and 196-7. For the late sixth-century expansion in central authority see Joseph, canon 15 and Ezekiel, canon 19 (Synodicon,104 and 121) for the patriarch's role in ordinations, 'from which all the eparchies of the East are generated'.

${ }^{2}$ F. Brightman, Western and Eastern Liturgies, 2 vols. (London, 1901), I, 276-81. These diptychs were read immediately before the peace.

This is an open access version of the publication distributed under the terms of the Creative Commons Attribution-NonCommercialNoDerivs licence (http://creativecommons.org/licenses/by-nc-nd/3.0/), which permits non-commercial reproduction and distribution of the work, in any medium, provided the original work is not altered or transformed in any way, and that the work is properly cited. For commercial re-use, please contact academic.permissions@oup.com 
anchorites', martyrs, and 'holy and Christ-loving kings'. ${ }^{3}$ Interspersed with these lists are also records of local monastic founders, missionaries, and martyrs whose relics are placed near the church. Some of these records may reflect modern figures, but they clearly supplement much older lists of holy men, grouped under different categories, that proceed from Biblical figures, through famous bishops, to other categories of holy men. Many of these lists are composed of figures from the Roman Empire, clustered in the fourth century but with representatives from the first six centuries.

Like the Urmia diptychs, the medieval compilations include material that is additional to succession of bishops of the Church of the East. The histories preserved in the Chronicle for the period 480-580 show a broad focus and great variety, incorporating information from Roman and Persian histories and partially integrating it into the central narrative that continues to focus on the catholicoi.

This process of the accumulation of additional material onto a pre-existent narrative culminates in the period 590-640. Here the Chronicle includes narratives that describe monastic foundations, as well as presenting fluid narrative histories that devote equal weight to the deeds of Persian shahs, Roman emperors, the catholicoi, and Christian aristocrats. The material employed in the Chronicle for the period before 590, while diverse, was clearly drawn from sources that focused on different institutions, and which were not used to create a single integrated narrative. Any links of causation between different 'spheres of interest' is achieved through juxtaposition. By contrast, the final part of the Chronicle, which covers 590-640, presents much more rounded protagonists and links the fates of several different institutions and groups. This more literary composition is probably the original work of the later ecclesiastical historians, some of whom also reordered and expanded much of the earlier material. These men were responsible for literary histories that described the destructive wars of Khusrau II (591-628) and their aftermath. But they were also responsible for the preservation of a large amount of earlier material, of the patriarchal histories, to which they added in various ways with new strands of history that were external to the deeds of the catholicoi per se.

\section{THE IDENTITY OF THE ECCLESIASTICAL HISTORIANS}

The Catalogue of the thirteenth-century theologian and scholar, 'Abdisho' of Nisibis, lists all the notable writers of the Church of the East. Within this

${ }^{3}$ Constantine and Helena, Jovian, Theodosius, Bishoi(?), Nu'man, and Maurice.

This is an open access version of the publication distributed under the terms of the Creative Commons Attribution-NonCommercialNoDerivs licence (http://creativecommons.org/licenses/by-nc-nd/3.0/), which permits non-commercial reproduction and distribution of the work, in any medium, provided the original work is not altered or transformed in any way, and that the work is properly cited. For commercial re-use, please contact academic.permissions@oup.com 
list are a number of historians whose works have not survived: Elias of Merv, Isho'dnah of Basra, Theodore bar Koni, Bar Sahde of Karka de Beth Slouq, Simon of Karka, Simon the Treasurer, Mshiha-zkha, Mikha of Beth Garmai, Gregory of Shushtar, the catholicos Isho'yahb II, and Daniel bar Maryam. ${ }^{4}$ These texts range from a 'short chronicon' by John of Beth Garmai to the three- and four-volume works by Isho'dnah and Daniel, whose work was also accompanied by an explanation of Eusebius' Chronicon. In addition, 'Abdisho' was aware of the chronicles of Theodoret of Cyrrhus and Socrates, and of the Chronicon of the 'Jacobite' Jacob of Edessa. And he also cites several figures who employed history without being historians, such as the liturgist Shahdost of Tirhan; ${ }^{5}$ Simeon of Beth Garmai, who translated Eusebius' Chronicon into Syriac; ${ }^{6}$ and Sergius, who gathered 'ancient traditions'?

There was, therefore, a wealth of historical production as well as the secondary use of history by translators and liturgists. The production built upon earlier texts transmitted from Greek, in addition to the gathering of indigenous material. It is also noticeable that the earliest date ascribed to any of these historians is the 590s (Mshiha-zkha) while the latest is the eleventh century. ${ }^{8}$ The production of history in the Church of the East exploded at the end of the Sasanian period and persisted beyond the fall of the Abbasids. These historians gathered, invented and juxtaposed earlier material as they wrote.

I do not propose that we can reconstruct the writings of any of the ecclesiastical historians that are included in the medieval compilations. But we can analyse the introduction of new categories of historical material and the way it was combined with the patriarchal histories. In this chapter I will examine the ecclesiastical historians' extension of historical inquiry back into the fourth century and before, through their inclusion of Roman ecclesiastical history and the apocrypha that surrounded it. Like the lists of names in the Urmia diptychs, the Western ecclesiastical history employed in the Chronicle of Seert illustrates awareness of theologians who were seen to have laid the foundations of all 'orthodox' churches. Though the style of material is often varied, all of it is shaped by the changing relationship of the Church of the East vis-à-vis the churches of the West, in terms of the awareness and elaboration of a shared 'orthodox' history; Ctesiphon's new claims to patriarchal authority and the

\footnotetext{
4 'Abdisho', Metrical Catalogue. See also the list in Fiey, Jalons, 9 and Degen, 'Daniel bar Maryam'.

${ }^{5}$ Chronicle of Seert, I/i, XVII (273); XVIII (277 and 280), all on Constantine and Nicaea.

${ }^{6}$ Assemani, BO, IIIa, 168.

7 Assemani, BO, IIIa, 171.

8 Assemani, BO, IIIa, 216. The attribution of the Arbela Chronicle to Mshiha-zkha is a twentieth-century forgery. See J.-M. Vosté, 'Alphonse Mingana', OCP 7 (1941), 514-18.
}

This is an open access version of the publication distributed under the terms of the Creative Commons Attribution-NonCommercialNoDerivs licence (http://creativecommons.org/licenses/by-nc-nd/3.0/), which permits non-commercial reproduction and distribution of the work, in any medium, provided the original work is not altered or transformed in any way, and that the work is properly cited. For commercial re-use, please contact academic.permissions@oup.com 
opposition between a church with a strong Dyophysite Christology and its 'Jacobite' adversaries.

\section{A NEW ROMAN PAST}

The Chronicle of Seert's coverage of Roman ecclesiastical history can be divided into two broad parts. Firstly, it contains a chronologically continuous ecclesiastical history drawn primarily from Eusebius' Chronicon and the fifthcentury Greek ecclesiastical histories of Theodoret and Socrates. ${ }^{9}$ This extends from before the start of the extant Chronicle to some point in the break that divides the middle, probably the deposition of Nestorius.

The second major tranche of Roman ecclesiastical history is a narrative based around the succession of the patriarchs of Constantinople and the Christological arguments before and during the reign of Justinian. This narrative strand may begin with the accession of John Chrysostom at Constantinople, but there is no substantive commentary on ecclesiastical politics in the city until the second half of the Chronicle (i.e. the very end of the fifth century). ${ }^{10}$ The continued reception of this ecclesiastical history points to its importance for the identity of the Church of the East as a Dyophysite church, in opposition to its Jacobite opponents.

This version of Roman ecclesiastical history represents a distinctive combination of the fourth- and fifth-century Greek sources that provides a chain of orthodoxy for the fathers of the Dyophysite Christology of the Church of the East, a chain that connects them to Diodore of Tarsus, Theodore of Mopsuestia, and Nestorius. This chapter will analyse the reception of this 'official' church history in the Sasanian and post-Sasanian world and focus on how and why Roman ecclesiastical history was epitomized and adapted. ${ }^{11}$ I begin by examining the Roman ecclesiastical history in Mari's Chronicle and the Chronicle of Seert to determine its original point of composition and the context for the embedding of this material in the 'patriarchal histories' centred on Ctesiphon. After this, I contrast this process to the use of Western history in the Nisibene ecclesiastical history of Barhadbeshaba, with its more explicit focus on the theology and person of Nestorius.

${ }^{9}$ Eusebius was important to the Iraqi ecclesiastical historians for his role in determining the date of Easter (Chronicle of Seert, I/i, XXI-XXII (285-7). His Chronicon was chiefly accessed through the translation of Simeon of Beth Garmai (c.600): Assemani, BO, IIIa, 168.

${ }_{10}$ Chronicle of Seert, II/i, III; VI; XXXIV.

11 The ecclesiastical historians discussed here have a tendency to reduce complex theology to slogans and chains of transmission. Though Christology was of real importance to some, here I investigate the historians' representation of theology as an issue of importance in itself.

This is an open access version of the publication distributed under the terms of the Creative Commons Attribution-NonCommercialNoDerivs licence (http://creativecommons.org/licenses/by-nc-nd/3.0/), which permits non-commercial reproduction and distribution of the work, in any medium, provided the original work is not altered or transformed in any way, and that the work is properly cited. For commercial re-use, please contact academic.permissions@oup.com 


\section{THE DYOPHYSITE FATHERS AND THE RECEPTION OF THE FIFTH-CENTURY HISTORIES}

The material for the third to fifth centuries is excerpted at varying levels of detail from Eusebius and his continuators. ${ }^{12}$ These Greek ecclesiastical histories have been mined to provide discrete biographies of fathers of the church, holy men, and heresiarchs: Peter of Alexandria, Arius, Ephraem, Paphnutius, Flavian of Antioch and Diodore of Tarsus, Basil, Macedonius, and Theodore of Mopsuestia (many of them 'Antiochene', Dyophysite theologians).The great level of detail given to these hagiographic vignettes points to the continued theological relevance of these post-Nicene theologians and to the deliberate assertion of a Dyophysite chain of inheritance stretching back to the fourth century and the conflict with the Arians. ${ }^{13}$ The Chronicle reflects the creation of a canon of theologians, which allows us to ask questions about the sources and intentions of the historians who incorporated this material in the late sixth century and beyond, and the changing self-identity of the Church of the East over the same period.

However, the break in the middle of the Chronicle obscures exactly how this 'chain of orthodoxy' might have continued into the controversies surrounding Chalcedon, the era of the fall of Nestorius at Ephesus, and the contest between Theodoret and other Dyophysites with Cyril of Alexandria. Here Mari's history provides an important point of comparison to the Chronicle. It shares many of the stories of the theologians of this era, often more heavily abbreviated, and his history can provide us with an impression of how the missing section of the Chronicle of Seert treated the fall of Nestorius, which probably concluded its list of 'orthodox' Roman fathers.

Roman ecclesiastical history in Mari exists in a single narrative arc, which extends from the fourth century to the middle of the fifth and is split across the reigns of multiple catholicoi. It is focused on the defeat of the Arians, as narrated in Socrates or Theodoret, and its aftermath in the councils of Ephesus

12 On the continuations of Eusebius' Chronicon in the Syriac tradition see H. Kesseling, 'Die Syrische Eusebius Chronik', OC (1927), 31-47 and 225-39 and (1928), 33-53; W. Witakowski, 'The Chronicle of Eusebius', Aram 12 (2000), 419-37 and R. Burgess, Studies in Eusebian and post-Eusebian Chronography (Stuttgart, 1999), esp. 121 for his comments on the Chronicle of Seert. Chronicle of Seert, I/i, X (247) cites Socrates directly, as well as Theodore of Mopsuestia.

${ }^{13}$ With a few exceptions, only post-Nicene authors were translated into Syriac. S. Brock, 'Syriac literature: a crossroads of cultures', $P d O 31$ (2004), 17-35, at 22. These sections also include figures who are only of peripheral importance to the development of theology, but who would have been significant in the original narratives of Socrates and Theodoret, e.g. the importance of Diodore's opponent Eunomius or his predecessor at Tarsus, Silvanus (XLIX), or the references to Meletius and Eusebius of Samosata in the section on the 'heretic' Macedonius (LII). Other sections, such as that on Basil (LI), may be drawn from Socrates but have been much more heavily epitomized, probably by another ecclesiastical historian.

This is an open access version of the publication distributed under the terms of the Creative Commons Attribution-NonCommercialNoDerivs licence (http://creativecommons.org/licenses/by-nc-nd/3.0/), which permits non-commercial reproduction and distribution of the work, in any medium, provided the original work is not altered or transformed in any way, and that the work is properly cited. For commercial re-use, please contact academic.permissions@oup.com 
and Chalcedon. Like the Chronicle of Seert, much of this narrative focuses on individual theologians, and the material taken from Socrates and Theodoret was summarized with an eye to these vignettes of important individuals and to the heretical opponents of the 'orthodox'.

To cover the middle of the fifth century, Mari uses a continuation of Socrates or Theodoret that links their anti-Arian history to the time of Nestorius. This continuation describes the alliance of the Roman Pope Celestine with Cyril of Alexandria and Cyril's attack on the memory of John Chrysostom, before narrating the failed attempt of John of Antioch to exile Cyril and defend Nestorius. Finally, Mari provides three vignettes, each with a different focus, which continue the main narrative in different ways and present Chalcedon in 451 as a vindication of Nestorius and his opposition to Cyril. There is no indication here that Chalcedon actually confirmed Nestorius' deposition or that John of Antioch ultimately sought to seek compromise with Cyril. Mari records how Marcian commanded the monks who supported Cyril to abandon their position and solicited the support of Pope Leo, whose Tome provided one of the major touchstones of Chalcedonianism, and a stumbling block to hopes of reconciliation with the Miaphysites. ${ }^{14}$ In a second vignette he describes the opposition of Dioscurus, Cyril's successor, and the extreme Monophysite Eutychius to Flavian of Constantinople, 'a disciple of Theodore'. He relates how Flavian was expelled to die in exile before Dioscurus and Euthychius were themselves condemned, and how the name of Flavian inscribed 'in the Book of Life', the lists of martyred patriarchs recited in the diptychs. Finally, in a third vignette, Mari describes the emperor Marcian, the convener of Chalcedon, as the man who restored the order of the church, and praises his marriage to 'the sister of Theodosius [II]' [Pulcheria]. ${ }^{15}$

Therefore Mari presents the Dyophysite fathers in a chain of orthodox succession, leading from Diodore to Theodore of Mopsuestia, followed by their successors Nestorius and Flavian, and completes this narrative arc with his description of Chalcedon as a victory for the Dyophysites. The whole narrative of Nestorius and Flavian is all of the same style, and it is joined together by the depiction of Cyrilians' fight with the Dyophysites from Chrysostom to Flavian. The critical point for our analysis here is that Mari has probably received his account of Nestorius from a Greek ecclesiastical history that, while it was violently opposed to Cyril, also had a positive vision of Chalcedon and found a hero in Flavian, the opponent of the Monophysite Eutyches and a prominent Dyophysite martyr. Nestorius is viewed sympathetically and prominently, but his fall is not the culmination of this narrative.

14 On the Tome see W. H. C. Frend, The Rise of the Monophysite Movement: Chapters in the History of the Church in the Fifth and Sixth Centuries (Cambridge, 1972), 212-13 and 217.

15 Mari, HE, 37-40/32-5.

This is an open access version of the publication distributed under the terms of the Creative Commons Attribution-NonCommercialNoDerivs licence (http://creativecommons.org/licenses/by-nc-nd/3.0/), which permits non-commercial reproduction and distribution of the work, in any medium, provided the original work is not altered or transformed in any way, and that the work is properly cited. For commercial re-use, please contact academic.permissions@oup.com 
The sixth-century ecclesiastical historian Evagrius refers to a little known history of Nestorius that he used for this period, and it may be this that has entered the Iraqi tradition. ${ }^{16}$ Given the emphasis on Chalcedon in this account, it may have come from within a Dyophysite Chalcedonian tradition (even if some of the invective against Cyril and the references to 'Lord Nestorius' are later additions). There was considerable difference of opinion on the orthodoxy of the protagonists of the debates before and after Chalcedon well into the sixth century in Chalcedonian circles in the Roman Empire, as well as ongoing debates about Theopaschism (the doctrine that one of the persons of the Trinity suffered in the flesh). Some Chalcedonians accepted Chalcedon by emphasizing its connection to Diodore and Theodore, while others (so called neo-Chalcedonians) accentuated the contributions of Cyril and argued for Theopaschism. These debates resulted in different florilegia of select fathers (or select quotations from fathers), as well as the production of ecclesiastical histories to defend these selections, such as that of Basil of Cilicia (d.527). ${ }^{17}$ In the 520s and 30s, Chalcedonians would increasingly assert their separation from Nestorius and attempt to reconcile Antiochene and Alexandrian traditions, but before this date, when the city of Cyrrhus could still hold processions for the Dyophysite fathers, some Chalcedonians continued to place heavy emphasis on the connections between Chalcedon and the Antiochene theologians. ${ }^{18}$

The aftermath of Chalcedon produced different attempts to orchestrate the quotations of a patristic past that all sides revered in favour of a theological position and the theologians who espoused it. These took the form of relatively detailed stories, such as those used by Mari, and lists of select fathers, rather than theological quotation. These lists include those who were directly implicated in the formation of Christology (such as Diodore and Theodore), and more famous theologians might accrue more details from hagiographies or older ecclesiastical histories. But these lists and stories also included a number of other figures who were co-opted because of their opposition to heretics (of the fourth century or earlier) who were seen as pre-cursors of the

${ }^{16}$ Evagrius, HE, I, 7.

17 P. Rorem and J. Lamoureaux, 'John of Scythopolis on Apollinarian Christology', Church History 62 (1993), 469-82; S. Harvey, 'Neochalcedoniansm', in The Oxford Dictionary of the Christian Church; R. Janin. 'Basile de Cilice', in DHGE.

18 A. Outler, 'The Three Chapters: a comment on the survival of Antiochene Christology', in A Tribute to Arthur Vööbus (Chicago, 1977), 357-64. Later florilegia of the Church of the East also seem to have been compiled in this formative era. The florilegium used by Giwargis I in 680 (Synodicon, 242-3) employs Cyril himself to contradict the Miaphysite position, implying that the text had originally been gathered with Cyril's followers in mind, seeking to expose the contradiction in Cyril's thought. Also see L. Abramowski, 'Zur geplanten Ausgabe von Brit. Mus. Add. 12156', in J. Dummer and J. Irmscher (eds.), Texte und Textkritik: eine Aufsatzsammlung (Berlin, 1987) and L. Abramowski and A. Goodman, Nestorian Christological Texts (Cambridge, 1972) for examples of florilegia of fifth-century figures translated en bloc from Greek to Syriac.

This is an open access version of the publication distributed under the terms of the Creative Commons Attribution-NonCommercialNoDerivs licence (http://creativecommons.org/licenses/by-nc-nd/3.0/), which permits non-commercial reproduction and distribution of the work, in any medium, provided the original work is not altered or transformed in any way, and that the work is properly cited. For commercial re-use, please contact academic.permissions@oup.com 
Miaphysites. Both kinds of figures were embedded into the Iraqi historical tradition to justify the quarrel with the Miaphysites and describe its history.

We can find good examples of the retrojection of the debate between Cyril and his Antiochene opponents in the selection of fourth-century material used by the Chronicle of Seert. Diodore is identified as an opponent of Photinus and Paul of Samosata, both of whom were traditionally employed as polemical comparisons in Christological debates of the fifth century and beyond. ${ }^{19}$ And Epiphanius of Salamis, the heresiographer, may be included, accompanied by a long hagiography with no theological content at all, because he was identified as an opponent of the fourth-century 'heretic' Apollinarius, who was often represented as the inspiration for the Miaphysitism of Cyril and Severus. ${ }^{20}$ Similarly, lists of 'fathers of the church' may include figures from the far West, such as Damasus of Rome and Ambrose of Milan, because they had opposed the Apollinarians and were subsequently employed in florilegia that were collated to oppose the Miaphysites. $^{21}$

\section{ISHO'YAHB I AND THE INCORPORATION OF ROMAN ECCLESIASTICAL HISTORY}

The lists of the fathers seen in the medieval compilations have their origins in debates in the Roman world in the late fifth and early sixth century. But how did these orthodox lists, and the heresies they opposed, become transmitted into the Church of the East?

The testimony of the synods of Ctesiphon provides the crucial theological background to this reception of history. In these synods there is a clear sense of the importance of the fourth-century councils of the Roman Empire, Nicaea (325) and Constantinople (381), which are referred to as the councils of 318 and 150, referring to the numbers of fathers that gathered there. The councils are seen as the basis for the orthodoxy of the Church of the East: doctrinal canons flow from their definitions. ${ }^{22}$ But specific debates about Christology are not informed by the technical language that had been developed at Chalcedon and before. Even though Aba had been responsible for bringing Nestorius' theological tract, the Bazaar of Heracleides, from the West, Aba's council only discusses Christ's nature by directly quoting Biblical passages. Until the middle of the sixth century, the theology in the Church of the East reflected in these synods, including attacks on Theopaschism, was done using

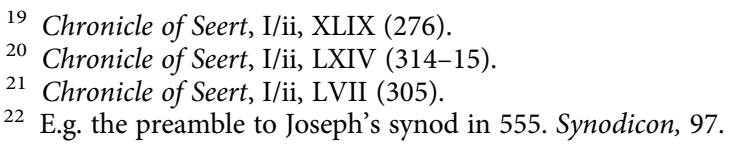

This is an open access version of the publication distributed under the terms of the Creative Commons Attribution-NonCommercialNoDerivs licence (http://creativecommons.org/licenses/by-nc-nd/3.0/), which permits non-commercial reproduction and distribution of the work, in any medium, provided the original work is not altered or transformed in any way, and that the work is properly cited. For commercial re-use, please contact academic.permissions@oup.com 
traditional, local theological terminology, at the same time as earlier Roman synods were represented as defining moments of orthodoxy and church authority.

However, the last quarter of the sixth century witnesses major developments in the self-definition of the theology of the Church of the East, as articulated at Ctesiphon. These were the definition of orthodoxy against a series of heretical opponents and an increasing concern with the technical language of creeds. Heretics are divided into two groups in Ezekiel's 576 synod: Mani, Marcion, and Bardaisan and Arius, Eunomius, and Apollinarius. ${ }^{23}$ The first group of heretics plays a defensive and internal role in Ezekiel's self-presentation: here he is trying to differentiate himself from longestablished nearby groups, drawing on parallels in earlier Syriac writing. ${ }^{24}$ Ezekiel's inclusion of the second group, by contrast, represents a reaction to the relatively recent arrival of the Jacobites in Iraq. It represents a comment on the Roman ecclesiastical history and the intellectual history of the catholicos' Jacobite foe.

Apollinarius, a pupil of Athanasius of Alexandria, had been condemned for his extreme Monophysitism at Constantinople, but one of his formulae, 'the one incarnate nature of God the Word' had circulated as Athanasian and had been used by Cyril. This Apollinarian legacy in the theology of Cyril and his followers had been attacked by Nestorius and Flavian of Constantinople, and Apollinarius could be represented as a precursor to later Miaphysites such as Severus and Philoxenus: a man who had been publicly condemned and whose heresy was renewed under Cyril. ${ }^{25}$ In addition to this, the association of Apollinarius with Arius and the neo-Arian Eunomius presents Apollinarius in the company of an Arian tradition that was opposed by all parts of the Christological spectrum in the sixth century. This association between Apollinarius (and by extension, all later Miaphysites) and the Arians is only presented here in a simple list. But it is the same association that is made at much greater length in the Chronicle of Seert and in Mari. The medieval compilations, drawing on Socrates and Theodoret, would establish the orthodoxy of Diodore of Tarsus and the Dyophysite fathers through their opposition to the Arians as a prelude to their conflict with the Miaphysite followers of Cyril. Similar associations are made in Ezekiel's synod, emphasizing the definition of the church as anti-Arian, in the tradition of Diodore and Nestorius, as well as the Apollinarian connections of later Miaphysites.

23 Synodicon, 114.

24 For Ephraem's writing on Manichees and Marcionites note Murray, Symbols, 78-9.

25 On Apollinarius and his legacy see P. Gray, 'The legacy of Chalcedon: Christological problems and their significance', in M. Maas (ed.), The Cambridge Companion to the Age of Justinian (Cambridge, 2005), 215-36, at 218-19.

This is an open access version of the publication distributed under the terms of the Creative Commons Attribution-NonCommercialNoDerivs licence (http://creativecommons.org/licenses/by-nc-nd/3.0/), which permits non-commercial reproduction and distribution of the work, in any medium, provided the original work is not altered or transformed in any way, and that the work is properly cited. For commercial re-use, please contact academic.permissions@oup.com 
The definition of orthodox doctrine becomes much more explicit in Isho'yahb I's synod of 585. Here the preamble lays a particular stress on the need 'to define the true faith', and, for the first time, issues of creed and the reputation of theologians are debated in the canons themselves. In particular, his first canon provides an exegesis of the creed declared at Constantinople at 381 and highlights the condemnation of the Macedonian heresy, the opponents of Theodore of Mopsuestia, in that council. ${ }^{26}$ This is followed in the second canon by a brief account of Theodore's life, which describes his birthplace, his intellectual succession, and his association with John Chrysostom. Ezekiel's synod had not focused on any particular Dyophysite theologian and was confined to the demarcation of heresy. But Isho'yahb concentrates on the figure of Theodore, confirming his role as the exegete par excellence. ${ }^{27}$

In a synodical letter that is appended to the acts of the 585 council, Isho $y$ yahb continues to refine his definition of orthodoxy. He explains the creed in terms of the avoidance of a series of heresies: the Marcionites, followed by Paulicians and Photinians and then Eutychians and Apollinarians. ${ }^{28}$ The Marcionites and Apollinarians had already been identified in 576, but the addition of other heresies is interesting because they correspond to the accusations made by Nestorius himself in the Bazaar of Heracleides and by Pope Leo of Rome and other Chalcedonians against Dioscurus. Similar accusations were also made in the Nisibene account of the struggle of the Dyophysite fathers, Barhadbeshaba's Ecclesiastical History (written c. 569). ${ }^{29}$

Some twenty years before Isho'yahb, the Jacobites had made substantial inroads into Iraq with the missions of Ahudemmeh, who converted the Arabs of the Jazira and prominent members of the court of Khusrau I. The arrival of the Jacobites presented a growing threat to the catholicoi, at a time when both Christian confessions sought greater political influence. The self-definition of Isho'yahb's synod through the complex heresiology we have seen here implies a more sophisticated and international vision of ecclesiastical history, whereby the Church of the East could use heresiologies developed in the debates of the middle fifth-century Roman world to attack contemporary Jacobites. In addition, Isho'yahb's emphasis on the primacy of Theodore of Mopsuestia was

26 Synodicon, 133-6 (Canon 1).

27 Synodicon, 137-9 (Canon 2).

28 Synodicon, 193-5. He also contrasts the doctrines of Severus with the orthodoxy of Ephraem at 196.

29 Barhadbeshaba, HE, XX (532). Also compare Bazaar of Heracleides, 2 and 99. The Bazaar names these heresies as Manichaeism and Photinianism, but the HE identifies the heresiarchs as Paul of Samosata and Apollinarius, who appear as frequent polemical comparisons in this debate. See further, A. Grillmeier, Christ in Christian Tradition, Volume One: From the Apostolic Age to Chalcedon (Louisville, 1975), 97, on the association of Eutyches with Manichaeans and Apollinarians.

This is an open access version of the publication distributed under the terms of the Creative Commons Attribution-NonCommercialNoDerivs licence (http://creativecommons.org/licenses/by-nc-nd/3.0/), which permits non-commercial reproduction and distribution of the work, in any medium, provided the original work is not altered or transformed in any way, and that the work is properly cited. For commercial re-use, please contact academic.permissions@oup.com 
also an attempt to prevent internal changes to the church's Christology within the School of Nisibis by Henana, whose teachings were represented as dangerous innovations. ${ }^{30}$

The synods of the late sixth century represent Miaphysitism as the continuation of earlier Roman heresy. This interest in the heresiological classification of Miaphysites through their supposed forebears also suggests an approximate dating for the initial inclusion of the Dyophysite ecclesiastical history into the Iraqi historical repertoire. This historical material, like the heresiology of Isho 'yahb's synod, set out the Roman history of the orthodoxy of the Church of the East. This reception of Western history may have been made possible by the prominence of the school of Nisibis, as point of contact for Western ideas and a centre of education for the East, as well as the personal diplomatic contact between the catholicos and the Roman emperor. ${ }^{31}$ In addition, the awareness of this new, theologically significant, history coincides with the first ecclesiastical historians mentioned by 'Abdisho': the availability of a Western historical tradition may have stimulated a late sixth-century flowering of historiography in this period.

\section{NISIBIS AND THE DYOPHYSITE HISTORY OF BARHADBESHABA}

The histories of the Dyophysite fathers that we find in the medieval compilations, and of Nestorius and Flavian of Constantinople in particular, should be seen in the context of another account of the same events composed in Nisibis, the Ecclesiastical History of Barhadbeshaba. This text was produced in c.569 as part of the attempt to link the founding theologians of the School of Nisibis,

\footnotetext{
${ }^{30}$ Fiey, Jalons, 127 notes phases of Jacobite expansion in the 520s, 536-42, and 550s in response to Roman persecution in Syria, when John of Ephesus presents 'Persia' as a major Miaphysite refuge. Also see Baumer, Church of the East, 83 on Henana. Isho' yahb himself was a product of the School of Nisibis, and its sometime governor: Chronicle of Seert, II/i, XXXVI (194) and II/ii, XLII (438). On the debate over Theodoran Christology and the 'innovation' of Henana, see G. Reinink, "Edessa grew dim and Nisibis shone forth": The school of Nisibis at the transition of the sixth-seventh century', in J.-W. Drijvers and A. MacDonald (eds.), Centres of Learning: Learning and Location in Pre-Modern Europe and the Near East (Leiden/New York/ Cologne, 1995), 77-89 and G. Reinink, "Tradition and the formation of the "Nestorian" identity in sixth- to seventh-century Iraq', in B. Ter Haar Romeny, The Religious Origins of Nations? The Christian Communities of the Middle East (Leiden, 2009), 217-50, which disposes of several misconceptions in the older literature (e.g. Morony, Iraq, 326). Reinink observes that both Henana and Babai could be seen as working within the framework of the traditional doctrine of the Church of the East. Also note the assessment of the historiography on Henana in Becker, Fear of God, 198-203.

31 The catholicos himself assumed a role as a diplomat from the shah Hormizd IV to the Roman emperor Maurice (582-602) in 587.
}

This is an open access version of the publication distributed under the terms of the Creative Commons Attribution-NonCommercialNoDerivs licence (http://creativecommons.org/licenses/by-nc-nd/3.0/), which permits non-commercial reproduction and distribution of the work, in any medium, provided the original work is not altered or transformed in any way, and that the work is properly cited. For commercial re-use, please contact academic.permissions@oup.com 
via the school of the Persians in Edessa, to the intellectual tradition of Diodore, Theodore, and Nestorius. Barhadbeshaba begins his history with Arius, and proceeds with a description of Nicaea, Athanasius' opposition to Arius at Alexandria, and then the conflicts between the neo-Arians of the fourth century (Aetius and Eunomius) and their 'orthodox' opponents (Basil, Flavian of Antioch, Diodore, John Chrysostom, Theodore, and Nestorius). This text illustrates the importance of Nisibis as a gateway for the heresiological and historical ideas deployed under Isho 'yahb's patronage, as well as Barhadbeshaba's focus on Nestorius as martyr.

Barhadbeshaba's narrative focuses heavily on the anti-Arian positions of the orthodox. Even his descriptions of later figures such as Theodore and Nestorius emphasizes their credentials as opponents of paganism and Arianism. ${ }^{32}$ Like the account preserved in Mari, Barhadbeshaba probably used the history of Nestorius referred to by the sixth-century Greek Chalcedonian historian Evagrius to compose the last part of this history, ${ }^{33}$ but he combined this with the information contained in the theological work attributed to Nestorius himself, the Bazaar of Herclaides, as well as a Life of Nestorius that provided additional hagiographic details. The density of material devoted to Nestorius makes it clear that he was the centre of this narrative of Dyophysitism in the Roman Empire and that, for Barhadbeshaba, he provided a crucial link to the School of Nisibis and to the Nisibene theologians Narsai and Abraham. ${ }^{34}$

Barhadbeshaba uses Roman ecclesiastical history to present the chain of orthodox teachers by whom Nestorius was educated, before describing his deposition and condemnation by Cyril of Alexandria. The arguments between theologians of the Antiochene school and Cyril culminated in the latter's campaign against the works of Diodore and Theodore, Cyril's condemnation of Nestorius at the 431 council of Ephesus and Nestorius' exile to Egypt. ${ }^{35}$ Barhadbeshaba notes that Nestorius ruled for seven years and was exiled for eighteen, and describes the miracles he performed while in Egypt. The overall effect of Barhadbeshaba's description of Nestorius' sojourn in Egypt may be to present Nestorius as a cipher for Dyophysite orthodoxy, preserved in exile like the scholars of Nisibis. ${ }^{36}$

32 Barhadbeshaba, HE, XIX (507-8) and XX (521).

33 Evagrius, HE, I, 7. The sections on Theodore and Nestorius are written in a similar style to Socrates and Theodoret, with lengthy quotations from letters and speeches.

${ }^{34}$ Unlike most other figures in the history, Nestorius receives two sections, and these are long, with a total of $c .70$ pages in Nau's edition. Sudden jumps in the narrative indicate that Barhadbeshaba is indeed mixing two or more different texts (e.g. XXI, 528-9).

35 Among various modern summaries of these events: H.-I. Marrou (ed.), Nouvelle histoire de l'église (Paris, 1963), I, 384-94.

36 See A. Shin, 'Nestorius and factions in the fifth century', Studia Patristica 39 (2003), 125-30.

This is an open access version of the publication distributed under the terms of the Creative Commons Attribution-NonCommercialNoDerivs licence (http://creativecommons.org/licenses/by-nc-nd/3.0/), which permits non-commercial reproduction and distribution of the work, in any medium, provided the original work is not altered or transformed in any way, and that the work is properly cited. For commercial re-use, please contact academic.permissions@oup.com 
Barhadbeshaba emphasizes both Nestorius' intellectual ancestry ('an Antiochene', 'a co-citizen of Theodore') and his status as a martyr ('a spiritual athlete'). His account of Nestorius' duel with Cyril focuses on his theology, drawing on the Bazaar of Heraclaides itself. The Bazaar influences the structure of the History as a whole: both texts assert the orthodox ancestry of Nestorius and of the sees of Antioch and Constantinople. ${ }^{37}$ The Ecclesiastical History also follows the Bazaar in typifying Nestorius' opponents as 'the Egyptians' and in its presentation of Nestorius' own theology, which emphasizes Mary's role as 'Mother of Christ' rather than 'Mother of God', as Cyril presented her. ${ }^{38}$ Both texts argue for the orthodoxy of Nestorius' position and present Cyril's 'Mother of God' formula as heretical. ${ }^{39}$

We are not concerned here with the accuracy of the claims of the Bazaar or of Barhadbeshaba to represent Nestorius' theology (or with the accuracy of that theology). But this vision of the orthodox succession in the West is not relegated to the past: there is no condemnation of the faith of the Roman world in either text, only a vicious polemic against the Egyptians. The argument is instead for the mistaken condemnation of Nestorius by those who have already realized the falsehood of a truly Monophysite position, such as that of Eutyches. Neither the Bazaar, nor the history of Barhadbeshaba composed over a century later, has abandoned the Roman world as the unredeemable site of heresy.

The Miaphysite historian Zachariah of Mytilene had accused Marcian of being a follower of Nestorius and Theodore in his orchestration of Chalcedon. ${ }^{40}$ Barhadbeshaba's History and the history that was ultimately inserted in Mari's Chronicle seem to have inverted this view, by adopting both Marcian and Nestorius as opponents of Cyril and of the Theodoran tradition. However, we should still note the important difference between the two Eastern histories: Barhadbeshaba is much more focused on Nestorius, as a martyr and as a theologian, while the history used by Mari treats him more simply as an opponent of Cyril. The difference is partly a reflection of the Nisibene author's richer sources and greater interest in theology. But it also raises a broader question of how much emphasis authors in the Church of the East were willing to place on Chalcedon and how far they were aware of the condemnation of Nestorius at Chalcedon or considered it important. Other authors based in Nisibis took very different stances on Chalcedon and placed the breach with Roman orthodoxy much earlier than Barhadbeshaba or the historians working under Isho' yahb I.

37 Bazaar of Heracleides gives a list of 'orthodox' bishops at 377.

${ }^{38}$ Barhadbeshaba, HE, XXI (532) and XXII (538).

39 Barhadbeshaba, HE, XXI (532). Bazaar, 96-8 calls Cyril an Apollinarian, and a Theopaschite (93).

40 Zachariah of Mytilene, HE, III, 1, c (tr. Greatrex, Horn, and Phenix, 101-2).

This is an open access version of the publication distributed under the terms of the Creative Commons Attribution-NonCommercialNoDerivs licence (http://creativecommons.org/licenses/by-nc-nd/3.0/), which permits non-commercial reproduction and distribution of the work, in any medium, provided the original work is not altered or transformed in any way, and that the work is properly cited. For commercial re-use, please contact academic.permissions@oup.com 


\section{CHALCEDON IN THE CHURCH OF THE EAST}

The transmission of a positive account of Chalcedon to the Church of the East occurred under unusual political and theological circumstances. ${ }^{41}$ Isho ${ }^{c}$ yahb I's prestigious diplomatic contacts with Maurice, and their mutual declarations of orthodoxy, occurred at a time when the Roman emperor was acting decisively against Miaphysites in the East. ${ }^{42}$ Maurice targeted Miaphysites leaders who used their religious differences with Chalcedon to assert a measure of political independence. He dismantled longstanding relations with the Ghassanid Arabs and attempted to force the conversion of their leaders to Chalcedonianism, and pursued a policy of rural missionary work, which was especially successful in the Caucasus. ${ }^{43}$ In addition, his reign saw small-scale persecutions of Miaphysites in Harran and Edessa. ${ }^{44}$

Maurice's religious policies may have made Isho'yahb's courting of the emperor a more obvious initiative under this emperor than under his predecessors, since Maurice, unlike Justinian (527-65) or Justin II (565-78), never made concessions to the Miaphysites and applied consistent pressure to prominent Miaphysite centres on the frontier. This relationship may leave an imprint in the image of Maurice preserved in the Chronicle of Seert. History writing in the Church of the East became especially prolific in the generation after Isho'yahb's death, in the reign of Khusrau II, and these histories, preserved in the dense final part of the extant Chronicle of Seert, remember Maurice as the pious supporter of the catholicos Sabrisho', the defender of Khusrau during his civil wars and as a Christian martyr, killed by the usurper Phocas. ${ }^{45}$ His reputation as one of the 'good kings', a successor to Constantine and Theodosius, as he is represented in the Urmia diptychs, was secured by these events.

Some authors in the Church of the East continued the pro-Chalcedon sentiments of the reign of Isho 'yahb I, especially those writing 'history' rather than 'theology'. The Chronicle of Seert includes several sections that continue Roman ecclesiastical history into the sixth century. Some of these focus on events in sixth-century Constantinople, and juxtapose the actions of the patriarchs of that city, such as Anatolius and Gennadius, with contemporary

41 For a survey of the sources and the theology involved see W. de Vries, 'Die syrischnestorianische Haltung zu Chalkedon', in A. Grillmeier and H. Bacht (eds.), Das Konzil von Chalkedon: Geschichte und Gegenwart. 3 vols. (Wurzburg, 1951), I, 603-35.

${ }^{42}$ Mari, HE, 57/49-50 describes Isho' yahb I taking communion with Maurice, but this may confuse the similar meeting between Isho'yahb II and Heraclius.

43 R. W. Thomson, 'The Armenians in the fifth and sixth centuries', in Cameron, WardPerkins, and Whitby (eds.), The Cambridge Ancient History XIV, 662-77, at 674-6; Evagrius, HE, VI, 22 (ed. Bidez and Parmentier, 238).

44 Dionysius of Tel-Mahre, HE, 3, 5, and 9 (tr. Palmer, 112-18).

45 Chronicle of Seert, II/ii, LXVIII (497) and LXX (499).

This is an open access version of the publication distributed under the terms of the Creative Commons Attribution-NonCommercialNoDerivs licence (http://creativecommons.org/licenses/by-nc-nd/3.0/), which permits non-commercial reproduction and distribution of the work, in any medium, provided the original work is not altered or transformed in any way, and that the work is properly cited. For commercial re-use, please contact academic.permissions@oup.com 
catholicoi and Roman Popes as allied opponents of the 'Theopaschites' ${ }^{46}$ This narrative of sixth-century events, focused on the patriarchs of Constantinople, probably provided a continuation of earlier sections that described Chalcedon. The same effect is produced in these sixth-century scenes as the fifth-century scene in Mari: Roman and Constantinopolitan patriarchs, and Chalcedonian emperors, are ranged against the Miaphysites and support the Dyophysite fathers, while the negative vision of Nestorius at Chalcedon is ignored.

However, not all authors within the Church of the East took such this positive view of Chalcedon or the Chalcedonians. The following sections of this chapter examine the genesis of this anti-Chalcedon tradition among certain Nisibene theologians and its dissemination in later generations. This was a version of Roman ecclesiastical history that suited the more extreme Diophysitism of later generations and laid the ground for the self-conception of the Church of the East as 'Nestorian', an idea that was retrojected onto fifthcentury figures such as Dadisho' and Acacius.

\section{THE ANTI-CHALCEDON TRADITION}

Isho'yahb I's positive relationship with Maurice was not matched by the relationship between other theologians of his church and Roman emperors. In the reigns of Justinian and Heraclius, emperors attempted to engage in dialogue with the Church of the East at the same time as presenting concessions to the Miaphysites, either through Justinian's condemnation of the Three Chapters in 553 (in which Theodore of Mopsuestia was denounced) or in Heraclius' doctrine of Monotheletism, that sought to produce a new compromise formula. Moreover, Guillaumont has observed that the opposition of the scholars of Nisibis to Justinian provided a historical precedent that was invoked against Isho $y$ yahb II (628-45), and those who took communion with Heraclius. ${ }^{47}$ In other words, a historical discourse evolved in the course of the late sixth century that asserted the theological boundaries of the Church of the East, in contrast to the more tolerant alternative presented under Isho ${ }^{\mathrm{y}}$ yahb $\mathrm{I}^{48}$

The account of Justinian's meeting with the theologians is preserved in the Chronicle of Seert, though its chronology has been disordered. ${ }^{49}$ It begins by

${ }^{46}$ Chronicle of Seert, II/i, III (104-5); VI (108); XI (123); XIX (138); and XXII (145).

47 A. Guillaumont, 'Justinien et l'église perse', DOP 23 (1970), 39-67.

48 W. de Vries, 'La conception de l'église chez les syriens séparés de Rome II', OS 3 (1958), 149-64, first pointed to the diversity of 'Nestorian' positions on Chalcedon in the sixth to eighth centuries.

${ }^{49}$ Chronicle of Seert, II/i, XXXII (186-8). This section on Justinian includes material from multiple different sources.

This is an open access version of the publication distributed under the terms of the Creative Commons Attribution-NonCommercialNoDerivs licence (http://creativecommons.org/licenses/by-nc-nd/3.0/), which permits non-commercial reproduction and distribution of the work, in any medium, provided the original work is not altered or transformed in any way, and that the work is properly cited. For commercial re-use, please contact academic.permissions@oup.com 
observing Justinian's decline into Julianism (a Miaphysite splinter group). Next it describes how the emperor received a delegation of theologians led by Paul of Nisibis, which also included the future catholicos Isho' $y$ yahb I. These theologians then convince Justinian that 'the nature cannot exist without hypostasis... and that the two natures cannot exist in a single hypostasis (qnūm-an wāhid-an)'. However, Justinian later goes on to anathematize Diodore and his Dyophysite companions, after which he dies.

This embassy occurred in $562,{ }^{50}$ shortly before the emperor's death, but the author has displaced the Three Chapters controversy (from their real date in 553) to maintain the illusion that Paul successfully convinced Justinian and that the emperor later broke faith with him. These events prompted Paul to write his lost 'Treaty against Caesar', whose content is discussed in a ninthcentury Miaphysite polemic. ${ }^{51}$ This text accuses Paul 'the Nestorian' of arguing for two hypostases, and argues that this would render God as a Quaternity and not a Trinity. If these accusations are true then it would present Paul as a more extreme Dyophysite than Isho' yahb I, at least as he comes across in the synods. The Synodicon only reflects Justinian's Three Chapters in the 585 synod, with its defence of Theodore, which is repeated in 596. The delay in reaction from Ctesiphon to Justinian's actions confirm the thesis that Isho'yahb I's reign saw a new international awareness in circles around the catholicos. But it is also notable that Isho'yahb I, unlike Paul, made no explicitly Christological statement to buttress his defence of Theodore. ${ }^{52}$ Ctesiphon appears both more isolated and less theologically developed in this period than Nisibis.

Sebastian Brock has noted that it is only under Babai the great (d.628) that the Church of the East adopted an extreme Dyophysite Christology, with its assertion of two hypostases (qnome) in the Son. ${ }^{53}$ However, as Guillaumont observes, this may reflect trends in the theology of the Church of the East that go back to Paul. ${ }^{54}$ Babai may also draw on Paul's ideas in other ways: he supplemented his Christology with an image of Justinian as a new Saul, 'a murderer of the priests of God', who 'composed heretical books against the orthodox' ${ }^{55}$ Babai composed his works at a time of considerable crisis for the

50 Scher (PO 7, 187 note 6) mistakenly dates this to 533: Guillaumont, 'Justinien', 51.

51 Assemani, BO, IIIa, 88; Guillaumont, 'Justinien', 52-3.

52 Paul was defeated in a political struggle with Isho' yahb's predecessor Ezekiel (Chronicle of Seert, II/i, XXXVI (193-4), and his highly defined Christological position may have seemed threatening to catholicoi inclined towards international compromise.

53 Brock, 'Christology of the Church of the East'; G. Chediath, The Christology of Mar Babai the Great (Kottayam, 1982), 87-8. Reinink, 'Nestorian identity', esp. 220 and 228, notes that Babai's two-qnome formulation was never canonized as part of a creed, and that the church tradition to which he appealed was ambiguous. On this ambiguity of tradition see also A. de Halleux, 'La christologie de Martyrius-Sahdona dans l'évolution du nestorianisme', OCP 23 (1957), 5-32.

${ }^{54}$ Guillaumont, 'Justinien', 61.

This is an open access version of the publication distributed under the terms of the Creative Commons Attribution-NonCommercialNoDerivs licence (http://creativecommons.org/licenses/by-nc-nd/3.0/), which permits non-commercial reproduction and distribution of the work, in any medium, provided the original work is not altered or transformed in any way, and that the work is properly cited. For commercial re-use, please contact academic.permissions@oup.com 
Church of the East, when Miaphysites had gained influence at court and forced their opponents, labelled for the first time 'Nestorians', to publicly justify their orthodoxy before the shah in 612. Like earlier synods of the church, Babai's theology was defined by its stance against Theopaschism, but this was now combined with a greater interest in technical Christology (in the hypostastic union) and in the vocabulary and slogans of Nestorius himself (such as 'Mother of Christ'). ${ }^{56}$ Here Babai articulated a much more extreme Dyophysitism than had previously been employed in the synods, and this period of reaction may underlie the opposition to Isho' yahb II in 630 when he accepted communion with Heraclius at Aleppo after the Romans defeated the Persians and the emperor seemed on the verge of settling differences between Christian groups. ${ }^{57}$

The controversy that surrounded Isho'yahb II's mission receives a lengthy description in the Chronicle of Seert, when a long letter written against the catholicos by one Barsauma of Susa is inserted into the text. ${ }^{58}$ Barsauma begins by praising the catholicos and praying that the church may always be protected from heresy, but he soon launches into criticism of Isho' yahb: 'I cry $\left(a z^{c} a q\right)$ with a loud voice...: there is a chasm ('amiqa) between us and the Greeks that has its origin at the council of Chalcedon, which robbed men of equality ... took away justice $(s a w \bar{a} b)$... forced the fathers to renounce their opinions ... and led to persecution'. He follows this with a further six objections to Chalcedon and to Isho 'yahb's behaviour. The council, he says, praised Cyril and Celestine, ratified the synod of Ephesus and exiled Nestorius. It also proclaimed that two natures could exist in a single hypostasis, and called Mary 'Mother of God', instead of 'Mother of Christ'. Finally, and most importantly, by saying mass with a Chalcedonian, Isho' ${ }^{c}$ yahb had agreed to avoid saying the names of the Dyophysite fathers in the diptychs and therefore abandoned the faith declared at Nicaea and Constantinople ('the faith of the 318 and 150').

Barsauma criticizes Chalcedon at a level of detail not seen before in the Eastern sources. I suggest that the contrast between the information shown here and the positive vision of Chalcedon in Isho' yahb I's historians is a product of the more extreme theological stance in the East after Babai's 'reign', and of ever increasing knowledge about the content of the Western councils, and the criticism of Nestorius at Chalcedon. Barsauma's criticisms follow Babai's agenda in highlighting the importance of the hypostatic union and the title of Mary. In Barhadbeshaba, Nestorius had been seen as a martyr

56 Chediath, Babai, 62-76; Reinink, 'Nestorian identity', 229.

57 Heraclius' patriarch Sergius was represented as 'a follower of Theodore' who apostasized by proposing his Monothelete formula. Chronicle of Seert, II/ii, LXXXII (528).

${ }^{58}$ Chronicle of Seert, II/ii, XCIV (562-78). Isho' yahb's mission to the west was also said to be the occasion for the 'apostasy' of the Eastern theologian Sahdona to the Chalcedonians. See A. de Halleux, 'Martyrius-Sahdona: la vie mouvementée d'un " hérétique " de l'église nestorienne', OCP 24 (1958), 93-128.

This is an open access version of the publication distributed under the terms of the Creative Commons Attribution-NonCommercialNoDerivs licence (http://creativecommons.org/licenses/by-nc-nd/3.0/), which permits non-commercial reproduction and distribution of the work, in any medium, provided the original work is not altered or transformed in any way, and that the work is properly cited. For commercial re-use, please contact academic.permissions@oup.com 
for a Dyophysite orthodoxy, but the condemnation of Nestorius that was confirmed at Chalcedon was never explored, both because of ignorance of the council's contents and because it was represented as a defeat for the followers of Cyril, especially his successor Dioscurus. Increasing awareness of the acts of the Greek church, increased Miaphysite pressure in the East, and the changing policies of the Roman emperors meant that these contradictions were revealed.

Barsauma goes on to present Isho'yahb's actions in terms of his predecessors, by comparing his compromise to their steadfastness. Barsauma compares Isho' yahb to Paul of Nisibis who stood up to Justinian 'though inferior to you in honour and rank', ${ }^{59}$ and recalls Ahai and Acacius, other catholicoi who went to the Romans as diplomats but maintained the honour of the church. ${ }^{60}$ $\mathrm{He}$ chastises Isho'yahb for 'receiving Caesar's gold and the patronage (kar$\bar{a} m a$ ) of Boran (the shahin)' and, calling to mind the last judgement, reminds him that it is a time when empires are being overturned: it is not an occasion when men can gather up treasure for themselves. ${ }^{61}$ In being the dupe of the emperor, Isho' yahb has allowed the beliefs of Cyril and Apollinarius, who have cast their shadows (zilm) over the West, and which have begun 'to encroach upon the lands of the East'. ${ }^{62}$

The historian of these events seems to have inserted Barsauma's letter verbatim. He does not deny Barsauma's vision of the faith, but he is still keen to exonerate Isho'yahb as well. The description of Isho'yahb's meeting with Heraclius corresponds fairly closely to Barsauma's image of orthodoxy: Heraclius is impressed by the catholicos' intelligence, and they discuss Paul of Nisibis' works against Justinian, and they agree that they are consistent with the faith of Nicaea. Heraclius also allows Isho' yahb to suppress the name of Cyril from the diptychs and hears Isho'yahb's defence of Mary's title as 'Mother of Christ'. ${ }^{63}$ Ultimately, Isho'yahb defends himself from Barsauma's accusation by emphasizing that he wanted to make peace with the emperor and that he had always confessed Christ 'in two natures and two hypostases', which 'stifled the flames of Barsauma's anger'. ${ }^{64}$

Though we cannot know what the private agreements actually were between Heraclius and Isho 'yahb II, the catholicos' discussion of Christology in a letter indicates that he saw Chalcedon as misguided, but not the kind of aberration that the Miaphysites represented. He describes Chalcedon as 'neither orthodox nor heretical': 'It was intended to restore the faith, but slipped away [from its intention] due to feeble phraseology.... It can never be said

${ }^{59}$ Chronicle of Seert, II/ii, XCIV (568).

${ }^{60}$ Chronicle of Seert, II/ii, XCIV (573).

${ }^{61}$ Chronicle of Seert, II/ii, XCIV (575).

${ }^{62}$ Chronicle of Seert, II/ii, XCIV (567).

${ }^{63}$ Chronicle of Seert, II/ii, XCIII (557-61).

${ }^{64}$ Chronicle of Seert, II/ii, XCIV (576-9).

This is an open access version of the publication distributed under the terms of the Creative Commons Attribution-NonCommercialNoDerivs licence (http://creativecommons.org/licenses/by-nc-nd/3.0/), which permits non-commercial reproduction and distribution of the work, in any medium, provided the original work is not altered or transformed in any way, and that the work is properly cited. For commercial re-use, please contact academic.permissions@oup.com 
that two hypostases existed within a single nature. ${ }^{65}$ This attitude may have allowed Isho' yahb to accept communion with Heraclius and to only raise certain issues that he considered important, leaving aside the names that Heraclius' bishops might employ in the diptychs or the rehabilitation of Nestorius. Notably, his letter avoids the controversial issue of the names of the diptychs. He only cites one 'father' specifically, Gregory of Nyssa, and only one council, Nicaea. ${ }^{66}$ Similarly, his condemnation of heretics only includes those who were anathematized in all Christian churches (with the exception of Severus). ${ }^{67}$

The concentration of Christological debate on individual reputations had previously been raised as a problematic issue in the Roman world in the early sixth century. In his informal conversations with the Miaphysites, Justinian had protested that 'they say nothing unorthodox, but do not want to communicate with us because of scruples [over] names in the diptychs' ${ }^{68}$ Like Justinian, Isho' ${ }^{c}$ yahb may have seen the possibility of the reconciliation of Christological views that respected the language and traditions of the Church of the East without raising the issue of differences in the diptychs. But, as we have seen, these names (and the rejection of parallel lists of heretics) had been an important feature of the self-definition of the church against the Miaphysites. Isho'yahb employed the sophisticated terminology of Paul and Babai, but also had to function as an intermediary with Heraclius after he had defeated the Persian empire in a twenty-year war. There must have been a great incentive to reach a compromise with an emperor with such dominant political importance, whose victory may have also implied the beginning of the last days, especially when Sasanian rulers were being regularly deposed and no longer offered regular patronage. But, at the same time, the concentration of the self-representation on the Church of the East on the person of Nestorius, which we see in Barhadbeshaba, ultimately revealed the internal contradictions of a canon of orthodoxy that tried to include both Chalcedon and Nestorius. Importantly, the course of events has been edited to limit the significance of Barsauma's objections. Bar Hebraeus, whose Jacobite compilation of the sources would have had less incentive to cover up embarrassing details, presents the meeting as a loss of face for Isho' yahb. He reports that Isho' yahb followed 'the Greek faith' and was dropped from the diptychs until he made a public declaration that he had not denied his faith. ${ }^{69}$

65 Christological Letter of Ishoyahb II (tr. Sako, 146-7).

66 Christological Letter of Ishoyahb II, 152 and 160-1.

67 Christological Letter of Ishoyahb II, 145-6.

68 S. P. Brock, 'Conversations with the Syrian Orthodox in 532', OCP 47 (1981), 87-121, at 109 , section 35 .

69 Bar Hebraeus, HE, III, 113-5.

This is an open access version of the publication distributed under the terms of the Creative Commons Attribution-NonCommercialNoDerivs licence (http://creativecommons.org/licenses/by-nc-nd/3.0/), which permits non-commercial reproduction and distribution of the work, in any medium, provided the original work is not altered or transformed in any way, and that the work is properly cited. For commercial re-use, please contact academic.permissions@oup.com 


\section{A NESTORIAN CHURCH}

The long-term impact of Babai's assertion of a more extreme Christology and a more marked identification with Nestorius and his slogans is apparent as early as the synod of Giwargis I in 680, which explicitly defends the theology of 'Nestorius and Theodore'. ${ }^{70}$ The figure of Nestorius becomes increasingly prominent in the ninth- and tenth-century texts that are contemporary with the Chronicle of Seert. The Haddad Chronicle, in a section devoted to ecclesiology and ritual, describes Ctesiphon as 'the chair of Nestorius' and explains the shape of the catholicos' staff with reference to the staves of Aaron and Nestorius. ${ }^{71}$ By contrast, Theodore of Mopsuestia is not granted any such importance in these accounts. The ninth-century liturgical and ecclesiological compilation formerly attributed to George of Arbela gives a major role to Nestorius in different contexts. Here a number of discussions of theology have their historical context attached, and, in a long text that refers to few individuals, Nestorius is mentioned as the great opponent of Cyril, as the target of the Theopaschite Trisagion and, strikingly, as the source of the church's name as 'Nestorians'. ${ }^{72}$ The fact that pseudo-George employs 'Nestorian' positively shows the shift in attitudes that must have occurred, in some parts of the church at least, between the polemical use of the term in 612 and the church's own use of the term by the ninth century.

Around the same time as George, the liturgist Shahdost of Tirhan also employed a positive image of Nestorius, this time embedded in a synchronized history of the Roman and Persian churches written with a focus on theology and liturgy. Shahdost's work, preserved in a later florilegium, repeats the 'Mother of Christ' slogan and focuses on Cyril's attack on Nestorius at Ephesus. ${ }^{73}$ He calls himself one of the 'Nestorian Christians', in contrast to his Miaphysite opponents, and 'Nestorius' is a common attribution for anonymous texts in the same florilegium. ${ }^{74}$

The identification of the Church of the East with the person of Nestorius did not initially have an impact of the church's vision of the council of Chalcedon. But the growing popularity of Nestorius in the work of Babai and beyond, and the increased definition of the church's Christology made the contradictions in the historical record more acute. Pseudo-Ishaq of Nineveh, in the same florilegium as Shahdost, presents Chalcedon as a moment of apostasy by the one-time opponents of Cyril: 'While some took exile ... others disregarded the fear of the

70 Synodicon, 235.

71 Haddad Chronicle, LXXVIII (118) and LXXXIII (122).

72 George of Arbela, Expositio Officiorum, I, 107; 129-30; 187-8.

73 Translated in L. Abramowski and A. Goodman, Nestorian Christological Texts. Cambridge University Library MS. Oriental 1319 (Cambridge, 1972), II, 13 and 17.

74 Abramowski and Goodman, Nestorian Christological Texts, 31.

This is an open access version of the publication distributed under the terms of the Creative Commons Attribution-NonCommercialNoDerivs licence (http://creativecommons.org/licenses/by-nc-nd/3.0/), which permits non-commercial reproduction and distribution of the work, in any medium, provided the original work is not altered or transformed in any way, and that the work is properly cited. For commercial re-use, please contact academic.permissions@oup.com 
heavenly king to avoid losing their position of leadership ... and assented to a single hypostasis. ${ }^{75}$ Shahdost, by contrast, was more prepared to defend Chalcedon. Well-read in the historical tradition of the Church of the East, Shahdost may have known of an earlier positive vision of Chalcedon that he tried to blend with the church's contemporary focus on Nestorius. ${ }^{76} \mathrm{He}$ asserts that

Acacius and Barsauma [of Nisibis] did not accept Chalcedon, but did not entirely reject it either... it will not mislead us that the heretics and the followers of the synod dare to say that the synod anathematized Nestorius. We say to them, 'You lie, for the synod called him lacking in understanding and placed no anathema on him, ${ }^{77}$

Shahdost attempts to maintain the positive vision of Chalcedon in the Church of the East by presenting the negative interpretation of the council as a plot by Miaphysites and Melkites. But even his attempts at compromise still show the retrojection of Acacius' synod of 486 as engaged with Chalcedon at all, when its only theological statement was a simple objection to Theopaschism.

Miaphysite sources in the ninth century and beyond would also place the break with the Roman church and the shift of the East to Nestorianism in the fifth century. The letter of pseudo-Philoxenus, ostensibly written to a fifthcentury Arab ruler but finally compiled in $c .750$, imagines that many people became Nestorian because of Persian persecution and that the 'Nestorian catholicosate' was created under 'the ungodly Acacius'. ${ }^{78}$ Bar Hebraeus also dates the split to Acacius: he presents this as the moment that the Church of the East became 'Nestorian' and the end of the 'orthodox' succession of catholicoi until its restoration by Ahudemmeh. ${ }^{79}$ The Miaphysite texts clearly intend to deny the legitimacy of the catholicoi after Acacius, and to lay claim to the earlier history of the Church of the East for themselves. But the presentation of Acacius as a 'Nestorian' also existed within the Church of the East. Pseudo-George was probably inspired by the coincidence of Nestorius' expulsion with Dadisho"s reign and Dadisho"s own claims to autocephaly: he dates the 'Nestorianization' of the church to his reign, to an even earlier date than the Miaphysites. ${ }^{80}$ Even men like Shahdost, with a more tolerant vision of Chalcedon, were forced to accommodate this prevailing image of the church as 'Nestorian'.

75 Abramowski and Goodman, Nestorian Christological Texts, 37.

${ }^{76}$ He notes (Nestorian Christological Texts, 18-19 and 23) that the Roman and Persian rulers at several points in his theological narrative, which implies he derives a portion of his information from histories as well as from theological material.

77 Abramowski and Goodman, Nestorian Christological Texts, 20.

78 A. Mingana, 'The early spread of Christianity in Asia and the Far East: a new document', BJRL 9 (1925), 297-371, at 360-7. Much of the letter is concerned with the conversion of the Turks, which implies a later dating.

${ }^{79}$ Bar Hebraeus, HE, III, 61-5.

${ }^{80}$ George of Arbela, Expositio Officiorum, I, 144.

This is an open access version of the publication distributed under the terms of the Creative Commons Attribution-NonCommercialNoDerivs licence (http://creativecommons.org/licenses/by-nc-nd/3.0/), which permits non-commercial reproduction and distribution of the work, in any medium, provided the original work is not altered or transformed in any way, and that the work is properly cited. For commercial re-use, please contact academic.permissions@oup.com 


\section{CONCLUSIONS}

Sebastian Brock has powerfully rebutted the idea that the Church of the East was Nestorian in a technical, theological sense. And, in so far as 'Nestorian' was a label that exaggerated the church's Dyophysitism, he must be correct, especially when it is applied to the period before Babai's creation of a new Christological language. ${ }^{81}$ The Acacian synod was anti-Theopaschite rather than Nestorian, and the praise for Nestorius by writers such as Narsai of Nisibis (d.503) was made without any real knowledge of his theology: Theodore was a much more important influence.

But the Church of the East was increasingly Nestorian in a historical sense, in that Nestorius played a critical role in the church's historical imagination. Initially, the reverence for Nestorius was accommodated within a wider history of the church fathers that had a positive image of the council of Chalcedon. This version of events, popularized under Isho 'yahb I, was preserved and elaborated in the church's historical tradition and embedded in the medieval compilations.

From the middle sixth century, Eastern theologians objected to the attempts of Roman emperors to compromise with the Miaphysites and this caused problems for a catholicos such as Isho' yahb II who sought a rapprochement with the Romans. This difference was exacerbated by Babai's focus on Nestorius' slogans, which would ultimately culminate in the self-identification of the church as 'Nestorian' in the Abbasid period, an initiative that emphasized the church's distinct heritage. This in turn involved the retrojection of the image of the church as Nestorian onto its earlier history and maintained the church's distinctiveness not only against Miaphysites, but against Chalcedonians as well.

${ }^{81}$ S. Brock, 'Nestorian church: a lamentable misnomer', BJRL 78 (1996), 23-53 at 23-30 and S. Brock, 'The Church of the East up to the sixth century and it absence from councils in the Roman Empire', in Syriac Dialogue: The First Non-Official Consultation on Dialogue within the Syrian Tradition, with Focus on the Theology of the Church of the East (Vienna, 1996), 68-85. In 'Nestorian church', 24, Brock remarks that the thirteenth-century canonist 'Abdisho' of Nisibis observed that 'Nestorius was not their patriarch, nor did they know his language'. N. Seleznyov, 'Nestorius of Constantinople: condemnation, suppression, veneration, with special reference to the role of his name in East-Syriac Christianity', Journal of Eastern Christian Studies 62 (2010), 165-90, at 185, observes that this cannot be read as an attempt to distance the Church of the East from Nestorius' legacy. In context, the quotation emphasizes the primacy of Dyophysite ideas in the Church of the East before Nestorius: 'It was Nestorius who followed them, not they who followed Nestorius, especially with regard to the appellation "the Mother of Christ".' 'Abdishoc, therefore, was engaged in an even more extreme retrojection of Dyophysitism into the past than pseudo-George of Arbela.

This is an open access version of the publication distributed under the terms of the Creative Commons Attribution-NonCommercialNoDerivs licence (http://creativecommons.org/licenses/by-nc-nd/3.0/), which permits non-commercial reproduction and distribution of the work, in any medium, provided the original work is not altered or transformed in any way, and that the work is properly cited. For commercial re-use, please contact academic.permissions@oup.com 


\section{6}

\section{Beyond Ctesiphon: Monasteries and Aristocrats in the Christian Histories}

The massive expansion of ecclesiastical history writing at the end of the Sasanian period coincided with two major social changes, centred on northern Iraq, on Izla, Adiabene, and Beth Garmai in particular, which left an impression on the developing historiography of the church. The first of these was the rapid expansion of monasticism in Iraq from the 550s, chiefly at the hands of the disciples of Abraham of Kashkar. This movement attempted to recover the initiative from the Miaphysite rivals of the Church of the East, and was, at times, closely allied to catholicoi and to the system of religious schools based on the School of Nisibis. The founders of these monasteries in the late sixth and seventh century are recorded in a series of hagiographic collections, with final redactions in the ninth and tenth centuries, one of which is preserved in the Chronicle of Seert. The second of these social changes was the increasing prominence of a Christian elite, many of whom were from an Iranian cultural background and converts from Zoroastrianism. These men appear as the sponsors of the new monasticism and as dominating figures in episcopal elections. Some families especially, such as that of Khusrau II's financier Yazdin of Karka de Beth Slouq, achieved impressive prominence at the court of the shah and are recognized in the sources as major protectors of the church. ${ }^{1}$ The prominence of these Christian elites occurred at the same time that other Iranian elites also sought to highlight their own distinctive histories and values as 'Parthian' lords, in a bid to oppose the centralizing reforms of the last shahs, especially those of Hormizd IV and Khusrau II.

The ecclesiastical histories that we examined in the last chapter represented novel versions of, or additions to, the accounts of the past that the Church of the East shared with other churches, the Jacobites and Melkites. These new histories established the prestige of the church using a theological and historical

${ }^{1}$ Isho 'yahb III, Letter B 8 (reflecting on the tribulation after Yazdin's death); Thomas of Marga, Book of the Governors, I, xxiii (47/81-2) (for Yazdin's family as monastic donors); Chronicle of Seert, II/ii, LXXXI (524-5) (for his prominence at court, alongside other secular figures).

This is an open access version of the publication distributed under the terms of the Creative Commons Attribution-NonCommercialNoDerivs licence (http://creativecommons.org/licenses/by-nc-nd/3.0/), which permits non-commercial reproduction and distribution of the work, in any medium, provided the original work is not altered or transformed in any way, and that the work is properly cited. For commercial re-use, please contact academic.permissions@oup.com 
vocabulary that would be understood by these rivals, that also sought to differentiate the Church of the East as '(more) orthodox', often using shared criteria valued by all three churches. New histories were also produced in the late sixth and seventh century that recorded the monastic foundations of the Church of the East and the deeds of Sasanian shahs. Unlike the ecclesiastical material, these histories sought to integrate newly significant institutions and social classes into a framework that had previously privileged the succession of the catholicoi. As such, these new histories reflect both an expansion of the power base of the Church of the East, and of the allies and patrons of the catholicoi, and a threat to the catholicos' dominance, as East Syrian influence at court and in society was no longer channelled through the catholicos alone.

The synods of the late sixth century reveal an institutional church that was increasingly closely administered and whose leaders took increasing interest in the 'everyday' morality of its members. Incestuous marriage, a custom associated with Zoroastrianism, was banned under Aba, and this was followed by Joseph's ban on the marriage of priests to pagans and that of all sections of society to heretics under Isho' yahb. ${ }^{2}$ Joseph also legislated against pagan amulets, auguries, and divination, the kind of activity that is so well attested in the magic bowls found in Uruk and elsewhere, and insists that blessed oil, which may have been intended as a substitute for these amulets, should not be used to perform ordinations. ${ }^{3}$ These bans were reiterated under Ezekiel, who also banned 'wild music and lamentation [by women]' at funerals, and by Isho' yahb I, who adds bans against attending the feasts of 'pagans, Jews and heretics'. The declarations of these synods reflect a greater concern for 'popular' religion. They may also imply that church leaders felt they had a greater capacity for these interventions to succeed, especially given the connections to the shah and to the school movement that also occurred at this time. The appearance of concern for religious boundaries and 'pagan practice' may reflect Christian communities that had recently expanded, to incorporate members who continued many older customs and still celebrated the festivals of their former religions. Indeed, we should not assume that amulet use or 'pagan and Jewish festivals' were seen as non-Christian by those who participated in them. Amulets often record prayers to Jesus and the angels alongside pagan gods $s^{5}$ and festivals, such as Nouroz and Mihragan, may have been seen as 'cultural' rather than religious continuations with the past. ${ }^{6}$ Thus, one way

2 Synodicon, 82 and 102 (Joseph, canon 10).

3 Synodicon, 106 (Joseph, canon 19).

4 Synodicon, 116-17; 150; 157-8 (Ezekiel, canons 3 and 4 and Isho'yahb I, canons 14, 24, and 27).

${ }^{5}$ See S. Shaked and J. Naveh, Amulets and Magic Bowls: Aramaic Incantations of Late Antiquity (Leiden, 1985).

6 A. Taqiazdeh, 'Iranian festivals adopted by Christians and condemned by Jews', BSOAS 10 (1942), 632-53.

This is an open access version of the publication distributed under the terms of the Creative Commons Attribution-NonCommercialNoDerivs licence (http://creativecommons.org/licenses/by-nc-nd/3.0/), which permits non-commercial reproduction and distribution of the work, in any medium, provided the original work is not altered or transformed in any way, and that the work is properly cited. For commercial re-use, please contact academic.permissions@oup.com 
of looking at the aspirations of the late sixth-century catholicoi is as an expression of the wish to regulate the boundaries of Christianity as an exclusive set of cultural practices, in a world where Christians did not all share the same cultural backgrounds and assumptions.

At the same time, church leaders were also increasingly concerned with the administration of the church as an institution. Joseph's ban on priests and abbots abandoning the livings attached to their office shows us both the church's need to safeguard its property through continued use, and the increased social status of certain priests, who might have preferred their own inherited dwellings to those attached to their position. ${ }^{7}$ Later demands that wills in support of churches, hospices, and monasteries be respected shows a parallel situation: the institutions of the church benefited from the donations of wealthy laymen, but also needed to defend this patrimony from the donors' family members and ensure that donors gave enough for a lasting endowment: in essence, we see the catholicoi asserting a higher value for a privileged relationship with the church and setting conditions to the donations of aristocrats. ${ }^{8}$

These greater economic resources also required greater oversight at each level of the ecclesiastical hierarchy: bishops were banned from resisting the division of their sees (presumably the bishops did so to retain importance after a growth in the Christian population or church resources). Archdeacons were appointed to dioceses to oversee day-to-day administration, and bans were placed against priests alienating church property. ${ }^{9}$ We cannot gauge the success of these laws in achieving what they set out to do, but they do illustrate the accumulation of wealth in the church and its source in lay donations, and the increased will and capacity of the catholicoi to intervene in lay behaviour more generally.

The priorities of this legislation provide a lens through which we can read the histories of monastic foundations and of the Sasanian shahs produced by Christians in the late sixth and seventh centuries. As well as asserting the importance of their own office as catholicoi, Joseph, Ezekiel, and Isho'yahb I also set out the limits of acceptable behaviour for Christians, in terms of their cultural and economic activities. But they do not articulate a vision of Christians as constituting a complete society set apart: they are also concerned with banning extremes of Christian asceticism and confirming basic aspects of the empire's social order. ${ }^{10}$ The canons show us that Christian elites and church institutions were increasingly significant features in the politics of the Sasanian world, where the catholicos was supported by and beholden to the shah, as

7 Synodicon, 101 (Joseph, canon 8).

8 Synodicon, 119 and 146-7 (Ezekiel, canon 11; Isho 'yahb I, canons 10 and 11).

9 Synodicon, 105 and 117-18 (Joseph, canon 18; Isho' yahb I, canons 6 and 19).

10 E.g. Synodicon, 115-19 (Ezekiel, canons 1 and 2 on asceticism and 5 and 12, which ban Christians from fleeing local law or ordaining slaves).

This is an open access version of the publication distributed under the terms of the Creative Commons Attribution-NonCommercialNoDerivs licence (http://creativecommons.org/licenses/by-nc-nd/3.0/), which permits non-commercial reproduction and distribution of the work, in any medium, provided the original work is not altered or transformed in any way, and that the work is properly cited. For commercial re-use, please contact academic.permissions@oup.com 
well as to Christian magnates. The new histories examined here show us stages in the negotiation of a series of compromises that set out the relationship between the secular clergy and monasticism.

\section{ABRAHAMIC MONASTICISM AT IZLA}

The greater organization and wealth of the Church of the East is seen most visibly in the rapid expansion of monasticism in the late sixth and early seventh centuries. Monasteries had, of course, existed in Iraq in the fifth century, and aroused controversy in the 486 synod of Acacius, which banned celibate monasticism as part of a wider reform of marriage practice in the Church of the East. Aba's restoration of celibate asceticism was accompanied by a renewal of monasticism by the ascetic Abraham of Kashkar, who, like Aba, had travelled to the Pachomian cenobitic monasteries of Egypt and studied at the School of Nisibis, as well as acting as a missionary in Hira in south-west Iraq. Abraham is said to have reformed the customs and dress of his monks, who 'had [formerly] been dressed like Egyptians', 'so that they could be distinguished from heretics [i.e. the Severans]. ${ }^{11}$ The most noticeable of these reforms was the Abrahamic tonsure, in the form of a crown, recalling the connection between ascetics and the 'crowned' martyrs of an earlier era. ${ }^{12}$

Abrahamic monasticism seems to have been set apart by its focus on a cenobium, a shared walled living space on the Pachomian model, which was set alongside their own churches and cells for lone ascetics. These reformed monasteries were referred to in Syriac as ' $u m r \bar{a}$, in distinction to the dayrā, which was employed for the ruined monasteries of earlier generations or the monasteries of the era of 'Abda. ${ }^{13}$ Yet, it is noticeable that Abraham's own monastic rules are not forthcoming on the significance of this new organization: instead they focus on the integration of fasting, prayer, and silence in monastic life and the importance of academic learning and physical labour. ${ }^{14}$ These sentiments certainly correspond to the hagiography's report

${ }^{11}$ Life of Abraham of Kashkar (esp. 163 for the connection to Pachomius); Chronicle of Seert, II/i, XVIII (133-5); XXXI (172-3); Thomas of Marga, Book of the Governors, I, iv (23/40-1). Abraham's contemporary, Abraham of Netpar also began his missions at Adiabene at this time. The image of Awgin as the first monk of the East is an anachronism that has been introduced later into the text.

12 See Thomas of Marga, Book of the Governors, I, iv (23/40-1) for the contrast with the Severan tonsure. Syriac hagiographies often describe the act of martyrdom as 'crowning'.

13 G. Hoffmann, Auszüge aus Syrischen Akten Persischen Martyrer (Leipzig, 1880), 172, n. 1332. This distinction did not last beyond the ninth century, when the words seem to become synonyms.

${ }^{14}$ Rules of Abraham of Kashkar, 154-8.

This is an open access version of the publication distributed under the terms of the Creative Commons Attribution-NonCommercialNoDerivs licence (http://creativecommons.org/licenses/by-nc-nd/3.0/), which permits non-commercial reproduction and distribution of the work, in any medium, provided the original work is not altered or transformed in any way, and that the work is properly cited. For commercial re-use, please contact academic.permissions@oup.com 
that Abraham had been trained in Egypt: the rules mirror important features of Pachomian monasticism. But Abraham's quotation from Antony, 'a monk outside his cell is like a fish out of water', does not sit well with the more public, urban monasticism that Joseph and his successors wished to promote. ${ }^{15}$

It is instructive to compare Abraham's rules with the rules of his successors as abbots of his great monastery at Izla in the far north of Iraq. Dadisho', his successor, wrote a series of rules that was much longer than Abraham's. They were, he notes in his introduction, created 'because communities are different from those who dwell alone'. Here, unlike in Abraham's rules, the focus on the cenobium is specifically acknowledged. Dadisho' begins his rules with an assertion that his monks must be orthodox: they are to follow the faith of the orthodox fathers, Diodore, Theodore, and Nestorius; to avoid soothsayers and heretics; and to avoid going into towns or wandering the countryside. ${ }^{16}$ Here, Dadisho ${ }^{c}$ added a creedal component to the division with the Severans that Abraham had established with his distinctive tonsure. Like the ecclesiastical historians of the same era, Dadisho' emphasizes the importance of the Dyophysite fathers in defining orthodoxy, and in practice this must have targeted any monks with Miaphysite sympathies or supporters of any intellectual compromise across Christological boundaries (such as that of Henana of Nisibis).

The third of Dadisho"s prescriptions addresses the issue of Messalianism, the 'heresy' of the rejection of the efficacy of the church's sacraments that was associated with ascetics wandering the countryside outside the formal jurisdiction of their bishops or of cenobitic monasteries. Ezekiel names this group explicitly at the beginning of his synod, accusing them of 'dressing as ascetics and plunging women into sin, abusing the sacrament, seducing widows and separating wives from their husbands'. ${ }^{17} \mathrm{He}$ immediately follows this with bans on self-castration and magic, which may have both been practices associated with extreme asceticism and heteropraxy.

These concerns broadly echo the accusations made against 'Messalians' in the synods of fourth-century Roman Syria and Anatolia and the heresiological tradition that grew from these declarations. ${ }^{18}$ These 'Messalians' did not generate a school or a defined canon of writings, but the name used in these early prosecutions was employed against various individuals who practiced extreme asceticism on behalf of a wider group of people and who challenged the primacy of the Eucharist. ${ }^{19}$ Dadisho ${ }^{\text {c }}$ and Ezekiel's legislation on orthopraxy

15 Rules of Abraham of Kashkar, 155.

16 Rules of Dadisho', 168-71 (canons 1, 2, 5, and 6).

17 Synodicon, 115 (Ezekiel, canon 1). On the 'Messalians' in the East note Labourt, Le christianisme, 213.

${ }^{18}$ C. Stewart, Working the Earth of the Heart: The Language of Christian Experience in the Messalian Controversy, the Writings of Pseudo-Macarius and the Liber Graduum (Oxford, 1991), 53-68.

19 Wood, We Have No King but Christ, 74.

This is an open access version of the publication distributed under the terms of the Creative Commons Attribution-NonCommercialNoDerivs licence (http://creativecommons.org/licenses/by-nc-nd/3.0/), which permits non-commercial reproduction and distribution of the work, in any medium, provided the original work is not altered or transformed in any way, and that the work is properly cited. For commercial re-use, please contact academic.permissions@oup.com 
mirrors fairly closely that of the West Syrian Rabbula of Edessa in the midfifth-century, who had also banned ascetical wandering and extreme public mortification. Rabbula's laws may have been caused by the increasing intensity of theological debate in his day, prompting bishops across the Christological spectrum to 'put their house in order' and ensure that ascetics in their dioceses corresponded to shared norms of orthopraxy. Essentially, conflict over orthodoxy in the fifth-century Roman world brought with it a wider concern to bring religious variation into line with a single orthopraxy, lest variations in religious practice provide a hostage to fortune that opponents might exploit. ${ }^{20}$ I suggest that the sixth-century Church of the East, like Roman Syria-Mesopotamia a century before, enjoyed international connections that brought greater awareness of the heresiological categories that had been employed further west.

The anxiety about Messalianism seen here may also reflect the political prominence of catholicoi in this era, when they were more heavily connected to the shah, but also supporting urban, celibate monasticism, reversing a policy of sixty years. Joseph decrees in his synod that 'monasteries and martyria should be built again in cities and villages' since the earlier ruling that had restricted them to the countryside, 'had caused the Jews and pagans to rejoice'. ${ }^{21}$ Monasticism, then, was connected to the public prestige of the Church of the East. But a more visible, public monasticism also meant that Christian asceticism could not represent a threat to the mores of an Iranian society that valued lineage and familial inheritance very highly. Ezekiel accused 'Messalians' of sexual licence and this (and its effects on aristocratic lineage) had been the crux of Khusrau I's attack on the millenarian Mazdakite movement, which he had purged towards the start of his reign. Christian bishops and abbots may have therefore been concerned that Christian ascetics were not branded as dangers to the Sasanian social order. ${ }^{22}$

Dadisho' was keen to stress norms of belief among his monks, but the majority of his rules actually concern the daily monastic life, most of all the way that power was distributed in his monastery. These rules assert that monks had to be literate, and govern the probationary time that any wouldbe hermits needed to spend in the cenobium, the communal part of the monastery. They also discuss the role of the abbot in spreading the peace within the monastery and the ban on bringing legal accusations against monks to the secular authorities. ${ }^{23}$ Some of these rulings may have been responses to actual disputes. Together, they show the working out of rules by a growing

${ }^{20}$ P. Wood, 'Syriac and the "Syrians"', in S. Johnson (ed.), The Oxford Handbook of Late Antiquity (Oxford, 2012), 170-95.

21 Synodicon, 106 (Joseph canon 20).

22 On Mazdak see T. Daryaee, Sasanian Iran: Portrait of a Late Antique Empire (Costa Mesa, 2008), 68-9.

${ }^{23}$ Rules of Dadisho', 171-5 (canons 7, 13, 14, 26).

This is an open access version of the publication distributed under the terms of the Creative Commons Attribution-NonCommercialNoDerivs licence (http://creativecommons.org/licenses/by-nc-nd/3.0/), which permits non-commercial reproduction and distribution of the work, in any medium, provided the original work is not altered or transformed in any way, and that the work is properly cited. For commercial re-use, please contact academic.permissions@oup.com 
community, and the wish of Dadisho' himself to regulate the behaviour of monks, ensuring that the monastery never became a source of political embarrassment, through the intervention of secular judges, or challenged the authority of its abbot. Under Dadisho', the monastery was envisioned as a self-sufficient community, both in terms of its self-governance and its production of goods, where monks tending olive groves and the fields, teaching, and producing books were trained in a Pachomian system that taught through imitation. ${ }^{24}$

\section{MONASTICISM AFTER THE HENANIAN CRISIS}

The monasteries of Dadisho ${ }^{c}$ and Abraham existed in close symbiosis with the catholicosate and with the School of Nisibis. Joseph's defence of urban monasticism and his regulation of the behaviour of abbots, and the connection of the catholicoi Isho' yahb I and Sabrisho' to Nisibis were accompanied by the close association of the abbots of Izla to the bishop of Nisibis and to the School. However, this early unity was ruptured with the Henanian crisis in the School of Nisibis, when Henana, the School's director, fell out with Gregory, bishop of Nisibis, who was himself a pupil of the Schools of Ctesiphon and Nisibis. Henana stood accused of departing from the traditions of Theodore, but retained his position during the reign of Sabrisho', who refused to expel him. This resulted in the departure of scholars from Nisibis, which the Chronicle of Seert depicts as a mass exodus, including the future catholicos Isho' yahb II. ${ }^{25}$

Camplani has suggested that this rupture with the School was the beginning of the independent power of the great monastery at Izla. He observes that Dadisho's successor Babai and his ascetic contemporaries, several of whom are connected to Izla, were also prominent interpreters in schools in the north of Iraq. ${ }^{26}$ In addition, the same era saw the temporary removal of the catholicosate, as the shah refused to make an appointment following the death of Sabrisho"s nepotistic successor, Gregory of Pherat in 607. This era, then, saw the apogee of the power of the great monastery, when its abbot Babai was instrumental in the assertion of an extreme Dyophysite Christology and functioned as a monastic visitor in the north of Iraq, with the support of the bishops of Karka de Beth Slouq, Nisibis, and Arbela.

Camplani has characterized the period of Babai's dominance as the victory of a 'conservative' approach to exegesis and Christology, ranged against the theological speculation encouraged by Henana. He argues that the transfer of

24 See further M. Tamcke, 'Theology and the practice of communal life according to Dadisho', The Harp 4 (1999), 173-88, at 181-4.

${ }^{25}$ Chronicle of Seert, II/ii, LXXIV (509).

${ }^{26}$ Book of Chastity, §39-42.

This is an open access version of the publication distributed under the terms of the Creative Commons Attribution-NonCommercialNoDerivs licence (http://creativecommons.org/licenses/by-nc-nd/3.0/), which permits non-commercial reproduction and distribution of the work, in any medium, provided the original work is not altered or transformed in any way, and that the work is properly cited. For commercial re-use, please contact academic.permissions@oup.com 
education to schools dominated by monks, where orthodoxy and learning by imitation were emphasized, aided this suppression of speculation at a time when the Church of the East was coming under heavy external pressure from the Jacobites and lacked coherent leadership. ${ }^{27}$

Still, there are also indications that several monasteries resented the centralization of Babai's reign and the intellectual role that they were expected to play. Thomas of Marga's Book of the Governors, a history of the monastery of Beth 'Abe, records Babai's visitation to the monastery, which accepted the monastery's orthodoxy but sought to change its liturgical practice (until the healing of a paralytic during the service persuaded him otherwise) ${ }^{28}$ Similarly, later chapters record how the monks prevented the catholicos Isho' yahb III (649-59) from building a school in Beth 'Abe, 'so that school and monastery might become one'. Here too, the monks reject a change that 'we have not found reported in any kind of writing' and which is contrary to 'what we have received from our father Mar Jacob'. In the face of Isho 'yahb's claims to rule over all monasteries as catholicos, and his personal claim as a major donor to Beth 'Abe, the abbot Qamisho' leads the monks away from the monastery, together with Jacob's relics, which finally causes Isho' yahb to back down. ${ }^{29}$

The monastic rules and the events that followed the Henanian crisis at Nisibis provide a skeleton for our understanding of the historiography of monasticism in the Church of the East. The emphasis on Pachomian cenobitism under Dadisho' and the dominant role of Babai during the breakdown in authority in Nisibis and Ctesiphon are both illuminated by a range of sources, some contemporary and some later in date. And it is against this backdrop that we must read the subsequent wealth of monastic history, written as hagiographic collections or as the histories of specific monasteries.

\section{THE HAGIOGRAPHIC COLLECTIONS: THE BOOK OF CHASTITY}

Three texts preserve hagiographic collections that record the deeds of Abraham and his disciples: Thomas of Marga's Book of the Governors (composed in 840), the related accounts of Isho'dnah of Basra's Book of Chastity (composed c.860) and in the Chronicle of Seert. In addition our knowledge of monastic culture and history-writing is enlarged by several Syriac saints' lives, especially the lengthy Life of Rabban Bar 'Idta (composed c.660), the Life of Rabban

27 A. Camplani, 'The revival of Persian monasticism: church structures, theological academy and reformed monks', in A. Camplani and G. Filoramo (eds.), Foundations of Power and Conflicts of Authority in Late Antique Monasticism (Louvain, 2007), 277-97.

28 Book of the Governors, I, xxix (54-6/97-9).

29 Book of the Governors, II, vii-ix (73-6/131-51). Quotations at 74-5/132 and 148.

This is an open access version of the publication distributed under the terms of the Creative Commons Attribution-NonCommercialNoDerivs licence (http://creativecommons.org/licenses/by-nc-nd/3.0/), which permits non-commercial reproduction and distribution of the work, in any medium, provided the original work is not altered or transformed in any way, and that the work is properly cited. For commercial re-use, please contact academic.permissions@oup.com 
Hormizd (composed before 1100), and the History of the Monastery of Beth Qoqa (composed c.850), which have a much closer focus on individual institutions than Thomas's work. In all these cases, authors discussed a monastic movement that had expanded rapidly in the period following Abraham's foundations at Izla, in the period c.580-660, but they described it through the lens of subsequent events and with different emphases depending on their position within the church. ${ }^{30}$

Abrahamic monasticism had become a prestigious aspect of the Church of the East in the Umayyad period and beyond, and there were clearly early efforts made to record the histories of the monks independently of the pre-existent histories of the catholicoi. But these histories were adapted and extended according to different motives in later centuries: like the medieval compilations of the ecclesiastical histories of Iraq, the hagiographic collections that are analysed here represent the tip of the iceberg of an extensive lost tradition

The simplest of the later collections is Isho'dnah's Book of Chastity. This is a series of very brief notes on individual monastic founders, often grouped around a major figure and his disciples who went on to found smaller monasteries. Its sections are often limited to the name of the saint, his origin, and the place of his monastery, but more extensive entries include the fate of his relics, the saint's miracles, his social origins and education, and his foundation of schools. A handful of sections stretch to a page or more and treat major figures in the movement, such as Abraham of Kashkar, Rabban Bar 'Idta, and Jacob of Beth 'Abe, as well as the controversial theologians Sahdona and Joseph Hazzaya.

Several different ways of organizing the entries on these monastic founders have been employed in the Book, which itself suggests that it is a compilation of several different lists of holy men (which may have also had a higher level of detail). Thus many biographies relate how the monk was connected to Abraham or another major figure: headings 14-29 contain figures directly trained by Abraham and many also conclude with a prayer formula, which may suggest that they once represented a shorter collection. ${ }^{31}$ Similarly, the section on Abraham ( $\$ 14)$ himself concludes with a long, unadorned list of his disciples: the sections that follow may represent a more developed version of such a list where further details have been added. However, it is also worth noting that the unadorned list of disciples in Abraham's section does not include the same names as the subsequent sections of the Book: this was a flexible format that could support additional 'minor characters'. ${ }^{32}$

${ }^{30}$ General accounts of the Abrahamic movement are provided by C. Jullien, Le monachisme en Perse: la réforme d'Abraham le Grand, père des moines de l'Orient (Louvain, 2008).

31 On these formulae, see J.-M. Fiey, 'Ishodnah, metropolitaine de Basra et son oeuvre', OS 11 (1972), 433-50, at 449-50.

32 A variant of these lists may be included in Book of the Governors, I, xiv (37/66-7).

This is an open access version of the publication distributed under the terms of the Creative Commons Attribution-NonCommercialNoDerivs licence (http://creativecommons.org/licenses/by-nc-nd/3.0/), which permits non-commercial reproduction and distribution of the work, in any medium, provided the original work is not altered or transformed in any way, and that the work is properly cited. For commercial re-use, please contact academic.permissions@oup.com 
As well as Abraham himself, other figures also receive clusters of followers and are seen as key points in the transmission of monastic authority, especially Sabrisho ' of Beth Qoqa in the region of Marga in Beth Garmai (\$59-64); Rabban Khoudawai in Khuzistan and central Mesopotamia (\$78-82); and the followers of Babai the scribe at Hira (\$72-4). These groups of disciples may have represented independent cycles that were added en masse to the hagiographic tradition surrounding Abraham, and may reflect the territorial histories of certain federations of monasteries with their own distinct identities. ${ }^{33}$

One feature of the Book of Chastity as a hagiographic collection is its interest in geography and ethnic origin: we are frequently told if a monk was a 'Persian' ${ }^{\text {'34 }}$ (rather than 'an Aramean') and the personal history of his career before becoming a monk, focusing on his training in different places. The result of this accumulation of geographical detail is to present the monastic movement as corresponding to a specific territory that is internally interconnected by ties between monasteries, the birth places of monks and the places where they worked as missionaries. Thus, Abraham himself was born in Kashkar, a missionary in Hira and a monk at Izla; John of Me'arre was born in Hira and a monk in Sinjar in the north; Job of Revardashir in Fars, who founded a monastery in Adiabene or Gregory, who was born at Kashkar, educated at Ctesiphon and became a monk at Nisibis. ${ }^{35}$

The overwhelming focus of the endeavours of the monks recorded here is the north of Iraq, in Nisibis, Izla, and Sinjar, as well as Beth Garmai and Adiabene. While the Book doesn't keep a specific focus on Abraham's own monastery, it does present the north of Iraq in general as the centre of Abrahamic monasticism. At the same time, the significance of the north is demonstrated by its role in uniting ascetics from all over the East, a broader territorial identity that is overlaid onto the regional cycles of Hira or Khuzistan. No specific geographical term is used for this wider territory, but it corresponds closely to the former Sasanian Empire, with monks coming from Fars, Khuzistan, and Merv. ${ }^{36}$ And this correspondence between the Sasanian Empire and Abrahamic monasticism is further reinforced by the record of the monks as missionaries to the different peoples of the empire, such as the Arabs of Hira and the Kurds,${ }^{37}$ and by the Iranian origins of many of the monks themselves. The Book of Chastity creates a sense of a holy land that covers the same territory as the empire, whose

${ }^{33}$ Monastic federation was a distinctive feature of Pachomian monasticism in Egypt. The History of the Monastery of Beth Qoqa might provide an example of this phenomenon, extended across several generations.

${ }^{34}$ Book of Chastity, $\S 7,21,36,86,88,100,106$. The text omits references to monks as 'Arabs', a term which could have used for monks from Hira (e.g. Book of the Governors, I, ix (28/51) for Mar Eliya, which is not mentioned in Book of Chastity, §19).

${ }^{35}$ Book of Chastity, $\S 14,43,46,56$.

36 Book of Chastity, e.g. \$36-7, 87 (Merv); 43 and 100 (Revardashir and Istakhr); 78-82 (Khuzistan).

37 Book of Chastity, $§ 5,17,34$, and 47.

This is an open access version of the publication distributed under the terms of the Creative Commons Attribution-NonCommercialNoDerivs licence (http://creativecommons.org/licenses/by-nc-nd/3.0/), which permits non-commercial reproduction and distribution of the work, in any medium, provided the original work is not altered or transformed in any way, and that the work is properly cited. For commercial re-use, please contact academic.permissions@oup.com 
places are linked by the careers of the monks, who are drawn from and serve many races. ${ }^{38}$

This vision of 'the East' as a land made holy by the monks is explicitly connected to the models established in Egypt and Palestine. Abraham and Dadisho' consciously adopted Pachomian models at the great monastery at Izla. Abraham himself refers to the 'pilgrim brothers of Izla', ${ }^{39}$ comparing monastic life to a pilgrimage to Jerusalem, which he himself had made and which had increased in popularity in his lifetime. ${ }^{40}$ Indeed, several monks begin their careers by visiting Jerusalem and Scetis, or make Jerusalem pilgrimages as extensions of pilgrimages within Iraq, such as the westward voyage of Joseph of Merv. ${ }^{41}$

The monastic careers described in the Book mainly span the period 580-660, though certain observations and place names clearly date from the Abbasid period and Isho'dnah's own lifetime. ${ }^{42}$ Given this clustering of the hagiographies, we can see the territorial identity of the text as a response to the increasing numbers of Persian Christians and to the disappearance of the Sasanian state in the early seventh century. The Church of the East, and, more specifically, its monasticism, is presented as the inheritor of the Sasanian world, seen here in terms of its geography and its component races, except that the focus of this monastic East is clearly on the north of Iraq rather than Ctesiphon or Fars. Moreover, this was a vision that remained relevant to Isho' dnah, who does not seem to have brought the earlier monastic collections that he used 'up to date' to his own day. Instead, the later editors of the Book added sections on monasticism before Abraham and on controversial theologians of the early seventh century: for later generations, the last generation of the Sasanian Empire, itself a great era of history writing, would be looked back on as another 'golden age', in which the nature of the Church of the East was defined.

\section{THE BOOK OF THE GOVERNORS}

Thomas of Marga's ninth-century monastic history represents a very different approach to the structure of monastic hagiography, which reveals the priorities

\footnotetext{
${ }^{38}$ Compare Wood, We Have No King but Christ, chapters 6 and 7 for similar patterns in the Miaphysite movement in the sixth century.

39 Rules of Abraham, 153.

40 See L. Perrone, 'Christian holy places and pilgrimage in an era of dogmatic conflict', POC 48 (1998), 4-37.

${ }^{41}$ Book of Chastity, $\$ 23,34,36-7$.

42 Two saints ( $\$ 124$ and 140) date from the reign of Henanisho ' I (690s). Isho ' dnah also refers to anathemas pronounced by Timothy I (780s) (\$125-6), which are seemingly ignored by the author, and to Baghdad, founded in 780 ( $\$ 82-3)$. Sections 1-13 are late (possibly ninth-century) additions.
}

This is an open access version of the publication distributed under the terms of the Creative Commons Attribution-NonCommercialNoDerivs licence (http://creativecommons.org/licenses/by-nc-nd/3.0/), which permits non-commercial reproduction and distribution of the work, in any medium, provided the original work is not altered or transformed in any way, and that the work is properly cited. For commercial re-use, please contact academic.permissions@oup.com 
in his vision of the Abrahamic movement as a whole and its relationship with other parts of the institutional church. His work was composed around the same time as Isho'dnah's, but is much more extensive, both in terms of sheer length and because it provides a continuous narrative of the monastery of Beth 'Abe and monasteries connected to it, right up to Thomas's own day. From the second of five books, the focus is on Beth 'Abe itself, but the first book covers the early period of the Abrahamic movement, tracing its Egyptian origins, the monks trained by Abraham at the Great monastery of Izla and Babai's reform movement.

One of the most interesting features of the work for our purposes is Thomas's concern for his sources, since it gives us some insight into Thomas's attempts to reconcile his own local traditions with those that stress the coherence of the monastic movement as a whole, and with earlier trends in monastic history-writing in the late sixth and seventh centuries. We have seen how the structure of the Book of Chastity seems to have been influenced by various lists of monks, sometimes only with very sparse annotation and sometimes based on longer accounts. Thomas's source lists likewise confirm the great variety of writing about monasticism even at an early stage in the movement. In his introduction he announces his intention to 'spin a thread from the stories of the monks of Beth 'Abe, formed from matters omitted by compilers of written and unwritten histories...that I should write down briefly the accounts scattered in the stories of others and in the ecclesiastical histories (eqlisyastiqās) of ancient authors... I will go into the gardens of their victorious acts and glean and gather chosen ears of wheat'. ${ }^{43}$

The Book of Governors is, therefore, a selection drawn from written and oral testimony, and the 'histories' that Thomas refers to may have been both ecclesiastical histories, of the kind employed in the medieval compilations, or hagiographies, referring to the careers of one or more saints. Thomas uses 'histories' of Abraham recorded by Rustam of Beth Qoqa (c.690) and Zkha' isho of Beth 'Abe and the information contained in the Life of Rabban Bar 'Idta by one John. ${ }^{44}$ For instance, for Jacob, founder of Beth 'Abe and a disciple of Dadisho', Thomas employs a 'history of Mar Jacob' written by Sahdona (later condemned for his compromises with the Melkites) to describe Jacob's succession. ${ }^{45}$ But he also uses two other authors, Solomon of Bar Garaph (fl. 686-701) and Rabban Apnimaran (fl. 640s) to furnish details of Jacob's exile into the wilderness after being expelled from Izla, and his encounters with lone ascetics on the mountain. ${ }^{46}$ Thomas treats the

43 Book of the Governors, I, ii (18/21).

44 Book of the Governors, I, iv (23/38).

45 Book of the Governors, I, vi (25/45).

46 Book of the Governors, I, xviii-xix (42/73-4). He recommends Solomon's account of the miracle performed by Jacob for the aristocrat Bastomagh, father of the future catholicos Isho'yahb III (I, xxiv) (48-9/83-5), as well as Apnimaran and Rustam's accounts of Joseph and Abraham of Beth Qoqa (I, xxxii) (60/108-9).

This is an open access version of the publication distributed under the terms of the Creative Commons Attribution-NonCommercialNoDerivs licence (http://creativecommons.org/licenses/by-nc-nd/3.0/), which permits non-commercial reproduction and distribution of the work, in any medium, provided the original work is not altered or transformed in any way, and that the work is properly cited. For commercial re-use, please contact academic.permissions@oup.com 
compositions of these earlier monastic authors as part of their ascetic endeavours. ${ }^{47}$ For Thomas, a characteristic of monasticism is its sense of its own history, and the recording of this history is one of the duties of monks, to recall the pious deeds of forebears as part of a quest for perfection in the present. ${ }^{48}$

At one point, Thomas comments directly on the importance of this genre of monastic history. He devotes a section to the historian Sergius of Beth Rasthaq (near Marga), who wrote in the reign of Isho' yahb III.

At the request of Mar Jacob he wrote a book of the victorious deeds and eulogies of the holy men who lived in the land of Beth Garmai, and this book is found everywhere and... excites praises to God [in whoever reads it]. And he called it The Destroyer of the Mighty, since he did not write about the great men of the church but those who were victorious in the houses of their fathers or the churches of their own villages, who were men of simple manners and despised themselves. ${ }^{49}$

Thus the beginning of the seventh century witnessed the evolution of a monastic hagiographic collection self-conscious of its difference from the kind of history that had come before it.

Sergius' history was imagined in contrast with the ecclesiastical histories that were produced under Isho' yahb I and afterwards. Notably, Sergius was writing at a time when Isho'yahb III was re-establishing the importance of the catholicosate after two decades without a catholicos, and when Babai, the most important abbot within the Church, had been its most important theologian and ruling spirit. Thomas does not quote directly from Sergius, but his description of his history suggests that it asserted the independence of the monastic movement by tracing a history independent of the catholicoi, reaching back to Abraham and the fathers of Scetis. Where the hagiographic collections that Isho'dnah used for his Book of Chastity presented monasticism as a phenomenon that bound together all the Sasanian realms after the end of the state, Sergius' work highlighted the independent history of the monastic movement in reaction to the reassertion of power by Isho' yahb III.

However, while Thomas reports Sergius' life sympathetically, he also used a wider variety of sources that had different emphases in the organization of their hagiographic material. We have already seen an illustration of this variation in the different sources for the life of Jacob: some focused on his relationship to the missionary Isho'zkha, others on his personal miracles and his ascetic life during his exile, others on his connections to Dadisho' ${ }^{c}$ and the Great monastery of Izla. These different focuses in the narrative show different assessments of monastic values, but they also point to political differences,

47 Note the sections on Apnimaran and Rustam of Beth Qoqa (II, iii (68-9/122) and xvii (8990/209-10)).

48 Book of the Governors, I, ii (18/22).

49 Book of the Governors, I, xxxiii (61/110).

This is an open access version of the publication distributed under the terms of the Creative Commons Attribution-NonCommercialNoDerivs licence (http://creativecommons.org/licenses/by-nc-nd/3.0/), which permits non-commercial reproduction and distribution of the work, in any medium, provided the original work is not altered or transformed in any way, and that the work is properly cited. For commercial re-use, please contact academic.permissions@oup.com 
over the relative importance of the great monastery within the monastic movement, or the importance of individual miracles or eremitic asceticism within Abrahamic monasticism.

Sergius had contrasted the mighty men of the church with his more humble, local heroes, but Thomas compiled his Book at a time when Beth 'Abe, in spite of the chequered career of its founder, had become an important ally of and nursery for eighth-century metropolitans and catholicoi. He could not afford to adopt Sergius' egalitarian approach to writing history. ${ }^{50}$ At several points in the Book, Thomas is forced to resolve tensions between his sources, where holy men came into conflict with one another or with the catholicoi and where different monastic 'histories' placed the focus on different figures or organized their material in different ways. An example of this is the contrasting treatment of Babai the Great, a leader of the Church of the East with a complex relationship to monasticism, and Mar Jacob, founder of Beth 'Abe.

\section{AUTHORITY AND CONFLICT IN THE ACCOUNTS OF BABAI THE GREAT}

The first story of Babai that Thomas tells presents him both as a holy man and as a man 'hasty in speech and harsh in command', and he accommodates his impressive reputation with his opposition to Jacob. Thomas opens his Book by charting the training of Jacob by Dadisho', but observes that he 'was thought to be of no account, since he was a stranger to the honour of the world'. ${ }^{51}$ This account is immediately followed by Babai's succession from Dadisho', and Thomas's source may imply a contrast between Babai and the unworldly Jacob. ${ }^{52}$ In the following scenes, Satan stirs up certain monks to evil deeds and inspires them to keep wives and children with them in the monastery (possibly following pre-Abrahamic custom). Next the famous Hiran ascetic Eliya visits the monastery and exposes the evil monks, 'the thorns fit for the fiery furnace' and laments that 'the children of Israel have forsaken the covenant and left the fatherhood of Abraham for that of Satan'. Taking the place of the abbot, Eliya commands the sacristan to summon the congregation with the gong and denounces the monks. Eliya asks Babai: 'How is it that those who are not under your headship tremble ... yet Sodom is raised again in this divine inheritance? ${ }^{53}$ While Babai was already famous for his leadership of the church, here Eliya charges him with failure in his primary role as abbot of Izla, when the monks' 'immorality' is discovered.

${ }^{50}$ E.g. Book of the Governors, IV, iii-iv (195-7/380-3) (on Timothy I); V, iv (257-61/478-81) (on Shubhal' isho of Gilan).

${ }_{51}$ Book of the Governors, I, vi (25/45). $\quad{ }^{52}$ Book of the Governors, I, vii (26/47).

53 Book of the Governors, I, viii-x (26-31/47-57). Quotations at 29-30/55-7.

This is an open access version of the publication distributed under the terms of the Creative Commons Attribution-NonCommercialNoDerivs licence (http://creativecommons.org/licenses/by-nc-nd/3.0/), which permits non-commercial reproduction and distribution of the work, in any medium, provided the original work is not altered or transformed in any way, and that the work is properly cited. For commercial re-use, please contact academic.permissions@oup.com 
These monks are then expelled from the monastery, but Satan also causes Jacob to be accused, since his cell was near the houses of the guilty: 'a tumult rose up against him, the most humble of men, who knew no sin existed beside his own in all creation... and he was driven out with tears in his eyes and penitence in his heart', and Babai placed a ban on him. Thomas refuses to record this ban, directing the reader to a letter of Isho' yahb III (then bishop of Balad). He observes: 'I do not record it out of respect for the holy man, who suffers defects like other men'. Babai is in turn chastised by other 'holy men' at Izla, who declare that Jacob was only a judge for himself and had left the monks for divine judgement. They also declare that the expelled monks should have been treated more leniently and 'been sanctified with prayer and fasting. ${ }^{54}$ The exile of Jacob and the sinful monks is then placed into a context of monastic expansion, with lists of the monasteries founded in this era. Exile is presented as an opportunity for repentance, vindicating Babai's critics. ${ }^{55}$

The narrative that stretches from Abraham of Kashkar through to the expulsion of Jacob seems to be of one piece, roughly modelled on Old Testament paradigms: it progresses from reference to the many children of the patriarch Abraham, through the sin of the chosen people to their exile, along with their sinless leaders. It is a narrative that clearly identifies Babai as the source of Jacob's expulsion, but cannot directly criticize the abbot or name those who opposed him in the monastery and allowed Jacob's return because of Babai's subsequent importance.

Thomas probably draws the account of Jacob's return to the monastery from another source, probably the monastic historian Apnimaran. Here he relates how the holy man Mar Yahb met a prophetess and her daughter in the wilderness near Izla, before recording that the same prophetess met Jacob and foretold his importance as a monastic founder. ${ }^{56}$ Moved by the Holy Spirit, Jacob then returns to the Great monastery, and Babai, also moved by the Spirit, receives him. Here the author notes that 'we are silent as to how Jacob left the monastery since we do not wish to bring the charge of strife against holy men'. ${ }^{57}$ It is this duplication of the earlier reluctance to criticize Babai that suggests that Thomas is using a different source here this time focused on Jacob's ascetic trial in the wilderness before his return to the Great monastery and his foundation of Beth 'Abe. ${ }^{58}$

The second group of stories relating to Babai is much more eulogistic in tone and represent him as the leader of the church while the catholicosate was in abeyance, though it still defends the independence of the monastery of Beth 'Abe. At this point, Thomas apologizes to his friend 'Abdisho', who requested his work, for including descriptions of political events 'so that the history will possess a continuous narrative'. His departure from Sergius' ideal of monastic

${ }^{54}$ Book of the Governors, I, xii-xiii (33-5/59-63).

55 Book of the Governors, I, xvi-xvii (39-41/69-71).

56 Book of the Governors, I, xviii-xix (41-3/72-5).

57 Book of the Governors, I, xxi (45/77).

${ }^{58}$ Scenes that describe the aid given to Jacob by Rabban Barhadbeshaba are also duplicated (Book of the Governors, I, xv (38/68-9) and xxi (45-78)).

This is an open access version of the publication distributed under the terms of the Creative Commons Attribution-NonCommercialNoDerivs licence (http://creativecommons.org/licenses/by-nc-nd/3.0/), which permits non-commercial reproduction and distribution of the work, in any medium, provided the original work is not altered or transformed in any way, and that the work is properly cited. For commercial re-use, please contact academic.permissions@oup.com 
history is caused by the prominence of Babai, a political actor on the same level as a shah or catholicos, and the controversy of his reign: could Babai be considered as catholicos and provide a prestigious history for monasticism vis à vis the later claims of catholicoi? This account of Babai as director of the church is split between asserting the independence of Beth 'Abe and emphasizing Babai's importance for the Abrahamic movement as a whole.

Thomas sets the scene for Babai's role as a monastic visitor and acting head of the church with a lengthy political account, detailing Khusrau II's love for the Christians and his later volte-face, in which the catholicosate was suppressed following the deaths of the catholicoi Sabrisho ${ }^{c}$ and Gregory of Pherat. ${ }^{59}$ In this chaotic atmosphere the northern metropolitans fear the appearance of Messalianism and heresy (probably Jacobitism) in the newly built monasteries and ask Babai to visit them and root out heresy, 'since it was clear to all that he was a solitary and not a bishop'. The author also notes that 'after the death of the wicked Khusrau, a catholicos was ordained and he [Babai] dwelt quietly in his cell'. 60

The next scene breaks off from this narrative for a digression: 'If anyone should ask "Didn't these metropolitans have sufficient power to end this wickedness without Mar Babai", I answer "Yes, but not all metropolitans are doctors, nor skilled in public disputation or able to argue against all the different false religions, but all these powers were found in Babai... as you may see from the eighty-four books he wrote."' The author goes on to address the specific concerns of the metropolitans: 'Since Messalianism began with monks, it is also right that monks should detect it, since they receive both divine grace and the crafty workings of the Devil.' Finally, the author also notes that several false accusations of Messalianism were made against the monasteries of Beth 'Abe and Rabban Sliba at the end of the seventh century. These were dismissed, and this fact seems to justify the use of monks to judge other monks. ${ }^{61}$

The author of this section admits the problem of Messalianism, but is also keen to assert that accusations against his own monastery are false and that the investigation of the issue should not be a matter for the regular clergy. Though the rules of Dadisho' and Babai emphasized the importance of cenobitism and tried to regulate the monastic wandering that was associated with the Messalians, it is clear that 'heroic eremeticism' remained an attractive part of monastic biography and practice, as we see in the stories from Jacob's exile and his meeting with the unnamed prophetess. Such controversial stories may have brought suspicion on their tellers, such as Apnimaran (himself accused of Messalianism), but it did not prevent their popularity. ${ }^{62}$

59 Book of the Governors, I, xxiii-vi (46-51/79-90).

60 Book of the Governors, I, xxvii (52/92). $\quad 61$ Book of the Governors, I, xxviii (52-3/93-5).

62 Thomas tries to defend Apnimaran as a cenobitic founder, and therefore an anti-Messalian, which is probably a deliberate simplification of the accusation of heteropraxy: Book of the Governors, II, iii (68-9/122). See further P. Escolan, Monachisme et l'église: le monachisme syrien du IVe au VIIe siècle (Paris, 1994) for ideas associated with 'Messalians' in theologians of the

This is an open access version of the publication distributed under the terms of the Creative Commons Attribution-NonCommercialNoDerivs licence (http://creativecommons.org/licenses/by-nc-nd/3.0/), which permits non-commercial reproduction and distribution of the work, in any medium, provided the original work is not altered or transformed in any way, and that the work is properly cited. For commercial re-use, please contact academic.permissions@oup.com 
This strand of the narrative defends Babai's importance as a monastic visitor. The narrative adds the weight of his prestigious reputation to the claims of the Abrahamic monasteries to regulate themselves. The author does this without directly challenging the powers of the episcopate. Babai is an example of how an abbot might be qualified in ways that a bishop was not. At the same time, Babai is not presented as a catholicos: he is primarily an example of the capacity of monastic self-leadership independent of the catholicos and his bishops, which might be invoked against the interference of the catholicoi of future generations. ${ }^{63}$ However, while Babai's investigation of Messalianism and his attempts to normalize monastic liturgy ${ }^{64}$ might be praiseworthy in themselves, these are only necessary for others, not the monks of Beth 'Abe: for the author, Messalianism was a problem in other peoples' monasteries.

The third and final narrative that Thomas centres around Babai is even more strongly linked to the political narrative of the shah and presents Babai as a catholicos. This political setting differs from the previous narrative: instead of charting the deaths of catholicoi, it focuses on the death of Yazdin, 'prince of the believers' and Khusrau's murder by his son, Shamta: '[after Khusrau's death] there was rest for all parts of the church and, at Shamta's command, Shiroë's troops proclaimed a good hope for men'. Next Shiroë, the new shah (628-9), assembles a synod, but Babai refuses the office of catholicos, despite being asked by all the bishops, and he prefers to end his days in his cell. After his refusal he is visited by an angel, the protector of the patriarchs of the East, who asks permission to accompany the new catholicos. Babai replies 'If I had known you were with me, then I should have accepted the office'. The section concludes the first book of the collection with a prayer: 'May Mar Babai's prayers be a wall for the church and her children'. ${ }^{65}$

The last scene of this narrative recapitulates the political background already given with a new focus on Yazdin, which suggests it comes from a different source. This brief final section asserts Babai as catholicos and a defender of the church, in an unproblematic statement of his role as maintainer of orthodoxy that gives no space to the vicissitudes of his relationship with Beth 'Abe and Mar Jacob. None of Thomas's sources could resist Babai's importance for the Church of the East, but they vary in their acceptance of his role as a force for centralization within the church, a variety of opinion that is

Church of the East, esp. 94 on Narsai (the function of all prayer as exorcism); 98 on Abraham of Netpar (the importance of audible prayer) and 191 for Sahdona (the bipartite model for asceticism in society).

${ }^{63}$ E.g. Book of the Governors, II, vii-ix (73-6/131-51) for Isho' yahb III's attempts to influence the election of an abbot and build a school at Beth 'Abe or II, xxvii (102/229) for Sliba-zkha's attempts to remove the monastery's illustrated service book.

${ }^{64}$ Book of the Governors, I, xxix (55-6/98-9). $\quad{ }^{65}$ Book of the Governors, I, xxxv (63-4/ 114-6).

This is an open access version of the publication distributed under the terms of the Creative Commons Attribution-NonCommercialNoDerivs licence (http://creativecommons.org/licenses/by-nc-nd/3.0/), which permits non-commercial reproduction and distribution of the work, in any medium, provided the original work is not altered or transformed in any way, and that the work is properly cited. For commercial re-use, please contact academic.permissions@oup.com 
preserved in Thomas thanks to his interest in Jacob. Notably, the more localized the focus of these stories, the more ambiguous Babai's role as a centralizer and reformer. We see a much more centralized image of the church, but with an emphasis on the continuing symbiosis of the catholicoi and Abrahamic monasticism in the final account of the movement, that of the Chronicle of Seert.

\section{MONASTIC HAGIOGRAPHY IN THE CHRONICLE OF SEERT: THE CATHOLICOI AND THE JACOBITES}

The Abrahamic movement receives a wide coverage in the Chronicle of Seert, extending from Abraham himself until the 660s. This chronological range is the same as the lists of monastic founders included in 'Amr's chronicle, so we probably have a relatively complete version of the monastic material used in the medieval compilations (i.e. it has not been cut short by the end of the Chronicle). This material is also similar in style to that used by the Book of Chastity, and occasionally sections mirror the wording closely, especially in the prayers that end some sections. However, there is also considerable divergence in the dramatis personae of the minor monks and in the much longer and more detailed sections in the Chronicle, supporting Fiey's assessment that the authors of both hagiographic collections used the same sources rather than being products of the same author. ${ }^{66}$

The structure of the Chronicle's material mirrors that found in the Book of Chastity, and a similar point can be made here about the sacred geography of the hagiographic collection incorporated into the Chronicle. But the more detailed sections of the Chronicle allow us to make additional observations about the prominence of other figures in these monastic texts, especially the catholicoi and aristocrats of different kinds. Likewise, just as in the Book of the Governors we saw how different monastic histories took different positions on the importance of the catholicos, on the nature of Abraham's inheritance and the prominence of Yazdin and Babai. Here too, the process of collection allowed our compiler to produce a collage of sources, which depicted monasteries, catholicoi, and aristocrats existing in symbiosis.

${ }^{66}$ Fiey, 'Ishodnah et la Chronique de Seert', 450. He addresses the argument of P. Nautin, 'L'auteur de la « Chronique de Seert »: Isho'denah de Basra', RHR 186 (1974), 113-26. These monastic narratives are broadly similar in form to those describing great theologians in earlier generations, but they are linked by references to the geography of the monks' foundations and their place of training, which implies that they have all been drawn from collections similar to those used by the Book of Chastity. The sections are Chronicle of Seert, II/i, XVIII, XXXI, XXXVI, XXXIX, LX; II/ii, XLIV-LVI, LXI, LXII, LXXIII, LXXVI, LXXVII, XC, XCV-XCIX, C, CXI.

This is an open access version of the publication distributed under the terms of the Creative Commons Attribution-NonCommercialNoDerivs licence (http://creativecommons.org/licenses/by-nc-nd/3.0/), which permits non-commercial reproduction and distribution of the work, in any medium, provided the original work is not altered or transformed in any way, and that the work is properly cited. For commercial re-use, please contact academic.permissions@,oup.com 
Several biographies are included in which the prominence of the saint's life or the importance of his monastery was tied to the reputation of individual catholicoi. Jacob of Beth 'Abe, the hero of the Book of the Governors, is remembered here for blessing Isho'yahb III whilst bishop of Adiabene, as well as for his birthplace at Lashom, former see of the catholicos Sabrisho ' (596-604), and his family's connections to the shah until they fell from favour. In addition, we are told of his education at the school of Marga, his role as a missionary among pagans and heretics, and his connection to Babai of Nisibis, Babai the Great, and Dadisho ${ }^{c}{ }^{67}$ However, no special note is given on his convent: the broader lens of the Chronicle has sacrificed a lot of what made Jacob distinctive and problematic, and the story of the saint is transformed into how he is connected to external social systems: to the catholicoi and the shah, to the school system and to the acceptable, cenobitic tradition of Dadisho ${ }^{c}$ and Babai.

The Chronicle's treatment of two other major figures is similar to that of Jacob. Sabrisho' of Beth Qoqa and Rabban Shapur are both the centre of a cluster of hagiographies in the Book of Chastity, and many of their followers founded 'related' monasteries. But the Chronicle focuses instead on their relationships to catholicoi, to Isho' yahb III and John bar Marta (682-4), who were blessed by them or treated their relics with particular devotion. ${ }^{68}$ The chief reasons for the prominence of these saints are left unmentioned and are replaced by their posthumous importance as accessories to the prestige of seventh-century catholicoi. ${ }^{69}$

Aside from the connection of these biographies to individual catholicoi, they are also connected more generally to the interests of the Church of the East. The biographies provide examples of the symbiosis of schools and monasteries led by the catholicos. As we have seen, the close relationship between the School of Nisibis, the catholicoi, and the monasteries broke down during the reign of Khusrau II (this is one of the underlying reasons for the different images of Babai in the Book of the Governors). Many of the hagiographies used here are probably a product of the late seventh century, given their references to the Arab invasions and the catholicoi and monasteries they include. But the presentation of material in these slightly stereotyped biographies invite us to think that nothing has changed beyond the proliferation of the school system beyond Nisibis: these monks trace their ascetic lineage back to Abraham, and are solely defined by their education and their relationship to catholicoi and aristocrats.

A particular issue for the catholicoi of the Church of the East was the threat posed by the Jacobites: as we have seen, the synods of the late sixth century

67 Chronicle of Seert, II/ii, LVI (462-3).

68 Chronicle of Seert, II/ii, LIV (459-61) and XCVI (584-5).

69 Contrast the section on Jacob of Beth Garmai in Book of Chastity, $\$ 140$, where the saint embarrasses the catholicoi Henanisho' ${ }^{c}$ and Giwargis by refusing to be ordained.

This is an open access version of the publication distributed under the terms of the Creative Commons Attribution-NonCommercialNoDerivs licence (http://creativecommons.org/licenses/by-nc-nd/3.0/), which permits non-commercial reproduction and distribution of the work, in any medium, provided the original work is not altered or transformed in any way, and that the work is properly cited. For commercial re-use, please contact academic.permissions@oup.com 
adopted an anti-Theopaschite position, which became entrenched in the seventh century as the church became increasingly Dyophysite. And Babai's theology and the expanded school system became an important means of defending this position. ${ }^{70}$ Yet at the same time, other celebrated figures in the monastic movement followed the more conciliatory position advocated by Henana, such as Sahdona, the prominent ascetic who proposed theological compromise, or Ishaq of Nineveh, whose mystical writings ask believers to abandon all literature that could divide Christians. ${ }^{71}$ These figures were also clearly popular in the monastic hagiographies: Thomas frequently uses Sahdona's monastic biographies and Sahdona and Ishaq both receive lengthy entries in the Book of Chastity. ${ }^{72}$

In contrast with the attitude of the other hagiographic collections, the Chronicle of Seert highlights the anti-Jacobite stance of several of its saints. ${ }^{73}$ This coincides with its image of the symbiosis of the school system and monasticism with the catholicosate: both institutions are important pillars of orthodoxy in the redefinition of the church around Babai's extreme Dyophysitism. ${ }^{74}$ This image of monasticism as anti-Jacobite was drawn from contemporary sources: it is a prominent feature of the Syriac Lives of Rabban Bar 'Idta and Rabban Hormizd. ${ }^{75}$ But, given the absence of references to it in the other collections, it appears to be a feature of the careers of these monks that has been exaggerated by the author/compiler of the biographies used in the Chronicle of Seert, probably writing in the ninth or tenth century, but using seventh-century sources. ${ }^{76}$

This point is reinforced when we note the absence of anti-Jacobite references in Abraham's Rules, in spite of the association of the reform of the tonsure with him in his Life and the account of the Chronicle of Seert. ${ }^{77}$ Indeed, the emphasis on a Dyophysite orthodoxy in Dadisho"s Rules may suggest that the tonsure reform was his innovation, and reflects the closer monitoring of ideas in a cenobitic environment. Thus, it is possible that this reform had been

70 The Miaphysite Life of Marutha of Takrit, 65, complains at 'Nestorian' schools and choirs in Beth Nuhadra winning over Miaphysite 'widows and virgins', prompting the saint to respond in kind and build his own schools.

${ }^{71}$ J.-M. Fiey, 'Sahdona', in DS.

72 Book of Chastity, §124 and 127.

${ }^{73}$ Chronicle of Seert, II/ii, XLVII, L, LVI, LXXXIV, XCIX. There is one direct reference in Book of Chastity, §32. Thomas omits the actions by Jacob of Beth 'Abe against the Jacobites that are mentioned in the Chronicle.

${ }_{74}$ This is also a marked feature of Isho'yahb III's recentralization of the institutional church, when his letters communicate the importance of Christological unity against dissidents such as Sahdona. R. Payne, 'Persecuting heresy in early Islamic Iraq: the Catholicos Isho' yahb III and the elites of Nisibis', in A. Cane and N. Lenski, The Power of Religion in Late Antiquity (Ashgate, 2009), 397-410.

75 They focus especially on the denial of Miaphysite sacraments (e.g. Life of Rabban Hormizd, 69-70/102-3) and attacks against Miaphysite monasteries (Life of Rabban Hormizd, 92-104/ 138-52).

${ }^{76}$ The reference to John bar Marta (d.684) is a terminus a quo for the sources used here.

77 Abraham's Life may have been composed by Babai. Chronicle of Seert, LXXXIV (533).

This is an open access version of the publication distributed under the terms of the Creative Commons Attribution-NonCommercialNoDerivs licence (http://creativecommons.org/licenses/by-nc-nd/3.0/), which permits non-commercial reproduction and distribution of the work, in any medium, provided the original work is not altered or transformed in any way, and that the work is properly cited. For commercial re-use, please contact academic.permissions@oup.com 
retrojected onto Abraham by the developing historical tradition, to unequivocally present the monastic movement as part of the struggle against the Jacobites and Abrahamic monasticism as a phenomenon closely associated with the defence of Dyophysite theology and missionary activity. In an environment where Jacobite missionaries were targeting a wide spectrum of unChristianized groups, ranging from nomadic Arabs to members of the shah's family, all missions to Kurds, Arabs, and Iranian aristocrats in the Seert biographies may have been seen as broadly anti-Jacobite, an attempt to convert all of the Sasanian world to Nestorianism. ${ }^{78}$

\section{MONASTIC FOUNDATIONS AND IRANIAN ARISTOCRACY}

The monastic hagiographies used in the Chronicle of Seert and the Book of Chastity emphasize at several points the close relationship between Iranian aristocrats and monks. Several monks are converted members of this aristocracy, often from areas such as Merv and Nisibis that were both centres of Sasanian government and longstanding Christian bishoprics. ${ }^{79}$ And the Chronicle in particular celebrates the close relationships between monks and the powerful family of Yazdin, whose association with a saint, like that between a saint and a catholicos, may have influenced the inclusion of these saints' lives in the collection: Yazdin appears receiving miracles of healing (in Izla and in Fars) and as a major donor to the church and intercessor on its behalf under Babai. ${ }^{80}$

This focus on the aristocratic connections and origins of monastic founders is an important change from the earlier presentation of the relationship between the Church of the East and the Sasanian Empire. In the fifth century, catholicoi from Fars such as $\mathrm{Ma}^{\text {' }}$ na had been valued for their ability to acquire patronage for the church at the court of the shah. This relationship between shah and catholicos strengthened through the sixth century, as we have seen reflected in the historical tradition, and reached its apogee in the sponsorship of Sabrisho ${ }^{c}$ by Khusrau II. ${ }^{81}$ But the greater focus on secular aristocrats who were also Christians in these hagiographic texts shows a broadening out of the interaction between the church and political leaders beyond the relationship of shah and catholicos.

${ }^{78}$ Chronicle of Seert, II/ii, XLV, L, LIV, LXXVI. For Miaphysite missions see Life of Ahudemmeh, esp. 25-7 (the Jazira Arabs) and 33-5 (Khusrau I's son).

79 Book of Chastity, \$36, 39, 54, 76; Chronicle of Seert, II/ii, XLIX, L, and LVI.

${ }^{80}$ Chronicle of Seert, II/ii, XLVI (447-8); LIII (458), and LXXXIV (532).

${ }^{81}$ See especially the Syriac Life of Sabrisho' and Chronicle of Seert, LXV-LXVII (474-94). For the relationship between the shah and this catholicos see chapter 7 .

This is an open access version of the publication distributed under the terms of the Creative Commons Attribution-NonCommercialNoDerivs licence (http://creativecommons.org/licenses/by-nc-nd/3.0/), which permits non-commercial reproduction and distribution of the work, in any medium, provided the original work is not altered or transformed in any way, and that the work is properly cited. For commercial re-use, please contact academic.permissions@oup.com 
The Synodicon confirms the growing prominence of these Christian elites: when the catholicos Aba toured the province of Khuzistan in 544, the local synods he convened also include lists of lay elites, frequently with their Middle Persian titles from the Sasanian administration or their positions in a variety of artisanal 'guilds'. ${ }^{82}$ Similarly, the seals collected by Rika Gyselen for the late Sasanian period show the prominence of Christians in the state administration. In some their names suggest their religious affiliation, while in others the cross or other Christian symbols display a public religious identity. ${ }^{83}$

However, this expansion in the prominence of Christian elites within the Sasanian Empire did not necessarily serve the purposes of a church centred on the catholicoi. Legislation against the involvement of lay elites in episcopal elections shows the difficulty of maintaining older rules about authority. But it does not follow that this involvement was resented at a local level, where the 'bribery' by elites condemned by the catholicos might have been seen as welcome sponsorship, and where it is possible that, as in the medieval West, bishops may have themselves been drawn from magnate families. ${ }^{84}$

Several literary phenomena of the late Sasanian period might similarly be associated with the development of local elites who were engaged in the patronage of the church. Local hagiographies in Karka de Beth Slouq and Arbela may have been composed as a result of aristocratic patronage, which sponsored texts that emphasized both the origins and antiquity of the cities' Christianity and the Iranian and Assyrian origins of its aristocracy. ${ }^{85}$ The investment of these kinds of elites in monasticism, whether as independent funders or as monks themselves, represents an additional channel through which aristocrats could make prestigious investments that also publicized their ('Nestorian') Christian status.

Cynthia Villagomez has argued that the economy of late Sasanian and early Islamic monasticism was integrated into a wider monetary economy, where its products of wine and oil were sold. Monasteries, she argues, were very receptive to external donations, an activity that was not seen to conflict with the poverty of individual monks. ${ }^{86}$ She observes the use of monasteries as

82 Synodicon, 79.

83 R. Gyselen, 'Les témoinages sigillographiques sur la présence chrétienne dans l'empire sasanide', in R. Gyselen (ed.), Chrétiens en terre de l'Iran 1: implantation et acculturation (Paris, 2006), 17-78.

84 Synodicon, 100 and 103 (Jospeh's canons 4 and 13).

85 J.-M. Fiey, 'Vers la réhabilitation de l'Histoire de Karka de Beth Slouq', AB 82 (1964), 199222; J. Walker, The Legend of Mar Qardagh: Narrative and Christian Heroism in Late Antique Iraq (Berkeley, 2006).

${ }^{86}$ C. Villagomez, The Fields, Flocks and Finances of Monks: Economic Life at Nestorian Monasteries, 500-850 (Los Angeles, 1998, unpublished PhD thesis, UCLA), esp. 173 for her observations on the money economy. Also compare L. Schachner, "I greet you and thy brethren. Here are fifteen šentaese of wine": wine-production in the early monasteries of Egypt and the Levant', Aram 17 (2005), 157-84.

This is an open access version of the publication distributed under the terms of the Creative Commons Attribution-NonCommercialNoDerivs licence (http://creativecommons.org/licenses/by-nc-nd/3.0/), which permits non-commercial reproduction and distribution of the work, in any medium, provided the original work is not altered or transformed in any way, and that the work is properly cited. For commercial re-use, please contact academic.permissions@oup.com 
'economic insurance' by aristocrats and notes a shift away from Abraham's insistence on monastic poverty within two generations of his foundation at Izla. ${ }^{87}$ This suggests that monasteries were closely tied to the aristocratic networks that could guarantee and protect their property, in terms of both land and labour. However, this relationship could also make monasteries more vulnerable to the changing attitudes of aristocratic patrons. These relationships were reflected in most of the monastic hagiographies, though they focus on different aristocratic patrons.

The late Sasanian period has been presented as one of intensive state investment, which saw a massive increase in the monetization of the economy; the expansion of foreign trade in glass and ceramics; the construction of great defensive walls, irrigation canals, and new cities; and the raising of armies to fight the Romans. ${ }^{88}$ The tradition of the Xwadāy-Nämag, the Middle Persian Book of Kings, strongly associates this with royal reform of administration and taxation, ${ }^{89}$ but the archaeological evidence suggests that the intensification and extension of land use may have been a phenomenon that was not solely associated with the shah's government. A survey of settlement patterns on the Deh Luran plain in south-western Iran may indicate that the late Sasanian period also saw the extension of settlement using the kind of irrigation technology employed for the large-scale hydraulic systems of Iraq, surface runoff regulators, deep wells, and underground qanats, on a much smaller scale in this peripheral highland area. ${ }^{90}$ The foundation of new monasteries might fit into the same pattern of agricultural expansion, and the Chronicle of Seert presents monks expelling wild beasts, performing agricultural miracles, and building canals to bring unused land under cultivation. ${ }^{91}$ The aristocratic sponsorship of these monasteries may then reflect another way in which the growing sophistication of the Sasanian world benefited not only the shah's 'government', but also semi-independent actors, such as monastic founders and their aristocratic allies.

87 Villagomez, Fields and Flocks, 100-7 and 140-3. See also M. Morony, 'Religious communities in late Sasanian and early Muslim Iraq', JESHO 17 (1974), 113-35, esp. 126.

${ }^{88}$ Surveyed in J. Howard-Johnston, 'The two great powers in late antiquity: a comparison', in J. Howard-Johnston, East Rome, Sasanian Persia and the End of Antiquity: Historical and Historiographical Studies (Ashgate, 2006), I. See further the Simpson, Mesopotamia, esp. 446-8, which emphasizes technological development.

${ }^{89}$ E.g. Al-Tabari, I, 896-8.

90 J. Neely, 'Sasanian and early Islamic water-control and irrigation systems on the Deh Luran plain', in T. Downing and M. Gibson (eds.), Irrigation's Impact on Society (Tucson, 1974), 21-41. Much of the Iranian plateau was unsuited to the scale of irrigation development seen in Iraq. See Naval Intelligence Report: Persia (Oxford, 1945), 423-9.

${ }^{91}$ Chronicle of Seert, II/ii, XLIV (wild beasts), XLVI, XLVIII, LIV, CXI (building a canal near Gundishapur). Also see Life of Rabban Bar'Idta (148/221).

This is an open access version of the publication distributed under the terms of the Creative Commons Attribution-NonCommercialNoDerivs licence (http://creativecommons.org/licenses/by-nc-nd/3.0/), which permits non-commercial reproduction and distribution of the work, in any medium, provided the original work is not altered or transformed in any way, and that the work is properly cited. For commercial re-use, please contact academic.permissions@oup.com 


\section{LOCAL HAGIOGRAPHIES AND IRANIAN PATRONS}

If this model is correct, then the same social and economic changes that strengthened the Sasanian 'state' and the power of the shah against his Roman opponents could also be employed by other actors within Iran and Iraq, in this case aristocrats and the Abrahamic monastic system. ${ }^{92}$ But just as we have not treated the Sasanian polity or the Church of the East as homogenous systems, we should also be careful to note that the aristocracies of the Iranian world, while they may have shared certain cultural features, were also divided vertically by religious affiliation and horizontally by rank. ${ }^{93}$ And just as the late sixth and early seventh church saw different voices from the centralized image of the catholicos, such as Sergius of Rasthaq's 'Destroyer of the Mighty', the same period also saw independent literary production by elite groups within the Sasanian Empire and their independent interaction with different actors within the Church of the East. Where the interaction between the Sasanian political system and the Church of the East had been limited to that between the catholicos and the shah in the fifth century (as far as we can tell), the relationship between the two systems becomes increasingly complex in the late sixth and seventh century, especially when the catholicosate was in abeyance or after the Arab conquest and the death of the last shah. We can acquire some sense of the diversity of these relationships between Sasanian elites and Christian religious institutions by contrasting the localized Syriac hagiographies composed in this era with the Iranian elite histories preserved in the Chronicle of Seert.

The relationship between political elites and the Church of the East was articulated at the most basic level between individual monasteries and individual local elites, where hagiographies asserted an ideal pattern for the relationship between donor and institution. The Life of Rabban Bar ' Idta describes how a Christian lord, Malbed of Barzane, who lived near the saint's monastery near Marga, was ruined in war and his house filled with demons. The saint exorcized the house and then installed Malbed as 'head of Marga' for many years. ${ }^{94}$ The original version of the life was written soon after the saint's death, so this representation of Malbed owing his fortune to Bar 'Idta may be a kind of contract: a public statement about the debt of honour held by Malbed's family to the monastery that would have been recognized by all who heard the story. ${ }^{95}$

Another scene from the same life, dated after Khusrau II's victory over the usurper Vahram Chobin in 592, presents the elite figure in a greater position

92 For the economic and political advantage of the Sasanians under Khusrau II see M. Morony, 'Economic boundaries? Late antiquity and early Islam', JESHO 47 (2004), 166-94.

93 See M. Zakeri, Sasanian Soldiers in Early Muslim Society: The Origins of 'Ayyawan and Futtuwa (Wiesbaden, 1995) on the gradation of this hierarchy.

94 Life of Rabban Bar 'Idta (144-5/215-6).

95 Sahdona's text, which is the surviving version, is a 660s rewriting of an earlier life by 'John'.

This is an open access version of the publication distributed under the terms of the Creative Commons Attribution-NonCommercialNoDerivs licence (http://creativecommons.org/licenses/by-nc-nd/3.0/), which permits non-commercial reproduction and distribution of the work, in any medium, provided the original work is not altered or transformed in any way, and that the work is properly cited. For commercial re-use, please contact academic.permissions@oup.com 
of power: here the saint is more of an equal intercessor between aristocrat and people. In this scene, the land of Marga is struck by a famine, and the saint requests for silver from the magnate Zandha-Farrokh to buy wheat from Nisibis, Media, and Khuzistan. He distributes this to the poor as famine relief, in spite of the complaints of his monks who fear there will not be enough for themselves. ${ }^{96}$ Zandha-Farrokh is a Middle Persian name, but he is explicitly said to be a 'believer' and he may have been a convert. As before, the story may be intended to maintain good relations with an established local family, but it also sets up the monastery as the distribution point for famine relief, establishing its importance to local villages (on whom the monastery itself might rely for labour and support in the future). Simultaneously, the dissemination of the story enabled a local noble to participate in a monastic exchange network at one remove, making use of Christian institutional structures to gain prestige while simultaneous endorsing the authority of Rabban Hormizd, who dispenses the food to the poor. ${ }^{97}$

However, monasteries also had to be able to control the patronage that they received, and be guaranteed a certain degree of independence from their donors. The Book of the Governors reports a scene from c.660 in which one Hugair wished to found a new monastery, 'not for a religious intentions, but for boasting and pride. Acting as if he was a good man, he named it HugairAbad, in the style of the Magians from whose race he had come.' However, Aha, metropolitan of Marga and former head of the monastery, refused to consecrate it and bring his monks and scribes there, saying 'The house of Hugair-Abad is ruined while it is still new. ${ }^{98}$

Maria Macuch notes that the Zoroastrian 'church' made no pious foundations of its own, and instead individuals made their own foundations, which provided ceremonies for the deceased, but also gave their founder inalienable rights of usufruct over their religiously dedicated estates. These estates would then grow cash crops, provide loans at interest, and be used for prestigious local 'charity', such as building bridges and canals. ${ }^{99}$ Hugair probably made similar assumptions about funding a monastery in his newly adopted religion, namely that he could enjoy a tax-protected investment as well as making a prestigious display of his wealth. The hagiography celebrates how a protégé of the monastery of Beth 'Abe maintained the principles of monastic independence in the face of this offer of 'tied funding' and the story itself serves as a

${ }^{96}$ Life of Rabban Bar 'Idta (153/230).

97 On these exchange networks and the prestige that accrued to their controllers in a late Roman context, see P. Brown, Power and Persuasion in Late Antiquity (Madison, 1992).

98 Book of the Governors, II, xliii (136-7/282-3). On Aha's election see II, xxxvi (120/256-8).

99 M. Macuch, 'Pious foundations in Byzantine and Sasanian law', in A. Carile, L. Ruggini, and G. Gnoli, La Persia e Bizansio (Rome, 2004), 181-95.

This is an open access version of the publication distributed under the terms of the Creative Commons Attribution-NonCommercialNoDerivs licence (http://creativecommons.org/licenses/by-nc-nd/3.0/), which permits non-commercial reproduction and distribution of the work, in any medium, provided the original work is not altered or transformed in any way, and that the work is properly cited. For commercial re-use, please contact academic.permissions@oup.com 
parable for the dependence of donors on the approval of the institutional church, in spite of whatever material goods they might offer.

Saints' lives set after the Arab conquest and the fall of the Sasanian Empire start to problematize the status of Iranians within Christianity to an even greater degree. These slightly later hagiographies go beyond the economic regulation of elite behaviour and address the cultural and linguistic differences of Iranian Christians. The Life of John of Daylam, set in the 710s during the reign of 'Abd al Malik, describes how the saint builds numerous churches in Daylam, the subtropical mountainous region south of the Caspian, and in Fars, and constructs the first monastery to use Persian alongside Syriac, where the monks quarrelled over this linguistic difference. ${ }^{100}$ Middle Persian had in fact been used as a medium for Christian writings since the fifth century, and Job of Revardahsir, a companion of Abraham of Netpar, had prepared translations of the monastic Rules for use in Fars and among Christians in India. ${ }^{101}$ But for this hagiographer, the issue of language seems to have become a problem that needed to be addressed, as well as an indication of the church's missionary success. This itself may indicate a faster conversion rate by Persian speakers in the seventh century, when the Arab conquests had stripped away much of the prestige of Zoroastrianism. Equally, this faster rate of change may have prompted missionaries like John to accommodate themselves to the expectations of new Christians, which accounts for the prominence of the Persian language in his community.

In Iraq, and even more in Fars, Daylam, or Central Asia, Persian language and culture occupied a 'liminal' state. It was the language of the other, whose absorption into Christianity was presented as sign of the religion's strength, but whose speakers also brought alien practices, ranging from incestuous marriage and Zoroastrian foundation laws to myths of ancient times and the values of a martial aristocracy. Persian notables might become important donors to monasteries, but hagiographers might also imagine Persian as the language spoken by the Devil. ${ }^{102}$ The hagiographers and historians of the Church of the East treated these new phenomena in different ways, dependent on local conditions, and asserted the boundaries of what practices might be normalized and included within Christianity. ${ }^{103}$ Significantly, this period of

${ }^{100}$ Life of John of Daylam, 19, 25, and 39.

101 Chronicle of Seert, II/i, XXXI (173). N. Sims-Williams, 'Christianity. iv. Christian literature in Middle Iranian languages', in EIr notes the existence of a sixth-century Middle Persian psalm fragment in Central Asia as well as the use of Persian in Christian inscriptions in India.

102 Life of Rabban Hormizd (25/38). Compare the suspicion directed against Syriac-speakers in the fifth-century Roman world, another era of Christian expansion into the countryside: Theodoret of Cyrrhus, Historia Religiosa 21.15 (ed. Canivet and Leroy-Molinghen, II, 94).

103 Examples of this process of normalization include the Christianization of the figure of Zoroaster as a prophet of Christ, in the sixth-century Cave of Treasures, xxvii, 1-5 (ed. Su-MinRi), See further J. Neusner, 'Note on Baruch ben Neriah and Zoroaster', Numen 12 (1965), 66-9.

This is an open access version of the publication distributed under the terms of the Creative Commons Attribution-NonCommercialNoDerivs licence (http://creativecommons.org/licenses/by-nc-nd/3.0/), which permits non-commercial reproduction and distribution of the work, in any medium, provided the original work is not altered or transformed in any way, and that the work is properly cited. For commercial re-use, please contact academic.permissions@oup.com 
cultural syncretism and the elucidation of boundaries was the result both of Christians adopting the culture of Iranian elites and of the religious conversion of former Zoroastrians, who brought their own expectations of what their religion should provide, both in terms of its institutional forms, its cultural production, and the behaviours it endorsed.

\section{IRANIAN HISTORIES AND CHRISTIAN AUTHORS: THE ACTS OF MAR QARDAGH}

Hagiographies rooted in individual monasteries illustrate how this process of accommodation was managed in relationships between individual lords and the communities near them. These texts, irrespective of how accurate they were as accounts of specific events, set out ideal patterns of behaviour between monasteries and their neighbours. Other hagiographies and local histories present their subjects within a wider context, emphasizing the connection between aristocratic subjects in their narratives and specific regions of Iraq and Iran (on a larger scale than individual monasteries), situating these aristocrats in relationships with the rest of the empire and with the Sasanian past and articulating more powerful fusions of local ancestry and Christian memory.

One good example of a text with this broader historical and geographical interest is the Acts of Mar Qardagh, the warrior saint of Melqi in Adiabene in northern Iraq. His Syriac Acts are set in the reign of Shapur II, and emphasizes his lineage, from the kings of Assyria, and his construction of a fire temple and fortress at the hilltop settlement of Melqi. The saint undergoes a vision of a mounted figure who foretells his martyrdom, and after this he is miraculously rendered unable to play polo or to hunt, the martial pursuits of an Iranian aristocrat. ${ }^{104}$ After consulting with a Christian holy man, he converts and gives all his money to Christian monasteries. ${ }^{105} \mathrm{He}$ does, however, continue to fight against the Romans after his conversion: wearing a relic of the True Cross, he 'triumphs over his enemies like the rising sun'. ${ }^{106}$ Following the war, he converts his fire temple into a church. At this the magi denounce him to the shah, who reluctantly requests that Qardagh perform Zoroastrian rituals to show that he is not a Christian. ${ }^{107}$ After his refusal, the shah fears rebellion and sends his armies against Qardagh, who defeats them, only to be stoned by his own father before a crowd of Jews, Christians and pagans. ${ }^{108}$ Later, the Acts

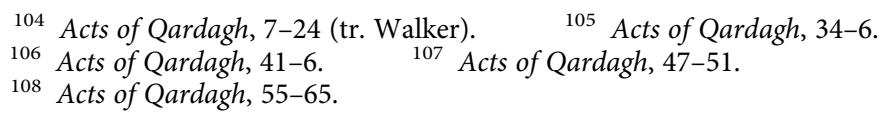

This is an open access version of the publication distributed under the terms of the Creative Commons Attribution-NonCommercialNoDerivs licence (http://creativecommons.org/licenses/by-nc-nd/3.0/), which permits non-commercial reproduction and distribution of the work, in any medium, provided the original work is not altered or transformed in any way, and that the work is properly cited. For commercial re-use, please contact academic.permissions@oup.com 
add, a great market was established at Melqi and a mighty church built at the same place. ${ }^{109}$

Joel Walker's study of the Acts describes its connection to the neo-Assyrian site of Melqi, and its role in Christianizing the memory of this earlier site and its market. ${ }^{110}$ And, like the monastic texts, the Acts set out an ideal role for the Christian aristocrat as monastic patron. The difference is that this text has a much greater focus on the person of the aristocrat than the other hagiographies we have looked at: it is Qardagh's deeds that mould Melqi, physically, through his fortifications and church building, and socially, through his acting as a fair judge. Instead of focusing on aristocratic duties and the limitations of the claims of patrons, the Acts set out a model of a society led by a Christian aristocrat and define Qardagh's importance through traits common to all Iranian elites, to his descent and his martial prowess. ${ }^{111}$

Furthermore, it is significant that Qardagh is not only active at a local level. The saint acts as a hinge-point in the narrative between his home of Melqi, and the people he governs and protects, and the shah and his court. He uses the martial abilities that God has given him to fight for the shah against the Romans. A topos of the fifth-century martyr acts had been the suspicion that fell on Christians as co-religionists of the Romans: here the saint's martial role can firmly rebut any accusations of disloyalty against the Christians. Similarly, those acts had emphasized the anger of the shah and his role as a persecutor and interrogator of the saints, but here the shah's traditional role is muted (he said to be 'sad rather than angry') and the mobads are blamed for inciting Qardagh's death and forcing the shah's hand. The presentation of Qardagh as a loyal servant of the empire against the Romans and the alteration of the shah's role suggest a positive relationship between the shah at the time of writing and an idealized Christian aristocracy. The text was probably composed under Khusrau II: its setting under Shapur II, famous for his persecutions and his wars against the Romans, distances the contemporary Sasanian ruler from the acts of his predecessor. Within the genre of the martyr act, the reader expects Shapur to be represented as a persecutor, but Qardagh's participation in the war against the Romans shows that toleration will be rewarded with loyal service and that physical rebellion against the shah is only occasioned by the mobads' demand that he choose between loyalty to the shah and to the true King of kings. ${ }^{112}$ Several earlier saints' lives had, of course, sought to lay the

\footnotetext{
109 Acts of Qardagh, 68.

110 Walker, The Legend of Mar Qardagh.

111 These are the traits spelled out in the royal rock inscriptions of the third century and in Sasanian silver plate. P. Harper, In Search of a Cultural Identity: Monuments and Artefacts of the Sasanian Near East (Third to Seventh Centuries A.D.) (New York, 2006).

112 Acts of Qardagh, 56: 'What is more grievous? That I should revolt against a wretched man who blooms today and is full of pride, but for whom there is no tomorrow? Or to revolt against the heavenly king of kings, whose kingdom does not pass away?'
}

This is an open access version of the publication distributed under the terms of the Creative Commons Attribution-NonCommercialNoDerivs licence (http://creativecommons.org/licenses/by-nc-nd/3.0/), which permits non-commercial reproduction and distribution of the work, in any medium, provided the original work is not altered or transformed in any way, and that the work is properly cited. For commercial re-use, please contact academic.permissions@oup.com 
blame for persecution with the mobads. But the Acts of Qardagh is set apart by the military role of its aristocratic hero in the wars of the shah.

\section{IRANIAN HISTORIES IN THE CHRONICLE OF SEERT}

The hagiography from northern Iraq shows a model of a powerful aristocrat, of trans-regional importance, converting to Christianity and helping the church. The text establishes the region of Arbela as a place of peculiar prestige within the Sasanian world, set apart by its history of Christian aristocratic sponsorship and the embedding of earlier legends and foundation stories into a Christian framework. But such stories of regional importance were also incorporated into the wider framework of the history of the Church of the East as a whole, and appear as sections in the Chronicle of Seert. ${ }^{113}$ Another regional history of this sort is found in the section devoted to the Life of Mar Shabbay, who converted a wife of Shapur II, and who went on to establish a cadet line of the Sasanian house in Merv and found many churches there. This Life celebrates Merv as a city founded by Alexander and traces its Greek community back to him. It recounts the succession of the princely house of Merv, which continued to sponsor Christianity in memory of their ancestor, in spite of their Zoroastrianism. ${ }^{114}$ Thus the Mervi story blends Iranian and Hellenistic memories of the past and places these in a Christian framework, which promotes a symbiosis of Iranian lordship and local Christianity. ${ }^{115}$

However, by placing Shabbay or Qardagh along with other Shapurian martyrs, the Chronicle of Seert emphasizes their place within the Church of the East as a whole, rather than their specific importance for Merv or Arbela. If these aristocratic hagiographies celebrate the Christian histories of specific regions, and the connection of aristocratic dynasties to these regions, then their inclusion in a universal history also subverts this regional emphasis and makes it part of the wider history of the Church of the East and its connection to various prestigious lay histories, whether Iranian, Assyrian, or Greek. $^{116}$

113 Qardagh appears at Chronicle of Seert, I/ii, XXXII (225-8).

114 Chronicle of Seert, I/ii, XL (253-8). A West Syrian version of the Life also survives, as do fragments in Sogdian from the Turfan oasis. See S. Brock, 'The Life of Mar Shabbay', in D. Burnazhov et al. (eds.), Bibel, Byzanz und Christlicher Orient: Festschrift für Stephen Gero zum 65 Geburtstag (Leuven, 2011), 259-81. Also note the connection between Alexander and Merv in Khuzistan Chronicle, 34. We have already seen the prominent role that ideas of Greek descent played for communities in Khuzistan in chapters 2 and 3.

115 Compare similar features in the sixth-century History of Karka de Beth Slouq, 509-11.

116 Walker, Mar Qardagh, 259 and 263 notes that Qardagh's connection to an Assyrian past is de-emphasized in favour of his Iranian identity in the ninth- and tenth-century accounts.

This is an open access version of the publication distributed under the terms of the Creative Commons Attribution-NonCommercialNoDerivs licence (http://creativecommons.org/licenses/by-nc-nd/3.0/), which permits non-commercial reproduction and distribution of the work, in any medium, provided the original work is not altered or transformed in any way, and that the work is properly cited. For commercial re-use, please contact academic.permissions@oup.com 
The local histories that were incorporated into the Chronicle all celebrate the Christianity of aristocrats alongside the relationship of these aristocrats to the Sasanian shah. Even though the texts were probably incorporated into ecclesiastical history after the end of the Sasanian Empire, this royal link is used to establish their prestige in a context where the Sasanians were still remembered with respect. Richard Payne has observed that the same era saw Christians adopting Sasanian laws of inheritance, preserving aspects of Sasanian culture at a time when formal Zoroastrian structures were withering away following the Muslim conquest. ${ }^{117}$ A parallel movement may be observed in 'Nestorian' historiography, whereby memories of the Sasanian past were included in Christian ecclesiastical histories, whether to be uncritically reused or adapted to suit their new context.

The chief example of this Christian deployment of the Sasanian past is the Chronicle of Seert's inclusion of sections from the Xwadāy-Nāmag, the Sasanian book of kings. The Xwadāy-Nämag, was already a multifaceted and complex cluster of texts by the end of the Sasanian period. It presented a variegated tradition, showing strong signs of central, legitimist editing in the reign of Khusrau I, but also incorporating local histories from the 'Parthian' aristocratic houses. ${ }^{118}$ This history is, in its turn, chiefly extant through tenthcentury compilations that used different strands of the Middle Persian material, chief among them the works of al-Tabari, al-Dinnawari, and Ferdowsi. ${ }^{119}$

The use of Sasanian royal histories in the Chronicle of Seert can be grouped under two broad tendencies. The first is the straightforward transmission of material from the Middle Persian sources, which may contradict the Christian view of a shah. Thus, sections on the short-lived reigns of Ardashir II (379-83) and Shapur III (383-8), or the account of Yazdegard I's murder, mirror the bias of al-Tabari's redaction of the Xwadāy-Nämag and describe their quarrels with the nobility and Yazdegard's 'sinful' reputation (that, ironically, stems in

117 R. Payne, Christianity and Iranian Society (unpublished PhD thesis, Princeton, 2010), ch. 4.

118 In a large literature, see P. Huyse, 'Late Sasanian society between orality and literacy', in Curtis and Stewart, The Idea of Iran, 140-53 and S. Shahbazi, 'On the Xwadāy-Nāmag', in D. Amin and M. Kasheef (eds.), Iranica Varia: Papers in Honor of Ehsan Yarshater (Brill, 1990), 208-29. On local histories and their significance, see T. Nöldeke, The Persian National Epic (tr. Bogdanov) (repr. Philadelphia, 1971), 12-19 and 66; C. E. Bosworth, 'Sistan and its local histories', Iranian Studies 33 (2000), 31-48; Z. Rubin, 'Nobility, monarchy and legitimation under the later Sasanians', in J. Haldon and L. Conrad (eds.), The Byzantine and Islamic Near East, Vol. 6: Elites Old and New (Princeton, 2004), 235-73, and Pourshariati, Decline and Fall, esp. 49-52 and 85-91. However, the aristocratic or 'Parthian' strands in these histories need not always represent active anti-state forces as many of these authors suppose: their incorporation into the Xwadāy-Nämag tradition may indicate the subversion or annexation of non-Sasanian histories. I hope to discuss the tradition of the Book of Kings in future work.

119 Z. Rubin, 'Ibn al-Muqaffa' and the account of Sasanian history in the Arabic Codex Sprenger 30', JSAI 30 (2005), 52-93; Z. Rubin, 'The lost Sasanian Book of the Lords as known to the 10th century Arabic historiographers' (unpublished paper, Oxford, 2008).

This is an open access version of the publication distributed under the terms of the Creative Commons Attribution-NonCommercialNoDerivs licence (http://creativecommons.org/licenses/by-nc-nd/3.0/), which permits non-commercial reproduction and distribution of the work, in any medium, provided the original work is not altered or transformed in any way, and that the work is properly cited. For commercial re-use, please contact academic.permissions@oup.com 
part from his favour to the Christians). ${ }^{120}$ Sometimes this material has been fleshed out with narratives that were readily available in other sources. Thus, the section on Shapur II, though it calls him Dhü al-Aktāf ('he of the shoulders') in accord with the other Arabic redactions of the Xwadāy-Nāmag, provides no explanation of his epithet and draws its narrative from Roman ecclesiastical history (his fear of Constantine and his attacks on Nisibis), supplemented by a list of the cities that Shapur founded in Khuzistan. ${ }^{121}$

Occasionally, the narrative of the shah's deeds has been used to provide the chronological setting for events in church history, though the events of the shah's reign and those in church history are often not related beyond a note to say that 'the shah favoured the Christians/the catholicos'. This is especially noteworthy during the reigns of Kavad and the short-lived shah Valash who ruled while he was imprisoned. The fact that church politics in this decade was especially significant may have meant that the rapid change in the royal patrons whose record was preserved in the patriarchal history prompted later historians to explain these political events with what material they could quarry from translations from the Middle Persian. ${ }^{122}$ Similarly, Shapur I's reign seems to have prompted great interest because of his role in the population exchanges that brought Demetrianus to Gundishapur during the reign of Papas, an event that was a major feature of the patriarchal history, and Shapur's fame as the patron of Mani. The material available to the author of this scene was primarily a list of civic foundations and buildings and a brief legend attached to one of these foundations, Hasa Shapur near Kashkar, and seems to have been selected from a longer account of his reign (such as those preserved in Ferdowsi or al-Tabari) to highlight his role in the population transfers. ${ }^{123}$

The second tendency visible in the authors embedded in the Chronicle is to make causative associations between the behaviour of a shah and his attitude to the Christians or to events in the Christian histories. For instance, Vahram II in the third-century is said to have been favourable to the Christians, even learning Syriac, until he changes his attitude because of the Manichees, whose dreadful reputation unfairly rubs off on the Christians and leads him to persecute them. ${ }^{124}$ Opposition to the Manichees and Vahram's persecution had both been important events in the patriarchal histories and in the fifthcentury hagiographies: here the historian seems to have connected the two

${ }^{120}$ Chronicle of Seert, I/ii, XLIII and LXV.

${ }^{121}$ Chronicle of Seert, I/ii, XXIII (287-8). Contrast the narrative in Ferdowsi, which devotes much more space to Shapur's siege of Hatra and to explaining the shah's nickname, (an issue on which classical authors give implausible and mutually contradictory suggestions). Shahnameh, V, 342-8.

${ }^{122}$ Chronicle of Seert, II/i, XI-XII (122-5).

${ }^{123}$ Chronicle of Seert, I/i, II (221-3). ${ }^{124}$ Chronicle of Seert, I/i, IX (237-9).

This is an open access version of the publication distributed under the terms of the Creative Commons Attribution-NonCommercialNoDerivs licence (http://creativecommons.org/licenses/by-nc-nd/3.0/), which permits non-commercial reproduction and distribution of the work, in any medium, provided the original work is not altered or transformed in any way, and that the work is properly cited. For commercial re-use, please contact academic.permissions@oup.com 
events as part of a wider disassociation of Christianity from extremes of asceticism, which would have suited the more politically prominent and 'anti-Messalian' Christianity of the end of the sixth century and beyond.

This variety in the deployment of the royal histories within the Chronicle points, therefore, to the variety of agendas of the different historians who used the deeds of the Sasanian kings to elucidate Christian history: to set the deeds of churchmen against an indigenous secular chronology, to describe acts of royal foundation, or to lament persecution. And this variety also hints at the many different attempts to reconcile Sasanian history with that of the church, and the many levels on which the relationship between the church and its rulers could be read.

\section{CONCLUSIONS}

The growing importance of monasticism and of lay patronage in the late sixth century is clearly visible in the Chronicle of Seert. But its deployment of local historical traditions was not a naïve duplication. The competition between different monastic founders, and between the monasteries, the school system and the catholicos, have all been winnowed out in the Chronicle, in favour of an image of monks as servants of the catholicos, missionaries, and guardians of a Dyophysite orthodoxy, working towards the 'Nestorianization' of the former Sasanian world. The emphasis on the relationship between catholicoi and the monasteries has also meant that the patronage of monasteries by aristocrats has been obscured in the Chronicle. The hagiographic sources suggest a social reality where the points of contact between Christian institutions and Iranian political culture were both expanding and diversifying, but the Chronicle only registers the relationship with the shahs and some of his greatest magnates, retrojecting these relationships deep into the past to give these connections legitimacy and antiquity.

The use of the Iranian royal tradition became important as the context for the history of the church, sometimes just as a chronological marker, but also because of the shahs' role in creating the cities and villages of Iraq and Iran and their role in supporting the church. This interest must have been shared by many different historians, for the Chronicle of Seert includes sections that combine the Christian and Iranian historical traditions in many different ways. Some of these may predate the end of the Sasanian Empire and reflect the ever-closer relationship between shah and catholicos. In particular, stories that focus on the power of Christian prayer fit into this milieu, where the Church of the East represented itself as a pillar of the rule of Khusrau II and

This is an open access version of the publication distributed under the terms of the Creative Commons Attribution-NonCommercialNoDerivs licence (http://creativecommons.org/licenses/by-nc-nd/3.0/), which permits non-commercial reproduction and distribution of the work, in any medium, provided the original work is not altered or transformed in any way, and that the work is properly cited. For commercial re-use, please contact academic.permissions@oup.com 
his short-lived successor Shiroë. ${ }^{125}$ Other stories may have been composed in the aftermath of the fall of the Sasanians, when important men with a residual loyalty to the old dynasty converted to Christianity ${ }^{126}$ and brought their histories with them. Sometimes this process even resulted in histories that presented many of the great shahs as closet Christians, mimicking the rumours that had circulated around Khusrau II and Shiroë. ${ }^{127}$ Stories such as these, which set out an ever closer relationship between Christians and the shah, even hinting at the possibility of conversion, lie at the heart of the dense body of material that is preserved by the Chronicle of Seert for the reign of Khusrau II, a period that will form the core of the next chapter.

${ }^{125}$ Solomon of Basra's Sasanian king list is concluded in the fifteenth year of Khusrau II, which indicates the importance of his reign for the Christian incorporation of Iranian histories. Book of the Bee, LII (120-3).

126 For instance, members of the noble house of Suren were Christian bishops who lived in exile in China into the eighth century. J. Harmatta, 'The Middle Persian-Chinese bilingual inscription from Hsian and Sasanian-Chinese relations', in E. Cerulli et al. (eds.), La Persia nel Medioevo (Rome, 1971), 363-76.

127 E.g. Nihayat al 'Arab on Ardashir and Vahram II (tr. Browne, 219-22) and the suspicion of Khusrau II as a closet Christian (240). These stories may have influenced the image of Vahram II above. 


\section{7 \\ The Last Great War of Antiquity: The Reaction of Christian Iraq}

The ecclesiastical historians whose works were used for the medieval compilations were responsible for incorporating new material into a historical tradition based around the lives of the catholicoi. This new material, which we have examined in the past two chapters, dealt with the ecclesiastical history of the Roman Empire, monastic and scholastic histories within the Church of the East, and royal and aristocratic histories in an Iranian tradition. The prominence of these new kinds of history from the 580s onwards was the product of greater international awareness by Iraqi authors and increased sponsorship from lay patrons. But it was also a reaction to the rapidly changing political and cultural environment of the period 580-660, which saw cordial relations between Rome and Persia turn to bitter war, followed by a brief period of Roman domination of Iraq and then the defeat of both empires by the Arab invasions.

This period of crisis prompted the development of greater historical interest in the Church under Isho' yahb I and his successors, as different churchmen defined its theology and ecclesiology against the West. At the same time, this era was itself regarded as a time of prime importance for the church, because it saw the genesis of Abrahamic monasticism and the conversion of Iranian elites to Christianity, who brought with them their own familial and regional histories. The crises of politics, theology, and ecclesiology that caused historians to introduce new kinds of history into the Iraqi tradition also represented opportunities for the same men and their patrons to determine the future direction of the Church of the East.

In particular, the period 607-30 saw an interregnum in the catholicosate, during years when the shah Khusrau II would turn against the Christians, and other lay figures would present themselves as patrons of the church. These men, such as the aristocrat and tax collector Yazdin, the general Shahrbaraz and Khusrau's son, Kavad II Shiroë, were themselves competing for political influence and their activities generated different strands in the dense and confused historiography of the period. Simultaneously, as the patronage of

This is an open access version of the publication distributed under the terms of the Creative Commons Attribution-NonCommercialNoDerivs licence (http://creativecommons.org/licenses/by-nc-nd/3.0/), which permits non-commercial reproduction and distribution of the work, in any medium, provided the original work is not altered or transformed in any way, and that the work is properly cited. For commercial re-use, please contact academic.permissions@oup.com 
the shah turned to persecution, various figures, such as Gregory of Nisibis and Babai the Great, asserted their credentials to lead the church. These claims are reflected in contradictory narrative strands embedded in the medieval compilations. Though the catholicosate would be re-established after the Arab invasions in the 650s, with regular succession and a clear theological policy, Isho' yahb III (649-59) and his successors had no clear lineage from their predecessors. The different ways that later historians tried to trace the 'settlement' of the Church of the East through the twisted politics of the last war between Rome and Persia and end of the Sasanian Empire show us how complex and rapidly changing the political positions of Christians in Iraq must have been.

\section{THE GREAT WAR BETWEEN ROME AND PERSIA}

The events of the last war between Rome and Persia forms a frame against which we can understand both the actions of Christians within the Sasanian world and the recording transmission of material by historians of the Church of the East. These events are widely recorded in Greek, Armenian, Syriac, and Arabic sources, and the complexities of the accounts reflect both the importance of the events and the absence of any dominating or authoritative view. ${ }^{1}$

In 590, Khusrau's father Hormizd IV alienated the powerful general Vahram Chobin and was blinded by his own palace troops as Vahram marched on Ctesiphon. Vahram had initially proclaimed his rebellion in the name of Khusrau, minting coins in the young man's name at his home town of Rayy. However, following the palace coup, Vahram opposed Khusrau and, after defeating him in battle, established himself as shah, the first non-Sasanian to do so since the establishment of the dynasty. Khusrau escaped to the Roman emperor Maurice and, in return for military support, undertook to protect the Christians and rebuild churches. After patronizing the Christian shrine of Rusafa, Khusrau returned to Iran in the following year and defeated Vahram and re-established himself as shah. ${ }^{2}$ Following this victory, Khusrau ceded

${ }^{1}$ A recent narrative account, supported by detailed source criticism, is J. Howard-Johnston, Witnesses to a World Crisis: Historians and Histories of the Middle East in the Seventh Century (Oxford, 2010), 436-45. Also see G. Greatrex and S. Lieu, Rome and Persia at War: A Narrative Sourcebook (London, 2002), 167-228; P. Sarris, Empires of Faith: The Fall of Rome to the Rise of Islam, 500-700 (Oxford, 2011), 235-58, and B. Dignas and E. Winter, Rome and Persia in Late Antiquity: Neighbours and Rivals (Cambridge, 2007), 115-19, 148-51, and 225-40. HowardJohnston's important collection of essays, East Rome, Sasanian Persia and the End of Antiquity: Historiographical and Historical Studies (Aldershot, 2006) relate to these events as well.

${ }^{2}$ For Khusrau's patronage at Rusafa, E. K. Fowden, The Barbarian Plain: Saint Sergius between Rome and Iran (Berkeley, 1999), 133-5. See Evagrius, HE, VI, 21 for rumours of Khusrau's near conversion.

This is an open access version of the publication distributed under the terms of the Creative Commons Attribution-NonCommercialNoDerivs licence (http://creativecommons.org/licenses/by-nc-nd/3.0/), which permits non-commercial reproduction and distribution of the work, in any medium, provided the original work is not altered or transformed in any way, and that the work is properly cited. For commercial re-use, please contact academic.permissions@oup.com 
large parts of Armenia to Maurice and abolished the payments the Romans had previously made to the Sasanians. ${ }^{3}$

The 590s witnessed unprecedented cooperation between the Persian and Roman Empires. Maurice was left unhindered in his attempts to enforce Chalcedonianism and Roman authority across his eastern border, especially against the Ghassanid Arabs and in his newly annexed Caucasian territories. Similarly, peace with Iran also gave the emperor a free hand to fight the Slavs and Avars in the Balkans. ${ }^{4}$ This cooperation is seen more directly in the diplomatic interchange between Khusrau II (591-628) and Maurice, where Khusrau's Christian patronage during his exile was continued through the exchange of Christian relics between Maurice and the court of Ctesiphon, most notably fragments of the True Cross and an image of the reigning catholicos Sabrisho ${ }^{c}$ (596-604). ${ }^{5}$ During this period Khusrau also fought and won a second civil war against his uncle Vistahm (d.602), in which he claimed his victory had been foretold by the future catholicos Sabrisho ${ }^{c}$ in a vision.

The shah and the emperor had periodically enjoyed close diplomatic relations throughout the fifth and sixth centuries. Matthew Canepa has emphasized the evolution of 'a familial language of international royal legitimacy' as increased diplomatic contact produced a rhetoric of accommodation, which coexisted with assertions of universal dominance by both empires. Indeed the relationship between Maurice and Khusrau revitalized the traditional rhetoric of Roman-Persian cooperation. Much of the language of fifth- and sixthcentury diplomacy had represented emperor and shah as unchangeable cosmic forces, 'the lights of the world', as part of an extra-religious, crosscultural discourse. ${ }^{6}$ But the diplomatic relationship between Khusrau and Maurice also had a new dimension. Diplomacy was increasingly conducted through a Christian medium, through the use of bishops, the gift of relics, and the sponsorship of cult sites like Rusafa, a display that was aimed as much at Christians under Sasanian rule as at the Romans.

It is ironic that it was this closely intertwined royal legitimacy, with its increasingly Christian character, that underlay the most bitter of the wars between Rome and Persia. In 602, Maurice and his family were assassinated in a palace coup by the Balkan general Phocas, precipitating a long civil war between Phocas and his rivals. This generated a martyr literature in honour of the murdered emperor, which was disseminated even among Syriac-speaking

\footnotetext{
${ }^{3}$ For narrative see M. Whitby, The Emperor Maurice and his Historian (Oxford, 1988), 292-303 and D. Frendo, 'Theophylact Simocatta on the revolt of Vahram Chobin and the early career of Khusrau II', BAI 3 (1989), 77-87.

${ }_{4}$ See M. Whittow, The Making of Orthodox Byzantium, 600-1025 (London, 1996), 50-2; Wood, We Have No King but Christ, ch. 7. On Armenia, note the account of pseudo-Sebeos, ch. 19 (91).

${ }^{5}$ Chronicle of Seert, II/ii, LXVII-LXVIII (492-7) and pseudo-Sebeos, ch. 14 (86).

${ }^{6}$ Canepa, The Two Eyes of the Earth, ch. 7.
} 
Miaphysites and in the Church of the East (in spite of his persecution of the former). ${ }^{7}$ It also granted a sense of legitimacy to Khusrau's subsequent intervention and his invasion of Dara in 604. This invasion was justified by the presence of Maurice's supposed son Theodosius, who was widely welcomed as emperor across Mesopotamia and Armenia. ${ }^{8}$ In addition, Khusrau affirmed this image of himself as Maurice's avenger among the Christians of both empires through the support of the catholicos Sabrisho', who had been closely involved in the exchange of relics with the dead emperor and who accompanied the opening stages of Khusrau's campaign. ${ }^{9}$

The second phase of Khusrau's war saw Persian forces break through the heavily fortified border regions into Egypt, the Levant and Anatolia in c.610. Jerusalem fell in 614, probably seized by Khusrau's general Shahrbaraz, ${ }^{10}$ and the True Cross was transferred to Ctesiphon. ${ }^{11}$ This event was followed by the production of hyperbolic accounts of the sack of the city in Palestinian monastic circles and of Persian alliance with the Jews, but neither should be taken at face value. Instead, such accounts should be understood alongside attempts by the Roman regime to assert its claims to Christian universal rule and the condemnation of the Persians as pagan invaders, to counter Khusrau's own claims to Christian and Roman sources of legitimacy.

Phocas was replaced in a coup by the new emperor Heraclius (610-28), son of the exarch of Africa, in 610, and it was under Heraclius that Roman efforts to stall the Persians, first in Anatolia and then before Constantinople, were accompanied by a propaganda campaign that proclaimed the religious mandate of the new emperor. James Howard-Johnston has emphasized the importance of prayer and ideas of military martyrdom in Heraclius' campaign, supplemented by the prominent use of Christian imagery on his silver hexagrams and his deliberate targeting of Zoroastrian religious sites during his counter-attack into Azerbaijan. ${ }^{12}$

The third phase of the war saw Khusrau refuse a desperate bid for peace by Heraclius, in which he pleaded to remain the ruler of a rump state under

${ }^{7}$ E.g. the Syriac Acts of Maurice. Chronicle of Seert, II/ii, LXX (499-500) echoes these martyrologies. See further comments by Whittow, Orthodox Byzantium, 44.

${ }^{8}$ Chronicle of Seert, II/ii, LXX (500) and LXXIX (519-20) and pseudo-Sebeos, ch. 31-3 (106-10).

9 Chronicle of Seert, II/ii, LXX (500).

10 The name 'Shahrbaraz' was in fact an nickname: the general's actual name was Farrukhan. He was known to Armenian sources as 'Khoream'. See the entry in PLRE III, 'Shahrbaraz'.

${ }^{11}$ For the testimony of different sources on the return of the True Cross see Y. Stoyanov, Defenders and Enemies of the True Cross: The Sasanian Conquest of Jerusalem in 614 and Byzantine Ideology of Anti-Persian Warfare (Vienna, 2011), 67-9; A. Stratos, Byzantium in the Seventh Century, tr. M. Oglivie-Grant, 6 vols. (Amsterdam, 1968), I, 249.

12 J. Howard-Johnston, 'Heraclius' Persian campaigns and the revival of the eastern Roman Empire', in J. Howard-Johnston, East Rome, VIII. For reception of Heraclius' propaganda and local reuse of these ideas in the coins of Georgian princes see M. Tsotselia, 'Recent Sasanian coin findings on the territory of Georgia', Histoire et mesure, XVII (<http://histoiremesure.revues.org/ document888.html $>$ ).

This is an open access version of the publication distributed under the terms of the Creative Commons Attribution-NonCommercialNoDerivs licence (http://creativecommons.org/licenses/by-nc-nd/3.0/), which permits non-commercial reproduction and distribution of the work, in any medium, provided the original work is not altered or transformed in any way, and that the work is properly cited. For commercial re-use, please contact academic.permissions@oup.com 
Persian vassalage. Instead, Persian and Avar forces laid siege to Constantinople. Leaving the city, Heraclius made a successful counter-attack through the Caucasus, using this as a base to launch a series of increasingly victorious campaigns that culminated in the 627 battle of Nineveh. In response to the Sasanian defeat that ensued, and the accumulation of grievances against the shah and the many years of war and taxation, nobles in Ctesiphon deposed and killed Khusrau and raised his son Kavad II Shiroë, who in turn purged Khusrau's other children.

The aftermath of the war saw a series of counter-coups within Ctesiphon, following Shiroë's death from plague in 629. Most significantly, for our purposes, one of these involved the general Shahrbaraz. He may have already conspired with the Romans in 626 to leave Khusrau unsupported and one of his sons was involved in the shah's murder. ${ }^{13} \mathrm{He}$ received Heraclius' sponsorship in return for the baptism of his son Nicetas, the return of the True Cross, and the evacuation of the Persian troops that continued to occupy Egypt and the Levant. ${ }^{14}$ So, as it is important to observe, it was not only Khusrau who employed Christian political display to legitimize his behaviour to certain groups. His successors might also adopt this behaviour, though it would vary considerably in its context and intention. Moreover, we should not imagine that all lay patrons of Christianity were in any sense allied. One of Khusrau's murderers, Shamta, was the son of the Christian magnate Yazdin, but fell out with Shiroë and was then crucified by Shahrbaraz. Shahrbaraz went on to kill Shiroë's son Ardashir in order to acquire the throne, even though Shiroë had intervened to restore the catholicosate and Ardashir had supposedly been born thanks to saintly intervention. ${ }^{15}$

Thus Christians at the court of Ctesiphon did not represent a single faction, nor does piety seem a strong motive for their actions. Indeed, the absence of any single group with a monopoly on the discourse of legitimate Christian behaviour is shown in the contradictory emphases of the medieval compilations for this period. Instead, the use of Christian self-representations by these different elites illustrates both the potential for experimentation with styles of rulership after the precedent of Khusrau's reign and the absence of any established patterns for this behaviour. Furthermore, this self-representation also implies the existence of increasingly numerous, or at least influential, Christian supporters.

13 Pseudo-Sebeos, ch. 39 (127) on Shahrbaraz remaining in the West.

14 C. Mango, 'Deux études sur Byzance et la Perse Sassanide', T\&M 9 (1985), 93-118 and D. Frendo, 'Byzantine-Iranian relations before and after the death of Khusrau II: a critical examination of the evidence', BAI 14 (2000) 27-47. Al-Tabari, I, 1046-55 and Chronicle of Seert, II/ii, XCII (551-2) emphasize the leaders of the coup against Khusrau rather than Heraclius' role, which may reflect contemporary domestic representations of events.

15 Chronicle of Seert, II/ii, XCII (552) and XCIII (556-7).

This is an open access version of the publication distributed under the terms of the Creative Commons Attribution-NonCommercialNoDerivs licence (http://creativecommons.org/licenses/by-nc-nd/3.0/), which permits non-commercial reproduction and distribution of the work, in any medium, provided the original work is not altered or transformed in any way, and that the work is properly cited. For commercial re-use, please contact academic.permissions@oup.com 
Pourshariati has observed the significance of Shahrbaraz as a member of a powerful aristocratic house and that he, like Vahram Chobin, was associated with the 'Parthian' aristocracy at a time of the renewed ethnic self-awareness of these magnates. ${ }^{16}$ This understanding of Khusrau's fall and the strife that followed it, drawn from al-Tabari, Ferdowsi and the evidence of the seals, is persuasive and important. But it also ignores the role several of the same sources ascribe to Shamta bar Yazdin or to the Christian self-representation and behaviour reported in Greek, Armenian, Syriac, and Arabic for both Sasanian shahs and Shahrbaraz, which coexist with the use of more traditional Zoroastrian images of pious rule and righteous rebellion that we see in Ferdowsi. Just as the Shahname preserves accounts of Khusrau II as a pious Zoroastrian, preparing for death with ritual silence before praying with barsom sticks, so too Christian sources also presented a legitimizing discourse for competing lay factions in the political confusion that followed the death of Khusrau, in a period without a clear political succession. ${ }^{17}$

\section{HISTORIOGRAPHY OF THE GREAT WAR}

This era of political crises had an equally marked effect on the institutions and leadership of the Church of the East. The catholicos Isho' $y$ yahb I was replaced by the more malleable holy man Sabrisho' after Khusrau's return from exile. Controversies over the election and behaviour of Sabrisho"s successor Gabriel of Pherat led to the suspension of the catholicosate and a long interregnum until the election of Isho yahb II in 630 after the fall of Shahrbaraz. ${ }^{18}$

We have seen how the histories of the Church of the East were based around the succession of catholicoi, and that this structure is clearly visible at least up to the reign of Isho' $y$ ahb I. Sections on catholicoi preserved in the Chronicle of Seert focus on their education and election, and sometimes on their theological statements or writings, and this material is mirrored fairly closely in the other medieval compilations.

But this focus seems to have generated a structural problem in the period following Isho'yahb's death. After this point, the Chronicle relies on individual hagiographies, rather than a continuous tradition of ecclesiastical history focused on the succession of catholicoi. The long text that the medieval compilations use for Sabrisho' is clearly drawn from the Syriac life of the

\footnotetext{
${ }^{16}$ Pourshariati, Decline and Fall, 146-54 and 183-90. I suspect, however, that this ethnic selfawareness is a new feature of the wars against Khusrau II, rather than a permanent characteristic of this class of magnates.

17 Shahnameh, VI, 320. On the rituals involving barsom sticks see M. Boyce and F. Kottwal, 'Zoroastrian "bāj" and "drōn"-II', BSOAS 34 (1971), 298-313.

${ }^{18}$ For a narrative, see Baumer, Church of the East, 92-7.
} 
holy man, written soon after his death by one Peter of Beth 'Abe (the Arabic version has several additional passages, though these seem to have been added soon after the text's original composition). ${ }^{19}$ Similarly, the record of Babai in the Chronicle of Seert is also a hagiography, which is stylistically close to the lives of his followers Henanisho' and Giwargis, and has elements of the monastic lives used by Thomas of Marga and elsewhere in the Chronicle. ${ }^{20}$ And though some sources that Thomas used did present him as catholicos, Babai is not given a section to himself in Mari or 'Amr's compilation and merely receives a one-line notice alongside Aba, archdeacon of Ctesiphon, whom 'Amr also credits with governing the church. ${ }^{21}$ Indeed, 'Amr and Mari's accounts, which are structured around reign-by-reign accounts of the catholicoi, are unusually sparse compared to the Chronicle of Seert over this period, which seems to indicate the difficulties these compilers had in maintaining a history based around the reigns of catholicoi. This seems in turn to reflect a change in the nature of the available sources: Sabrisho"s controversial posthumous reputation led to several different continuations, many of which were composed as hagiography rather than history per se, and there was little clear consensus on his successors.

But over the same period that the traditional patterns of historical recording were stretched by changing events, the Chronicle of Seert produces several, better-integrated sections of narrative with much more rounded protagonists, above all in the case of Khusrau II. Khusrau's reign was an important dating marker (in a way that his predecessors' had not been) for the historians Mikha of beth Garmai and Allahazkha, both of whom may have written during this period. ${ }^{22}$ His reign also saw the introduction of material from the Persian royal histories into Christian histories: the Sasanian king list preserved in Solomon of Basra is dated to the fifteenth year of Khusrau ${ }^{23}$ and the account of the fall of Hormizd in the Chronicle of Seert proclaims itself drawn from the royal annals, which suggests that it was inserted during Khusrau's reign as well. ${ }^{24}$ So Khusrau's reign saw the importation of a Sasanian royal tradition into Christian historical writing and may have seen some attempts to rebuild history writing around the shah, rather than the catholicoi.

These patterns in the historical writing of the period allow us to make some general observations about the motivations of the historians. Royal patronage, coupled with the patronage of lesser elite figures, lies at the background of the more integrated narratives of this period, which set the shah and his activities more clearly in the centre stage. The absence of a catholicos during this same

${ }^{19}$ Chronicle of Seert, II/ii, LXV-LXXI.

${ }^{20}$ Chronicle of Seert, II/ii, LXXXIV-LXXXVI.

21 'Amr, 52/30.

22 Quoted in Elias of Nisibis (ed. Brooks), I, 124-5. See also Assemani, BO, IIIa, 216.

23 Solomon of Basra, Book of the Bee LII (tr. Wallis-Budge, 123).

${ }^{24}$ Chronicle of Seert, II/ii, XLIII (443-4).

This is an open access version of the publication distributed under the terms of the Creative Commons Attribution-NonCommercialNoDerivs licence (http://creativecommons.org/licenses/by-nc-nd/3.0/), which permits non-commercial reproduction and distribution of the work, in any medium, provided the original work is not altered or transformed in any way, and that the work is properly cited. For commercial re-use, please contact academic.permissions@oup.com 
period must also have stimulated the shift towards more secular history and attempts to integrate this into the tradition of ecclesiastical history. In addition, the political chaos of Khusrau's reign was felt keenly by the Church of the East. This situation may have encouraged historians' attempts to combine new strands of narrative, and to understand Khusrau's reign in terms of earlier events.

We can gain further insight into how this union of traditions was attempted through an extant chronicle composed in Syriac, the so-called Khuzistan Chronicle. ${ }^{25}$ The coverage of this text spans the period from Vahram's revolt to the death of Maremmeh (646-9), and the detail of its information for the deeds of this short-lived catholicos suggest a final composition date of $c .652 .{ }^{26}$ The chronicler does not provide a flowing narrative, but a series of short notes on a varied set of sources that he had collected. His focus is on how individuals change the course of history, through their own grievances and biases (such as Khusrau's grudges against Isho' yahb I or the Lakhmid phylarch $\mathrm{Nu}^{\text {c } m a n, ~ o r ~}$ Gabriel of Sinjar's hatred for the Church of the East). ${ }^{27}$

The Khuzistan Chronicle's information is chiefly domestic, and, more than any other source, confirms our impression of the importance of Yazdin, 'a defender of the church like Constantine or Theodosius', and of the oscillating attitude of Christians to Khusrau as his policy changed course. ${ }^{28}$ In addition, the Chronicle also provides information for specific phases in Khusrau's war with the Romans that left an impression on Christians in Iraq: the invasion of Dara and the borderlands of Mesopotamia; the fall of Jerusalem and Alexandria (where it credits the involvement of Shahrbaraz and Yazdin) and the final invasion of Heraclius. ${ }^{29}$

The Khuzistan Chronicle is especially significant for its testimony to how history was composed in this era. If we ignore the last quarter of the text, which is a later continuation by another hand, it appears that the author, probably one Elias of Merv, ${ }^{30}$ scoured a number of available histories (and possibly even documentary evidence) and combined this with his own recollection of events to produce a history of the past two generations. The

25 See the useful comments of J. Watt, 'The Portrayal of Heraclius in Syriac Historical Sources', in Reinink and Stolte, Reign of Heraclius, 63-79; Hoyland, Seeing Islam, 182-9; and Howard-Johnston, Witnesses, 128-35.

26 The opening section describes the text as '[a collection] from ecclesiastical and secular history from the reign of Hormizd to the end of the Persians' (i.e. to the death of Yazdegard III).

27 Khuzistan Chronicle, 15-17; 19-20.

${ }^{28}$ Khuzistan Chronicle, 23-4 on Yazdin.

${ }^{29}$ Khuzistan Chronicle, 25-8. J. Howard-Johnston, 'Al-Tabari on the last great war of antiquity', in J. Howard-Johnston, East Rome, VI, points to the shared 'Eastern' material on this warfare in the Chronicles of Seert and Khuzistan and al-Tabari, which may suggest a shared (Christian?) source.

30 P. Nautin, 'L'auteur de la « Chronique anonyme de Guidi »: Élie de Merw', RHR 199 (1982), 303-13.

This is an open access version of the publication distributed under the terms of the Creative Commons Attribution-NonCommercialNoDerivs licence (http://creativecommons.org/licenses/by-nc-nd/3.0/), which permits non-commercial reproduction and distribution of the work, in any medium, provided the original work is not altered or transformed in any way, and that the work is properly cited. For commercial re-use, please contact academic.permissions@oup.com 
proximity of these events to his own days may account for the accuracy of its chronology and the gossipy nature of some of the entries (such as the account of Khusrau's flight), and it may suggest that he frequently used oral sources to supplement these written accounts. In particular, this Chronicle confirms our impression from the medieval compilations that several accounts of this period were produced, often with personalized portraits of well-known court figures and with considerable disagreement in their attitude to these figures. ${ }^{31}$ Given the date of the Khuzistan Chronicle, it also appears that attempts were made relatively quickly following the restoration of the catholicosate to produce a collection of these accounts. Still, the polyphonic texture of the narratives for this period in the Chronicle of Seert suggest that, while there were early attempts to epitomize and correlate the accounts of this period, these did not render the diverse contemporary accounts obsolete. Multiple versions of the events of 580-660 continued to circulate and could be consulted in following centuries and embedded in the Chronicle of Seert.

The beginning of the seventh century saw historians gather information from previous generations in reaction to the changing situation of the Church of the East and its ability to attract a much wider range of patrons. But this expanded patronage base also meant that the multiple continuators of the older historical tradition had to reconcile a much wider variety of interest groups, as bishops and aristocrats competed for influence after the dissolution of the catholicosate. The rapidly changing political and religious environment produced a profusion of different sources, and this in turn explains the sheer density and complexity of the account of the period in the Chronicle of Seert. Yet, at the same time, the absence of straightforward narratives based around the succession of catholicoi for the same period may explain the paucity of seventh-century material in Mari and 'Amr and the disjointed structure of the Khuzistan Chronicle.

\section{NARRATIVE FAMILIES IN THE HISTORY OF THE GREAT WAR}

The Chronicle of Seert for the period 590-660 devotes sections to a range of figures, secular leaders, catholicoi, and pseudo-catholicoi who occupy a central position in each given narrative. By tracing the treatment of these dramatis personae, I suggest that we can break the Chronicle of Seert's accounts for this

31 On the presence of the Khuzistan Chronicle in the Great Synodicon see chapter 8 under 'Writing Christian history under Arab rule'.

This is an open access version of the publication distributed under the terms of the Creative Commons Attribution-NonCommercialNoDerivs licence (http://creativecommons.org/licenses/by-nc-nd/3.0/), which permits non-commercial reproduction and distribution of the work, in any medium, provided the original work is not altered or transformed in any way, and that the work is properly cited. For commercial re-use, please contact academic.permissions@oup.com 
era into 'families' of narratives, each of which concentrated on different chains of individuals, and which were adapted in the light of later events. By and large, the compiler of the Chronicle has placed these narratives one after another, without attempting to reconcile the material.

Each narrative family probably originated in a single author, and most have only been subjected to limited adaptation. Many of these adaptations also make sense as early reactions to constantly changing circumstances: especially where the controversial protagonists they discuss were representatives of Sasanian factional politics, there would have been much less incentive to alter these narratives after the fall of the empire. Additionally, the restoration of the catholicosate seems to have been accompanied by a recentralisation of the historical tradition. ${ }^{32}$ If this is true, then we should see adaptations as pre-dating this mid-seventh-century recentralization, or as immediate consequences of it, rather than products of a much later period. ${ }^{33}$

These narrative families are as follows:

Section XLII: Isho yahb I. Drawn from a patriarchal history common to all the compilations: blames the Romans and Khusrau for Isho 'yahb's fall.

Section XLIII and LVIII: Hormizd and Khusrau. An account of Hormizd's death drawn from a Sasanian royal history, followed by several different continuations written at different points during and after Khusrau's reign (but all from a Christian perspective).

Section LX: The conversion of the Lakhmid Nu'man by Sabrisho'. Emphasizes the good relations between the Arabs of Hira and Khusrau, therefore predating Khusrau's assassination of $\mathrm{Nu}^{\text {' }}$ man after c.602.

Sections LXV-LXXI: The Life of Sabrisho'. Modelled on an extant Syriac saint's life that describes the close relationship of Sabrisho', Khusrau, and Shirin and their protection of Christians. Codas have been added that emphasize Sabrisho"s wish to avoid accompanying Khusrau's invasion and Sabrisho"s antipathy for the Miaphysite Gabriel of Sinjar, which may reflect the need to preserve the catholicos' posthumous reputation as Khusrau's war began to be perceived in a bad light and the shah began to support the Jacobites.

Following this, there is a long lacuna in political history until the accounts of the end of the war (no information is given on the fall of Jerusalem in 614, instead the focus is on ecclesiastical controversies within the empire).

Section LXXIV: Gregory of Nisibis. An extended hagiography of the great opponent of Henana and his party at the School of Nisibis. The scene

32 Note the date for the compilation of the Khuzistan Chronicle, which can be seen as an attempt to stabilize the diverse traditions of the previous generation.

33 Mari, HE, 62/55 observes that Isho'yahb III's reign saw the composition of 'the first ecclesiastical histories', which may reflect this seventh-century consolidation. See chapter 8.

This is an open access version of the publication distributed under the terms of the Creative Commons Attribution-NonCommercialNoDerivs licence (http://creativecommons.org/licenses/by-nc-nd/3.0/), which permits non-commercial reproduction and distribution of the work, in any medium, provided the original work is not altered or transformed in any way, and that the work is properly cited. For commercial re-use, please contact academic.permissions@oup.com 
strongly connects him to Isho $y$ yahb I, in the previous generation, and to Isho'yahb II and Isho' yahb III in the following generation, but also presents him as suffering under Khusrau and Sabrisho', who continues to defend Henana. Section LXXII provides a generalized summary of the conflict with the Henanians, in which all personal names have been removed. Section LXXV represents a sequel to his Life, in which the nobles of Nisibis are killed following a revolt, which is seen as divine punishment for their support of Henana. Section LXXX represents a different sequel to Gregory's Life, which focuses instead on his failure to be elected catholicos, Shirin's deceitful machinations in the election of Gregory of Pherat, and Khusrau's subsequent persecutions.

Section LXXXIII: The excommunication of heretics. The scene focuses on the conflict with Gabriel of Sinjar and the Henanians on one hand and the Dyophysites on the other in the assembly of 612 (which is preserved in the Synodicon). Though short, this is the most inclusive narrative of the whole period, since it sympathetically explains away Babai's absence and gives Yazdin an important role in uniting the Dyophysites. The text also (dubiously) asserts the unity of Paul of Nisibis, Gregory of Nisibis, Isho' yahb I, and Sabrisho' in condemning the Henanians. Its broad overview, and its conciliatory outlook, may suggest a date of composition some time after the events it describes, by an author trying to combine earlier traditions.

Sections LXXXIV-VI: Babai and his followers. These hagiographies describe their opposition to the Henanians and their establishment/maintenance of a Dyophysite orthodoxy against figures like Gabriel of Sinjar.

Political events are considered once more from the Heraclian invasion, where new secular rulers compete, all giving some form of patronage to Christians. Sections XCII and XCIII also represent two different attempts to correlate political events to the reign of the new catholicos Isho' yahb II.

Section XCII: The death of Khusrau. Describes Shamta's assassination and Shiroë's opposition to him after his accession. The section praises Shiroë for his secret Christianity and discusses the miraculous birth of his son Ardashir following a miracle by Babai of Nisibis.

Section XCIII: Isho' yahb [II] of Gdala. Includes an account of Shahrbaraz's arrival in Ctesiphon as a client of Heraclius in 629, where he kills Shamta and Ardashir and returns the True Cross before his own assassination. The background to this event is given in section LXXXVII, which describes Heraclius' 626 agreement with Shahrbaraz, which may be true, or an invention in the light of Shahrbaraz's 629 compact.

The account of Shahrbaraz is followed in the same section by a description of Isho'yahb's role as Boran's ambassador and a brief account of the fall of the last shah Yazdegard III to the Arabs. The inclusion of so much material in a single section named after the catholicos indicates the attempts

This is an open access version of the publication distributed under the terms of the Creative Commons Attribution-NonCommercialNoDerivs licence (http://creativecommons.org/licenses/by-nc-nd/3.0/), which permits non-commercial reproduction and distribution of 
to re-create a history based around politically active catholicoi. The narrative spills over into Section CV, which deals with this catholicos' theological controversies. The use of Hijri dates suggests a date of composition in the tenth century. ${ }^{34}$

In addition, though the Chronicle of Seert preserves no narrative family devoted to Yazdin, I suggest that one historian at least took him as a particular focus and described his role in the government of Jerusalem and as a patron of the church. A contiguous section of the Khuzistan Chronicle (23-4) focuses on him, and this may be a précis of a longer piece written in the generation before this text's compilation. Yazdin was also particularly prominent in hagiographies and monastic literature composed at this time, so it seems likely that some writers of history also emphasized his political role.

The modern understanding of the domestic politics of Christianity in Iraq has been hampered by a willingness to accept the absolute categories of the partisan narratives, e.g. to see Shirin, Khusrau's chief wife, as 'a Jacobite' (as opposed to a 'Nestorian') or to view the Henanians as a fifth column within the Church of the East. ${ }^{35}$ Sources have been used to confirm or deny the factional membership of different protagonists, rather than to examine the construction of these political and religious factional categories as idealized patterns of loyalties and behaviour. Crucial to such an examination is knowledge of when political events were recorded and adapted and how they manipulate and explain publicly known events to assert certain kinds of ideal behaviour for different communities and groups.

In what follows, I intend to examine the different narrative families that have been embedded in the Chronicle of Seert to see how historians participated in contemporary debate through successive reconstructions of the past, which established different hero figures for Iraqi Christians during a political vacuum, and connected this to assertions of the religious and political behaviour of their readership. I shall begin by examining the contradictory focus of sources on the churchmen Sabrisho', Gregory of Nisibis, and Babai, before turning to lay sponsors of Christianity, to the family of Yazdin, to Shiroë, and to Shahrbaraz.

${ }^{34}$ S. Brock, 'Use of Hijri dating in Syriac manuscripts', in J. van Ginkel, H.-M. van den Berghe, and T. M. van Lint (eds.), Redefining Christian Identity: Cultural Interaction in the Middle East since the Rise of Islam (Leuven, 2005), 275-90, at 279-80 observes that the earliest extant example is 918 (and comes from Mosul).

${ }^{35}$ On Shirin, Pseudo-Sebeos ch. 13 (85) and the comments of J. Howard-Johnston and R. Thomson, The Armenian History Attributed to Sebeos (Liverpool, 1999), II, 174; on the Henanians, see B. Flusin, Saint Anastase le Perse et l'histoire de la Palestine au début du VIIe siècle, 2 vols. (Paris, 1992), II, 108-10. These ideas may go back to Labourt, Le christianisme, 214-16.

This is an open access version of the publication distributed under the terms of the Creative Commons Attribution-NonCommercialNoDerivs licence (http://creativecommons.org/licenses/by-nc-nd/3.0/), which permits non-commercial reproduction and distribution of the work, in any medium, provided the original work is not altered or transformed in any way, and that the work is properly cited. For commercial re-use, please contact academic.permissions@oup.com 


\section{KHUSRAU AND THE CHRISTIANS}

Political and military events form the context for an equally rapidly changing

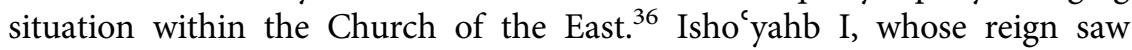
coherent attempts to assert the importance of Ctesiphon as a patriarchate, fell foul of the new shah Khusrau after his victory in the civil war. The Khuzistan Chronicle reports how Isho'yahb was unable to join Khusrau in his flight because he was afraid of what Vahram might do to the Christians in his absence. In consequence, the Chronicle reports, 'the leader of the Christians' was hated by Khusrau and fled to Hira where he died in exile. ${ }^{37}$ The Chronicle of Seert and the other medieval compilations echo this account in a developed scene that records Isho' yahb's interview with Khusrau. Here the shah accuses him of ignoring his cause in the civil war, showing him disrespect and praying for Vahram. Isho yahb's reply seems an attempt to put a positive gloss on the catholicos' inaction during the political ambiguity of the civil war: 'I only prayed for the king's life and his safety and for the security of his kingdom'. ${ }^{38}$

The reasons given in the Chronicle of Seert for Khusrau's animosity are also tied to his new alliance with Maurice. Khusrau's 'Greek' soldiers are said to be opposed to Isho'yahb, because he had provided knowledge of Roman troop movements to Hormizd IV while bishop of Nisibis. It may be that Isho yahb had been a personal selection of Hormizd's, in which case the interests of the Roman kingmakers and Khusrau might well have intersected in ensuring Isho' yahb's removal. But though Isho' yahb was condemned for being a false friend to Khusrau and for his earlier actions against the Romans, Isho'yahb's actions and position are signs of how integrated the catholicosate and the royal court had become. As an informant against the Romans and probable appointee of Hormizd, Isho yahb fell victim to a 'reshuffle' of personnel, but without the civil war he would have seemed an insider and a loyalist.

Khusrau searched for many similar qualities to those Hormizd had sought in Isho' ${ }^{c}$ ahb in his successor. But while Isho' yahb was noted for his 'beauty and erudition', his successor Sabrisho' was an aged ascetic and son of a shepherd. In spite of Sabrisho's reputation, he was far-removed from the educational background of other catholicoi and may have seemed very much an outsider to the politics of the catholicosate and the scholastic system, and certainly produced none of the theological works that are recorded for other catholicoi.

The main sources for Sabrisho"s reign are hagiographic. There is an extant Syriac Life composed by a contemporary, Peter of Beth 'Abe, but this is

${ }^{36}$ Note here the important article by G. Greatrex, 'Khusro II and the Christians of his empire', Journal of Canadian Syriac Studies 3 (2003), 78-88.

${ }^{37}$ Khuzistan Chronicle, 15-17. $\quad{ }^{38}$ Chronicle of Seert, II/ii, XLII (440-2).

This is an open access version of the publication distributed under the terms of the Creative Commons Attribution-NonCommercialNoDerivs licence (http://creativecommons.org/licenses/by-nc-nd/3.0/), which permits non-commercial reproduction and distribution of the work, in any medium, provided the original work is not altered or transformed in any way, and that the work is properly cited. For commercial re-use, please contact academic.permissions@oup.com 
primarily interested in the miracles of Sabrisho"s early life and his missionary endeavours. Peter's Life passes over Sabrisho"s time as catholicos and the controversial stage management of his election. The account in the Chronicle of Seert may have used Peter's Life, since he describes several of the same miracles. ${ }^{39}$ But the core account of Sabrisho"s Life (sections LXV-LXVIII) has been chiefly drawn from another hagiographic account, which was also written by a contemporary, but one who had a much keener interest in affairs at court. ${ }^{40}$ In what follows, I will refer to this core account in the Chronicle of Seert as the Life of Sabrisho', but we should bear in mind that it was made up of at least two different Syriac hagiographies and that the Chronicle also includes several 'codas' to the core account, each of which was also written by different hands.

The Life of Sabrisho ${ }^{c}$ embedded in the Chronicle of Seert refers to a number of public appearances by the shah and catholicos, and describes and comments on the stage management of these appearances in considerable detail. The text also bears a message of the shah's close relationship with Maurice and his love for the Christians within his own empire, mediated through Shirin. Sabrisho ${ }^{c}$ himself is present as a passive symbol of the Church of the East, to whom the shah can show honour but who never takes the political initiative. Seen together, the precise discussion of the reception of Sabrisho ${ }^{c}$ at court and the strongly loyalist perspective the Life takes on the shah and his invasion of the Roman empire all suggest that it was composed very soon after Sabrisho"s death, before Khusrau's dissolution of the catholicosate. Moreover, given Sabrisho"s fame as a prophet of Khusrau's victory in his second civil war and the esteem in which he was held in the Roman world, oral stories about Sabrisho' probably circulated in the holy man's lifetime. In sum, the Life reflects the court's management and dissemination of the shah's image as a Christian sponsor, and is markedly different in style and form to earlier records of catholicoi produced within the historical tradition of the Church itself.

\section{THE LIFE OF SABRISHO}

The Life closely models the pattern of its hero's life on that of Christ. Sabrisho"s parents receive an angelic visitation foretelling the birth of their son and the young Sabrisho' is recognized as the future patriarch by an aged

39 E.g. Sabrisho's healing of an infertile woman from Istakhr: Syriac Life of Sabrisho', 318 and Chronicle of Seert LXV (478).

${ }^{40}$ On transmission of texts relating to Sabrisho' see M. Tamcke, Der Katholikos-Patriarch Sabrišo I. (596-604) und das Mönchtum (Frankfurt, 1988), esp. 13 and the stem diagram in his appendix.

This is an open access version of the publication distributed under the terms of the Creative Commons Attribution-NonCommercialNoDerivs licence (http://creativecommons.org/licenses/by-nc-nd/3.0/), which permits non-commercial reproduction and distribution of the work, in any medium, provided the original work is not altered or transformed in any way, and that the work is properly cited. For commercial re-use, please contact academic.permissions@oup.com 
monk, who prevents his father from scolding him. Later he studies with Abraham at Nisibis, before retreating to a monastic cell on the mountain of Sha'aran, living on wild herbs and berries. After exorcizing a local man whose house is plagued by demons, he receives a visit from two 'monks' in a vision who ordain him and give him the pastoral rod of office carried by a bishop. Immediately after this, the people of Lashom take him before Isho' yahb who ordains him bishop of the city. ${ }^{41}$

As bishop, Sabrisho ${ }^{c}$ is responsible for a series of miracles: he prevents a downpour on Palm Sunday, he quells a flood on the river Zab, and cures an infertile Zoroastrian woman. These miracles culminate in his conversion of the Lakhmid phylarch $\mathrm{Nu}^{\text {' } m a n, ~ a ~ m a j o r ~ a l l y ~ o f ~ K h u s r a u ~ b a s e d ~ i n ~ t h e ~ c i t y ~ o f ~}$ Hira on the desert frontier, and in his prophecy of Khusrau's victory in his civil war against Vistahm in 602. The text does not dwell on the causes of Vistahm's rebellion; its focus instead is on Khusrau's vision of the saint and his distinctive appearance ('a small old man with a cap on his head and a rod in his right hand'). Sabrisho"s appearance allows him to be recognized by Shirin following the battle at Rayy as a famous miracle-worker and holy man, contradicting those of his supporters who believed that it had been his grandfather, Khusrau I, who had foretold the victory. ${ }^{42}$

The next long scene concentrates on Sabrisho"s election as catholicos. Isho'yahb dies following Khusrau's battle at Rayy. In this account the shah mourns the death of the catholicos: 'We thank God for saving the blood of this old man who died a natural death. Despite the crime (dhanbihi) he committed against me, this man was holy.' Khusrau's statement in the Life seems to reflect the awkwardness felt by a hagiographer who wished to praise the shah's special friendship for the Christians, despite Isho'yahb's fall from grace. Khusrau here is made to deny the antagonistic reputation he has in stories dedicated to Isho' $y$ yahb and to highlight the fact that he is not a persecutor: Isohyahb's death is natural and his exile is left unmentioned.

On hearing of the death of Isho' yahb, Khusrau summons his Christian courtier Takhrid, who informs him that the Christians will delay electing a new catholicos until they have his permission. Khusrau orders the Christian notables, laymen, and clergy, to gather at his door to praise him and ask for a new leader, and Khusrau informs them, through Takhrid, that they should make an election and present the candidate before the shah. Khusrau reminds them that no one should be motivated by personal interest and that the candidate should be able to govern to the satisfaction of all and uphold the

${ }^{41}$ Chronicle of Seert, II/ii, LXV (474-7).

42 Chronicle of Seert, II/ii, LXV (477-82). The emphasis on the saint's appearance may also be linked to the popularity of the saint's image in his own lifetime. An icon of Sabrisho' was painted for Maurice, and his cap and rod are frequently mentioned in the Life, which suggests that they were a widely recognized part of his image (e.g. Syriac Life of Sabrisho', 320, when pagans in Shahrzur rip off his cap).

This is an open access version of the publication distributed under the terms of the Creative Commons Attribution-NonCommercialNoDerivs licence (http://creativecommons.org/licenses/by-nc-nd/3.0/), which permits non-commercial reproduction and distribution of the work, in any medium, provided the original work is not altered or transformed in any way, and that the work is properly cited. For commercial re-use, please contact academic.permissions@oup.com 
empire through his prayers. Finally, he warns them that if they choose a candidate who cannot do this, then the choice will return to him. The Christians meet on the third Thursday of Lent to make an election but they are divided and cannot make a decision. Takhrid presses them and asks where Sabrisho ' is, and they reply that he is too old to govern. After the meeting Takhrid reports this news to Khusrau. The shah furiously tells the bishops that 'Each of you only wants to be elected himself. It is I who will choose and I will make him leader over you' and the Christians acclaim his announcement. ${ }^{43}$

Sabrisho' arrives at Ctesiphon on Palm Sunday and is summoned to Shirin's palace, accompanied only by Timothy of Beth Bagash. On Maundy Thursday, Khusrau orders the clergy to gather outside the palace where Takhrid addresses them: 'This is the chief whom God has sent you from the heavens, whom the shah has approved and placed at your head. Celebrate his election according to your canons... and receive his blessing'. Then the bishops fall to the floor to kiss Sabrisho"s feet and praise Khusrau.

Sabrisho ${ }^{c}$ is then ordained patriarch and celebrates the Eucharist, before setting out for Khusrau's palace. However, his way is blocked by a large crowd and he is unable to continue, so Takhrid goes to him with a horse. Sabrishoc initially refuses to mount the horse, claiming that he is a poor horseman, and he is eventually placed on the horse by the soldiers at the urging of the bishops. The horse, then, refuses to move after the saint commands it to remain still in the name of Christ, and all Jews, Zoroastrians, and Marcionites in the crowd are struck with wonder, saying, 'Your leader is indeed great.' Eventually, a solution is found that does not compromise the patriarch's humility: the soldiers create a path in the crowd, allowing Sabrisho' to reach Khusrau at three in the morning.

Khusrau greets Sabrisho' and recognizes him as the miraculous messenger who announced his victory at Rayy. He declares, 'You indeed are the stone whom the masons have rejected, who has become the head of the corner' (Psalm 118 and Matthew 21:24), embarrassing the bishops present for their failure to elect him. The next day, Khusrau visits him again in Shirin's palace and tells him, 'Your predecessors were the slaves of my fathers and ancestors, but now I have become your son and my wife your daughter.' He concludes this second audience by requesting that he give Shirin communion 'whenever she so desires' and to pray for 'my Empire and my life'. Finally, the bishops thank Takhrid and return home, after Sabrisho ' has designated a new bishop, Miles of Senna. ${ }^{44}$

Following Sabrisho's election, Maurice enters a correspondence with the new catholicos and requests Sabrisho"s image, as well as his cap. In return, Sabrisho ' requests a fragment of the True Cross and the freedom of the Christian captives seized by the Romans in northern Iraq. However, Khusrau

${ }^{43}$ Chronicle of Seert, II/ii, LXV (483-5).

44 Chronicle of Seert, II/ii, LXVII (487-91). LXVI is a section that has been added later, in which Sabrisho ${ }^{c}$ is warned of the events narrated here in a vision.

This is an open access version of the publication distributed under the terms of the Creative Commons Attribution-NonCommercialNoDerivs licence (http://creativecommons.org/licenses/by-nc-nd/3.0/), which permits non-commercial reproduction and distribution of the work, in any medium, provided the original work is not altered or transformed in any way, and that the work is properly cited. For commercial re-use, please contact academic.permissions@oup.com 
takes this fragment of the Cross, 'because of his love for Shirin', and Sabrisho' asks Maurice for a second piece. Later, Sabrisho' receives Maurice's ambassador, Marutha, who is amazed and embarrassed to realize the full extent of Sabrisho's ascetic life at court. In a continuation of the core text of the Life, this Marutha then witnesses Sabrisho' heal a boy who has been struck dumb by a Marcionite sorcerer (who curses 'the children of the Jewish Mary') and goes to visit Khusrau's palaces and the school of Ctesiphon, before celebrating the Eucharist. When Marutha leaves, Sabrisho' presents him with perfumes from India and China, and dispatches the newly elected Miles of Senna as an envoy to Maurice. ${ }^{45}$

This election narrative dominates the Seert Chronicle's Life of Sabrisho': it may have been an official account of Sabrisho's election, whose interest in Maurice's ambassador dates from before the breakdown in relations with Rome. In particular, this narrative has a dramatic unity that follows the Gospels, where the early portents of Sabrisho's future are followed by his ascetic withdrawal, public miracles, and his entry into the royal city. It is also bound together by the person of Takhrid, the Christian courtier who manages Sabrisho"s election, and the arrival and reception of the Roman ambassador. The sections in the Chronicle of Seert that describe Sabrisho"s death replace Takhrid with Yazdin as 'chief layman', which further suggests that this later section is a continuation of the core text of the Life.

The text's chief protagonists, Khusrau and Sabrisho', are presented in connection with a series of other figures: with $\mathrm{Nu}^{\text {' }}$ man the phylarch, with Shirin, with the Christian bishops, and with the Roman ambassador. Each set of relationships can be read as an aspect of the shah's policy towards Christianity, but it is important to emphasize that the peripheral figures have no mutual interaction: the only way in which they can participate in 'political Christianity' in this text is through their relations with the shah and his catholicos. The following sections focus on specific scenes in the Life of Sabrisho ${ }^{c}$ and its continuations to examine these relationships in detail.

\section{NU'MAN AND SABRISHO'}

The conversion of Hira and the Lakhmids is attested from a number of different sources embedded in the Chronicle of Seert and did not always focus on Sabrisho's involvement. ${ }^{46}$ In particular, Section LX focuses on the person of $\mathrm{Nu}^{c}$ man and makes him the hero of the conversion story: 'Just as

${ }^{45}$ Chronicle of Seert, II/ii, LXVII (492-5) and LXVIII (495-8).

${ }^{46}$ On Hira and the Lakhmids more generally, as well as their Ghassanid opponents, see G. Fisher, Between Empires: Arabs, Romans and Sasanians in Late Antiquity (Oxford, 2011).

This is an open access version of the publication distributed under the terms of the Creative Commons Attribution-NonCommercialNoDerivs licence (http://creativecommons.org/licenses/by-nc-nd/3.0/), which permits non-commercial reproduction and distribution of the work, in any medium, provided the original work is not altered or transformed in any way, and that the work is properly cited. For commercial re-use, please contact academic.permissions@oup.com 
Paul loved Judaism and Aba Magianism, so Nu'man loved paganism'. Here his conversion is brought about by Symeon Jabara, the bishop of Hira, together with Sabrisho' and Isho'zkha, which reduces the primacy of the catholicos. This account is still 'loyalist', since Nu'man's son Hassan is praised for aiding Khusrau against Vistahm, so it must have been composed before Nu'man's assassination after 602 , but the emphasis in the text is primarily on $\mathrm{Nu}^{\prime}$ man (rather than Khusrau) as an orthodox ruler, chasing away the Jacobites and in a close relationship with his bishop Symeon, and only secondarily on the role of the Lakhmids within the Sasanian Empire. ${ }^{47}$

The account of the conversion in the Life gives us many more details about the mechanics and chronology of the event, but also presents it from the perspective of Khusrau's court, as one of the miracles of the future catholicos. In it, Symeon of Hira is initially unsuccessful in converting $\mathrm{Nu}^{c}$ man and the phylarch then receives a vision of a beautiful young man promising wealth and power if he converts. $\mathrm{Nu}^{\prime}$ man is initially reluctant to renounce his goddess

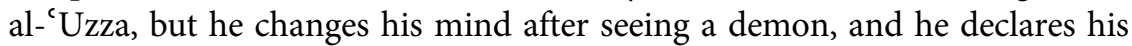
decision to convert on waking. Nu'man informs Symeon that he must first request Khusrau's permission, which he does before allowing Symeon to baptize the members of his household.

However, Jacobites in league with a demon later come to $\mathrm{Nu}^{\text {cmman }}$ and he falls under their influence, eventually relapsing into paganism. Then Symeon writes to Isho 'yahb, asking him to send the miracle-working Sabrisho' to Hira, which he arranges together with the shah. Then Sabrishoc, accompanied by the holy man Isho' $z \mathrm{kha}$, comes to $\mathrm{Nu}^{\text {' }}$ man and exorcizes the demon that had possessed him and he is cured. ${ }^{48}$ In the Syriac version of the Life by Peter (though not in the Arabic text in the Chronicle of Seert), the converted king then drives the Jacobites out of Hira. ${ }^{49}$

This account probably predates Khusrau's volte-face against $\mathrm{Nu}^{\text {' } m a n}$, and it gives a clear idea of the chain of command between $\mathrm{Nu}^{\mathrm{c}}$ man and Khusrau: the shah has to authorize the conversion of the former and has a role in dispatching Sabrisho' to sort out an internal dispute. The account contradicts any idea that $\mathrm{Nu}^{\text {' } m a n ' s ~ c o n v e r s i o n ~ s o m e h o w ~ w e n t ~ a g a i n s t ~ K h u s r a u ' s ~ p o l i c y . ~}{ }^{50}$ Given that Hira had held a large and important Christian population since the fifth century, conversion must have long been advantageous from an internal perspective, especially since the Arabs of Hira might have been attracted to cult sites in the Roman Empire such as Qala' at Sem ${ }^{c}$ ann, the shrine of Symeon

${ }^{47}$ Chronicle of Seert, II/ii, LX (468-9). Cf. Chronicle of Seert, II/ii, XCVI-XCVII for conversion of Arabs near Hira with no reference to the Lakhmids.

${ }^{48}$ Chronicle of Seert, II/ii, LXV (478-81).

49 Syriac Life of Sabrisho c, $322 \mathrm{ff}$.

50 E.g. E. Hunter, 'The Christian Matrix of al-Hira', in C. Jullien (ed.), Les controverses des chrétiens dans l'Iran sassanide (Paris, 2008), 41-56.

This is an open access version of the publication distributed under the terms of the Creative Commons Attribution-NonCommercialNoDerivs licence (http://creativecommons.org/licenses/by-nc-nd/3.0/), which permits non-commercial reproduction and distribution of the work, in any medium, provided the original work is not altered or transformed in any way, and that the work is properly cited. For commercial re-use, please contact academic.permissions@oup.com 
the stylite. ${ }^{51}$ The timing of Nu'man's late conversion indicates a change in the shah's policy towards Christians and the shah's confidence that he could control the behaviour of churchmen within Iraq, and through them this newly Christian vassal state.

Still, the second account does not seem to have been simplified to fit this pro-Khusrau agenda. Like the rest of the Life, it preserves the complexities of political situations while still asserting the primary roles of Khusrau and Sabrisho'. Thus Symeon's role and Nu'man's vision are included, before being overlaid by a second conversion in which Sabrisho' is made the hero in the final instance. The contemporary story is historically accurate, making Isho'yahb the reigning catholicos, and preserves widely known elements of a narrative that might have originally been generated for a Hiran audience, but it concludes by giving the final agency to Khusrau and Sabrisho'. The intricacy of this account could well imply that it is a true reflection of the course of events and their contemporary reporting. But equally it is also sympathetic to Khusrau's usurpation of the roles of Symeon and Isho'yahb and written with foreknowledge of Sabrisho's significance, which causes it to suppress the politically unimportant Isho' $\mathrm{zkha}$ from the story. ${ }^{52}$ Notably, both stories of

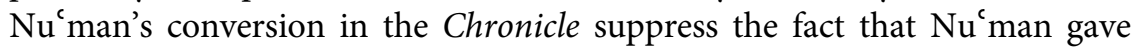
exile to the disgraced Isho'yahb, which suggests both that Isho' yahb had a greater role in Sabrisho's mission than is admitted here and that Nu'man's Christianity also allowed him greater political leverage within the Sasanian Empire than is visible in these idealized accounts. ${ }^{53}$

\section{THE ELECTION OF SABRISHO'}

The account of Nu'man's conversion in the Life seems to be based on reports generated at the time, before Sabrisho's election, which have not removed the activities of other churchmen. However, the shah and his court, already an important 'off-stage' source of authority in this account, become the focus of the narrative for the rest of the Life. The story of Sabrisho's election is written from the perspective of the court, disseminating a narrative of this highly managed encounter between shah and catholicos for the benefit of a domestic Christian audience.

51 Syriac Life of Symeon 67.

52 The Book of Chastity, $\$ 47$ makes Symeon, Sabrisho', and Isho'zkha equal participants in the conversion of $\mathrm{Nu}^{\text {' }} \mathrm{man}$.

${ }_{53}$ Cf. Khuzistan Chronicle, 16-17. Khuzistan Chronicle, 20 describes Khusrau's poisoning of $\mathrm{Nu}^{c}$ man.

This is an open access version of the publication distributed under the terms of the Creative Commons Attribution-NonCommercialNoDerivs licence (http://creativecommons.org/licenses/by-nc-nd/3.0/), which permits non-commercial reproduction and distribution of the work, in any medium, provided the original work is not altered or transformed in any way, and that the work is properly cited. For commercial re-use, please contact academic.permissions@oup.com 
Sabrisho"s importance is set out through his appearance at Rayy. The hagiographer is keen to assert that Khusrau himself denies those who say the vision is of his grandfather. Sabrisho"s distinctive appearance and Shirin's advice are part of an explanation for Khusrau's shift in his public religious support towards the Christians and away from a more neutral, nonreligious interpretation of the vision that some at court may have advocated. During his first civil war, Khusrau had sought legitimacy in the Roman world through his patronage of the cult of Sergius and spreading rumours of imminent conversion. This second civil war seems to have prompted a further move towards additional, alternative bases for his legitimacy in this miraculous relationship with an Iraqi holy man, which had the further advantage of independence from cult sites under Roman control.

The controversy over the election of Isho'yahb's successor suggests that the bishops assembled by Takhrid failed to take this hint, or to realize the importance the shah wished to place on his relationship with Sabrisho ${ }^{c}$. The other contenders in the election are left unmentioned, and Khusrau is forced to renounce the illusion of choice that he had given to the bishops. Instead, Khusrau emphasizes his own authority and the significance of his miraculous encounter. Takhrid reminds them that the shah's choice is for the man 'whom God has sent down from the heavens', eliding the shah's authority with that of God in a manner that was long familiar to Sasanian kings but had never been employed so explicitly by the shah with regard to Christians or in an episcopal election. ${ }^{54}$ At the same time, the Khusrau of the Life is also able to justify his decision in Psalmic language, where Sabrisho' is 'the stone that the masons rejected'. Here Khusrau sets himself up as the instrument of God in elevating the Christ-like Sabrisho' to his rightful role as catholicos over the feuding bishops.

Sabrisho"s ceremonial passage from the palaces of Shirin and Khusrau represents an opportunity to show off Khusrau's new catholicos and to highlight the new prominence of Christians through Shirin's patronage, while still distancing the shah from any accusations of full conversion. ${ }^{55}$ However, Sabrisho"s inability to make his way through the crowd potentially represented an embarrassment to the shah, even a vindication of those who had said he was too old to be elected catholicos. Takhrid's failed attempt to remedy the situation by bringing Sabrisho ${ }^{\prime}$ a horse has been developed into a miracle by the hagiographer, representing a theatrical failure as another indication of Sabrisho"s holiness. The Life represents an official version of events where a public mishap on the streets of Ctesiphon has been retold to confirm the catholicos' right to rule.

54 On the relationship between the shahs' authority and Ohrmazd see J. Choksy, 'Sacred kingship in Sasanian Iran', BAI 2 (1988), 35-53, basing his argument on the Denkard.

${ }_{55}$ An accusation of conversion is recorded in the Nihayat $u l^{\circ}$ Arab (tr. Browne, 240).

This is an open access version of the publication distributed under the terms of the Creative Commons Attribution-NonCommercialNoDerivs licence (http://creativecommons.org/licenses/by-nc-nd/3.0/), which permits non-commercial reproduction and distribution of the work, in any medium, provided the original work is not altered or transformed in any way, and that the work is properly cited. For commercial re-use, please contact academic.permissions@oup.com 
The concluding part of this scene establishes Sabrisho ${ }^{c}$ as the catalyst for Khusrau's articulation of a new policy towards Christians inside and outside his empire. He explicitly renounces the persecuting legacy of his predecessors and ties this to an expectation of Christian loyalty, whereby prayers are directed for him and the empire. Moreover, he emphasizes Shirin's role in this arrangement, receiving Sabrisho"s assurance that Shirin will always be able to receive the Eucharist. Shirin's public Christianity allows Khusrau a means of participating in the religion by proxy. By presenting Shirin as the defender of the Christians, Khusrau could resist Zoroastrian calls for persecution as well as reducing the influence of 'traditional' channels of Christian influence on the shah, such as a catholicos with greater independent agency than Sabrisho' or the other bishops, who remain anonymous in this account. It may also be significant that only royal palaces are used during Sabrisho"s arrival: the importance of the royal receptions also reduces the emphasis within the ceremonial sequence on Sabrisho"s actual ordination at the church in Seleucia. Sabrisho"s passive presence at the centre of the Church of the East allowed Khusrau a much greater degree of control over its internal structures, and the story of this ideal loyalist relationship was disseminated through this court-focused Life.

Finally, Sabrisho is also made a vehicle for a much closer diplomatic correspondence between shah and emperor. Here too, Khusrau could distance himself from the actual exchange of relics, only intervening after Maurice has sent a piece of the Cross, by giving it to Shirin. Similarly, Sabrisho"s reception of Marutha reflects on both the scholarly and ascetic prestige of the Church of the East, on public affirmation of its orthodoxy in the eyes of the Romans, and on Khusrau's own role as beneficent sponsor of Christianity. Sabrisho's gift of Indian and Chinese perfumes also articulates the position of the Sasanian world vis-à-vis Rome, and the value of peaceful relations with a trading partner who can control access to these foreign luxuries. In this respect, Sabrisho' magnifies Khusrau's standing in Roman eyes, and the visit is both a vehicle for traditional diplomacy and an opportunity to show Khusrau's new special relationship with the Christians, in a manner that simultaneously fulfils Roman hopes for toleration and emphasizes Khusrau's independence from his Roman sponsors. If Khusrau had appealed to Roman Christian sources of legitimacy before his first civil war, at his second he turned to an Iraqi Christian sponsor, a living holy man.

\section{CHRISTIANS IN A TIME OF WAR: THE INVASION OF DARA}

This symbiosis between the shah and the catholicosate did not long survive Sabrisho'. The Life of Sabrisho' had been written as part of a peaceful

This is an open access version of the publication distributed under the terms of the Creative Commons Attribution-NonCommercialNoDerivs licence (http://creativecommons.org/licenses/by-nc-nd/3.0/), which permits non-commercial reproduction and distribution of the work, in any medium, provided the original work is not altered or transformed in any way, and that the work is properly cited. For commercial re-use, please contact academic.permissions@oup.com 
relationship between Rome and Persia. But the murder of Maurice made the catholicos himself a symbol of the legitimacy of Khusrau's vengeance for the martyred emperor because of Maurice's (alleged) personal devotion to Sabrisho'. Khusrau summoned Sabrisho' to his side during his 604 invasion of Dara. However, following Sabrisho's death, the new catholicos Gregory of Pherat de Maishan was accused of corruption and his property expropriated by the shah. The interregnum that followed Gregory's rule saw increased power accorded to the Miaphysites through the court physician, Gabriel of Sinjar. Gabriel had converted to the Church of the East but had been rejected for bigamy with two Persian wives, after divorcing a Christian noblewoman. The Khuzistan Chronicle makes Gabriel responsible for the replacement of Eastern monks by Jacobites in a number of sites in northern Iraq and for the denunciation of the theologian Giwargis, an important ally of Babai, as a Magian apostate in $612 .^{56}$

Both events, the war with Rome and the rise of Gabriel, are discussed in codas to the Life that are preserved in the Chronicle, though they are absent from the Syriac text. In a section dedicated to the death of Maurice, the text echoes the representation of Maurice as a martyr, and the praise of the emperor in the Life becomes the basis for Khusrau's claim to a just war to put his son Theodosius on the throne. In this respect the continuation of the Life follows the older story's 'loyalist' emphasis and turns it to a new context with a war legitimated as a re-enactment of Maurice's own restoration of Khusrau. However, Sabrisho"s death during the opening phases of the war meant that Khusrau had lost an element of his Christian legitimacy. The author explains his death away as Sabrisho"s wish to avoid the sight of blood during the invasion. Khusrau must content himself with a promise of Sabrisho's prayer, after which Sabrisho' reminds him 'to rule with kindness (rifq) and with mercy (rahma)'. ${ }^{57}$ Khusrau's management of the invasion did not proceed smoothly, and this death scene represents a hagiographer's attempt to preserve the image of a symbiosis between shah and catholicos during the opening stages of the war.

A second 'coda' to the Life concerns the relationship between Gabriel and Sabrisho'. Gabriel's rise to power is dated by 'Amr to the 'reign' of Gregory, and the full significance of his support for the Miaphysites may have only been apparent after Sabrisho"s death. ${ }^{58}$ At any rate, though the story of his condemnation by Sabrisho' for bigamy may be true, it had not seemed important enough for inclusion in the original text of the Life. Two different versions of these events are recorded in the Chronicle: in both Gabriel pleads with

${ }^{56}$ Khuzistan Chronicle, 19 and 22-3. On Gabriel see Flusin, Saint Anastase, II, 110-11.

57 Chronicle of Seert, II/ii, LXX (498-501), with an epitome in Khuzistan Chronicle, 21.

58 'Amr, HE, 51/30: I assume that the reference to the doctor Abraham of Nisibis is a slip, replacing the name of the more famous doctor.

This is an open access version of the publication distributed under the terms of the Creative Commons Attribution-NonCommercialNoDerivs licence (http://creativecommons.org/licenses/by-nc-nd/3.0/), which permits non-commercial reproduction and distribution of the work, in any medium, provided the original work is not altered or transformed in any way, and that the work is properly cited. For commercial re-use, please contact academic.permissions@oup.com 
Sabrisho ${ }^{c}$ to allow him to remain in the Church, but Sabrisho ${ }^{c}$ refuses. ${ }^{59}$ The overwhelming agenda of the Life's author had been to play down strife between Miaphysites and the Church of the East: Sabrisho"s miracles in Ctesiphon are all directed against Jews, Zoroastrians, and (most especially) Marcionites. It may be that the objective of the hagiographer was to present Sabrisho' (and through him Khusrau) as the governor of all Christians in the empire, defined against the Marcionites as an obvious 'out-group' that was rejected by all. Though it is not mentioned in the Life, Sabrisho' was also notorious for his refusal to condemn the Henanians, whose opponents would represent them as crypto-Miaphysites. ${ }^{60}$ These accounts of the confrontation between Gabriel and Sabrisho ${ }^{c}$ then insert an anti-Miaphysite agenda into the story of a holy man who had originally been rendered famous through his miracles and his relationship with the shah. They associate him more closely with the theological position that the Church of the East adopted in the following decades, which are a terminus a quo for the addition of these scenes.

A third coda, which follows on from the denunciation of Gabriel, is the description of Sabrisho"s death and burial. Here a large crowd comes to see Sabrisho' on his deathbed before he is embalmed, and the Nisibenes and the Hirans compete over who will have the honour of receiving his body for burial, the former because he died there and the latter because it had been the traditional burial place of the catholicos. However, the camel that takes his body away 'miraculously' transports him to his monastery of Karka de Guedan, the monastery that he had founded. En route, the Christian magnate Yazdin attempts to take the piece of the Cross given to Sabrisho' by the emperor, but he is prevented by Sabrisho"s disciples, who guard the body and burn incense over it before burial. ${ }^{61}$

This third coda shares the Life's concern for the orchestration of public ceremony and the justification of acts of Realpolitik as miraculous intervention. And, though this has been partially suppressed, it also shares the Life's focus on Khusrau's importance as a patron of Christianity, over and above the influence of any other leadership figures. The account of the same events in the Khuzistan Chronicle makes explicit that Sabrisho's burial in his new monastery was Khusrau's decision, ${ }^{62}$ and, with this in mind, we can see the description of the ceremony of Sabrisho's burial as an illustration of the circumvention of older centres of power. In particular Nisibis' Christian aristocrats had recently risen in revolt against Khusrau, and $\mathrm{Nu}^{\text {'man }}$ in Hira may have been increasingly perceived as an over-mighty vassal. Thus, this account can be read as a snub to these older centres in the shah's favour.

59 Chronicle of Seert, II/ii, LXIX (498) and LXXI (502-3), mirrored in epitomes in Khuzistan Chronicle, 19 and 22.

60 See below in this chapter on Gregory of Nisibis.

${ }^{61}$ Chronicle of Seert, II/ii, LXXI (503-4). $\quad{ }^{62}$ Khuzistan Chronicle, 22.

This is an open access version of the publication distributed under the terms of the Creative Commons Attribution-NonCommercialNoDerivs licence (http://creativecommons.org/licenses/by-nc-nd/3.0/), which permits non-commercial reproduction and distribution of the work, in any medium, provided the original work is not altered or transformed in any way, and that the work is properly cited. For commercial re-use, please contact academic.permissions@oup.com 
Similarly, by preventing Yazdin from claiming a piece of the Cross, Khusrau maintained his own monopoly on the relic, which recalled his personal relationship with Maurice. This focus on Khusrau's patronage may date this passage to the period immediately following Sabrisho"s death, but the removal of any mention of the shah in the Arabic account also suggests later alterations, in the immediate wake of Khusrau's subsequent persecution of the Christians.

The continuations of the Life of Sabrisho' were written in the aftermath of his death (c.604-12), and follow a similar emphasis on Khusrau's role as supreme patron of the Christians and Sabrisho"s relationship with him. All three coda passages seem to have been conceived independently, since they are inserted one after the other at the end text of the Life in the Chronicle of Seert and appear in a different order, and in epitome, in the Khuzistan Chronicle. The independent existence of these scenes may suggest they were all episodes in different ecclesiastical histories that were excerpted by later compilers. The fact that they appear in the Khuzistan Chronicle in c.652 without the text of the Life may indicate that the symbiosis that the Life proposed between shah and catholicos was now obviously obsolete, after Khusrau's persecution and the fall of the Sasanians, and that the continuations set at the end of Sabrisho"s Life represented the least 'politically contaminated' material, that could be edited to present him as peace-loving (praying to be spared the sight of the fall of Dara) and as an opponent of Gabriel and the Miaphysites.

\section{CHRISTIANS IN A TIME OF WAR: KHUSRAU} AND THE MIAPHYSITES

Khusrau's policy during Sabrisho"s burial suggests that he had wished to maintain his relationship with the Church of the East. And during his occupation of Roman Mesopotamia he initially attempted to impose a 'Nestorian' bishop on his conquered province. ${ }^{63}$ However, the period of 607-30 saw the shah give increased patronage to Miaphysites in the Empire. Under the patronage of Gabriel, 'a protector of the church in this land like the victorious emperor Constantine', Marutha of Takrit established himself as the leader of the Miaphysite church in the East and found favour at Khusrau's court. ${ }^{64}$ The same era saw the establishment of twelve new Miaphysite sees among the Arabs of Jazira and in northern Iraq, as well as a Miaphysite presence in Ctesiphon itself. ${ }^{65}$ This pro-Miaphysite policy was even more marked in Khusrau’s newly

63 Bar Hebraeus, HE, I, 263. ${ }^{64}$ Life of Marutha of Takrit, 73-7.
Chronicle of Seert, II/ii, LXXXVIII (543).

This is an open access version of the publication distributed under the terms of the Creative Commons Attribution-NonCommercialNoDerivs licence (http://creativecommons.org/licenses/by-nc-nd/3.0/), which permits non-commercial reproduction and distribution of the work, in any medium, provided the original work is not altered or transformed in any way, and that the work is properly cited. For commercial re-use, please contact academic.permissions@oup.com 
conquered territories in the Roman Empire, where he convened an antiChalcedonian council in Dvin in Armenia in 608, which reversed Maurice's pro-Chalcedonian policies in the same territory. ${ }^{66} \mathrm{~A}$ state that was favourable to the Miaphysites provided greater incentives to unity and cooperation. Above all, Khusrau used Miaphysite bishops from Iraq's newly organized episcopal structures to staff the sees of Roman Mesopotamia, areas with large Miaphysite populations whose bishops had been removed under Maurice (in spite of some resistance from earlier Miaphysite incumbents).

As the centre of Khusrau's expanding empire shifted, the shah was prepared to make a parallel shift in his ecclesiastical patronage, playing the role of a central arbitrator to long-divided Miaphysite groups and reversing many of Maurice's pro-Chalcedonian policies in the frontier zone. The account embedded in Bar Hebraeus reports that 'all the churches seized by Maurice were returned' and 'the memory of Chalcedon was expunged from the Euphrates to the east' ${ }^{37}$ For the West Syrian Life of Cyriacus of Amida, written in the early seventh century, Khusrau's conquest is a divine decision, and his removal of the Chalcedonians 'inspired by God and counselled by Shirin'. ${ }^{68}$ If Maurice had sought to suppress the religious and political independence of Ghassanids and Armenians in this frontier zone, ${ }^{69}$ Khusrau proved capable of claiming the mantel of Christian rulership for himself, as patron and judge of the Miaphysites of the Roman East. ${ }^{70}$

At the same time as Khusrau sponsored different Christian groups, he never ceased to claim legitimacy from more traditional Zoroastrian patterns of royal behaviour. The typologies of his coins were twice updated after his victories in civil wars and refer to his xwarrah, his divinely ordained right to rule, the Avestan power that allows good to defeat evil. ${ }^{71}$ Moreover, Khusrau was also prepared to make selective examples of Christian troublemakers,

66 Also note the sponsorship of church building under Khusrau in Armenia: Pseudo-Sebeos, ch. 24 (100) on a new church in Dvin and the restoration of the exiled bishop Abraham; ch. 37 (121) on new church building in Valarshapat.

${ }^{67}$ Bar Hebraeus, HE, I, 263-5.

68 Life of Cyriacus of Amida.

69 See Wood, We Have No King but Christ, chapters 6 and 7; R. W. Thomson, 'The Armenians in the fifth and sixth centuries', in Averil Cameron, B. Ward-Perkins, and M. Whitby (eds.), The Cambridge Ancient History XIV, 662-77, at 674-6, and G. Greatrex, 'Moines, militaires et défense de la frontière orientale au VIe s.', in A. Lewin and P. Pellegrini (eds.), The Late Roman Army in the Near East from Diocletian to the Arab Conquest (Oxford, 2007), 285-97, at 292-3. Evagrius, HE, VI, 22 (ed. Bidez and Parmentier, 238) describes Maurice's anti-Miaphysite initiative.

${ }^{70}$ Note, in general, I. Dorfmann-Lazarev, 'Beyond empire I: Eastern Christianities from the Persian to the Turkish conquest, 604-1071', in T. Noble and J. Smith (eds.), The Cambridge History of Christianity III (Cambridge, 2008), 65-85, at 70-1.

${ }^{71}$ T. Daryaee, 'Religio-political propaganda on the coinage of Xusro II', American Journal of Numismatics 9 (1997), 41-53. Also note J. Howard-Johnston, 'Kosrow II', in EIr, for his description of Khusrau's rock inscription at Taq-e-Bostan, where he is shown together with his fravaši (tutelary spirit).

This is an open access version of the publication distributed under the terms of the Creative Commons Attribution-NonCommercialNoDerivs licence (http://creativecommons.org/licenses/by-nc-nd/3.0/), which permits non-commercial reproduction and distribution of the work, in any medium, provided the original work is not altered or transformed in any way, and that the work is properly cited. For commercial re-use, please contact academic.permissions@oup.com 
most of whom were from the Church of the East, especially those who publicly renounced Zoroastrianism. Beginning with Nathaniel of Shahrzur in 611, he killed a series of apostates to Christianity: Giwargis in 615, Isho'sabran in 621, and Anastasius in $628 .^{72}$

The timing and selection of these martyrs fits with the general impression of Khusrau turning his patronage away from the Church of the East in the 610s. Sabrisho"s death was followed by the short and unsuccessful reign of Gregory of Pherat, who died in 607. Following this, Khusrau allowed Gabriel of Sinjar to convene the highly polemical assembly of 612 , which represented the Miaphysites as 'the monks' against their 'Nestorian' opponents. ${ }^{73}$ Here, it seems, the Miaphysites were able to seize the initiative and present themselves before the shah as true representatives of ascetic, orthodox Christianity. Gabriel's opponents, led by the northern bishops Yonadab and Shubhalmaran, continued to praise the shah as one who 'lights up the whole earth like the sun' and to present the 'Severans' as a foreign intrusion, akin to the Marcionites and Manichees. By asserting their own position as members of an indigenous, orthodox Christianity and exaggerating their praise for the shah, the bishops may have hoped for a last-ditch defeat of Gabriel. They end their statement by hoping that 'When you have subjected the whole of the Roman world, you will confirm the apostolic faith in a single true God, master of all, who preserves your rule over the whole universe for all time'. ${ }^{74}$

If the Life of Sabrisho' had avoided any mention of conflict between Miaphysites and the Church of the East, the 612 assembly saw direct competition for the shah's patronage and the claim to represent the Christianity of the East. This squabble had massive significance as the shah came to control an ever-growing portion of Christian world. ${ }^{75}$ This assembly may have also been the last time that bishops of the Church of the East used the language of loyalism to the shah to present Khusrau as a friend of the Christians or as a universal ruler: the kind of symbiosis imagined in the Life of Sabrisho evaporated after the assembly, when the martyrdom of Giwargis (an opponent of Gabriel's) made clear the shah's preference for the Miaphysites in his newly expanded empire. ${ }^{76}$

72 Flusin, Saint Anastase, II, 118-19.

${ }^{73}$ On this assembly see G. Reinink, 'Babai the Great's Life of George and the propagation of doctrine in the late Sasanian Empire', in J.-W. Drijvers and J. Watt (eds.), Portraits of Spiritual Authority: Religious Power in Early Christianity, Byzantium and the Christian Orient (Leiden/ Boston/Cologne, 1999), 171-93, esp. 178-80, for Babai's attempt to hide the role of Gabriel of Sinjar in convening the assembly.

${ }_{74}$ Synodicon, 567. Cf. Chronicle of Seert, II/ii, LXXXIII (529).

75 E.g. Khuzistan Chronicle, 22.

${ }^{76}$ Greatrex, 'Khusro II and the Christians', 82 argues for the shah's neutrality between the confessions. He underlines Khusrau's grant of monastic governance in the north of Iraq to Yonadab even after the catholicosate had fallen into abeyance (Khuzistan Chronicle, 22), but this

This is an open access version of the publication distributed under the terms of the Creative Commons Attribution-NonCommercialNoDerivs licence (http://creativecommons.org/licenses/by-nc-nd/3.0/), which permits non-commercial reproduction and distribution of the work, in any medium, provided the original work is not altered or transformed in any way, and that the work is properly cited. For commercial re-use, please contact academic.permissions@oup.com 


\section{GREGORY OF NISIBIS}

The collapse of the relationship between Eastern bishops and the shah coincided with a twenty year period in which there was no reigning catholicos. Historians attempted to present different figures as the links in an orthodox chain of succession during this period of anarchy, sometimes differentiating them from potential rivals within the Church. We have already seen one example of this in the stories that clustered around Babai the Great, which present him as an opponent of heretics, a theologian, and monastic leader. The presentation of Babai as a preserver of orthodoxy and head of the Church must be weighed against the reticence of other accounts, where he is not presented as catholicos or where his conflicts with other significant figures have to be explained away, such as his conflicts with the monastic leader Jacob of Beth 'Abe. ${ }^{77}$ In such cases, hagiographers in alternative traditions might also accentuate the connections of their heroes with other prestigious leaders of the church (such as the connection between Jacob and Sabrisho $\left.{ }^{c}\right)^{78}$ or attempt to posthumously reconcile enemies who were both seen as orthodox in a later tradition. As the Chronicle of Seert puts it, apologizing for this conflict, 'no one can reach perfection, and, because of human nature, everyone must have some faults of character'. In spite of Babai the Great's later reputation, it is clear that his role as a monastic inspector was limited to the north of Iraq $^{79}$ and that he was absent from the assembly of $612,{ }^{80}$ and further that his strong personality alienated several of his potential allies. Together, these characteristics made him a problematic subject for historians.

The hagiographies written in support of Babai occur primarily within monastic circles: his authority as a monastic leader seems to have underlain his political activity and represented a support base that would later emphasize his memory. A second, parallel attempt to trace the succession of orthodoxy in this period of anarchy comes in the stories surrounding Gregory of Nisibis, a figure more closely connected to factions within the School of Nisibis. If the school system, the catholicosate, and monasticism had all existed in symbiosis in the previous generation, the removal of the shah's sponsorship of a catholicos prompted institutions to produce histories presenting different candidates as crucial links in the chain of the succession of orthodox authority. ${ }^{81}$

event predates the 612 Assembly, which I would see as a major turning point, where the Dyophysites were clearly on the defensive.

77 See especially Chronicle of Seert, II/ii, XCII (553) and Book of the Governors, I, vii-x (26-31/ 46-57).

78 Book of Chastity, $\$ 34$.

79 Book of the Governors, I, xxvii-xxviii (51-3/90-6).

${ }^{80}$ Chronicle of Seert, II/ii, LXXXIII (529).

${ }^{81}$ Babai would make use of Gregory's posthumous reputation (Life of Giwargis, 428), but their patronage circles do not seem to have intertwined substantially in their own lifetimes.

This is an open access version of the publication distributed under the terms of the Creative Commons Attribution-NonCommercialNoDerivs licence (http://creativecommons.org/licenses/by-nc-nd/3.0/), which permits non-commercial reproduction and distribution of 
The Chronicle of Seert includes a Life of Gregory, which, like the Life of Sabrisho', has probably been epitomized and translated from a Syriac hagiography. ${ }^{82}$ The Life relates how Gregory, a native of Kashkar, was trained at the schools of Ctesiphon and Nisibis before going on to found new schools at Adiabene and in a village near Kashkar. Here he led his pupils and was an active missionary in Maishan, as well as protecting Kashkar from the plague through his prayers.

Gregory's reputation led to his promotion to bishop of Kashkar by Isho yahb I, after which he was promoted again to metropolitan of Nisibis. Here he came into conflict with the head of the School, Henana of Adiabene, 'who investigated heterodox ideas and performed exegesis contrary to the ideas of Theodore'. Gregory condemned Henana's writings, but, the Life reports, Henana's contrition was only temporary, until he had the opportunity of an alliance with Gabriel of Sinjar (who had been condemned by Gregory and not Sabrisho', according to this version of events). After Henana continued his 'false' exegesis, Gregory wrote to Sabrisho' asking for his support against him. This request was accepted by 'the company of the [orthodox] fathers', but was rejected by the catholicos, who received Henana's defence favourably. In response, Gregory and his supporters left the city of Nisibis.

The Life represents Gregory's exile as an ascetic act. Gregory gives away all the material wealth of the exiles, save their liturgical garments, books, and censers, which they displayed in their procession out of the city. The hagiographer asserts that while Gregory's party numbered three hundred, only twenty, 'together with some women and children', remained in Nisibis with Henana. There follows a brief list of the famous men who were part of this exile, among them Isho' yahb of Gdala and Isho' yahb of Adiabene (both later catholicoi) and Barhadbeshaba 'Arbaya, the later metropolitan of Hulwan, as well as other theologians of note. At Khusrau's order, Gregory departed to the desert of Niffar, near Kashkar, where he lived out his life converting local pagans. ${ }^{83}$

By noting the future careers of the exiles, the author presents the event as a defining moment in the church's orthodoxy. Henana is seen as an ally of the Miaphysite Gabriel, and both men are represented as opponents of Gregory, above anyone else. Gregory is represented in turn as the vehicle for the succession of orthodox interpretation in the School of Nisibis, and for the other schools he was associated with in the south of Iraq, and Henana is reduced to the leader of a rump party, unrepresentative of the School and its Theodoran traditions.

82 The Seert Chronicle's direct sources are named as the historians Theodore bar Koni and Elias of Merv. The latter is probably Khuzistan Chronicle, 17-18.

${ }^{83}$ Chronicle of Seert, II/ii, LXXIV (507-13). See also Khuzistan Chronicle, 18, which describes Khusrau learning of widespread dislike for Gregory.

This is an open access version of the publication distributed under the terms of the Creative Commons Attribution-NonCommercialNoDerivs licence (http://creativecommons.org/licenses/by-nc-nd/3.0/), which permits non-commercial reproduction and distribution of the work, in any medium, provided the original work is not altered or transformed in any way, and that the work is properly cited. For commercial re-use, please contact academic.permissions@oup.com 
Reading between the lines of the account, it is clear that Gregory and his party experienced a dramatic loss of face in this incident. Henana's radicalism probably did not represent a drift towards Miaphysitism, but rather a wish to use more innovative exegesis than was allowed by a sole focus on Theodore of Mopsuestia. ${ }^{84}$ Gregory, a man already trained in the methods of the School and who was accustomed to directing schools elsewhere in Iraq, may have been unwilling to accept Henana's independence when he (Gregory) returned to Nisibis as metropolitan, that is, as an important man, but one who now belonged to a different institutional hierarchy and who had no direct control over the School. Sabrisho ' himself was unwilling to support Gregory's bid for control, perhaps because Henana's exegetical innovation promised to reconcile more moderate Dyophysites and Miaphysites (a sentiment that coheres with the irenic tendencies of the Life of Sabrisho ${ }^{c}$ ) or merely through a wish to prevent discord between important but distinct institutions within the Church. Gregory and his exiled party were subsequently represented as the wronged party, supported by 'the fathers', who were crucial links in the chain of orthodoxy. This portrayal of events probably began under Babai, who wrote a Life of Gregory soon after his death in $c .611,{ }^{85}$ but the emphasis on the role of Gregory as the leader of future catholicoi probably dates the version of the Life of Gregory in the Chronicle of Seert to at least the 660s.

\section{GREGORY AND THE SACK OF NISIBIS}

The full political significance of the Life of Gregory is only made apparent through two narratives that continue it, expanding the hagiography by adding material that describes the fallout from Gregory's exile in terms of secular and ecclesiastical politics, in which the shah was closely involved. Both of these were probably generated by contemporary historians who integrated the hagiography into their histories and sought to link it into broader political narratives.

The first of these stories describes events in Nisibis following Gregory's exile. The narrator relates how, on the anniversary of Gregory's departure, those who had supported Henana and 'gone in league with those who defended bigamy and concubinage', revolted against Khusrau and killed the marzban of the city. Furious at this, Khusrau dispatched an army to Nisibis,

${ }^{84}$ Reinink, 'Nestorian identity', esp. 226 and 244.

${ }^{85}$ Life of Giwargis, 428. Babai presented Gregory as a martyr because he died in exile, and associates him with Giwargis, a Zoroastrian convert who was denounced at the 612 Assembly and who Babai presented as a 'martyr' for Dyophysite orthodoxy. The Book of Chastity also places Gregory in the company of Giwargis (\$56-7).

This is an open access version of the publication distributed under the terms of the Creative Commons Attribution-NonCommercialNoDerivs licence (http://creativecommons.org/licenses/by-nc-nd/3.0/), which permits non-commercial reproduction and distribution of the work, in any medium, provided the original work is not altered or transformed in any way, and that the work is properly cited. For commercial re-use, please contact academic.permissions@oup.com 
and Sabrisho ${ }^{c}$, together with metropolitans from northern Iraq, ${ }^{86}$ offered to spare the city if it surrendered. However, once the city surrendered, the army put it to the sword 'and killed all they encountered'. The author takes this opportunity to condemn both the Nisibenes and Khusrau: the former deserve punishment for their treatment of Gregory, while Khusrau is compared to Antiochos, the villain of the books of Maccabees, in his destruction of Jerusalem and, more pointedly, to his predecessor Yazdegard, who had also shown favour to the Christians before turning against them. These events also allow the author to provide a suitable ending to the problematic stance taken by Sabrisho ' against Gregory in the Life. At the conclusion of this narrative, Sabrisho' condemns the general of the army and laments: 'I have sinned (atimtou) against them [the Nisibenes], for I made them a promise that I did not keep'. Finally, the author spells out the results of Sabrisho"s compromise with secular power and Gregory's ultimate vindication: 'They say that after Sabrisho"s disagreement with Gregory he lost all his powers of prophecy. After the death of Gregory the metropolitan, the citizens of Nisibis wrote his [i.e. Gregory's] name once more amongst those of the fathers ${ }^{\prime}{ }^{87}$

The Life of Gregory had focused on Gregory's opposition to the Henanians: Sabrisho ${ }^{c}$ and Khusrau had remained further behind the scenes, with the hagiographer's disapproval implied, but never explicit. Yet other historians were much more forthright in their analysis: the Khuzistan Chronicle opened its discussion of the exile by observing that 'Satan excited a squabble between Gregory and Sabrisho" and remarked that it had been Sabrisho' who had insisted that Gregory be deprived of the bishopric. ${ }^{88}$ The narrative of the chastisement of Nisibis in the Chronicle of Seert seems to belong to this tradition of more explicit criticism, possibly written longer after the deaths of Sabrisho' and Gregory than Babai's account of Gregory of Nisibis.

This continuation presents Khusrau as a betrayer of the Christians and represents a reaction to the volte-face of his policy towards the Church of the East. This attitude also has consequences for the text's view of Sabrisho'. The author is not prepared to reject Sabrisho"s reputation as a miracle-worker: this may reflect the success of the image provided in the Life of Sabrisho' during the catholicos' own lifetime, as well as the holy man's close relationship with other prestigious figures of the Church. But he does criticize the idea of the close relationship between Christians and the state: Khusrau is a new Yazdegard and Sabrisho' is taken in by the promises of the shah's general. This relationship is perceived here as a source of corruption: it retrospectively undermines Sabrisho's reputation as prophet of Khusrau's victory and his importance vis-à-vis Gregory.

86 The text has 'Beth Garmai, Mosul, and Nisibis', but Mosul must be an anachronism.

${ }^{87}$ Chronicle of Seert, II/ii, LXXV (513-15). Also see Khuzistan Chronicle, 19.

${ }^{88}$ Khuzistan Chronicle, 18.

This is an open access version of the publication distributed under the terms of the Creative Commons Attribution-NonCommercialNoDerivs licence (http://creativecommons.org/licenses/by-nc-nd/3.0/), which permits non-commercial reproduction and distribution of the work, in any medium, provided the original work is not altered or transformed in any way, and that the work is properly cited. For commercial re-use, please contact academic.permissions@oup.com 
In addition to its treatment of Sabrisho' and Gregory, the continuation also brings together the Nisibenes with the Henanians and the 'supporters of bigamy'. This connection echoes the Life by asserting that Gregory was an orthodox leader and that all his opponents might be tarred with the same brush. We have already seen how some hagiographers emphasized Sabrisho"s role as an enemy of the bigamist Gabriel, and this may well have been a defence against attacks on Sabrisho"s character such as the one seen here. The author presents the Henanians as allies of Gabriel, and by extension Miaphysites and heteropract bigamists, when their actual theological differences were likely much smaller and their connection to Gabriel is elsewhere unattested. However, the idea that the Nisibenes who planned the revolt were justly punished does add a further layer to our perception of events on the ground, since it suggests that the citizens were themselves pro-Henanian, and that Gregory's support base was a slender one, limited to a group of scholars within the School, while Henana could command local lay support. This support in turn makes the refusal of Sabrisho ${ }^{c}$ and Khusrau to support Gregory much more comprehensible: before the revolt at Nisibis, Henana was the stronger of the two rivals. It was only after Khusrau's change in behaviour towards the Church of the East in the 610s, coupled with the rising influence of Gabriel of Sinjar, that partisans of Gregory of Nisibis could retrospectively undermine the reputation of Sabrisho' by claiming he was a creature of the shah and present the Henanians as a Miaphysite fifth column in a bid to rehabilitate Gregory in the eyes of the Nisibenes and the wider Church.

\section{THE ELECTION OF GREGORY OF PHERAT (605-9)}

The second of the two continuations of the Life of Gregory concentrates on the abortive election of Sabrisho's successor, Gregory of Pherat, and attempts to preserve the structure of the ecclesiastical histories around the reigns of catholicoi. Like some other sections on the catholicoi it opens with the physical description and background of the protagonist: 'he was from Maishan, with a beautiful face, a doctor of theology who had been taught by Isai at the school of [Ctesiphon]'. The opening description seems to have been inserted into a continuous narrative that focuses on political events in the Church: the author goes on to describe how Khusrau convened an election on his return from Dara and how 'the fathers' selected Gregory of Nisibis. Through the offices of Shirin, the fathers receive the royal order to convene at Ctesiphon to ordain Gregory.

However, certain doctors at Ctesiphon, led by one Abraham of Nisibis, believe that Gregory will oppose them once he became catholicos, since they had fought against him in Nisibis. This party secures the support of Aba of

This is an open access version of the publication distributed under the terms of the Creative Commons Attribution-NonCommercialNoDerivs licence (http://creativecommons.org/licenses/by-nc-nd/3.0/), which permits non-commercial reproduction and distribution of the work, in any medium, provided the original work is not altered or transformed in any way, and that the work is properly cited. For commercial re-use, please contact academic.permissions@oup.com 
Kashkar, the royal astronomer, and Shirin tells the fathers to elect Gregory of Pherat instead. After the election of Gregory of Pherat, the doctors of Nisibis introduce Gregory before the shah to pray for him, but Khusrau is surprised, saying 'it was not you I selected to be ordained, but Gregory of Nisibis.' Aba replies 'It was the queen Shirin who selected him because he is her countryman: surely the shah will accept him because of her, for he is a wise and intelligent man'.

In a passage that seems to have been heavily abbreviated from a longer source, Khusrau examines the catholicos and is initially overawed by his beauty, but soon discovers that 'his inner being was the opposite of his appearance'. Khusrau then reproaches Shirin. Gregory is said to turn against equality, justice and love to acquire wealth, whereupon 'the joy of the Christians turned to sadness' and Gabriel of Sinjar, 'whom Sabrisho' had condemned' defamed them. At this time, pictures of Gregory circulated that showed him squeezing a hen to judge its fatness, testing the weight of a gold coin, and balancing a girl on his knee, all of which came into Khusrau's possession.

The text goes on to suggest that it was due to Gregory that Khusrau changed his attitude towards the Christians. It relates that Khusrau forced Gregory to buy the books that his troops had looted from Dara at a huge price and that he confiscated all his wealth after his death. Following this, he continued his exactions against ordinary Christians and levied new taxes against them and confiscated their goods. After this, 'the church remained widowed for seventeen years, and was directed by Aba the archdeacon and Babai until the accession of Shiroë, 89

Unlike the account of the fall of Nisibis, this narrative is highly uneven in its depiction of protagonists and in its style, which seems to indicate the use of numerous oral sources and abbreviated accounts that may have been contemporary to events. That said, the organizer of this material also perceives events to proceed from the failure to elect Gregory of Nisibis, and represents the calamities of the 611-28 period as the result of the machinations of other Christian leaders against Gregory and against the will of 'the fathers', whose authority the Life of Gregory had already invoked against Henana and Sabrisho $^{c}$. Therefore this narrative is little focused on Sabrisho ${ }^{c}$ or on Nisibis, and is concentrated instead on factions within Ctesiphon and on Gregory's position as a potential catholicos.

Where the Nisibis account had opposed the propaganda of the Life of Sabrisho' in an attempt to undermine the catholicos' refusal to support Gregory of Nisibis, this account defends Gregory's position through an attack on Shirin, who is represented as an ally of the doctors at court who wished to promote a fellow southerner. There is no suggestion that religious motives are at work here, 
instead the accusation is one of straightforward corrupt patronage, but it does also illustrate another level of the factional politics that surrounded Gregory. We are told in this account that Gregory of Nisibis was opposed by a faction of doctors and that this prompted their actions at court through Aba of Kashkar. The author (or his informant) has emphasized the role of these men as the villains of a chain of events that link the exile of Gregory of Nisibis, the election of Gregory of Pherat and Khusrau's persecutions.

The gossip about Aba's arrangement of the election may be a fanciful reconstruction of how Khusrau was persuaded to accept the new catholicos, circulating before Khusrau's decisive move against the Church and when criticism was still directed against the shah's advisors (in this case, a faction of court Christians and the queen), rather than against the shah himself. This displacement of blame away from the shah is a recurrent theme of much of the rest of this staccato narrative. The remark that Khusrau was in awe of Gregory is another attempt to explain the shah's willingness to accept the new catholicos, a scenario in which the shah only gradually learns that Shirin has deceived him. And the story in which Khusrau is made aware of Gregory of Pherat's reputation as a greedy philanderer can similarly be read in a way that was positive to the shah, who is imagined to be responding to corruption within the Church. The last paragraph, where Khusrau's extortions against all Christians are represented as a continuation of his attack on Gregory, reflects the final evolution of this gossip, in which older stories directed against the catholicos were bent to make Gregory responsible for the persecutions that occured after his death. Such stories, which probably circulated orally, were then integrated into a text that sought an explanation for events that reached back to the exile of the other Gregory from Nisibis and which built on the more subtle criticism of the catholicosate in the reign of Sabrishoc.

Thus, the Life of Gregory of Nisibis provided a vehicle for a number of different reactions against the close alliance between the court and elements of the Church of the East. The Life of Sabrisho ${ }^{c}$ had asserted the legitimacy of the shah's right to rule in Christian terms, stressing at the same time the importance of his queen Shirin as patron of all the empire's Christians. This image of symbiosis was increasingly challenged by those who were suspicious of Sabrisho"s alliance or who stood outside the patronage circles of court Christians. The metropolitan Gregory of Nisibis, a powerful theologian who had fallen foul of lay and scholastic interests during his attempts to expel Henana from Nisibis, proved a suitable vehicle for those who opposed the court. Babai's Life of Gregory, written around the time of the coerced assembly of 612, was an early example of this criticism, issued at a time when Khusrau was moving towards the Miaphysites. Continuations of this Life would represent Gregory as a crucial link in the transmission of orthodoxy, especially because of the prominence of his disciples Isho' yahb II and Isho'yahb III. The Life itself criticized Sabrisho ${ }^{c}$ for his opposition to Gregory, and this idea was extended

This is an open access version of the publication distributed under the terms of the Creative Commons Attribution-NonCommercialNoDerivs licence (http://creativecommons.org/licenses/by-nc-nd/3.0/), which permits non-commercial reproduction and distribution of the work, in any medium, provided the original work is not altered or transformed in any way, and that the work is properly cited. For commercial re-use, please contact academic.permissions@oup.com 
by historians who redeployed its material, with attacks on the lay elites of Nisibis, court doctors, and the queen Shirin, and which escalated into criticism of the shah (though the latter may in fact be posthumous, after his defeat by the Christian Romans had sealed his fate and his reputation). Their choice of targets suggest that many of these continuations predate the Arab conquests.

However, we should remember that the testimony of these sources, when read together, illustrates the weakness of Gregory's position, and that, to many other Christian groups, he had been a troublemaker, sensibly excluded from power and exiled. It was only the dependence of these other groups of Christians on the influence of Khusrau, and the completeness of his fall, that meant that they did not produce their own alternative versions of events, or that such accounts were not preserved. Instead, figures like Gregory and Babai, who were highly divisive and controversial in their own day, were appealed to as 'bridges' of respectable, orthodox behaviour between the reigns of Isho' yahb I and Isho' yahb II.

Finally, it worth noting that the extreme positions that survive in the source may give a skewed impression of the attitudes of most Christians at the time. One record of 'Christians in the service of Khusrau', written in the light of Arab Islamic exclusion of Christians from influence, would look back fondly on Khusrau's reign and give great prominence to court figures such as Aba of Kashkar, who features as a villain in the section on Gregory of Pherat. ${ }^{90}$ To this later commentator, the confessional and factional divisions of the period would seem irrelevant. Similarly, we should understand Gabriel of Sinjar's support for the Miaphysites as an indication of how far individual laymen, even those at a high level, could switch confessions.

Much modern scholarship has understood Shirin in terms of her 'conversion' from 'Nestorianism' to 'Miaphysitism', partially on the grounds of the ascription of the birth of her son Mardanshah to the help of Gabriel and the survival of accounts in praise of her as a friend of the Christians in Miaphysite sources such as the Armenian account of pseudo-Sebeos. ${ }^{91}$ Above all, the account of the Life of Marutha of Takrit, future maphrian (chief bishop) of the Miaphysites of the East, praises Shirin for her gift of the church of Sergius in Ctesiphon to the Miaphysites. However, we should also remember that the hagiographer's complaint that 'Nestorians' continued to come to worship in the church, that is, that the laity did not observe differences between confessions and that, apparently, these were not enforced by the state. ${ }^{92}$ Church canons, such as the ban on social intercourse with heretics,

90 Chronicle of Seert, II/ii, LXXXI (524-5).

91 Khuzistan Chronicle, 19 and Pseudo-Sebeos, ch. 13 (85): the latter account explains the outbreak of persecution by dating Shirin's death to the middle of Khusrau's reign. This dating is probably false (s.v. 'Shirin', PLRE III).

92 Life of Marutha of Takrit, 74-6. On the spread of the cult of Sergius in Iraq in the last decade of the sixth century, and his popularity among Nestorians as well as Mipahysites, see J.-M. Fiey, 'Les saints Serge d'Iraq', AB 79 (1961), 102-14.

This is an open access version of the publication distributed under the terms of the Creative Commons Attribution-NonCommercialNoDerivs licence (http://creativecommons.org/licenses/by-nc-nd/3.0/), which permits non-commercial reproduction and distribution of the work, in any medium, provided the original work is not altered or transformed in any way, and that the work is properly cited. For commercial re-use, please contact academic.permissions@oup.com 
were only imposed gradually, after Marutha had 'instructed' the laity. ${ }^{93}$ These canons probably opposed not only 'Nestorian' liturgical practices and beliefs, but also 'pagan' practices of court, such as bigamy, which receives particular criticism. This dissatisfaction with the initial situation at Ctesiphon gives us an important insight into how the different confessions interacted. The Miaphysites that surrounded Marutha, a man linked to the monastery of Mar Mattai in Iraq, were trying to impose their own canonical rules on a lay population that did not respect confessional divisions and which might conclude Persian-style bigamous marriages, possibly for political gain. In this sense, these Miaphysite newcomers to Ctesiphon were trying to build boundaries in similar ways to authors of the Gregory tradition, who lumped together their opponents within the Church of the East with external heretics and 'defenders of bigamy'. Furthermore, both Shirin and Gabriel, though they originally came from opposite corners of Iraq, may have been much closer to the norms of Christian behaviour in Ctesiphon and other major cities than Marutha of Takrit or Gregory of Nisibis. Shirin and Gabriel were willing to engage with multiple Christian patronage networks and therefore drew criticism from our clerical sources. They were even willing to employ 'un-Christian' devotional and marriage practices, such as Shirin's donation of a fire temple in Khusrau's memory. ${ }^{94}$ Both Gabriel and Shirin seem prepared to use church connections to expand their influence, but do not seem heavily motivated by ideas of 'theology' or by confessional boundaries.

\section{RIVALS AND SUCCESSORS: CHRISTIAN POLITICAL IDEAS AFTER 612}

The careers of Shirin and Gabriel remind us that lay elites were not necessarily bound by the divisions between Christian confessions that are emphasized in our sources. The competition between other lay elites, this time with the backing of the armed forces of Rome and Persia, confirms this idea that the allegiances of Christians, and the political ideas they employed, were much more divided and complex than a mere difference between Dyophysites and Miaphysites.

As we have seen, Khusrau's prosecution of the war with Rome was accompanied by a concerted effort to legitimize his invasion in terms of appealing to Christian institutions (such as the catholicosate) and to win the loyalty of

93 Life of Marutha of Takrit, 77. See also M. Hutter, 'Shirin, Nestorianer und Monophysiten: königliche Kirchenpolitik im späten Sasanidenreich', in R. Lavenant (ed.), VII Symposium Syriacum (Uppsala, 1998), 373-86 for a clear summary of the material.

94 Shahnameh, VII, 327.

This is an open access version of the publication distributed under the terms of the Creative Commons Attribution-NonCommercialNoDerivs licence (http://creativecommons.org/licenses/by-nc-nd/3.0/), which permits non-commercial reproduction and distribution of the work, in any medium, provided the original work is not altered or transformed in any way, and that the work is properly cited. For commercial re-use, please contact academic.permissions@oup.com 
Miaphysites in 'Roman' Mesopotamia. By acting as a sponsor and adjudicator of Christians, Khusrau was usurping the role traditionally ascribed to the Roman Emperor, whose mandate for rule was stripped away by an illegitimate succession.

Yet, at the same time, it is apparent that other elites within the Sasanian world also sought to assert their own roles as Christian protectors within the empire and beyond it. At a time when the legitimacy of the Roman emperor and the survival of the empire were in jeopardy, Gabriel of Sinjar was praised in the Life of Marutha as 'a new Constantine', and Yazdin was acclaimed as 'a new Constantine' in the Khuzistan Chronicle. ${ }^{95}$ While Takhrid in the Life of Sabrisho' had played a role as the voice of the shah, organizing the Christians for the shah's benefit, other elites developed a more independent reputation in the historical tradition.

\section{THE FALL OF JERUSALEM IN THE KHUZISTAN CHRONICLE}

Yazdin is celebrated in the monastic hagiographies and the Khuzistan Chronicle as a founder of churches. The scion of a Christian family that could trace its ancestry back to fifth-century martyrs in Karka de Beth Slouq, he rose to a powerful position as tax collector and governor of Adiabene and Beth Garmai, the whole of northern Iraq. ${ }^{96}$ Yazdin is said to have been 'famous in both Roman and Persian lands', and his influence beyond Iraq, in the pattern of a Roman emperor, is chiefly seen in the stories connecting him to the fall of Jerusalem in the Khuzistan Chronicle. The Chronicle reports that the general Shahrbaraz was responsible for the initial capture of Jerusalem in 614, and that he tortured monks to find the location of the True Cross which he dispatched back to Ctesiphon. Here, most of the relic was received by Khusrau, but some was also received by Yazdin. This is followed by an account of the fall of city for a second time, which seems to have been a reaction to fighting between Jews and Christians in the city where Sasanian troops were used to restore order. ${ }^{97}$ Though this may have been a 'police action' from the point of view of the shah, it is represented in the Chronicle as a deliberate attack on the Jews in defence of the Christians. The Jews seek to destroy Constantine's church of the

95 Khuzistan Chronicle, 23.

96 T. Nöldeke, Geschichte der Araber und Perser (Leipzig, 1887), 383, note 1; Flusin, Saint Anastase, II, 246-54.

97 The Sasanian occupation of the Roman East has been recently reassessed as a relatively moderate affair: C. Foss, 'The Persians in the Roman Near East (602-630 AD)', Journal of the Royal Asiatic Society series 3, 13 (2003), 149-70.

This is an open access version of the publication distributed under the terms of the Creative Commons Attribution-NonCommercialNoDerivs licence (http://creativecommons.org/licenses/by-nc-nd/3.0/), which permits non-commercial reproduction and distribution of the work, in any medium, provided the original work is not altered or transformed in any way, and that the work is properly cited. For commercial re-use, please contact academic.permissions@oup.com 
resurrection and the burial place of Jesus, but Yazdin oversees the defeat and crucifixion of the Jews and the rebuilding of the churches and monasteries of the city. ${ }^{98}$

Yazdin's actions in Jerusalem took place during the lacuna in clerical authority within Iraq, so that his image as a protector of Christians was independent of any catholicos. His reputation as 'prince of believers', which Thomas of Marga reports, may have even been a quasi-official title. ${ }^{99}$ Yazdin's persecution of Jews and his acquisition of a piece of the True Cross represents a bid to share in the special relationship with Christianity enjoyed by the shah. ${ }^{100}$ The Life of Sabrisho' had described Maurice's gift of the Cross to Sabrisho' and Shirin. The importance of this gift as a symbol of Khusrau's relationship with the Christians and his right to intervene in the Roman world is further indicated by the continuation of the Life, where Yazdin's earlier failure to acquire a piece of the Cross is specifically noted. Yazdin's success here may be a true story, whereby Yazdin was able to acquire a piece of the prestigious relic in an era when there was no reigning catholicos, or a fiction, in which the capture of Jerusalem was used as an opportunity to emphasize Yazdin's importance. At any rate, either analysis has important consequences from the perspective of Khusrau's court. It indicates both that Yazdin and groups of court Christians remained significant (even if some authors contested the power of Yazdin as an individual) and that Khusrau was still keen to show his power to the Christians of Ctesiphon after the dissolution of the catholicosate. Khusrau's martyrdom of individual troublemakers, his dissatisfaction with Gregory of Pherat and his taxation of Church property need not represent systematic and wholesale persecution, but rather an attempt to remove traditional clerical privilege and hierarchies, and the application of a heavy tax regime in time of war. And Yazdin in particular seems to have benefited from this policy, at least in the short term. In sum, the seizure of the True Cross can be seen as an effort to redefine the centre of the Christian world as Ctesiphon, and to assert the Roman emperor's loss of a religious mandate to rule, rather than a Zoroastrian-inspired attack on an opposing religion.

98 Khuzistan Chronicle, 25-7.

99 Book of the Governors, I, xxiii (47/82).

100 Christian pressure on the Jews of the Levant was a marked feature of Heraclius' reign. Note especially the discussions of Stoyanov, Defenders and Enemies, 47-57 and 68-70; Sarris, Empires of Faith, 258 and D. Olster, Roman Defeat, Christian Response and the Literary Construction of the Jew (Philadelphia, 1994), 72-98. Yazdin's behaviour in Jerusalem may be read in the context of growing antipathy to the Jews by Christians in the Roman Empire. On the background to this in the West Syrian world also note Wood, We Have No King but Christ, chapters 4-6.

This is an open access version of the publication distributed under the terms of the Creative Commons Attribution-NonCommercialNoDerivs licence (http://creativecommons.org/licenses/by-nc-nd/3.0/), which permits non-commercial reproduction and distribution of the work, in any medium, provided the original work is not altered or transformed in any way, and that the work is properly cited. For commercial re-use, please contact academic.permissions@oup.com 


\section{THE FALL OF JERUSALEM IN ANTIOCHOS STRATEGOS}

However, this representation of events should be read against very different accounts that came out of Roman Chalcedonian sources. Even in the Khuzistan Chronicle, Shahrbaraz's actions in torturing the monks seem to stem from Roman black propaganda that found a receptive audience in Eastern authors opposed to Khusrau's general and sometime opponent and successor. ${ }^{101}$ The lamentations of the Palestinian monk Antiochos Strategos, preserved in Georgian and Arabic from a Greek original written in the aftermath of Heraclius' victory, record how the Persians,

who had no pity in their hearts, raced to every place in the city and with one accord destroyed all the people... Lamentation and terror were seen in Jerusalem. Holy churches were burned with fire, others demolished ... sacred crosses trampled underfoot, life-giving icons spat upon by the unclean. Then their wrath fell upon priests and deacons: they slew them in their churches like dumb animals. ${ }^{102}$

Furthermore, the conflict between Jews and Christians in the city is represented as a Jewish alliance with the Persians, whereby the Persians hold the Jews in high regard as betrayers of the Christians and sell Christian prisoners to the Jews to be killed, 'just as they had bought the Lord with silver'. ${ }^{103}$

A group of priests, led by the patriarch Zachariah, are taken to Ctesiphon, and made to kneel, 'not before a Roman emperor, but before the shah Khusrau'. Here Zachariah outwits Khusrau's chief mobad in a public debate and the shah has the mobad executed. After this display, the author's informant, one Abba Symeon, reports that the courtiers began to show much reverence for Zachariah and that he and other exiles were taken as guests by one of the wives of Khusrau, 'a Christian in name, but a follower of the heresy of Nestorius, the impious and despised of God'. This queen receives the exiles in her palace alongside the True Cross, which Khusrau had bestowed on her as a gift. As an exile in Ctesiphon, Symeon also reports that Zachariah defeated a plot by the Jews to accuse him of fornication and successfully cured the queen's infertility, allowing her to have a child. ${ }^{104}$

The core of the text clearly focuses on the image of the Persians as pagans, and this image is preserved by the account of Zachariah's exile. But this account, which Antiochus ascribes to Symeon, show us that Zachariah's

101 Khuzistan Chronicle, 26-7.

102 Antiochos Strategos, 507. Also see the comments of B. Wheeler, 'Imagining the Sasanian capture of Jerusalem', OCP 57 (1991), 69-85; Averil Cameron, 'Blaming the Jews: The seventhcentury invasions of Palestine in context,' T\&M 14 (2002), 57-78; Averil Cameron, 'The Jews in seventh-century Palestine', Scripta Classica Israelica 13 (1994), 75-93.

103 Antiochos Strategos, 508.

104 Antiochos Strategos, 512-14.

This is an open access version of the publication distributed under the terms of the Creative Commons Attribution-NonCommercialNoDerivs licence (http://creativecommons.org/licenses/by-nc-nd/3.0/), which permits non-commercial reproduction and distribution of the work, in any medium, provided the original work is not altered or transformed in any way, and that the work is properly cited. For commercial re-use, please contact academic.permissions@oup.com 
prestige also played the role of the Christian holy man at court, one that had long been established in the Syriac hagiographies of the Church of the East and popularized in Greek translation. Zachariah has developed several of the characteristics of Eastern saints, as a debater against the mobads and the Jews and as the healer of the queen, although her orthodoxy is denied. Though the text presents Zachariah as an exile in Ctesiphon, with Khusrau as a new Nebuchadnezzar, his visit might in fact have been an attempt to negotiate with Jerusalem's Chalcedonian hierarchy (or at least to remove local leaders during a politically sensitive period). Reading between the lines, Symeon's stories show Zachiariah behaving according to an Iraqi model, asserting the importance of Jerusalem's Chalcedonians in Khusrau's new empire. ${ }^{105}$ It may be that, in reality, Shirin played an important role in arranging the visit of the Jerusalem clergy, which might account for the shrill denunciation of the queen as a heretic and a collaborator in a pagan plan to remove the True Cross. Read against the grain, the text confirms our impression that, by acquiring the Cross, Khusrau was attempting to enhance the status of Ctesiphon and that, working through Shirin, he was also willing to reach out to all Christian groups that were willing to cooperate.

The stories of Zachariah as the healer of Shirin suggest that the Jerusalem Chalcedonians may have become willing participants in this symbiosis. Zachariah's miracles challenge the claims of other confessions, in particular the association between Gabriel of Sinjar and the birth of Shirin's son Mardanshah, but they also show that this competition in the court was centripetal, uniting all three major Christian confessions in a discourse that emphasized debates judged at court and miracles and prayers for the shah's benefit.

However, these accounts of court miracles are embedded within a text that focuses on the Persians as agents of persecution and presents them as allies of the Jews and despoilers of the holy sites. ${ }^{106}$ The Khuzistan Chronicle reworked Khusrau's capture of Jerusalem to present his servant Yazdin as the protector of Christians and enemy of the Jews, but for Antiochos this history has been inverted and almost all the Persians are straightforwardly presented as pagans.

105 We have already seen Christian debates against the Magi as a major theme of sixthcentury hagiography (see chapter 4). The healing of royal figures is a major feature of several accounts. Those that occurred during Marutha's embassy may be the most famous: Socrates, $H E$, VII.8; Armenian Life of Marutha 7 (62). Opposition to Jews at court is a less prominent theme, but it is found in the accounts of fourth-century martyrs, the Acts of Symeon and the Acts of Tarbo (esp. 254).

106 Anti-Jewish rhetoric is the common theme for all these Jerusalem accounts. Chronicle of Seert, I/i, XIV (272-3) tells the story of Khusrau seizing the Cross and giving it to Shirin, and Heraclius' subsequent recapture, in a section dedicated to the fourth-century discovery of the Cross and the anti-Jewish Legend of Judas Kyriakos. See further J.-W. Drijvers and H. J.W. Drijvers, The Finding of the True Cross: The Judas Kyriakos Legend in Syriac: Introduction, Text and Translation (Leiden, 1997).

This is an open access version of the publication distributed under the terms of the Creative Commons Attribution-NonCommercialNoDerivs licence (http://creativecommons.org/licenses/by-nc-nd/3.0/), which permits non-commercial reproduction and distribution of the work, in any medium, provided the original work is not altered or transformed in any way, and that the work is properly cited. For commercial re-use, please contact academic.permissions@oup.com 
Essentially, the complexity of a religiously and politically divided Christian world has been forgotten for the purposes of polemic.

The Palestinian accounts of bloodshed fit into a broader pattern of Heraclian propaganda that would restore the cultural initiative to the emperor and present him as a ruler of all Christians, helped by God in his war against God's enemy. By specifically targeting fire temples during his invasion of Iraq, and circulating accounts of Christian martyrs under Khusrau (most notably the converted soldier Anastasius), Heraclius and his allies presented a black-andwhite view of the war as a war between religions. However, we should remember that this view was a construction of the late 620s; that it was an instrument for Heraclius' success and that its preservation a result of this same military success. ${ }^{107}$

\section{THE MURDER OF KHUSRAU}

Heraclius' invasion of Iraq in 628 was the occasion for a palace coup against the shah, in which a group of nobles replaced Khusrau with Kavad Shiroë, his son by his Greek wife Maria. ${ }^{108}$ Several different versions of Khusrau's death circulated in the Eastern sources, suggesting both confusion about the actual events and the different representations of the shah that were spread by his competing successors. These accounts reflect the protean political situation, in which the legacies of Heraclius and Khusrau were unclear throughout the death-throes of the Sasanian Empire.

For the Muslim Arabic compilations, Khusrau's fall was chiefly the product of internal dissension within the court rather than of the actions of Heraclius, a perspective that may have flattered Shiroë and the noble conspirators. For them, it was Khusrau's long war that led to his fall, and al-Tha 'alibi makes this the crux of Shiroë's accusation, of keeping soldiers away from their wives and children. This report makes Shiroë merciful, but he is forced to kill Khusrau by

107 J.-W. Drijvers, 'Heraclius and the restitutio crucis: notes on symbolism and ideology' in Reinink and Stolte, The Reign of Heraclius, 175-91, notes that the focus on the Cross is only seen after Khusrau's death and is absent from the poems of George of Pisidia, Heraclius' official poet. A. Frolow, 'La vraie croix et les expéditions d'Héraclius en Perse', Revue des études Byzantines 11 (1953), 87-105, at 99, observes that Heraclius distributed fragments of the Cross in Armenia, so perhaps Heraclius expropriated Khusrau's earlier emphasis on the Cross in an attempt to win over former allies of the shah in the Caucasus. Also note Flusin, Saint Anastase, II, 312-19 and D. Frendo, 'The religious factor in Byzantine-Iranian relations', BAI 11 (1997), 105-23.

108 Chronicle of Seert, II/ii, LVIII (466-7) is confused over whether Maria and Shirin are the same person, but the ascription of different church buildings at the end of the passage to each queen implies that they are indeed distinct. On Maria as Maurice's daughter see al-Tabari, I, 991, though Dignas and Winter, Rome and Persia, 230 are sceptical of this association, which does not occur in any Roman sources. See the entries in PLRE III on 'Shirin' and 'Maria 6'.

This is an open access version of the publication distributed under the terms of the Creative Commons Attribution-NonCommercialNoDerivs licence (http://creativecommons.org/licenses/by-nc-nd/3.0/), which permits non-commercial reproduction and distribution of the work, in any medium, provided the original work is not altered or transformed in any way, and that the work is properly cited. For commercial re-use, please contact academic.permissions@oup.com 
the marzban and the generals: 'There cannot be two swords in a scabbard or two shahs in Eranshahr.' Al-Tha' alibi reports that Khusrau was killed by 'a wretched man' who is later killed by Shiroë, and he does not identify the anonymous nobles who orchestrate the shah's death and then those of his other sons. ${ }^{109}$ For al-Tha' alibi, there was no prestige to be gained from being remembered as Khusrau's killer, and Shiroë's behaviour is explained as a constraint of fate.

Al-Tabari's account is more extensive and provides prosopographical details. Here Shiroë is forced to act by men of power, Fayruz and Shamta, son of the great Christian aristocrat Yazdin, but his accusations against Khusrau are much more extensive. ${ }^{110}$ The accusation scene presents an opportunity for the author to gather together the various allegations he knew to have been made against Khusrau and rebut them. Several of these mirror the criticisms in al-Tha'alibi, of excessive taxation, hoarding wealth and the long service of soldiers, which are credible charges after two decades of fighting. But other allegations are likely to be products of authors reflecting on the (often mythical) tales of Khusrau in the historical tradition: his murder of Hormizd, his imprisonment of his sons, his treatment of women and his theft of the True Cross. ${ }^{111}$ In particular, the accusations relating to the Cross are anachronisms and are connected to the importance that the Cross assumed in the reigns of Shiroë's son, Ardashir III (d.629), and Shahrbaraz (d.630), for whom the return of the Cross was a leitmotif of their Roman policy.

A slightly different version of the same events is preserved in the Eastern Christian sources. The Khuzistan Chronicle shares several basic features with the narrative of al-Tabari, such as Khusrau's capture in a garden, but, despite its brevity, the earlier Syriac text also provides incidental details that the other texts lack (e.g. the name of Mihraspand, the garden's owner). It names Shamta and Nehormizd as the chief conspirators-the difference with al-Tabari may simply be a matter of one individual known by two names. Interestingly, it reports that Shamta was unable to kill the shah and that Nehormizd had to do the deed, an account that may reflect publicly witnessed events, or a later wish to distance Shamta from the event after his later falling out with Shiroë. The Khuzistan Chronicle reports this dispute in the next scene, when Shamta is forced to flee to Hira, where he remains in hiding until he is captured and executed in the reign of Shahrbaraz. ${ }^{12}$

The later account of Thomas of Marga gives Shamta a much larger role, as the sole conspirator against Khusrau, and Shiroë's kingmaker. Thomas

109 Al-Tha' alibi, 722-7.

110 Yazdin had died before this point, possibly executed by the shah. See Flusin, Saint Anastase, II, 252.

${ }^{111}$ Al-Tabari, I, 1046-58. $\quad{ }^{112}$ Khuzistan Chronicle, 28-9.

This is an open access version of the publication distributed under the terms of the Creative Commons Attribution-NonCommercialNoDerivs licence (http://creativecommons.org/licenses/by-nc-nd/3.0/), which permits non-commercial reproduction and distribution of the work, in any medium, provided the original work is not altered or transformed in any way, and that the work is properly cited. For commercial re-use, please contact academic.permissions@oup.com 
ignores any strife between Shiroë and Shamta, and focuses instead on Shiroë's restoration of the catholicos and Khusrau's role as an enemy of Christianity: 'Shamta went into Khusrau's quarters with his servants and killed him, and there was peace for the churches' ${ }^{113}$ Both of the Christian accounts play up the role of Shamta (as does al-Tabari, possibly drawing on Christian sources) but Thomas's account may reflect rumours early in Shiroë's reign when Shamta's supporters were proud of his role in defeating the tyrant Khusrau. The later collapse in relations between Shiroë and Shamta may have led to these same supporters emphasizing instead the role of Nehormizd, in an effort to defend the reputation of Shamta and his family.

The account of the Chronicle of Seert represents yet another source in the same tradition, where events in Ctesiphon, seen from an Iraqi perspective, have been combined with a simple account of the war and Heraclius' advance. The Chronicle makes Shamta's coup a reaction against Khusrau's appropriation of Yazdin's wealth, and presents him as a ringleader, along with other unnamed 'marzbans'. But, unlike the other accounts, this author focuses on Shiroë's reign, on how he reduced taxes and ruled wisely. This account of Shiroë as a just king accords with other impressions of Shiroë's reputation: the Book of the Crown, an Abbasid-era etiquette collection, praises Shiroë for his low taxes and improving the access of the people to the shah. ${ }^{114}$ But the Chronicle's account goes one step further by making the just king a secret Christian, who kept a piece of the Cross round his neck, established peace, and restored the catholicos. ${ }^{115}$

Unlike the account in Thomas, the Chronicle is clearly in favour of Shiroë rather than Shamta: it emphasizes Shamta's role in killing Mardanshah, the son of Shirin, and implies that Shamta's subsequent flight and imprisonment are suitable rewards for his actions. Where Shamta's deeds are explained by Realpolitik, the author finds piety and justice much more significant character traits in accounting for Shiroë's actions. Like Khusrau and Shirin, Shiroë seems to have deliberately cultivated a public relationship with Christian holy men, and the same section also celebrates the birth of Ardashir III through the intervention of Babai of Nisibis. The presence of such hagiographical notices in a Christian account of Shiroë's coup suggests the effectiveness of his public display of support for Christians, as well as of the hints of complete conversion that the shah may have also given. ${ }^{116}$ Moreover, this is also clearly a contemporary report: since Shiroë and Ardashir would be dead within sixteen months, the account of Babai's miracle and Shamta's fall were probably composed in Shiroës own reign.

113 Book of the Governors, I, xxxv (63/114).

114 Pseudo al-Jahiz, Kitāb al-tāj (tr. Pellat), 133 for Shiroë's coronation speech.

115 Chronicle of Seert, II/ii, XCII (551). $\quad{ }^{116}$ Chronicle of Seert, II/ii, XCII (552).

This is an open access version of the publication distributed under the terms of the Creative Commons Attribution-NonCommercialNoDerivs licence (http://creativecommons.org/licenses/by-nc-nd/3.0/), which permits non-commercial reproduction and distribution of the work, in any medium, provided the original work is not altered or transformed in any way, and that the work is properly cited. For commercial re-use, please contact academic.permissions@oup.com 


\section{THE REIGN OF SHAHRBARAZ}

The Chronicle's account of Khusrau's fall and Shiroë's accession seems to have been based around stories that circulated in Shiroë's reign itself. But the section that follows it (XCIII) has been much more heavily overwritten, uniting a narrative of political history with an account of the controversial reign of the new catholicos Isho'yahb II. Its Hijri dates suggest a point of composition in the tenth century. At any rate, the author of this section has sought to unite and unify different histories into the structure based around the reign of the catholicos, in a way that is not apparent in the previous section.

The account opens by describing Shiroë's role in the election of the new catholicos and lamenting his death from the plague at Hulwan. The alternative story it reports, of his poisoning by Shirin in revenge for the death of Mardanshah, has the mark of the later development of Shirin as a heroine in the later Muslim tradition. The compiler has included this story as another plausible explanation of Shiroë's death. In a slightly confused sequel, the section continues by recounting how Shahrbaraz was summoned from the Levant, where he was in the service of Heraclius, and how he returned to Iraq with Roman troops, led by one David, to defeat and kill Ardashir. After defeating a revolt by one of his generals, Shahrbaraz honours the 'Greeks' who had helped him and returns the True Cross to Heraclius. Finally, he executes Shamta, before he in turn is killed by one of the relatives of Khusrau. ${ }^{117}$

Shahrbaraz is not portrayed favourably in al-Tabari either: he kills the high nobility and rapes their wives before being hacked down on the paradeground by his cavalry officers. ${ }^{118}$ Similarly, the Greek historian Theophanes numbers the sons of Shahrbaraz amongst Khusrau's assassins, and the Shahnameh makes Shahrbaraz ('Goraz') one of the three men of state responsible for Khusrau's fall. ${ }^{119}$

In addition to this direct role in the assassination, Shahrbaraz was also seen as responsible for Khusrau's fall by remaining in the Levant and refusing to move his army to help the shah. Several sources explain this through the motif of an intercepted letter, by which the general learns of a plot against him by the shah, sometimes thanks to the Roman emperor, and defects to the Romans or begins to oppose the shah. ${ }^{120}$ If we accept the idea of a secret arrangement between Shahrbaraz and Heraclius in 626, then this may underlie his later opportunism in 629-30, when he acquired Roman support for a second putsch

117 Chronicle of Seert, II/ii, XCIII (554-6). Cf. Khuzistan Chronicle, 29-30.

118 Al-Tabari, I, 1062.

119 Theophanes (tr. Mango and Scott, 454, ed. de Boor, 326); Shahnameh, VII, 269-83.

120 D. Frendo, 'Byzantine-Iranian relations before and after the death of Khusrau II: a critical examination of the evidence', BAI 14 (2000), 27-47.

This is an open access version of the publication distributed under the terms of the Creative Commons Attribution-NonCommercialNoDerivs licence (http://creativecommons.org/licenses/by-nc-nd/3.0/), which permits non-commercial reproduction and distribution of the work, in any medium, provided the original work is not altered or transformed in any way, and that the work is properly cited. For commercial re-use, please contact academic.permissions@oup.com 
in Ctesiphon, which Mango suggests was connected to the conversion of the new shah to Christianity and greater territorial concessions. ${ }^{121}$

The prominence of the Roman general David in the account of the Chronicle of Seert is the lynchpin of Mango's analysis here, around which the Greek and Syriac sources fall into place. The Chronicle's account highlights Shahrbaraz's transfer of the Cross to Heraclius: it presents Shahrbaraz as a Roman client, accepting Roman claims to Christian universal rule. Shahrbaraz's relationship with Christianity seems to have been pragmatic: though he had his sons baptized he was unrestrained in killing other Iranian elites who had courted Christian legitimacy. Where Shirin had provided an instrument for Khusrau to interact with and control Christians in Iraq at one remove, the nature of the relationship had changed by Shiroë's reign, when the shah gave direct patronage and support to Christians much more openly and personally. Under Shahrbaraz this relationship changed again, as the shah's Christianity became closely associated with his rule as a non-Sasanian Roman client.

However, for the family of Yazdin, the emergence of shahs who were engaged in more direct displays to Iraqi and Roman Christians removed the need for Shamta as an interlocutor in the style of Takhrid or Yazdin. Shamta's involvement in the regicide made him an easy scapegoat for first Shiroë and then Shahrbaraz, as well as adding to suspicion of him as a potential candidate for shah himself. For one author employed in the Chronicle of Seert, this dispute between Shamta and Shahrbaraz was a defining narrative of the era, and their personal animosity was imagined to be the root of Shahrbaraz's defection from Khusrau. ${ }^{122}$

\section{CONCLUSIONS}

The final part of Scher's edition of the Chronicle of Seert shows, by its very density, the importance of the events of Khusrau's reign and its aftermath for the Christians of the Sasanian world. On one hand, this profusion of material is a sign of Christians' increased political prominence, and the wish of contemporaries to integrate secular and religious historical narratives, as well as to understand an ever-shifting relationship with the Romans. But on the other, the density of the accounts is also a product of a diversity of perspectives, both on what constituted religious orthodoxy and on where authority lay for Sasanian Christians, especially in the era when the catholicos was suppressed.

The potential rewards of political involvement and the uncertain relationship between different Christian leaders, the shah, and the Romans produced

121 C. Mango, 'Deux études sur Byzance et la Perse Sasanide’, Tઐ 99 (1985), 93-118.

122 Chronicle of Seert, II/ii, LXXXVII (540-1).

This is an open access version of the publication distributed under the terms of the Creative Commons Attribution-NonCommercialNoDerivs licence (http://creativecommons.org/licenses/by-nc-nd/3.0/), which permits non-commercial reproduction and distribution of the work, in any medium, provided the original work is not altered or transformed in any way, and that the work is properly cited. For commercial re-use, please contact academic.permissions@oup.com 
numerous different claims to leadership, both ecclesiastical and secular. Many of these claimants left their imprint in the histories of the period, which were then messily stitched together in later generations. The reign of Sabrisho' saw the involvement of the court in producing an image of Khusrau and Shirin as the sponsors and protectors of an obedient catholicos. But this image became increasingly damaged as Khusrau turned his patronage towards the Miaphysites, a volte-face that benefited the opponents of doctrinal or political compromise, such as Gregory of Nisibis.

In a similar vein, we find that lay Christian figures each have their own partisans. Historians' judgement of these men varies greatly depending on their assessment of Khusrau. Even after his death, debate over his reputation dominated the interpretation of the deeds of other political actors, such as Shiroë, Shamta, and Shahrbaraz. For a Christian historical tradition that had focused hitherto on the deeds of catholicoi and monks, the reign of Khusrau II was a period that demanded new ways of thinking about the (recent) past and its ramifications in the present. 


\section{8}

\section{The Church of Baghdad: A New Past for Christian Iraq}

The Chronicle of Seert presents a very dense narrative for the period between the accession of Hormizd IV and the death of Khusrau II and its aftermath. This period, from c.590-630, represented a time of change for the leaders of the Church of the East, both high-ranking clergy and leading aristocrats. And they, and their supporters, wrote a number of different histories of the period, both as events took place and after the dust had settled, at a time when various rival paths of succession could be traced between the reign of Sabrisho ${ }^{c}$ and those of Isho' yahb II and Isho' yahb III.

For the reign of Khusrau II, we have been able to use the Chronicle of Seert to trace the different political stances taken by churchmen during this difficult time, in part because of these disagreements over authority. This rich and varied perspective is stopped abruptly with the termination of the Chronicle shortly before the section on Isho' yahb III. However the Chronicle, like those of 'Amr and Mari, was a product of the Abbasid caliphate, and was much more than a mere translation of earlier Syriac sources. I have suggested that the compilers' attitudes were normally conservative, and that many sections make sense as pre-Islamic compositions, although the text is in Arabic. Yet, as Robert Hoyland has observed, the text also periodically looks forward to the Islamic era, especially in its anachronistic use of place names and ecclesiology, calling Nineveh after the nearby seventh-century foundation of Mosul and anticipating the foundation of the Abbasid capital of Samarra. ${ }^{1}$

Some parts of the Chronicle of Seert can be compared to contradictory accounts in other, earlier texts in Syriac from the Church of the East. These seem to be historical inventions that correspond more closely to the political and cultural agenda of Christians in Abbasid Baghdad than to their predecessors.

${ }^{1}$ For Mosul see e.g. Chronicle of Seert, II/i, XII (125); XXXVIII (197). It is anachronistically called a metropolitanate at II/ii, XCIX (597). Sometimes the Chronicle's source is aware of the distinction between Mosul and Nineveh, as at II/ii, CVIII (630), where Mosul is reserved as a term for the region, and at II/ii, CVII where the source describes the foundation of Mosul and Kufa. For Samarra see II/ii, XLVII (450-1). See further Hoyland, Seeing Islam, 443.

This is an open access version of the publication distributed under the terms of the Creative Commons Attribution-NonCommercialNoDerivs licence (http://creativecommons.org/licenses/by-nc-nd/3.0/), which permits non-commercial reproduction and distribution of the work, in any medium, provided the original work is not altered or transformed in any way, and that the work is properly cited. For commercial re-use, please contact academic.permissions@oup.com 
This final layer of additional material, like the material produced around the end of the sixth century, does not merely represent the continuation of the account of the deeds of the catholicoi, but also encompasses the elaboration of earlier sections of a universal history to suit a later political context. As they had done at the end of the Sasanian period, Iraqi ecclesiastical historians retrojected the history of the Church of the East to reflect changing contemporary realities in the context of close relations with a new political power. In so doing, they incorporated hagiographic material relating to fourth-century Egypt, to the reign of Constantine and to pre-Islamic Arabia, giving their church a more respectable pedigree in a background of debate between Christians, Jews, and Muslims, and between Nestorians, Melkites, and Jacobites.

\section{AN INDIAN SUMMER}

The reconstruction of how and when this final cohort of new material was added to the earlier historical tradition must be understood against the changing political context of Islamic rule. The shorter compilations of Mari and 'Amr leave a broad impression of the reduced intensity of historical composition in the generations that followed the conquests.

The Arab invasions saw the rapid disintegration of the Sasanian state, as rival shahs tried and failed to organize lasting resistance to the Arabs. Significantly, many of the lower ranked lords, the dihqäns, seem to have gone over to the Muslims and retained a measure of their influence. But the empire-wide institutions of the Zoroastrian Magi, who served as state-sanctioned bureaucrats and judges, withered away in the course of the seventh and eighth centuries. As Michael Morony has observed, Zoroastrianism was a religion closely aligned to the Sasanian state, and when this state failed it ceased to retain its former importance, especially beyond its heartlands in Fars. ${ }^{2}$

Yet this period did not see immediate, rapid conversion to Islam: the Arab invaders were, at least initially, cloistered away in mișrs, new foundations divided along tribal lines where Arab settlers were paid from the booty gathered in war and the taxes raised from the settled population. The most famous of these cities were Basra and Kufa in southern Iraq, adjacent to the sites of Sasanian Perat de Maishan and Hira, but they also included Mosul (adjacent to Sasanian Nineveh), Shiraz, and Merv. ${ }^{3}$ This settlement process, in

2 Morony, Iraq, 300-2.

${ }^{3}$ Kennedy, 'From shahrestan to medina', 23-7. Also note Morony, Iraq, 52 on the distribution of taxes as payment to the troops in Basra. On Shiraz see D. Whitcomb, Before the Roses and the Nightingales: Excavations at Qasr-i Abu Nasr, Old Shiraz (New York, 1985).

This is an open access version of the publication distributed under the terms of the Creative Commons Attribution-NonCommercialNoDerivs licence (http://creativecommons.org/licenses/by-nc-nd/3.0/), which permits non-commercial reproduction and distribution of the work, in any medium, provided the original work is not altered or transformed in any way, and that the work is properly cited. For commercial re-use, please contact academic.permissions@oup.com 
which certain older locations were favoured as sites of settlement and represented centres for tax collection and the redistribution of wealth, probably made Islamic Iraq more focused on fewer individual cities than the region had been in Sasanian times. ${ }^{4}$ But it also meant that, at least in the short term, the land beyond the cities was left relatively ungoverned by the new Muslim conquerors: here the dihqāns, Zoroastrian, Christian, and newly Muslim, appear to have been given free reign, in what Chase Robinson has termed the 'Indian summer' of the Sufyanid period, when the 'jihad state' was focused on the prosecution of war, rather than on the administration and settlement of the conquered lands. ${ }^{5}$

In some ways the absence of the Sasanian state, and of its support for Zoroastrian mobads, seems to have allowed a religious free market that was highly advantageous for seventh-century Christians. This was the era of John of Daylam's missions into Fars and the foothills of the Caspian, where the saint is said to have spread Christianity into new, Persian-speaking regions that formerly lay beyond the missionary scope of the church. ${ }^{6}$ And monastic hagiographies, of the kind that are embedded in the Chronicle of Seert, report an increase in the conversion of polytheists in the former Sasanian world in the aftermath of the conquest. ${ }^{7}$ The impressive extent of these missions beyond the borders of the old empire is testified by the famous bilingual inscription at Xi'an, written in Chinese and Syriac in 781, which commemorated the beginning of the church's presence in the Far East in $635 .{ }^{8}$ Moreover, the advantages of this 'free market' were not limited to Christians: the same era also saw the re-establishment of contacts between Manichees in Iraq and Central Asia and attempts to reunite the two groups under a single archegos, who eventually converted the Uyghur Turks to the 'good religion' in $762 .{ }^{9}$

The seventh century also allowed great freedom to the local government of the conquered lands, which, in former Roman territories and parts of Iraq, often remained in the hands of Christian elites. In Egypt, Christian aristocrats used the opportunity afforded by the absence of the Roman state to levy much higher taxes on their subjects, and in Iraq, aristocrats benefited in a similar

${ }^{4}$ Kennedy, 'From shahrestan to medina', 22-3.

${ }^{5}$ C. Robinson, Empire and Elites after the Muslim Conquest: The Transformation of Northern Mesopotamia (Cambridge, 2000), 50-62; For early Islamic prohibitions on purchasing the sawäfi, (in this instance) the conquered land of the alluvial plain of southern Iraq, the sawäd, see M. Kister, 'Land, property and jihad: a discussion of some early traditions', JESHO 34 (1991), 270-311.

${ }^{6}$ Life of John of Daylam, 19, 25, and 39.

7 Chronicle of Seert, II/ii, LXXVI (516) for the Kurds near Izla; XCVII (587-8), for the Khurasanis of 'Ain al-Namir; CIX (631) for two pagan villages near Shahrzur.

${ }^{8}$ Baumer, The Church of the East, 168-74 (on Central Asia) and 179-86 (on China); E. de la Vaissière, Sogdian Traders: A History (Leiden/Boston, 2005), 314-15 on the ninth-century peak of this Nestorian presence in the East.

${ }^{9}$ F. de Blois, 'Zindik', in EI2.

This is an open access version of the publication distributed under the terms of the Creative Commons Attribution-NonCommercialNoDerivs licence (http://creativecommons.org/licenses/by-nc-nd/3.0/), which permits non-commercial reproduction and distribution of the work, in any medium, provided the original work is not altered or transformed in any way, and that the work is properly cited. For commercial re-use, please contact academic.permissions@oup.com 
fashion, forcing vulnerable smallholders to appeal to the catholicos Henanisho ${ }^{c}$ for his intervention. ${ }^{10}$ In this environment of light government surveillance, the elites of the former Sasanian empire might operate as tax collectors for the Muslims, while taking a substantial additional income for themselves and expropriating the former crown lands of the shah as their own private possessions. ${ }^{11}$

It is in this same period of relative absence of external interference that commentators have also placed a growth in the judicial power of bishops over their communities, as they stepped in to fill the vacuum left by the state. John of Phenek (c.690), the apocalyptic writer, objects both to the worldliness of bishops in this period, 'clamouring like princes ... being caught up in public affairs and unlawful dispute', and to the absence of any constraints on the activities of heretics, the consequence of an undesirable and novel freedom of religion. ${ }^{12}$ John provides a negative gloss on the retreat of the Sasanian state and older channels for administering justice and enforcing boundaries, but it is clear that this arrangement benefited many of his coreligionists: missionaries, aristocrats, and bishops. These last, as Payne has observed, developed an important role as arbitrators invoking the norms of late Sasanian practice to suit the requirements of a Christian Iranian elite, in an environment where the Sasanian state itself no longer existed as a rival. ${ }^{13}$

\section{THE CATHOLICOI AND THE ARABS}

The relative political vacuum of the seventh century witnessed Isho' $y$ ahb III's great reform of the liturgy and his affirmation of Babai's Christology, with the condemnation of Sahdona and his compromise formula. ${ }^{14}$ Isho 'yahb's reign also saw extensive efforts to assert the authority of the catholicos over other bishops, most notably the sees of Fars and Beth Qatraye (the Persian Gulf),

${ }^{10}$ In general see C. Robinson, Empire and Elites after the Muslim Conquest: the Transformation of Northern Mesopotamia (Cambridge, 2000), 91-17. For Egypt, John of Nikiu, CXXI, 5 for the excessive taxation of the aristocrat Menas, theoretically acting on behalf of the Muslims. See also P. Sijpesteijn, 'Landholding patterns in early Islamic Egypt', Journal of Agrarian Change 9 (2009), 120-33 on the retention of Christian pagarchs until the Marwanid period. For Iraq, see R. Payne, Christianity and Iranian Society, 233-5.

11 See Morony, Iraq, 113 and 205. For the use of dihqāns to collect taxes, al-Tabari, II, 458 and for the use of the Christian 'Ibad of Hira, Synodicon Orientale, 225.

${ }^{12}$ John of Phenek (ed. and tr. Mingana), 148-9/176-7.

13 Payne, Christianity and Iranian Society, 191-235. Also see Wood, We Have No King but Christ, 262 on material prosperity and academic production in Mesopotamia.

14 J.-M. Fiey, Mossoul chrétienne: essai sur l'histoire, l'archéologie et l'état actuel des monuments chrétiens de la ville de Mossoul (Beiruit, 1953), 127-8; J.-M Fiey, 'Isho'yaw le grand', OCP 35-6 (1969-70), 305-33 and 15-46.

This is an open access version of the publication distributed under the terms of the Creative Commons Attribution-NonCommercialNoDerivs licence (http://creativecommons.org/licenses/by-nc-nd/3.0/), which permits non-commercial reproduction and distribution of the work, in any medium, provided the original work is not altered or transformed in any way, and that the work is properly cited. For commercial re-use, please contact academic.permissions@oup.com 
and to restructure the church through the creation of new bishoprics for Central Asia, India, and China. ${ }^{15}$

Isho yahb sought to position himself as an orthodox leader in the mould of Babai, and his letters show a him eager to intervene in local disputes and to publicize his Dyophysite vision, firmly opposed to the Miaphysites of Takrit or to compromise formulae. And his self-presentation as liturgical reformer, monk of Izla, aristocrat, and scion of Babai the Great may all have left their traces in the histories of the previous decades that we have just examined: it is for his reign that Mari notes 'the beginning of the composition of ecclesiastical histories'. ${ }^{16}$

However, we should also be aware that Isho' yahb, and his successor Giwargis (661-80), were themselves members of aristocratic, landowning families, and that their powers to organize synods or to exclude opponents must have rested in part on their influence with other aristocrats. ${ }^{17}$ Giwargis attempted to continue Isho'yahb's efforts to retain authority over Fars, holding a synod at Dairin in Beth Qatraye in 676, but he seems to have met with resistance from other bishops and aristocrats. ${ }^{18}$ Some of these, Bar Hebraeus narrates, reported him to the Arab governor for collecting tithes, prompting him to imprison the catholicos and destroy churches in Kufa to encourage him to give up his wealth. ${ }^{19}$

Following 'Abd al-Malik's victory over his rivals in Iraq and the Hijaz in the course of the second fitna (civil war), the Marwanid caliphate adopted much more centralized state structures, most notably in a tax census, and in the expansion of infrastructure. ${ }^{20}$ At the same time, the caliphate also began to issue clear public statements as an Islamic polity, most notably in monumental religious architecture, such as the Dome of the Rock in Jerusalem, and in the issuing of epigraphic coinage that replaced the various figural coins previously in circulation. ${ }^{21}$ In Iraq, Marwanid rule was cemented by the new foundation

15 Fiey, 'Isho'yaw', 36-46 and J.-M. Fiey, Nisibe, métropole syriaque orientale et ses suffragants, des origines à nos jours (Louvain, 1977), 1-2.

${ }^{16}$ Mari, HE, 62/55.

17 Isho' $y a h b$ was 'of the line of Bastomagh' (Chronicle of Seert, II/ii, XCVI (584), which would produce other contenders for the catholicosate (Book of the Governors, IV, ii (194/378)), and Giwargis was 'descended from a noble family of Kaphra in Beth Garmai', whose father owned several large estates (Book of the Governors, II, xii (80/179)). Isho'yahb's correspondence dwells on the role of Yazdin as a protector of the Christians (B 8) and relies on persuasion to keep fellow aristocrats on the Dyophysite side (e.g. B 19-20 to Yazdshapur and B 22 to Yazdegard). The personal names here may suggest the continued Iranian culture of these Christian magnates.

${ }^{18}$ Such as Giwargis of Nisibis and Giwargis of Perat de Maishan, both of whom were Persians unreconciled to the election of this Giwargis. Book of the Governors, II, xiii-iv (83-5/183-7).

19 Bar Hebraeus, $H E$, III, 131.

${ }^{20}$ C. Robinson, 'Abd al-Malik (Oxford, 2005), esp. 77 and 116-17 on construction in Jerusalem and the creation of uniform infrastructure.

${ }^{21}$ O. Grabar, The Dome of the Rock (Cambridge, Mass., 2006); Robinson, 'Abd al-Malik, 77-9, 102-3, 113-20.

This is an open access version of the publication distributed under the terms of the Creative Commons Attribution-NonCommercialNoDerivs licence (http://creativecommons.org/licenses/by-nc-nd/3.0/), which permits non-commercial reproduction and distribution of the work, in any medium, provided the original work is not altered or transformed in any way, and that the work is properly cited. For commercial re-use, please contact academic.permissions@oup.com 
of Wasit, adjacent to the city of Kashkar, under the notorious governor alHajjaj. Wasit served as a base for the Syrian army in the centre of the region, who fought against endemic Kharijite rebellions. ${ }^{22}$

This tightening of state structures seems to have spelt the end for the influence of many older indigenous aristocracies, who mostly disappear from our sources at this point. ${ }^{23}$ Some, such as the magnate Sergius of Kashkar, were direct victims of al-Hajjaj. ${ }^{24}$ The Marwanid period also represents a low point in the abilities of the catholicoi to project their authority beyond Ctesiphon or to develop a positive relationship with their rulers. Giwargis' imprisonment may be an indicator of how governors of Iraq viewed the catholicosate, as a means of extracting wealth in the short term by intimidation, but not an institution worth cultivating in itself. Similarly, the next governor, Bishr ibn Marwan, deposed Giwargis' successor Henanisho ${ }^{c}$ I (686-98) following an 'insult' against Islam and a bribe to Bishr from a rival candidate. ${ }^{25} \mathrm{Al}-\mathrm{Hajjaj}$ then suppressed the catholicosate altogether for sixteen years. ${ }^{26}$ When the office was restored after his death, incumbents continued to have difficulties in asserting their authority over other parts of Iraq, or even Ctesiphon. Sliba-zkha (714-28), the first of the new line of incumbents, failed to reclaim an illuminated service book given by Isho 'yahb III in an embarrassing standoff with the monks of Beth 'Abe, and Aba II (741-51) proved incapable of preserving the revenues of the patriarchal school at Ctesiphon from the priests who ran it. ${ }^{27}$ In sum, the Marwanid period, with rule centred on Damascus, encouraged governors to maximize profits from the Christians to fund an expanded state, or for personal gain. In this situation, Christian leaders within Iraq had no access to the highest-ranking political leaders. Catholicoi were therefore very vulnerable to the accusations of rivals and eventually lost the legitimacy that had allowed their predecessors to maintain authority: the young monks who opposed Sliba-zkha, it must be remembered, might have never known a catholicos, let alone one who tried to exercise his theoretical powers.

${ }^{22}$ Al-Tabari, II, 869-70 and M. Sakly, 'Wasit', EI2. The foundation is mentioned by Mari, HE, $157 / 65$.

${ }^{23}$ P. Sijpesteijn, 'New rule over old structures: Egypt after the Muslim conquest', in H. Crawford (ed.), Regime Change in the Ancient Near East and Egypt (Oxford, 2007), 183-200, at 196-8 for the situation in Egypt. The defeat of Ibn al-Ash'ath's revolt marked a similar threshold for the converted dihqāns of Iran. For Christians, partial exceptions may be the dihqäns of Adiabene and shahrigan of Mosul (Book of the Governors, II, xxxvi; III, iii): see the discussion in Robinson, Empire and Elites, 108.

${ }^{24}$ Chronicle of Seert, II/ii, LXXXI (525).

25 Bar Hebraeus, HE, III, 136-40; John of Phenek, 156/184.

${ }^{26}$ Called 'a persecution of the church' in the prophecy of one holy man: Chronicle of Seert, II/ ii, XCVIII (593).

${ }^{27}$ Book of the Governors, II, xxvii (102/229); Bar Hebraeus, HE, III, 152-4.

This is an open access version of the publication distributed under the terms of the Creative Commons Attribution-NonCommercialNoDerivs licence (http://creativecommons.org/licenses/by-nc-nd/3.0/), which permits non-commercial reproduction and distribution of the work, in any medium, provided the original work is not altered or transformed in any way, and that the work is properly cited. For commercial re-use, please contact academic.permissions@oup.com 
The Abbasid era coincides with a resurrection of the production of writing within the catholicosate, and this suggests a more general restoration of fortunes, though on a rather different basis to that of the late Sasanian period. Bar Hebraeus observes that the Abbasids were more favourable to the Christians than their predecessors. ${ }^{28}$ This pattern is especially marked after the transfer of the capital to the new city of Baghdad, which was almost immediately followed by the transfer of the catholicosate and the vigorous rule of Timothy I (780-823), who achieved his position at a very young age and remained incumbent for some fifty-two years, far longer than any of his predecessors. $^{29}$

The transfer of the catholicosate was a crucial step in the creation of a good relationship with a series of caliphs. A government resident in Iraq meant that the educational expertise of the Church of the East became increasingly important as a political tool for the Abbasid regime: Timothy's election was helped by a secretary to the caliph, with whom he had been educated, and Christian pharmacists and physicians reclaimed a political importance that they had held in the late Sasanian period. ${ }^{30}$ This expertise developed older traditions of Christians receiving knowledge from the West and acting as doctors and translators, and Timothy appears to have built on this deliberately by founding a number of monasteries and schools in Baghdad itself. ${ }^{31}$ In addition to this, Timothy himself was proficient at maintaining Christian difference while remaining inoffensive to Islamic sensibilities (which his predecessor Henanisho' had failed to do). Timothy's Apology to the Caliph, which circulated in both Syriac and Arabic, provides an important illustration of how this balancing act might be performed, as well as being an important waypoint in the sophisticated use of Arabic by Christians. ${ }^{32}$ Another significant part of the development of a shared intellectual culture by Christians and Muslims was their adoption of religiously neutral forms of logical debate (kalām), a forum in which Timothy's translation and use of Aristotle was a widely respected achievement. ${ }^{33}$

The new city of Baghdad may have witnessed significant social mobility by Christians. This may explain the sumptuary laws directed against Christians in

28 Bar Hebraeus, HE, III, 153-5.

29 On Timothy see V. Berti, Vita e Studi di Timotheo I: Patriarca Cristiano di Baghdad (Paris, 2009).

30 J.-M. Fiey, Chrétiens syriaques sous les Abbasides, surtout à Baghdad (Louvain, 1980), 12 and 36.

${ }_{31}$ M. Allard, 'Les chrétiens à Baghdad', Arabica 9 (1962), 375-88, esp. 377-9. Fiey, Chrétiens syriaques, 38-9 also draws attention to Timothy's personal role as a translator.

32 Note L. Cheiko, 'La discussion religieuse entre le calife al-Mahdi et Timothée le catholicos', Al-Machriq 21 (1921), 359-74, 408-18.

33 S. Griffith, The Church in the Shadow of the Mosque (Princeton, 2008), 46-7 and 117. Also note Timothy's Letter 25, where he demands a logician to be made bishop of Herat to debate with the Jacobites.

This is an open access version of the publication distributed under the terms of the Creative Commons Attribution-NonCommercialNoDerivs licence (http://creativecommons.org/licenses/by-nc-nd/3.0/), which permits non-commercial reproduction and distribution of the work, in any medium, provided the original work is not altered or transformed in any way, and that the work is properly cited. For commercial re-use, please contact academic.permissions@oup.com 
the city, where their command of 'middle-class' professions, as scholars, philosophers, and doctors, gave some individuals an entrée into high society. ${ }^{34}$ Part of the context for this development may have been the development of a prestigious civilian culture, a world where Muslim Arabs were no longer warriors set apart from the rest of the population, but also prized the technical skills of dhimmis. Joel Kraemer has written of the period from the foundation of Baghdad to the Seljuk invasions as an Islamic renaissance, where Greek philosophy and sciences were patronized by a socially and physically mobile middle class, who were united across religious boundaries by shared cultural interests, the adab al-kātib (scribal culture). ${ }^{35}$ The cultural efflorescence of this era bears many comparisons to the paideia of the Second Sophistic in the Roman Empire, but perhaps we should emphasize how novel it was in the former Sasanian world, where the martial values of etiquette texts such as Xusrau ud rēdag were replaced by a much broader and more accessible literary culture, rooted in a new class of administrators with a keen sense of their own prestige and importance as a group. ${ }^{36}$

It was in this context that individuals who were Christians, or who were associated with Christian institutions, rose to prominence in the caliphal administration, or to other positions of influence, in the ninth and tenth centuries. ${ }^{37}$ Good examples of this process were the Bokhtisho ${ }^{c}$ family of Gundishapur, who, as royal doctors, held periodic royal influence for several centuries following the ascendance of Gabriel Bokhtisho ${ }^{c}$ in the reign of Timothy. ${ }^{38}$ Like his sixth-century predecessors, Timothy recognized the importance of these prominent court laymen as guarantors of ecclesial independence, in an environment where the rewards of cooperation with the state might be very great indeed. ${ }^{39}$ However, there were also significant differences:

${ }^{34}$ For these laws, see Fiey, Chrétiens syriaques, 46 and M. Levy, A Baghdad Chronicle (Cambridge, 1929), 66. Griffith, Church in the Shadow, 63 observes the shock of provincial Muslims at the use of kaläm in arguments with dhimmis.

${ }^{35} \mathrm{~J}$. Kraemer, Humanism in the Renaissance of Islam: The Cultural Revival during the Buyid Age (Leiden, 1993), 2-10. The immense Fihrist of al-Nadim, a commentary on writers, writing, and scripts in many different languages is perhaps the most impressive testimony to this literary culture.

${ }^{36}$ On kitāba see S. Toorawa, Ibn Tāhir Tayfar and Arabic Writerly Culture: A Ninth-century Bookman in Baghdad (New York, 2005), 8. B. Shoshan, 'High culture and popular culture in medieval Islam', Studia Islamica 73 (1973), 66-107 emphasises the role of litterateurs in the dissemination of 'polite' culture down the social spectrum, beginning in this era.

37 See H. Putman, L'église et l'islam sous Timothée I (Beiruit, 1986), 93-108 and C. Cabrol, 'Secrétaires nestoriens sous les Abbassides (762-1252) à Baghdad', PdO 25 (2000), 407-91 for the importance of scribes, doctors, and translators under Timothy and his successors.

38 Baumer, Church of the East, 155 and 158; Mari, HE, 78/69.

39 T. Hurst, The Syriac Letters of Timothy I: A Study in Muslim-Christian Controversy (Catholic University of America, unpublished $\mathrm{PhD}$ thesis, 1988), 20-1, citing an unpublished letter in MS Vat. Syr. 605. See chapter 4 for the involvement of court doctors in the election of sixth-century catholicoi.

This is an open access version of the publication distributed under the terms of the Creative Commons Attribution-NonCommercialNoDerivs licence (http://creativecommons.org/licenses/by-nc-nd/3.0/), which permits non-commercial reproduction and distribution of the work, in any medium, provided the original work is not altered or transformed in any way, and that the work is properly cited. For commercial re-use, please contact academic.permissions@oup.com 
the Abbasid state was even larger than the Sasanian, and Christian lay courtiers existed in higher numbers and with greater permanence.

\section{WRITING CHRISTIAN HISTORY UNDER ARAB RULE}

The histories that we have examined in previous chapters evolved from a tradition centred on the catholicosate, and this genre sits at the core of East Syrian historical writing. The ecclesiastical historians of the late sixth and early seventh centuries embedded their narratives of a politicized catholicosate into their accounts of the turbulent secular events of their own days. But this stream of material seems to have come to a dramatic halt in the second half of the seventh century. Mari's chronicle only provides very brief notices for quite prominent catholicoi such as Isho' yahb III and Giwargis. This situation is all the more striking when we contrast it to the long notices Mari gives for the usurper Surin in 753 and his successors Henanisho' II, Timothy I, and Isho ${ }^{c}$ bar Nun. ${ }^{40} \mathrm{~A}$ similar pattern is visible from the sources cited by the eleventh-century chronographer Elias of Nisibis in his Chronicle: there is a dearth of East Syrian sources for all of his entries on the Umayyad period. ${ }^{41}$ Though it is hard to tell, this may suggest a dry period in the composition of histories centred on the catholicoi in the aftermath of Isho'yahb III's reign. This does not mean that no history was composed: we are, for instance given detailed accounts of Giwargis's reign by Thomas of Marga. ${ }^{42}$ But the pattern of later citations does suggest that the focus of composition shifted away from Ctesiphon in the seventh century, so that we only know about Giwargis because of his interaction with prominent monasteries whose histories are preserved.

Mari's sections for the catholicoi of the Abbasid era are highly focused on their relations with the caliphs and the court, which probably reflects the interests of Mari's sources. The history for which we have the most information, that of Isho'dnah of Basra, written in 850, also seems to have contained large amounts of information relating to Muslim history. ${ }^{43}$ Though we cannot date his fellow historians very closely, I suggest, based on

40 Mari, HE, 67-79/59-67.

${ }^{41}$ Elias of Nisibis, I, 160 and 165, probably uses Isho' dnah for his notices on Sliba-zkha (his ordination in Wasit and his death) and, at 168 and 179, he uses Pethion for an account of a Jacobite episcopal election and the court influence of the doctor George of Gundishapur. Neither account need have been very detailed.

42 Book of the Governors, II, xii-xvi (80-9/179-209).

43 Extant portions of his history extend to 793 (W. Wright, A Short History of Syriac Literature (London, 1894), 195), but he must have written at a later date since he is also the author of the Book of Chastity.

This is an open access version of the publication distributed under the terms of the Creative Commons Attribution-NonCommercialNoDerivs licence (http://creativecommons.org/licenses/by-nc-nd/3.0/), which permits non-commercial reproduction and distribution of the work, in any medium, provided the original work is not altered or transformed in any way, and that the work is properly cited. For commercial re-use, please contact academic.permissions@oup.com 
the density of material reused in Mari and Elias of Nisibis, that their works focused on the period after the Abbasid revolution and represent the resurrection of a historical genre based around the deeds of the catholicoi in a court context, and that this corresponds to the revival of the importance of the institution under Timothy and his successors. ${ }^{44}$ This chronological pattern also corresponds to the 'ecclesiastical historians' referred to in 'Abdisho's Catalogue: only one historian, Bar Sahde of Karka de Beth Slouq, was active during the Marwanid period, during the $730 \mathrm{~s}^{45}$

If this assessment of the historiography is accurate, it means that the greater power of the catholicosate under Timothy was also accompanied by a return to older forms of ecclesiastical history focused on the catholicos. As we have mentioned, there is no way to reconstruct this production in any detail, but we are given an important insight into the historical interests of the early ninthcentury Church of the East by the manuscript from the monastery of Alqosh (169) from whose second volume Chabot edited the Synodicon Orientale. The Synodicon proper was produced under Timothy. ${ }^{46}$ But the collection of texts in which it is embedded (the Great Synodicon) seems to have been compiled in the eleventh century and includes a wide variety of other historical and pseudo-historical materials that were collected to address a wide variety of related questions of the laws and authority structures of the Church of the East. This medieval collection of texts forms an important testimony to the intellectual and political interests of the catholicosate at Baghdad, especially in terms of how they deployed their historical legacy. And, as such, it also forms an important tool for dating parts of the Chronicle of Seert and understanding their composition and inclusion.

The first volume of the Alqosh manuscript includes the history of Constantine and Helena, the canons of Nicaea, subscription lists for Nicaea, letters from the Roman Popes against heretics, the acts of the Anatolian synods of the fourth century, the Letter of the Western Fathers to Papas, a history of the beginnings of monasticism, and the correspondence between Papas and a variety of semi-fictitious fourth-century figures. The third volume of this manuscript contains the Khuzistan Chronicle, monastic canons of the sixth

44 This new focus in Mari's history may show his use of the historian Simeon the Treasurer (Bar Tabache), whose history extended $c .754-c .900$ and described the prominence of doctors and secretaries at court. See BO IIIa, 215.

${ }^{45} B O$, IIIa, 229, note 3. See also Fiey, Jalons, 9-10 for his list of historians (drawn from Assemani).

${ }^{46}$ It claims to be comprehensive and, since its last synod is that of Henanisho' II in 774, it must have been produced between 774 and Timothy's first synod in 790. See further, W. Selb, Orientalisches Kirchenrecht: Band I, Die Geschichte des Kirchenrechts der Nestorianer (von den Anfängen bis zur Mongolenzeit) (Vienna, 1981), esp. 165 and Assemani, BO, IIIa, 162. Timothy's own synodal canons are preserved in a later part of the Alqosh manuscript and are repeated in 'Abdisho's thirteenth-century compilation: A. Mai, Scriptorum Veterum Nova Collectio, Vol. X (Vatican, 1838), 98-105.

This is an open access version of the publication distributed under the terms of the Creative Commons Attribution-NonCommercialNoDerivs licence (http://creativecommons.org/licenses/by-nc-nd/3.0/), which permits non-commercial reproduction and distribution of the work, in any medium, provided the original work is not altered or transformed in any way, and that the work is properly cited. For commercial re-use, please contact academic.permissions@oup.com 
and seventh centuries, the letters of Timothy, and a series of legal judgements that conclude with those of Timothy and Isho' bar Nun (d.828). ${ }^{47}$ A final tranche of material dates from the eleventh-century patriarch Elias I (d.1049) and seems to have been added much later, as an appendix to a document that dates chiefly from the sixth, seventh, and ninth centuries. ${ }^{48}$

The collection of the Synodicon points to the wish for a comprehensive, encyclopaedic assemblage of authoritative statements by the catholicoi of the past that could be invoked in current debates. In organizing their statements chronologically, it gives the impression of the progressive recognition of their authority, stemming from the missions of the apostles and the recognition of the Western church, and worked out legitimately in laws to regulate the Eastern clergy. This act of collection neatly writes over the challenges made to the authority of Ctesiphon and retrojects the title of patriarch onto all incumbents of the see. ${ }^{49}$

This movement of collection and codification shows both the self-conception of the authority of the catholicos and the institutional structures that made such a work possible: we must at least envisage the existence of libraries where this kind of diachronic succession could be traced and where the rulings of earlier catholicoi were preserved and reproduced. ${ }^{50}$ It is an institutional context that would fit Timothy's patronage of new monasteries and schools during the transfer of the catholicosate to Baghdad. In addition, the content of the collections also shows us the changing importance of the catholicosate as a representative of a group of dhimmis within the caliphate. The collection of the Synodicon proper was accompanied by the collection of 'civil law', dating back to the time of Aba. This was concerned with the behaviour of laymen as much as clerics, especially different rulings on the laws of inheritance and marriage. The contents of these lawcodes points both to the cultural changes that were occurring in this period as Iranian norms were replaced by Islamic ones, and to the central role of the catholicos as the theoretical 'supreme judge' of all of his flock. ${ }^{51}$

${ }^{47}$ Selb, Orientalisches Kirchenrecht, 59-63 for a detailed list of the manuscript's contents. Also note J. Chabot, Synodicon Orientale (Paris, 1902), 4-9.

48 Selb, Orientalisches Kirchenrecht, 175.

49 Gero, 'The status of the patriarchs', 49, suggests that the claims of autocephaly in Dadisho"s synod of 424 were altered under Timothy I using the idea of succession from the apostle Peter. He draws on Westphal, Untersuchungen, 162.

${ }^{50}$ On Timothy's efforts to collect books on a variety of topics, seen through his own correspondence, see Berti, Vita e Studi, 217-20.

${ }^{51}$ For the different law codes and their dating see J. Dauvillier, 'Chaldéen (Droit)', Dictionnaire du droit canonique, 346-50 and Selb, Orientalisches Kirchenrecht, 174-8. On the social significance of this legislation see, in general, U. Simonsohn, A Common Justice: The Legal Allegiances of Christians and Jews under Early Islam (Philadelphia, Pa, 2011), esp. 109; H. Kaufhold, 'Der Richter in den syrischen Rechtsquellen: Zum Einfluss islamischen Rechts, auf die christliche-orientalische Rechtsliteratur', OC 68 (1984), 91-114; R. Rose, 'Islam and the development of personal law among Christian dhimmis', MW 72 (1982), 159-79; N. Edelby,

This is an open access version of the publication distributed under the terms of the Creative Commons Attribution-NonCommercialNoDerivs licence (http://creativecommons.org/licenses/by-nc-nd/3.0/), which permits non-commercial reproduction and distribution of the work, in any medium, provided the original work is not altered or transformed in any way, and that the work is properly cited. For commercial re-use, please contact academic.permissions@oup.com 
The Syriac Synodicon produced under Timothy was therefore the start of a textual tradition that affirmed the catholicosate as the site of authoritative lawmaking for Christians of all ranks. But in recognizing its importance we should not lose sight of the (pseudo) historical texts that were transmitted alongside it, in the first and third volumes of the Alqosh manuscript.

These supplementary texts buttress the claims of authority that are implicit in the Synodicon proper, creating a link between the era of Constantine and Nicaea, the great act of lawgiving that is seen in the ecclesiastical histories as the defining moment of orthodoxy, and the synod of Ishaq, via the agency of Marutha of Maypherkat. These pseudo-histories were collected alongside the synodical canons to reinforce the claims being made by catholicoi in the Abbasid era and, given the resurgence of history-writing in this period, they were probably composed at a similar time.

Several sections in the Chronicle of Seert and the Haddad Chronicle correspond closely to this material. In what follows, I argue that these sections, which deal with the Constantine and Nicaea; with Mar Awgin and Egyptian monasticism or with the massive apostolic claims of the catholicos, all correspond to this era of historical invention and codification. I go on to investigate the relationship between the claims of authority made by Timothy and his successors and the pseudo-histories shared by the Alqosh manuscript and the long chronicles. However, before we proceed, a word of caution is necessary on the dating of this relationship. Timothy seems to have been responsible for the collection or composition of a large amount of the material in the Great Synodicon, but there is no way of knowing whether parallel arguments in the historical compilations were produced in this era or reflect the enduring importance of Timothy's work to future generations. We must therefore keep a deliberately vague definition of Timothy's 'successors', one that takes us up to the generation of the compiler of the Chronicle of Seert in the late tenth or early eleventh century.

\section{TALES OF CONSTANTINE}

The early parts of the Chronicle of Seert devote some eight long sections to the era of Constantine and his successors, material that is paralleled in Mari and in the Haddad Chronicle. ${ }^{52}$ Some of this material is drawn from Greek ecclesiastical histories composed in the fourth and fifth centuries, but much belongs

'L'autonomie législative des chrétiens en terre de l'Islam', Archive d'histoire du droit orientale 5 (1951), 307-51; Payne, Christianity and Iranian Society, 191-235.

52 Westphal, Untersuchungen, 67-81 discusses this material in Mari (where it has been placed in the reign of Papas).

This is an open access version of the publication distributed under the terms of the Creative Commons Attribution-NonCommercialNoDerivs licence (http://creativecommons.org/licenses/by-nc-nd/3.0/), which permits non-commercial reproduction and distribution of the work, in any medium, provided the original work is not altered or transformed in any way, and that the work is properly cited. For commercial re-use, please contact academic.permissions@oup.com 
to a later genre of historical fantasy. This cluster of stories relate the accession of Constantine and his conversion to Christianity, followed by the attempted reversal of his good deeds by his wicked nephew Julian. Various additions were made to this central narrative that relate the discovery of the cross, Constantine's baptism in Rome, the council of Nicaea, and precursors to Constantine's actions in the reign of Abgar of Edessa (in the Doctrina Addai). ${ }^{53}$

The textual history of these stories is complex, but it is clear that they arose in a West Syrian environment that concentrated on Edessa. The focus of the narrative corresponds closely to the sixth-century Julian Romance, an Edessene Syriac legend of Edessa's resistance to Julian, and the stories of Constantine that are included in the Chronicle seem to have been composed within the same tradition. Following the geographical interests of the Julian Romance, part of the agenda of this narrative seems to be to represent Edessa as a great city of the Roman world, alongside Constantinople, Rome, and Nicaea. ${ }^{54}$

The transmission of this material lies beyond the immediate scope of this study, but I wish to note here the focus on Constantine as an orthodox ruler around whom new stories were freely invented. Fascinatingly, these stories seem to have stimulated a wish for further information about the West. The Syriac Julian Romance represents Rome as a holy city that joins Edessa in defying Julian, and the later historians were moved to transmit various (contradictory) stories about Roman Popes ${ }^{55}$ and to generate a description of Rome, which is ascribed to the well-known West Syrian figure Jacob of Nisibis. It is, we are told, 28 miles wide and broad, and built around the river Qūsțanțiya. Rome, Jacob informs us, holds a thousand bazaars for Easterners and Westerners and its aqueducts, supported by ranges of marble columns, contain sea water and are used by the merchant fleets. The city is also home to 1,270 baths and the great church of Peter and Paul. ${ }^{56}$

'Jacob's' description is not only fabricated, it is also fantastic. Rome appears like a Western projection of an Iraqi city, rendered on an even more massive scale. Even though the author is aware of the existence of aqueducts, their function can only be imagined on Iraqi lines, where great cities were opened to riverine trade that connected them to the sea. Al-Muqaddasi's tenth-century geography catalogued cities by their trade and production, by their religious buildings and their baths. This very Abbasid vision of urban greatness has

53 Chronicle of Seert, I/i, XIII-XXIV; I/ii, XXIII-XXIV. See S. P. Brock, 'The transformation of the Edessa portrait of Christ', Journal of Assyrian Academic Studies 18 (2004), 46-56 for a useful summary of the Edessene story.

${ }^{54}$ On these geographical interests, see Wood, We Have No King but Christ, 150-7.

55 Chronicle of Seert, I/i, XIII-XIV (255-6); XVII (268-9) for the confusion over Sylvester and Eusebius as Popes of Rome. The latter is the name given in the Julian Romance. The history of these legends is given by G. Fowden, 'Last days of Constantine: oppositional versions and their influence', JRS 84 (1994), 146-70.

${ }^{56}$ Chronicle of Seert, I/i, XX (284-5).

This is an open access version of the publication distributed under the terms of the Creative Commons Attribution-NonCommercialNoDerivs licence (http://creativecommons.org/licenses/by-nc-nd/3.0/), which permits non-commercial reproduction and distribution of the work, in any medium, provided the original work is not altered or transformed in any way, and that the work is properly cited. For commercial re-use, please contact academic.permissions@oup.com 
been applied here to Rome, with its baths and its great church, whose dedication connected it with the stories of Constantine and the visitation of Peter and Paul. ${ }^{57}$ Most importantly of all, this Rome has no history: it can only be imagined in connection with Constantine, whose name supplies the identity of the unknown river.

The tales surrounding Constantine also gave weight to the reputations of other Roman cities that were already famous in the East, to Jerusalem, Constantinople, and Nicaea. Here too, historians employed legendary material that had been received from the West or invented to elaborate on the history and geography of a wider Christian world beyond the 'East'. Jerusalem is the setting for the miraculous transformation of water into oil, a Christianized version of the Maccabean miracle, and for Helena's discovery of the Cross. ${ }^{58}$ And both events were used to explain the origins of contemporary celebrations, the date of Easter and the Festival of the Cross, which Muslim commentators saw as a particularly important 'Nestorian' festival. ${ }^{59}$

Constantinople, like Rome, is given an apocryphal geographic description, where it is remembered as the burial place for kings, saints, and patriarchs, in an account attributed to Mar Aba. ${ }^{60}$ Aba may have indeed visited the city, and we might attribute the invention to a scholar with access to a Syriac library, even if he had little actual information on the city. For him it was chiefly remembered as a city of relics and fabulous wealth associated with Constantine. In any case, the description primarily serves to provide the wider context for an account of Nicaea. Here the historians' main interest seems to have been Constantine's veneration for the survivors of persecution and his denunciation of Arius, but the importance of Nicaea also stimulated the invention of numerous different lists of the Easterners thought to have been present. All of these are fictitious, but they indicate both the wish to establish connections between the past history of the Church of the East, especially early catholicoi such as Simeon bar Sebba'e, Shahdost, and Papas, and the revered orthodox past of the Roman Empire. But the inclusion of a selection of contradictory lists suggests that they were all produced by later historians with access to earlier accounts of the fourth century that were organized chronologically, allowing them to suggest suitable, but different, Eastern representatives at Nicaea. ${ }^{61}$

57 E.g. the works of al-Yaqut or al-Muqaddasi (discussed in Le Strange, Eastern Caliphate, ch. 1). For Peter and Paul, Chronicle of Seert, I/i, XIV (256) and XV (261).

${ }_{58}$ Chronicle of Seert, I/i, XVII (270-1) and XXII (287).

59 See M. Espionnier, 'Al-Nuwayri: les fêtes islamiques, persanes, chrétiennes et juives', Arabica 32 (1985), 80-100, at 94-5: al-Nuwayri also offers a historical explanation for the feast of the Cross, based on a garbled record of the battle of the Milvian bridge.

${ }^{60}$ Chronicle of Seert, I/i, XIX (281-3).

${ }^{61}$ Chronicle of Seert, I/i, XVIII (276-7). The only one of these figures who is real is probably John of Beth Garmai (John the Persian in the Greek lists): see the discussion in J. Kollaparambil, 'The identity of Mar John of Persia and Great India who attended the first council of Nicaea', in VI Symposium Syriacum, 281-97 (though his assertion of an Indian connection is not credible).

This is an open access version of the publication distributed under the terms of the Creative Commons Attribution-NonCommercialNoDerivs licence (http://creativecommons.org/licenses/by-nc-nd/3.0/), which permits non-commercial reproduction and distribution of the work, in any medium, provided the original work is not altered or transformed in any way, and that the work is properly cited. For commercial re-use, please contact academic.permissions@oup.com 
This interest in the West and its past was not new. The Jerusalem pilgrimage was a significant feature of the reign of Isho' $y$ ahb I, and some knowledge of Constantine and Nicaea is evident in the council of $410 . .^{62}$ But the Abbasid period does seem to have experienced a greater interest in the West and an accompanying wish to fill in the gaps in the received history of the fourth century. The Syro-Roman law book, a West Syrian translation of laws of Constantine, Theodosius II and Leo I, seems to have entered Eastern collections in the middle of the eighth century, and its appearance may have heightened awareness of Constantine as an orthodox lawmaker and predecessor of the catholicoi in this role. ${ }^{63}$

The correspondence of Papas that circulated alongside the Synodica, includes his letters to Helena, mother of Constantine, to Judas Kyriakos, the converted Jew who revealed the True Cross, and to Pope Eusebius of Rome, and this content suggests that it represents a series of parallel historical inventions to those seen in the Chronicle of Seert. Though invented letters had been ascribed to Papas in the fifth and sixth centuries, these other letters seem to be inventions of Timothy's reign, a time when there was a deliberate effort to collect different sources about the past to buttress the claims of the present. ${ }^{64}$ Moreover, it seems plausible that this correspondence, like the stories in the Chronicle, is also a reaction to the availability and popularity of the West Syrian Julian Romance in this era, meaning that its pseudo-history of the fourth century had to be incorporated into the histories and their protagonists tied to famous figures from the past of the Church of the East.

Timothy's own correspondence sheds further light on the context and motivation for these pseudo-histories. His Letter 26, composed in 785, is a discussion of the customs shared by the Church of the East and other Christians, but also of the primacy of his own church as a sort of primus inter pares. He begins by emphasizing the unity of baptism among 'Severans, Nestorians, and Chalcedonians'. All of them, he remarks, believe in the unity of the Trinity, in baptism, Incarnation, prayer to the East, the Eucharist, the testaments of the prophets, eternal life and resurrection, and in the Last Judgement. However, it is the East that has primacy over the other parts of the world, since Nimrod, the first king, ruled in the East and since Ctesiphon is the see of Peter. The East, he goes on to argue, was the first land to embrace Christianity and the point of origin of Christ's own family (presumably via Abraham).

62 Synodicon, 183-4 (canon 15). See further the comments of J.-M. Fiey, 'Le pélérinage des Nestoriens et Jacobites à Jerusalem', Cahiers de civilisation médiévale 12 (1969), 113-26 and L. Perrone, 'Christian holy places and pilgrimage in an era of dogmatic conflict', POC 48 (1998), 4-37.

${ }^{63}$ Dauvillier, 'Chaldéen', 355. Constantine is still celebrated by 'Abdisho' of Nisibis as a lawgiver , 'who bound the church together by a single chain' (Mai, Scriptorum, X, I, iii: 31).

${ }^{64}$ Westphal, Untersuchungen, 55 argues for Timothy's invention of stories of the early catholicoi found in Mari, which correspond to later ideas of canon law.

This is an open access version of the publication distributed under the terms of the Creative Commons Attribution-NonCommercialNoDerivs licence (http://creativecommons.org/licenses/by-nc-nd/3.0/), which permits non-commercial reproduction and distribution of the work, in any medium, provided the original work is not altered or transformed in any way, and that the work is properly cited. For commercial re-use, please contact academic.permissions@oup.com 
The letter, with its polemical use of history and geography, asserts the position of the Church of the East and Timothy as the centre of all 'Christendom'. The differences between Christians are minimized as part of a wider project to assert the East's importance as the origin of civilization and true religion, and the continued focus of prayer for Christians (which distinguishes them from Muslims and Jews). ${ }^{65}$ The emphasis on connections to co-religionists further west may have been an attempt by Timothy to bolster his prestige within the caliphate. At the same time, Timothy claims a pre-eminent position for his see within this Christian world-system. He asserts the status of the East by concentrating on its claims to antiquity and its importance as the site of Old Testament narrative. But he also seems to be aware of Western claims to Petrine supremacy (which could have applied to both Rome and Antioch). Timothy also claims this for the East and he may have retrojected this idea into the 424 synod of Dadisho' to give this idea a greater antiquity. ${ }^{66}$

The Chronicle's interest in Constantinople and Rome can therefore be understood against this background. I suggest that the elaboration of the Constantine narratives and the descriptions of the cities of the West that were included in the Chronicle of Seert took place in a context where the catholicosate tried to emphasize the greatness of the Christian past within an Islamic environment, especially through the memory of the Roman world before Islam. Moreover, the pseudo-history of the Chronicle and the 'fourthcentury' correspondence emphasized the pre-eminence of the see of Ctesiphon as the heir to this Christian heritage, over and above Melkite and Jacobite rivals with a longer history of attachment to the Western sees. Such assertions grew out of an earlier awareness of the Mediterranean patriarchates, but, even if they do not replicate the bombastic claims that Timothy makes in his letter, the sections of the Chronicle of Seert that we have seen here fit a lateeighth- and ninth-century renewal of interest in the cities of the West and in the deeds of Constantine.

\section{AN EXPANDING CHURCH}

The claims of dominance made in Timothy's letter, even if they were not widely recognized, reflect the confidence of an individual in command of court connections, who could generate large donations from the caliph, who fund

${ }^{65}$ For Timothy's emphasis on Eastern prayer in his unpublished letters see Hurst, 'The Syriac letters of Timothy', 202-15.

${ }^{66}$ On this letter, see the useful translation and commentary of F. Briquel-Chattonet et al., 'Lettre du patriarche Timothée a Maranzekhä', Journal Asiatique 288 (2000), 1-13. On the Petrine succession, see S. Gero, 'The status of the patriarchs', 49.

This is an open access version of the publication distributed under the terms of the Creative Commons Attribution-NonCommercialNoDerivs licence (http://creativecommons.org/licenses/by-nc-nd/3.0/), which permits non-commercial reproduction and distribution of the work, in any medium, provided the original work is not altered or transformed in any way, and that the work is properly cited. For commercial re-use, please contact academic.permissions@oup.com 
impressive missions deep into the East and buy up land in Baghdad. ${ }^{67}$ The greater power of the catholicos within the church is immediately visible from the reorganization of dioceses, specifically the expansion of the number of dioceses immediately subject to the catholicos (which went from six to thirteen) $;{ }^{68}$ the creation of a new category of 'external' metropolitanates who had no rights of election, ${ }^{69}$ and the elevation of new metropolitanates in the East and West (especially Damascus, Daylam, Turkestan, Gurgan, and Tibet). ${ }^{70}$

Timothy is rightly famous for the missionary expansion of the Church of the East under his rule, but it is also notable that this process had already begun in the seventh century, with the missions of John of Daylam and of Alopen in China. But Timothy was personally associated with the missions, in monastic and ecclesiastical histories as well as in his own correspondence, ${ }^{71}$ whereas the earlier missions are known from hagiographies, and the Xi'an inscription, and are not publicly identified as initiatives driven by the catholicos. ${ }^{72}$ The catholicosate, therefore, used its material wealth and influence to drive missionary expansion, and bolstered its own prestige among its clerics and monks.

Yet at the same time as the Nestorian church was engaged in expansion in the East and West, so too were the Melkites and Jacobites. Both rival groups developed important communities in Iraq in the course of the seventh and eighth centuries: Takrit, a former Roman army base, emerged as a very important Jacobite centre, alongside their older base of Mar Mattai, and Jacobites in Iraq were organized into a series of dioceses soon after the Arab conquest by their patriarch Athanasius the Camel-driver. Perhaps most importantly, beginning with Marutha of Takrit, the leader of the Iraqi Jacobites was labelled a maphrian, second-in-command to the patriarch at Antioch. ${ }^{73}$ Parallel developments are also seen for the Melkites, who established a church

67 See Letters 8 (the caliph's donation) and 44 (purchasing land).

${ }^{68}$ Fiey, AC III, 148-9.

69 Fiey, Nisibe, 2 on the 'external' metropolitans. This division remains apparent in the list of metropolitans at the end of 'Amr's chronicle (126/73).

${ }^{70}$ Letter 47. Fiey summarises all of his administrative reforms in Pour Un Oriens Christianus Novus: répertoire des diocèses Syriaques orientaux et occidentaux (Beiruit, 1993). This expansion was also reflected in 'updated' apostolic claims. Where some texts in the Haddad Chronicle report that the apostles made Mari 'patriarch of Babylon, Ahwaz [Khuzistan] and the Tigris region, up to the borders of Fars' (Haddad Chronicle, LXXVI (110), reflecting the pre-Islamic situation, other, later accounts in this Chronicle made him ruler of 'Fars, Ahwaz, Iraq, China, Turkestan, India and the islands [the Persian Gulf]' (Haddad Chronicle, LXXII (122). These claims also became attached to the thirteenth-century canonical collections, e.g. Mai, Scriptorum, 8 for the missions to the borders of India.

${ }_{71}$ Mari, 73/64 (missions to Turkestan); Book of the Governors, V, iv-vii (missions to Daylam).

72 This volume, chapter 6 .

73 J.-M. Fiey, 'Les diocèses de maphrianat syrien, 629-1860', PdO 5 (1974), 133-65; J.-M. Fiey, 'Syriaques occidentaux du Pays des Perses', PdO 17 (1992), 113-27; J.-M. Fiey. 'Tagrit: esquisse d'histoire chrétienne', OS 8 (1969), 289-341. For the Iraqi dioceses see Chronicle of Seert, II/ii, LXXXVIII (543). Also see M. Allard, 'Les chrétiens à Baghdad', 379 for the Jacobite church of Mar Tuma.

This is an open access version of the publication distributed under the terms of the Creative Commons Attribution-NonCommercialNoDerivs licence (http://creativecommons.org/licenses/by-nc-nd/3.0/), which permits non-commercial reproduction and distribution of the work, in any medium, provided the original work is not altered or transformed in any way, and that the work is properly cited. For commercial re-use, please contact academic.permissions@oup.com 
at Kufa in 723 and whose monastery in Baghdad became the centre of the district of Dar al-Rum, which would be the seat of a metropolitan by the tenth century. ${ }^{74}$

Similar expansion was also seen further east. In Central Asia, Nestorian expansion is seen in the spread of their network of bishops across Khurasan and Segestan, but by the 630s the Jacobites too had established bishops in the same region, where the Nestorians had previously been the only Christians, and these were upgraded to metropolitanates by the ninth century. ${ }^{75}$ Further east, in the longstanding Nestorian centre of Merv, the Melkites had established an important community that provided the Muslim scholar al-Biruni with informants in the eleventh century. ${ }^{76}$ This expansion may reflect conversions of local pagans, but the migration of Greeks and Armenians, as prisoners and soldiers, may have also prompted this shift in ecclesiastical organization, ${ }^{77}$ and, in time, this was followed by the eastward diffusion of Mediterranean centres of Christian scholarship, such as the West Syrian schools of Alexandria and Antioch, which relocated to Baghdad and Merv in the early Abbasid period. $^{78}$

For all three Christian groups, the creation of the caliphate meant the dissolution of older borders, geographical expansion and a new, more immediate exposure to one another. This overlapping of missionary activity and connections to the same circles of power meant that the different groups were placed in direct competition: another way of understanding the claims made by the Nestorians to the lands of the East is as a means of excluding newcomers from their zone of influence in Central Asia. Michael Morony has portrayed the Umayyad period as an era of conflict between Christian groups, pointing to the Nestorians' destruction of a Jacobite church in Nisibis in 707 and to the use of Old Testament imagery by historians to present each different church as a chosen people. ${ }^{79}$ However, in spite of the divisive language of some of these histories, we should also remember that the Abbasid period saw important points of rapprochement between the communities, where, for instance, the Jacobites were permitted to build churches in Nisibis and Mosul in exchange for allowing a Nestorian church in their centre of Takrit. In this 767 agreement, the irenic policies of church elders overcame the prejudice of younger

74 J. Nasrallah, L'église melchite en Iraq, en Perse et en Asie Centrale (Jerusalem, 1976), 41, 58, and 64.

${ }^{75}$ J.-M. Fiey, 'Chrétientés syriaques du Horāsān et Ségēstan', LM 86 (1973), 75-104, esp. map at 78 .

${ }^{76}$ Nasrallah, L'église melchite, 45.

77 See Chronicle of Seert, II/ii, LXXXIX (545-6).

78 S. Samir, 'Rôle des chrétiens dans la nahda abbasside en Irak et en Syrie (750-1050)', MUSJ 58 (2002), 541-72, esp. 555.

79 M. Morony, 'History and identity in the Syrian Churches', in J. J. van Ginkel, H. L. Murrevan den Berg, and T. M. van Lint (eds.), Redefining Christian Identity: Cultural Interaction in the Middle East since the Rise of Islam (Leuven, 2005), 1-33, esp. 1-5.

This is an open access version of the publication distributed under the terms of the Creative Commons Attribution-NonCommercialNoDerivs licence (http://creativecommons.org/licenses/by-nc-nd/3.0/), which permits non-commercial reproduction and distribution of the work, in any medium, provided the original work is not altered or transformed in any way, and that the work is properly cited. For commercial re-use, please contact academic.permissions@oup.com 
church members, angry at compromise. ${ }^{80}$ I suggest that, though rivalry between groups did not stop, it was increasingly conducted against a background of everyday communication between different kinds of Christians in Abbasid Iraq. This had a direct effect on Christian conceptions of the past, where, in some instances, shared histories from the patristic era (and new inventions inspired by these) represented a body of knowledge that was respected by all. This is the kind of social context we must suppose to explain Timothy's declaration of the common ground of the three main denominations, at the same time as his assertion of the fundamental pre-eminence of 'the East'.

Several sections in the Chronicle of Seert are only comprehensible through this kind of ecumenical interchange. In the ninth century, clergy of different churches were prepared to share rare books on philosophy and theology, which corresponded to a shared Christian heritage, ${ }^{81}$ and to criticize the extremism of their own predecessors in order to generate compromise across theological boundaries. ${ }^{82}$ This environment fostered two-way pilgrimage between regions which had previously had restricted contact, such as Egypt and Iraq. ${ }^{83}$ And it also enabled Easterners to gain easier access to writings in Greek through the settlement of Greek-speakers in Baghdad and elsewhere, writings that preserved knowledge about the prestigious Christian history of the later Roman Empire. ${ }^{84}$

The longest of the ninth-century additions in the medieval compilations are the sections on the deeds of the Roman emperors, which are built around summaries of their church politics and natural disasters. These sections, which are extremely brief until the reigns of Maurice and Phocas, may derive from a West Syrian source, since they are dated by AG, in the same manner as the

${ }^{80}$ Bar Hebraeus, HE, III, 157. Also see the narrative in J.-M. Fiey, Mossoul chrétienne (Beiruit, 1959), 19. The church in Mosul (Mar Zuma) continued to be known as the 'church of the Takritis'.

${ }^{81}$ Timothy, Letter 19 to Sergius asking for books on logic and Greek grammar; Letter 43 to Pethion for philosophy; Letter 48 asking Sergius of Elam to act as a go-between with the Melkite patriarch on a scholarly problem. See the discussion in S. P. Brock, 'Two letters of Timothy from the late eighth century on translations from Greek', Arabic Science and Philosophy 9 (1999), 233-47.

82 A. Saadi, 'Moshe bar Kepha and Christian communities', The Harp 15 (2002), 161-73 writes that Moshe emphasised the 'incomprehensibility' of Christology and criticised Philoxenus as well as Theodore of Mopsuestia. He restricted the term 'heresy' to ancient heresies such as Arianism. Timothy, Letter 1, asserts that it is not desirable to rebaptize 'Cyrillians', contradicting the more extreme stance attributed to Rabban Hormizd in the seventh century (Life of Rabban Hormizd, 70/103).

${ }^{83}$ E.g. the Life of John the Little, which records Coptic pilgrimage to sites in Baghdad and Khuzistan in the ninth century.

${ }^{84}$ See G. Strohmaier, 'Hunayn ibn Ishaq: an Arab scholar translating into Syriac', Aram 3 (1991), 163-70 for Hunayn's education in Baghdad. For the wider context see D. Gutas, Greek thought, Arabic Culture: The Graeco-Arabic Translation Movement in Baghdad and Early 'Abbä sid Society (2nd-4th/8th-10th centuries) (London/New York, 1998).

This is an open access version of the publication distributed under the terms of the Creative Commons Attribution-NonCommercialNoDerivs licence (http://creativecommons.org/licenses/by-nc-nd/3.0/), which permits non-commercial reproduction and distribution of the work, in any medium, provided the original work is not altered or transformed in any way, and that the work is properly cited. For commercial re-use, please contact academic.permissions@oup.com 
Syriac minor chronicles. ${ }^{85}$ The lack of detailed information for early emperors implies that they may have been composed in the seventh century, not long after the Arab conquests. The degree to which these sections are isolated from the other narratives that were used in Chronicle indicates that they represent a very late addition that has not been integrated with the earlier sources. However, the anti-Severan bias of these brief histories may also indicate that they stemmed from a Chalcedonian source, and that they were transmitted by the Melkites into a Nestorian environment. ${ }^{86}$

A second cluster of Melkite material is found in the stories of Constantine and Nicaea. Here a compiler has used the work of Qusțā ibn Lūqā (d.910), a Melkite from Baalbek in the Lebanon and confidant of the caliphs, whose work, also dated by AG, has been employed to furnish additional details on these central events. ${ }^{87}$ Qustāa, the latest of the historians named by the Chronicle of Seert, has been used to provide an account of Constantine's vision of the Cross at the Milvian Bridge and Helena's discovery of the Cross. ${ }^{88}$ Both scenes were probably discussed by Qustā as explanations of the origins of the important Feast of the Cross, and it is interesting that the chronicler also includes his explanation of the different dates for the festival. The Nestorians, he says, celebrate the discovery, and the Melkites, Helena's dedication of the church on the following day, which explains why the two communities keep the feast on different days. Though the different traditions of the churches might have originally served to emphasize the divisions of the two communities, Qusțā, followed by the Nestorian chronicler who has reused his material, has preferred to emphasize the legitimacy of both dates for the celebration. Both here, and in the anonymous history of the emperors, Melkite sources were used by a compiler keen to marshal all possible information that could elucidate Christianity's pre-Islamic past in the exotic far West, especially in the deeds of orthodox emperors.

Much less material seems to have entered the Chronicle from Jacobite sources. But even here, though confessional borderlines were bitterly defended in the sixth and seventh centuries, we may be able to detect an improvement in the relationship between the two groups. We saw in chapter 5 how Greek Dyophysite ecclesiastical histories painted a very negative picture of Cyril and his followers. These histories, transmitted into the East, were also continued using other information, such as the deeds of patriarchs of Constantinople ${ }^{89}$

${ }^{85}$ Such as the Chronicle of Edessa or the Chronicle of 724. None of the pre-Islamic East Syrian histories, such as Barhadbeshaba, include any dates at all, and they are rare in the Chronicle of Seert.

${ }^{86}$ For this bias, e.g. Chronicle of Seert, II/i, X (118-19) on Anastasius.

87 On Qustāa see J. Nasrallah, Histoire du mouvement littéraire dans l'église melchite du Ve siècle au XXe siècle (Paris/Louvain, 1981), II, ii, 52-64.

${ }^{88}$ Chronicle of Seert, I/i, XVII (267 and 273-4).

${ }^{89}$ Chronicle of Seert, II/i, III, VI, XI, XIX, XXII.

This is an open access version of the publication distributed under the terms of the Creative Commons Attribution-NonCommercialNoDerivs licence (http://creativecommons.org/licenses/by-nc-nd/3.0/), which permits non-commercial reproduction and distribution of the work, in any medium, provided the original work is not altered or transformed in any way, and that the work is properly cited. For commercial re-use, please contact academic.permissions@oup.com 
or those of the Jacobite leadership during the sixth-century persecutions, and they continued to pursue the same invective. ${ }^{90}$ These continuations could have been received at various points from the middle of the sixth century to the ninth, when Chalcedonian anti-Jacobite accounts might have passed into the hands of Nestorian historians. But these accounts should also be contrasted with other sections that present much more neutral descriptions of the Jacobites. In particular, two narratives of the succession of Athanasius the Camel-driver after the death of Khusrau II and his creation of new dioceses, and the account of the spread of Jacobites in Iraq after the war both seem to derive from Jacobite sources. ${ }^{91}$ The use of neutral information from Jacobite sources to explain current realities did not prompt the chronicler to jettison or alter the deep anti-Jacobite bias of much of the material he inherited, but it does at least suggest that a history of the Jacobite patriarchs was accessible to him or his predecessors, even if used anonymously. ${ }^{92}$

\section{A NEW HISTORY OF MONASTICISM: THE NESTORIANS IN THE WEST}

The intermixing of the historical traditions of different confessions in the Chronicle of Seert was a product of the new proximity of these different communities. But this process was not limited to Iraq and lands further east: the Nestorians also acquired a major presence in the West. There had already been a bishop in Damascus at the time of the Arab conquests, but the Abbasid period witnessed the founding of new communities, together with an episcopal structure in Syria, Anatolia, and Egypt. ${ }^{93}$ Egypt in particular saw Nestorians establish themselves as traders and as government representatives, acquiring a bishop in the region by 750 and a metropolitanate by $c .1000$ and establishing a large monastery to the south of Cairo. Governance from Baghdad allowed Nestorians an important role as agents of the caliphs in his dealings with other Christians. ${ }^{94}$

${ }^{90}$ Chronicle of Seert, II/i, X(?), XX(?), XXI, XXII. The first two sections in the list have probably been mixed with the Melkite history of the emperors.

${ }_{91}$ Chronicle of Seert, II/ii, LXXXVIII-LXXXIX (542-5); CX (634). Also see II/i, XXXII (184) for an anecdote on the plague of the 540s drawn from the historian John of Ephesus (wr. 580s) without attribution.

92 Compare the anonymous circulation of the West Syrian ascetic John of Apamea in East Syrian circles: B. Coless, 'The biographies of John Saba', PdO 13 (1972), 45-65, at 53.

93 J. Dauvillier, 'Les provinces chaldéennes de «l'extérieur' au môyen âge », in Mélanges Cavallera (Toulouse, 1948), 261-316, at 273-4 lists a metropolitan at Damascus and bishops at Aleppo, Jerusalem, Manbij, Mopsuestia, Tarsus, Melitene, Cyprus.

${ }^{94}$ O. Meinardus, 'The Nestorians in Egypt', OC 15 (1967), 114-29.

This is an open access version of the publication distributed under the terms of the Creative Commons Attribution-NonCommercialNoDerivs licence (http://creativecommons.org/licenses/by-nc-nd/3.0/), which permits non-commercial reproduction and distribution of the work, in any medium, provided the original work is not altered or transformed in any way, and that the work is properly cited. For commercial re-use, please contact academic.permissions@oup.com 
As we have seen, Egypt held an important place in the imagination of the Church of the East, as it did across all post-Nicene branches of Christianity, as the home of Antony and Pachomius, the founders of monasticism, known through the ecclesiastical histories. Its fame made it a point of interest for visitors to the West such as Mar Aba and Abraham of Kashkar, and an Egyptian cenobitic model of monasticism was an important feature of the Abrahamic reformation of the sixth century. However, just as Iraqi historians retrojected the authority of the catholicoi, they also desired a deeper history for the cenobitic monasticism of the East. The first stage of this elaboration of the past of Abrahamic monasticism was the early seventh-century translation of Palladius' Lausiac History by the monk Ananisho', a friend of Isho' yahb III. ${ }^{95}$ These tales of Antony and Pachomius gave an older, and therefore more legitimate, pedigree to Abraham's reformation, and are placed at the beginning of Thomas of Marga's Book of the Governors. The acquisition of this new history meant that Abraham no longer stood at the beginning of the historical tradition: like the ancestry of the church's theology, this translation meant that its monastic practices too could be traced back to an authoritative Western source.

The second step in the elaboration of the church's monastic history was the presentation of Abraham as a restorer of cenobitism. The translation of Ananisho' shows curiosity about the past and a wish to give monastic history the same credentials as ecclesiastical history in general. We might also speculate that the invention of an earlier cenobitic revolution in Iraq may have been stimulated by the criticisms of rivals, by 'Messalians' who objected to the controls of the Abrahamic monastic structures or by Jacobites who claimed to have brought cenobitic monasteries into the East themselves. This second level of monastic histories represented a new wave of hagiographies devoted to the fictional Egyptian monastic founder Awgin, and to his disciples Shallita, Phinehas, and Yonan, all of whom are the subjects of long Syriac hagiographies. ${ }^{96}$

These saints' lives give their heroes suitable fourth-century pedigrees, as opponents of Arius and Egyptian paganism, and it may be that this was intended to enhance their appeal and importance across confessional boundaries. I do not intend to examine these lives closely here, but it is clear that a compiler whose material was included in the Chronicle of Seert was chiefly interested in embedding these heroes into the pre-existent history of the Church of the East. Thus Awgin is portrayed as an opponent of Shapur II who, like the heroes of the fifth-century hagiographies, endures standing in a fire to prove the truth of his belief and the falsehood of the shah's religion. ${ }^{97}$ Other stories, which follow this one immediately, recount how Awgin's

${ }^{95}$ Book of the Governors, II, xi (78/174-5).

96 N. Sims-Williams, 'Eugenius (MarAwgen)', in EIr, notes that the Awgin is first attested as a monastic founder in East Syrian sources in the seventh century.

97 Chronicle of Seert, I/ii, XXXV (247-9).

This is an open access version of the publication distributed under the terms of the Creative Commons Attribution-NonCommercialNoDerivs licence (http://creativecommons.org/licenses/by-nc-nd/3.0/), which permits non-commercial reproduction and distribution of the work, in any medium, provided the original work is not altered or transformed in any way, and that the work is properly cited. For commercial re-use, please contact academic.permissions@oup.com 
disciples paved the way for their successors in the seventh century, how Mar Yonan appeared in a dream to 'Abda bar Hanif and commanded him to bring his body to Anbar, or how the disciple Aha founded the monastery of Zarnouqa, which was refounded by one of the companions of Sabrisho ${ }^{\text {c }} .98$

These stories connect seventh-century figures to the fourth century, and they may well indicate that the authors of foundation stories in the seventh century were aware of earlier heroes in a barely known past. But these primordial founders had not yet been connected to Awgin as a body of disciples, and they are absent from the Book of the Governors. It is only with the composition of Isho'dnah of Basra's Book of Chastity in 860s that they appear as a group, incorporating several martyrs of the fourth and fifth centuries as monastic founders, in a list that probably stands as a later addition to the rest of the text. ${ }^{99}$

The appearance of Awgin in the Chronicle of Seert, therefore, represents part of the 'backwards' expansion of the text's monastic history, in parallel with the retrojection of its ecclesiastical history, where an author with knowledge of the hagiography and history of his own church has inserted this primordial monastic founder at the relevant point in his collected material. Employing a wide knowledge of the early period in which these new hagiographies were set, the authors of such hagiographies connected their saints to prestigious and notorious figures of the past, to the family of Constantine, ${ }^{100}$ the fictional monastery of Pachomius, ${ }^{101}$ and the Shapurian martyrs, ${ }^{102}$ as well as to sixth- and seventh-century monastic stories. In addition, this invention did not only supplement the authority of the monastic movement within Iraq, but also emphasized its connections to Egypt, where its members' newfound influence might be presented as a restoration of a very old connection between the two regions. The creation of a deeper history for cenobitic monasticism in the Church of the East, therefore, also created legitimacy for its colonies in Cairo and the Fayyum.

\section{REMEMBERING MUHAMMAD: TAXATION AND NARRATIVES OF SURRENDER}

The creation of new passages of fourth-century history in the Abbasid period was connected to the changing relationship between the Church of the East

98 Chronicle of Seert, I/ii, XXXV (250) and XXXVIII (252). Also see Book of Chastity, §3, 7, 10.

99 Book of Chastity, §1-13. One of this group (9), added to the beginning of the collection, refers to the relocation of a saint's body in $128 \mathrm{AH}$, which provides a terminus a quo for their inclusion. These short lives focus on different episodes than the longer stories used in the Chronicle of Seert.

100 Book of Chastity, §4. $\quad{ }^{101}$ Book of Chastity, §5. $\quad{ }^{102}$ Book of Chastity, §8.

This is an open access version of the publication distributed under the terms of the Creative Commons Attribution-NonCommercialNoDerivs licence (http://creativecommons.org/licenses/by-nc-nd/3.0/), which permits non-commercial reproduction and distribution of the work, in any medium, provided the original work is not altered or transformed in any way, and that the work is properly cited. For commercial re-use, please contact academic.permissions@oup.com 
and other Christian groups: the fourth century represented an era that all major Christian groups respected, and historical invention here might generate the kind of legitimacy that could transcend inter-confessional boundaries. The events of the early seventh century, the life of Muhammad, and the conquests of the early caliphs, represented a similar formative period for Muslims, where assertions about the past could also create paradigms for the behaviour of contemporary Christians and Muslims. ${ }^{103}$

Some sources written within the Church of the East, and embedded in the Chronicle of Seert or Thomas of Marga, represent the Arab conquests as a violent experience, where the intervention of holy men was necessary to save the common people, as if from a natural disaster, and where the Arabs are included in prophecies of the destruction of convents. ${ }^{104}$ These texts, especially the monastic hagiographies among them, were probably composed in the mid-seventh century, and, in a few cases, updated later. ${ }^{105}$ They may well reflect the turbulent situation of the invasions. Yet they contrast radically with the accounts of Muhammad and the Rashidun (the first four caliphs) given later in the Chronicle, where the Christians are represented as important allies of the Muslims, and are recognized by Muhammad in a lengthy document, apparently discovered in 878 by a monk named Habib. ${ }^{106}$ This difference, I suggest, reflects the Abbasid-era rewriting of the past to remove images of Arab violence and to emphasize cooperation between Christians and Muslims through an invented seventh-century past.

The Chronicle contains four sections of varying lengths on the beginnings of Islam. The first (CI) is an abbreviated account of the rise of Muhammad, dated to the reigns of Heraclius, Isho'yahb II, and Ardashir III. Notably it also includes the Islamic praise formula for Muhammad, his Abrahamic descent, his flight to Yathrib (Medina), and his war with Meccans, so the account has used an Islamic source. ${ }^{107}$ It has then located the material in a pre-existent account of the war of 604-28. This addition of Islamic material to an older structure implies that this episode was written in an era when history writing in Arabic was accessible to a Christian author, rather than being an indigenous' account of the new prophecy, such as the one found in the Khuzistan

103 On the 'intercultural transmission' of historical scenes between Greek, Syriac, and Arabic in this period note especially the contributions of L. Conrad, 'Theophanes and the Arabic historical tradition: some indications of intercultural transmission', Byzantinische Forschungen 15 (1990), 1-44; R. Hoyland, 'Arabic, Syriac, and Greek historiography in the first Abbasid century: an inquiry into inter-cultural traffic', Aram 3 (1991), 211-33; Borrut, Entre mémoire et pouvoir.

104 Chronicle of Seert, II/i, XL (200-1); II/ii, LXI (470). Also Book of the Governors, II, xxix.

105 This volume, chapter 6.

106 Chronicle of Seert, II/ii, CII (601-10).

107 Probably transmitted via the Melkite Theophilus of Edessa. See Hoyland, Seeing Islam, 400-9 and 631-5.

This is an open access version of the publication distributed under the terms of the Creative Commons Attribution-NonCommercialNoDerivs licence (http://creativecommons.org/licenses/by-nc-nd/3.0/), which permits non-commercial reproduction and distribution of the work, in any medium, provided the original work is not altered or transformed in any way, and that the work is properly cited. For commercial re-use, please contact academic.permissions@oup.com 
Chronicle. ${ }^{108}$ As such this text was probably originally composed in Arabic, rather than in Syriac.

However, the focus of this one page section is not really on the deeds of Muhammad, but on his relationship to the Christians of Najran in Yemen in southern Arabia. We are told how the Yemenis, unlike the Meccans, supported Muhammad and how he corresponded with the Christian leader, Sayyid Ghassani, who helped him and brought him presents, and how he, and his successor Umar, wrote a treaty for them.

This account is magnified in later sections by a full description of this treaty and the deeds of the caliphs, a description that was written by a second author. CII is the text of Muhammad's letter, in which he bans Muslims from imposing any additional requirements on Christians, since they 'refused to fight God and his messenger'. The Christians are contrasted to 'those people who follow the old sects and ancient books who are enemies of God and his messenger and opposed to the mission set out in His Book [i.e. the Qur'an]'. These people, the letter adds, assault men with false arguments, as well as allying with the pagans of the Quraysh (the pre-Islamic guardians of the Ka'ba) and trying to kill 'the Prophet'. For this, they deserve 'to be stripped of God's covenant, because of their activities against Muhammad in the days of the Banū Qaynuqā' the Banū Qurayẓa and the Banū Naḍr (the Jewish tribes of Medina)'. ${ }^{109}$

These people, thus far unnamed, are only identified as Jews at the end of this narrative: while the Christians help the 'messenger of God', 'the Jews and pagans have the greatest hatred for the believers and those who love them most are those who say "we are Christians" (Qur'an V, 85-7). The Christians are said to be allies in war against the Jews and to have proved faithful allies and obeyed the pact that they have drawn up, at the request of the leaders of Najran, which 'is compulsory for all believers and Muslims', an alliance that should be followed by all who wish to follow in 'my [Muhammad's] footsteps' and which applies to 'all Christians'. Bishops and monks, he says, have been loyal to my cause, while Jews have only been motivated by greed. ${ }^{110}$

The letter is extremely lengthy and repetitive, far too much so to be anything other than an invention. It was composed by an author who was familiar with the accounts of the Life of Muhammad, such as that composed by Ibn Ishaq in the 780s, and with the Qur'an. The core of the narrative that he describes is Muhammad's conflict with several of the Jewish tribes of Medina, who were initially included in a treaty with Muhammad, but who later fell out with him and allied themselves to his pagan enemies in Mecca. Christians were essentially absent from Ibn Ishaq's story as a political force, though Yemenis

${ }_{108}$ Khuzistan Chronicle, 38.
109 Chronicle of Seert, II/ii, CII (602-4).
${ }_{110}$ Chronicle of Seert, II/ii, CII (605-10).

This is an open access version of the publication distributed under the terms of the Creative Commons Attribution-NonCommercialNoDerivs licence (http://creativecommons.org/licenses/by-nc-nd/3.0/), which permits non-commercial reproduction and distribution of the work, in any medium, provided the original work is not altered or transformed in any way, and that the work is properly cited. For commercial re-use, please contact academic.permissions@oup.com 
did become important members of the umma (community) after Muhammad's victory over the Meccan pagans. The Najranite embassy, and the story of the treaty, has been added to the rest of the story by the Christian author, inspired in part by verses in the Qur'an that compare Christians favourably to the Jews. ${ }^{111}$ His agenda was to insert the Christians, undifferentiated by denomination, into early Muslim history, and into an Arabian context, as allies of the Muslims and opponents of the Jews, that is, as good dhimmis who are rewarded by Muhammad for their loyalty.

This reward consists of a series of promises made by Muhammad to Sayyid Ghassani and 'all members of the Christian religion, in East and West'. This 'authentic diploma' represents itself as an unbreakable contract: 'whoever observes it, demonstrates his attachment to Islam and deserves its benefits, but whoever breaks it or alters its commands, violates God's covenant'. The letter asserts the requirements of Muslim armies to defend the Christians. It forbids them from forcing a bishop from his see or a monk his monastery, and demands a from of 4 dirhams per person or an embroidered Yemeni cloth, with a 12 dirham tax for landowners, merchants, or owners of mines. Christians are to be exempt from military service, or additional war taxes, and they are to be treated with justice and not subject to forced marriage or to marriages that contradict the wishes of their parents. Muslims are also required to respect the faith of their spouse and to help Christians rebuild churches or monasteries in disrepair. Finally, the letter is concluded by a long list of signatures, all of whom are well-known Companions of the Prophet. ${ }^{112}$

The stipulations made here fit into a wider discourse about the duties of Christians (and other dhimmis) towards their rulers, especially in terms of taxation and public religious behaviour. These debates took into account the different status of territories across the caliphate, of whether they had been seized by force or through a negotiated treaty with inhabitants, as well as considering the requirements imposed upon dhimmis who emigrated to the newly founded cities, where there were no established rules for their treatment. Different Islamic jurists took a variety of positions on the ability of Christians in particular to hold processions, rebuild churches or ring bells, as well as debating the level of jizya (poll tax) and kharāj (land tax) that they were subject to. It was a discussion that gradually veered towards intolerance by the end of the tenth century. ${ }^{113}$

111 Al-Jahiz complains that Christians 'won over the riff-raff' by invoking the Qur'an (e.g. 5.82: 'The Christians are closest in love to the believers.'). Cited in S. Griffith, 'Jews and Muslims in Christian Syriac and Arabic texts of the ninth century', Jewish History 3 (1988), 65-95, at 66.

112 Chronicle of Seert, II/ii, CIII (610-18).

113 M. Levy-Rubin, 'Shurūt 'Umar and its alternatives: the legal debate on the status of the dhimmis', JSAI 30 (2005), 170-206. She observes that these formulae moved away from an emphasis on Christian loyalty to the caliphate to protecting the superior status of Muslims over Christian immigrants to the mișrs.

This is an open access version of the publication distributed under the terms of the Creative Commons Attribution-NonCommercialNoDerivs licence (http://creativecommons.org/licenses/by-nc-nd/3.0/), which permits non-commercial reproduction and distribution of the work, in any medium, provided the original work is not altered or transformed in any way, and that the work is properly cited. For commercial re-use, please contact academic.permissions@oup.com 
This was a debate in which historical reports were extremely important, since they established precedents for how relations with dhimmis, or those who had acquired conquered land, should be managed. The arguments about tax status in particular hinged upon accounts of the seventh-century conquests: it is this interest that seems to motivate the ninth-century historian alBaladhuri in his Kitāb Futūh al-Buldān (Book of the Conquest of the Nations) where he records the conditions under which different settlements were conquered. Robinson proposes that the material that al-Baladhuri drew upon reflects 'the production of knowledge' as the significance of these arrangements grew, as citizens opposed tax collection and the state tried to raise revenue. ${ }^{114}$ In the same vein, a manual on taxation from the same era, Abu Yusuf's Kitāb al-Kharāj (Book of the Land Tax) includes a number of discussions of the conquest in order to justify its novel application of set levels of poll tax and land tax across the entire caliphate. Nigel Calder observed how this compiler strung together juristic fragments and hadith (sayings attributed to Muhammad) to legitimise this innovation and did so in the face of 'locals skilled in argument' who put forward stories of agreements with Muhammad or tax assessments under early caliphs to justify lower rates of payments in goods (in the case of Najran), payment according to means, or payment at a lower fixed rate (in the case of Edessa). ${ }^{115}$

Debates over taxation pitted the claims of such locals against compilers like Abu Yusuf, both sides marshalling their own proof texts of history, real and invented. This was an Islamic debate, in the sense that al-Baladhuri's proof texts are all futūh (conquest) narratives, stories of a divinely ordained conquest. But Christians were also capable of producing such histories, to defend their religious activities and their tax rights through collecting their own bodies of proof texts, in the acts of caliphs in more recent times ${ }^{116}$ and those of their predecessors, especially Muhammad and the Rashidun, who provided the most prestigious examples (stories which are also most likely to be invented) ${ }^{117}$ Several examples of the latter are presented in the ecclesiastical histories for individual cities: Bar Hebraeus notes how Marutha of Takrit, the first maphrian, surrendered the city to the Arabs and assured the property

114 See the comments of Robinson, Empire and Elites, 1-10.

115 N. Calder, Studies in Early Muslim Jurisprudence (Oxford, 1993), ch. 5, esp. 137-44. Also see F. Løkkegaard, Islamic Taxation in the Classical Period (Copenhagen, 1950), 16 for Abu Yusuf as a defender of the state's rights over all forms of property.

116 E.g. Chronicle of 1234, II, 3, for the Edessenes' success in persuading Harun al-Rashid not to demolish a church associated with the Roman emperor, a scene that may have served as a valuable precedent for later Muslim rulers, and the Life of John of Daylam, 26-31 (138) for 'Abd al-Malik's promise to John to spare monks, priests, and teachers (malfäne) from taxation.

117 On the clustering of stories of ideal behaviour around early caliphs: A. Hakim, 'Death of an ideal leader: predictions and premonitions', JAOS 126 (2006), 1-16 (on 'Umar I) and A. Borrut, 'Entre tradition et l'histoire: genèse et diffusion de l'image de Umar II', MUSJ 53 (2005), 329-78.

This is an open access version of the publication distributed under the terms of the Creative Commons Attribution-NonCommercialNoDerivs licence (http://creativecommons.org/licenses/by-nc-nd/3.0/), which permits non-commercial reproduction and distribution of the work, in any medium, provided the original work is not altered or transformed in any way, and that the work is properly cited. For commercial re-use, please contact academic.permissions@oup.com 
rights of its citizens and the Melkite Theophilus of Edessa, preserved in the Greek history of Theophanes, gives a similar account of peaceful surrender for Edessa. ${ }^{118}$ All of these accounts emphasise peaceful surrender in the past to press for lower taxation in the present. As Robinson observes, there would have been no advantage to preserving histories of resistance for demilitarized Christian communities. ${ }^{119}$

The surrender accounts preserved in the Chronicle of Seert tend to be more generalized than the stories for Takrit and Edessa. Though they may have originated as treaty narratives for individual places, they have been transformed into promises made by Muslim commanders to holy men on behalf of entire religious groups. Thus, the holy man Theodore is granted an exemption from the jizya for all priests by the caliph ${ }^{c}$ Umar, and Sabrisho' of Beth Garmai is promised a similar exemption for all monks ('those who wear wool'). ${ }^{120}$ Both of these accounts seem to be adaptations of monastic hagiographies, but the most extensive conquest narrative in the Chronicle is 'Umar's meeting with Isho' yahb II, in a continuation of the blend of Islamic and Christian history that we saw in Section CI. Here we are told that Isho ${ }^{c}$ yahb dispatched a messenger, Gabriel of Maishan, to Muhammad, to bring presents and announce that the Christians are tributaries of the Persians. Later, after Muhammad's death, he is succeeded by Abu Bakr and then 'Umar, who sets the level of the poll tax according to wealth. Isho' $y$ ahb comes to see 'Umar in person, and he receives a letter from him, 'to Seleucia, its catholicos, priests, and deacons' that proclaims the protection of Christians and announces that any who break this pact are separated from their covenant with God. 'Umar promises Isho'yahb security, stating that no churches will be stolen for use as mosques or private houses, and that Christians will not be obliged to fight in war, in return for the Christians' loyalty in their alliance. ${ }^{121}$

The agreement with 'Umar, to whom Muslim jurists also attributed normative agreements with dhimmis, touches on several of the issues seen in the treaties discussed by Abu Yusuf. ${ }^{122}$ Isho' yahb's agreement confirms that tax should be paid according to ability to pay and that the Christians should have freedom of worship. The former in particular is a detail that appears in the arguments rebutted by the Kitäb al-Kharāj. The claims of Christians in

118 Bar Hebraeus, HE, III, 123-6; Theophanes (ed. de Boor, 340, tr. Mango and Scott, 473). Al-Tabari, I, 2474-7 notes that the Takritis possessed a document that recorded their treaty with the Muslims.

119 Robinson, Empire and elites, 20.

120 Chronicle of Seert, II/ii, C (598) and CIX (633).

121 Chronicle of Seert, II/ii, CIV (619-23). Another account of the Islamic conquest embedded in the Chronicle (II/ii, CVI (628) also observes that the Muslims favoured the Christians over other religions, especially Zoroastrianism.

122 See Levy-Rubin, 'Shurūt 'Umar', 179-88 and Calder, Early Muslim Jurisprudence, 116 (for the importance of 'Umar).

This is an open access version of the publication distributed under the terms of the Creative Commons Attribution-NonCommercialNoDerivs licence (http://creativecommons.org/licenses/by-nc-nd/3.0/), which permits non-commercial reproduction and distribution of the work, in any medium, provided the original work is not altered or transformed in any way, and that the work is properly cited. For commercial re-use, please contact academic.permissions@oup.com 
these conquest narratives are not consistent: there is, for instance, nothing said here about the freedom of priests or monks from the jizya.

The agreement between 'Umar and Isho' yahb is also concerned with the role of the catholicos and his clergy as representatives of all the Christians before the caliph, a claim that was realized, in theory at least, in the course of the ninth century. In these sections on the conquest, the compiler of the Chronicle has brought together a series of different conquest narratives, some written from the perspective of the catholicosate or individual monasteries and others inspired by pro-Christian (or anti-Jewish) sections of the Qur'an and the Life of Muham$\mathrm{mad}$, and used them to generate the illusion of a consistently tolerant paradigm of good Muslim rule, which, as Calder argued, opposed the rival production of legal paradigms in the 'juristic contrivance' of men such as Abu Yusuf.

\section{REMEMBERING MUHAMMAD: THE HISTORIES OF NAJRAN}

In addition to the interest in tax that is apparent in these stories of the Arab conquest, two other features that mark them out are their opposition to the Jews and the emphasis on the presence of Christians in the Arabia of $\mathrm{Mu}$ hammad's day. Heightened tensions between Christians and Jews were a notable feature of Islamic rule. In the former Roman Empire in particular, Jews were now exempt from the discriminatory laws they had once been subjected to. The interest in the Najranites and in very early contact with Muhammad is, of course, connected to the prestige of such an early example, over and above encounters with later Muslim leaders. But it also corresponds to a wider interest of Abbasid intellectuals in Arabia. For Arabic-speakers long settled in Iraq, both for poets and religious scholars, Arabia represented a glimpse of the jāhilizya, of the pure language and customs of Arabs uncorrupted by exposure to the cultures of the Fertile Crescent. ${ }^{123}$

Adam Talib has emphasised the special role of the former Lakhmid capital of Hira in this imagination of the past. Its history as a Sasanian satellite with Arab history and culture, set apart by its courtly culture and its Christianity, made it an appropriate site for poetic ruminations on the fragility of men's fortunes. Hira presented a timeless place where Muslim authors such as al-Isfahani and Yaqut, could situate stories of the city's fall to contrast a Lakhmid Christian Arabia with their Muslim conquerors. These stories ranged from the refusal of $\mathrm{Nu}$ 'man's daughter Hind to marry a Muslim suitor, to Khalid ibn al-Walid's

123 See R. Dory, 'The Abbasid construction of the Jahiliyya: cultural authority in the making', Studia Islamica 83 (1983), 33-50.

This is an open access version of the publication distributed under the terms of the Creative Commons Attribution-NonCommercialNoDerivs licence (http://creativecommons.org/licenses/by-nc-nd/3.0/), which permits non-commercial reproduction and distribution of the work, in any medium, provided the original work is not altered or transformed in any way, and that the work is properly cited. For commercial re-use, please contact academic.permissions@oup.com 
assurance that he will respect and defend the Christians. Yet, as Talib argues, these stories do not only show a poetic fondness for the bittersweet, but may also incorporate native Hiran reactions to the conquests, defending their property and religious freedoms through their own Arabic poetry, that have been taken up and disseminated across religious boundaries. ${ }^{124}$

Interest in Hira's fame, and its tribal alliances in the pre-Islamic period, are a feature shared by the Haddad Chronicle and by Muslim historians such as alTabari. For al-Tabari, the history of Hira was an important source of the prestigious legends of the jähilìya, and a site of pre-Islamic monotheism. For the compiler of the Christian history, it represented a means of showing off the genealogy of its ascetic kings and connecting the deeds of the bishops and monks of the city to a site that was already famous as a home of warriors and poets. ${ }^{125}$ For both historians, Hira was a shared site of interest, a prestigious source for an obscure pre-Islamic past.

A similar pattern, of Christian participation in the Abbasid construction of a pre-Islamic past, is also visible for the southern city of Najran, the source of the embassy to Muhammad in the Chronicle of Seert. The story of the Najranite embassy in the Chronicle represents a claim to Christian support for Muhammad's conquest. It is rendered convincing through its early date, and the aristocratic Arab credentials of the Najranites' embassy. Though it goes unmentioned in the Chronicle, the Najranites were presented in the Islamic histories as early allies of Muslims, paying a tax to Muhammad and supporting his successor Abu Bakr against rebellions in the Yemen during the Ridda wars, and this may have increased the town's importance in the eyes of an Abbasid-era audience. ${ }^{126}$ These features of Arab ancestry and participation in the wars of the Muslims lie behind the assertions of the story in the Chronicle that the Najranites were allies of the Muslims, representatives of a brother religion. Furthermore, this story of the seventh century was written against a context of a continued Christian presence in Arabia at the time of writing. As recent ceramic studies have emphasised, Christian monasteries such as al-Qusur and Kharg flourished along the western seaboard of the peninsula in the eighth and ninth centuries, and Nestorian bishoprics were created here, and in San'a and Socotra. ${ }^{127}$

124 A. Talib, 'Topoi and topography in the history of al-Hirah', in P. Wood (ed.), History and Identity in the Middle East, 500-1000 (New York, 2013), 123-48.

125 Al-Tabari, I, 822, 834, 850-3; Haddad Chronicle, LXXXIV-LXXXVII (130-42).

126 See al-Tabari, I, 1854-5 (on the rebellion of Al-Aswad) and 1998 (on Najran providing troops to fight the rebels). These events are discussed in E. Shoufani, Al-Riddah and the Muslim Conquest of Arabia (Toronto, 1973), 77, 90-1, and 137.

127 R. Carter, 'Christianity in the Gulf during the first centuries of Islam', $A A E 19$ (2008), 71-108. For bishoprics see entries in J.-M. Fiey, Pour un Oriens Christianus Novus: répertoire des diocèses Syriaques orientaux et occidentaux (Beiruit, 1993), on 'Socotra', 'San'a', and 'Najran'. J.-M. Fiey, 'Diocèses syriens orientaux du Golfe Persique', in Memoria G. Khoury Sarkis (Louvain, 1969), $177-219$ is probably overly pessimistic and must be read in the light of the redating of the archaeology.

This is an open access version of the publication distributed under the terms of the Creative Commons Attribution-NonCommercialNoDerivs licence (http://creativecommons.org/licenses/by-nc-nd/3.0/), which permits non-commercial reproduction and distribution of the work, in any medium, provided the original work is not altered or transformed in any way, and that the work is properly cited. For commercial re-use, please contact academic.permissions@oup.com 
But if Najran was important as a symbol of the presence of Christians in Arabia, past and present, it was even more famous, across religious divides, as the site of a famous martyrdom of local (Miaphysite) Christians by the Jewish king Dhū Nuwās in 522, who was eventually defeated by an invasion of the Christian kings of Axum. These events were widely described at the time in Syriac, Greek, and Ethiopic and went on to form the inspiration for Sura 85 of the Qur'ān, a sign of how far Muslim memory production was rooted in 'older, more pervasive systems of memorializing. ${ }^{128}$ Significantly, the sura represented the Christian martyrs of Najran as Muslims, martyred for their faith by their (Jewish) persecutors, in a scene that would be embellished by later Muslim historians. ${ }^{129}$ It was, as Sizgorich has observed, a troubling story because it presented other monotheists as part of the umma (community), a detail that may have been close to the reality of the fluid boundaries of the political-religious alliance that crystallized around Muhammad, and which later scholars, such as the great jurist Ibn Hanbal, tried hard to suppress. ${ }^{130}$

Najran, then, provided an important vehicle through which Christians could emphasise their own presence in pre-Islamic history, with its prestigious genealogies that connected the town to other Arabs of real or imagined Yemeni origin throughout the caliphate, as well as giving Christians a place as members of the umma, a situation that is invoked to justify the terms of the treaty embedded in the Chronicle of Seert. However, we must also recognize that the history of the real Najran did not have the neat and continuous history that Christian commentators wished, and that the story in the Chronicle involves considerable suppression of inconvenient details and falsification to appropriate this example for its own use. Firstly, stories of Najran in the Yemen were applied in the taxation debates to a second city of Najran, founded near Kufa and Hira in the village of Nahr Aban, where descendants of the Najranites claimed the special tax rights that had been given to their ancestors. ${ }^{131}$ Claims to special tax rights for the Najranites in Abu Yusuf pertain to this city, and not to the older city in Arabia, and the suppression of the claims of these exiles are given as an example of the tyranny of al-Hajjaj. ${ }^{132}$ By

Notably (211-12), the bishops of Fars retained their title to 'the isles', which need not be an anachronism. Christian expansion may have accompanied a broader expansion of settlement in eastern Arabia: D. Kennett, 'The decline of eastern Arabia in the Sasanian period', AAE 18 (2007), 86-122.

128 The sixth-century sources are discussed in I. Gadja, Le royaume de Himyar à l'époque monothéiste (Paris, 2009). The Islamic reception of these narratives is discussed in T. Sizgorich, 'Become infidels or we will throw you into the fire: the martyrs of Najran in early Muslim historiography, hagiography and Qur'anic exegesis', in A. Papaconstantinou, M. Debié, and H. Kennedy (eds.), Writing True Stories: Historians and Hagiographers in the Late Antique and Early Medieval Near East (Leiden, 2009), 125-47.

129 E.g. Al-Tabari, I, 919-22 and 927-9.

130 T. Sizgorich, 'Ka'ab al-Ahbār' (unpublished document).

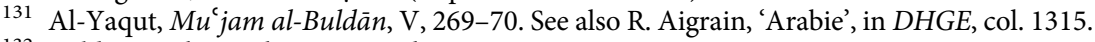

132 Calder, Early Muslim Jurisprudence, 141.

This is an open access version of the publication distributed under the terms of the Creative Commons Attribution-NonCommercialNoDerivs licence (http://creativecommons.org/licenses/by-nc-nd/3.0/), which permits non-commercial reproduction and distribution of the work, in any medium, provided the original work is not altered or transformed in any way, and that the work is properly cited. For commercial re-use, please contact academic.permissions@oup.com 
invoking the story of Najran, the chronicler is presenting their arrangement as a normative claim on behalf of all Christians, when it had formally been used to put forward the claims of one settlement.

Secondly, the inclusion of the story in the Chronicle of Seert represents a Nestorian appropriation of a place and of a story that was much more firmly connected to Miaphysite circles and to writing in western Syriac: the first testimony of the martyrdom is, after all, attributed to the sixth-century Miaphysite missionary Simeon beth Arsham. ${ }^{133}$

In spite of its fame as a city of martyrs, Najran, perhaps because it was located so far from major Christian polities, became a place of refuge for the Julianists, the Miaphysite opponents of Severus of Antioch who were rejected by the Jacobite church of the seventh century and beyond. ${ }^{134}$ The Julianist presence here is explained as a result of their earlier expulsion from Hira, and Timothy continues to lament their presence until a missionary drive 'reunites' thirteen of their churches to the Nestorians, when a bishop is appointed for the city in $790 .{ }^{135}$ Even so, it is clear that Najranite Christianity was divided between several different authorities, since Bar Hebraeus and Michael the Syrian claim that there were Jacobite bishops of Najran in the ninth and tenth centuries who were periodically also styled bishops of the Banu Tanukh or the Ma'ad, tribal confederations of northern Arabia. ${ }^{136}$

Part of the unseen historiographical context of the Chronicle's account lies in a cluster of Nestorian missionary stories for Najran that have survived embedded in Muslim sources. Hirschberg collected three of these accounts, which tell how saintly heroes in the distant past destroyed the palm tree that the people worshipped or survived persecution from the king and converted all the people. ${ }^{137}$ Though there are three distinct accounts, all share several features in their narrative, most importantly the impression that Najran was subsequently taken over by heretics. The Chronicle of Seert's section on Najran, drawn from the historian Bar Sahde (c.730) and placed in the middle of the fifth century, though it is much less detailed, also claims the precedence of the Church of the East as missionaries to the south. ${ }^{138}$

We should not follow Hirschberg in seeing these later sources as a guide to fifth-and sixth-century realities. It seems more likely that they represent

133 Wood, We Have No King but Christ, 224-6.

134 On the Julianists in general see M. Jugie, 'Gainanites', Dictionnaire de théologie catholique.

135 Chronicle of Seert, II/i, XXII (142-4); Timothy, Letters 27 and 41; Fiey, Pour un oriens christianus novus, s.v. 'Najran'.

${ }^{136}$ See Fiey, AC III, 227-30. It may be that bishops of Najran were located in both the old and the new settlements (in Arabia and Iraq respectively).

137 W. Hirschberg, 'Nestorian sources of north Arabian traditions on the establishment and persecution of Christianity in the Yemen', Rocznik Orientalistyczny 15 (1939), 321-38, citing alTabari, I, 920-5. Also see the discussion of R. Tardy, Najran: chrétiens d'Arabie avant l'islam (Beiruit, 1999), 84-108.

${ }^{138}$ Chronicle of Seert, I/ii, LXXIII (330-1).

This is an open access version of the publication distributed under the terms of the Creative Commons Attribution-NonCommercialNoDerivs licence (http://creativecommons.org/licenses/by-nc-nd/3.0/), which permits non-commercial reproduction and distribution of the work, in any medium, provided the original work is not altered or transformed in any way, and that the work is properly cited. For commercial re-use, please contact academic.permissions@oup.com 
eighth- and ninth-century attempts to write over the sixth-century Jacobite accounts of the persecution of a very young church in Najran, and to assert an earlier Nestorian claim. Bar Sahde's story, and others like it, represent postIslamic attempts to appropriate a 'southern' past for the Nestorians, to match the expansionist claims of their own episcopal structures under Muslim rule, in parallel with the claims of a western connection in the Awgin legend. Furthermore, it was especially important for the Church of the East to appropriate Najran and its memory because of its role as a symbol of Muslim cooperation with the Christians, a means of asserting a pro-Christian paradigm for Muslim rule.

Najran in the Chronicle of Seert has been rendered as a symbol of this cooperation with all Christians. It was not a story that was only useful to one denomination or only to the Najranites themselves. However, by claiming precedence in Najran, and by establishing it as a bishopric, the Nestorians may have also sought to emphasise their own role as intermediaries with the Muslim authorities. In an era when Timothy asserted the unity of belief of the main Christian groups in order to increase his own prestige, his church generated stories of Najran that were translated into Arabic and that eclipsed the older Syriac stories of Najran that had been written by the Jacobites.

\section{REMEMBERING MUHAMMAD: CHRISTIANS, JEWS, AND MUSLIMS}

The final feature of the narratives of surrender in the Chronicle of Seert that we will examine here is the juxtaposition of Christians and Jews as good and bad dhimmis. The treaty between Muhammad and the Najranites contrasts the Muslims and their Christian allies with the tribes of Jews and pagans known from the Life of Muhammad, tribes who are then represented as standing for all Jews in general. ${ }^{139}$ In the account of the conquest that follows this polemic, the relationship between Christians and Jews within the caliphate is discussed by a second means, through the figure of a distrusted Jewish convert to Islam, $\mathrm{Ka}^{\mathrm{c}} \mathrm{ab}$ al-Aḥbār, who tries to influence the caliph Abu Bakr against the Christians and is rejected. ${ }^{140}$

The use of Najran as a symbol for Muslim-Christian cooperation already has an anti-Jewish background. The martyrs of Najran, famous to both communities, were widely seen as victims of a Jewish persecutor, Dhū Nuwās, and al-Tabari even reports a connection between this king and the

139 Note the shift in language in section CII, where the author moves from the specifics of the deeds of the Banū Qurayża (604) to the general characteristics of the Jews as greedy and deceitful (607).

140 Chronicle of Seert, II/ii, CIV (619).

This is an open access version of the publication distributed under the terms of the Creative Commons Attribution-NonCommercialNoDerivs licence (http://creativecommons.org/licenses/by-nc-nd/3.0/), which permits non-commercial reproduction and distribution of the work, in any medium, provided the original work is not altered or transformed in any way, and that the work is properly cited. For commercial re-use, please contact academic.permissions@oup.com 
Jews of Medina who opposed Muhammad. ${ }^{141}$ The persecution of Christians here could be represented as a forerunner of the struggle of the Prophet, a story where Christians and Muslims were both participants.

The insertion of $\mathrm{Ka}^{\mathrm{c}} \mathrm{ab}$ al-Aḥbār fills a parallel role to that of the Jews of Najran and Medina, except that it here it allows the Christian historian to make a tacit criticism of certain attitudes held by Muslims as un-Islamic, as innovations introduced by a Jew into Islam and opposed by the caliph. $\mathrm{Ka}^{c} \mathrm{ab}$ plays an important role in the hadith of the caliphs Abu Bakr and 'Umar and in the fad $\bar{a}^{\prime} i l$ of Jerusalem, the legends of the city and its monuments. ${ }^{142}$ Sizgorich has observed that $\mathrm{Ka}^{\mathrm{c}} \mathrm{ab}$ represents 'a tradent for the stories of preIslamic prophets ... a means [of] emplotting the Muslim community into an older Abrahamic tradition'. $\mathrm{Ka}^{\mathrm{C}} \mathrm{ab}$ is used, for instance, as a vehicle for providing access to earlier monotheist prophecies of Islam in the Old Testament, and accounts of this Jewish convert to Islam incorporate Biblical and midrashic ideas and ascribe them to him, justifying their presence in Islamic exegesis through this Muslim Jew. Yet, alongside this positive image, $\mathrm{Ka}^{\mathrm{c}} \mathrm{ab}$ also represented a foil for the caliphs to demonstrate true orthodoxy against a false opinion, an opinion that is shown to be Judaizing through its association with $\mathrm{Ka}^{\mathrm{c}} \mathrm{ab}$. Thus 'Umar is said to have refuted $\mathrm{Ka}^{\mathrm{c}} \mathrm{ab}$ 's suggestion that the qibla at Jerusalem (the direction of prayer) should be oriented through the site of the Temple as well as towards Mecca, and polygynous Muslims who are reprimanded by the caliph are said to have imported Jewish practices into Islam. ${ }^{143}$

Timothy famously referred to the Muslims as 'the new Jews' in a private letter, and emphasised the degree to which Muslims were influenced by the Jews in terms of dietary laws and circumcision. ${ }^{144}$ Yet, speaking before the caliph, he gave a more positive view of Islam: here he said that Muhammad, while not a prophet, was one who walked in the way of the prophets, one who had brought the pagan Arabs towards belief in the one God. ${ }^{145}$ Both views were available to the catholicos, for whom the Muslims might be depicted as Judaizers or as fellow monotheists.

The carefully balanced account in the Chronicle of Seert makes both of these assertions simultaneously, as part of a wider intervention in Islamic political thought by Christians. Muslims were already divided over how to treat a liminal figure like $\mathrm{Ka}^{\mathrm{c}} \mathrm{ab}$, who could represent a conduit of Abrahamic

\footnotetext{
${ }^{141}$ See Tardy, Najran, 84.

142 On these legends in general see J. Johns (ed.), Bayt al-Maqdis II: 'Abd al-Malik's Jerusalem (Oxford, 1999).

${ }^{143}$ Sizgorich, 'Ka'ab al-Ahbār' (citing al-Tabari, I, 2408); U. Rubin, The Eye of the Beholder: The Life of Muhammad as Viewed by the Early Muslims, A Textual Analysis (Princeton, 1995), ch. 1.

${ }^{144}$ Cited in Griffith, 'Jews and Muslims in Christian Syriac and Arabic', 65.

145 Timothy, Apology to the Caliph. A similar image is found in the Khuzistan Chronicle, 32.
}

This is an open access version of the publication distributed under the terms of the Creative Commons Attribution-NonCommercialNoDerivs licence (http://creativecommons.org/licenses/by-nc-nd/3.0/), which permits non-commercial reproduction and distribution of the work, in any medium, provided the original work is not altered or transformed in any way, and that the work is properly cited. For commercial re-use, please contact academic.permissions@oup.com 
legitimacy or a source of Jewish pollution for the new religion. By placing the disagreement of $\mathrm{Ka}^{\mathrm{c}} \mathrm{ab}$ and $\mathrm{Abu}$ Bakr over the treatment of the Christians into a narrative that concentrated on the betrayal of the Jews of Medina and the loyalty of the Christians of Najran, the author emphasises this negative interpretation of $\mathrm{Ka}^{\mathrm{c}} \mathrm{ab}^{.146}$ Within this discourse of Jewish falsehood within Islam, which was common to Timothy and to the Muslim Arab histories, mistreatment of the Christians is ranked alongside polygyny or the Jerusalem qibla as a Jewish practice that had been introduced into Islam. The subtext that this debate evokes is therefore the eternal struggle between Jews and Christians, a struggle that, the reader infers, should leave good Muslims on the side of the Christians, protected by the precedent of Muhammad, Abu Bakr, and 'Umar themselves.

\section{CONCLUSIONS}

The compilation of the synodica and the great histories, of which the Chronicle of Seert is the longest and most detailed, was part of a wider expansion of scholarship that occurred in the reign of Timothy and his successors. The collection of a wide variety of texts from different sources and traditions is part of a broader encyclopaedic interest, where literate Christians, Muslims, and Jews came together in the new cities of the caliphate. But the role of the patriarchate itself as an institution that collected texts also allowed certain patriarchs great powers to shape the communal memory of the Church of the East. The absence of any Sasanian precursors to the Great Synodicon that could rival it for its length or diversity of material suggests that the linking of different ways of writing about the church through representations of the past, through synods, letters, histories, and laws, was a product of the Islamic period and the flourishing of Christians in the cities of Abbasid Iraq.

In the Church of the East, the process of compilation was accompanied by the invention of new strands of historical writing that extended the church's history to give it a prestigious connection to the West, as well as incorporating historical material gathered under rival Christian denominations. In both cases, these new pasts reflect a broader field of activity for the Church of the East within the Abbasid caliphate, whereby new bishoprics were established beyond the former Sasanian Empire. There are also important signs of cooperation between Christian groups in the contents of the medieval compilations, which show that different denominations shared prestigious histories, invented and real, such as the deeds of Constantine or the glories of Rome.

146 For other Christian legends of Ka'ab see Griffith, 'Jews and Muslims in Christian Syriac and Arabic', 81.

This is an open access version of the publication distributed under the terms of the Creative Commons Attribution-NonCommercialNoDerivs licence (http://creativecommons.org/licenses/by-nc-nd/3.0/), which permits non-commercial reproduction and distribution of the work, in any medium, provided the original work is not altered or transformed in any way, and that the work is properly cited. For commercial re-use, please contact academic.permissions@oup.com 
Moreover, in a Muslim context, appeals to the shared Western past of all Christians underlined the roles of Christians as the gatekeepers of a world of exotic lost knowledge, as well as presenting the fundamental unity of the religion.

At the same time, the Abbasid context of the Church of the East necessitated a relatively 'ecumenical' attitude to Islam, and the imagination of the shared past of Muslims and Christians. Here too, the Nestorians' missionary expansion, this time to the Arabian peninsula, was used to anchor these invented histories and to imagine events in Najran as part of the wider history of the Church of the East. In the narratives of Muhammad's career, the Chronicle of Seert presents Najran as a metonym for Christians everywhere. The Christians as a whole are presented as the allies of the Muslims, and this 'fact' is used to provide a justificatory narrative for Christian demands for protection as dhimmis and to use a discourse of 'Islamic' taxation to argue for the exemption of monks from the poll tax.

Through the reworking of the Life of Muhammad, a Christian author expressed his needs in Islamic terms. He seems to have been well aware of the proof texts for this debate on taxation. Like Timothy's diplomatic defence of Christianity before the caliph al-Mahdi, the production of this story shows us a patriarchate that had become highly sensitized to the attitudes and language of its Muslim rulers and neighbours, from whom it also derived substantial material rewards. Strikingly, it was the environment of Abbasid rule, with the patronage that it brought to Iraq, that facilitated the greatest expansion of the church, and that, concomitantly, generated the great classifying projects of the catholicoi of the ninth and tenth centuries.

This is an open access version of the publication distributed under the terms of the Creative Commons Attribution-NonCommercialNoDerivs licence (http://creativecommons.org/licenses/by-nc-nd/3.0/), which permits non-commercial reproduction and distribution of the work, in any medium, provided the original work is not altered or transformed in any way, and that the work is properly cited. For commercial re-use, please contact academic.permissions@oup.com 


\section{Conclusions}

The Chronicle of Seert, as we have received it, is a product of the Abbasid period, and represents an ambitious attempt by one author to compose a universal history, focused on the deeds of the catholicoi of Ctesiphon and Baghdad that had formed the traditional core of Iraqi Christian historiography since the fifth century. Its compiler wrote in the environment of the recentralized catholicosate of Timothy's successors, under whom the Church of the East reached new heights of power, in terms of both its missionary expansion and its relationship with lay authorities. A narrative of the development of the powers of Timothy's predecessors and of the relations between catholicoi and earlier secular rulers represented an important means of justifying these new powers and this new centralization. The Abbasid period witnessed the consummation of trends seen deep into the pre-Islamic period, which predated the relatively anarchic situation of the Church of the East under Umayyad rule. Like the contemporaneous collection of law codes and synodica, the historical compilations represent an attempt by the catholicoi to articulate the identity and behaviour of ('Nestorian') Christians in Iraq and beyond.

I have argued that it is possible to date much of its Syriac raw material by reading the Chronicle together with the other medieval compilations and comparing its testimony to that of other late antique sources. This material suggests a gradual expansion in the awareness of alternative historical traditions, culminating in the importation of additional narratives into a tradition that began as a history of the catholicoi. At the end of the sixth century, new traditions from the Roman world, from Iranian secular traditions, and from Christian institutions in the north of Iraq came to be embedded into Iraqi historiography. In this era increasing numbers of men of learning in Sasanian Iraq turned their hand to the creation of ecclesiastical history.

For each stage of expansion in the historical tradition, we can see historywriting itself as a technology for articulating Christian identity and for defining the political stance of the catholicoi. Monastic histories and Iranian secular traditions embraced a new symbiosis between a developing class of Christian lay elites and the institutional church. And Roman ecclesiastical history provided a new narrative that explained theological differences with Miaphysite

This is an open access version of the publication distributed under the terms of the Creative Commons Attribution-NonCommercialNoDerivs licence (http://creativecommons.org/licenses/by-nc-nd/3.0/), which permits non-commercial reproduction and distribution of the work, in any medium, provided the original work is not altered or transformed in any way, and that the work is properly cited. For commercial re-use, please contact academic.permissions@oup.com 
'invaders' and propagated a 'Nestorian' identity amongst members of the Church of the East, an idea that guarded against conversion across confessions and emphasized the role of the priests as theologians who provided necessary definition to the faith.

The addition of these new strands of history was not merely a feature of centralization. Lay sponsors such as Yazdin might seem to eclipse the role of the catholicos at the court of the shah, and the development of priests as theologians and monastic leaders periodically threatened to factionalize the clerical elites responsible for selecting a catholicos. So, we might also see the addition of these new narratives to an older patriarchal history as a means of normalizing a potentially disruptive shift in power from Ctesiphon to the aristocrats and monasteries of northern Iraq, and as a means of articulating a new broader relationship between institutions and regions in Christian Iraq.

In many cases, the various strands employed by this generation of Iraqi ecclesiastical historians can all be seen as borrowings from the Roman world. The very idea of a patriarchal history, linking the deeds of the catholicoi to the deeds of the martyrs, may itself show a debt to the Ecclesiastical History of Eusebius, with its own striking record of the Diocletianic martyrs, and which was probably one of the first Greek texts translated into Syriac. In the same vein, the monastic histories of Egypt, such as the Lausiac History of Palladius, stimulated the development of monastic histories focused on Izla. Thus, the continuators of Eusebius in the fifth and sixth centuries made possible the juxtaposition of the history of the catholicoi with the ecclesiastical history of the Roman world and the assertion of a Dyophysite identity in the Church of the East. It is here, in the transmission of the facts and ideas of Western history, that the School of Nisibis seems to have been especially important as a gateway for new information. Moreover, it was these historical ideas that facilitated the evolution of the Church of the East as an imagined community that claimed to encompass all of Iraq. Historians interwove the pasts of different Christian institutions into a single whole, set in a Dyophysite 'East' and led by a catholicos-patriarch in Ctesiphon, and placed it all into the context of a broader Christian world in the West.

If renewed contact with the West should be seen as the stimulus for a broader conception of the Church of the East as part of a universal church, then diplomatic contacts of catholicoi and bishops with Rome as representatives of the shah also show us how this conception came to pay political dividends for the catholicosate. Sasanian shahs had long sought to use the leaders of minority religions to ensure the legitimacy of their own rule or the effectiveness of their bureaucracy and taxation system, as the examples of Symeon bar Sebba ${ }^{c}$ and Ishaq remind us. However, the end of the sixth century witnessed a more dramatic attempt by the shah Khusrau II to co-opt Christian leaders, as Christians cooperated in propagating an image of the shah as the sponsor of a holy man revered across political borders. Sabrisho"s death, however, left the Church without a suitable figurehead who was acceptable

This is an open access version of the publication distributed under the terms of the Creative Commons Attribution-NonCommercialNoDerivs licence (http://creativecommons.org/licenses/by-nc-nd/3.0/), which permits non-commercial reproduction and distribution of the work, in any medium, provided the original work is not altered or transformed in any way, and that the work is properly cited. For commercial re-use, please contact academic.permissions@oup.com 
both to the shah and to Christian elites. In this era of turmoil, the numerous distinct narratives preserved in the Chronicle of Seert testify to the importance that history-writing had acquired as a means of tracing connections to an orthodox golden age that gave the present its identity. The Chronicle also illustrates the many different ways of establishing these connections to the past in the confused period at the end of Sasanian rule, where no single narrative strand could be identified as legitimate by the later compiler.

Despite the changeable relationship between the Church and Khusrau, the Chronicle of Seert shows that, after the fall of the Sasanians, Christians continued to see their relationship with the fallen empire as an important part of their past. Alongside assertions of the Church as a community defined by its Dyophysitism or its episcopal succession, a major thrust of the narratives of catholicoi is their relations with the shah. The account of this relationship is supplemented by Iranian secular histories and by the monastic histories of a territory that closely matches that of the former Sasanian Empire. Like the preservation of Sasanian laws of inheritance within the Church of the East, the ecclesiastical histories provided a vehicle for Persian memory in a world where a Sasanian state no longer existed and where Zoroastrianism had thereby lost its former prestige and organization. This role for the Church as a refuge for these histories and identities may have been one factor in encouraging the conversion to Christianity of Iranian elites during the political anarchy of the Umayyad period.

The importance of Abbasid era compilations such as the Chronicle of Seert and the Haddad Chronicle for the times of their compilers is best illustrated by comparison to equivalent, contemporary compilations in other Christian communities. Robert Hoyland has grouped the Chronicle of Seert in particular with other Syrian and Egyptian compilations produced in Melkite and Miaphysite ('Coptic') circles in the end of the tenth century, the chronicles of Eutychius and Agapius and the History of the Patriarchs of Alexandria. ${ }^{1}$

All of these compilations are Arabic translations of older material in Coptic and Syriac: in no cases does there appear to have been direct translation from Greek. All four texts reflect an active scholarly culture in Syriac or Coptic where a variety of indigenous and foreign sources could be accessed in libraries and deployed in new compositions. Some of these texts already existed in Arabic translation, while others were translated by the compilers (though the history of this process of translation requires further investigation). All four histories reflect a universalizing ambition, which sought to describe the history of Christians and Christianity from Jesus (or from Creation, in the case of Agapius), even if this was done with a particular regional focus. In particular, all four follow Eusebius' history for the early period, though sometimes only as a précis,

${ }^{1}$ Hoyland, Seeing Islam, 440-8.

This is an open access version of the publication distributed under the terms of the Creative Commons Attribution-NonCommercialNoDerivs licence (http://creativecommons.org/licenses/by-nc-nd/3.0/), which permits non-commercial reproduction and distribution of the work, in any medium, provided the original work is not altered or transformed in any way, and that the work is properly cited. For commercial re-use, please contact academic.permissions@oup.com 
and the Diocletianic persecutions and the reign of Constantine form a common feature of all of the accounts, a historical identity which is still reflected in the liturgical commemoration of all the oriental churches.

These Christian compilations all therefore aim to preserve their churches' historical identity in an era when lay, urban Christians at least were beginning to abandon their traditional languages in favour of Arabic. As Erica Degen has observed, the Chronicle of Seert and the Chronicles of 'Amr and Mari all share enough important passages to indicate the use of a single translation from Syriac into Arabic, even though they all use a variety of other sources in both languages. ${ }^{2}$ This preservation of tradition can be seen as a bid for continued cultural independence in an Arabic-speaking environment, but we should note that it took very different forms in different regions. There is a particularly striking contrast between the constrained focus of The History of the Patriarchs, which rarely discusses events beyond Egypt, and the disparate sources of the Chronicle of Seert.

The History tends to emphasize the suffering of the Egyptian church as a church of the martyrs, ${ }^{3}$ whose subject matter is defined by the apostolic succession of its priesthood ${ }^{4}$ and their ability to decide who is worthy to receive communion. ${ }^{5}$ Indeed, for the author, all of the formative events of the church are persecutions, by the pagan Diocletian and by the Dyophysite 'heretics' Marcian, Justinian, and Heraclius. ${ }^{6}$ His focus is reminiscent of the histories of the martyrs and catholicoi that were used in the fifth century in Iraq, except that the theme of persecution is now continued into the Islamic period, where the Coptic church maintains an embattled boundary against its religious opponents.

The Chronicle, by contrast, describes much more than the relentless string of persecutions that characterizes the early sections of the History of the Patriarchs. Though it retains a core structure based on the succession of the catholicoi, it is based on a much greater variety of different historical traditions: secular, monastic, scholastic, and episcopal. And, though its fifth-century core has a geographical focus in southern Iraq, sections composed or incorporated in the sixth, seventh, and eighth centuries increasingly look beyond Ctesiphon, to the north of Iraq, to the Roman world and to the lands of the later missions such as Merv or Himyar. If the History of the Patriarchs represents a turning inwards of the Christian worldview of Eusebius, then the Chronicle of Seert

2 Degen, 'Daniel bar Maryam', esp. 67-80. See also C. F. Seybold, 'Histoire nestorienne (Chronique de Séert) par Addai Scher', ZDMG 66 (1912), 742-6 for his comments on the different terms for the Hepthalites in the Chronicle as indications of different translations into Arabic.

${ }^{3}$ History of the Patriarchs, II, 141-8 for martyrdom as a source of converts and VI, 390 for Diocletian.

${ }^{4}$ History of the Patriarchs, VI, 401-2.

${ }^{5}$ History of the Patriarchs, IV, $156 . \quad{ }^{6}$ History of the Patriarchs, XIII, 451-2; XIV, 491.

This is an open access version of the publication distributed under the terms of the Creative Commons Attribution-NonCommercialNoDerivs licence (http://creativecommons.org/licenses/by-nc-nd/3.0/), which permits non-commercial reproduction and distribution of the work, in any medium, provided the original work is not altered or transformed in any way, and that the work is properly cited. For commercial re-use, please contact academic.permissions@oup.com 
demonstrates its adaptation and expansion. Perhaps the greatest sign of the difference in attitudes between the two regions occurs in the pro-Christian image of Muhammad that is presented in the Chronicle of Seert. In this Chronicle the cultural independence of Iraqi Christians, magnified through their connections to the shahs of the past, and to the exotic Christian lands of the West, was to be deployed within the caliphate. The Chronicle, therefore, is both a record and a celebration of the prestigious culture of the 'Nestorians' at a time when they were active participants in the government, bureaucracy, and trade of the Abbasid world. 


\section{Episcopal and Regnal Lists}

\section{Bishops of Seleucia-Ctesiphon}

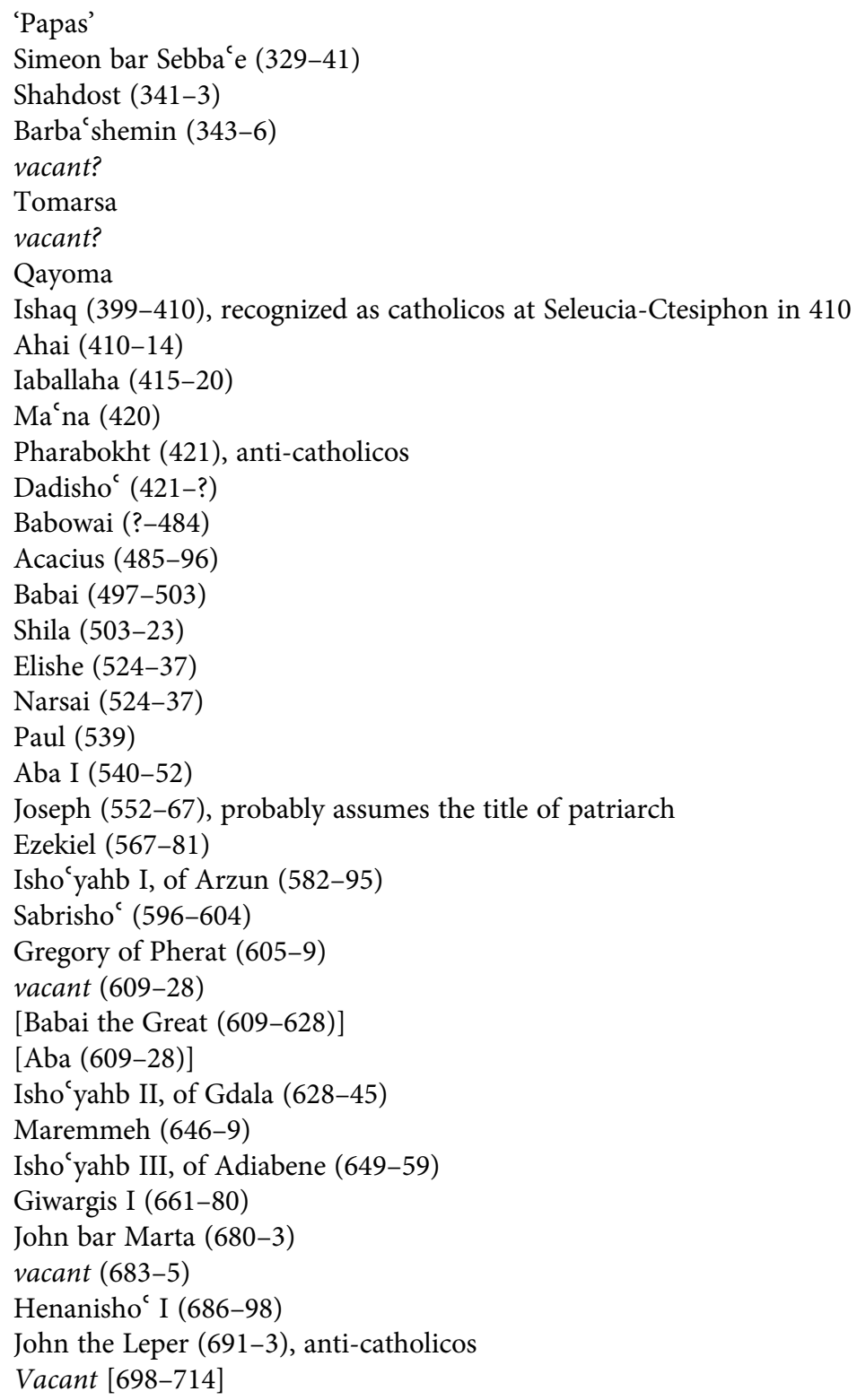


Sliba-zkha (714-28)

vacant $(728-31)$

Pethion (731-40)

Aba II (741-51)

Surin(753), anti-catholicos

Jacob (753-73)

Henanisho ' II (773-80): The patriarchate transfers to Baghdad.

Timothy (780-823)

Isho' bar Nun (823-8)

Abbots of the Great Monastery of Izla

Abraham of Kashkar (571-88)

Dadisho' (588-604)

Babai the Great (604-28)

\section{Directors of the School of Nisibis}

Narsai (-503)

Elishe bar Qozbaye (503-10)

Abraham of Beth Rabban

John of Beth Rabban

Isho'yahb of Arzun

Abraham

Henana (571-612)

\section{Sasanian Shahs}

Ardashir I (224-41)

Shapur I (241-72)

Hormizd I (272-3)

Vahram I (273-6)

Vahram II (276-93)

Vahram III (293)

Narses (293-302)

Hormizd II (302-9)

Shapur II (309-79)

Ardashir II (379-83)

Shapur III (383-8)

Vahram IV (388-99)

Yazdegard I (399-420)

Vahram V ('Gur') (420-38)

Yazdegard II (438-57)

Hormizd III (457-9)

Peroz (457-84)

Valash (484-8) 


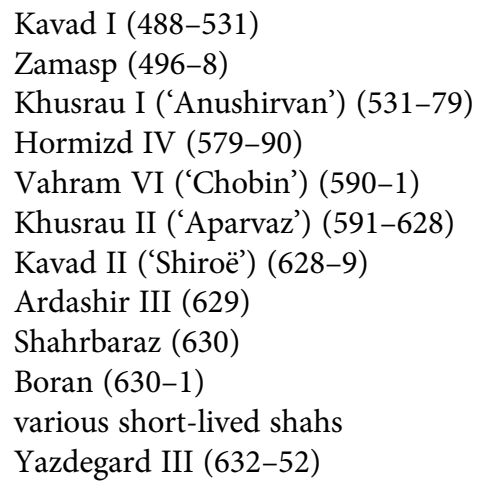

\section{Eastern Roman Emperors}

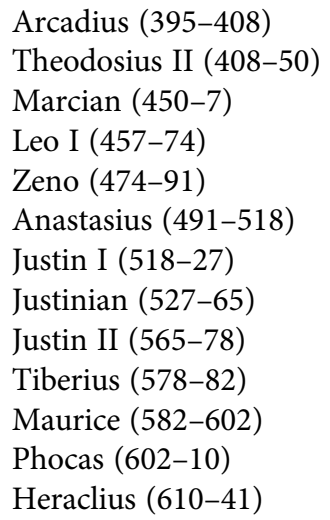




\section{Synods of the Church of the East}

$\begin{array}{ll}410 & \text { Synod of Ishaq } \\ 420 & \text { Synod of Iabalaha } \\ 424 & \text { Synod of Dadisho }^{c} \\ 484 & \text { Synod of Barsauma, bishop of Nisibis } \\ 486 & \text { Synod of Acacius } \\ 497 & \text { Synod of Baboi } \\ 544 & \text { Synod of Aba } \\ 554 & \text { Synod of Joseph } \\ 576 & \text { Synod of Ezekiel } \\ 585 & \text { Synod of Isho'yahb I } \\ 596 & \text { Synod of Sabrisho } \\ 605 & \text { Synod of Gregory of Pherat } \\ 612 & \text { Assembly of Ctesiphon } \\ 680 & \text { Synod of Giwargis I } \\ 774 & \text { Synod of Henanisho }{ }^{c} \text { II } \\ 790 & \text { Synod of Timothy }\end{array}$

This is an open access version of the publication distributed under the terms of the Creative Commons Attribution-NonCommercialNoDerivs licence (http://creativecommons.org/licenses/by-nc-nd/3.0/), which permits non-commercial reproduction and distribution of the work, in any medium, provided the original work is not altered or transformed in any way, and that the work is properly cited. For commercial re-use, please contact academic.permissions@oup.com 


\section{History-writing in the Church of the East}

(Bold text is used to indicate firmly dateable material)

Fourth century: Local lists of martyrs and bishops.

411: Edessa martyrion, including lists of the Shapurian martyrs.

c.414: Collection of acts of the Shapurian martyrs by Ahai. Composition of a hagiographic cycle for Mar 'Abda, the founder of a school near Ctesiphon.

before 424: Earliest versions of the Acts of Miles.

424: The story of Papas first used by Agapetus of Beth Lapet in the synod of Dadisho'.

c.420s: An account of the catholicoi of the period 410-24.

mid-fifth century: Composition of Abgar's Ctesiphon hagiographies, the Acts of 'Abda of Hormizd-Ardashir, and the Acts of Symeon A.

c.480s: 'Acacian history', focused on the catholicoi, combines the accounts of the 420 s with earlier hagiographic material and continues it to the compiler's own day. Several parts of this history are later overwritten.

530s: Composition of the Acts of Symeon B.

530s: Continuation of the 'Acacian history' under Narsai.

530s: Earliest histories of the school of Nisibis (now lost).

550s: Continuation of Narsai's history under Joseph, composition of the Syriac Acts of Aba.

late sixth century: Composition of the Syriac Acts of Mar Miles.

c.569: Ecclesiastical history written in Nisibis by Barhadbeshaba.

580s-660s: Expansion of the historical traditions beginning under Isho' ${ }^{c}$ ahb I: new strands of history are blended with the history of the catholicoi and this richer tradition is continued to the compilers' own times.

c.580s: Composition of the Syriac Acts of Mar Mari.

c.600: Barhadbeshaba 'Arbaya's Cause of the Foundation of Schools.

c.650: Early version of the Khuzistan Chronicle by Elias of Merv. (The extant text includes a later appendix.)

c.660s: Life of Rabban Bar 'Idta.

c.660s: Early monastic hagiographic collections: forms the basis for monastic material in the Chronicle of Seert and the Book of Chastity.

c.660s: Reform of the liturgy under Isho' yahb III.

This is an open access version of the publication distributed under the terms of the Creative Commons Attribution-NonCommercialNoDerivs licence (http://creativecommons.org/licenses/by-nc-nd/3.0/), which permits non-commercial reproduction and distribution of the work, in any medium, provided the original work is not altered or transformed in any way, and that the work is properly cited. For commercial re-use, please contact academic.permissions@oup.com 
780s-c.900: Compilation of earlier histories, synodica, and canons in the reign of Timothy I and his successors.

c.840: Thomas of Marga writes the Book of the Governors, using eastern saints' lives going back to the late sixth century.

860s: Compilation of Isho'dnah of Basra's Book of Chastity. 


\section{Contents of the Chronicle of Seert}

\section{Part I}

I Valerian

II Death of Valerian

III Young Roman martyrs

IV Mani

V Paul of Samosata

VI Gregory Thaumaturgus

VII Awgin

VIII Names of doctors of the church

IX Vahram II

ii) Peter of Alexandria.

$\mathrm{X}$ Arius

XI Paphnutius

XII Sergius and Bacchus

XIII Sylvester of Rome

XIV Sylvester and the dragon

XV Constantine

XVI Discovery of the Cross

XVII Helena and Constantine

XVIII Council of Nicaea

XIX Description of Constantinople

XX Description of Rome

XXI Eusebius' Chronicon

XXII Easter and the Resurrection

XXIII Shapur (II) Dhū al-Aktāf

XXIV Death of Constantine

XXV Eminent men contemporary with Papas

XXVI Ephraem the doctor

XXVII Simeon Bar Sebba'e, ninth catholicos

XXVIII Sons of Constantine

XXIX Shahdost, tenth catholicos

XXX Untitled (on Gregory of Nazianzen)

XXXI Barba'shemin, nephew of Bar sabba'e, eleventh catholicos

XXXII Mar Qardagh

Précis of the Syriac Life of Qardagh.

XXXIII Julian the Apostate

XXXIV Julian the Apostate

Précis of the Syriac Julian Romance.

XXXV (Yonan of Anbar)

Much of this text is dedicated to Yonan's master Awgin.

This is an open access version of the publication distributed under the terms of the Creative Commons Attribution-NonCommercialNoDerivs licence (http://creativecommons.org/licenses/by-nc-nd/3.0/), which permits non-commercial reproduction and distribution of the work, in any medium, provided the original work is not altered or transformed in any way, and that the work is properly cited. For commercial re-use, please contact academic.permissions@oup.com 
XXXVI John of Beth Zabde

XXXVII Rabban Sari

XXXVIII Zarnouqa Monastery

XXXIX Cyprian of Africa

XL Barshaba of Merv

XLI Rabban Shalita

XLII Earthquakes

In Roman cities and three cities of Persia, including Nisibis and Constantinople.

XLIII Ardashir, brother of Shapur

XLIV Valentinian and Gratian

XLV Theodosius I

Council of Constantinople.

XLVI The penance of Theodosius.

The massacre at Thessalonica.

ii) Succession of patriarchs on Constantinople: Chrysostom follows Nectarius.

XLVII Destruction of the temple of Sarkis [Serapion]

XLVIII Doctors named Gregory

XLIX Flavian and Diodore

L The heretical monks Simeon, Hermas, Dado and Eusebius

Labelled as Messalians.

LI Basil of Caesarea

LII The heretic Macedonius of Constantinople

LIII Theodore of Mopseustia

LIV Ephraem, the Syrian prophet

LV Julian Saba

LVI Epiphanius of Salamis

LVII The martyrs and great men of this era

LVIII Tomarsa, twelfth catholicos

LIX Bahram Farmanshah

LX Rabban Mar 'Abda of Dayr Qoni

LXI Convent of Sliba

Miracles that occur here are compared to the discovery of the Cross in the time of Claudius and to the death of the early seventh-century martyr, Nathaniel of Shahrzur.

LXII 'Abdisho', who built a convent at Hira

LXIII Qayoma, thirteenth catholicos

LXIV Arcadius and Honorius

LXV Yazdegard (I)

LXVI Ishaq, fourteenth catholicos

LXVII John Chrysostom

LXVIII Iaballaha, later elected catholicos.

ii) Doctors of the church in this time.

iii) Nectarius patriarch of Constantinople.

LXIX Ahai, fifteenth catholicos

LXX Theodosius the Younger

LXXI Iaballaha, sixteenth catholicos

This is an open access version of the publication distributed under the terms of the Creative Commons Attribution-NonCommercialNoDerivs licence (http://creativecommons.org/licenses/by-nc-nd/3.0/), which permits non-commercial reproduction and distribution of the work, in any medium, provided the original work is not altered or transformed in any way, and that the work is properly cited. For commercial re-use, please contact academic.permissions@oup.com 
LXXII Ma'na, seventeenth catholicos, who was deposed

LXXIII Conversion of Najran

LXXIV Death of Yazdegard

LXXV Jacob the Sliced

LXXVI 'Aqbalaha of Beth Garmai

Ends with lacuna.

\section{Part II}

I Babowai, twentieth catholicos

II Leo

III Anatolius of Constantinople

IV Zeno

V Death of Peroz

VI Gennadius of Constantinople

VII Tale of the demon and the monk

VIII Acacius, twenty-first catholicos

IX Mar Narsai

Scholastic account detailing education, academic composition and disciples.

ii) $\mathrm{Ma}^{\text {c }}$ na metropolitan of Fars a contemporary of Narsai at Edessa. Similar scholastic account.

$\mathrm{X}$ Anastasius

ii) List of solar eclipses and earthquakes.

iii) Life of Severus and the conversion of Jacob of Serug by Severus.

XI 'Milas' king of Persia

ii) Jacobite 'invasion' and response of Acacius the catholicos.

iii) Euphemius succeeds Acacius as patriarch of Constantinople.

XII Kavad

XIII Elisah the doctor, metropolitan of Nisbis

Scholastic account. Author of On the Foundation of Schools.

XIV Zamasp

XV Babai, twenty-second catholicos

XVI Story of the mouse and the pearls

XVII Kavad's attack on Amida

XVIII Abraham the Great

XIX Shila, twenty-third catholicos

ii) Anastasius exiles Macedonius the patriarch.

XX Justin

ii) Account of natural disasters.

XXI Jacob Baradeus

XXII Heretics under Justin

Expulsion of Jacobites to Hira.

Later Julianists come to Najran and Pairam, but the latter are later converted to

Nestorianism.

ii) Succession of patriarchs at Constantinople

XXIII Justinian

This is an open access version of the publication distributed under the terms of the Creative Commons Attribution-NonCommercialNoDerivs licence (http://creativecommons.org/licenses/by-nc-nd/3.0/), which permits non-commercial reproduction and distribution of the work, in any medium, provided the original work is not altered or transformed in any way, and that the work is properly cited. For commercial re-use, please contact academic.permissions@oup.com 
XXIV Khusrau Anushirvan

XXV Narsai and Elisha, twenty-fourth and twenty-fifth catholicoi

XXVI Paul of Susa, twenty-sixth catholicos

XXVII Mar Aba, twenty-seventh catholicos

Based on the Syriac Acts of Aba.

XXVIII The catholicos and a Zoroastrian

XXIX Questions posed to Aba

XXX Aba's Disciples

XXXI Abraham of Netpar and his disciple Job

XXXII Joseph, twenty-eighth catholicos

ii) In his wars Khusrau founds a city of Roman captives

iii) Plagues in Iraq and the Levant.

iv) Justinian writes a book of theology and inclines to Julianism.

Deputation of Paul of Nisibis and Isho' yahb of Arzun.

XXXIII Justin II

XXXIV Patriarch Eutychius [of Constantinople]

XXXV Baboukabr

XXXVI Ezekiel, twenty-ninth catholicos

ii) In this era Isho'yahb of Arzun, followed by Abraham, followed by Henana were interpreters at Nisbis.

XXXVII Hormizdad

XXXVIII The death of Khusrau I

XXXIX Daniel the penitent

XL Rabban Qoure

Predicts coming of the Arabs: this section looks ahead to the foundation of Mosul.

XLI Tiberius

XLII Isho'yahb (I) of Arzun, thirtieth catholicos

XLIII The Royal Annals on the murder of Hormizd by Khusrau

Deeds that occurred in this era:

XLIV Rabban Elia, who founded Deir Sa'id at Mosul

XLV Rabban Bar 'Idta

XLVI Rabban Symeon

Takrit and Samarra compete over his body in the Abbasid period.

XLVII Rabban Giwargis

XLVIII Rabban John, founder of An'el

XLIX Rabban Haia

L Rabban Babai of Nisibis

LI Rabban Yaunan

LII Sahrona

LIII Mar Yahb

LIV Rabban Shapur

LV Maurice

LVI Rabban Jacob of Beth 'Abe

LVII The priest and the demon

LVIII Khusrau Parviz

This is an open access version of the publication distributed under the terms of the Creative Commons Attribution-NonCommercialNoDerivs licence (http://creativecommons.org/licenses/by-nc-nd/3.0/), which permits non-commercial reproduction and distribution of the work, in any medium, provided the original work is not altered or transformed in any way, and that the work is properly cited. For commercial re-use, please contact academic.permissions@,oup.com 
Account of his war with Vahram and his patronage of Christians.

LIX The story of the apostate priest

LX Nu'man son of Mundhir

LXI Yaunan founder of Bar Toura

LXII Jacob of Hbisha

LXIII Jacobite patriarchs

LXIV Titus of Hdatta

LXV Sabrisho', thirty-first catholicos

Parallels to the Syriac Life of Sabrisho' in the early part of this section.

LXVI Sabrisho"s vision while bishop of Lashom

LXVII After Sabrisho's election

LXVIII Miracle of Sabrisho ` before Marutha [the Roman ambassador]

LXIX Gabriel of Sinjar

Sabrisho' excommunicates Gabriel for bigamy.

LXX The murder of Maurice and Khusrau's change in opinion regarding the Christians

LXXI Death of Sabrisho'

LXXII Events in this time

Complaints about the Henanians and their expulsion from Nisibis.

LXXIII Zinai

LXXIV Gregory, metropolitan of Nisibis

LXXV The struggles at Nisibis because of Gregory

LXXVI Rabban Isho' yahb

LXXVII Rabban Gabrona

LXXVIII Maurice

LXXIX Theodore son of Maurice

LXXX Gregory of Pherat, thirty-second catholicos

LXXXI Christians in the service of Khusrau

LXXXII Heraclius (Western account)

LXXXIII History of the heretics and the excommunication of Henana

LXXXIV Babai the great

LXXXV Henanisho'

LXXXVI Giwargis, killed by Khusrau

LXXXVII Heraclius and Khusrau

LXXXVIII The Jacobite bishoprics and their new sees under Athanasius

LXXXIX The spread of the Jacobites

XC Babai the scribe

$\mathrm{XCI}{ }^{\mathrm{C}}$ Abda the old

XCII The death of Khusrau and the reign of Shiroë

XCIII The catholicos Isho'yahb (II) of Gdala

XCIV The correspondence of Barsauma of Susa with the catholicos

XCV Rabban Oukhama

XCVI Rabban Sabrisho', founder of Beth Qoqa

XCVII 'Abda b. Hanif

XCVIII Rabban Khoudawai of Beth Hale

XCIX Rabban Hormizd

This is an open access version of the publication distributed under the terms of the Creative Commons Attribution-NonCommercialNoDerivs licence (http://creativecommons.org/licenses/by-nc-nd/3.0/), which permits non-commercial reproduction and distribution of the work, in any medium, provided the original work is not altered or transformed in any way, and that the work is properly cited. For commercial re-use, please contact academic.permissions@,oup.com 
C Rabban Theodore

CI Appearance of Islam, which God upholds, and its triumph

CII Pact of Muhammad bin 'Abdallah and the men of Najran and all the Christians of the earth

CIII The document he [Muhammad] copied and wrote

CIV The death of Muhammad, peace be upon him

CV Death of Isho' yahb the catholicos

CVI Heraclius

His retreat from Syria. The reigns of $\mathrm{Abu} B a k r$ and 'Umar. The defeat of Yazdegard.

CVII Death of Heraclius

CVIII Maremmeh, the catholicos

CIX Sabrisho', metropolitan of Beth Garmai

CX Athanasius Gamalaya, Jacobite patriarch

CXI Malkisho' of 'Oumra Hadtha

CXII Isho' yahb (III) of Adiabene

No content: final lacuna. 


\section{Bibliography}

\section{Primary Sources}

Arabic

Agapius, Kitāb al- 'unwān (Part 2.2), tr. A. Vasiliev, PO 8.

'Amr, Kitāb al-magdal, ed. and tr. H. Gismondi, Maris, Amri, et Salibae: De Patriarchis

Nestorianorum Commentaria I: Amri et Salibae textus arabicus et versio Latina (Rome, 1899).

al-Azdi, Tārīkh al-Mawșil, ed. anon. (Cairo, 1967).

al-Baladhuri, Futūh al-buldān, ed. M. de Goeje (Cairo, 1901) and tr. P. Hitti, The

Origins of the Islamic State (New York, 1916).

al-Biruni, Āthār al-baqìya, tr. E. Sachau, The Chronology of the Nations (London, 1879).

Chronicle of Seert, ed. A Scher and tr. A. Scher, R. Griveau et al., PO 4 (I/i), 5 (I/ii), 7 (II/ i), and 13 (II/ii).

al-Dinawari, Akhbār al-tiwāl, ed. V. Guirgass (Leiden, 1888).

Haddad Chronicle, ed. B. Haddad, Mukhtașar al-akhbār al-bi ${ }^{\complement} \bar{y} y a$ (Baghdad, 2000).

History of the Patriarchs of Alexandria, ed. and tr. B. Evetts, PO 1, 5, and 10.

Ibn Ishaq, Sìrat Rasūl Allāh, ed. F. Wüstenfeld, 2 vols. (Göttingen, 1859-60).

Ibn al-Tayyib, ed. and tr. W. Hoenerbach and O. Spies, Fiqh al-Nașrānīya: 'Das recht des Chistenheit', 2 vols, CSCO 161-2, 167-8, Scriptores Arabici 16-9 (Louvain, 1957).

(pseudo-) al-Jahiz, Kitāb al-tāj fì akhlāq al-mulūk, tr. C. Pellat, Le livre du couronne (Paris, 1957).

Mari ibn Sulayman, Kitāb al-magdal, ed. and tr. H. Gismondi, Maris, Amri, et Salibae:

De Patriarchis Nestorianorum Commentaria II: Maris textus arabicus et versio Latina (Rome, 1899).

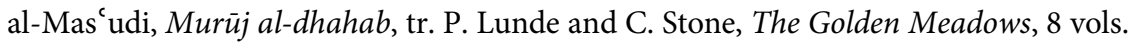
(London/New York, 1989).

al-Muqaddasi, Ahssan al-taqāsīm fī ma rifat al-aqālìm, tr. B. Collins, The Best Divisions for Knowledge of the Regions (Reading, 1996).

Nihāyat al-' $a r a b$ fì akhbār al-furs wa-l-'arab, partial tr. E. Browne, JA (new series) 32 (1900), 195-259.

al-Tabari, Tārīkh al-rusūl wal-mulūk, ed. M. de Goeje, 3 vols. (Leiden, 1879-98) and tr. various, 39 vols. (New York, 1986-2007), esp. C. E. Bosworth, Vol. 5: The Säsānids, the Byzantines, the Lakhmids, and Yemen (New York, 1999).

al-Tha' alibi, Ghurar akhbār mulūk al-Furs, ed. and tr. H. Zotenberg, Histoire des rois des perses (Paris, 1890).

al-Yaqut, Mu'jam al-buldān, ed. F. Wüstenfeld, Jacut's geographisches Wörterbuch, 6 vols. (Leipzig, 1866-73).

\section{Armenian}

Life of Marutha of Maypherkat, tr. R. Marcus, HTR 25 (1932), 41-72.

pseudo-Sebeos, tr. R. Thomson and comm. J. Howard-Johnston, The Armenian History attributed to Sebeos, 2 vols. (Liverpool, 1999).

This is an open access version of the publication distributed under the terms of the Creative Commons Attribution-NonCommercialNoDerivs licence (http://creativecommons.org/licenses/by-nc-nd/3.0/), which permits non-commercial reproduction and distribution of the work, in any medium, provided the original work is not altered or transformed in any way, and that the work is properly cited. For commercial re-use, please contact academic.permissions@oup.com 
Ethiopic

John of Nikiu, Chronicle, tr. R. H. Charles (London, 1916).

\section{Georgian}

Acts of Golinducht, ed. and tr. G. Garitte, 'La passion géorgienne de Sainte Golindouch', $A B 74$ (1956), 405-40.

Antiochos Strategos, tr. F. Conybeare, 'Antiochus Strategos' account of the sack of Jerusalem (614)', English Historical Review 25 (1910), 506-17.

\section{Greek}

Acts of Shirin, ed. and tr. P. Devos, 'La jeune martyre perse sainte Shirin $(+559)$ ', $A B$ 112 (1994), 4-31.

Evagrius, HE, ed. J. Bidez and L. Parmentier (London, 1898) and tr. Michael Whitby, TTH 33 (Liverpool, 2000).

Eusebius, HE, ed. G. Bardy SC 31, 41, 55, 73 (Paris, 1952-60), ed. and tr. H. Lawlor and J. Oulton, Loeb edn. (Cambridge, Mass., 1973).

Procopius, Works, tr. H. Dewing, Loeb edn. (Cambridge, Mass., 1992).

Socrates, HE, ed. G. Hansen, GCS n.f. 1 (Berlin, 1995).

Sozomen, HE, ed. J. Bidez and G. Hansen, GCS n.f. 4 (Berlin, 1995).

Theodoret of Cyrrhus, HE, ed. GT. Hansen, GCS n.f. 5 (Berlin, 1998).

Theodoret of Cyrrhus, Historia Religiosa, ed. and tr. P. Canivet and A. Leroy-Molinghen, L'histoire des moines de Syrie: Histoire Philothée, SC 234 (Paris, 1979).

Theophanes, Chronographia, tr. R. Scott and C. Mango, Theophanes Confessor: Byzantine and Near Eastern History AD 284-813 (Oxford, 1997).

\section{Middle Persian}

Karnamag Ardashir-i Papakan, tr. E. K. Antia (Bombay, 1900).

Khusrau and the Page, ed. and tr. D. Monchi-Zadeh, 'Xusrau ut Retak', Acta Iranica 22 (Leiden, 1982), 47-91.

Letter of Tansar, tr. M. Boyce (Rome, 1968).

Shahrestan-i Eranshahr, tr. T. Daryaee, Šahrestānīhā ì Ėrānšahr, A Middle Persian Text on Geography, Epic and History (Costa Mesa, 2002).

Shahnameh, tr. J. Mohl, Le Livre des Rois, 7 vols. (Paris, 1878).

Zamasp-Nameh, tr. H. Bailey, BSOAS 6 (1930-2), 55-85 and 581-600.

\section{East Syriac}

40 martyrs of Ctesiphon, ed. AMS II, 325-47.

'Abdisho' of Nisibis, Metrical Catalogue, ed. and tr. in Assemani, BO, IIIa.

'Abdisho' of Nisibis, Canon Law, ed. and tr. A. Mai, Scriptorum Veterum Nova Collectio, Vol. X (Vatican, 1838).

Acts of Aba, ed. P. Bedjan, Histoire de Mar Yabalaha, de trois autres patriarches, d'un prêtre et de deux lä̈ques nestoriens (Paris/Leipzig, 1896).

Acts of 'Abda, ed. AMS II, 250-3.

Acts of Babowai, ed. AMS II, 633-4.

Acts of Barba'shemin, ed. AMS II, 296-303.

Acts of Candida, tr. S. P. Brock, 'A Martyr at the Sasanian Court under Vahrām II: Candida', $A B 96$ (1978), 167-81. 
Acts of the Captives, ed. AMS II, 316-24.

Acts of Christina, ed. AMS IV, 201-7.

Acts of Dadu, ed. AMS IV, 218-222.

Acts of Giwargis, ed. P. Bedjan, Histoire de Mar Yabalaha, de trois autres patriarches,

d'un prêtre et de deux lä̈ques nestoriens (Paris/Leipzig, 1896).

Acts of Jacob the Notary, ed. AMS IV, 189-201.

Acts of John of Arbela, ed. AMS II, 254-60.

Acts of Mar Mari, ed. and tr. F. Jullien and C. Jullien, Les Actes de Mar Mari (Louvain/

Paris, 2003).

Acts of Mihrshapur, ed. AMS II, 535-9.

Acts of Miles, ed. AMS II, 260-76.

Acts of Narsai, ed. AMS IV, 170-81.

Acts of Peroz, ed. AMS IV, 253-62.

Acts of Pusai, ed. AMS II, 208-22.

Acts of Qardagh, ed. AMS II, 442-507, tr. J. Walker, The Life of Mar Qardagh:

Narrative and Christian Heroism in Late Antique Iraq (Los Angeles/London, 2006). Acts of Shahdost, ed. AMS II, 276-81.

Acts of Symeon A, ed. and tr. M. Kmosko, Patrologia Syriaca 2.

Acts of Symeon B, ed. and tr. M. Kmosko, Patrologia Syriaca 2.

Acts of Tarbo, ed. AMS II, 254-60.

Acts of Tataq, ed. AMS IV, 181-4.

Acts of the Martyrs of Gilan, ed. AMS IV, 166-70.

Acts of Thecla, ed. AMS II, 308-13.

Acts of Yazdin, Adur-Hormizd, his daughter Anahid and Pethion, AMS II, 559-631,

partial tr. J. Corluy, 'Historia sancti Mar Pethion martyris', $A B 7$ (1888), 5-44;

partial tr. Brock and Harvey, Holy Women, 82-99.

Aphrahat, Demonstration, tr. K. Valavanolickal (Kottayam, 2005).

Babai, Book of Union, ed. and tr. A. Vaschalde, Liber de Unione, CSCO 79/80 Scriptores Syri 34/5 (Louvain, 1915).

Barhadbeshaba 'Arbaya, Cause of the Foundations of the Schools, ed. and tr. F. Nau, PO 4', tr., A. Becker, Sources for the Study of the School of Nisibis, TTH 50 (Liverpool, 2008). Barhadbeshaba, HE, ed. and tr. F. Nau, PO 9 and 23, partial tr. Becker, Sources.

Bazaar of Heracleides, tr. G. Driver and L. Hodgson (Oxford, 1925).

Cave of Treasures, ed. and tr. A. Su-Min-Ri, La caverne des trésors: les deux recensions syriaques, CSCO 486-7 Scriptores Syri 207-8 (Louvain, 1987).

Christological Letter of Isho' yahb II, ed., tr. and comm. L. Sako, Lettre christologique du patriarche syro-oriental Iŝoc yahb de Gdala (628-646) (Rome/Mosul, 1983).

Elias of Nisibis, Chronography, ed. and tr. E. W. Brooks and J.-B. Chabot, Opus Chronologicum, CSCO 62-3 Scriptores Syri ser. 3, 7-8 (Paris, 1910).

Pseudo-George of Arbela, Expositio Officiorum, ed. and tr. R. H. Connolly, Anonymi auctoris Expositio Officiorum Ecclesiae ad Georgio Arbelensi vulgo adscripta, CSCO 67, 71 Scriptores Syri series 2, 91 (Leuven, 1911).

History of Karka de Beth Slouq, ed. AMS II, 507-35.

History of the Convent of Sabrisho' of Beth Qoqa, ed. and tr. A. Scher, ROC 11 (1906), 182-97.

Isho'dnah of Basra, Book of Chasitity, ed. and tr. J.-B. Chabot, Mélanges d'archéologie et de l'histoire 16 (1896), 225-90.

This is an open access version of the publication distributed under the terms of the Creative Commons Attribution-NonCommercialNoDerivs licence (http://creativecommons.org/licenses/by-nc-nd/3.0/), which permits non-commercial reproduction and distribution of the work, in any medium, provided the original work is not altered or transformed in any way, and that the work is properly cited. For commercial re-use, please contact academic.permissions@oup.com 
Isho'yahb III, Letters, ed. and tr. R. Duval, Ishoyahb Patriarchae III: Liber Epistularum, CSCO 11-12 (Louvain, 1962) and partial tr. P. Scott-Moncrieff, The Book of Consolations or the Pastoral Epistles of Mar Ishoyahb of Kuphlana in Adiabene (London, 1904).

John of Phenek, Book of the Main Points, ed. and partially tr. A. Mingana, Sources syriaques I (Leipzig, 1908).

Khuzistan Chronicle, ed. and tr. I. Guidi, Chronicum Anonymum in I. Guidi, Chronica Minora I, CSCO 1-2 (Paris 1903).

Laws of Mar Aba, ed. and tr. E. Sachau, Syrische Rechtsbücher III (Berlin, 1914), 258-85.

Letters of the Western Fathers, see 'Abdisho of Nisibis, Canon Law.

Life of Abraham of Kashkar, ed. and tr. F. Nau, ROC 21 (1916), 161-72.

Life of John of Daylam, ed. and tr. S. P. Brock, PdO 10 (1981-2), 123-90.

Life of Rabban Bar 'Idta, in E. Wallis-Budge (ed. and tr.), The Histories of Rabban Hormizd and Raban Bar 'Idta (London, 1904).

Life of Rabban Hormizd, in E. Wallis-Budge (ed. and tr.), The Histories of Rabban Hormizd and Raban Bar 'Idta (London, 1904).

Life of Sabrisho', ed. P. Bedjan, Histoire de Mar Yabalaha, de trois autres patriarches, d'un prêtre et de deux lä̈ques nestoriens (Paris/Leipzig, 1896).

Nestorian Urmia liturgy, tr. in F. Brightman, Eastern and Western Liturgies, 2 vols. (Oxford, 1901), I, 276-81.

Rules of Abraham of Kashkar, in A. Vööbus (ed. and tr.), Syriac and Arabic Documents Regarding Legislation relative to Syrian Asceticism (Stockholm, 1960).

Rules of Dadisho', in A. Vööbus (ed. and tr.), Syriac and Arabic Documents Regarding Legislation Relative to Syrian Asceticism (Stockholm, 1960).

Solomon of Basra, Book of the Bee, tr. E. Wallace-Budge (Oxford, 1886).

Synodicon Orientale, ed. and tr. J.-B. Chabot (Paris, 1902).

The 10 Martyrs of Beth Garmai, ed. AMS IV, 184-9.

The Martyrs of Khuzistan, ed. AMS II, 241-8.

Thomas of Marga, Book of the Governors, ed. and tr. E. Wallis-Budge, 2 vols. (London, 1893).

Timothy, Apology to the Caliph al-Mahdi, tr. A. Mingana (Cambridge, 1928).

Timothy, Letters, ed. and tr. O. Braun, Timothei Patriarchae I Epistulae (Louvain, 1914) CSCO 74-5 Scriptores Syri series 2, 67-8 [Letters 1-38], partially ed. and tr. R. Bidawid, Les lettres du patriarche nestorien Timotheé, Studi e Testi 187 (Vatican City, 1953).

\section{West Syriac}

411 Martyrion, ed. and tr. F. Nau, Martyrologies et ménologes orientaux, PO 10.

Acts of Maurice, ed. and tr. F. Nau, Les légendes syriaques d'Aaron de Saroug, de Maxime et Domèce, d'Abraham, maître de Barsoma et de l'empereur Maurice, PO 5. Bardaisan, The Book of the Laws of Countries: A Dialogue on Fate by Bardaisan of Edessa, ed. and tr. H. J.-W. Drijvers (Assen, 1965).

Bar Hebraeus, HE, ed. and tr. J. Abeloos and T. Lamy, Gregorii Barhebraei chronicon ecclesiasticum, 3 vols. (Paris/Louvain, 1872-7).

Chronicle of 1234, ed. and tr. J.-B. Chabot, Chronicon Anonymum ad Annum Christi 1234 Pertinens, CSCO 81-2 Scriptores Syri 36-7, 2 vols. (Leuven, 1916-20).

This is an open access version of the publication distributed under the terms of the Creative Commons Attribution-NonCommercialNoDerivs licence (http://creativecommons.org/licenses/by-nc-nd/3.0/), which permits non-commercial reproduction and distribution of the work, in any medium, provided the original work is not altered or transformed in any way, and that the work is properly cited. For commercial re-use, please contact academic.permissions@,oup.com 
Dionysius of Tel-Mahre, HE, reconstructed and tr. A. Palmer, The Seventh Century in the West Syrian Chronicles, TTH 15 (Liverpool, 1993).

Legend of Judas Kyriakos, tr. H. J.-W. Drijvers and J.-W. Drijvers, The Finding of the True Cross: The Judas Kyriakos Legend in Syriac: Introduction, Text and Translation (Leiden, 1997).

Life of Ahudemmeh, ed. and tr. F. Nau, PO 3.

Life of Cyriacus of Amida, ed. and tr. F. Nau, ROC 7 (1902), 196-217.

Life of John the Little, ed. and tr. F. Nau, ROC 17 (1912), 347.

Life of Marutha of Takrit, ed. and tr. F. Nau, PO 3.

Michael the Syrian, Chronicle, reproduced and tr. J.-B. Chabot, 4 vols. (Paris, 1899-1910).

Syriac Life of Symeon the stylite, tr. R. Doran, The Lives of Symeon Stylites (Kalamazoo, 1992).

Zachariah of Mytilene, HE, ed. E. W. Brooks, Historia ecclesiastica Zachariae Rhetori vulgo adscripta, CSCO 83-4 Scriptores Syri III. 5-6 (Paris/Louvain, 1919-24); tr. F. Hamilton and E. W. Brooks, The Syriac Chronicle known as that of Zachariah of Mytilene (London, 1899); tr. G. Greatrex, C. Horn, and R. Phenix, The Chronicle of Pseudo-Zachariah: Church and War in Late Antiquity, TTH 55 (Liverpool, 2011).

\section{Secondary Literature}

Naval Intelligence Survey: Iraq and the Persian Gulf (Oxford, 1944).

Naval Intelligence Survey: Persia (Oxford, 1945).

Abramowski, L. and A. Goodman, Nestorian Christological Texts. Cambridge University Library MS. Oriental 1319 (Cambridge, 1972), 2 vols. (Cambridge, 1972).

Abramowski, L., 'Zur geplanten Ausgabe von Brit. Mus. Add. 12156', in J. Dummer and J. Irmscher (eds.), Texte und Textkritik: eine Aufsatzsammlung (Berlin, 1987), 23-8.

Abramowski, L., 'Martyrius-Sahdona and dissent in the Church of the East', in C. Jullien (ed.), Controverses chrétiens dans l'iran sasanide (Paris, 2008), 13-29.

Adams, R., The Land Behind Baghdad: A History of Settlement on the Diyala Plains (Chicago, 1967).

Adams, R. and D. Hansen, 'Archaeological reconnaissance and soundings in JundiShapur', Ars Orientalis 7 (1968), 158-70.

Aigrain, R., 'Arabie', in DHGE.

Alizadeh, K. and J. Ur, 'Formation and destruction of pastoral and irrigation landscapes of the Mughan steppe, North-west Iran', Antiquity 81 (2007), 148-60.

Allard, M., 'Les chrétiens à Baghdad', Arabica 9 (1962), 375-88.

Allison, C., The Yezidi Oral Tradition in Iraqi Kurdistan (Richmond, 2001).

Altheim, F. and R. Stiehl, Finanzgeschichte der Spätantike (Frankfurt, 1957).

Amadouni, G., L'autocephalie du Katholicat arménien, OCA 181 (1968), 137-78.

Anastos, M., 'Nestorius was orthodox', DOP 16 (1962), 119-40.

Assemani, J. S., Bibliotheca Orientalis, 4 vols. (Vatican City, 1719-28).

Assmann, J., 'Introduction: what is cultural memory?', in J. Assmann (ed.), Religion and Cultural Memory (Stanford, 2006), 1-30.

Azarnoush, M., The Sasanian Manor House at Hājjīābād (Florence, 1994).

This is an open access version of the publication distributed under the terms of the Creative Commons Attribution-NonCommercialNoDerivs licence (http://creativecommons.org/licenses/by-nc-nd/3.0/), which permits non-commercial reproduction and distribution of the work, in any medium, provided the original work is not altered or transformed in any way, and that the work is properly cited. For commercial re-use, please contact academic.permissions@oup.com 
Barnes, T., Constantine and Eusebius (Cambridge, MA, 1981).

Barnes, T., 'Constantine and the Christians of Persia', JRS 75 (1985), 126-36.

Bartelink, G., 'PARRHESIA', Greacitas et Latinitas Christianorum, supp. 3 (Nijmegen, 1970), 5-57.

Bauer, W. Orthodoxy and Heresy in Earliest Christianity, tr. Philadelphia Seminar on Christian Origins (Miflintown, 1996).

Baumer, C., The Church of the East: An Illustrated History of Assyrian Christianity (London, 2006).

Baum, W. and D. Winkler, The Church of the East: A Concise History (London/New York, 2003).

Becker, A. H., The Fear of God and the Beginning of Wisdom: The School of Nisibis and Christian Scholastic Culture in Late Antique Mesopotamia (Philadelphia, 2006).

Becker, A. H., 'Anti-Judaism and care for the poor in Aphrahat's Demonstration 20', JECS 20 (2002), 305-27.

Bedjan, P., Acta Martyrorum et Sanctorum (Paris, 1896).

Berti, V., Vita e Studi di Timotheo I, Patriarca Cristiano di Baghdad (Paris, 2009).

Blum, G., 'Zur religionspolitischen Situation der persischen Kirche im 3. und 4. Jahrhundert', Zeitschrift für Kirchengeschichte 91 (1980), 11-32.

Bitel, L., Isle of the Saints: Monastic Settlement and Christian Community in Early Ireland (Cornell, 1990).

Bonner, M. R. J., Three Neglected Sources of Sasanian History in the Reign of Khusraw Anushirvan, Studia Iranica Cahier 46 (Paris, 2011).

Borrut, A., 'Entre tradition et l'histoire: genèse et diffusion de l'image de Umar II', MUSJ 53 (2005), 329-78.

Borrut, A., Entre mémoire et pouvoir: l'espace syrien sous les derniers Omeyyades et les premiers Abbassides (v. 72-193/692-809) (Leiden, 2011).

Bosworth, C. E., 'Sistan and its local histories', Iranian Studies 33 (2000), 31-48.

Boucharlat, R., 'Suse à l' époque sassanide', Mesopotamia 22 (1987), 316-22.

Boyce, M., 'The Parthian Gosan and Iranian minstrel tradition', JRAS (1957), 1-45.

Boyce, M., The Zoroastrians: Their Religious Beliefs and Practices (London, 2nd edn., 2001).

Boyce, M. and F. Kotwal, 'Zoroastrian “baj” and “dron” -II', BSOAS 34 (1971), 298-318.

Breuker, R., Establishing a Pluralist Society in Medieval Korea, 918-1170. History, Ideology and Identity in the Koryo Dynasty (Leiden, 2010).

Brightman, F., Western and Eastern Liturgies, 2 vols. (London, 1901).

Briquel-Chattonet, F. et al., 'Lettre du patriarche Timothée à Maranzekhā', Journal Asiatique 288 (2000), 1-13.

Brock, S. P., 'Review of G. Wiessner, Untersuchungen ...', JTS (new series) 19 (1968), 300-9.

Brock, S. P., 'Jewish traditions in Syriac Sources', JJS 30 (1979), 212-32.

Brock, S. P., 'Conversations with the Syrian Orthodox in 532', OCP 47 (1981), 87-121.

Brock, S. P., 'From antagonism to assimilation: Syriac attitudes to Greek learning', in N. Garsoian (ed.), East of Byzantium (Washington D.C., 1982), 17-35.

Brock, S. P., 'Christians in the Sasanian Empire: a case of divided loyalties', Studies in Church History 18 (1982), 1-19.

This is an open access version of the publication distributed under the terms of the Creative Commons Attribution-NonCommercialNoDerivs licence (http://creativecommons.org/licenses/by-nc-nd/3.0/), which permits non-commercial reproduction and distribution of the work, in any medium, provided the original work is not altered or transformed in any way, and that the work is properly cited. For commercial re-use, please contact academic.permissions@oup.com 
Brock, S. P., 'The Christology of the Church of the East in the synods of the fifth century to the early seventh century: preliminary considerations and materials', in Aksum Thyateira (London, 1985), 126-32.

Brock, S. P., 'The Church of the East up to the sixth century and it absence from councils in the Roman Empire', in Syriac Dialogue: The First Non-Official Consultation on Dialogue within the Syrian Tradition, with Focus on the Theology of the Church of the East (Vienna, 1996), 68-85.

Brock, S. P., 'Nestorian church: a lamentable misnomer', BJRL 78 (1996), 23-53.

Brock, S. P., 'Two letters of Timothy from the late eighth century on translations from Greek', Arabic Science and Philosophy 9 (1999), 233-47.

Brock, S. P., 'The transformation of the Edessa portrait of Christ', Journal of Assyrian Academic Studies 18 (2004), 46-56.

Brock, S. P., 'Du grec en syriaque: l'art de traduction chez les syriaques', in M. Attallah (ed.), Les syriaques: transmetteurs des civilisations (Antelias, 2005), 10-33.

Brock, S. P., 'Liturgical texts', in P. Khoury (ed.), Nos sources: arts et littératures syriaques (Beirut, 2005), 238-51.

Brock, S. P., 'Use of Hijri dating in Syriac manuscripts', in J. van Ginkel, H.-M. van den Berghe, and T.M. van Lint (eds.), Redefining Christian Identity: Cultural Interaction in the Middle East since the Rise of Islam (Leuven, 2005), 275-90.

Brock, S. P., 'Saints in Syriac: a little-tapped resource', JECS 16 (2008), 181-96.

Brock, S.P., The History of Mar Ma' in, with a Guide to the Persian Martyr Acts (Piscataway, NJ, 2008).

Brock, S. P., 'Regulations for an association of artisans in the late Sasanian or early Arab period', in P. Rousseau and M. Papoutsakis (eds.), Transformations of Late Antiquity: Essays for Peter Brown (Farnham, 2009), 51-63.

Brock, S. P., 'The Life of Mar Shabbay', in D. Burnazhov et al. (eds.), Bibel, Byzanz und Christlicher Orient: Festschrift für Stephen Gero zum 65 Geburtstag (Leuven, 2011), 259-81.

Brown, P., Augustine of Hippo: A Biography (London, 1967).

Brown, P., 'The diffusion of Manichaeism in the later Roman Empire', JRS 59 (1969), 92-103.

Brown, P., Power and Persuasion in Late Antiquity (Madison, 1992).

Brown, P., 'The study of elites in late antiquity', Arethusa 33 (2000), 321-46.

Buell, D. K., Why this New Race?: Ethnic Reasoning in Early Christianity (New York, 2005).

Bundy, D. 'Marcion and the Marcionites', LM 101 (1988), 3-32.

Burgess, R., 'The dates of Simeon bar Sebba'e and the "Great Massacre"', $A B 117$ (1999), 9-48.

Burgess, R., Studies in Eusebian and post-Eusebian Chronography (Stuttgart, 1999).

Cabrol, C., 'Secrétaires nestoriens sous les Abbassides (762-1252) à Baghdad', PdO 25 (2000), 407-91.

Calder, N., Studies in Early Muslim Jurisprudence (Oxford, 1993).

Callieri, P., 'Demons and magic in the everyday life of pre-Islamic Iran', in R. Gyselen (ed.), Démons et merveilles en Orient (Bures-sur-Yvettes, 2001), 9-35.

Callieri, P., 'Dionysiac iconographic themes in the context of Sasanian religious architecture', in D. Kennet and P. Luft (eds.), Current Research in Sasanian Archaeology, Art and History (Durham, 2008), 115-25.

This is an open access version of the publication distributed under the terms of the Creative Commons Attribution-NonCommercialNoDerivs licence (http://creativecommons.org/licenses/by-nc-nd/3.0/), which permits non-commercial reproduction and distribution of the work, in any medium, provided the original work is not altered or transformed in any way, and that the work is properly cited. For commercial re-use, please contact academic.permissions@oup.com 
Cameron, Averil, 'The Jews in seventh-century Palestine', Scripta Classica Israelica 13 (1994), 75-93.

Cameron, Averil, 'Form and meaning: the Vita Constantini and the Vita Antonii', in T. Hägg and P. Rousseau (eds.), Greek Biography and Panegyric in Late Antiquity (Berkeley, 2000), 72-88.

Cameron, Averil, 'Blaming the Jews: the seventh-century invasions of Palestine in context,' T\&M 14 (2002), 57-78.

Cameron, Averil, 'Jews and heretics: a category error?', in A. H. Becker and A. Y. Reed (eds.), The Ways that Never Parted: Jews and Christians in Late Antiquity and the Early Middles Ages (Tübingen, 2003), 345-60.

Campenhausen, H., Ecclesiastical Authority and Spiritual Power in the Church in the First Three Centuries, tr. J. Baker (London, 1967).

Camplani, A., 'The revival of Persian monasticism: church structures, theological academy and reformed monks', in A. Camplani and G. Filoramo (eds.), Foundations of Power and Conflicts of Authority in Late Antique Monasticism (Louvain, 2007), 277-97.

Canepa, M., The Two Eyes of the Earth: Art and Ritual of Kingship between Rome and Sasanian Iran (Berkeley/Los Angeles/London, 2009).

Caner, D., Wandering, Begging Monks: Spiritual Authority and the Promotion of Monasticism in Late Antiquity (Berkeley, 2002).

Carter, R., 'Christianity in the Gulf during the first centuries of Islam', AAE 19 (2008), 71-108.

Chadwick, H., Priscillian of Avila: The Occult and the Charismatic in the Early Church (Oxford, 1976).

Chaumont, M.-L., 'Le culte d'Anahita à Staxr et les premiers Sassanides', RHR 153 (1958), 154-75.

Chaumont, M.-L., La christianisation de l'empire iranien, des origines aux grandes persécutions du IVe siècle (Louvain, 1988).

Chediath, G., The Christology of Mar Babai the Great (Kottayam, 1982).

Cheiko, L., 'La discussion religieuse entre le calife al-Mahdi et Timothée le catholicos', Al-Machriq 21 (1921), 359-74, 408-18.

Chestnut, R., 'The Two Prosopa in Nestorius' Bazaar of Heracleides', JTS 29 (1978), 392-409.

Choksy, J., 'Sacred kingship in Sasanian Iran', BAI 2 (1988), 35-53.

Christensen, P., The Decline of Iranshahr: Irrigation and Environments in the History of the Middle East, 500 B.C. to A.D. 1500 (Copenhagen, 1999).

Coless, B., 'The biographies of John Saba', PdO 13 (1972), 45-65.

Conrad, L. 'Theophanes and the Arabic historical tradition: Some indications of intercultural transmission', Byzantinische Forschungen 15 (1990), 1-44.

Crone, P. and M. Cook, Hagarism: The Making of the Islamic World (Cambridge, 1977).

Curtis, V., 'Iranian revival in the Parthian period', in V. Curtis and S. Stewart (eds.), The Idea of Iran II: The Age of the Parthians (London, 2006), 7-25.

Curtis V. and S. Stewart (eds.), The Idea of Iran III: The Age of the Sasanians (London, 2008).

Daryaee, T., 'Religio-political propaganda on the coinage of Xusro II', American Journal of Numismatics 9 (1997), 41-53.

This is an open access version of the publication distributed under the terms of the Creative Commons Attribution-NonCommercialNoDerivs licence (http://creativecommons.org/licenses/by-nc-nd/3.0/), which permits non-commercial reproduction and distribution of the work, in any medium, provided the original work is not altered or transformed in any way, and that the work is properly cited. For commercial re-use, please contact academic.permissions@oup.com 
Daryaee, T., 'Mind, body and the cosmos: chess and backgammon in ancient Persia', Iranian Studies 35 (2002), 281-312.

Daryaee, T., 'History, epic and numismatics: on the title of Yazdegard I', AJN 16 (2004), 89-92.

Daryaee, T., 'Ethnic and territorial boundaries in late antique and medieval Persia', in F. Curta (ed.), Borders, Barriers and Ethnogenesis: Frontiers in Late Antiquity and Middle Ages (Louvain, 2005), 123-38.

Daryaee, T., 'Kingship in early Sasanian Iran', in V. Curtis and S. Stewart (eds.), The Sasanian Era: The Idea of Iran, vol. III (London, 2008), 60-6.

Daryaee, T., Sasanian Iran: Portrait of a Late Antique Empire (Costa Mesa, 2008).

Daryaee, T., 'The idea of Ėānshahr: Jewish, Christian and Manichaean views in late antiquity', in C. Cereti (ed.), Iranian Identity in the Course of History (Rome, 2010), 91-107.

Dauvillier, J., 'Les provinces chaldéens de 'l'éxterieur' au môyen âge', in Mélanges Cavallera (Toulouse, 1948), 261-316.

Dauvillier, J., 'Chaldéen (droit)', in Dictionnaire du droit canonique, eds. A. Villien and A. Magnin (Paris, 1924-35).

Davis, D., Epic and Sedition: the Case of Ferdowsi's Shahnameh (Fayetteville, 1992).

Davis, S., The Early Coptic Papacy (Oxford, 2004).

de Blois, F., 'Zindik', in EI2.

de Blois, F., 'Freemen and nobles in Iranian and Semitic languages', JRAS (1985), 5-15. de Blois, F., Burzōy's Voyage to India and the Origin of the Book of Kalilah wa Dimnah (London, 1990).

de Blois, F., 'Naşrānī and hanîf: studies on the religious vocabulary of Christianity and Islam', BSOAS 85 (2002), 1-31.

de Halleux, A., 'La christologie de Martyrius-Sahdona dans l'évolution du nestorianisme', OCP 24 (1957), 5-32.

de Halleux, A., 'Martyrius-Sahdona: la vie mouvementée d'un « hérétique » de l'église nestorienne', OCP 24 (1958), 93-128.

de Jong, A., 'Zoroastrian religious polemics and their contexts: interconfessional relations in the Sasanian empire', in T. Hettema and A. van der Kooij (eds.), Religious Polemic in Context (Leiden, 2004), 49-68.

de la Vaissière, E., Sogdian Traders: A History (Leiden/Boston, 2005).

de Vries, W., 'Die syrisch-nestorianische Haltung zu Chalkedon', in A. Grillmeier and H. Bacht (eds.), Das Konzil von Chalkedon: Geschichte und Gegenwart, 3 vols. (Wurzburg, 1951), I, 603-35.

de Vries, W., 'Zum Kirchenbegriff der nestorianischen Theologen', OCP 17 (1951), 95-132.

de Vries, W., 'La conception de l'église chez les syriens séparés de Rome II', OS 3 (1958), 149-64.

de Vries, W., 'The college of patriarchs', Concilium 8 (1965), 35-43.

Debié, M., 'Record keeping and chronicle writing in Antioch and Edessa', Aram 12 (2000), 409-17.

Debié, M., 'L'héritage grecque', in M. Debié (ed.), L'historiographie syriaque (Paris, 2009), 11-3.

Debié, M., 'Syriac historiography and identity formation', in B. Ter Haar Romeny (ed.), The Religious Origins of Nations? The Christian Communities of the Middle East (Leiden, 2009), 93-114.

This is an open access version of the publication distributed under the terms of the Creative Commons Attribution-NonCommercialNoDerivs licence (http://creativecommons.org/licenses/by-nc-nd/3.0/), which permits non-commercial reproduction and distribution of the work, in any medium, provided the original work is not altered or transformed in any way, and that the work is properly cited. For commercial re-use, please contact academic.permissions@oup.com 
Debié, M. (ed.), L’historiographie syriaque (Paris, 2009).

Decret, F., 'L'affrontement des empires romain et sassanide', Recherches Augustiniennes 14 (1979), 91-152.

Degen, E., 'Daniel bar Maryam: ein nestorianischer Kirchenhistoriker', OC 52 (1968), 45-80.

Degen, R., 'Zwei Miszellen zur Chronik von Se'ert', OC 54 (1970), 76-95.

Devos, P., 'Le dossier hagiographique de S. Jacques l'Intercis I: la passion grecque inédite (BHG, 772)', AB 71 (1953), 157-210.

Devos, P., 'Le dossier hagiographique de S. Jacques l'Intercis: la passion grecque inédite (deuxième article)', $A B 72$ (1954), 213-56.

Devos, P., 'Abgar: un hagiographe perse méconnu', AB 83 (1965), 303-28.

Devos, P., 'Les martyrs persans à travers leurs actes syriaques', in La Persia e il mondo Greco-romano (Rome, 1966), 213-25.

Dignas, B. and E. Winter, Rome and Persia in Late Antiquity: Neighbours and Rivals (Cambridge, 2007).

Donner, F., Narratives of Islamic Origins: The Beginnings of Islamic Historical Writing, Studies in Late Antiquity and Islam 14 (Princeton, 1998).

Dorfmann-Lazarev, I., 'Beyond empire I: Eastern Christianities from the Persian to the Turkish conquest, 604-1071', in T. Noble and J. Smith (eds.), The Cambridge History of Christianity III (Cambridge, 2008), 65-85.

Dory, R., 'The Abbasid construction of the Jahiliyya: cultural authority in the making', Studia Islamica 83 (1983), 33-50.

Drijvers, H. J.-W., 'Edessa und das jüdische Christentum', VC 22 (1970), 4-33.

Drijvers, H. J.-W., 'Odes of Solomon and Psalms of Mani: Christians and Manichaeans in third-century Syria', in G. Quispel (ed.), Studies in Gnosticism and Hellenic Religions Presented to Gilles Quispel (Louvain, 1981), 117-30.

Drijvers, H. J.-W., 'Addai und Mani: Christentum und Manichaismus im dritten Jahrhundert', OCA 221 (1983), 171-85.

Drijvers, H. J.-W., 'Syriac culture in late antiquity: Hellenism and the local', Mediteraneo Antico 1 (1998), 95-113.

Drijvers, J.-W., 'Heraclius and the restitutio crucis: notes on symbolism and ideology', in Reinink and Stolte, The Reign of Heraclius (610-41): Crisis and Confrontation (Leuven, 2002), 175-91.

Drijvers, J.-W. and H. J.-W. Drijvers, The Finding of the True Cross: The Judas Kyriakos Legend in Syriac: Introduction, Text and Translation (Leiden, 1997).

Ebied, R. and M. Young, 'List of the Nestorian patriarchs', LM 87 (1974), 87-113.

Edelby, N., 'L'autonomie législative des chrétiens en terre de l'Islam', Archive de l'histoire du droit orientale 5 (1951), 307-51.

Erhart, V., 'The development of Syrian Christian canon law in the Sasanian Empire', in R. Mathisen (ed.), Law, Society and Authority in Late Antiquity (Oxford, 2001), 115-30.

Escolan, P., Monachisme et l'église: le monachisme syrien du IVe au VIIe siècle (Paris, 1994).

Espionnier, M., 'Al-Nuwayri. Les fêtes islamiques, persanes, chrétiennes et juives', Arabica 32 (1985), 80-100.

Ettinghausen, R., 'Bahram Gur's hunting feats or the problem of identification', Iran 17 (1979), 25-31.

This is an open access version of the publication distributed under the terms of the Creative Commons Attribution-NonCommercialNoDerivs licence (http://creativecommons.org/licenses/by-nc-nd/3.0/), which permits non-commercial reproduction and distribution of the work, in any medium, provided the original work is not altered or transformed in any way, and that the work is properly cited. For commercial re-use, please contact academic.permissions@oup.com 
Ferré, J., 'Chrétiens de Syrie et de Mésopotamie aux deux premiers siècles d'Islam', Islamochristiana 14 (1988), 71-106.

Fiey, J.-M., Mossoul chrétienne: essai sur l'histoire, l'archéologie et l'état actuel des monuments chrétiens de la ville de Mossoul (Beiruit, 1953).

Fiey, J.-M., 'Jean du Dailam et l'imbroglio de ses fondations', POC 10 (1960), 195-211.

Fiey, J.-M., 'Les saints Serge d'Iraq', $A B 79$ (1961), 102-14.

Fiey, J.-M., 'Aones, Awun et Awgin (Eugène): aux origines du monachisme mésopotamien (Sozomenos VI, 33-34)', AB 80 (1962), 73-119.

Fiey, J.-M. 'Diptyques nestoriens du XIVe siècle', $A B 81$ (1963), 371-414.

Fiey, J.-M., 'Vers la réhabilitation de l'histoire de Karka de Beth Slouq', AB 82 (1964), 199-222.

Fiey, J.-M., 'L'apport de Mgr Addai Scher (+1915) à l'hagiographie orientale', $A B 83$ (1965), 121-43.

Fiey, J.-M., 'Tables du noms propres de la seconde partie de la Chronique de Seert', MUSJ 42 (1966), 201-38.

Fiey, J.-M., L'Assyrie chrétienne: contribution à l'étude de l'histoire et de la géographie ecclésiastiques et monastiques du Nord de l'Iraq, 3 vols. (Beiruit, 1966-8).

Fiey, J.-M., 'Topographie chrétienne de Mahoze', OS 2 (1967), 407-19.

Fiey, J.-M., 'Les étapes de la prise de conscience de son identité patriarcale par l'église syrienne orientale', OS 12 (1967), 3-22.

Fiey, J.-M., 'Notule de la littérature syriaque', LM 81 (1968), 449-54.

Fiey, J.-M., 'Les laïcs dans l'histoire de l'eglise syrienne orientale', POC 14 (1969), 169-83.

Fiey, J.-M., 'Tagrit: esquisse d'histoire chrétienne', OS 8 (1969), 289-341.

Fiey, J.-M., 'Le pèlerinage des Nestoriens et Jacobites à Jerusalem', Cahiers de civilisation médiévale 12 (1969), 113-26.

Fiey, J.-M., 'Diocèses syriens orientaux du Golfe Persique', in Memoria G. Khoury Sarkis (Louvain, 1969), 177-219.

Fiey, J.-M., Jalons pour l'histoire de l'église en Iraq (Beiruit, 1970).

Fiey, J.-M., 'Isho'yaw le grand', OCP 35-6 (1969-70), 305-33, and 15-46.

Fiey, J.-M., 'L'Elam: la première des métropoles ecclésiastiques syriennes orientales', Melto 5 (1969), 221-69 and PdO 1 (1970), 123-55.

Fiey, J.-M., 'Les Marcionites dans les textes historiques de l'église de Perse', LM 83 (1970), 183-88.

Fiey, J.-M., 'Ishodnah: métropolitain de Basra et son oeuvre', OS 11 (1972), 433-50.

Fiey, J.-M., 'Chrétientés syriaques du Horāsān et Ségēstan', LM 86 (1973), 75-104.

Fiey, J.-M., 'Les diocèses de maphrianat syrien, 629-1860', PdO 5 (1974).

Fiey, J.-M., 'Ishodnah et la Chronique de Seert', PdO 7 (1976), 447-59.

Fiey, J.-M., Nisibe, métropole syriaque orientale et ses suffragants, des origines à nos jours (Louvain, 1977).

Fiey, J.-M., Chrétiens syriaques sous les Abbasides, surtout à Baghdad (Louvain, 1980).

Fiey, J.-M., 'Résidences et sépultures des patriarches syriaques orientaux', LM 98 (1985), 149-68.

Fiey, J.-M., 'Syriaques occidentaux du Pays des perses', PdO 17 (1992), 113-27.

Fiey, J.-M., Pour un Oriens Christianus Novus: répertoire des diocèses Syriaques orientaux et occidentaux (Beiruit, 1993).

This is an open access version of the publication distributed under the terms of the Creative Commons Attribution-NonCommercialNoDerivs licence (http://creativecommons.org/licenses/by-nc-nd/3.0/), which permits non-commercial reproduction and distribution of the work, in any medium, provided the original work is not altered or transformed in any way, and that the work is properly cited. For commercial re-use, please contact academic.permissions@oup.com 
Fiey, J.-M. Saints syriaques, ed. L. Conrad, Studies in Late Antiquity and Early Islam 6 (Princeton, 2004).

Fiey, J.-M., 'Kashkar', in DHGE.

Fiey, J.-M., 'Sahdona', in DS.

Fisher, G., Between Empires: Arabs, Romans and Sasanians in Late Antiquity (Oxford, 2011).

Flusin, B., Saint Anastase le Perse et l'histoire de la Palestine au début du VIIe siècle, 2 vols. (Paris, 1992).

Foss, C., 'The Persians in the Roman Near East (602-630 AD)', Journal of the Royal Asiatic Society series 3, 13 (2003), 149-70.

Fowden, E. K., The Barbarian Plain: Saint Sergius between Rome and Iran (Berkeley, 1999).

Fowden, G., 'Last days of Constantine: Oppositional versions and their influence', JRS 84 (1994), 146-70.

Fowden, G., 'Varieties of religious community', in P. Brown, G. Bowersock, and O. Grabar (eds.), Interpreting Late Antiquity: Essays on the Postclassical World (Cambridge, Mass., 2001), 82-107.

Fraser, J. B., Travels in Koordistan, Mesopotamia etc., including an account of those parts hitherto unvisited by Europeans, 2 vols. (London, 1840).

Frend, W. H. C., The Rise of the Monophysite Movement: Chapters in the History of the Church in the Fifth and Sixth Centuries (Cambridge, 1972).

Frendo, D., 'Theophylact Simocatta on the revolt of Bahram Chobin and the early career of Khusrau II', BAI 3 (1989), 77-87.

Frendo, D., 'The religious factor in Byzantine-Iranian relations', BAI 11 (1997), 105-23.

Frendo, D., 'Byzantine-Iranian relations before and after the death of Khusrau II: a critical examination of the evidence', BAI 14 (2000), 27-47.

Frolow, A., 'La vraie croix et les expéditions d'Héraclius en Perse', Revue des études Byzantines 11 (1953), 87-105.

Gadja, I., Le royaume de Himyar à l'époque monothéiste (Paris, 2009).

Garsoian, N. and J.-P. Mahé, Des Parthes au Califat: La formation de l'identité arménienne (Paris, 1997).

Garsoian, N., 'Two voices of medieval Armenian historiography: the Iranian index', StIr 25 (1996), 7-45.

Gero, S., Barsauma of Nisibis and Persian Christianity in the 5th Century (Louvain, 1981).

Gero, S., 'The status of the patriarchs of Seleucia-Ctesiphon', in N. Garsoïan, Th. F. Mathews, R. W. Thomson (eds.), East of Byzantium: Syria and Armenia in the Formative Period (Washington 1982), 45-51.

Gibson, M., 'Violation of fallow: an engineered disaster in Mesopotamian civilisation', in T. Downing and M. Gibson (eds.), Irrigation's Impact on Society (Tucson, 1974), 8-20. Gignoux, P., 'Aneran', in EIr.

Gignoux, P., 'Une categorie de mage à la fin de l'époque sasanide: le mogveh', JSAI 9 (1987), 19-23.

Gignoux, P., 'Dietary laws in pre-Islamic and post-Sasanian Iran', JSAI 17 (1994), $16-42$.

Gnoli, G., The Idea of Iran: An Essay on its Origin (Rome, 1989).

This is an open access version of the publication distributed under the terms of the Creative Commons Attribution-NonCommercialNoDerivs licence (http://creativecommons.org/licenses/by-nc-nd/3.0/), which permits non-commercial reproduction and distribution of the work, in any medium, provided the original work is not altered or transformed in any way, and that the work is properly cited. For commercial re-use, please contact academic.permissions@oup.com 
Goffart, W., 'Conspicuously absent: martial heroism in the Histories of Gregory of Tours and its likes', in W. Goffart, Barbarians, Maps and Historiography (Aldershot, 2009), VI. Goodblatt, D., 'The poll-tax in Sasanian Babylonia: The Talmudic evidence', JESHO 22 (1979), 233-95.

Graf, G., La littérature nestorienne, tr. J. Sanders (Heemstede, 1985).

Gray, P., 'The legacy of Chalcedon: Christological problems and their significance', in M. Maas (ed.), The Cambridge Companion to the Age of Justinian (Cambridge, 2005), 215-36.

Greatrex, G., 'The two fifth-century wars between Rome and Persia', Florilegium 12 (1993), 1-14.

Greatex, G., 'Khusro II and the Christians of his empire', Journal of Canadian Syriac Studies 3 (2003), 78-88.

Greatrex, G. 'Moines, militaires et défense de la frontière orientale au VIe s.', in A. Lewin and P. Pellegrini (eds.), The Late Roman Army in the Near East from Diocletian to the Arab Conquest (Oxford, 2007), 285-97.

Greatrex, G. and S. Lieu, Rome and Persia at War: a Narrative Sourcebook (London, 2002).

Greenwood, T., 'Sasanian reflections in Armenian sources', E-Sasanika 5 (2008), 1-30.

Griffith, S., 'Jews and Muslims in Christian Syriac and Arabic texts of the ninth century', Jewish History 3 (1988), 65-95.

Griffith, S., The Church in the Shadow of the Mosque (Princeton, 2008).

Grillmeier, A., Christ in Christian Tradition: Volume One, from the Apostolic Age to Chalcedon (Louisville, 1975).

Guidi, I., 'Nomina Catholicorum', Rendiconti. Reale Accademia dei Lincei, ser. 4, vol. 2, pt. 2 (1885-6), 556-7.

Gutas, D., Greek thought, Arabic Culture: The Graeco-Arabic Translation Movement in Baghdad and Early 'Abbāsid Society (2nd-4th/8th-10th centuries) (London/ New York, 1998).

Guillaumont, A., 'Justinien et l'église perse', DOP 23 (1970), 39-67.

Gyselen, R. and P. Gignoux, 'Empreintes des sceaux sasanides', StIr 93 (1992), 49-56.

Gyselen, R., La géographie administrative de l'empire sasanide (Paris, 1989).

Gyselen, R., Sceaux magiques en Iran sasanide (Paris, 1995).

Gyselen, R., 'New evidence for Sasanian numismatics: the collection of Ahmad Saeedi', in R. Gyselen (ed.), Contributions a l'histoire et geographie historique de l'empire sasanide (Bures-sur-Yvette, 2004), 49-140.

Gyselen, R., 'Les témoinages sigillographiques sur la présence chrétienne dans l'empire sasanide', in R. Gyselen (ed.), Chrétiens en terre de l'Iran 1: implantation et acculturation (Paris, 2006), 17-78.

Hage, W., Die syrisch-jakobitisch Kirche in frühislamischer Zeit: Nach orientalischen Quellen (Wiesbaden, 1966).

Haldon, J., 'The resources of late antiquity', in C. F. Robinson (ed.), New Cambridge History of Islam, 1: The Formation of the Islamic World, Sixth to Eleventh Eenturies (Cambridge, 2010), 19-71.

Hakim, A., 'Death of an ideal leader: predictions and premonitions', JAOS 126 (2006), $1-16$.

This is an open access version of the publication distributed under the terms of the Creative Commons Attribution-NonCommercialNoDerivs licence (http://creativecommons.org/licenses/by-nc-nd/3.0/), which permits non-commercial reproduction and distribution of the work, in any medium, provided the original work is not altered or transformed in any way, and that the work is properly cited. For commercial re-use, please contact academic.permissions@oup.com 
Hameen-Antilla, J., The Last Pagans of Iraq: Ibn Wahshiyya and His Nabatean Agriculture (Leiden, 2006).

Harmatta, J., 'The Middle Persian-Chinese bilingual inscription from Hsian and Sasanian-Chinese relations', in E. Cerutti et al. (eds.), La Persia nel Medioevo (Rome, 1971), 363-76.

Harper, P., In Search of a Cultural Identity: Monuments and Artefacts of the Sasanian Near East (Third to Seventh Centuries A.D.) (New York, 2006).

Harvey, S. A., 'Neochalcedonianism', in Oxford Dictionary of the Christian Church, 3rd edn., ed. E. Livingstone (Oxford, 2005).

Hatch, W., An Album of Dated Syriac Manuscripts (Boston, Mass., 1946).

Hauser, S., Chronologische und historisch-politische Untersuchungen zur östlichen Gazira in vorislamischen Zeit (Berlin, unpublished $\mathrm{PhD}$ thesis, 1994).

Hen, Y., 'The Annals of Metz and the Merovingian past', in Innes and Hen, Uses of the Past, 175-90.

Hendriks, O., 'L'activité apostolique du monachisme monophysite et nestorien', POC 10 (1960), 1-25.

Herrmann, G., The Iranian Revival (Oxford, 1977).

Higgins, M., 'Metropolitans of Seleucia-Ctesiphon', Traditio 9 (1953), 46-99.

Hirschberg, W., 'Nestorian sources of north Arabian traditions on the establishment and persecution of Christianity in the Yemen', Rocznik Orientalistyczny 15 (1939/ 49), 321-38.

Hoffmann, G., Auszüge aus Syrischen Akten Persischen Martyrer (Leipzig, 1880).

Hogel, C., Symeon Metaphrastes: Rewriting and Canonization (2002).

Holmberg, B., Israel of Kashkar: A Treatise on the Unity and the Trinity (Lund, 1989).

Holmberg, B.,'A reconsideration of the Kitab al-Magdal', PdO 18 (1993), 256-73.

Holum, K., 'Pulcheria's crusade A.D. 421-2 and the ideology of imperial victory', GRBS 18 (1977), 164-71.

Horn, C., Asceticism and Christological Controversy in Fifth Century Palestine (Oxford, 2006).

Howard-Johnston, J., 'Al-Tabari on the Last Great War of Antiquity', in J. HowardJohnston, East Rome, Sasanian Persia and the End of Antiquity: Historical and Historiographical Studies (Ashgate, 2006), VI.

Howard-Johnston, J., East Rome, Sasanian Persia and the End of Antiquity (Aldershot, 2006).

Howard-Johnston, J., 'Heraclius' Persian campaigns and the revival of the eastern Roman Empire', in Howard-Johnston, East Rome, VIII.

Howard-Johnston, J., 'The two great powers in late antiquity: a comparison', in Howard-Johnston, East Rome, I.

Howard-Johnston, J., 'State and society in late antique Iran', in Curtis and Stewart, The Sasanian Era, 127-50.

Howard-Johnston, J., Witnesses to a World Crisis: Historians and Histories of the Seventh-Century Middle East (Oxford, 2010).

Howard-Johnston, J., 'Kosrow II', in EIr.

Hoyland, R., 'Arabic, Syriac and Greek historiography in the first Abbasid century: an inquiry into inter-cultural traffic', Aram 3 (1991), 211-33.

This is an open access version of the publication distributed under the terms of the Creative Commons Attribution-NonCommercialNoDerivs licence (http://creativecommons.org/licenses/by-nc-nd/3.0/), which permits non-commercial reproduction and distribution of the work, in any medium, provided the original work is not altered or transformed in any way, and that the work is properly cited. For commercial re-use, please contact academic.permissions@oup.com 
Hoyland, R., Seeing Islam as Others Saw It: A Survey and Evaluation of Christian, Jewish and Zoroastrian Writings on Early Islam (Princeton, NJ, 1997).

Huff, D., 'Formation and ideology of the Sasanian state in the context of archaeological evidence', in V. Curtis and S. Stewart, The Idea of Iran, volume III: The Sasanian Era (London, 2008), 32-39.

Humphreys, R. S., Islamic History: A Framework for Enquiry (Princeton, 1992).

Hunter, E., 'The Christian matrix of al-Hira', in C. Jullien (ed.), Les controverses des chrétiens dans l'Iran Sassanide (Paris, 2008), 41-56.

Hurst, T., The Syriac Letters of Timothy I: A Study in Muslim-Christian Controversy (Catholic University of America, unpublished PhD thesis, 1988).

Hutter, M., 'Manichaeism in the early Sasanian Empire', Numen 40 (1993), 2-15.

Hutter, M., 'Shirin, Nestorianer und Monophysiten: königliche Kirchenpolitik im späten Sasanidenreich', in R. Lavenant (ed.), VII Symposium Syriacum (Uppsala, 1998), 373-86.

Hutter, M., 'Mar Aba and the impact of Zoroastrianism on Christianity', in C. Cereti, M. Maggi, and E. Provasi (eds.), Religious Themes and Texts of Pre-Islamic Iran and Central Asia. Studies in Honour of Professor Gherardo Gnoli (Wiesbaden, 2003), 167-72.

Huyse, P., 'Die sasanidische Königstitulatur: eine Gegenüberstellung der Quellen', in P. Huyse and J. Wiesehöfer (eds.), Ėrān ud Anērān: Studien zu den Beziehungen zwischen dem Sasanidenreich und der Mittelmeerwelt (Stuttgart, 2006), 182-201.

Huyse, P., 'Late Sasanian society between orality and literacy', in Curtis and Stewart, The Idea of Iran, 140-53.

Innes, M. and Y. Hen (eds.), The Uses of the Past in the Early Middle Ages (Cambridge, 2000).

Invernizzi, A., 'Ten years' Research in the al-Mada'in area, Seleucia and Ctesiphon', Sumer 32 (1976), 167-75.

Janin, R., 'Basile de Cilice', in DHGE.

Johns, J. (ed.), Bayt al-Maqdis II: 'Abd al-Malik's Jerusalem (Oxford, 1999).

Jugie, M., 'Gainanites', in Dictionnaire de théologie catholique, ed. A. Vacant and E. Mangenot (Paris, 1923-37).

Jullien, C., 'La minorité chrétienne grecque en terre d'Iran a l'époque sasanide', in R. Gyselen (ed.), Les chrétiens en terre de l'Iran (Yves, 2006), 105-43.

Jullien, C., 'Kaškar la sublime et sa singulière prééminence sur la siège de SéleucieCtésiphon', in A. Panaino and A. Piras (eds.), Proceedings of the 5th Conference of the Societas Iranologica Europaea (Bologna, 2006), 543-52.

Jullien, C., Le monachisme en Perse: la réforme d'Abraham le Grand, père des moines de l'Orient (Louvain, 2008).

Jullien, C. and F. Jullien, 'La Chronique d'Arbèles: propositions pour la fin d'une controverse', Oriens Christianus 85 (2001), 41-83.

Jullien, C. and F. Jullien, Apôtres des confins: processus missionnaires chrétiens dans l'empire iranien (Paris, 2002).

Jullien, C. and F. Jullien, Aux origines de l'église perse: les actes de Mar Mari (Louvain, 2003). Jullien, F., 'Les « frères du Seigneur » sur le siège primatiale de Perse', Apocrypha 14 (2003), 225-36.

Jullien, F., 'La passion syriaque de Mār 'Abdā: quelques relations entre chrétiens et mazdéens', in R. Gyselen, C. Jullien, and F. Jullien (eds.), Rabban l'Olmyn: Florilège offert à Phillippe Gignoux pour son 80e anniversaire (Leuven, 2011), 195-205.

This is an open access version of the publication distributed under the terms of the Creative Commons Attribution-NonCommercialNoDerivs licence (http://creativecommons.org/licenses/by-nc-nd/3.0/), which permits non-commercial reproduction and distribution of the work, in any medium, provided the original work is not altered or transformed in any way, and that the work is properly cited. For commercial re-use, please contact academic.permissions@oup.com 
Jullien, F. and C. Jullien, 'Aux frontières de l'iranité: Nasraye et kristyone dans les inscriptions du mobad Kartir', Numen 49 (2002), 282-335.

Kalmin, R., Jewish Babylonia between Persia and Roman Palestine (Oxford, 2006).

Kaufhold, H., 'Der Richter in den syrischen Rechtsquellen: zum Einfluss islamischen Rechts, auf die christliche-orientalische Rechtsliteratur', OC 68 (1984), 91-114.

Kennedy, H., 'From Shahrestan to Medina', Studia Islamica 102 (2006), 5-35.

Kennett, D., 'The decline of eastern Arabia in the Sasanian period', AAE 18 (2007), 86-122.

Kesseling, H., 'Die Syrische Eusebius Chronik', OC (1927), 31-47 and 225-39 and (1928), 33-53.

Kettenhoffen, E., 'Deportations ii. in the Pathian and Sasanian periods', in EIr.

Kister, M., 'Land, property and jihad: a discussion of some early traditions', JESHO 34 (1991), 270-311.

Kollaparambil, J., 'The identity of Mar John of Persia and Great India who attended the first council of Nicaea', in R. Lavenant (ed.), VI Symposium Syriacum (Rome, 1994), 281-97.

Koltun-Fromm, N., 'A Jewish-Christian controversy in fourth century Persian Mesopotamia', JJS 47 (1996), 45-64.

Kraemer, J., Humanism in the Renaissance of Islam: the Cultural Revival during the Buyid Age (Leiden, 1993).

Kreyenbroek, P., 'Iran ix. Religions in Iran: Religions in pre-Islamic Iran', in EIr.

Labourt, J., Le christianisme dans l'empire perse (Paris, 1904).

Lee, A.D., 'Evagrius, Paul of Nisibis and the problem of loyalties in the mid-sixthcentury', Journal of Ecclesiastical History 44 (1993), 569-85.

Levene, D., A Corpus of Magic Bowls (London, 2003).

Lévi, I., 'The Prophecy of Zerubabel', Revue des études juives 68 (1914), 130-51.

Levy, M., A Baghdad Chronicle (Cambridge, 1929).

Levy-Rubin, M., 'Shurūt 'Umar and its alternatives: the legal debate on the status of the dhimmīs', JSAI 30 (2005), 170-206.

Le Strange, G., Lands of the Eastern Caliphate (London, 1905).

Lieu, S. and I. Gardner, Manichaean Texts from the Roman Empire (Cambridge, 2004).

Lieu, S., Manichaeism in the Later Roman Empire and Medieval China (1992).

Løkkegaard, F., Islamic Taxation in the Classical Period (Copenhagen, 1950).

Mackenzie, D., 'Eranshahr', in EIr.

Mackenzie, D., 'Mani’s Šāburaghān', BSOAS 42 (1979), 500-34.

Mackenzie, D., 'Kerdir's inscription', in G. Herrmann, D. MacKenzie, and R. Howell (eds.), The Sasanian Rock Reliefs at Naqsh-i Rustam: Naqsh-i Rustam 6 (Berlin, 1989), 35-72.

Macomber, W., 'The Christology of the synod of Seleucia-Ctesiphon, AD 486', OCP 24 (1958), 142-54.

Macomber, W., 'The authority of the catholicos-patriarch of Seleucia-Ctesiphon', OCA 181 (1968), 179-200.

Macomber, W., 'The vicissitudes of the patriarchate of Seleucia-Ctesiphon from the beginning to the present day', Diakonia 9 (1974), 35-55.

This is an open access version of the publication distributed under the terms of the Creative Commons Attribution-NonCommercialNoDerivs licence (http://creativecommons.org/licenses/by-nc-nd/3.0/), which permits non-commercial reproduction and distribution of the work, in any medium, provided the original work is not altered or transformed in any way, and that the work is properly cited. For commercial re-use, please contact academic.permissions@oup.com 
Macuch, M., 'Zoroastrian Principles and the Structure of Kinship in Sasanian Iran', in C. Cereti, M. Maggi, and E. Provasi (eds.), Religious Themes and Texts of pre-Islamic Iran and Central Asia: Studies in honour of Professor Gherardo Gnoli (Wiesbaden, 2003), 231-46.

Macuch, M., 'Pious foundations in Byzantine and Sasanian law', in A. Carile, L. Ruggini, and G. Gnoli (eds.), La Persia e Bizansio (Rome, 2004), 181-95.

Macuch, M., 'Pahlavi Literature', in R. Emmerick and M. Macuch (eds.), The Literature of Pre-Islamic Iran (London, 2009).

Madelung, W., 'Abū Îsā al-Warrāq über die Bardesaniten, Marcioniten und Kantäer', in H. R. Roemer and A. Noth (eds.), Studien zur Geschichte und Kultur des Vorderen Orients: Festschrift für Bertold Spuler zum siebzigsten Geburtstag (Leiden, 1981), 221-4. Madelung, W., 'Battai Yazdani', in EIr.

Mai, A., Scriptorum Veterum Nova Collectio, Vol. X (Vatican, 1838).

Mango, C., 'Deux études sur Byzance et la Perse Sassanide', T\&M 9 (1985), 93-118.

Maricq, A., 'Res Gestae Divi Saporis', Syria 35 (1958), 295-360.

Marrou, H.-I. (ed.), Nouvelle histoire de l'église (Paris, 1963).

McDonough, S., Power by Negotiation: Institutional Reform in the Fifth-Century Sasanian Empire (UCLA, 2002, unpublished $\mathrm{PhD}$ thesis).

McDonough, S., 'A second Constantine? The Sasanian king Yazdegard I in Christian history and historiography', JLA 1 (2008), 127-40.

McKitterick, R., History and Memory in the Carolingian World (Cambridge, 2004).

McKitterick, R., Charlemagne: The Formation of a European Identity (Cambridge, 2008). Menze, V.-L., Justinian and the Making of the Syrian Orthodox Church (Oxford, 2008). Meinardus, O., 'The Nestorians in Egypt', OC 15 (1967), 114-29.

Mingana, A., 'The early spread of Christianity in Asia and the Far East: a new document,' BJRL 9 (1925), 297-371.

Morony, M., Iraq after the Muslim Conquest (Princeton, 1984).

Morony, M., 'Religious communities in Late Sasanian and Early Muslim Iraq', JESHO 17 (1974), 113-35.

Morony, M., 'Economic boundaries? Late antiquity and early Islam', JESHO 47 (2004), 166-94.

Morony, M., 'History and identity in the Syrian Churches', in J. J. van Ginkel, H. L. Murre-van den Berg, and T. M. van Lint (eds.), Redefining Christian Identity. Cultural Interaction in the Middle East since the Rise of Islam (Leuven, 2005), 1-33.

Murray, R., Symbols of Church and Kingdom: A Study in the early Syriac Tradition (London, 2004).

Nasrallah, J., L'église melchite en Iraq, en Perse et en Asie Centrale (Jerusalem, 1976).

Nasrallah, J., Histoire du mouvement littéraire dans l'église melchite du Ve siècle au XXe siècle (Paris/Louvain, 1981).

Nautin, P., 'L'auteur de la "Chronique de Seert »: Isho'denah de Basra', RHR 186 (1974), 113-26.

Nautin, P., 'L'auteur de la « Chronique anonyme de Guidi »: Élie de Merw', RHR 199 (1982), 303-14.

Neely, J., 'Sasanian and early Islamic water-control and irrigation systems on the Deh Luran plain', in T. Downing and M. Gibson (eds.), Irrigation's Impact on Society (Tucson, 1974), 21-41.

This is an open access version of the publication distributed under the terms of the Creative Commons Attribution-NonCommercialNoDerivs licence (http://creativecommons.org/licenses/by-nc-nd/3.0/), which permits non-commercial reproduction and distribution of the work, in any medium, provided the original work is not altered or transformed in any way, and that the work is properly cited. For commercial re-use, please contact academic.permissions@,oup.com 
Neusner, J., A History of the Jews in Babylonia, 6 vols. (Leiden, 1960).

Neusner, J., 'Note on Baruch ben Neriah and Zoroaster', Numen 12 (1965), 66-9.

Neusner, J., Aphrahat and Judaism, The Christian-Jewish Argument in Fourth Century Iran (Leiden, 1971).

Neusner, J., Israel's Politics in Sasanian Iran (Lanham, 1986).

Neusner, J., Judaism, Christianity and Zoroastrianism in Talmudic Babylonia (Atlanta, 1990).

Newman, J., Agricultural Life in Jewish Babylonia (Oxford, 1930).

Nöldeke, T., Geschichte der Araber und Perser (Leipzig, 1887).

Nöldeke, T., The Persian National Epic (tr. Bogdanov) (repr. Philadelphia, 1971).

Noth, M., The Deuteronomistic History (2nd edn., Sheffield, 1995).

Olster, D., 'The Chalcedonian-Monophysite union of 616', Bulletin de la Société d'Archéologie Copte 27 (1985), 93-108.

Olster, D., Roman Defeat, Christian Response and the Literary Construction of the Jew (Philadelphia, 1994).

Oppenheimer, A., Babylonia Judaica in the Talmudic Period (Wiesbaden, 1983).

Outler, A., 'The Three Chapters: a comment on the survival of Antiochene Christology', in A Tribute to Arthur Vööbus (Chicago, 1977), 357-64.

Panaino, A., 'Women and Kingship: some remarks about the enthronisation of Queen Boran and her sister Azarmigduxt', in J. Wiesehöfer and P. Huyse (eds.), Ërān ud Anērān: Studien zu den Beziehungen zwischen dem Sasanidenreich und der Mittelmeerwelt (Stuttgart, 2006), 221-40.

Panaino, A., 'The Zoroastrian incestuous unions in Christian sources and canonical laws: their (distorted) aetiology and some other problems', in C. Jullien (ed.), Controverses des chrétiens dans l'Iran sassanide (Paris, 2008), 69-87.

Papaconstantinou, A., 'Historiography, hagiography, and the making of the Coptic "church of the martyrs" in early Islamic Egypt', DOP 60 (2006), 65-86.

Payne, R., 'Persecuting heresy in early Islamic Iraq: the Catholicos Ishoyahb III and the elites of Nisibis', in A. Cane and N. Lenski (eds.), The Power of Religion in Late Antiquity (Ashgate, 2009), 397-410.

Payne, R., Christianity and Iranian Society 500-700 CE (unpublished PhD thesis, Princeton, 2010).

Payne, R., 'The emergence of martyr shrines in late antique Iran', in P. Sarris, P. Booth, and M. Del Santo (eds.), An Age of Saints? Power, Conflict and Dissent in Early Medieval Christianity (Leiden, 2011), 89-113.

Peeters, P., 'Une passion arménienne des SS Abdas, Hormisdas, Šahin (Suenes) et Benjamin', $A B 28$ (1909), 399-415.

Peeters, P., 'S. Eleutherios-Guhishtazad', $A B 29$ (1910), 151-6.

Peeters, P., 'Jacob de Nisibe', $A B 38$ (1920), 287-373.

Peeters, P., 'Demetrianus, évêque d'Antioche?', $A B 42$ (1924), 288-314.

Peeters, P., 'Le Passionaire d'Adiabene', AB 43 (1925), 261-304.

Peeters, P., 'Observations sur la vie syriaque de Mar Aba, catholicos de l'église perse (540-52)', in Miscellanea Giovanni Mercati V: Storia ecclesiastica-Diritto (Vatican City, 1946), 69-112.

Perrone, L., 'Christian holy places and pilgrimage in an era of dogmatic conflict', POC 48 (1998), 4-37.

This is an open access version of the publication distributed under the terms of the Creative Commons Attribution-NonCommercialNoDerivs licence (http://creativecommons.org/licenses/by-nc-nd/3.0/), which permits non-commercial reproduction and distribution of the work, in any medium, provided the original work is not altered or transformed in any way, and that the work is properly cited. For commercial re-use, please contact academic.permissions@oup.com 
Pigulevskja, N., Les villes de l'état Iranien aux époques parthe et sassanide: contribution à l'histoire sociale de la basse antiquité (Paris, 1963).

Pohl, W., 'Telling the difference: Signs of ethnic identity', in W. Pohl and H. Reimitz (eds.), Strategies of Distinction (Leiden/Cologne, 1998), 19-71.

Potts, D., The Archaeology of Elam: Formation and Transformation of an Iranian State (Cambridge, 1999).

Pourshariati, P., Decline and Fall of the Sasanian Empire. The Sasanian-Parthian Confederacy and the Arab Conquest of Iran (London/New York, 2008).

Putman, H., L'église et l'islam sous Timothée I (Beiruit, 1986).

Putrus, G., Kitab al-Magdal (Paris, Sorbonne, unpublished $\mathrm{PhD}$ thesis, 1968).

Reinink, G., "Edessa grew dim and Nisibis shone forth": The school of Nisibis at the transition of the sixth-seventh century', in J.-W. Drijvers and A. MacDonald (eds.), Centres of Learning: Learning and Location in Pre-Modern Europe and the Near East (Leiden/New York/Cologne, 1995), 77-89.

Reinink, G., 'Babai the Great's Life of George and the propagation of doctrine in the late Sasanian Empire', in J.-W. Drijvers and J. Watt (eds.), Portraits of Spiritual Authority. Religious Power in Early Christianity, Byzantium and the Christian Orient (Leiden/ Boston/Cologne, 1999), 171-93.

Reinink, G., 'Tradition and the formation of the "Nestorian" identity in sixth- to seventh-century Iraq', in B. Ter Haar Romeny (ed.), The Religious Origins of Nations? The Christian Communities of the Middle East (Leiden, 2009), 217-50.

Reinink, G. and B. Stolte (eds.), The Reign of Heraclius (610-41): Crisis and Confrontation (Leuven, 2002).

Rist, J., 'Die Verfolgung der Christen im spätantiken Sasanidenreich', OC 80 (1996), 17-42.

Robinson, C., Empire and Elites after the Muslim Conquest: The Transformation of Northern Mesopotamia (Cambridge, 2000).

Robinson, C., Islamic Historiography (Cambridge/New York, 2003).

Robinson, C., 'Abd al-Malik (Oxford, 2005).

Rorem, P. and J. Lamoureaux, 'John of Scythopolis on Apollinarian Christology', Church History 62 (1993), 469-82.

Rose, R., 'Islam and the development of personal law among Christian dhimmis', $M W$ 72 (1982), 159-79.

Rubin, U., The Eye of the Beholder: The Life of Muhammad as Viewed by the Early Muslims, A Textual Analysis (Princeton, 1995).

Rubin, Z., 'The reforms of Khusro Anushirwān', in Averil Cameron (ed.), The Byzantine and Early Islamic Near East III: States Resources and Armies (Princeton, 1995), 225-97.

Rubin, Z., 'Nobility, monarchy and legitimation under the later Sasanians', in Haldon and Conrad (eds.), The Byzantine and Islamic Near East, vol. 6 (Princeton, 2004), 235-73.

Rubin, Z., 'Ibn al Muqaffa' and the account of Sasanian history in the Arabic Codex Sprenger 30', JSAI 30 (2005), 52-93.

Rubin, Z., 'The lost Sasanian Book of the Lords as known to the 10th century Arabic historiographers' (unpublished paper, Oxford, 2008).

Russell, J., 'Burial iii. In Zoroastrianism', in EIr.

Russell, J., 'Sages and scribes at the courts of ancient Iran', in J. Gammie and L. Perdue (eds.), The Sage in Israel and the Ancient Near East (Winona Lake, 1990), 141-6.

This is an open access version of the publication distributed under the terms of the Creative Commons Attribution-NonCommercialNoDerivs licence (http://creativecommons.org/licenses/by-nc-nd/3.0/), which permits non-commercial reproduction and distribution of the work, in any medium, provided the original work is not altered or transformed in any way, and that the work is properly cited. For commercial re-use, please contact academic.permissions@,oup.com 
Saadi, A., 'Moshe bar Kepha and Christian communities', The Harp 15 (2002), 161-73. Sakly, W., 'Wasit', in EI2.

Sako, L., Le rôle de l'hiérarchie syrien orientale dans les rapports diplomatiques entre la Perse et Byzance aux Ve-VIIe siècles (Paris, 1986).

Sako, L., 'Les sources de la chronique de Seert', PdO 14 (1987), 155-67.

Samir, S., 'Rôle des chrétiens dans la nahda Abbasside en Irak et Syrie', MUSJ 58 (2002), 541-72.

Sarris, P., Empires of Faith: The Fall of Rome to the Rise of Islam, 500-700 (Oxford, 2011). Schachner, L., 'I greet you and thy brethren. Here are fifteen šentaese of wine': wineproduction in the early monasteries of Egypt and the Levant', Aram 17 (2005), 157-84.

Schaeder, H., 'Die Kantäer', Welt des Orients 1 (1952), 288-98.

Schrier, O., 'Syriac evidence for the Romano-Persian War of 421-422', GRBS 33 (1992), 75-86.

Schilling, A., Die Anbetung der Magier und Taufe der Sāsāniden: Zur Geistgeschichte des iranischen Christentums in der Spätantike (Louvain, 2008).

Sears, S., 'Monetary revision and monetisation in the late Sasanian empire', in R. Gyselen and M. Szuppe (eds.), Matériaux pour l'histoire économique du monde iranien (Paris, 1999), 149-63.

Selb, W., Orientalisches Kirchenrecht: Band I, Die Geschichte des Kirchenrechts der Nestorianer (von den Anfängen bis zur Mongolenzeit) (Vienna, 1981).

Seleznyov, N. N., 'Nestorius of Constantinople: condemnation, suppression, veneration, with special reference to the role of his name in East-Syriac Christianity', Journal of Eastern Christian Studies 62 (2010), 165-90.

Seybold, C. F., 'Histoire nestorienne (Chronique de Séert) par Addai Scher', ZDMG 66 (1912), 742-6.

Shahbazi, S., 'On the Xwaday-Namag', in D. Amin and M. Kasheef (eds.), Iranica Varia: Papers in Honor of Ehsan Yarshater (Brill, 1990), 208-29.

Shahbazi, S., 'Gundishapur', in EIr.

Shaked, S., Dualism in Transformation: Varieties of Religion in Sasanian Iran (Jerusalem, 1994).

Shaked, S., 'Popular religion in Sasanian Babylonia', JSAI 21 (1997), 103-15.

Shaked, S., 'Religion in the late Sasanian period: eran, aneran and other designations', in Curtis and Stewart, Sasanian Era, 98-109.

Shaked, S. and J. Naveh, Amulets and Magic Bowls: Aramaic Incantations of Late Antiquity (Leiden, 1985).

Shaked, S. and J. Naveh, Magic Spells and Formulae (Jerusalem, 1993).

Schippman, K., Die iranische Feuerheiligtümer (Berlin, 1971).

Shin, A., 'Nestorius and factions in the fifth century', Studia Patristica 39 (2003), 125-30.

Shoshan, B., 'High culture and popular culture in medieval Islam', Studia Islamica 73 (1973), 66-107.

Shoufani, E., Al-Riddah and the Muslim Conquest of Arabia (Toronto, 1973).

Sijpesteijn, P., 'New rule over old structures: Egypt after the Muslim conquest', in H. Crawford (ed.), From Sargon to Saddam Hussein: Regime Change in the Ancient Near East and Egypt (Oxford, 2007), 183-200.

This is an open access version of the publication distributed under the terms of the Creative Commons Attribution-NonCommercialNoDerivs licence (http://creativecommons.org/licenses/by-nc-nd/3.0/), which permits non-commercial reproduction and distribution of the work, in any medium, provided the original work is not altered or transformed in any way, and that the work is properly cited. For commercial re-use, please contact academic.permissions@oup.com 
Sijpesteijn, P., 'Landholding patterns in early Islamic Egypt', Journal of Agrarian Change 9 (2009), 120-33.

Simonsohn, U., A Common Justice: The Legal Allegiances of Christians and Jews under Early Islam (Philadelphia, 2011).

Simpson, S., Aspects of the Archaeology of the Sasanian Period in Mesopotamia (unpublished DPhil thesis, Oxford, 1992).

Simpson, S., 'Mesopotamia in the Sassanian period: settlement patterns, arts, crafts', in V. Curtis (ed.), Mesopotamia and Iran in the Parthian and Sasanian Periods: Rejection and Revival, c.238 BC-AD 642 (London, 2000), 57-67.

Simpson, S., 'Ancient Merv: archaeological insights into the economy of the city during the Sasanian period (3rd - 7th centuries $\mathrm{AD}$ )', in The Turkmen Land as a Centre of Ancient Cultures and Civilizations: Materials of the International scientific conference, 1-3 October 2008 (Ashgabat, 2008), 247-57.

Sims-Williams, N., 'Christianity. iv. Christian literature in Middle Iranian languages', in EIr.

Sims-Williams, N., 'Eugenius (MarAwgin)', in EIr.

Sims-Williams, N., Sogdian Manuscript C2 (Berlin, 1985).

Sizgorich, T., Violence and Belief in Late Antiquity: Militant Devotion in Christianity and Islam (Philadelphia, 2009).

Sizgorich, T., "Become infidels or we will throw you into the fire": the martyrs of Najran in early Muslim historiography, hagiography and Qur'anic exegesis', in A. Papaconstantinou, M. Debié, and H. Kennedy (eds.), Writing True Stories: Historians and Hagiographers in the Late Antique and Early Medieval Near East (Leiden, 2009), 125-47.

Sizgorich, T., 'Ka'ab al-Aḥbār', unpublished document (Los Angeles, 2010).

Smith, K., The Persian Persecution: Martyrdom, Politics and Religious Identity in Late Ancient Syriac Christianity (Duke University, unpublished PhD thesis, 2011).

Stewart, C., Working the Earth of the Heart: The Language of Christian Experience in the Messalian controversy, the Writings of Pseudo-Macarius and the Liber Graduum (Oxford, 1991).

Stoyanov, Y., Defenders and Enemies of the True Cross: The Sasanian Conquest of Jerusalem in 614 and Byzantine Ideology of anti-Persian Warfare (Vienna, 2011).

Stratos, A., Byzantium in the Seventh Century, tr. M. Oglivie-Grant, 6 vols. (Amsterdam, 1968).

Strohmaier, G., 'Hunayn ibn Ishaq: an Arab scholar translating into Syriac', Aram 3 (1991), 163-70.

Sundermann, W., Mitteliranische manichäische Texte kirchengeschichtlichen Inhalts, Berliner Turfantexte 11 (Berlin, 1981).

Sundermann, W., 'Manichaean literature in Iranian languages', in R. Emmerick and M. Macuch (eds.), The Literature of Pre-Islamic Iran (London, 2009), 197-265.

Swanson, M., The Coptic Papacy in Islamic Egypt (641-1517).

Takahashi, H., Barhebraeus: A Bio-Bibliography (Piscataway, NJ, 2005).

Talib, A., 'Topoi and topography in the history of al-Hirah', in P. Wood (ed.), History and Identity in the Middle East, 500-1000 (New York, 2013), 123-48.

Tamcke, M., Der Katholicos-Patriarch Sabriŝo (596-604) und das Mönchtum (Göttingen, 1988).

This is an open access version of the publication distributed under the terms of the Creative Commons Attribution-NonCommercialNoDerivs licence (http://creativecommons.org/licenses/by-nc-nd/3.0/), which permits non-commercial reproduction and distribution of the work, in any medium, provided the original work is not altered or transformed in any way, and that the work is properly cited. For commercial re-use, please contact academic.permissions@oup.com 
Tamcke, M.,'Theology and the practice of communal life according to Dadisho', The Harp 4 (1999), 173-88.

Tamil, D., 'The syncretistic goddess Anahit', Iranica Antiqua 27 (1992), 189-225.

Taqiazdeh, A., 'Iranian festivals adopted by Christians and condemned by Jews', BSOAS 10 (1942), 632-53.

Tardy, R., Najran: chrétiens d'Arabie avant l'islam (Beiruit, 1999).

Teixidor, J., 'Aristote en syriaque: les philosophes de la Haute Mésopotamie au VIème siècle’, Annuaire du Collège de France 97 (1997), 723-43.

Ter Har Romeny, B., 'Les pères grecs dans les florilèges exégetiques syriaques', in A. Schitt and D. Gornet (eds.), Les pères grecs dans la traduction syriaque (Paris, 2007), 63-76.

Teule, H., 'L'abrégé de la chronique ecclésiastique Muhtasar al-akhbar al-bi'iyya et la chronique de Séert: quelques sondages', in Debié, L'historiographie syriaque, 161-77.

Thomson, R. W., 'The Armenians in the fifth and sixth centuries', in Averil Cameron, P. Garnsey, and B. Ward-Perkins (eds.), The Cambridge Ancient History, vol. XIV: Late Antiquity: Empire and Successors A. D. 425-600 (Cambridge, 2000), 662-77.

Tisserant, E., 'Nestorienne (L'église)', in Dictionnaire de théologie catholique, ed. Vacant and E. Mangenot (Paris, 1923-37).

Toorawa, S., Ibn Tāhir Tayfar and Arabic Writerly Culture: A Ninth-century Bookman in Baghdad (New York, 2005).

Tsotselia, M., 'Recent Sasanian coin findings on the territory of Georgia', Histoire et mesure, XVII (<http://histoiremesure.revues.org/document888.html >).

van Bekkum, W., 'Jewish messianic expectations in the age of Heraclius', in Reinink and Stolte, The Reign of Heraclius, 94-112.

van den Berghe, L., 'Nouvelles découvertes de monuments de feu d'époque sassanide', IrAnt 5 (1965), 128-47.

van Esbroek, M., 'Abraham le confesseur (Ve s.), traducteur des passions des martyres perses', $A B 95$ (1977), 169-79.

van Rompay, L., 'Impetuous martyrs? The situation of the Persian Christians in the last years of Yazdegard I (419-20)', in M. Lamberigts and P. van Deun (eds.), Martyrium in a Multi-Disciplinary Perspective: Memorial Louis Reekmans (Louvain, 1972), 363-75.

van Rompay, L., 'Ephrem in the works of Philoxenus of Mabbug: respect and distance', Hugoye 7 (2004), 1-13.

Vansina, J., Oral Tradition: A Study in Historical Methodology (London, 1961).

Vansina, J., Oral Tradition as History (Madison, 1985).

Venco Ricciardi, R., 'The Excavations at Choche', Mesopotamia 3-4 (1968-69), 57-68.

Venco Ricciardi, R., 'Trial Trench at Tell Baruda', Mesopotamia 12 (1977), 11-14.

Venetis, E., 'The Zoroastrian priests and the foreign affairs of Sasanian Iran and the Later Roman Empire (5th Cent.)', Nāme-ye Irān-e Bāstān 3 (2003), 47-78.

Verkinderen, P., Tigris, Euphrates, Karun, Karhe and Jarahi: Tracing the Changes of Five Rivers in Lower Iraq and Khuzistan in the Early Islamic Period (unpublished PhD thesis, Ghent, 2009).

Villagomez, C., The Fields, Flocks and Finances of Monks: Economic Life at Nestorian Monasteries, 500-850 (Los Angeles, 1998, unpublished PhD thesis).

Vööbus, A. History of Asceticism in the Syrian Orient: A Contribution to the History of Culture in the Near East, 3 vols., CSCO 184, 197, 500, Subsidia 14, 17, 81 (Louvain, 1958-80).

This is an open access version of the publication distributed under the terms of the Creative Commons Attribution-NonCommercialNoDerivs licence (http://creativecommons.org/licenses/by-nc-nd/3.0/), which permits non-commercial reproduction and distribution of the work, in any medium, provided the original work is not altered or transformed in any way, and that the work is properly cited. For commercial re-use, please contact academic.permissions@oup.com 
Vosté, J., 'Alphonse Mingana', OCP 7 (1941), 514-18.

Walker, J., The Legend of Mar Qardagh: Narrative and Christian Heroism in Late Antique Iraq (Berkeley, 2006).

Walker, J., 'The legacy of Mesopotamia in late antique Iraq: The Christian martyr shrine at Melqi (Neo-Assyrian Milqia), Aram 19 (2007), 471-96.

Watt, J., 'The portrayal of Heraclius in Syriac historical sources', in Reinink and Stolte, The Reign of Heraclius, 63-79.

Weitzmann, M., The Syriac Version of the Old Testament (London, 1996).

Wellhausen, J., Die Composition des Hexateuchs und der historischen Bücher des Alten Testaments (Berlin, 1899).

Wenke, R., 'Parthian and Sasanian Khuzistan', Mesopotamia 10 (1975), 31-217.

Wenke, R., 'Elymaeans, Parthians and the evolution of empires in southwestern Iran', JAOS 101 (1981), 303-13.

Westphal, G., Untersuchungen über die Quellen und die Glaubwürdigkeit der Patriarchenchroniken des Marī ibn Sulaimān, 'Amr ibn Mattai und Șaliba ibn Johannān. Abschnitt 1 Bis zum Beginn des Nestorianischen Streites (Kirchain, 1901).

Wheeler, B., 'Imagining the Sasanian capture of Jerusalem', OCP 57 (1991), 69-85.

Whitby, M., The Emperor Maurice and his Historian (Oxford, 1988).

Whitcomb, D., Before the Roses and the Nightingales: Excavations at Qasr-i Abu Nasr, Old Shiraz (New York, 1985).

Whittow, M., The Making of Orthodox Byzantium, 600-1025 (London, 1996).

Wickham, C., Framing the Early Middle Ages: Europe and the Mediterranean 400-800 (Oxford, 2005).

Widengren, G., 'The status of the Jews in the Sasanian Empire', Ir Ant 1 (1961), 117-62. Wiesehöfer, J., Ancient Persia: From 550 B.C. to 650 A.D. (2nd edn., London, 2001).

Wiessner, G., Untersuchungen zur syrischen Literaturgeschichte I: Zur Martyrenüberlieferung aus der Christenverfolgung Shapurs II (Göttingen, 1967).

Wiessner, G., 'Zum Problem der zeitlichen und örtlichen Festlegung der erhaltenen syro-Persichen Märtyrerakten: Das Pusai-Martyrium', in Paul De Lagarde und die syrische Kirchengeschichte (Göttingen 1968), 231-51.

Wiessner, G., 'Christlicher Heilgenkult im Umkreis eines sassanidischen Grosskönigs', in W. Eilers (ed.), Festgabe deutscher Iranisten zur 2500 Jahrfeier Irans (Stuttgart, 1971), 141-55.

Williams, R. L., Bishop Lists: The Formation of Ecclesiastical Succession in Ecclesiastical Crises (Piscataway, NJ, 2005).

Winkler, D., 'An obscure chapter in Armenian church history', Revue des études arméniennes (new series) 19 (1985), 85-180.

Witakowski, W., 'The Chronicle of Eusebius', Aram 12 (2000), 419-37.

Wood, P., We Have No King but Christ: Christian Political Thought in Greater Syria on the Eve of the Arab Conquest (c.400-580) (Oxford, 2010).

Wood, P., 'Syriac and the "Syrians", in S. Johnson (ed.), The Oxford Handbook of Late Antiquity (Oxford, 2012), 170-95.

Wright, W., A Short History of Syriac Literature (London, 1896).

Yarshater, E., 'Iranian National History', in E. Yarshater (ed.), The Cambridge History of Iran, vol. III: The Seleucid, Parthian and Sasanian Periods (Cambridge, 1983), 359-481.

This is an open access version of the publication distributed under the terms of the Creative Commons Attribution-NonCommercialNoDerivs licence (http://creativecommons.org/licenses/by-nc-nd/3.0/), which permits non-commercial reproduction and distribution of the work, in any medium, provided the original work is not altered or transformed in any way, and that the work is properly cited. For commercial re-use, please contact academic.permissions@oup.com 
Yousif, E., Les chroniqueurs syriaques (Paris, 2002).

Zaehner, F., Zurvan. A Zoroastrian Dilemma (Oxford, 1955).

Zakeri, M., Sasanian Soldiers in Early Muslim Society: The Origins of 'Ayyawan and Futtuwa (Wiesbaden, 1995).

This is an open access version of the publication distributed under the terms of the Creative Commons Attribution-NonCommercialNoDerivs licence (http://creativecommons.org/licenses/by-nc-nd/3.0/), which permits non-commercial reproduction and distribution of the work, in any medium, provided the original work is not altered or transformed in any way, and that the work is properly cited. For commercial re-use, please contact academic.permissions@oup.com 


\section{This page intentionally left blank}

This is an open access version of the publication distributed under the terms of the Creative Commons Attribution-NonCommercialNoDerivs licence (http://creativecommons.org/licenses/by-nc-nd/3.0/), which permits non-commercial reproduction and distribution of the work, in any medium, provided the original work is not altered or transformed in any way, and that the work is properly cited. For commercial re-use, please contact academic.permissions@oup.com 


\section{Index}

Aba (catholicos) 11, 94, 105, 108-18, 128,193

Aba (locum tenens) 207

'Abd al-Malik 168, 225, 248 note 116

'Abdisho' of Arphelouna 76

'Abdisho' of Nisibis (Bar Brikha) 7, 122-3, 131,142 note 81,230

Abgar the monk (fifth-century hagiographer) $40,44-9,51-3$

Aborsima 81

Abraham of Kashkar 146-7, 162

represented in later history $152-4,157$, $160,162-3,242$

Abu Bakr 248, 250, 253-5

Abu Yusuf 247-51

Acacius (catholicos), described in the Chronicle of Seert 11-12, 99-101, 106, 113

later reputation 108, 138, 141

role in commissioning history $73-5$, 77,94

synod of $96-8$

Acacius of Amida (Roman emissary) 35-6, 54,72

Addai (apostle) 67, 71, 101, 121, 233

Adiabene 33, 143, 161

government of 211

hagiography of $36,55,146,169-70$

monasteries in 152,170

Schools in 203, 225-6

Agapetus of Beth Lapet 79-88, 90

Agapius (Melkite historian) 259

agricultural investment 23-6, 165

Ahai

as ambassador 38,138

collecting relics and commissioning

history $9-10,54,66,72,74-7$

relations with the shah 9-10, 35

Ahudemmeh 68, 130, 141

Aleppo (Beroea) 33, 137, 241

Alexandria 69, 94, 107, 132, 238

Allahazkha 182

Amida 33, 35, 74, 200

'Amr 49 note 70, 63, 68-71, 88, 100, 102 note $34,160,182,184,197,222,260$

Anatolius (patriarch) 12, 134

angels 81, 144, 189, 195

Anoshazad (Sasanian pretender) 94, 103 note $38,110,113,116$
Antioch

Antiochene theology 125-8

connection to eastern sees $26,33-4,69$, $88-91,133,236$

patriarchs of $12,67,126,237$

school of 238

sack of 90

Antony 70, 78, 81, 133, 242

Aphrahat 21 note 65, 82-3

Apollinarius 128-30, 138

Arabia see Bahrayn; Najran

Arbela 22, 24, 149

hagiography of 61,72 note $18,89,164$, $169-71$

school of 107 note 58

Arbela Chronicle 4 note 12

Arcadius 33, 74

Ardashir I 13-15, 175 note 127

Ardashir II 172

Ardashir III 180, 186, 216-18

Ardashir-Khurrah 36

Arius 125, 129, 132, 230, 234, 242

Armenia

in the fifth-century persecutions 36 note $22,49,75$

as Miaphysite 68

migration from 238

in Roman-Persian relations 178-9, 200, 215 note 107

Armenian language texts 54, and see Pseudo-Sebeos

Aspanir (suburb of Ctesiphon) 101-3

Assur 22

Assyria 26-30, 143, 169-71

astronomers 207

Athanasius of Alexandria 107, 129, 132

Athanasius the Camel-driver (Jacobite patriarch) 237, 241

Awgin 10, 78, 146 note 12, 232, 242-3

Baalbek 240

Babai (catholicos)

Babai of Nisibis 161,217

Babai the great (abbot of Izla)

Dyophysite theologian 135-42, 149-50, 224-5

and Gregory of Nisibis 197, 202, 204 note 85 representation in the Chronicle of Seert $182,186-7$

This is an open access version of the publication distributed under the terms of the Creative Commons Attribution-NonCommercialNoDerivs licence (http://creativecommons.org/licenses/by-nc-nd/3.0/), which permits non-commercial reproduction and distribution of the work, in any medium, provided the original work is not altered or transformed in any way, and that the work is properly cited. For commercial re-use, please contact academic.permissions@oup.com 
Babai the great (abbot of Izla) (cont.) reputation in the Book of the Governors 156-60

Babowai 10-12, 73, 94-100, 108, 112 note 73

Baghdad anachronistic reference to 153 note 42 Christian settlement in 231, 237-9 foundation of 227-8

Bahrayn 76, 103

al-Baladhuri 6, 247

Bar Hebraeus 82, 85-6, 108, 139, 141, 200, 227, 252

Bar Sahde (historian) 252-3

Barba'shemin 62-3, 101, 121

Barhadbeshaba 'Arbaya 78 note 36, 107, 203

Barhadbeshaba 108, 130, 132-3, 137, 139

Barsauma of Nisibis 93-9, 106-8

Barsauma of Susa $137-8$

Basil of Caesarea 125, 132

Basil of Cilicia (historian) 127

Basra (see also Maishan) 222

Belashparr 36, 44 note 47

Beth'Abe 154-9, 167, 226

Beth Aramaye see Ctesiphon

Beth Garmai

bishop of 29, 33, 205

government of 211

martyrs of 44,53

monasteries in $143,152,155$

See also John of Beth Garmai; Mikha of Beth Garmai; Sabrisho'; Simeon of Beth Garmai

Beth Lapet see Gundishapur

Bishapur 16

bishop lists $61,66-7,72,92,117$

Bokhtisho' (holy man) 78

Bokhtisho' family 228

Book of Chastity 150-3, 161-2, 204 note 85,243

Book of Life 126

Book of the Governors see Thomas of Marga

Bouzaq of Susa 101, 112

Cairo 241-3

catholicoi

from Fars 49, 163

from northern Iraq 29, 143

trained at Nisibis $28,94,109,120,203-4$

trained at the school of 'Abda 76-8

Catholicosate see Ctesiphon

Celestine (Pope) 137

China 9, 35, 175 note 126, 192, 237

church centralization 31-6, 51, 105, 143-6, $224-5,230-6$

civic foundation $15-16,25-6,90-1,173-4,222$

clerical marriage $12,95-106$

coinage reform 17, 38, 225
Constantine

imagined in the Abbasid period 232-5, 240,260

imagined in the Sasanian period 2, 33, 58, 122 note 3

as a model for Sasanian rulers and nobles $33,210-11$

Constantinople 128-33, 137, 179, 233-4, 236

Constantinople, patriarchs in ecclesiastical history $12,69,124,134-5,240-1$

court connections of churchmen 103, 113-18, $143,194-6,208,213-14,228-9$

Ctesiphon apostolic and patriarchal authority $22-3$, 140,235

archaeology 102-3

assertions of authority through the Acacian history $61,71-7,84-91$

assertion of authority under Joseph 117, 121 assertion of authority under Narsai 101-2 early assertions of authority $33-6,78-80$ ecclesiastical province $23-5$

Jacobites in 209-10

links to other royal foundations $87-91$

martyrs of 54-60, 61

School of Ctesiphon 108-12, 206

site of Khusrau II's murder 215-19

site of the ordination of a catholicos 189-92, 194-6, 206-7

Cyprian of Carthage 4

Cyril of Alexandria 126-9, 132-3, $137-40,240$

Dadisho' (catholicos) collapse of authority $48-50$

imagined as declaring autocephaly 141, 236 and the Letter of the Western Fathers 79-80 opposed by dissidents $43,79,90$

Dadisho' (monastic leader) 147-50, 153-8, 161-2

Daniel bar Mariam (historian) 9-10, 75, 88 note $71,123,260$

Dara 196-9

Darabhar 22

David (Roman general) 218

David of Merv 102

Daylam 168-9, 223, 237

Deh Luran 165

Deir Qoni 23, 75

Demetrianus (exiled bishop) 88-91

democratic language $42-4$

Diocletian 39, 258, 260

Diodore of Tarsus $124-6,129-32$, 136,147

dissident traditions $40-4,55-7,81-4$, $202-10$

This is an open access version of the publication distributed under the terms of the Creative Commons Attribution-NonCommercialNoDerivs licence (http://creativecommons.org/licenses/by-nc-nd/3.0/), which permits non-commercial reproduction and distribution of the work, in any medium, provided the original work is not altered or transformed in any way, and that the work is properly cited. For commercial re-use, please contact academic.permissions@oup.com 
doctors (medical) 197, 208-9, 227-8

Dyophysitism 106-8, 124-42

See also Babai the great

ecclesiology 87-91, 236-41

Edessa 2, 27, 33, 95, 134, 247-8

and the story of Abgar 233

school of the Persians 11-12, 28, 73, 77, 94,

98, 106-7, 120, 132

source of missions 22

Egypt 179-80, 223, 239

ecclesiastical history 257-60

'Nestorian' monasteries 241-2

and the story of Nestorius 132-3

as source of cenobitic monasticism 78, 84, $146-7,153-4,232,242$

Eilya of Hira 156

Elias of Merv 123, 183, 203 note 82 See further Khuzistan Chronicle

Elias of Nisibis 182 note 22, 229-30

Elishe (catholicos) 26, 61, 87, 93-4, 100-4, 107

Ephraem 7, 27, 71, 84-5, 107, 125

Epiphanius of Salamis 71, 128

èrān 15 notes $37-8,33,216$

Eunomius 129-32

Eusebius (fictional Pope) 233-5

Eusebius of Caesarea 55, 62, 69, 91, 123-5, 258-60

as a model for Iraqi histories $62-3,69-70$, 124-6, 258-60

Eutychius (Melkite historian) 259

Eutychius (Monophysite 'heretic') 126

Evagrius 127, 132

exile 35, 87-91, 104, 132, 157, 194, 203-5, 214-16, 251

Ezekiel (catholicos) 110, 120, 129-30, 137 note 52, 144-9

Fars

catholicoi from 49

and church centralization 33-5, 88-90, 105

martyrs in 54

missions to 168

monks in 152-3

as a Sasanian province $9,13-15,18,22$, $25,222-5$

Felix III (Pope) 12

Flavian of Antioch 125, 132

Flavian of Constantinople 126, 129

florilegia 127

Gabriel of Sinjar 185-6, 197-201, 203, 206-7, 209-11, 214

Gennadius 12, 134

Ghassanids 134, 178, 200

Giwargis (convert and martyr) 201, 204
Giwargis I 140, 161 note 69, 225-6, 229

Gospels 46, 80-2, 192

Gregory of Nisibis 149, 177, 185-7, 202-9

Gregory of Pherat 73 note 21, 149, 158, 181, 206-12

Gundishapur 35, 102-3, 165 note 91, 228

foundation of 25

rebellion of $94,110,114$

rights of $87-91$

Haddad Chronicle 70-1, 84-5, 88, 237 note 70 hagiographic cycles 61,152

Al-Hajjaj bin Yusuf 226

Helena (mother of Constantine) 84, 122 note 3, 230, 234-5, 240

Henana 131 note $30,149,162,185,203-8$

Henanisho' I 153 note 42, 224, 226-7

Henanisho' II 229

Hephthalites 19,72 note 16

Heraclius

ecclesiastical politics 135-9

invasion of Iraq 179-83, 186, 215-19, 260

Hira

histories of 70,185

missions to $146,192-4$

monks in 152,156

and the Muslims 70, 222, 249-52

place of burial for the patriarch 198

place of refuge 188,216

schools in 107 note 58

History of Karka de Beth Slouq 171 note 115

Holy Spirit 88, 157

Hormizd IV 143, 177, 182, 185, 188, 216

Hormizd-Ardashir 36, 40, 43, 61, 89-90

Hosea (martyr and holy man) 41-3, 48-50, 74-5

Iaballaha 35-6, 48-50, 53-4, 74-5, 76-80, 92

Ibn al-Tayyib 84, 87, 96

incest 98 note $20,105,111,115$ note 82,116 , 144,168

India

adventures of Vahram Gur 37

Christians in 168, 225, 237 note 70

knowledge from 116

source of luxury 35, 192, 196

inscriptions $14-15,33,175$ note 126 , 200, 233

Ishaq (catholicos) 9-10, 31-6, 51

composition of history under $74,78-80$

Ishaq of Nineveh 162

Isho' bar Nun 229, 231

Isho'dnah of Basra 78 note $36,150-4$, 229, 243

Isho'yahb I

and the embassy to Justinian 135-6

This is an open access version of the publication distributed under the terms of the Creative Commons Attribution-NonCommercialNoDerivs licence (http://creativecommons.org/licenses/by-nc-nd/3.0/), which permits non-commercial reproduction and distribution of the work, in any medium, provided the original work is not altered or transformed in any way, and that the work is properly cited. For commercial re-use, please contact academic.permissions@oup.com 
Isho'yahb I (cont.)

legislation 144, 149

and involvement in the Sasanian civil

war 181, 183, 185-8, 193-4, 203

and transmission of Western history 128-31, 134,142

Isho'yahb II 137-9, 218, 244, 248-9

Isho' yahb III 3, 150, 155, 157, 161, 177, 224-6, 229,242

Isho' yahb IV 3

Isho'zkha (missionary) 193-4

Istakhr $14-15,152$ note 36,189 note 39

Izla $28,143-57,164-5,225,258$

Jacob of Beth 'Abe 150-1, 154-5, 156-8, 161

Jacob of Gundishapur 102-4

Jacob of Nisibis 81, 84-5, 107, 233

Jacob of Serug 104

Jacob the Notary 46, 48, 53

Jacob the Sliced 53

Jacobites

in the Abbasid period 222, 225, 235-7, $240-2,252-3$

anti-Jacobite hagiography 162-3

associated with Henana $147,198,204$, 206, 225

attack on Barsauma of Nisibis 108

invasion of Iraq 96, 99, 106, 129-30, 138, $150,163,201,257-8$

expelled from Hira 193

maphrian 68

monks 146-7, 201

patronage from Khusrau II 199-201, 220

on the Roman Empire 134, 139, 178-9

theology 106, 129, 131, 135, 138-42

See also Cyril of Alexandria; Gabriel of

Sinjar; Julianists; Marutha of Takrit; Shirin

Jazira (the region between Mosul and

Jerusalem Aleppo) 130, 163 note 78, 199

and the Dome of the Rock 225

and Helena 234

Muslim stories of 254-5

under Persian occupation 211-15

pilgrimage to $81,153,235$

Jesus, model for hagiography 56-60

Jews

conflict with Christians in Arabia 245-6, $249,253-5$

conflict with Christians in Iraq 41-2, 57, 144, 148, 191, 198

conflict with Christians in Jerusalem 179, 211-15

John of Beth Garmai 123
John of Daylam 168, 233, 247 note 116

John of Phenek 224, 226

Joseph (catholicos) composer of history 86-7, 95, 117, 121

legislation $144-5,148-9$

Joseph Hazzaya 151

Judas Kyriakos 235

Julian (emperor) 233

Julian Romance 235

Julianists $136,252-3$

Justinian 124, 135-8, 139, 260

Karka de Beth Slouq 24, 27, 29, 149, 164

See also Bar Sahde; Yazdin

Karka de Ledan 25, 36, 53, 58, 61, 63, 89-90

Kartir $14-15$

Kashkar 23, 26, 33, 103-4, 152, 203, 226

Kavad I 19-20, 103, 112, 173

Kavad II see Shiroë

Kayanid 18, 38-9, 42

Khusrau I 103, 110, 113-17

Khusrau II

in Christian history-writing 182,185

murder of 159, 215-18

relations with Christians 158, 188-202, 207-9, 211-15

war with Rome, 176-80, 199-202

as a Zoroastrian 200-1, 210

Khuzistan Chronicle 183-4, 188, 198, 211-13, 216, 230

Khuzistan

as ecclesiastical province $16,25-6,103$

monks of 152

relations with Ctesiphon 33, 35, 39, 87-91, 103,164

as a site of martyrdom $54-8$

Kokhe 23-4, 44 note 49, 97, 102-4

Kurds 152, 163, 223 note 7

Lakhmids 192-3, 249-50

Lawarne 45, 53

Leo I (Pope) 126, 130

Ma'na (catholicos) 37, 49-50, 75

Maccabees 53, 56, 59-60, 205, 234

magic 56, 144, 147

Maishan 26, 33, 76-8, 105, 203, 206

Mamai (wife of Barsauma of Nisibis) 108

Mani (prophet), and Manichees 14, 74, 76-7, 129-30, 173, 201, 223

Mar 'Abda of Deir Qoni (monastic founder) 9-10, 27, 75-8, 101 note 31

Mar 'Abda of Hormizd-Ardashir (saint and vandal) $39-44,48-51,60,90$

This is an open access version of the publication distributed under the terms of the Creative Commons Attribution-NonCommercialNoDerivs licence (http://creativecommons.org/licenses/by-nc-nd/3.0/), which permits non-commercial reproduction and distribution of the work, in any medium, provided the original work is not altered or transformed in any way, and that the work is properly cited. For commercial re-use, please contact academic.permissions@oup.com 
Mar Mattai monastery 68, 70, 108, 210

Mar Narsai of Nisibis (theologian) 106-8, $111,120,132,142$

Mar Qardagh 169-71

Marcian (emperor, convenor of Chalcedon) 126, 133-4, 260

Marcion and Marcionites 9, 74-7, 129-30, 191-2, 198, 201

Mardanshah (son of Khusrau II) 211, 217-8

Mari ibn Sulayman (historian) 68-9, 75, 80, 126-7, 133, 182, 222, 229-30, 232,260

Maria (wife of Khusrau II) 215

Martha (daughter of Pusai) 53, 62

martyr lists 1-2, 10, 64, 70, 121

Marutha of Maypherkat (Roman emissary)

Marutha of Takrit (Miaphysite maphrian)

Maurice 135, 177-9, 188-92, 196-200, 212, 239

Mazdak (prophet) 20, 148

Media 16 note 45, 19, 167

Melqi $169-70$

Merv 103, 152-3, 171, 222, 238

Meshmahig 35

Messalianism 147-8, 158-9, 174, 242

Miaphysites see Jacobites

Middle Persian language 14-15, 38, 164-5, $167-8,172-3,182,223$

Mihr Narseh (chief mobad) 19-21, 37-9

Mikha of Beth Garmai 123, 182

Miles of Susa $61-2,82-7,89$

miracle-working 76-7, 132, 151, 155-6, 163, $165,189-93,198,214$

Mobads

in conflict with shah $19-21,37-9,44-7$

leader of 109-10, 113, 213

role in the state $14,19-21,117,223$

stimulate persecution 44-7, 53-9, 113-14, 170

See also Zoroastrianism

monastic foundation $76-7,150-3,167-8$

monastic rules $147-50,162,168$

monastic visitation 156-8, 226

Monotheletism 137 note 57

Mosul (see also Nineveh) 27, 221-2, 226 note $23,238,239$ note 80

Mshiha-zkha (historian) 123

Muhammad (prophet) 244-55

Muslims

conquest by and settlement of $224-8$

negotiation with $244-56$

Najran 245-6, 249-53, 254-6

Naqsh-i-Rustam 14

Narsai (catholicos) 26, 61, 87, 93-5, 100-4, 112

Narsai (martyr) 44-53, 75

Nehormizd (Persian aristocrat) 216-17
Nestorius 124-42

Nicaea, council of $69,84-5,88,128,132$, $137-9,230-5,240$

Nineveh 72 , note $16,180,221-2$

Nisibis

city of $22,63,99,152,186,188,198,204-7$, 238 see also Barsauma of Nisibis;

Gregory of Nisibis; Jacob of Nisibis

school of 77, 106-12, 135, 146, 149, 202-7

see also 'Abdisho' of Nisibis; Babai of

Nisibis; catholicoi, trained at Nisibis;

Elias of Nisibis; Henana; Paul of Nisibis

school of Nisibis and historiography 26, 95,

$107,11,120-1,132-3$

Nouroz 144

Nu'man (Arab phylarch) $192-4$

Pachomius 78,146 note $11,242-3$

Papas 79-92, 117, 173, 230, 234-5

Paul of Nisibis 136-9, 186

Paul of Samosata 91, 128, 130 note 29

Paul the Persian 116 note 91

pearl trade $9,35,74$

Peroz (martyr) 47, 54

Peroz (shah) 78, 96, 112 note 73, 114

persecution

in the fourth century $55-65$

in the fifth century $40-54,75$

in the sixth century 113

in the seventh century 200-1

in northern Iraq 5, 44, 53

shah excused from blame for $114-18,170$

Persian Christians 36-7, 40, 49, 106-8, 113

note $73,152-3,168$

Persians, depicted as pagan $213-15$

Peter of Beth Abe 188-9

Pharabokht (anti-catholicos) 36-7, 49 note 68,77

Phocas 178-9, 249

pilgrimage to the west $81,153,235,239$

polygamy 105

proselytism

banned by the Sasanians $40-4,50,94$,

110,201

by ascetics 9

facilitated by the Arab conquests 224

in the Caucasus 134

to China and Central Asia 237-9

to Fars 168,223

to Himyar 260

to Hira 146, 189, 192-4, 252

in Maishan 76-8, 203

in northern Iraq 162-3

See also Jacobites

Pseudo-Ishaq of Nineveh 140-1

Pseudo-George of Arbela 140

This is an open access version of the publication distributed under the terms of the Creative Commons Attribution-NonCommercialNoDerivs licence (http://creativecommons.org/licenses/by-nc-nd/3.0/), which permits non-commercial reproduction and distribution of the work, in any medium, provided the original work is not altered or transformed in any way, and that the work is properly cited. For commercial re-use, please contact academic.permissions@oup.com 
Pseudo-Sebeos 178, 180-1, 187, 200, 209

Pulcheria (empress) 36 note 17, 126

Pumbedita 23

Pusai 53, 62, 89

Qayoma 73-4, 77-8, 92

Qusțā ibn Lūqā 3, 240

Rabban Apnimaran 154-5, 157-8

Rabban Bar' Idta (holy man) 150, 162, $165-7$

Rabban Hormizd (holy man) 168, 239

Rabbula of Edessa 148

Rayy (Beth Raziqaye) 44, 50, 103, 177, $190-1,195$

relic cult 52-4, 61, 72, 89, 150-1, 161

see also True Cross

religious vandalism $39-46,50$

Roman-Persian relations $36-7,96,135-9$, $177-80,186,192$

Rome, city 12, 69, 128, 233-6, 254

Rumagan 24, 92 note 84

Rusafa $177-8$

Sabrisho' (catholicos) 161, 179 connection to Jacob of Beth Abe 161 and Gregory of Nisibis 203-5 impression in the historiography 182, 185 saint's Life 188-99

Sahdona 151, 154, 159 note 62, 162, 224

Samarra 27, 221

Samuel of Kashkar (bishop) 102-4

Sawmai of Karka de Ledan (bishop and collector of relics) 53-4, 89-90

School of 'Abda 9-10, 23, 27, 76-7, 92, 102 note 31

Seleucia-Ctesiphon see Ctesiphon

Sergius of Beth Rasthaq (monastic historian) 155, 166

Severans see Jacobites

Severus of Antioch 128-30, 139

Shahdost (catholicos) 22 note $66,62-3,85$, 121, 235

Shahdost of Tirhan 123, 140-1

Shahrqart 22

Shahrbaraz 176, 179-83, 186-7, 211-13, 216, 218-19

Shalupha 69

Shamta bar Yazdin 159, 180-1, 186, 216-19

Shapur I 14-15, 20, 33, 89

Shapur II $21,39,56,86,89,170-1$, 173,242

Shapur III 172

Shapurian persecutions $1-2,19-22,33,44$, 52-65, 79, 89-91, 243
Shila $100-4,112$

Shiraz 222

Shirin (wife of Khusrau II) 185-9, 195-6, 206-12, 214, 217

Shiroë 159, 175-6, 180, 186, 208, 215-19

Shushtar 25, 90, 123

Simeon of Beth Garmai 124 note 9

Sinjar 152

Slibazkha (catholicos) 226

Sliq Harubta 44

Socrates Scholasticus (historian) 38, 123-9

Sogdian 171 note 114

Solomon of Basra 71, 175 note 125,182

state centralization $17-18,143$

Sura (rabbinic school) 23

Susa 25, 89-90, 112, 137

Symeon bar Sebba'e 21, 25, 52-65, 79-80, 88-9, 105, 113-14

Symeon of Hira 193-4

Synodicon Orientale see references under individual catholicoi

al-Tabari

on Arabia 250, 253

on the death of Yazdegard $37-8$

on the murder of Khusrau II 216-18

preserving Middle Persian material 172

Takhrid (courtier) 190-5, 211, 219

Takrit 27, 68, 70, 237-9, 248

Talmud 16, 20

Tataq (martyr) 44, 47, 53

taxation

collaboration of Christians 21, 56-60, 211-12

Islamic-era debates 222-3, 246-51, 256

of monasteries and churches 167

reform 18,38

as tyranny $56-60,63,180,207,216-17$

Tella (Roman city) 33

Tella (village in Maishan) $76-7,90-1$

al-Tha'alibi 216

Theodore of Mopsuestia 71, 98, 125-7, 130-7, 140,149

tradition at Nisibis $106-7,111,203-4$

Theodoret of Cyrrhus 39-40, 47, 124-9

Theodosius II 35, 126, 235

Theodoulos (theologian) 11, 106

Thomas (apostle) 67

Thomas of Marga 153-60, 162, 182, 212, $216-17,224,229$

Tibet 237

Timothy I 153 note 42,156 note $50,227-37$, $239,252-7$

Tomarsa $70,74-8,92$

translation into Arabic 4-6, 68, 221, 227, $259-60$

This is an open access version of the publication distributed under the terms of the Creative Commons Attribution-NonCommercialNoDerivs licence (http://creativecommons.org/licenses/by-nc-nd/3.0/), which permits non-commercial reproduction and distribution of the work, in any medium, provided the original work is not altered or transformed in any way, and that the work is properly cited. For commercial re-use, please contact academic.permissions@oup.com 
translation into Greek 53 note 5, 214

translation into Syriac 94, 116, 122-6, 173, 235,242

True Cross 169, 178, 196, 199, 211-12

'Umar I 248-54

universal rule $33,178-9,201,219$

Urmia liturgy 121-3

Vahram II 14-15, 19-20, 174, 175 note 127

Vahram V (Vahram Gur) 18 note 53, 36-9, $46-9,54,76$

Vahram VI (Vahram Chobin) 166, 177, 188

Valash 96, 113, 173

Veh Ardashir 24

Vistahm (Sasanian pretender) 178, 190, 193

Wasit (see also Kashkar) 24 note 76, 26 note $84,227,230$ note 41

Western embassies see Roman-Persian relations

Xwaday-Namag 13, 18, 37-8, 165, 172-4, 182,185
Yamama 76

Yazdegard I 9, 14-15, 19-20, 31-49, 75, 78, 172,205

Yazdegard II 25

Yazdegard III 186

Yazdin

in the Book of the Governors 159-60

in Jerusalem 211-14

in the Khuzistan Chronicle 183, 187

in the Chronicle of Seert 162, 192

prominence as an aristocrat 143

recipient of miracles 163

see also Shamta bar Yazdin

Zab rivers 27, 190

Zachariah of Mytilene 117 note 93, 133

Zamasp (shah) 113-15

Zeno 11, 96, 99

Zoroastrian practices used by

Christians 115, 144, 167-70, 209-10

Zoroastrianism

collapse of 168, 222-3, 259

disputations with Christians 41-4, 109-16

This is an open access version of the publication distributed under the terms of the Creative Commons Attribution-NonCommercialNoDerivs licence (http://creativecommons.org/licenses/by-nc-nd/3.0/), which permits non-commercial reproduction and distribution of the work, in any medium, provided the original work is not altered or transformed in any way, and that the work is properly cited. For commercial re-use, please contact academic.permissions@oup.com 